\title{
GEOHYDROLOGY, WATER QUALITY, AND NITROGEN GEOCHEMISTRY IN THE SATURATED AND UNSATURATED ZONES BENEATH VARIOUS LAND USES, RIVERSIDE AND SAN BERNARDINO COUNTIES, CALIFORNIA, 1991-93
}

By Terry F. Rees, Daniel J. Bright, Ronald G. Fay, Allen H. Christensen, Robert Anders, Brian S. Baharie and Michael T. Land

U.S. GEOLOGICAL SURVEY

Water-Resources Investigations Report 94-4127

Prepared in cooperation with the EASTERN MUNICIPAL WATER DISTRICT, the METROPOLITAN WATER DISTRICT OF SOUTHERN CALIFORNIA, and the ORANGE COUNTY WATER DISTRICT

$\frac{0}{8}$ 


\section{U.S. DEPARTMENT OF THE INTERIOR BRUCE BABBITT, Secretary}

\section{U.S. GEOLOGICAL SURVEY \\ Gordon P. Eaton, Director}

Any use of trade, product, or firm names in this publication is for descriptive purposes only and does not imply endorsement by the U.S. Government.

For sale by the U.S. Geological Survey

Earth Science Information Center

Open-File Reports Section

Box 25286, MS 517

Denver Federal Center

Denver, CO 80225

For additional information write to:

District Chief

U.S. Geological Survey

Federal Building, Room W-2233

2800 Cottage Way

Sacramento, CA 95825 
Abstract

Introduction

Statement of problem

Purpose and scope

Background

Nitrogen cycling

Sources of nitrate

Rain nitrogen

Soil nitrogen

Geologic nitrogen

Row-crop agriculture

Animal wastes and sewage $\ldots \ldots \ldots \ldots \ldots \ldots \ldots \ldots$

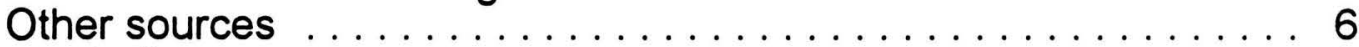

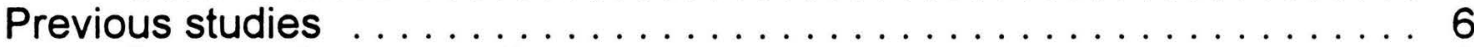

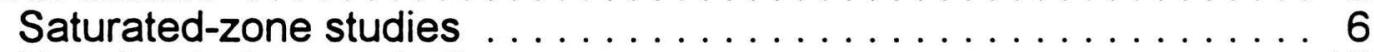

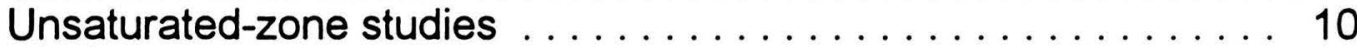

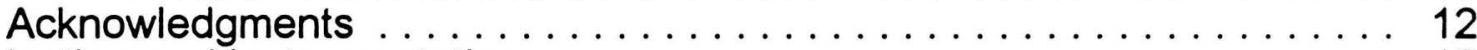

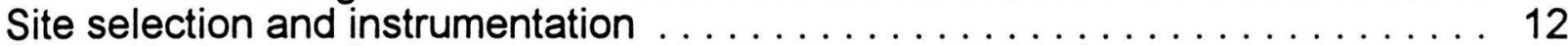

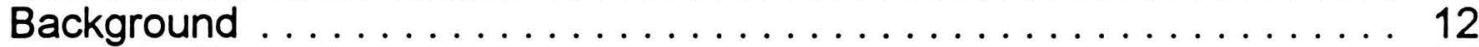

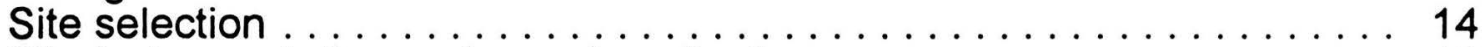

Site instrumentation and sample collection $\ldots \ldots \ldots \ldots \ldots \ldots \ldots 16$

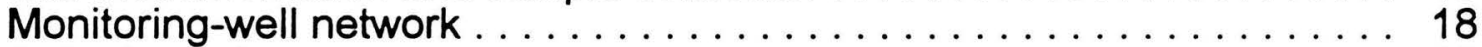

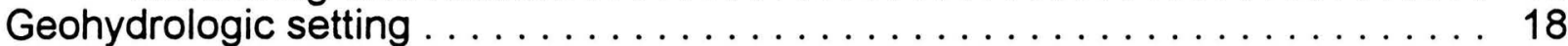

Hemet ground-water subbasin . . . . . . . . . . . . . . . 18

Distribution of alluvial deposits in the Hemet subbasin . . . . . . 18

Ground-water storage and ground-water . . . . . . . . . . 31 flow, 1991-92

Menifee ground-water subbasin and Chino ground-water basin . . . . . . 34

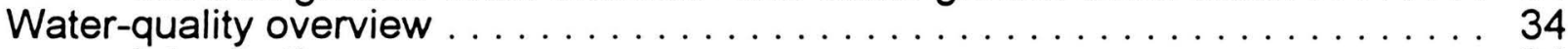

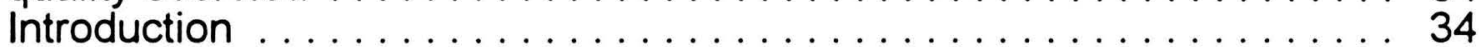

Diamond Valley area .......................... 47

Bautista Outwash area ... . . . . . . . . . . . . . . . . . . 48

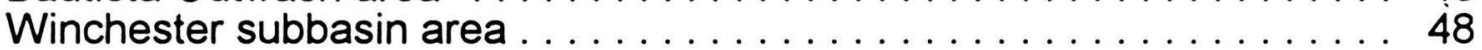

Main Basin area ............................. 48

San Jacinto, Winchester, and Domenigoni Basins . . . . . . . . 48

Lakeview Mountains . . . . . . . . . . . . . . . . . . . . . . . . 49

Geohydrology, water quality, and nitrogen geochemistry at . . . . . . . 49

the study sites

Residential site

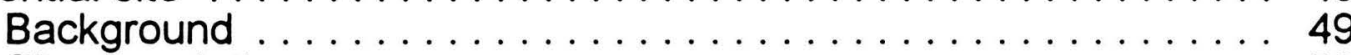

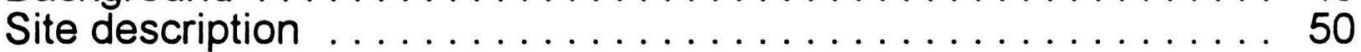

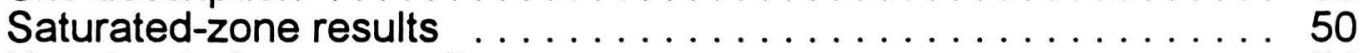

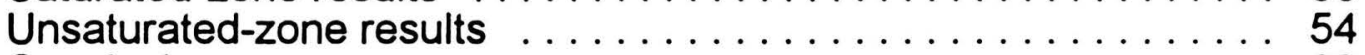

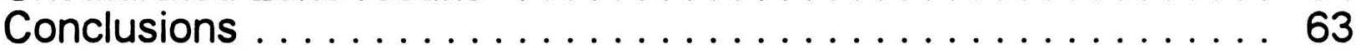

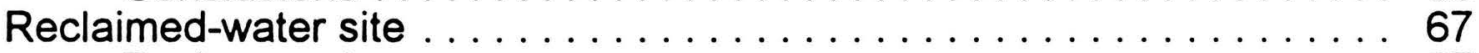

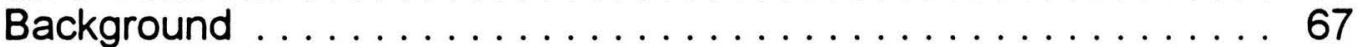

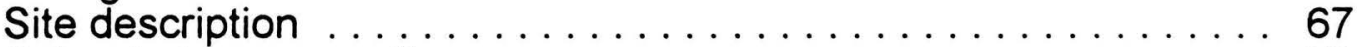

Saturated-zone results $\ldots \ldots \ldots \ldots \ldots \ldots \ldots \ldots \ldots \ldots$

Unsaturated-zone results $\ldots \ldots \ldots \ldots \ldots \ldots \ldots \ldots \ldots \ldots$

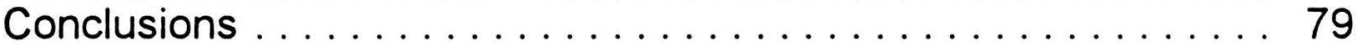


Citrus Grove site . . . . . . . . . . . . . . . . . . . . . . . . 79

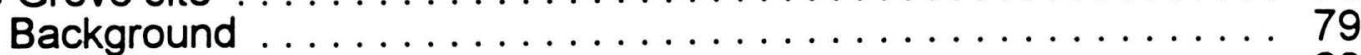

Site description $\ldots \ldots \ldots \ldots \ldots \ldots \ldots \ldots \ldots \ldots \ldots$

Saturated-zone results $\ldots \ldots \ldots \ldots \ldots \ldots \ldots \ldots \ldots$

Unsaturated-zone results $\ldots \ldots \ldots \ldots \ldots \ldots \ldots \ldots \ldots \ldots$

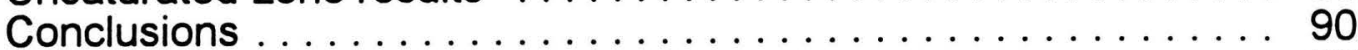

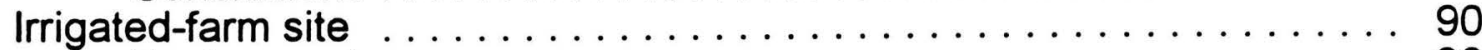

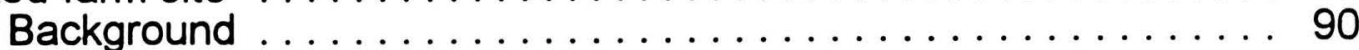

Site description $\ldots \ldots \ldots \ldots \ldots \ldots \ldots \ldots \ldots \ldots \ldots \ldots \ldots \ldots$

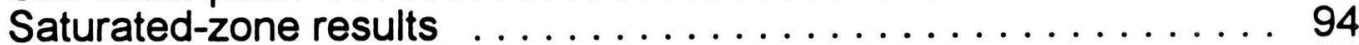

Unsaturated-zone results . . . . . . . . . . . . . . . . . . 94

Conclusions . . . . . . . . . . . . . . . . . . . . . . . . . . . . 104

Poultry-farm site ... . . . . . . . . . . . . . . . . . . . . . . . . . 104

Site description .......................... 104

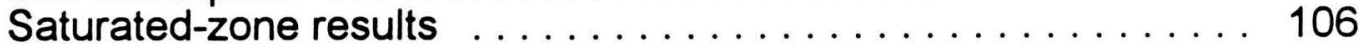

Unsaturated-zone results . . . . . . . . . . . . . . . . . . 108

Conclusions .................................. 114

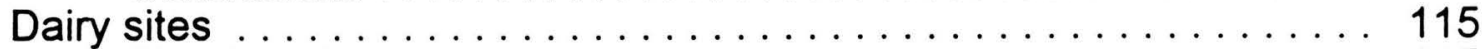

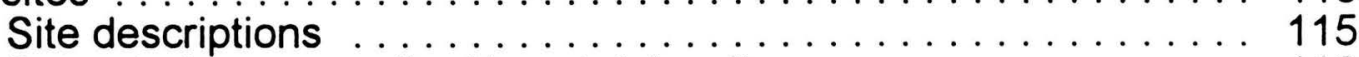

Saturated-zone results--Hemet dairy site $\ldots \ldots \ldots \ldots \ldots \ldots 118$

Saturated-zone results--Chino dairy site $\ldots \ldots \ldots \ldots \ldots \ldots \ldots 118$

Unsaturated-zone results $\ldots \ldots \ldots \ldots \ldots \ldots \ldots \ldots \ldots \ldots$

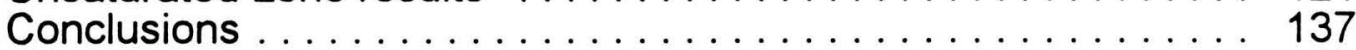

Summary

Supplementary data 1 . Water levels in monitoring network wells, . . . . . . . 147 1990-92

Supplemental data 2. Analytical data for wells and springs in

Supplemental data 3. Analytical data for wells and lysimeters at

the instrumented land-use sites:

A. Residential site . . . . . . . . . . . . . . . . . . . . . . . . . . 160

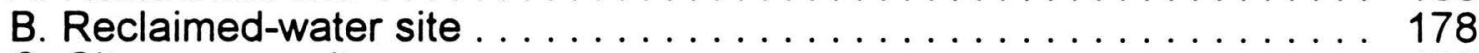

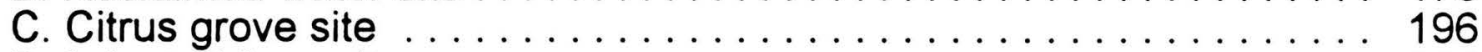

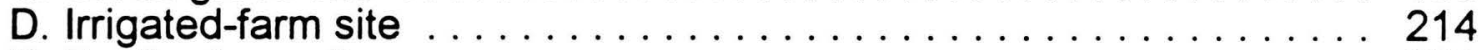

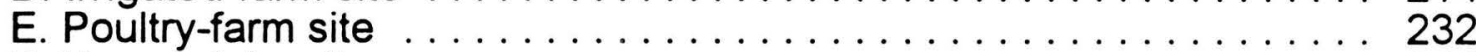

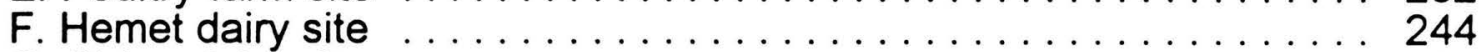

G. Chino dairy site . . . . . . . . . . . . . . . . . . 250

\section{ILLUSTRATIONS}

Figure 1. Diagram showing the nitrogen cycle $\ldots \ldots \ldots \ldots \ldots$

2-4. Maps showing:

2. Location of the study area . . . . . . . . . . . . . . . . 13

3. The Hemet Subbasin and the monitoring-well network . . . . . . 15

4. Altitude of bedrock surface in the Hemet subbasin . . . . . . . . 19

5-10. Maps showing texture, for selected depth intervals,

of the alluvial deposits of the Hemet subbasin:

5. 0 to 100 feet ...................... 20

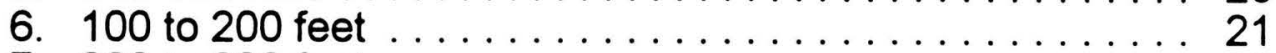

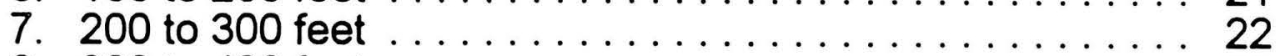

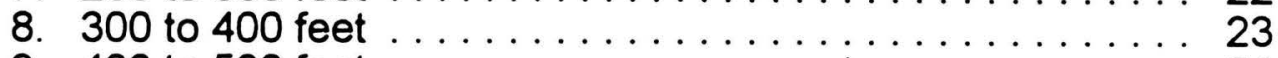

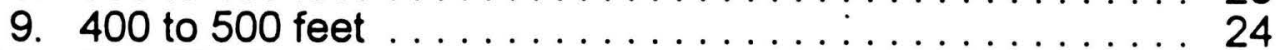

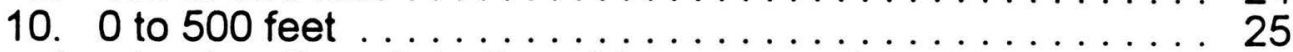

11. Map showing location of stratigraphic cross sections $\left(A-A^{\prime}, \ldots \ldots 26\right.$ $A-A^{\prime \prime}, B-B^{\prime}$, and $C-C^{\prime}$ ) shown in figures $12-15$ 
12. Lithologic profiles for stratigraphic cross section $A-A^{\prime} \ldots \ldots 27$

13. Lithologic profiles for stratigraphic cross section $A-A^{\prime \prime} \ldots \ldots \ldots 28$

14. Lithologic profiles for stratigraphic cross section $B-B^{\prime} \ldots \ldots \ldots 29$

15. Lithologic profiles for stratigraphic cross section $C-C^{\prime} \ldots \ldots \ldots 29$

16. Map showing water-table elevation in the Hemet subbasin and . . . 32 vicinity, spring 1991

17. Map showing water-table elevation in the Hemet subbasin and . . 33 vicinity, autumn 1992

18-27. Maps showing areal distribution of selected constituents and properties in the Hemet subbasin and vicinity:

18. Dissolved-solids concentration ............... 35

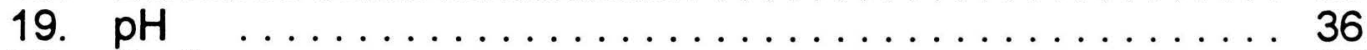

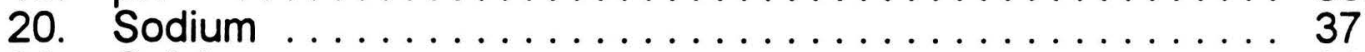

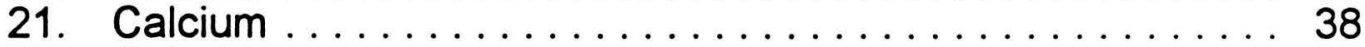

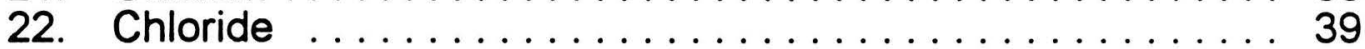

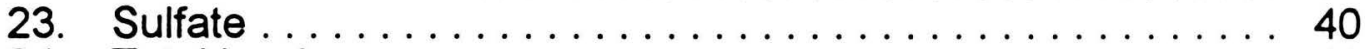

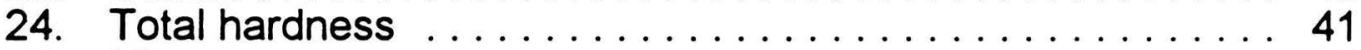

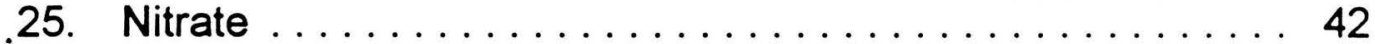

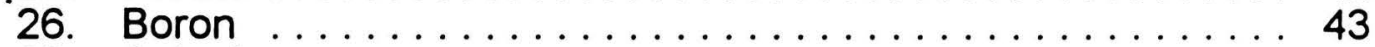

27. Selenium ....................... 44

28. Graph showing relation of delta oxygen-18 to annual . . . . . . 45 mean air temperature

29. Graph showing relation of delta deuterium to delta . . . . . . . . 46 oxygen-18

30. Geophysical logs, and diagram showing well construction, . . . . 51 cored interval, and lithology for the residential site

31. Graph showing particle-size distribution at selected depths . . . . . 52 for cores from the residential site

32. Unsaturated-zone pore-moisture profiles, for selected dates . . . . 55 in 1991-93, for the residential site

33. Tritium-concentration profile for pore water at the . . . . . . . . 56 residential site

34. Organic-nitrogen-concentration profile, from core extracts, . . . . 59 for the unsaturated zone at the residential site

35. Nitrate-concentration profile, from core extracts, for the .......66 unsaturated zone at the residential site

36. Graph showing nitrate concentration, for selected dates in .....66 62 1991-92, in unsaturated-zone pore water at the residential site

37. Geophysical logs, and diagram showing well construction, cored . 68 interval, and lithology for the reclaimed-water site

38. Graph showing particle-size distribution at selected depths ..... 69 for cores from the reclaimed-water site

39. Unsaturated-zone pore-moisture profiles for selected dates . . . . 72 in 1991-93 for the reclaimed-water site

40. Tritium-concentration profile for pore water at the . . . . . . . 73 reclaimed-water site

41. Organic-nitrogen-concentration profile, from core extracts, . . . . 76 for the unsaturated zone at the reclaimed-water site

42. Nitrate-concentration profile, from core extracts, for the . . . . . . 77 unsaturated zone at the reclaimed-water site

43. Graph showing nitrate concentration, for selected dates in . . . . 78 1991-92, in unsaturated-zone pore water at the reclaimedwater site

44. Geophysical logs, and diagram showing well construction, cored . 81 interval, and lithology for the citrus grove site 
45. Graph showing particle-size distribution at selected depths . . . 82 for cores from the citrus grove site

46. Unsaturated-zone pore-moisture profiles for selected dates . . . . . 84 in 1991-93 for the citrus grove site

47. Tritium-concentration profile for pore water at the citrus . . . . . . 86 grove site

48. Graph showing nitrate concentration, for selected dates in ..... 1991-92, in unsaturated-zone pore water at the citrus grove site

49. Geophysical logs, and diagram showing well construction, cored . 92 interval, and lithology for the irrigated-farm site

50. Graph showing particle-size distribution for cores from . . . . . . . .93 the irrigated-farm site

51. Unsaturated-zone pore-moisture profiles, for selected dates . . . . 95 in 1991-93, for the irrigated-farm site

52. Tritium-concentration profile for unsaturated-zone pore water . . . 97 at the irrigated-farm site

53. Organic-nitrogen-concentration profile, from core extracts, . . . . . 99 for the unsaturated zone at the irrigated-farm site

54. Ammonia-concentration profile for unsaturated-zone pore water . 100 at the irrigated-farm site

55. Nitrate-concentration profile, from core extracts, for the . . . . . . 101 unsaturated zone at the irrigated-farm site

56. Graph showing nitrate concentration, for selected dates in . . . 102 1991-92, in unsaturated-zone pore water at the irrigated-farm site

57. Geophysical logs, and diagram showing well construction, .... . 105 cored interval, and lithology for the poultry-farm site

58. Graph showing particle-size distribution at selected depths for cores from the poultry-farm site

59. Unsaturated-zone pore-moisture profiles for selected dates . . . . 109 in 1991-92 for the poultry-farm site

60. Organic-nitrogen-concentration profile, from core extracts, . . . . 110 for the unsaturated zone at the poultry-farm site

61. Ammonia-concentration profile, from core extracts, for the . . . . . 111 unsaturated zone at the poultry-farm site

62. Nitrite-concentration profile, from core extracts, for . . . . . . 112 the unsaturated zone at the poultry-farm site

63. Nitrate-concentration profile, from core extracts, for . . . . . . . . 113 the unsaturated zone at the poultry-farm site

64. Geophysical logs, and diagram showing well construction, ..... 116 cored interval, and lithology for the Hemet dairy site

65. Graph showing particle-size distribution at selected depths . . . . 117 for cores from the Hemet dairy site

66. Geophysical logs, and diagram showing well construction, . . . . 119 cored interval, and lithology for the Chino dairy site

67. Graph showing particle-size distribution at selected depths . . . . 120 for cores from the Chino dairy site

68. Unsaturated-zone pore-moisture profiles for selected dates . . . . 122 in 1991-92 for the Hemet diary site

69. Unsaturated-zone pore-moisture profiles for selected dates . . . . 123 in 1991-92 for the Chino diary site 
70. Tritium-concentration profile for pore water at the Hemet . . . . . 125 dairy site

71. Tritium-concentration profile for pore water at the Chino . . . . 126 diary site

72. Organic-nitrogen-concentration profile, from core extracts, . . . 128 for the unsaturated zone at the Hemet dairy site

73. Ammonia-concentration profile, from core extracts, for . . . . . . 129 the unsaturated zone at the Hemet dairy site

74. Nitrate-concentration profile, from core extracts, for . . . . . . 130 the unsaturated zone at the Hemet dairy site

75. Organic-nitrogen-concentration profile, from core extracts, . . . 131 for the unsaturated zone at the Chino dairy site

76. Ammonia-concentration profile, from core extracts, for . . . . . . 132 the unsaturated zone at the Chino dairy site

77. Nitrate-concentration profile, from core extracts, for . . . . . . . 133 the unsaturated zone at the Chino dairy site

78. Nitrate-concentration profile, for selected dates in 1991-92, . . . 135 in unsaturated-zone pore water at the Hemet dairy site

79. Nitrate-concentration profile, for selected dates in $1991-92, \ldots \ldots 136$ in unsaturated-zone pore water at the Chino dairy site

\section{TABLES}

Table 1. Water-quality and water-level monitoring network in the ...... 19a study area

2. Bacteria populations in the unsaturated zone beneath the . . . . . . 64 instrumented land-use sites

3. Nitrogen-isotope and nitrogen-to-chloride ratio data for . . . . . . . 65 unsaturated-zone pore water beneath the instrumented land-use sites

4. Concentrations of selected gases in unsaturated-zone pore . . . . .66 66 water beneath the instrumented land-use sites 


\begin{tabular}{rcl} 
Multiply & By & To obtain \\
acre-foot (acre-ft) & 1,233 & cubic meter \\
foot per mile (ft/mi) & 0.1894 & meter per kilometer \\
foot per second (ft/s) & 0.3048 & meter per second \\
foot per year (ft/yr) & 0.3048 & meter per year \\
gallon (gal) & 3.785 & liter $(\mathrm{L})$ \\
inch (in.) & 25.4 & millimeter \\
centimeter \\
inch per year (in/yr) & 2.54 & millimeter per year \\
mile (mi) & 1.609 & kilometer \\
square mile (mi $\left.{ }^{2}\right)$ & 2.590 & square kilometer \\
pound per acre (lb/acre) & 0.8922 & kilogram per hectare \\
pound per acre per year & 0.8922 & kilogram per hectare \\
[(lb/acre)/yr] & & per year \\
& & \\
\hline
\end{tabular}

Temperature is given in degrees Celsius $\left({ }^{\circ} \mathrm{C}\right)$, which can be converted to degrees Fahrenheit $\left({ }^{\circ} \mathrm{F}\right)$ by the following equation:

$$
{ }^{\circ} \mathrm{F}=1.8\left({ }^{\circ} \mathrm{C}\right)+32 .
$$

\section{WATER-QUALITY (AND PARTICLE-SIZE) INFORMATION}

Metric units were used for chemical concentration and particle size. To convert metric units to inchpound units, multiply the metric unit by the reciprocal of the applicable conversion factor listed above.

Chemical concentrations are given in milligrams per liter $(\mathrm{mg} / \mathrm{L})$ or micrograms per liter $(\mu \mathrm{g} / \mathrm{L})$. Milligrams per liter is approximately equivalent to parts per million. Micrograms per liter is approximately equivalent to parts per billion. Tritium concentrations are expressed in picocuries per liter $(\mathrm{pCi} / \mathrm{L})$, which car be converted to tritium units (TU) by dividing by 3.2 .

\begin{aligned} & \multicolumn{1}{c}{ ABBREVIATIONS } \\ EMWD: & Eastern Municipal Water District \\ MWD: & Metropolitan Water District of Southern California \\ $\mathrm{MCL}: & \begin{array}{l}\text { Maximum Contaminant Level (U.S. Environmental Protection } \\ \text { Agency, 1992) }\end{array} \\ \mathrm{mg} / \mathrm{Kg} &$ milligram per kilogram \\ $\mathrm{mg} / \mathrm{L}: &$ milligram per liter \\ $\mathrm{pCi} / \mathrm{L}: &$ picocurie per liter \\ $\mu \mathrm{g} / \mathrm{L}: &$ microgram per liter \\ $\mu \mathrm{S} / \mathrm{cm}: &$ microsiemen per centimeter at $25^{\circ}$ Celsius \end{aligned}

\section{VERTICAL DATUM}

Sea Level: In this report, "sea level" refers to the National Geodetic Vertical Datum of 1929--a geodetic datum derived from a general adjustment of the first-order level nets of the United States and Canada, formerly called Sea Level Datum of 1929. 
Wells, lysimeters, and springs are identified and numbered according to their location in the rectangular system for subdivision of public lands in California. Identification consists of the township number, north or south; the range number, east or west; and the section number. Each section is divided into sixteen 40 -acre tracts lettered consecutively (except I and O), beginning with " $\mathrm{A}$ " in the northeast corner of the section and progressing in a sinusoidal manner to " $R$ " in the southeast corner. Within the 40 -acre tract, wells are sequentially numbered in the order they are inventoried. The final letter refers to the base line and meridian. In California, there are three base lines and meridians: Humboldt (H), Mount Diablo (M), and San Bernardino (S). All wells in the study area are referenced to the San Bernardino base line and meridian (S). Well numbers consist of 15 characters and follow the format $005 \mathrm{~N} 001 \mathrm{~W} 28 \mathrm{~J} 001 \mathrm{~S}$. The letters "LYS" following a sequence number indicate a lysimeter, and the letter " $S$ " inserted before the sequence number indicates a spring. In this report, well numbers are abbreviated and written $5 \mathrm{~S} / 1 \mathrm{~W}-28 \mathrm{Jl}$. Wells in the same township and range are referred to only by their section designation, 28J1. The following diagram shows how the number for well $5 \mathrm{~S} / 1 \mathrm{~W}-28 \mathrm{~J} 1$ is derived.

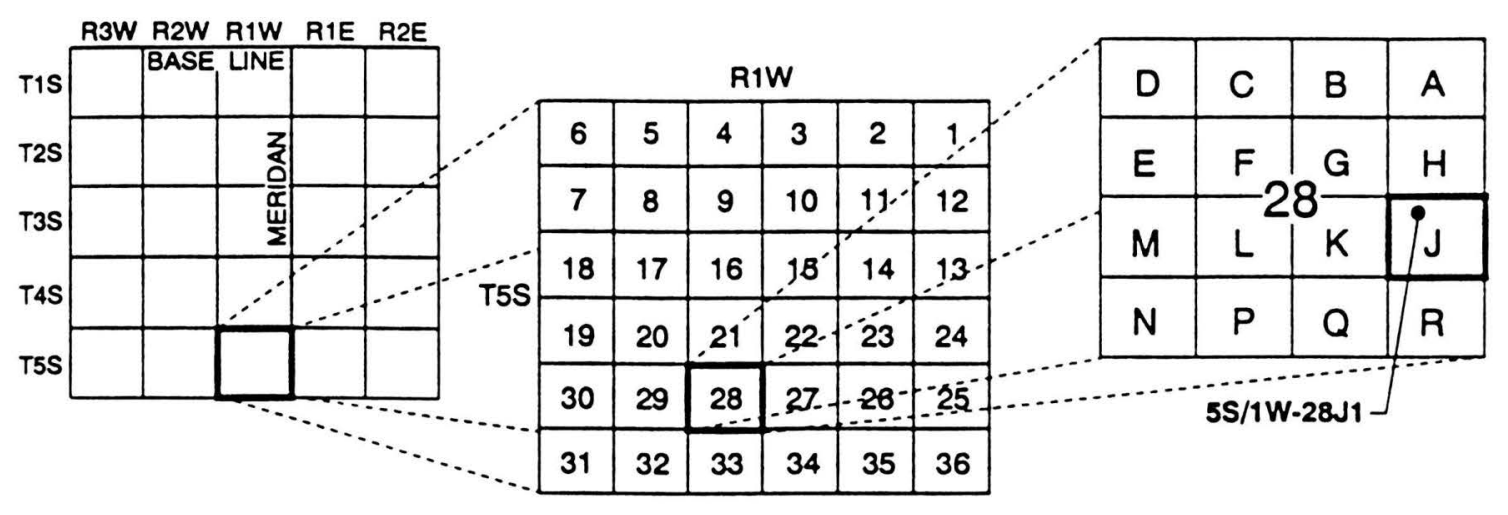





\title{
Geohydrology, Water Quality, and Nitrogen Geochemistry in the Saturated and Unsaturated Zones beneath Various Land Uses, Riverside and San Bernardino Counties, California, 1991-93
}

\author{
By Terry F. Rees, Daniel J. Bright, Ronald G. Fay, Allen H. Christensen, \\ Robert Anders, Brian S. Baharie, and Michael T. Land
}

\begin{abstract}
The U.S. Geological Survey, in cooperation with the Eastern Municipal Water District, the Metropolitan Water District of Southern California, and the Orange County Water District, has completed a detailed study of the Hemet groundwater basin. The quantity of ground water stored in the basin in August 1992 is estimated to be 327,000 acre-feet. Dissolved-solids concentration ranged from 380 to $700 \mathrm{mg} / \mathrm{L}$ (milligrams per liter), except in small areas where the concentration exceeded $1,000 \mathrm{mg} / \mathrm{L}$. Nitrate concentrations exceeded the U.S. Environmental Protection Agency Maximum Contaminant Level (MCL) of $10 \mathrm{mg} / \mathrm{L}$ nitrate (as nitrogen) in the southeastern part of the basin, in the Domenigoni Valley area, and beneath a dairy in the Diamond Valley area.
\end{abstract}

Seven sites representing selected land uses-residential, turf grass irrigated with reclaimed water, citrus grove, irrigated farm, poultry farm, and dairy (two sites)--were selected for detailed study of nitrogen geochemistry in the unsaturated zone. For all land uses, nitrate was the dominant nitrogen species in the unsaturated zone.

Although nitrate was seasonally present in the shallow unsaturated zone beneath the residential site, it was absent at moderate depths, suggesting negligible migration of nitrate from the surface at this time. Microbial denitrification probably is occurring in the shallow unsaturated zone. High nitrate concentrations in the deep unsaturated zone (greater than $100 \mathrm{ft}$ ) suggest either significantly higher nitrate loading at some time in the past, or lateral movement of nitrate at depth.

Nitrate also is seasonally present in the shallow unsaturated zone beneath the reclaimed-water site, and (in contrast with the residential site), nitrate is perennially present in the deeper unsaturated zone.
Microbial denitrification in the unsaturated zone and in the capillary fringe above the water table decreases the concentrations of nitrate in pore water to below the MCL before reaching the water table.

Pore water in the unsaturated zone beneath the citrus grove site contains very high concentrations of nitrate. Even though there are zones of microbial denitrification, nitrate seems to be migrating downward to the water table.

The presence of a shallow perched-water zone beneath the irrigated-farm site prevents the vertical movement of nitrate from the surface to the regional water table. Above the perched zone, nitrate concentrations in the unsaturated zone are variable, ranging from below the MCL to four times the MCL. Periodically, nitrate is flushed from the shallow unsaturated zone to the perched-water zone.

The unsaturated zone pore-moisture quality could not be adequately addressed because of the very dry conditions in the unsaturated zone beneath the poultry-farm site. Surficial clay deposits prevent water from percolating downward.

At the two dairy sites, nitrate loading in pore water at the surface was very high, as great as 7,000 $\mathrm{mg} / \mathrm{L}$. Microbial denitrification in the unsaturated zone causes such concentrations to decrease rapidly with depth. At a depth of $20 \mathrm{ft}$, nitrate concentration was less than $100 \mathrm{mg} / \mathrm{L}$. In areas where the depth to water is less than $20 \mathrm{ft}$, nitrate loading to ground water can be very high, whereas in areas where depth to water is greater than $100 \mathrm{ft}$, most of the nitrate is microbially removed before reaching the water table. 


\section{INTRODUCTION}

\section{Statement of Problem}

In the urbanized areas of southern California, one-third of the water supply for 15 million people is from local ground-water sources. The Metropolitan Water District of Southern California, principal water wholesaler to the region, estimates that it is losing 4 percent of its ground-water-based drinking-water supply annually to high nitrate concentrations, in comparison with 0.5 percent lost because of toxic organic chemicals (Metropolitan Water District of Southern California, 1987). The geographic area and the number of wells contaminated by nitrate are projected to increase over the next 50 to 100 years as a result of past and present agricultural practices. The problems caused by high nitrate concentrations in the ground water of southern California--and the questions asked regarding source, long-term trends, and cleanup--are similar to those faced in many parts of the United States where urban and agricultural land uses coexist, and where urbanization is rapidly displacing agriculture (Smith and Duff, 1988). Many smaller communities face similar problems. In parts of Nebraska, for example, water from 70 percent of the rural wells exceeds the U.S. Environmental Protection Agency (USEPA) maximum contaminant level (MCL) for nitrate (Pirnir, 1989).

\section{Purpose and Scope}

The San Jacinto River drainage basin in Riverside County, California, is expected to undergo rapid development over the next decade. The 1990 estimated basin population of 272,000 is expected to increase to more than 570,000 by the year 2000 (Eastern Municipal Water District, 1988). Water for this expanded population will be supplied by increased importation of California State Water Project water, continued use of Colorado River water, use of reclaimed water, and increased utilization of ground-water resources. Computer models are being developed by local water-management agencies to analyze various ground-water management alternatives, including banking of artificially recharged water from aqueducts in the State Water Project (Metropolitan Water District of Southern California, 1988).

With the exception of the San Jacinto groundwater subbasin, little is known about the ground- water hydrology within the basin. Water-quality problems include areas of high dissolved-solids concentration; localized zones of high-temperature water; high boron concentrations along the Casa Loma Fault; iron, taste, and odor problems throughout the system; and high nitrate concentrations in the southeastern and northern parts of the watershed, particularly in the Hemet and Perris ground-water subbasins (Spencer and others, 1990). There is a paucity of depth-related chemical data in the saturated zone, and almost no information on nitrate concentrations and nitrogenaltering processes in the unsaturated zone. Moreover, current ground-water models assume complete vertical mixing (Taghavi and others, 1988), which is unlikely to occur in ground-water systems.

To investigate alternative management strategies, one must have accurate estimates of the hydraulic properties of the individual subbasins within the San Jacinto drainage basin. The effective management of the ground-water resources and identification of future mitigating measures require that chemical, biological, and hydraulic processes that affect nitrogen speciation and concentration be determined for a variety of representative land-use and hydrologic conditions. This need is particularly evident in the southeastern part of the Hemet subbasin, where a steady trend of increasing nitrate concentrations has been observed. The quantity of nitrate reaching the water table, the vertical distribution of nitrate in the saturated zone, and the depth to which physical mixing affects that vertical distribution need to be determined.

The purposes of this study were to determine (1) current ground-water conditions in the Hemet subbasin, including thickness and extent of water-bearing materials, directions of ground-water flow, and chemical quality of ground water; (2) the effects of chemical, biological, and hydraulic processes on nitrogen speciation and concentration in the unsaturated zone; (3) the quantity of nitrate reaching the water table; and (4) the degree of mixing and vertical distribution of nitrate in the saturated zone. This report presents the results of this study.

This study was jointly funded by the U.S. Geological Survey, the Eastern Municipal Water District, the Metropolitan Water District of Southern California, and the Orange County Water District. 


\section{Background}

Typically, nitrate concentrations are given either as nitrate as nitrogen or as nitrate as nitrate. 10 $\mathrm{mg} / \mathrm{L}$ nitrate as nitrogen is equivalent to $45 \mathrm{mg} / \mathrm{L}$ nitrate as nitrate. The MCL for nitrate is 10 milligrams per liter $(\mathrm{mg} / \mathrm{L})$ (nitrate as nitrogen) (U.S. Environmental Protection Agency, 1990). This standard is based on the incidence of methemoglobinemia in infants under 6 months of age who consume water with higher nitrate concentrations (Comly, 1945). Methemoglobinemia occurs when an oxidizing agent, such as nitrite, oxidizes the iron in hemoglobin to form methemoglobin, thus reducing the oxygen-carrying capacity of the blood. Adults and children on solid foods are not susceptible to nitrate toxicity, but infants are at risk for several reasons. Infants have lower activity of the enzyme that reduces methemoglobin; infant hemoglobin is more susceptible to oxidation than child or adult hemoglobin; and infants have higher $\mathrm{pH}$ in the stomach and intestines, which promotes the bacterial reduction of nitrate to nitrite.

\section{Nitrogen Cycling}

Nitrogen in the environment can be present in a variety of chemical forms. The most reduced inorganic form is ammonia $\left(\mathrm{NH}_{3}\right)$. Nitrogen in ammonia is in the (-3) oxidation state. In water, ammonia can exist either as a non-charged dissolved gas, or it can react with the water to form ammonium $\left(\mathrm{NH}_{4}^{+}\right)$and hydroxide $\left(\mathrm{OH}^{-}\right)$ions. Because of its positive charge, ammonium ions can sorb onto typically negatively charged soil particles and be immobilized. Elemental nitrogen $\left(\mathrm{N}_{2}\right)$ is the most common component of the atmosphere, and is a colorless gas. It has an oxidation state of zero. When dissolved in water, elemental nitrogen is present as a non-charged dissolved gas. Nitrous oxide $\left(\mathrm{N}_{2} \mathrm{O}\right)$ and nitric oxide (NO) are slightly oxidized $(+1$ and +2 , respectively) forms of nitrogen; they too remain uncharged dissolved gases when dissolved in water. Nitrite $\left(\mathrm{NO}_{2}{ }^{-}\right)$is a more oxidized form of nitrogen and has an intermediate oxidation state $(+3)$. Because of its intermediate oxidation state, nitrite can act either as an oxidizing agent or as a reducing agent. Nitrite is an intermediate product of three biological reactions: nitrification, denitrification, and dissimilatory nitrate reduction to ammonium. Nitrification is the process by which ammonia/ammonium ion is oxidized to form nitrate. Denitrification is the process by which nitrate is reduced, usually to elemental nitrogen.
Nitrite has a negative charge when dissolved in water, and it generally does not sorb to soil particles. The toxicological problems associated with nitrate exposure actually are due to the reactivity of nitrite. Nitrate $\left(\mathrm{NO}_{3}{ }^{-}\right)$is the most oxidized form for nitrogen $(+5)$ and is the conjugate base of nitric acid $\left(\mathrm{HNO}_{3}\right)$. Nitrate has a negative charge when dissolved in water and generally does not sorb onto soil particles.

The nitrogen cycle is illustrated in figure 1 . Nitrogen can undergo numerous reactions that can lead to storage in the subsurface, or conversion to gaseous forms that can remain in the soil for periods of minutes to many years. The main reactions include (1) immobilization/mineralization, (2) nitrification, (3) denitrification, and (4) plant uptake and recycling (Keeney, 1990). Immobilization is the biological assimilation of inorganic forms of nitrogen by plants and microorganisms to form organic compounds such as amino acids, sugars, proteins, and nucleic acids. Mineralization is the inverse of immobilization. It is the formation of ammonia/ammonium ions during microbial digestion of organic nitrogen. Nitrification is the microbial oxidation of ammonia/ammonium ion first to nitrite, then ultimately to nitrate. Nitrification is a key reaction leading to the movement of nitrogen from the land surface to the water table because it converts the relatively immobile ammonium form to a much more mobile nitrate form. Denitrification is the biological process that utilizes nitrate to oxidize (respire) organic matter into energy usable by microorganisms. This process converts the nitrate to more reduced forms, ultimately yielding nitrogen gas that can diffuse into the atmosphere. Uptake of nitrogen by plants also removes nitrogen from the soil column and converts it to chemicals needed to sustain the plants. Because the plants eventually die, the nitrogen incorporated into the plant tissues ultimately is released back to the environment, thus completing the cycle.

The environmental cycling of nitrogen is heavily controlled by microorganisms. Nitrification is believed to be carried out primarily by the chemosynthetic autotrophic bacteria of the family Nitrobacteriaceae. Ammonium oxidizers, including the genera Nitrosomonas, Nitrosospira, Nitrosolobus, and Nitrosvibrio, oxidize ammonium to nitrite. The nitrite oxidizing bacteria, which oxidize nitrite to nitrate, include the genus Nitrobacter. Nitrification can also be carried out by heterotrophic bacteria and fungi.

Nitrification by methane-oxidizing bacteria has been suggested (Verstraete, 1981) but not yet 


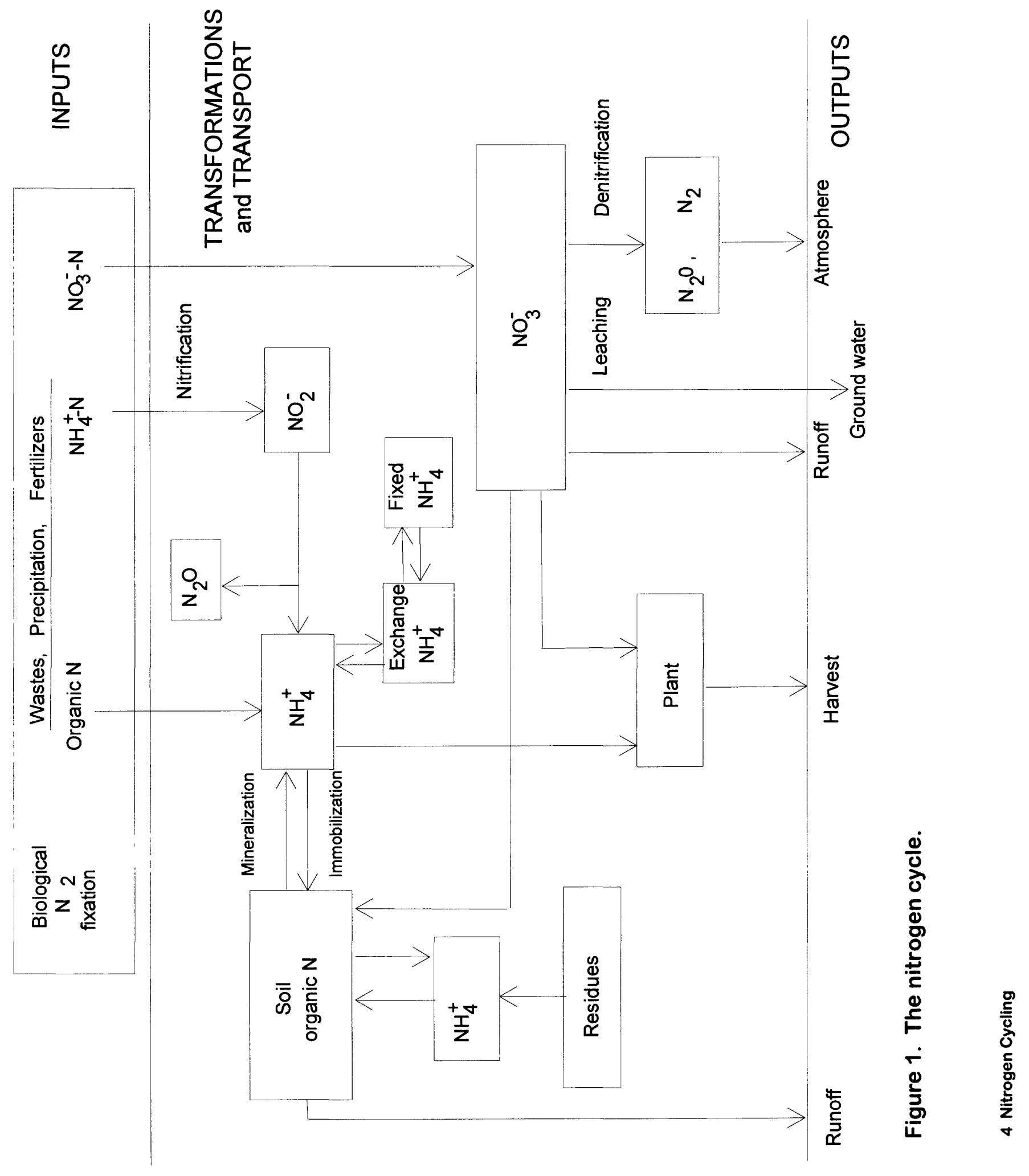


proven. Ammonium oxidizers are notoriously sensitive to many inorganic and organic chemicals, including pesticides. Some commercial fertilizers contain chemicals specifically formulated to inhibit the functioning of ammonium-oxidizing bacteria. In contrast with the small number of known nitrifying microorganisms, there are at least 14 genera of known denitrifying microorganisms. Until recently, it was believed that denitrification could occur only under anaerobic conditions (Keeney, 1990), but denitrification now has been demonstrated under conditions in which oxygen concentrations exceeded air saturation values (Lloyd and others, 1987).

\section{Sources of Nitrate}

\section{Rain Nitrogen}

Rainwater typically contains measurable concentrations of nitrate and ammonium. Heaton (1984) estimated that non-industrially contaminated rain has a total nitrogen concentration of about $6 \mathrm{mg} / \mathrm{L}$. Rainfall of $10 \mathrm{in} / \mathrm{yr}$ would yield a nitrogen load to the soil column of about 13 pounds per acre per year [(lb/acre)/yr]. Significant evaporation of the rainwater could result in high concentrations of nitrogen in the infiltration water.

\section{Soil Nitrogen}

Numerous plants and bacteria can transform atmospheric nitrogen into ammonium or nitrate. In undisturbed forests and grasslands, the quantity of nitrogen deposited by rain and the quantity fixed by soil bacteria and plants is roughly equal to the nutrient requirements of the plants. Young forest stands on fertile sites can have nitrogen uptake comparable to cultivated crops, and residual soil nitrogen can be depleted. As the stands mature, their need for nitrogen decreases, and steady-state soil nitrogen concentrations are maintained. Should there be a disturbance to the mature stands, such as clearcutting of forests, or tillage of grasslands, nitrogen incorporated in decaying plant tissues will be released to the soils, greatly increasing the quantity of nitrogen moving through the soil column. In grasslands and forests that have dormant periods (during the winter, for instance), the leaf mass can release significant quantities of nitrogen that can be transported back to and through the soil column.

\section{Geologic Nitrogen}

Minerals deposited during the geologic past are a potential source of nitrate in ground water. Lithologic units that typically have high nitrate concentrations include shales and Pleistocene-age loess that were deposited during periods favoring plant growth. In California, the alluvium beneath the San Joaquin Valley has relatively high natural nitrate concentrations in some areas. Mineralogical nitrogen also has been suggested as a source of the high nitrogen concentration in ground water in the Paradise Valley area near Phoenix, Arizona (Silver and Fielden, 1980).

\section{Row-Crop Agriculture}

Approximately 24 percent of the land in the 48 conterminous states is devoted to agriculture. Each year, 170 to 200 million acres of major crops such as corn, cotton, soybeans, and wheat is harvested (Stewart, 1975). Typical farming practices rely heavily on external nitrogen input--from animal wastes or from commercial fertilizers. For economic reasons, fertilizers tend to be applied in slight excess to crop needs to help ensure adequate yields. Typical nitrogen-fertilizer application rates for row crops are about 125 (lb/acre)/yr. Agricultural practices that rely on natural rainfall for crop moisture needs tend to use the applied nitrogen less efficiently than those that rely on irrigation. This is because rainfall tends to occur at rates that cause the nitrogen to be washed out of the root zones before it can be incorporated into plants. Because yields tend to be less for crops grown exclusively with natural precipitation, nitrogen demand of these plants also is less. Irrigation tends to increase yields, thereby increasing crop demand for nitrogen. Therefore, irrigated crops tend to utilize the applied nitrogen more effectively, and less nitrogen leaches beneath the root zone.

\section{Animal Wastes and Sewage}

Animal waste and sewage are believed to be the main sources of nitrate contamination of surface and ground water. Animal manures frequently are concentrated in small areas such as commercial poultry operations, and dairy, hog, and beef feed lots. These operations have a high potential for nitrate leaching. The surface of the feedlot is high in organic material that is mixed with the surface soil at the site. Beneath this high-organic layer is the resident soil that usually is highly compacted owing to the continual walking of the animals. Previous researchers have assumed that because this layer is 
so compacted, the permeability must be low, and thus nitrate leaching during feedlot use must be low. However, when the feedlot is abandoned, or empty during cleaning operations, nitrate can be leached into the soil column, achieving loading in excess of $890 \mathrm{lb} /$ acre. Land disposal of manures also can result in high nitrate accumulation in the soil column.

Sewage effluents, septic tanks and leach fields, and use of reclaimed wastewater for irrigation also are sources of nitrogen loading of the soil column. Generally, regulations covering the use of reclaimed water, and the location, construction, and operation of individual septic systems, have been based on bacterial contamination concerns rather than concerns about nitrate contamination of the ground water. Land disposal of sewage effluents, and septic installations, tend to be in areas where soils are sandy, allowing rapid infiltration of the water. These high infiltration rates also virtually assure that nitrate in the water can be rapidly transported to the water table.

\section{Other Sources}

Other potential sources of nitrate in the environment include industrial discharges; petroleum processing wastes; agricultural processing wastes, including slaughterhouses; and atmospheric deposition from smog.

\section{Previous Studies}

\section{Saturated-Zone Studies}

Nitrate is the most common ground-water contaminant, and the scientific communities of many countries have produced publications describing various aspects of this problem. In 1982, the International Institute for Applied Systems Analysis held a symposium to discuss the problems of nitrate pollution of municipal water supplies in Europe (Zwirnmann, 1982). The symposium took a systems-analysis approach and summarized hydrologic concerns, agricultural economics, control options for agriculture and water supply, design of monitoring networks, and the design and implementation of computer models to help minimize the impacts of nitrate contamination on municipal water supplies.

In many regions of Europe, a statistical relation has been demonstrated between the quantity of nitrogen fertilizer applied to crops and the nitrate concentration in the ground water. Pekny and others (1989) found that areas with adequate soil organic carbon had relatively low concentrations of nitrate. Hagebro and others (1983) reported long-term increases in the nitrate loading to Danish rivers and found a correlation with increased use of nitrate fertilizers in that country.

Several reports have been published as a result of nitrate studies in the United Kingdom. The Central Water Planning Unit in Reading (Young and Morgan-Jones (1980) produced a report describing nitrate contamination in England and Wales and identifying areas in the regions' two main aquifers, the Chalk and the Permo-Triassic sandstone, that are likely to become contaminated in the near future. Young (1981) did a follow-up study in 1980 and found that nitrate concentrations were near, or higher than, the World Health Organization's recommended European standard of $11.3 \mathrm{mg} / \mathrm{L}$ as nitrogen. Young also collected deep core material (generally to a depth of $100 \mathrm{ft}$, but at one site, to a depth of $270 \mathrm{ft}$ ) and analyzed the unsaturated-zone pore water for nitrate concentration. Nitrate concentrations in the unsaturated-zone pore water were generally low near land surface, increasing to a depth of about $33 \mathrm{ft}$, then decreasing to the bottom of the core. Howard (1985) studied the Chalk aquifer and concluded that, even though denitrification was thermodynamically favored, most of the observed decrease in nitrate concentrations were the result of dilution with lower nitrate ground water. Lawrence and Foster (1986), however, concluded that significant denitrification was occurring in the same aquifer, and that the diffusion of nitrate into the chalk matrix was further attenuating nitrate concentrations with depth.

Nitrate concentrations in chalk aquifers in France also have been studied. Bouton and Froment (1985) found that nitrate concentrations in water from chalk formations were considerably lower than concentrations in water in alluvial deposits overlying the chalk. Nitrate concentrations were in excess of $50 \mathrm{mg} / \mathrm{L}$ in the alluvial deposits, but less than $10 \mathrm{mg} / \mathrm{L}$ in the chalk directly beneath those deposits. Bouton and Froment suggested that the lower nitrate concentrations in the chalk were the result of denitrification in the chalk matrix.

Nitrate research in Germany can be illustrated by three publications. Lahl and others (1983) found vast areas in Germany where nitrate concentrations in ground water exceeded the World Health Organization standard. In the district around Dusseldorf, for example, water from more than 
50 percent of the wells exceeded the standard. The concentrations varied seasonally, and were highest during the early winter rains, apparently owing to the flushing of nitrate fertilizers applied during the summer. Kolle and others (1983) studied denitrification in a reducing aquifer in northern Germany. They found that the nitrate reduction was directly coupled to the oxidation of iron pyrite in the aquifer matrix; as the nitrate concentrations decreased, there was a resultant increase in sulfate concentrations. Rodelsperger (1989) found both heterotrophic and autotrophic denitrification in noncultivated areas of his study catchment. Under intensely cultivated areas, however, the heterotrophic activity became overwhelmed by the nitrate inputs. Specifically, too much nitrate, and not enough organic carbon, was present for total denitrification to occur. Rodelsperger also observed the oxidation of pyrite under non-cultivated areas.

Kanfi and others (1983) studied temporal trends of nitrate concentration in the coastal plain aquifer of Israel. The rate of nitrate-concentration increase was $0.33 \mathrm{mg} / \mathrm{L}$ per year during the $1950 \mathrm{~s}$, decreasing to $0.13 \mathrm{mg} / \mathrm{L}$ per year during the 1960 's. By 1973, the average nitrate concentration in 932 pumped wells was $12 \mathrm{mg} / \mathrm{L}$. During 1973-83, the rate of nitrate-concentration increase remained at $0.13 \mathrm{mg} / \mathrm{L}$ per year.

In Canada, Hill (1982) studied the distribution of nitrate in ground water near Alliston, Ontario. He found extensive nitrate contamination where potatoes were grown in sandy areas and where heavily fertilized crops such as corn, sod, and asparagus were grown. Nitrate concentrations were relatively low beneath forests and pasture areas. Trudell and others (1986) studied saturated-zone denitrification by injecting nitrate into a shallow unconfined aquifer and monitoring the diminution in nitrate concentration with time. Their study suggested that with adequate soil organic carbon ( 0.08 to 0.16 percent), virtually all of the injected nitrate was denitrified within 356 hours. Starr and Gillham (1989) observed that denitrification occurred in some nitrate-contaminated surficial aquifers, but not in others. They found that it was not the soil organic carbon that was important, but that it was the labile organic carbon in the dissolved phase that allowed denitrification to occur. Because labile organic carbon generally decreases with depth, they suggested that unsaturated-zone processes must be important in controlling overall denitrification at any given site.
The United States also has a long history of nitrate pollution research. Pratt and others (1976) found that a fertilizer application rate for corn of 200 (lb/acre)/yr resulted in no nitrate leaching below $15 \mathrm{ft}$, and that an application rate of $320(\mathrm{lb} / \mathrm{acre}) / \mathrm{yr}$ resulted in significant nitrate leaching. The relation of soil particle size and denitrification also was evaluated in that study. Denitrification was most closely associated with the presence of clay-sized particles. A correlation between irrigation rate and denitrification also was found. High infiltration rates resulted in virtually complete nitrate leaching, whereas low infiltration rates resulted in virtually complete denitrification in the soil.

A National Research Council study (National Research Council, 1978) concentrated on specific environmental issues related to nitrates--including the effects of nitrates on human health, the effects of anthropogenic nitrogen fluxes on the terrestrial and aquatic environments, and the potential depletion of stratospheric ozone by activities that fix nitrogen. Addressed in the report are the lack of accurate information about unsaturated-zone processes, and how this lack makes developing control strategies for nitrate difficult.

In 1990, the U.S. Environmental Protection Agency released its Phase I Report (U.S. Environmental Protection Agency, 1990b) on the National Pesticide Survey, a 5-year project to evaluate the presence of pesticides, pesticide degradates, and nitrate in drinking-water wells in the United States. According to the report, water from at least one-half of the Nation's drinking-water wells contains detectable amounts of nitrate, and about 1.2 percent of community water systems and about 2.4 percent of rural domestic wells are contaminated with nitrate above the maximum contaminant level of $10 \mathrm{mg} / \mathrm{L}$. In its Phase II Report (U.S. Envrironmental Protection Agency, 1992), the U.S. Environmental Protection Agency found that shallow wells and wells penetrating unconfined aquifers had a higher probability of nitrate contamination, as did wells in areas where flood irrigation is used to augment natural rainfall.

The preceding reports deal with nitrate contamination on a national level, but in several parts of the United States, detailed investigations have been done on locally contaminated areas. One such area receiving detailed investigation is Long Island, New York. Baier and Rykbost (1976) studied nitrogen fertilization of potatoes and turf grasses. They estimated that application rates in excess of 150 (lb/acre)/yr would lead to significant 
leaching of nitrate below the root zone. $\mathrm{Ku}$ and Sulam (1976) reported that nitrate concentrations in the Magothy aquifer in Nassau County, New York, were steadily increasing during 1950-73, approaching $10 \mathrm{mg} / \mathrm{L}$ in many areas. Soren (1978) reported evidence for human-induced degradation of water quality in the aquifer underlying Shelter Island (between the north and south forks of eastern Long Island), but nitrate concentrations were not excessively high. Ragone and others (1980) reported that for the period 1952-76, median nitrate concentrations in the sewered part of the island were not significantly different from the median for the unsewered area. They suggest that these data reflect the slow rate at which domestic nitrate introduced prior to sewering was flushed through the upper glacial aquifer, and that other present-day sources of nitrogen, such as fertilizer, might mask decreases in nitrogen that have resulted from sewerage. Kimmell (1984) reported that nitrate and organic chemicals have penetrated deeply into the Magothy aquifer. He reported that much of the aquifer is contaminated, particularly in the central part of the island, and that denitrification is being used as a treatment of the drinking-water supply in some systems. Eckhardt and others (1989) studied 10 land uses and their effects on the water quality of the upper glacial aquifer underlying Long Island. The highest nitrate concentrations were found in water from wells in agricultural and high-density residential areas.

Barton and others (1987) studied the Potomac-Raritan-Magothy aquifer system in New Jersey and found that nitrate concentrations in ground water were lowest under undeveloped land, highest under urban land, and intermediate under agricultural lands. They also found that the statistical relations between water quality and land use differed depending on where in the aquifer system the data were collected.

The Delaware-Maryland-Virginia (Delmarva) peninsula also has been the subject of detailed investigations. Miller (1972) studied nitrate in the water-table aquifer in Delaware. Miller found that many areas of the peninsula are susceptible to nitrate contamination from septic systems as a result of occasional waterlogging during wet seasons. In these areas, the water table generally is less than 5 $\mathrm{ft}$ below land surface. Ritter and Chirnside (1984) found that in coastal Sussex County, samples from 32 percent of the wells had nitrate concentrations that exceeded the MCL. In non-coastal Sussex and Kent Counties, 21 percent and 8 percent, respectively, of the wells were contaminated. The highest nitrate concentrations were in areas of large poultry operations, and poultry manure was one of the major causes of nitrate contamination in four of the five top-priority ground-water problem areas in those counties. Bachman (1984) studied the Columbia aquifer and found that nitrate concentration in samples from 15 percent of the wells exceeded the MCL. Nitrate concentrations were highest under urban and agricultural lands that had well-drained soils. In a U.S. Geological Survey National Water Quality Assessment program pilot study of the Delmarva peninsula, Hamilton and others (1991) reported that nitrate concentration in samples from 18 percent of the wells in the surficial aquifer exceeded the MCL, and that the concentrations were highest under agricultural and urban lands that had well-drained soils.

Studies on a smaller scale have been done in Massachusetts (Smith and Duff, 1988; Smith and others, 1991), Florida (Waller, 1983), Pennsylvania (Kastrinos and White, 1989), and Tennessee (Rima and others, 1977). In these studies, it was found that saturated-zone denitrification occurs in narrow zones characterized by abrupt changes in the oxidizing/reducing character of the water.

Recently, several nitrate-related studies have been done in Iowa. Detroy and others (1988) reported that nitrate concentrations exceeded the MCL in 6 percent of wells shallower than $200 \mathrm{ft}$. Wehmeyer (1988a) found that denitrification was occurring in the shallow alluvial aquifer west of the Des Moines River in Palo Alto County, Iowa. Estimated rates of denitrification were 1.1 to $8.9 \mathrm{mg} / \mathrm{L}$ per day. Detroy and others (1990) studied the alluvial aquifers in Carroll and Guthrie Counties, Iowa, and found that up to 55 percent of the wells had nitrate concentrations exceeding the MCL. Highest nitrate concentrations were observed in the shallower wells, and the concentrations were higher than had been previously reported for shallow municipal wells. Hallberg (1990) reported that nitrate concentrations in the Big Spring Basin have increased dramatically over the past 30 years. He estimates that 50 to 70 percent of the nitrogen being applied as fertilizer is leaching beneath the root zone and contaminating the ground water.

A few nitrate-related studies have been done in Missouri, Kansas, and Oklahoma. Feder (1986) reported that ground water in gently dipping low-transmissivity aquifers is more likely to contain reduced nitrogen species than is ground water in high-transmissivity karst aquifers in which nitrate is common. Stullken and others (1987) studied the High Plains aquifer in the area of the Great Bend 
Prairie. They found that there was no statistically significant difference between nitrate concentrations in ground water in areas that were being irrigated and concentrations in areas under dryland cultivation. Parkhurst and others (1989) analyzed water-quality data through 1987 for the Central Oklahoma aquifer. They found that 8.6 percent of the samples from wells shallower than $300 \mathrm{ft}$ had nitrate concentrations exceeding the MCL. Cohenour and Knox (1990) reported similar results for the same aquifer.

Nebraska has one of the most serious nitratecontamination problems of any state. Pirnir (1989) reported that in some areas of Nebraska, concentrations in water from 70 percent of the rural supply wells exceeded the MCL. Piskin (1973) reported that water from 13 percent of the wells in Hall County, Nebraska, had nitrate concentrations that exceeded than the MCL. Concentrations generally decreased with increasing well depth, and high nitrate concentrations tended to be stratified in the upper few feet of the aquifer. Spalding (1984) reported that nitrate concentrations in shallow ground water downgradient from irrigated fields in Hall County were relatively high, indicating probable inputs from those fields. She also reported large temporal variations that corresponded to fertilizer applications. Nitrate concentrations decreased in the area of a delineated redox front in the aquifer. Adelman and others (1985) indicated that ground water in parts of Holt County and the entire Central Platte River region is significantly contaminated by nitrogen fertilizers applied to irrigated land. He attributed the widespread contamination to the presence of coarse-textured soils and the excessive use of irrigation water, which combine to induce rapid leaching of applied fertilizers to the water table. Chen and Druliner (1987) found that nitrogen concentrations in the High Plains aquifer in Nebraska were significantly higher in more intensively irrigated areas than in less intensively irrigated areas. Gosselin (1991) reported that for the Ogallala aquifer in the area of Verdigre Creek, Bazille Creek, and the North Fork of the Elkhorn River, nitrate concentrations ranged from 0.7 to $39 \mathrm{mg} / \mathrm{L}$, and that water from only one well exceeded the MCL. This is one of the few areas in Nebraska in which nitrate contamination is reported to be at a low level.

In the southern part of the Ogallala aquifer, Jones (1973) studied the problem of very high (greater than $1,000 \mathrm{mg} / \mathrm{L}$ ) nitrate concentrations in ground water of Runnels County, Texas. Most of the nitrate contamination was from geologic nitrate, but the highest concentrations were due to barnyards and feedlots. He attributed the contamination to rising water tables owing to increased infiltration following leveling of land for agriculture, and several years of above normal precipitation. Also in Runnels County, Kreitler and Jones (1975) used isotopic techniques to show that more than 66 percent of the nitrate in ground water was due to release of natural soil nitrate. They speculated that dryland farming during the period 1900-50 led to oxidation of soil nitrogen to nitrate, which leached below the root zone over time. This leachate remained in the unsaturated zone until a period of heavy rainfall washed the nitrate to the water table. Reeves and Miller (1978) reported widespread areas of poor-quality water in the 27-county area underlain by the Ogallala aquifer. Nitrate concentrations were generally low, but in areas having sandy soils that have been extensively cultivated, concentrations greater than $10 \mathrm{mg} / \mathrm{L}$ were found.

Patt and Hess (1976) characterized the nitrate found in ground water beneath a ranch near Las Vegas, Nevada. On the basis of mass-balance considerations, they concluded that the quantity of nitrogen fertilizer applied at the ranch could not account for the very high nitrate concentrations in the ground water and that, therefore, there must be a natural, mineral source for the nitrate. This is one of the few documented cases in which high nitrate concentrations in ground water have been attributed to natural sources rather than to human activities.

Bulgar and others (1989) reported dissimilatory nitrate reduction in a North Dakota aquifer contaminated with infiltrating wastewater. The wastewater plume has low redox potentials, high dissolved organic carbon, and abundant microbial populations. Virtually all the nitrogen in the plume is in the ammonium form. Upgradient of the wastewater plume is an abandoned landfill that has a high-nitrate plume. As the high-nitrate plume merges with the wastewater plume, the microbes use the nitrate to oxidize the organic carbon. As a result, the nitrate is rapidly converted to ammonium, and the ammonium concentration is greater than the concentration in the input wastewater.

In Montana, Lewis and others (1979) interpreted high nitrate concentrations at a seep to be the result of oxidation of organic matter from native sod after it had been plowed under during cultivation. 
Edwards and others (1979) found relatively low concentrations of nitrate in ground water upgradient of the Idaho National Engineering Laboratory.

In California, the Fresno-Clovis metropolitan area was one of the first places where nitrate contamination of ground water was recognized as a problem. High nitrate concentrations in ground water in the area were related to sewage-effluent percolation ponds, septic-tank disposal systems, industrial wastewater, and agricultural fertilizers. Schmidt (1972) reported that the concentrations were highest in the upper 50 to $60 \mathrm{ft}$ of the aquifer, and he related high nitrate concentrations to poor well-construction practices, artificial recharge of surface runoff, cooling-water leaks, recharge from unlined irrigation canals, and recharge of irrigation return water. In the Anza-Terwilliger area of Riverside County, California, Moyle (1976) found five wells in which the nitrate concentration exceeded the MCL. Ayers and Branson (1973) reported water-quality degradation by nitrates in the upper Santa Ana River Basin; degradation was severe in the Bunker Hill Basin, the Chino Basin, and the Riverside-Arlington Basin. Nitrate concentrations were highest in soil moisture beneath citrus groves and active dairies, and somewhat lower beneath vegetable crops. Ayers (1978) also documented serious nitrate problems in the upper Santa Ana River Basin, where nitrate "hot spots" were associated with sewage-disposal basins, largescale dairy operations in the Chino Basin, and citrus groves. Nitrate concentrations tended to be highest in areas of coarse-textured soils. Consistent nitrogen leaching was observed under citrus groves, but row crops did not display this consistent pattern. Soil cores collected beneath dairies showed nitrate concentrations as high as $65 \mathrm{mg} / \mathrm{L}$. The results of several studies of nitrate contamination in the Redlands area (Eccles and others, 1976; Eccles and Bradford, 1977; Klein and Bradford, 1979) indicate that the single greatest input of nitrate is the Redlands sewage-treatment facility. Nitrate concentrations were greatest within the upper $50 \mathrm{ft}$ of the saturated zone, suggesting that nitrate is moving through the unsaturated zone to the water table and mixing with lower-nitrate-concentration water in the aquifer. Further, it was determined that nitrate concentrations correlated directly with well depth and with adequacy of the well sanitary seal. Considerable nitrate was stored in the unsaturated zone, particularly underlying abandoned feedlots. Nitrate concentration was lowest in the shallow unsaturated zone in the near surface beneath citrus groves; however, concentrations beneath the groves were significantly higher in the deep unsaturated zone at depths greater than $130 \mathrm{ft}$. In the HighlandsEast Highlands area of San Bernardino County, California, Eccles and Klein (1978) found that nitrate in water from most wells shallower than $500 \mathrm{ft}$ exceeded the $10 \mathrm{mg} / \mathrm{L} \mathrm{MCL}$, and that concentrations in water from a few wells were greater than $20 \mathrm{mg} / \mathrm{L}$. Furthermore, Eccles (1979) concluded that the area where nitrate concentrations exceeded the MCL was greater in 1977-78 than it was in 1968-69. Anton and others (1988) presented an overview of nitrate in drinking-water supplies for the State of California in a report to the Legislature. Duell and Schroeder (1989) reported that water from about one-fourth of the wells in the Bunker Hill Basin of San Bernardino County had nitrate concentrations exceeding the MCL.

\section{Unsaturated-Zone Studies}

In comparison with the saturated-zone studies, relatively few studies of nitrate in the unsaturated zone have been done. Furthermore, more than half the unsaturated zone papers come from Europe, and most of those deal with the Chalk aquifer in England.

Englund and Haldorsen (1986) determined nitrogen species in soil profiles in a sand-silt aquifer at Haslemoen, Solor, south Norway. They found that concentrations of both total nitrogen and nitrate were higher beneath agricultural lands and that concentrations decreased with depth. Changes in iron and organic carbon concentrations were correlated with the diminution of nitrate. Ernstsen (1990) attributed the removal of nitrate in clayey till to the reduction caused by structural ferrous iron in the clays. Similarly, Ernstsen and others (1990) found measurable nitrate beneath arable lands only in the oxidized zone of the clayey silts. Pedersen and others (1991) studied sediment profiles in a sandy aquifer in Denmark. They observed a distinct redox horizon in the soil column, above which the soil was oxidized and nitrate was present, and below which nitrate was absent. Detailed pore-water profiles indicated that denitrification occurred at this horizon.

Singh and Sekhon (1976) found that excessive irrigation leached nitrate beneath the wheat root zone, leading to higher nitrate concentrations in the unsaturated-zone pore water. They also found that a single large application of nitrogen fertilizer led to higher unsaturated-zone pore-water nitrate concentrations than did several smaller applications totaling the same amount. 
Ho and others (1988) found that ammonium in secondary treated wastewater was completely removed in the unsaturated zone if the spreading basin was periodically allowed to dry. They postulated that the ammonium sorbs onto the soil particles while the basin is wet and is oxidized to nitrate during the dry cycles. The denitrifying bacteria then consume the nitrate, liberating nitrogen, and freeing up sorption sites on the soil. When the basin is re-wetted, the process is repeated.

In a study of soil profiles in central Canterbury, New Zealand, Adams and others (1979) found that concentrations of nitrate in soil moisture were equal to the concentrations observed in ground water from adjacent wells. Also in New Zealand, Keeley and Quin (1979) studied soil moisture beneath a disposal pit for slaughterhouse wastes and found that nitrate concentrations in soil moisture were about the same as those in water from the underlying aquifer. It was concluded in both studies that nitrate was being transported virtually unchanged from the land surface to the water table and that denitrification was insignificant.

During the 1980 's, a series of studies were done on unsaturated-zone pore-water chemistry in soils overlying the Chalk aquifers in the United Kingdom. Young and Morgan-Jones (1980) found that recharging water moved rapidly from the land surface to the water table, particularly where the unsaturated zone is thin. They also found that in fast-recharge areas, more nitrate was leached through the unsaturated zone. Their results suggest that nitrate-rich ground water was generally restricted to the upper layers of the aquifer. Wellings and Bell (1980) compared the effects of cow manure and inorganic fertilizers on the distribution of nitrate in $10-\mathrm{ft}$ cores beneath pasture grass. The use of inorganic fertilizers resulted in very low unsaturated-zone nitrate concentrations, but concentrations below the manured plots were as great as $80 \mathrm{mg} / \mathrm{L}$. The nitrate concentrations were lowest near the land surface, increasing to a primary maximum at a depth of about $1.5 \mathrm{ft}$. The concentrations then decreased to a secondary minimum at about $5 \mathrm{ft}$, and then increased to a secondary maximum at about $8 \mathrm{ft}$. Wellings and Bell interpreted these results to represent the yearly nitrate slug moving through the soil column. Whitelaw and Rees (1980) found significant aerobic denitrification beneath grasslands. A large percentage of the denitrification occurred just above the water table, and where the largest populations of denitrifying bacteria were found. Foster and Bath (1986) collected cores to a depth of
$50 \mathrm{ft}$. As in the study by Wellings and Bell, two nitrate maximums, at about 13 and $26 \mathrm{ft}$, were identified. Foster and Bath interpreted these maximums as representing the nitrate slug from two separate years moving through the soil column. The maximum unsaturated-zone pore-moisture nitrate concentration observed was about $50 \mathrm{mg} / \mathrm{L}$. Geake and Foster (1989) concluded that more than half the nitrogen fertilizer being applied to crops in fields overlying the Chalk aquifer is being leached through the thick unsaturated zone. Much of this leaching nitrate has not yet reached the water table, and the authors believe that nitrate concentrations in the saturated zone will continue to increase into the foreseeable future.

A few reports come from China, Greece, and Israel. Zakosek and Zepp (1988) did a study in the subtropical areas of China and found seasonal variations in soil-moisture nitrate concentrations. Nitrate concentrations were highest immediately after fertilization with inorganic fertilizers. Over a period of 2 months, the nitrate leached beneath the root zone. They also found that soil-moisture nitrate concentrations varied significantly with different land uses. The concentrations were lowest under forests; intermediate under crops such as wheat, barley, celery, and cabbage; and highest under crops such as beans, cauliflower, and lettuce. They also observed nitrate eluting through the soil over time. Kosmas and others (1991) were able to demonstrate that nitrate movement through the unsaturated zone was not due to flow through soil cracks and fissures, but rather to slow downward percolation of nitratebearing water associated with classic unsaturated pore-water flow. Shevah and Waldman (1989) reported that the nitrogen loading of Israel's aquifers has decreased by 20 percent as a result of better agricultural practices, and that unsaturated-zone nitrate concentrations have decreased by similar amounts in the past 20 years.

Only a few unsaturated-zone studies have been done in the United States, almost all of which were related to determining the optimum fertilizer-application rates for various crops. Langdale and others (1979), in a study done in the Piedmont area of Georgia, found that for corn fertilized at the rate of 125 (lb/acre)/yr, virtually no nitrate moved beneath the root zone. Although most of the nitrogen is incorporated in the corn crop, as much as 27 (lb/acre)/yr of the applied nitrogen can be lost through denitrification in the shallow unsaturated zone. Morris and others (1988), studying deep sediments on Parris Island, South Carolina, found that significant denitrification can 
occur even at depths as great as $600 \mathrm{ft}$ if sufficient nitrate and carbon are present. Schuman and others (1975) studied nitrate distributions in 20-ft cores underlying a cornfield in southwestern Iowa. Nitrogen was fully utilized by the corn crop at application rates less than $150(\mathrm{lb} / \mathrm{acre}) / \mathrm{yr}$; at higher rates, nitrate was leached beneath the root zone. Most of the leaching occurred during rains. In Nebraska, Spalding and Kitchen (1988) found nitrate leaching beneath the root zone in a cornfield at fertilizer application rates exceeding 80 (lb/acre)/yr; they found, also, that the pore-water nitrate concentrations doubled with each additional 45 (lb/acre)/yr applied. They did not attempt to quantify nitrate concentration variations with depth.

Several papers on nitrate in the unsaturated zone have been produced by researchers at the University of California, Riverside. Pratt and others (1972) determined the nitrate concentrations in pore-water extracts from $100-\mathrm{ft}$ cores collected in a citrus grove. Nitrogen-fertilization application rates less than 135 (lb/acre)/yr resulted in negligible nitrate leaching, whereas higher rates applied to porous soils led to increased nitrate concentrations in the pore water beneath the root zone. A nitrogen balance did not require denitrification to account for all the applied nitrogen when less than 135 (lb/acre)/yr was applied per year, but in order to account for all the nitrogen at higher application rates, or application to soils that had distinct silt or clay layering, denitrification had to be assumed. The authors, however, did not have enough data to prove that denitrification was occurring. Lund and others (1974) related nitrate concentrations in deep (26 ft) soil cores to the soil-profile characteristics. Clay content and particle-size distributions did not correlate with nitrate concentrations, but cation exchange capacity did. However, nitrate concentrations tended to be lower beneath clay layers than above the layers. Gilliam and others (1978) studied the effect of soil-profile characteristics on denitrification. They found that fine-textured soils readily reduced nitrate. They concluded that any soil that impedes the downward movement of water potentially can denitrify the water.

Researchers in the U.S. Geological Survey (USGS) also have produced several reports describing the behavior of nitrate in the unsaturated zone. Klein and Bradford (1979) studied nitrogen in the unsaturated zone in the Highland-East Highlands area of San Bernardino County. They found that the maximum concentrations occurred within $10 \mathrm{ft}$ of the surface. The highest nitrate concentrations in the unsaturated zone were associated with citrus groves, a feedlot, and an abandoned sewage-treatment plant. Umari and others (1993) found that wastewater from septictank seepage pits percolating through a thick unsaturated zone (greater than $100 \mathrm{ft}$ ) had almost all the nitrogen removed before the wastewater reached the water table. They also observed a decrease in the nitrate-to-chloride ratio. On the basis of these observations, they concluded that denitrification in the thick unsaturated zone probably was responsible for the nitrogen removal.

\section{Acknowledgments}

The authors thank the following land owners who generously allowed access to their properties for the duration of this investigation: Mr. Max L. Cardey; The Cherry Hills Golf Club, Inc.; Mr. Edward Demler; Mr. Herman Douma and Mr. Fred Douma; Douma's Desert Dairy; The city of Hemet; and Mrs. Jane Williamson and Mr. Dale Williamson. We also thank the Hemet-San Jacinto Ground Water Pumpers Association for their suggestions and support. Finally, the authors thank the following people whose comments contributed to this report: Ms. Amy Swancar (USGS), Drs. Alan Williams (University of California-Riverside), Richard L. Smith (USGS), and Behrooz Mortozavi (Eastem Municipal Water District).

\section{SITE SELECTION AND INSTRUMENTATION}

\section{Background}

The Eastern Municipal Water District (EMWD), in Riverside County, California, extends from Moreno Valley in the north to Temecula in the south, and from the San Jacinto Mountains in the east to Perris in the west (fig. 2). About one-half of the freshwater used within the $534-\mathrm{mi}^{2}$ service area is supplied by EMWD, and the rest is supplied by local water retailers. The local suppliers include the cities of Hemet, San Jacinto, and Perris, the Lake Hemet Municipal Water District, the Rancho California Water District, the Nuevo Water Company, and the Edgemont Gardens Mutual Water Company. Local ground water, which supplies 20 percent of EMWD needs, is extracted from the San Jacinto, Hemet, Perris, and Nuevo subbasins. In 

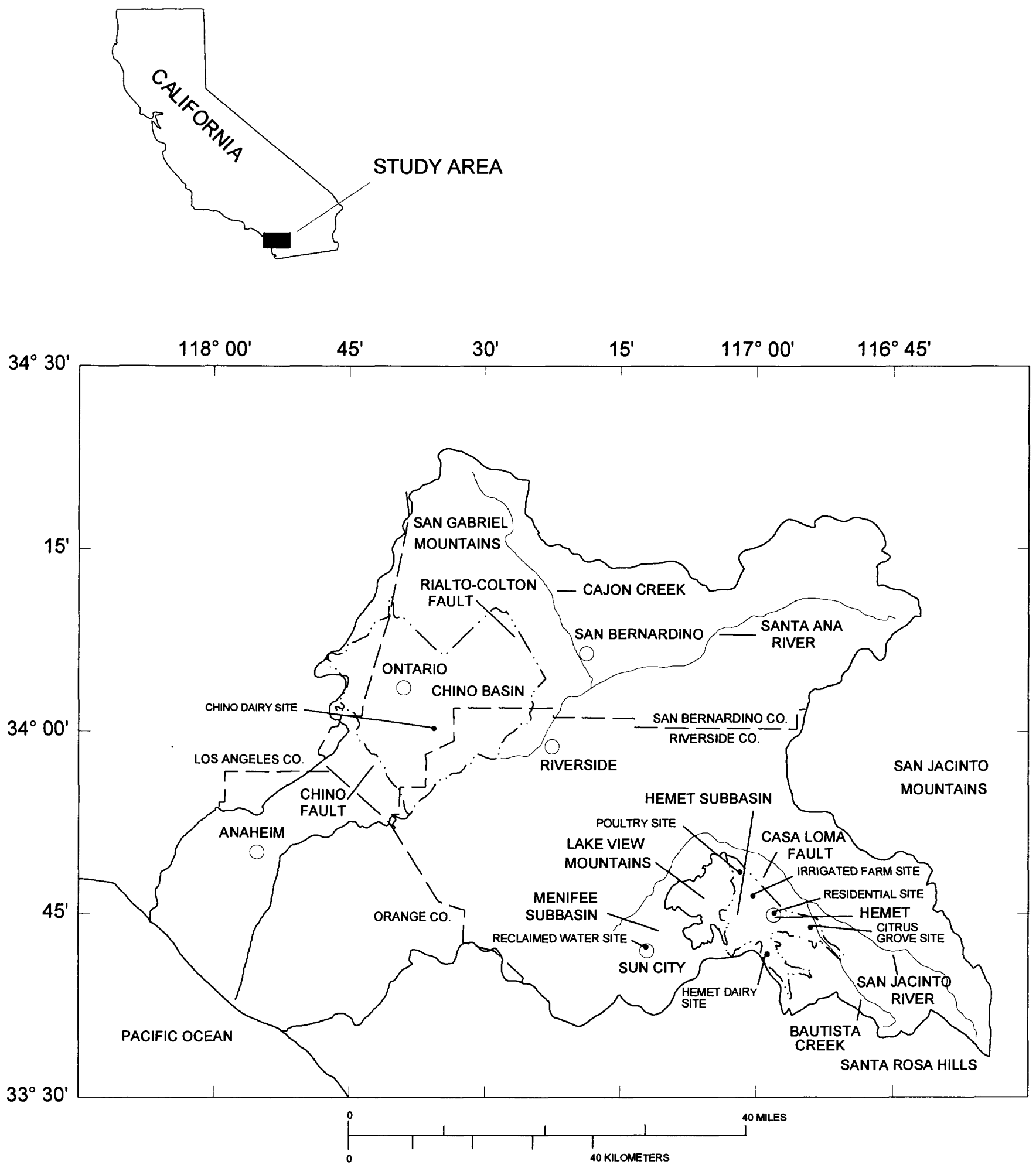

Figure 2. Location of the study area. 
addition, the Domenigoni and Lakeview subbasins have potentially usable ground-water resources.

The study reported here was done in the Hemet and Menifee subbasins within the EMWD service area, and at an auxiliary site in the Chino groundwater basin outside the EMWD service area. The Hemet subbasin is $25 \mathrm{mi}$ southeast of Riverside, California (figs. 2 and 3), covers an area of $85 \mathrm{mi}^{2}$, and has a relatively level valley floor of about 39 $\mathrm{mi}^{2}$. The Menifee subbasin is $25 \mathrm{mi}$ south of Riverside, California (fig. 2), and is about 6 mi west of the Hemet subbasin. The $40-\mathrm{mi}^{2}$ basin includes $30 \mathrm{mi}^{2}$ of valley floor. The $200-\mathrm{mi}^{2}$ Chino Basin is $35 \mathrm{mi}$ east of Los Angeles (fig. 2). Complete geohydrologic descriptions of these basins are given in the "Geohydrologic Setting" section of this report.

\section{Site Selection}

The study was done at seven sites that represent selected land and water uses. The primary sites were: (1) an urban residential area; (2) a golf course using reclaimed water for irrigation; (3) a citrus grove; (4) an irrigated farm using imported water; (5) a poultry farm; and (6) a dairy. In addition, an auxiliary dairy site was selected as the seventh site. Most sites were located in the Hemet ground-water subbasin. However, for those land uses not represented in the Hemet subbasin, sites were selected in one of the other ground-water basins within the EMWD service area.

To help determine the current geohydrologic conditions throughout the Hemet subbasin-including the thickness and extent of water-bearing materials, directions of ground-water flow, and chemical quality of ground water--study sites distributed throughout the basin were sought. In June 1990, a reconnaissance visit to the basin was made to evaluate areas for site selection. As a result of the reconnaissance, the following determinations were made: (1) The only residential areas within the Hemet subbasin were in the city of Hemet; (2) No locations utilizing reclaimed water were available in the Hemet subbasin; (3) Citrus groves were present only in the Bautista Canyon outwash area in the southeast part of the basin; (4) Large areas outside the city limits of Hemet were devoted to agriculture, mostly potato growing; (5) Two poultry operations were present, a turkey farm on Sanderson Avenue near Seventh Street and a large egg farm on Warren Road near the Ramona Expressway; and (6) There were several dairies in the northwest part of the basin (most along Warren Road north of Esplanade
Avenue) and one (in the Diamond Valley area) in the southern part of the basin.

For the residential site, a small house and adjacent yard owned by the city of Hemet near the intersection of State Street and Florida Avenue was selected. The small yard, which is landscaped with turf grass and two small trees, has an automatic irrigation system that uses city-supplied water. This property is about $50 \mathrm{~m}$ from a City of Hemet Water District supply well that yields water in which nitrate concentrations exceed the MCL (E.L. Starner, City of Hemet Water District, oral commun., 1990).

For the reclaimed-water site, EMWD supplied a list of customers that purchase reclaimed wastewater for irrigation. From the list, a golf course (owned by the Cherry Hills Golf Club) in the Menifee subbasin was selected. This site is within the city limits of Sun City.

Several owners of citrus groves, after reading in the local newspaper that the study was to be done, volunteered their groves for one of our research sites. After a detailed evaluation of each grove for suitability as the citrus grove site, the authors selected a site surrounded on all sides by at least one-half mile of groves on the west side of Bautista Canyon in the Hemet subbasin.

The site selected for the irrigated-farm site is near the center of the Hemet subbasin. At this site, near the intersection of Sanderson and Esplanade Avenues, the predominant crop historically has been potatoes.

An egg farm in the northwest corner of the Hemet subbasin near Warren Road and Ramona Expressway was selected as the poultry-farm site. In typical poultry operations, manure is spread in drying beds to evaporate excess moisture and the dried manure is sold as high-grade fertilizer. The egg farm selected raises approximately 1,000,000 birds, and it has three separate manure-drying areas. The research site was located in the middle of these three drying areas.

With the help of the Milk Producers Council in Chino, California, the dairy research site was selected within a feedlot in the Diamond Valley area of the Hemet subbasin. This relatively new dairy has been in operation less than 5 years and is in an area where the water table is relatively shallow (less than $20 \mathrm{ft}$ below land surface). These considerations prompted the selection of an auxiliary dairy site (a 


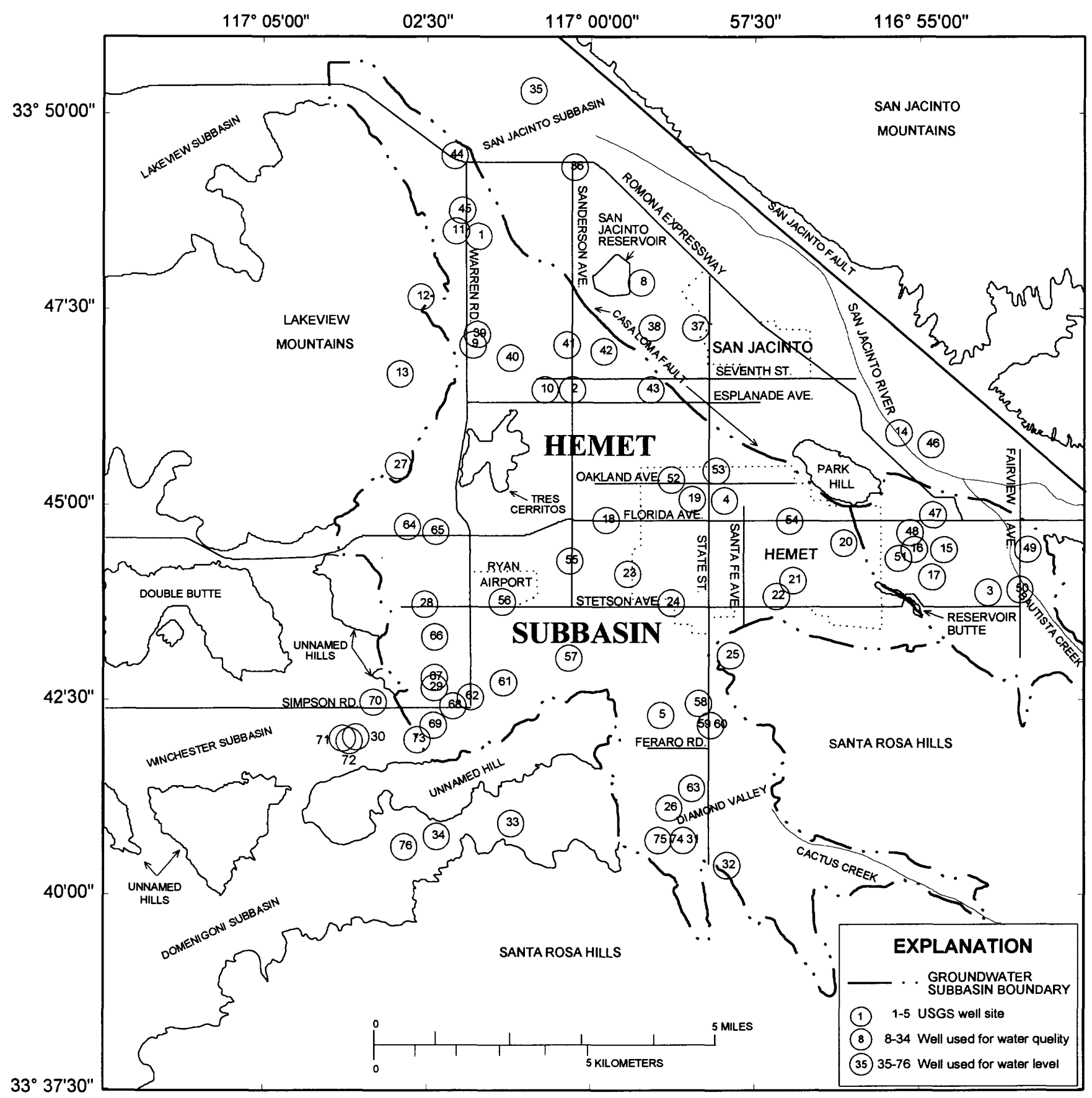

Base digitized from U.S. Geological

Sure digitized from W.S. Geological

and San Jacinto, California Quadrangles

Figure 3. The Hemet Subbasin and the monitoring-well network. (State well or spring number and latitude/longitude are given in table 1.) 
seventh site) in the Chino Basin. This site has been in operation for about 50 years, and the water table is about $120 \mathrm{ft}$ below land surface. An advantage of this site is that it is in a part of the Chino Basin that has a high dairy density, yet nitrate contamination of the ground water (which has been observed in the southernmost part of the Chino Basin) has not occurred.

\section{Site Instrumentation and Sample Collection}

Instrumentation was the same at each of the seven sites. The first test hole at each site was drilled using a hollow-stem auger to the maximum depth achievable by the equipment or $150 \mathrm{ft}$, whichever was less. Continuous cores were collected using a Central Mine Equipment (CME) wire-line 3.5 -inch split-spoon coring system. Because this coring system cuts the core material ahead of the auger bit, the cores are virtually undisturbed. To prevent chemical and biological contamination of the hole, the hollow-stem auger flights and the core barrels were steam cleaned prior to each use. As a further precaution, the split-spoon core barrels were flamed with a propane torch prior to collection of the core samples. The cores were cut in 3-foot sections using the sterilized split-spoon coring system. After placing the core barrel onto a clean work surface, the spoons were split apart to expose the core. Approximately 0.4 in. of the periphery of the core, the material in contact with the steel spoon sections, was removed using sterilized spatulas to expose undisturbed core material. This undisturbed material then was lithologically described; sampled aseptically for determination of chemistry, particlesize distribution, and bacterial population; and placed in sterilized plastic bags. The bags were sealed and immediately placed on ice for temporary storage and shipment. Within 24 hours of collection, the samples were transferred to a freezer for storage prior to analysis.

Additional samples were collected for poremoisture-content analysis. Pore moisture was determined gravimetrically by comparing the mass of the core material as collected from the split spoon with the mass of the core material after drying at $110^{\circ} \mathrm{C}$ to a constant mass.

The core samples for chemical analysis were thoroughly homogenized after thawing and then were coned-and-quartered (Shugan and Ballinger, 1990 ) to achieve a proper split aliquot of 170 to 200 $\mathrm{g}$ for extraction. The core material was divided equally and placed in four $250-\mathrm{mL}$ centrifuge bottles. After $150 \mathrm{~mL}$ of deionized water was added to each of the bottles, the bottles were agitated for 30 minutes using a wrist-action shaker. Several sets of bottles without core material also were subjected to extraction for blank corrections. After extraction, the bottles were centrifuged at $10,000 \times \mathrm{g}$ for 20 min. The supernatant solutions from the four centrifuge bottles were decanted carefully into a single clean bottle and mixed to form a homogenized extract. The homogenized extracts were preserved using mercuric chloride prior to analysis for ammonia, nitrite, nitrate, and organic nitrogen. (Nitrite concentrations were near or less than detection limits in all samples.) Analyses were done at the U.S. Geological Survey's National Water Quality laboratory in Arvada, Colorado, using procedures described by Fishman and Friedman (1989). Analyte concentrations were corrected for the blank concentrations and adjusted to account for the dilution of the resident pore water by the added deionized water. As a result of these corrections, a few data points that are less than the detection limit plot higher than data points having measurable concentrations. This artifact of the data presentation is most pronounced in samples having very low moisture contents.

Samples for particle-size distribution were analyzed using the methods described by Guy (1969). The measured distributions then were converted to unsaturated-soil moisture retention curves using the method of Arya and Paris (1981). These curves were used to determine unsaturated hydraulic conductivities $\left(\mathrm{K}_{\mathrm{u}}\right)$ using the method of Mualem (1976), and the $K_{u}$ values were used, along with the measured unsaturated-zone moisture saturation index (described later in this section), to estimate unsaturated-zone moisture velocities through the different strata. These individual stratigraphic velocities were integrated to estimate unsaturated-zone transit times for each of the sites.

Several techniques were applied to determine if microbial processes in the unsaturated zone are important in controlling nitrate concentrations. The most direct method involved quantifying the populations of bacteria present in the unsaturated zone that either could form nitrate from reduced forms of nitrogen (the nitrifying bacteria), or could utilize nitrate as a terminal electron acceptor during bacterial respiration (the denitrifying bacteria). The nitrifying bacteria include the Nitrosomonas group that oxidize ammonia to nitrite, and the Nitrobacter group that oxidize nitrite to nitrate. The denitrifying bacteria include Pseudomonas, Alcaligenes, Flavobacter, Bacillus, and Paracoccus. Bacterial 
populations were determined by culturing aliquots of the aseptically collected core material with appropriate media, incubating the inoculated cultures, and using the statistically based most probable number (MPN) method. (The three-tube series dilution method was used to determine probable numbers of viable bacteria.) These procedures have been described in detail by Britton and Greeson (1987).

A 2-inch galvanized steel neutron-probe access pipe was installed in the first test hole at each site. Attached to the pipe at various depths were 0.25 inch copper tubes with copper screen attached over the tubing end. The pipe-tube assembly was lowered through the hollow-stem auger flights, and the auger flights then were removed. As the flights were removed, cuttings from appropriate depths were backfilled into the hole and vibration compressed. This process was repeated until the hole was backfilled to within $5 \mathrm{ft}$ of the land surface. Bentonite chips then were used to form a hydraulic seal at the surface. The hole then was completed, and access maintained, using a watertight utility cover imbedded in a concrete surface seal. The 0.25 inch copper tubes were used to collect soil-gas samples from selected depths below land surface. A major shortcoming of previous nitrate studies was the lack of soil-gas results to support the conclusion that denitrification was occurring in the unsaturated zone.

Unsaturated-zone moisture-saturation profiles were measured periodically using a calibrated neutron-attenuation logging tool that was lowered into the neutron-probe access tube. This tool consists of a high-flux, high-energy neutron source mounted below a thermal neutron detector. Both the source and the detector are mounted inside a 1.875-inch tube that can be lowered into the 2-inchdiameter neutron-probe access tube. Because the mass of the neutron is very much less than the mass of the atoms making up either the tool-housing or the galvanized steel access tube, the high-energy neutrons can pass easily through these materials into the surrounding geologic matrix. But as soon as the neutron encounters something that has a mass similar to itself (such as a hydrogen atom in a water molecule), it transfers some of its energy and slows down slightly. After numerous collisions whereby energy is transferred, the fast neutron becomes "thermalized." The detector in the tool is designed to not "see" fast neutrons, but to be very sensitive to thermal neutrons. That is to say, the detector can see only the neutrons that have encountered a large number of hydrogen atoms and been reflected back into the detector. The number of thermalized neutrons reflected back to the detector is related in a simple way to the volume percentage of hydrogen present within the geologic matrix surrounding the detector. The moisture-saturation index is determined by dividing the volume percentage of hydrogen (assumed to be water) by the porosity for each stratum as determined using the Arya and Paris (1981) approach described earlier.

The second test hole at each site was augerdrilled to the same depth as the first hole, and at those depths at which core was not recoverable from the first hole, cores were recovered from the second. Four to five ceramic-cup suction lysimeters were installed in each of the second holes. Large quantities of water are stored in the unsaturated zone, but the water cannot be extracted readily because it is held tightly within the soil by capillary and molecular soil-tension forces. A suction lysimeter is a device which is designed to sample unsaturated-zone pore water and which consists of a porous ceramic cup sealed to a plastic sampling tube. When a vacuum is applied to the plastic tube, the ceramic cup develops a tension greater than the tension of the surrounding soil. As a result, the soilpore moisture moves from the adjacent soil particles through the porous ceramic cup and into the plastic tube. By applying pressure to the tube at land surface, one can retrieve for analysis the water that has collected in the lysimeter. At each site, the lysimeters were installed at selected depths on the basis of the lithology determined from the cores. In this hole, all the lysimeters were installed at depths greater than $25 \mathrm{ft}$ in order to collect water from the deep unsaturated zone.

The third hole at each site was auger-drilled to a depth of $25 \mathrm{ft}$. Suction lysimeters also were installed in this hole, but at shallower depths and closer together vertically. The assumption during the design phase of the research sites was that most of the biological and geochemical transformations would be occurring in the top few feet of the profile, hence the concentration of instrumentation in this zone of expected reactivity.

The fourth hole at each site was drilled using the mud-rotary technique to a depth several hundred feet beneath the water table. Detailed driller's logs were made, and borehole geophysical logs were collected. The geophysical logs included spontaneous potential, short-normal resistivity, long-normal resistivity, gamma activity, and hole caliper. On the basis of these logs, at least four completion depths were selected for saturated-zone 
monitor wells. Individual 2 -inch wells with 5 -foot screens were placed at the identified completion depths. The procedure that was used in constructing the hole is as follows. The deepest completion depth was selected, and the hole was backfilled with bentonite to $5 \mathrm{ft}$. beneath that depth. The 2-inch casing was hung in the hole, and sand was tremied around the casing to a depth $5 \mathrm{ft}$. above the top of the screen. A bentonite slurry grout then was tremied from the top of the sand pack to a depth 5 $\mathrm{ft}$. below the next completion depth. The grout was allowed to cure and harden, then the process was repeated until all the wells were installed. The hole then was grouted from the top of the last sand pack to $20 \mathrm{ft}$. below land surface, and a concrete seal was installed from the top of the grout to the land surface. Finally, the hole was completed at land surface by installing a watertight access utility cover.

Specific construction and instrumentation details for the sites are given in "Site Description" sections for each of the seven sites.

\section{Monitoring-Well Network}

The research sites give seven points of excellent data control within the study area. Additional wells (and two springs) were selected in the Hemet subbasin, on the basis of location and quality of well logs available for the wells, to allow better definition of hydrologic conditions, water movement, and water-quality distributions within the Hemet subbasin. The monitoring-well network thus established is shown in figure 3. State well and spring numbers for the 75 sites in the Hemet subbasin network and 2 sites in the Chino Basin and Menifee subbasin are given in table 1.

\section{GEOHYDROLOGIC SETTING}

\section{Hemet Ground-Water Subbasin}

The Hemet ground-water subbasin is in southwestern Riverside County, California (figs. 2,3). The basin is adjacent to the Winchester ground-water subbasin and the Lakeview Mountains on the west, and to the Santa Rosa Hills and Domenigoni Mountains on the south. The Casa Loma Fault forms the eastern basin boundary and separates the relatively shallow Hemet subbasin from the much deeper San Jacinto ground-water subbasin, which is a graben between the Perris block and the San Jacinto Mountains.
The Hemet subbasin is underlain by granitic and metamorphic bedrock. Biehler and Lee (1993) recently completed an extensive gravity survey of the Hemet subbasin to determine the altitude and topography of the buried bedrock surface. The results of this survey, illustrated in figure 4 , indicate a buried drainage channel or streambed in the area currently traversed by Salt Creek. This buried drainage extends into the adjacent Winchester ground-water subbasin, indicating that there is no geologic barrier between the two basins. Results of the study also indicate that the Casa Loma Fault forms a buried bedrock cliff at the Hemet-San Jacinto subbasins boundary, with as much as 8,000 $\mathrm{ft}$ of relief to the bottom of the San Jacinto graben.

Distribution of Alluvial Deposits in the Hemet Subbasin

\section{Methods of analysis}

The Hemet subbasin fill consists of sand, silt, and clay eroded principally from the San Jacinto Mountains and the Santa Rosa Hills, and deposited by the San Jacinto River and Bautista Creek, respectively. To gain a better understanding of the alluvial deposits, the authors derived estimates of areal and vertical grain-size distribution from driller's logs for 71 wells and used them to create a series of contoured "texture" maps. These texture maps (figs. 5-10) show the percentage of coarsegrained material at different depths in the alluvial deposits. In addition, lithologic descriptions from driller's logs of 29 wells were used to construct four generalized stratigraphic cross sections (figs. 1115).

To construct the texture maps, the authors divided the driller's logs into 100 -foot sections. The upper boundary of each $\log$ analyzed was land surface; the lower boundary was the total well depth or the bedrock contact, whichever was shallower. However, if less than 80 percent of the depth interval was represented, that section of the well was excluded from the analysis of that interval. For example, a well $470 \mathrm{ft}$ deep would be included in the tabulation for each 100-foot section between 0 and $400 \mathrm{ft}$, but not included in the 400 - to 500 -foot section. Because driller's logs for wells deeper than $500 \mathrm{ft}$ are sparse in the Hemet Basin, grain-size distributions in this depth interval were included only in the texture map representing the total thickness of the deposits penetrated in each well.

In this report, coarse-grained sediment is considered to consist principally of sand; clayey and 


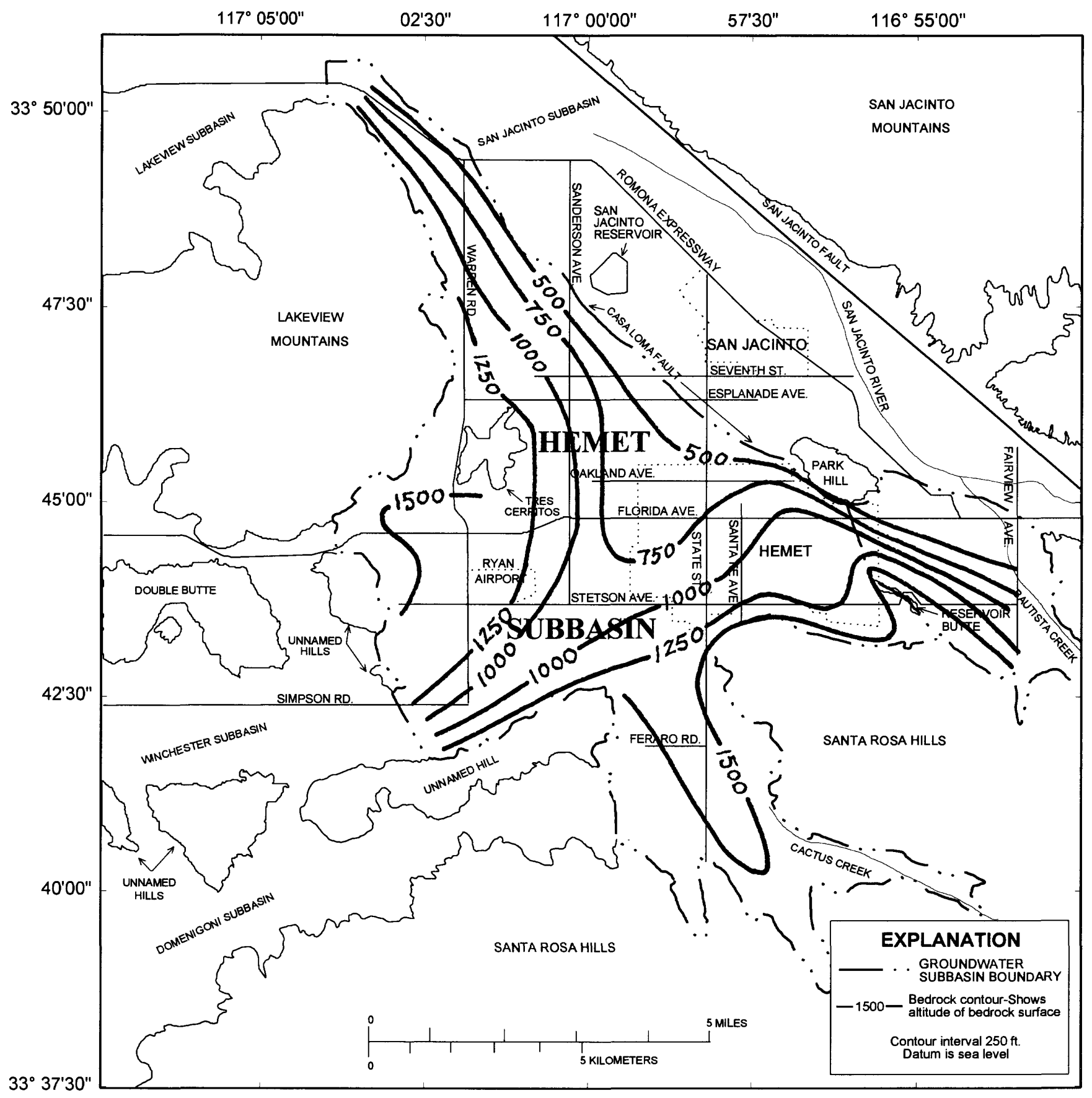

Base digitized from U.S. Geological and San Jacinto, California Quadrangles

Figure 4. Altitude of bedrock surface in the Hemet Subbasin (after Biehler and Lee, 1993). 
Table 1. Water-quality and water-level monitoring network in the study area

[Location of sites shown in figures 2 and 3 (except sites 1 and 7 outside map area of fig. 3). State well or spring No.: The numbering system, which is described in the text, is identical for wells and springs, except the letter " $\mathrm{S}$ " is added before the final digit in spring numbers]

$\begin{array}{lccccccc} & \text { State well } & & & \text { State well } & & \\ \text { Site } & \text { or spring } & \text { Latitude } & \text { Longitude } & \text { Site } & \text { or spring } & \text { Latitude } & \text { Longitude } \\ \text { No. } & \text { No. } & \text { (north) } & \text { (west) } & \text { No. } & \text { No. } & \text { (north) } & \text { (west) }\end{array}$

Multiple wells (U.S. Geological Survey)

Water-level wells

$\begin{array}{llll}1 & 4 \mathrm{~S} / 1 \mathrm{~W}-19 \mathrm{M} 1 & 33^{\circ} 48^{\prime} 27^{\prime \prime} & 117^{\circ} 01^{\prime} 46^{\prime \prime} \\ 2 & 4 \mathrm{~S} / 1 \mathrm{~W}-32 \mathrm{Q} 2 & 33^{\circ} 46^{\prime} 29^{\prime \prime} & 117^{\circ} 00^{\prime} 20^{\prime \prime} \\ 3 & 5 \mathrm{~S} / 1 \mathrm{E}-17 \mathrm{Q} 4 & 33^{\circ} 43^{\prime} 53^{\prime \prime} & 116^{\circ} 54^{\prime} 01^{\prime \prime} \\ 4 & 5 \mathrm{~S} / 1 \mathrm{~W}-10 \mathrm{~K} 2 & 33^{\circ} 45^{\prime} 04^{\prime \prime} & 116^{\circ} 58^{\prime} 01^{\prime \prime} \\ 5 & 5 \mathrm{~S} / 1 \mathrm{~W}-28 \mathrm{~J} 1 & 33^{\circ} 42^{\prime} 19^{\prime \prime} & 116^{\circ} 58^{\prime} 59^{\prime \prime} \\ 6 & \text { 2S/7W-13P2 } & 33^{\circ} 59^{\prime} 26^{\prime \prime} & 117^{\circ} 34^{\prime} 00^{\prime \prime} \\ 7 & 5 \mathrm{~S} / 3 \mathrm{~W}-28 \mathrm{M} 1 & 33^{\circ} 42^{\prime} 17^{\prime \prime} & 117^{\circ} 12^{\prime} 05^{\prime \prime}\end{array}$

\section{Water-quality wells and springs}

\begin{tabular}{|c|c|c|c|}
\hline 8 & $4 \mathrm{~S} / 1 \mathrm{~W}-28 \mathrm{G} 1$ & $33^{\circ} 47^{\prime} 51^{\prime \prime}$ & $116^{\circ} 59^{\prime} 17^{\prime \prime}$ \\
\hline 9 & $4 \mathrm{~S} / 1 \mathrm{~W}-31 \mathrm{D} 1$ & $33^{\circ} 47^{\prime} 03^{\prime \prime}$ & $117^{\circ} 01^{\prime} 51^{\prime \prime}$ \\
\hline 10 & $4 \mathrm{~S} / 1 \mathrm{~W}-32 \mathrm{~N} 1$ & $33^{\circ} 46^{\prime} 29^{\prime \prime}$ & $117^{\circ} 00^{\prime} 45^{\prime \prime}$ \\
\hline 11 & $4 \mathrm{~S} / 2 \mathrm{~W}-24 \mathrm{~J} 2$ & $33^{\circ} 48^{\prime} 31^{\prime \prime}$ & $117^{\circ} 02^{\prime} 01^{\prime \prime}$ \\
\hline 12 & $4 \mathrm{~S} / 2 \mathrm{~W}-25 \mathrm{FS} 1$ & $33^{\circ} 47^{\prime} 40^{\prime \prime}$ & $117^{\circ} 02^{\prime} 39^{\prime \prime}$ \\
\hline 13 & $4 \mathrm{~S} / 2 \mathrm{~W}-36 \mathrm{M} 1$ & $33^{\circ} 46^{\prime} 41^{\prime \prime}$ & $117^{\circ} 02^{\prime} 58^{\prime \prime}$ \\
\hline 14 & 5S/1E-06L2 & $33^{\circ} 45^{\prime} 56^{\prime \prime}$ & $116^{\circ} 55^{\prime} 22^{\prime \prime}$ \\
\hline 15 & $5 \mathrm{~S} / 1 \mathrm{E}-18 \mathrm{~A} 1$ & $33^{\circ} 44^{\prime} 26^{\prime \prime}$ & $116^{\circ} 54$ \\
\hline 16 & $5 \mathrm{~S} / 1 \mathrm{E}-18 \mathrm{C} 1$ & $33^{\circ} 44^{\prime} 26^{\prime \prime}$ & $116^{\circ} 55^{\prime} 0$ \\
\hline 17 & $5 \mathrm{~S} / 1 \mathrm{E}-18 \mathrm{~K} 1$ & $33^{\circ} 44^{\prime} 05^{\prime \prime}$ & $116^{\circ} 54^{\prime} 5$ \\
\hline 18 & $5 \mathrm{~S} / 1 \mathrm{~W}-08 \mathrm{R} 1$ & $33^{\circ} 44^{\prime} 49^{\prime \prime}$ & $116^{\circ} 59^{\prime} 49^{\prime \prime}$ \\
\hline 19 & $5 \mathrm{~S} / 1 \mathrm{~W}-10 \mathrm{E} 1$ & $33^{\circ} 45^{\prime} 05^{\prime \prime}$ & $116^{\circ} 58^{\prime} 30^{\prime \prime}$ \\
\hline 20 & $5 \mathrm{~S} / 1 \mathrm{~W}-13 \mathrm{C} 1$ & $33^{\circ} 44^{\prime} 31^{\prime \prime}$ & $116^{\circ} 56^{\prime} 1$ \\
\hline 21 & $5 \mathrm{~S} / 1 \mathrm{~W}-14 \mathrm{~K} 1$ & $33^{\circ} 44^{\prime} 02^{\prime \prime}$ & $116^{\circ} 56^{\prime} 5$ \\
\hline 22 & $5 \mathrm{~S} / 1 \mathrm{~W}-14 \mathrm{P} 1$ & $33^{\circ} 43^{\prime} 50^{\prime \prime}$ & $116^{\circ} 57^{\prime} 1$ \\
\hline 23 & $5 \mathrm{~S} / 1 \mathrm{~W}-16 \mathrm{~L} 1$ & $33^{\circ} 44^{\prime} 07^{\prime \prime}$ & $116^{\circ} 5$ \\
\hline 24 & $5 \mathrm{~S} / 1 \mathrm{~W}-21 \mathrm{~A} 1$ & $33^{\circ} 43^{\prime} 45^{\prime \prime}$ & $116^{\circ} 58^{\prime} 49^{\prime \prime}$ \\
\hline 25 & $5 \mathrm{~S} / 1 \mathrm{~W}-22 \mathrm{RS} 1$ & $33^{\circ} 43^{\prime} 05^{\prime \prime}$ & $116^{\circ} 57^{\prime} 5$ \\
\hline 26 & 5S/1W-33R1 & $33^{\circ} 41^{\prime} 07^{\prime \prime}$ & $116^{\circ} 58^{\prime} 5$ \\
\hline 27 & $5 \mathrm{~S} / 2 \mathrm{~W}-02 \mathrm{R} 1$ & $33^{\circ} 45^{\prime} 31^{\prime \prime}$ & $117^{\circ} 02^{\prime} 5$ \\
\hline 28 & $5 \mathrm{~S} / 2 \mathrm{~W}-24 \mathrm{C} 2$ & $33^{\circ} 43^{\prime} 44^{\prime \prime}$ & $117^{\circ} 02^{\prime} 3$ \\
\hline 29 & $5 \mathrm{~S} / 2 \mathrm{~W}-25 \mathrm{Cl}$ & $33^{\circ} 42^{\prime} 40^{\prime \prime}$ & $117^{\circ} 02^{\prime}$ \\
\hline 30 & $5 \mathrm{~S} / 2 \mathrm{~W}-26 \mathrm{P} 1$ & $33^{\circ} 42^{\prime} 02^{\prime \prime}$ & $117^{\circ} 03^{\prime} 3$ \\
\hline 31 & $6 \mathrm{~S} / 1 \mathrm{~W}-03 \mathrm{M} 2$ & $33^{\circ} 40^{\prime} 42^{\prime \prime}$ & 058 \\
\hline 32 & 6S/1W-03R1 & $33^{\circ} 40^{\prime} 23^{\prime \prime}$ & $116^{\circ} 57^{\prime}$ \\
\hline 33 & $6 \mathrm{~S} / 1 \mathrm{~W}-06 \mathrm{G} 1$ & $33^{\circ} 40^{\prime} 55^{\prime \prime}$ & $117^{\circ} 01^{\prime} 1$ \\
\hline 34 & $6 \mathrm{~S} / 2 \mathrm{~W}-01 \mathrm{~F} 1$ & $33^{\circ} 40^{\prime} 45^{\prime \prime}$ & \\
\hline
\end{tabular}

35

36

37

38

39

40

41

42

43

44

45

46

47

48

49

50

51

52

53

54

55

56

57

58

59

60

61

62

63

64

65

66

67

68

69

70

71

72

73

74

75

76

77
4S/1W-07H1

$4 \mathrm{~S} / 1 \mathrm{~W}-17 \mathrm{~K} 3$

$4 \mathrm{~S} / 1 \mathrm{~W}-27 \mathrm{P} 5$

$4 \mathrm{~S} / 12-28 \mathrm{~N} 3$

4S/1W-31D2

4S/1W-31G2

4S/1W-32C 3

4S/1W-32H4

4S/1W-33Q1

4S/2W-13H1

4S/2W-24A1

5S/1E-06K2

5S/1E-07K1

5S/1E-07Q2

5S/1E-16D1

5S/1E-16N1

$5 \mathrm{~S} / 1 \mathrm{E}-18 \mathrm{~F} 1$

5S/1W-09A1

$5 \mathrm{~S} / 1 \mathrm{~W}-10 \mathrm{~B} 2$

$5 \mathrm{~S} / 1 \mathrm{~W}-11 \mathrm{Q} 1$

$5 \mathrm{~S} / 1 \mathrm{~W}-17 \mathrm{~F} 2$

$5 \mathrm{~S} / 1 \mathrm{~W}-18 \mathrm{P} 1$

$5 \mathrm{~S} / 1 \mathrm{~W}-20 \mathrm{P} 2$

$5 \mathrm{~S} / 1 \mathrm{~W}-27 \mathrm{~F} 1$

$5 \mathrm{~S} / 1 \mathrm{~W}-27 \mathrm{Q} 1$

$5 \mathrm{~S} / 1 \mathrm{~W}-27 \mathrm{Q} 2$

$5 \mathrm{~S} / 1 \mathrm{~W}-30 \mathrm{C} 1$

5S/1W-30E2

$5 \mathrm{~S} / 1 \mathrm{~W}-34 \mathrm{~N} 2$

$5 \mathrm{~S} / 2 \mathrm{~W}-12 \mathrm{~N} 2$

$5 \mathrm{~S} / 2 \mathrm{~W}-12 \mathrm{Q} 2$

$5 \mathrm{~S} / 2 \mathrm{~W}-24 \mathrm{G} 1$

$5 \mathrm{~S} / 2 \mathrm{~W}-25 \mathrm{C} 2$

$5 \mathrm{~S} / 2 \mathrm{~W}-25 \mathrm{~J} 1$

$5 \mathrm{~S} / 2 \mathrm{~W}-25 \mathrm{P} 2$

$5 \mathrm{~S} / 2 \mathrm{~W}-26 \mathrm{G} 3$

$5 \mathrm{~S} / 2 \mathrm{~W}-26 \mathrm{~N} 1$

5S/2W-35D1

5S/2W-36D4

$6 \mathrm{~S} / 1 \mathrm{~W}-03 \mathrm{M} 1$

$6 \mathrm{~S} / 1 \mathrm{~W}-04 \mathrm{Gl}$

6S/2W-01M1

$6 \mathrm{~S} / 2 \mathrm{~W}-02 \mathrm{~J} 2$ $33^{\circ} 50^{\prime} 18^{\prime \prime}$

$33^{\circ} 49^{\prime} 20^{\prime \prime}$

$33^{\circ} 47^{\prime} 16^{\prime \prime}$

$33^{\circ} 47^{\prime} 16^{\prime \prime}$

$33^{\circ} 47^{\prime} 11^{\prime \prime}$

$33^{\circ} 46^{\prime} 51^{\prime \prime}$

$33^{\circ} 47^{\prime} 08^{\prime \prime}$

$33^{\circ} 46^{\prime} 58^{\prime \prime}$

$33^{\circ} 46^{\prime} 29^{\prime \prime}$

$33^{\circ} 49^{\prime} 29^{\prime \prime}$

$33^{\circ} 48^{\prime} 47^{\prime \prime}$

$33^{\circ} 45^{\prime} 47^{\prime \prime}$

$33^{\circ} 44^{\prime} 53^{\prime \prime}$

$33^{\circ} 44^{\prime} 39^{\prime \prime}$

$33^{\circ} 44^{\prime} 26^{\prime \prime}$

$33^{\circ} 43^{\prime} 55^{\prime \prime}$

$33^{\circ} 44^{\prime} 19^{\prime \prime}$

$33^{\circ} 44^{\prime} 49^{\prime \prime}$

$33^{\circ} 45^{\prime} 27^{\prime \prime}$

$33^{\circ} 44^{\prime} 48^{\prime \prime}$

$33^{\circ} 44^{\prime} 17^{\prime \prime}$

$33^{\circ} 43^{\prime} 46^{\prime \prime}$

$33^{\circ} 43^{\prime} 03^{\prime \prime}$

$33^{\circ} 42^{\prime} 28^{\prime \prime}$

$33^{\circ} 42^{\prime} 11^{\prime \prime}$

$33^{\circ} 42^{\prime} 12^{\prime \prime}$

$33^{\circ} 42^{\prime} 44^{\prime \prime}$

$33^{\circ} 42^{\prime} 33^{\prime \prime}$

$33^{\circ} 41^{\prime} 22^{\prime \prime}$

$33^{\circ} 44^{\prime} 44^{\prime \prime}$

$33^{\circ} 44^{\prime} 40^{\prime \prime}$

$33^{\circ} 43^{\prime} 19^{\prime \prime}$

$33^{\circ} 42^{\prime} 48^{\prime \prime}$

$33^{\circ} 42^{\prime} 26^{\prime \prime}$

$33^{\circ} 42^{\prime} 11^{\prime \prime}$

$33^{\circ} 42^{\prime} 29^{\prime \prime}$

$33^{\circ} 42^{\prime} 01^{\prime \prime}$

$33^{\circ} 41^{\prime} 59^{\prime \prime}$

$33^{\circ} 42^{\prime} 00^{\prime \prime}$

$33^{\circ} 40^{\prime} 41^{\prime \prime}$

$33^{\circ} 45^{\prime} 04^{\prime \prime}$

$33^{\circ} 40^{\prime} 37^{\prime \prime}$

$33^{\circ} 40^{\prime} 33^{\prime \prime}$ $117^{\circ} 00^{\prime} 56^{\prime \prime}$

$117^{\circ} 00^{\prime} 18^{\prime \prime}$

$116^{\circ} 58^{\prime} 27^{\prime \prime}$

$116^{\circ} 59^{\prime} 07^{\prime \prime}$

$117^{\circ} 01^{\prime} 47^{\prime \prime}$

$117^{\circ} 01^{\prime} 15^{\prime \prime}$

$117^{\circ} 02^{\prime} 59^{\prime \prime}$

$116^{\circ} 59^{\prime} 51^{\prime \prime}$

$116^{\circ} 59^{\prime} 08^{\prime \prime}$

$117^{\circ} 02^{\prime} 08^{\prime \prime}$

$117^{\circ} 02^{\prime} 01^{\prime \prime}$

$116^{\circ} 54^{\prime} 53^{\prime \prime}$

$116^{\circ} 54^{\prime} 51^{\prime \prime}$

$116^{\circ} 55^{\prime} 12^{\prime \prime}$

$116^{\circ} 53^{\prime} 25^{\prime \prime}$

$116^{\circ} 53^{\prime} 32^{\prime \prime}$

$116^{\circ} 55^{\prime} 22^{\prime \prime}$

$116^{\circ} 58^{\prime} 49^{\prime \prime}$

$116^{\circ} 58^{\prime} 08^{\prime \prime}$

$116^{\circ} 57^{\prime} 01^{\prime \prime}$

$117^{\circ} 00^{\prime} 22^{\prime \prime}$

$117^{\circ} 01^{\prime} 24^{\prime \prime}$

$117^{\circ} 00^{\prime} 23^{\prime \prime}$

$116^{\circ} 58^{\prime} 24^{\prime \prime}$

$116^{\circ} 58^{\prime} 13^{\prime \prime}$

$116^{\circ} 58^{\prime} 13^{\prime \prime}$

$117^{\circ} 01^{\prime} 23^{\prime \prime}$

$117^{\circ} 01^{\prime} 53^{\prime \prime}$

$116^{\circ} 58^{\prime} 30^{\prime \prime}$

$117^{\circ} 02^{\prime} 51^{\prime \prime}$

$117^{\circ} 02^{\prime} 25^{\prime \prime}$

$117^{\circ} 02^{\prime} 26^{\prime \prime}$

$117^{\circ} 02^{\prime} 26^{\prime \prime}$

$117^{\circ} 02^{\prime} 09^{\prime \prime}$

$117^{\circ} 02^{\prime} 27^{\prime \prime}$

$117^{\circ} 03^{\prime} 22^{\prime \prime}$

$117^{\circ} 03^{\prime} 50^{\prime \prime}$

$117^{\circ} 03^{\prime} 44^{\prime \prime}$

$117^{\circ} 02^{\prime} 42^{\prime \prime}$

$116^{\circ} 58^{\prime} 38^{\prime \prime}$

$116^{\circ} 58^{\prime} 04^{\prime \prime}$

$117^{\circ} 02^{\prime} 54^{\prime \prime}$

$117^{\circ} 02^{\prime} 57^{\prime \prime}$ 


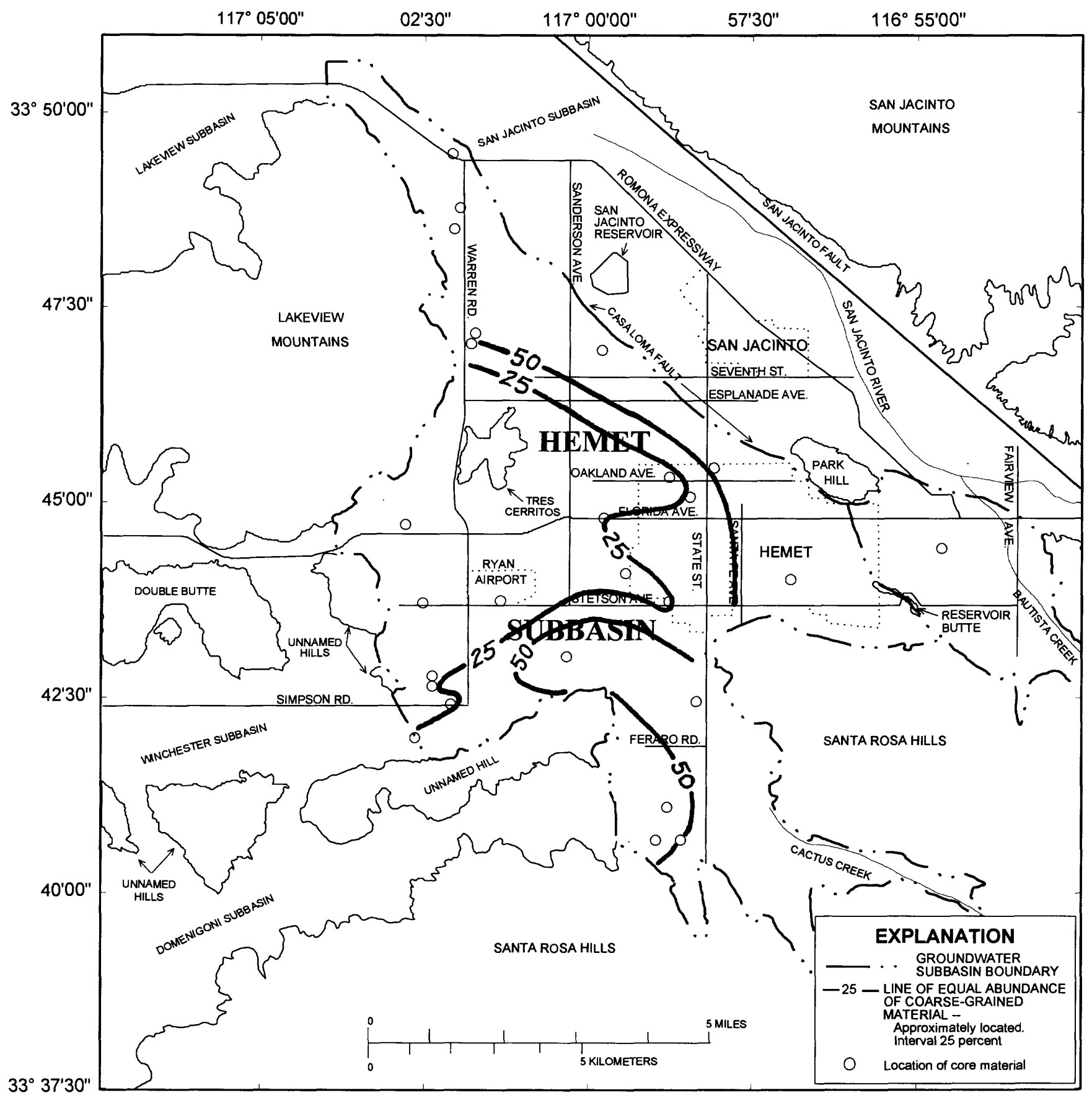

Base digitized from U.S. Geological

Survey Lakeview, Winchester, Hemet.

and San Jacinto, California Quadrangles

Figure 5. Texture in the $0-100$ foot depth interval of the alluvial deposits of the Hemet Subbasin. 


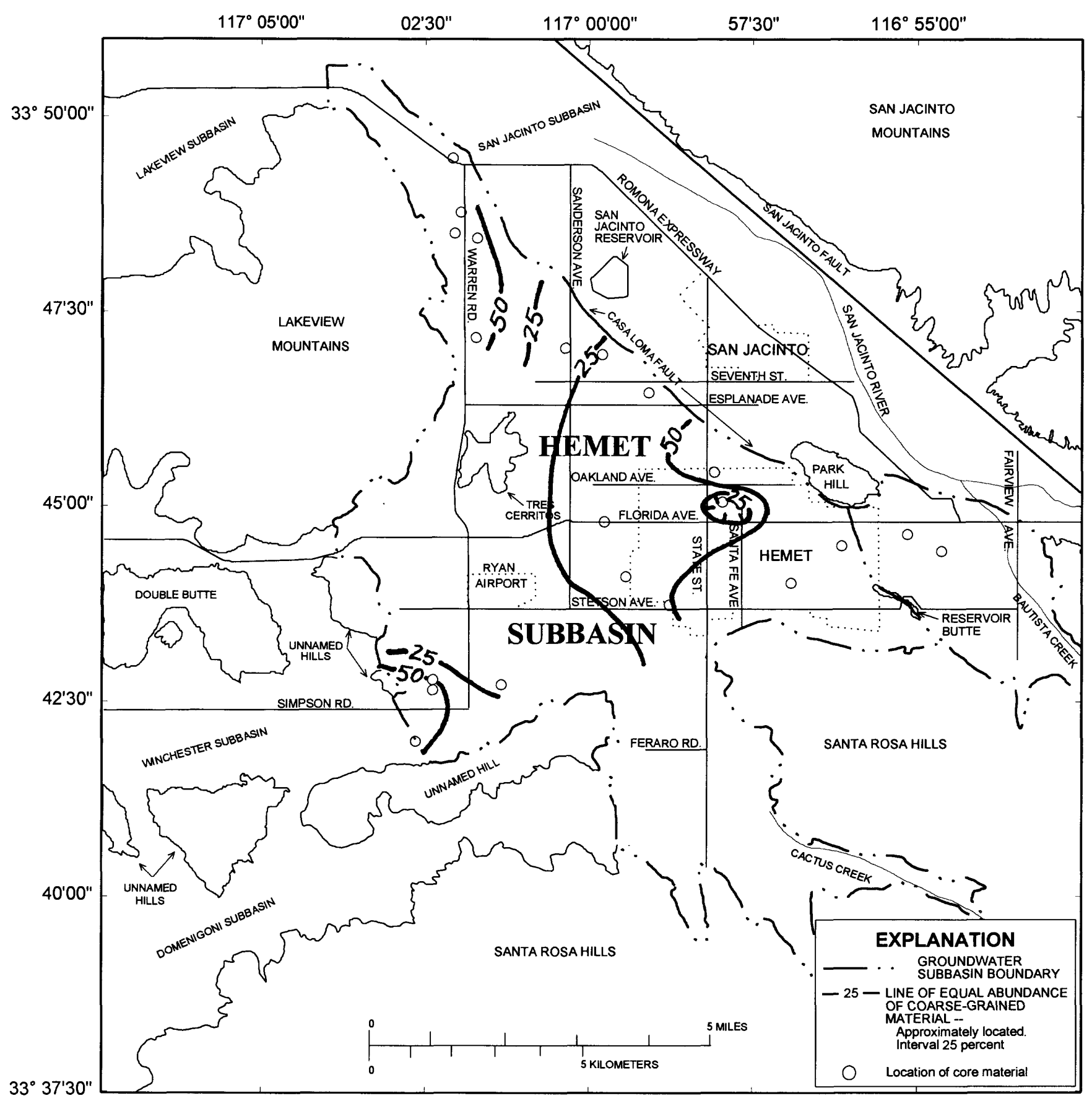

Base digitized from U.S. Geological

Survey Lakeview, Winchester, Hemet,

Figure 6. Texture in the 100-200 foot depth interval of the alluvial deposits of the Hemet Subbasin. 


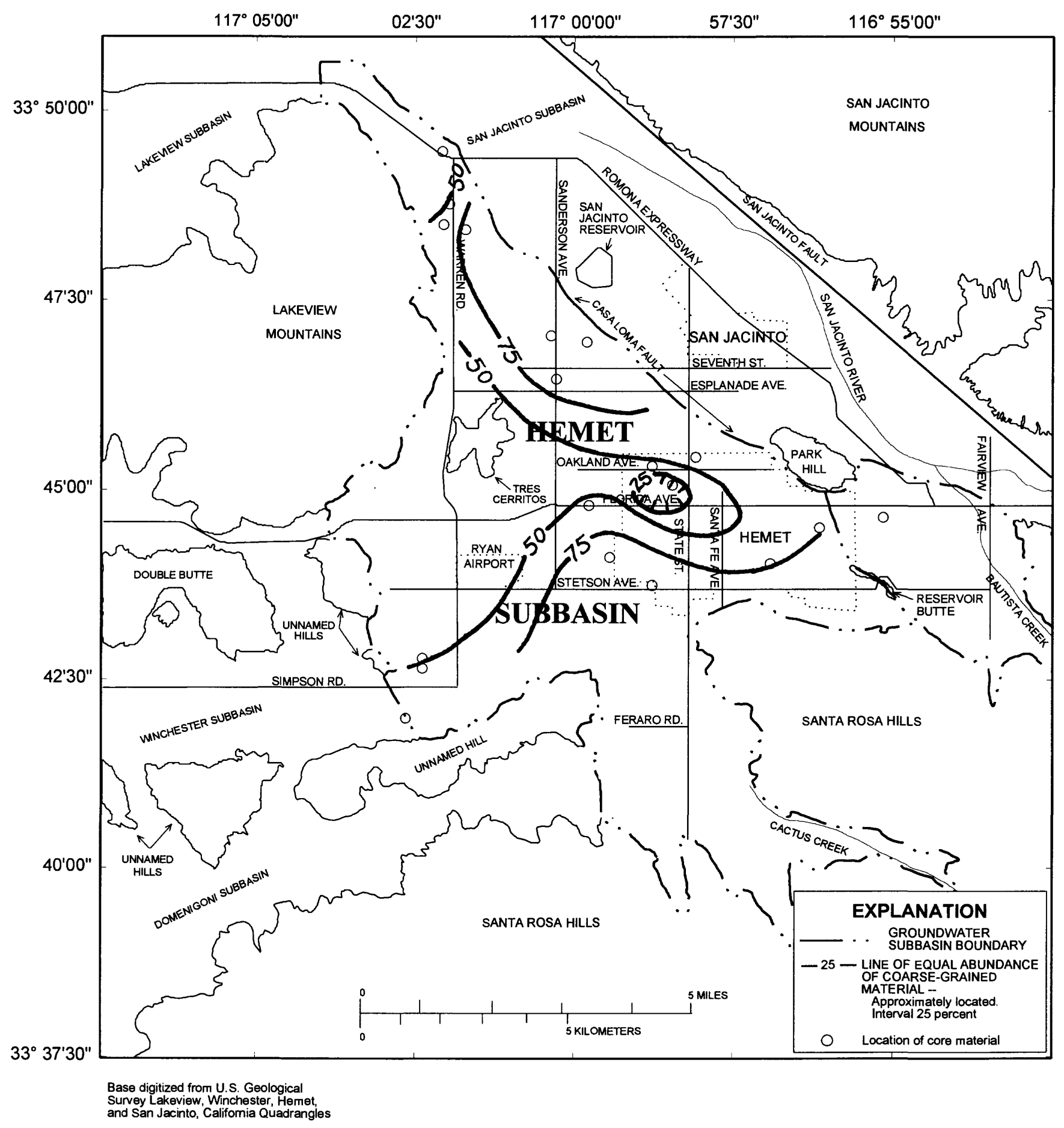

Figure 7. Texture in the 200-300 foot depth interval of the alluvial deposits of the Hemet Subbasin. 


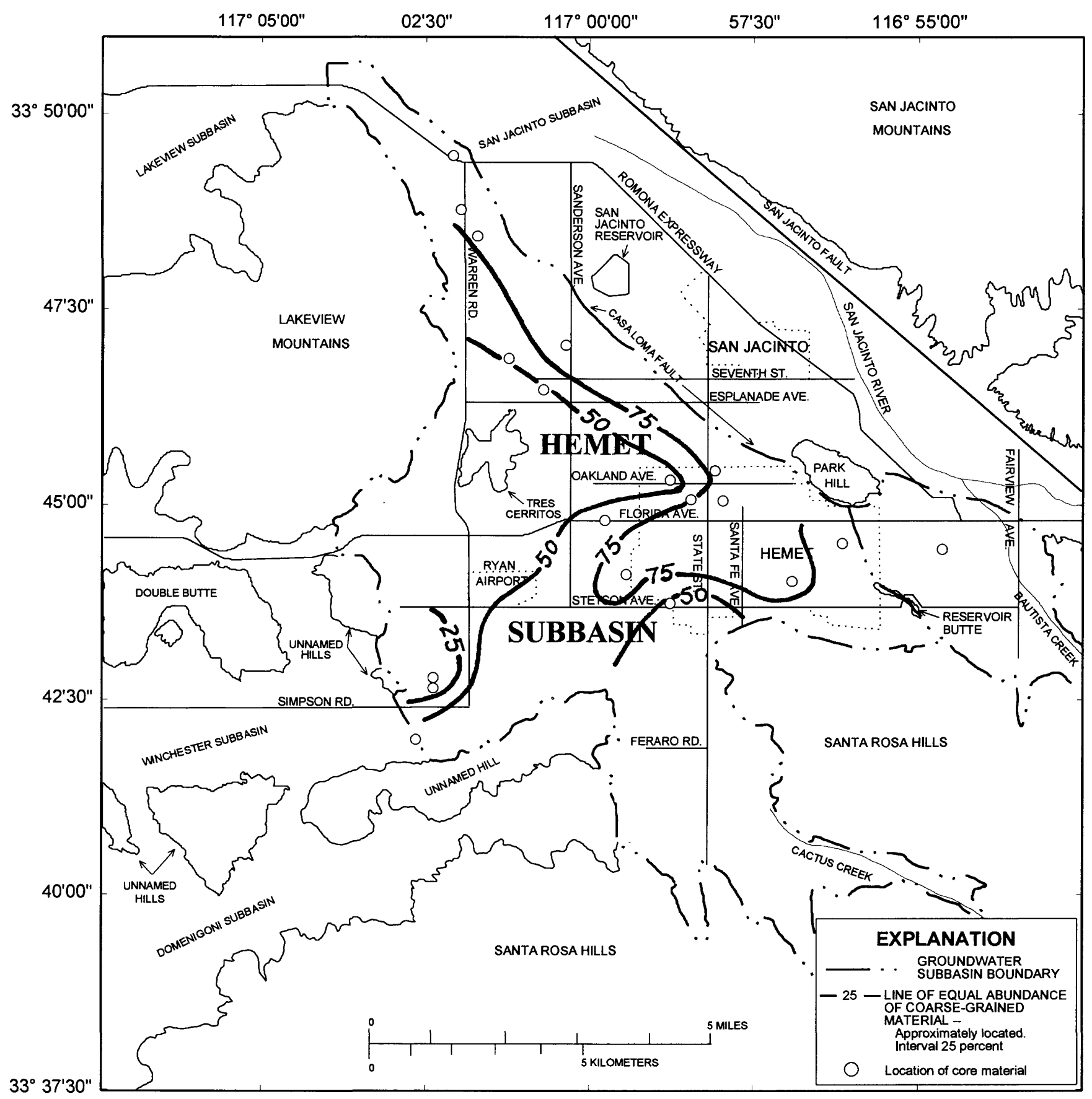

Base digitized from U.S. Geological

Survey Lakeview, Winchester, Hemet.

and San Jacinto, Califomia Quadrangles

Figure 8. Texture in the $300-400$ foot depth interval of the alluvial deposits of the Hemet Subbasin. 


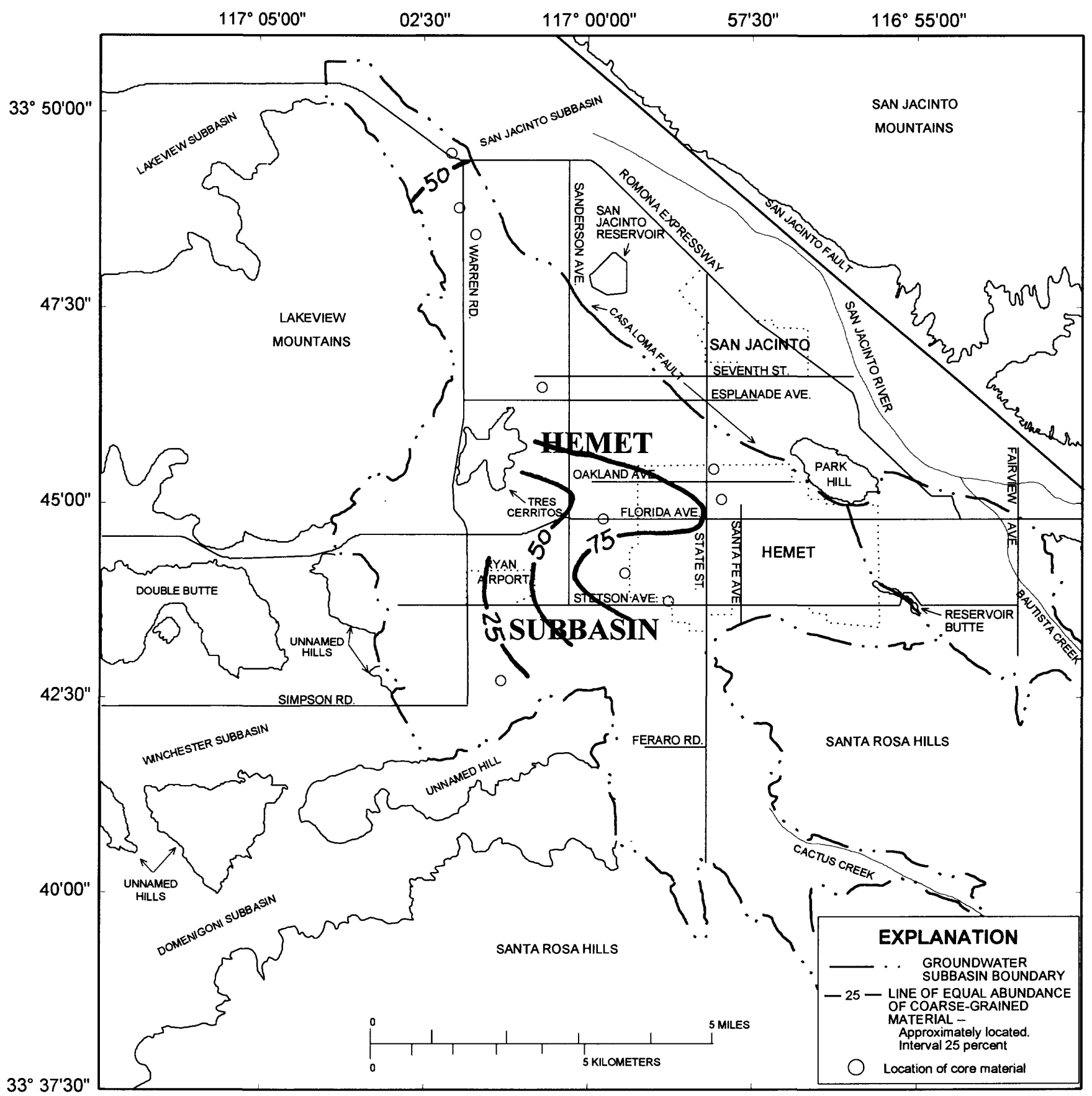

Base digitized from U.S. Geological

Survey Lakeview. Winchester Hemet.

and San Jacinto, Califomia Quadrangles

Figure 9. Texture in the 400-500 foot depth interval of the alluvial deposits of the Hemet Subbasin. 


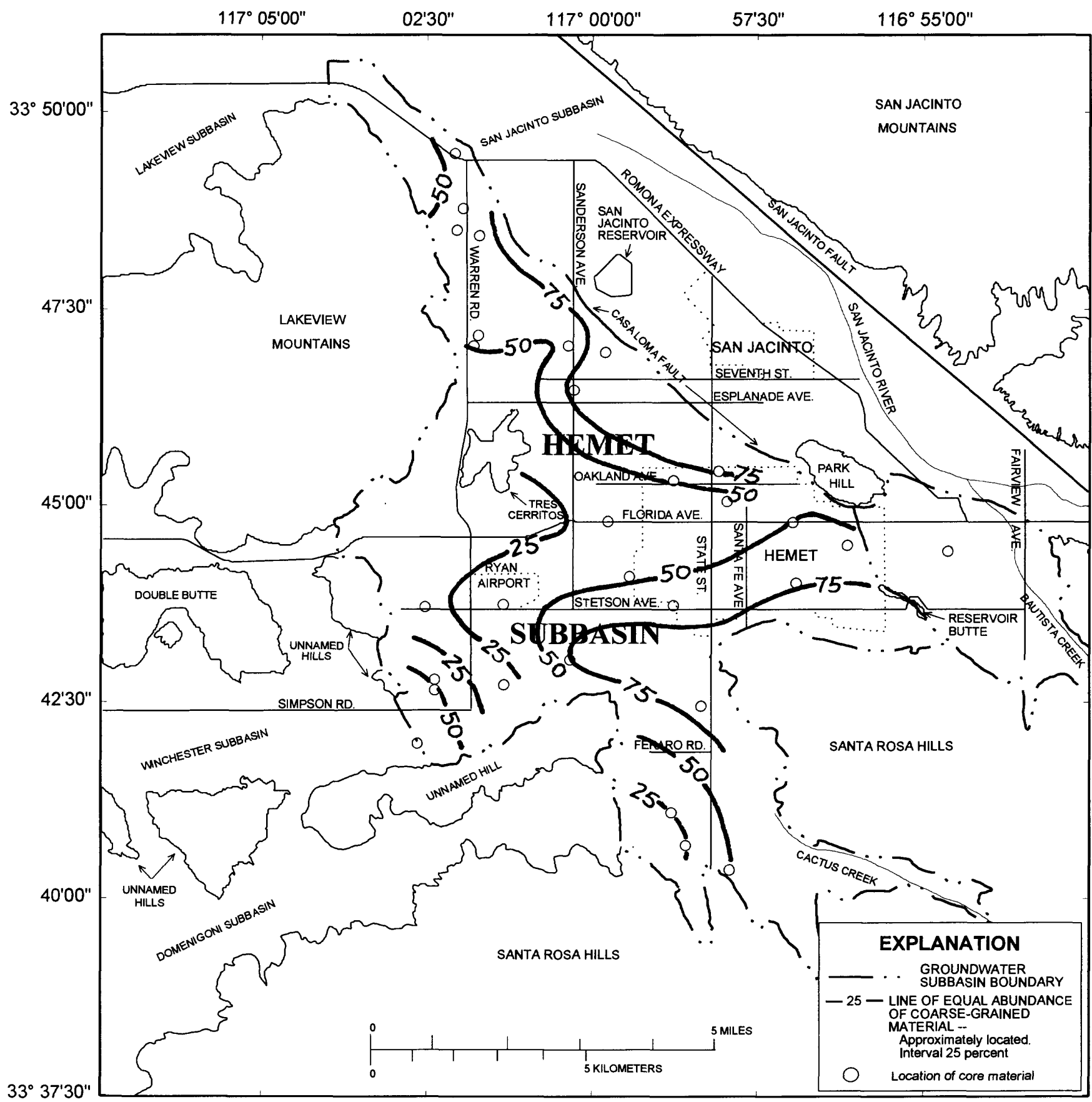

Base digitized from U.S. Geological

Survey Lekeview, Winchester, Hemet,

and San Jecinto, California Quadrangles

Figure 10. Texture in the 0-500 foot depth interval of the alluvial deposits of the Hemet Subbasin. 


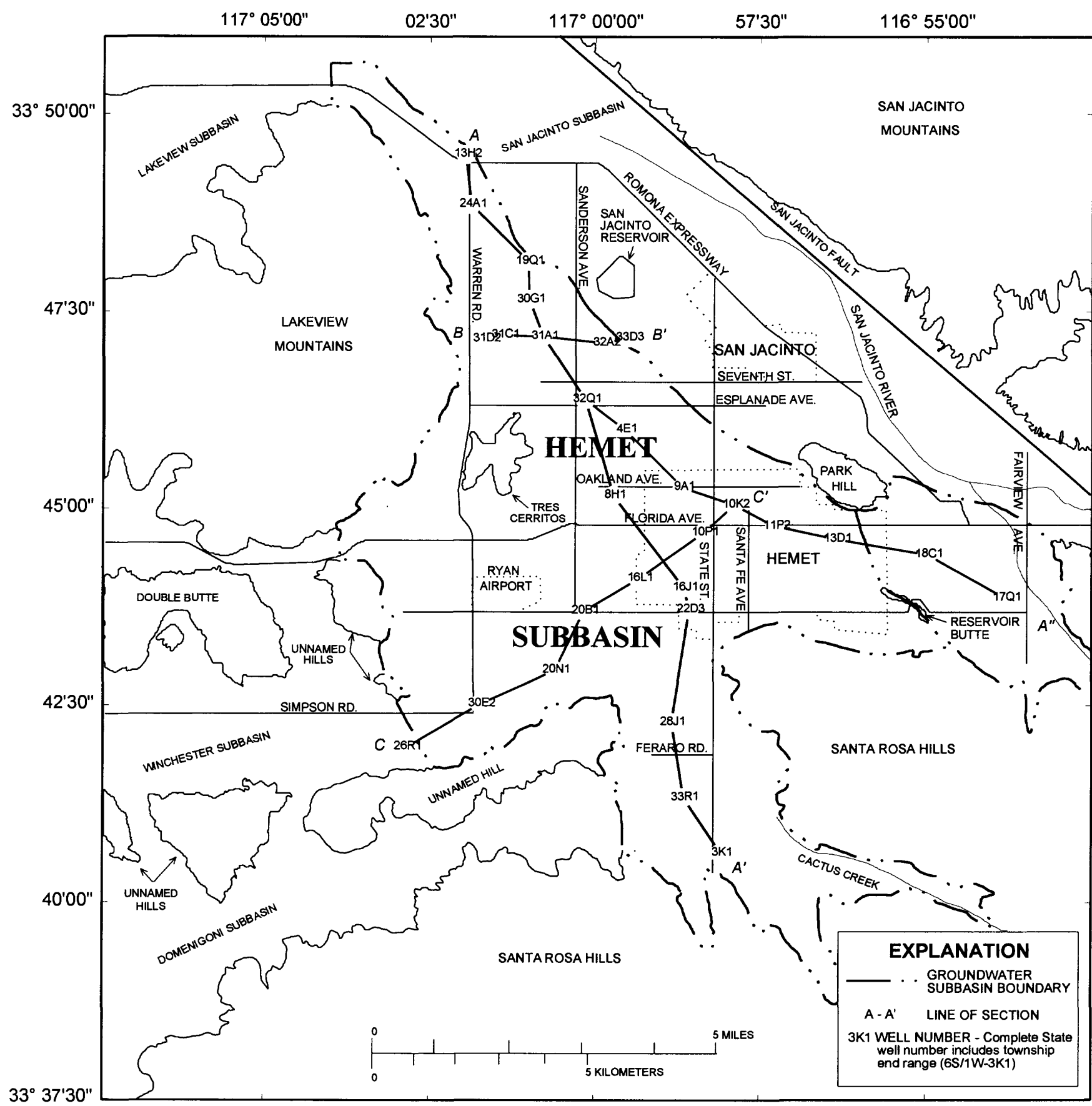

Base digitized from U.S. Geological

and San Jacinto, California Quadrangles

Figure 11. Location of stratigraphic cross sections (A-A', A-A", B-B', C-C') shown in figures 12-15. 


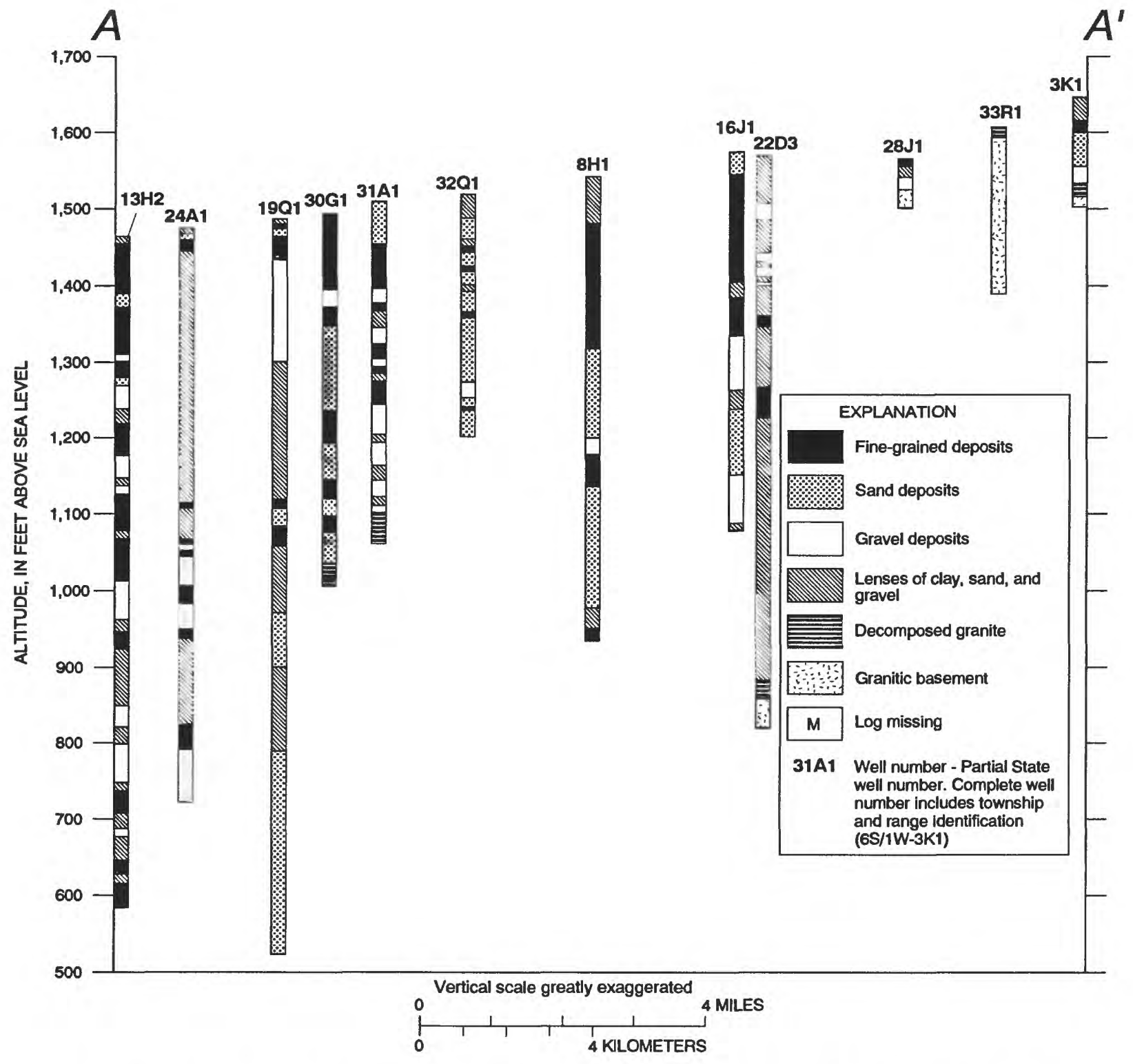

Figure 12. Lithologic profiles for stratigraphic cross section A-A'. Line of section is shown in figure 11. 


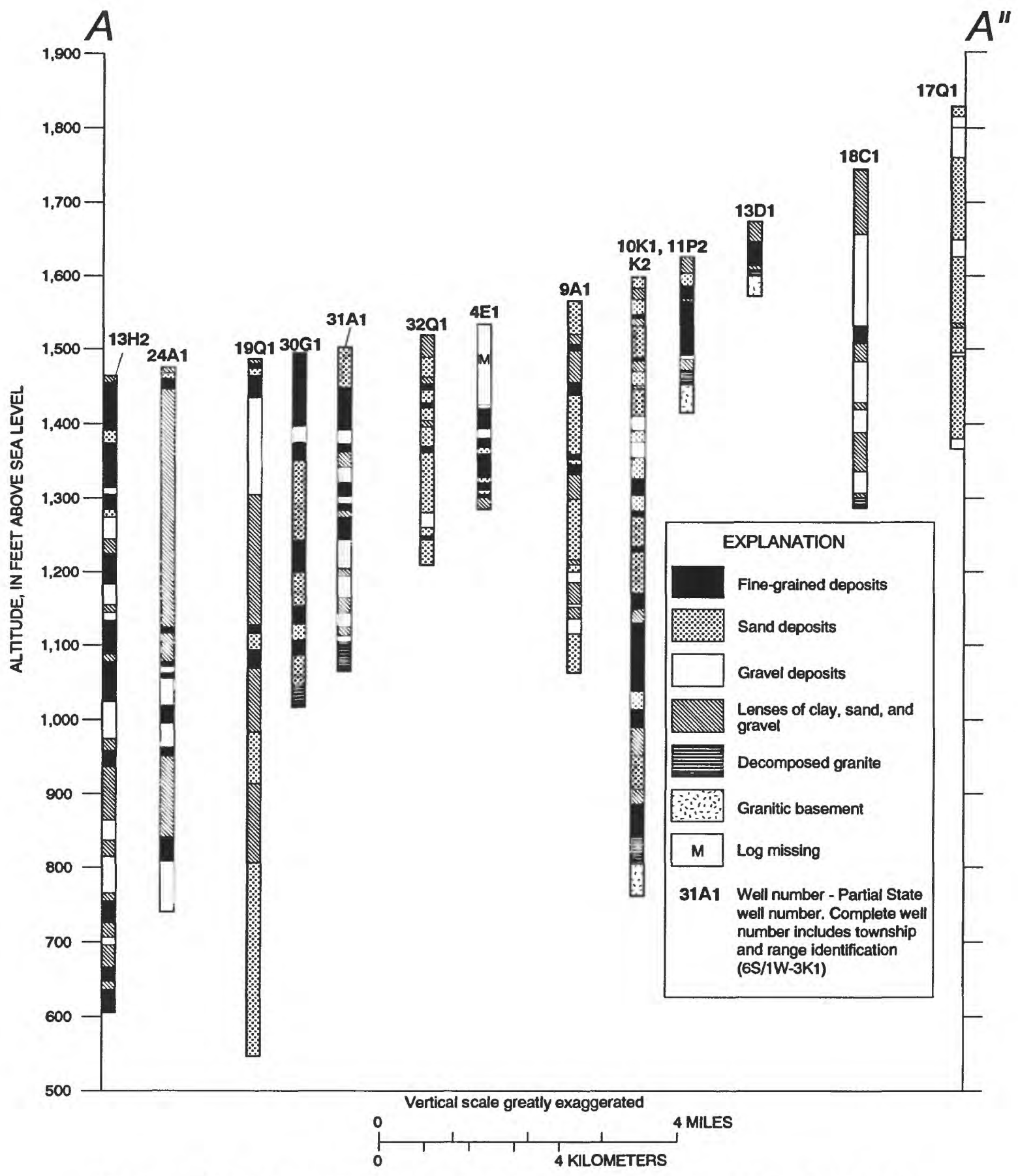

Figure 13. Lithologic profiles for stratigraphic cross section $A-A^{\prime \prime}$. Line of section is shown in figure 11. 

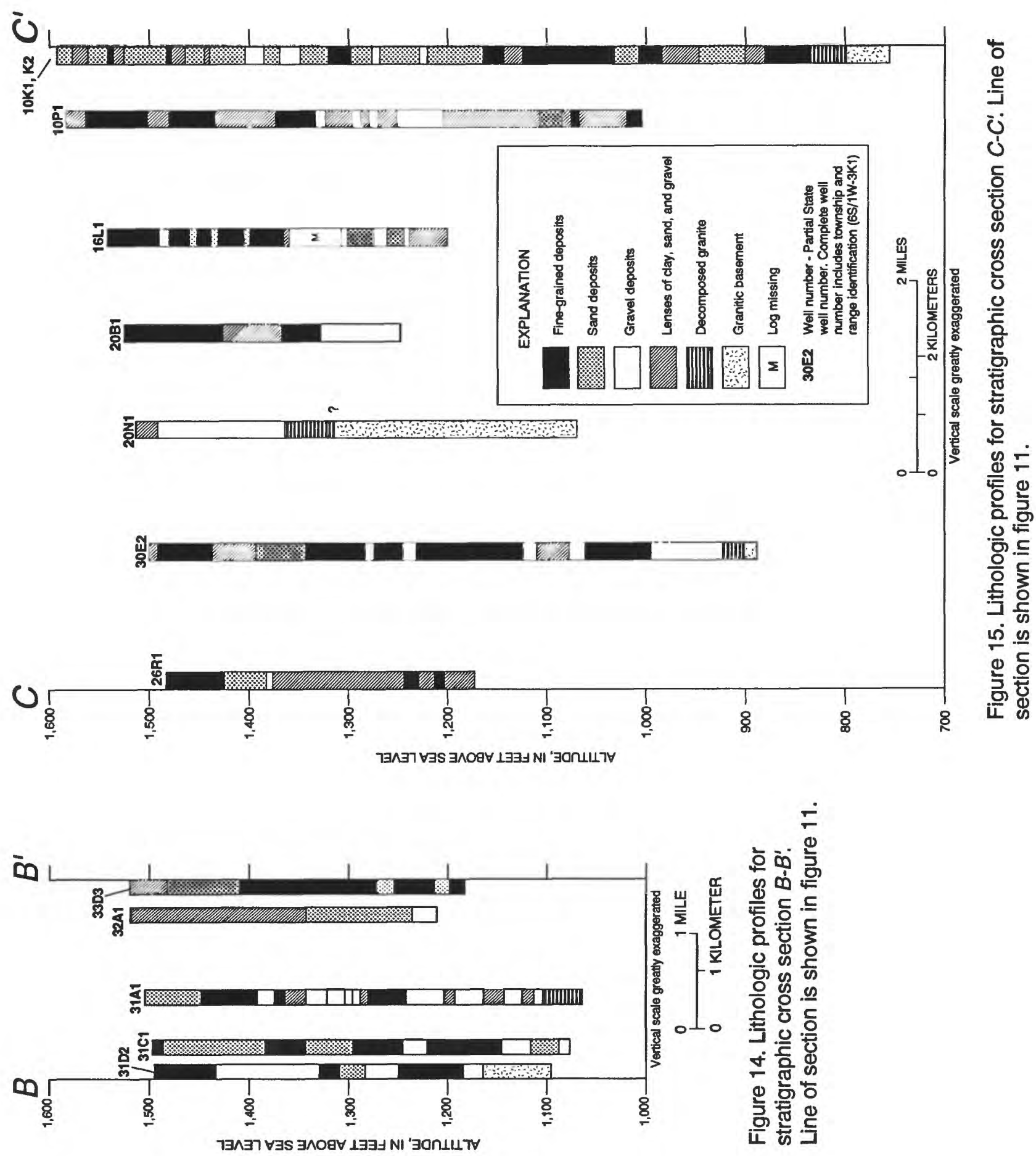
silty sand; gravel; and clayey, silty, and sandy gravel. Fine-grained sediment consists principally of clay, sandy clay, and silt. Compound descriptions were broken down into fractions for tabulation. For example, "sand and clay" was counted as 50 percent sand and 50 percent clay for the described interval. Also, descriptive modifiers such as "streaks" or "lavers" were assigned a value of 34 percent for the described interval. For example, "sand with streaks of clay" was counted as 66 percent sand and 34 percent clay.

The contoured percentages of coarse-grained sediment shown on each texture map were grouped into three broad categories: (1) greater than 80 percent, (2) between 50 and 80 percent, and (3) less than 50 percent. Category 3 represents areas of primarily fine-grained sediment.

Four generalized stratigraphic cross sections were constructed to gain a better understanding of the stratigraphy and thickness of alluvial deposits in the Hemet subbasin. On the basis of interpretation of driller's logs, alluvial sediment was grouped into four broad categories: (1) fine-grained sediment, including clay, sandy clay, silt, and topsoil; (2) sand deposits, including clayey, fine, medium, and coarse sand; (3) gravel deposits, including sand and gravel, cobbles, and boulders; and (4) interbedded layers of clay, sand, and gravel. In this report, the term "sand" designates coarse sand. For wells penetrating the underlying bedrock or residuum, two additional categories were used: (5) decomposed granite and (6) granitic basement rocks. In the Hemet subasin, most of the bedrock material consists of granitic rock. Decomposed granite, formed by the in-place weathering of the granitic basement rocks, represents a transition zone between the overlying alluvium and the underlying basement rocks.

It was not possible to determine the geologic contact between "younger" and "older" alluvium from the lithologic descriptions given in the driller's logs because these logs do not consistently describe color, cementation, or drilling time. Borehole geophysical-log data would aid in the interpretation of the contact; however, such data are sparse in the Hemet subbasin.

\section{Results of analysis}

Although this analysis does not provide a detailed description of the alluvial stratigraphy or an account of the geomorphic history of the basin, the texture maps and geologic sections can be used as a general guide to the areal and vertical distribution of deposits in the basin.

As shown on the texture maps (figs. 5-10), relatively thick deposits of coarse-grained sediment are concentrated in two main areas of the subbasin. The first is near the base of Bautista Canyon, the principal drainageway into the Hemet Basin, and the second is south of San Jacinto Reservoir, in the north-central part of the basin. This second area corresponds to the outwash area of the buried stream channel identified by Biehler and Lee (1993) on the basis of gravity surveys. Relatively shallow deposits of coarse-grained sediment also are concentrated near minor drainages. The delineation of these areas is based on lithologic data derived from a single driller's log.

Fine-grained sediment (less than 50 percent coarse-grained materials) dominates in the central part of the subbasin between Park Hill and the Winchester subbasin boundary, and in the extreme northern and southern parts of the subbasin. Concentrations of fine-grained sediment also are present east and west of the coarse-textured deposits in the north-central part of the subbasin.

Also, shallow sediment (to a depth of about 100 $\mathrm{ft}$ below land surface) is predominantly fine grained throughout most of the subbasin. With increasing depth below land surface, the percentage of fine-grained sediment decreases in most parts of the subbasin; in the western and extreme northern parts of the subbasin, however, it remains relatively high. In the southern part of the subbasin (the Domenigoni and Diamond Valleys), lithologic data are shown only in the texture maps representing the first 100-foot section because the thickness of alluvium is less than $180 \mathrm{ft}$.

In the eastern part of the subbasin and near the Casa Loma Fault, the percentage of coarse-grained sediment increases with increasing depth below land surface, reaching a maximum at a depth of 300 to $400 \mathrm{ft}$.

As indicated in the stratigraphic cross sections (figs. 12-15), alluvial deposits in most parts of the subbasin consist of interbedded layers of clay, sand, and gravel. These layers range in thickness from a few feet (at well 5S/1W-22D3, for example) to tens of feet (well 4S/1W-31A1) (fig. 13).

Deposits of coarse-grained sediments ranging in thickness from 40 to more than $100 \mathrm{ft}$ are present in some parts of the subbasin. Generally, these deposits are composed of fine-to-coarse sand and 
are present in the north-central and central parts of the basin at depths greater than $150 \mathrm{ft}$ below land surface (see fig. 12, wells $4 \mathrm{~S} / 1 \mathrm{~W}-30 \mathrm{G} 1$ and $5 \mathrm{~S} / 1 \mathrm{~W}$ $8 \mathrm{H} 1$, and fig. 13, well 5S/1W-9A1). In comparison, thick deposits of coarse sediment composed of gravel or sand and gravel are present, in general, along the perimeter of the basin, near Bautista Canyon (fig. 13, well 5S/1E-18C1) and at the base of the Lakeview Mountains (fig. 13, wells $4 \mathrm{~S} / 2 \mathrm{~W}-13 \mathrm{H} 2$ and $-24 \mathrm{Al}$; fig. 14, well 4S/1W-31D2).

Thick deposits of fine-grained sediment are present in some parts of the subbasin. Generally, these deposits are at depths of less than $200 \mathrm{ft}$ below land surface (fig. 13, well $4 \mathrm{~S} / 2 \mathrm{~W}-13 \mathrm{H} 2$; fig. 12 , well 5S/1W-8H1; fig. 15 , well 5S/1W-20B1).

The thickness of alluvial deposits varies considerably within the Hemet subbasin. For example, the thickness of alluvium increases by more than $700 \mathrm{ft}$ in less than $1 \mathrm{mi}$ near the northeast side of the city of Hemet (fig. 13, wells $5 \mathrm{~S} / 2 \mathrm{~W}-13 \mathrm{D} 1,5 \mathrm{~S} / 1 \mathrm{~W}-11 \mathrm{P} 2$, and $5 \mathrm{~S} / 1 \mathrm{~W}-10 \mathrm{~K} 1$ ). The greatest thickness of alluvial deposits (more than $900 \mathrm{ft}$ ) is in the northern part of the subbasin (fig. 12, well 4S/1W-19Q1). In comparison, in the southern part of the basin (Diamond Valley) and southeast of the city of Hemet, the thickness of alluvium commonly is less than $150 \mathrm{ft}$.

Deposits of clay, sand, or gravel in the Hemet subbasin are not continuous over large distances, even in areas where relatively thick sections of the deposits occur. Over short distances, however, some deposits may be continuous. For example, gravel and clay deposits at wells $4 \mathrm{~S} / 2 \mathrm{~W}-13 \mathrm{H} 2$ and $4 \mathrm{~S} / 2 \mathrm{~W}-24 \mathrm{Al}$ show some continuity at altitudes of 800 and $1,000 \mathrm{ft}$ (figs. 12, 13). Also, continuous deposits of both gravel and clay may exist between wells 4S/1W-31D2, 4S/1W-31Cl and 4S/1W-31A1 (fig. 14) at altitudes of approximately $1,200 \mathrm{ft}$. Because of the inconsistency of lithologic descriptions between driller's logs, however, the continuity of alluvial deposits cannot be reliably determined without the aid of borehole geophysical data.

\section{Ground-Water Storage and Ground-Water Flow, 1991-92}

Ground water stored in the alluvial deposits of the Hemet subbasin is a major resource for the people of southwestern Riverside County, California. EMWD (1990) estimated that groundwater storage in the Hemet subbasin in 1975 was
640,000 acre-ft, which represented 14 percent of the total ground-water storage within the EMWD service area. The value of 640,000 acre-ft of water at the 1990 Metropolitan Water District of Southern California (MWD) wholesale price of $\$ 384$ per acre-foot (Metropolitan Water District of Southern California, 1990) was $\$ 246$ million. Total storage capacity for the Hemet subbasin was estimated (Eastern Municipal Water District, 1990) to be $1,000,000$ acre-ft.

One of the objectives of this study was to determine 1990-92 ground-water conditions in the Hemet subbasin. A water-level and water-quality network of 73 wells, including wells installed at the land-use sites, and 2 springs was established. Wells were selected on the basis of location within the basin, as well as the quality and quantity of available information about the wells and their installation. Forty-three wells in the network were monitored for water-table altitude quarterly for the duration of the study. From these water-table data (given in Supplemental Data 1), a map of the potentiometric surface or water table can be constructed and ground-water flow patterns in the basin can be determined. Then, by integrating between the water-table surface and the bedrock surface determined by Biehler and Lee (1993), one can calculate the volume of alluvial-fill material saturated by water. The intergrain porosity can be calculated for that saturated volume using the grainsize distributions described in the preceding section. Finally, multiplying the porosity by the saturated volume gives the volume of water stored in the basin.

The water-table surfaces for 1991 and 1992 (shown in figures 16 and 17, respectively) illustrate that, with the exception of the Diamond Valley area where the water table has risen, the water table has dropped significantly during the course of this study. The greatest declines have been in the Bautista Canyon outwash area in the southeast part of the basin, and in the northern parts of the subbasin. In these areas, the water-table decline ranges from 13 to $20 \mathrm{ft}$. The decline has been less dramatic (about $5 \mathrm{ft}$ ) in the central part of the subbasin. By integrating the volume of water in storage in January 1991 (343,000 acre-ft) and comparing it with the volume in storage in August $1992(327,000$ acre-ft), one finds that 16,000 acre$\mathrm{ft}$ has been removed from storage in 2 years. Rainfall in the Hemet subbasin during 1991 was 14.56 in (National Oceanic and Atmospheric Administration, 1991), which is 3.14 in more than the long-term average. However, more than half, 


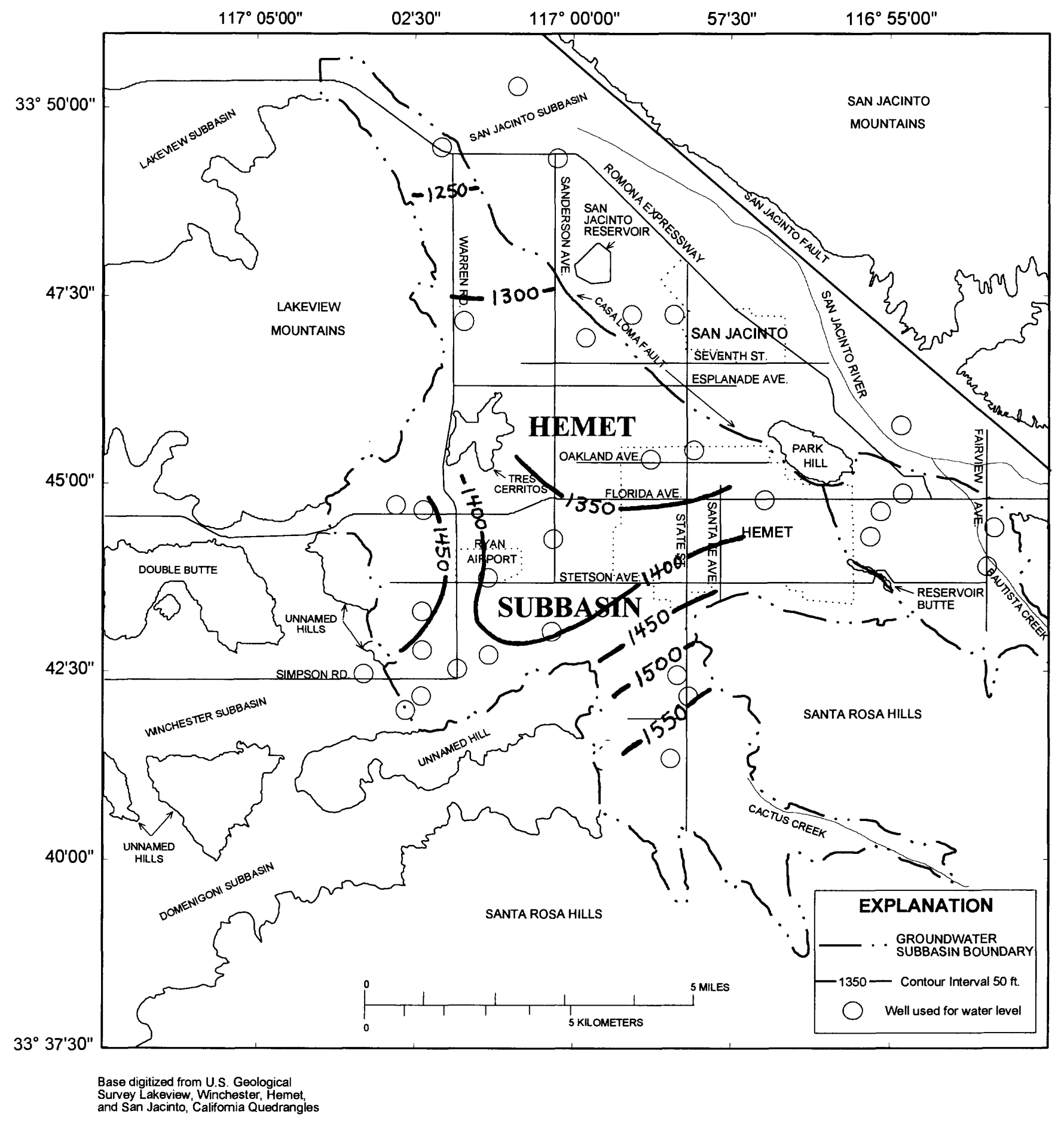

Figure 16. Water table elevations in the Hemet Subbasin and vicinity for Spring, 1991. 


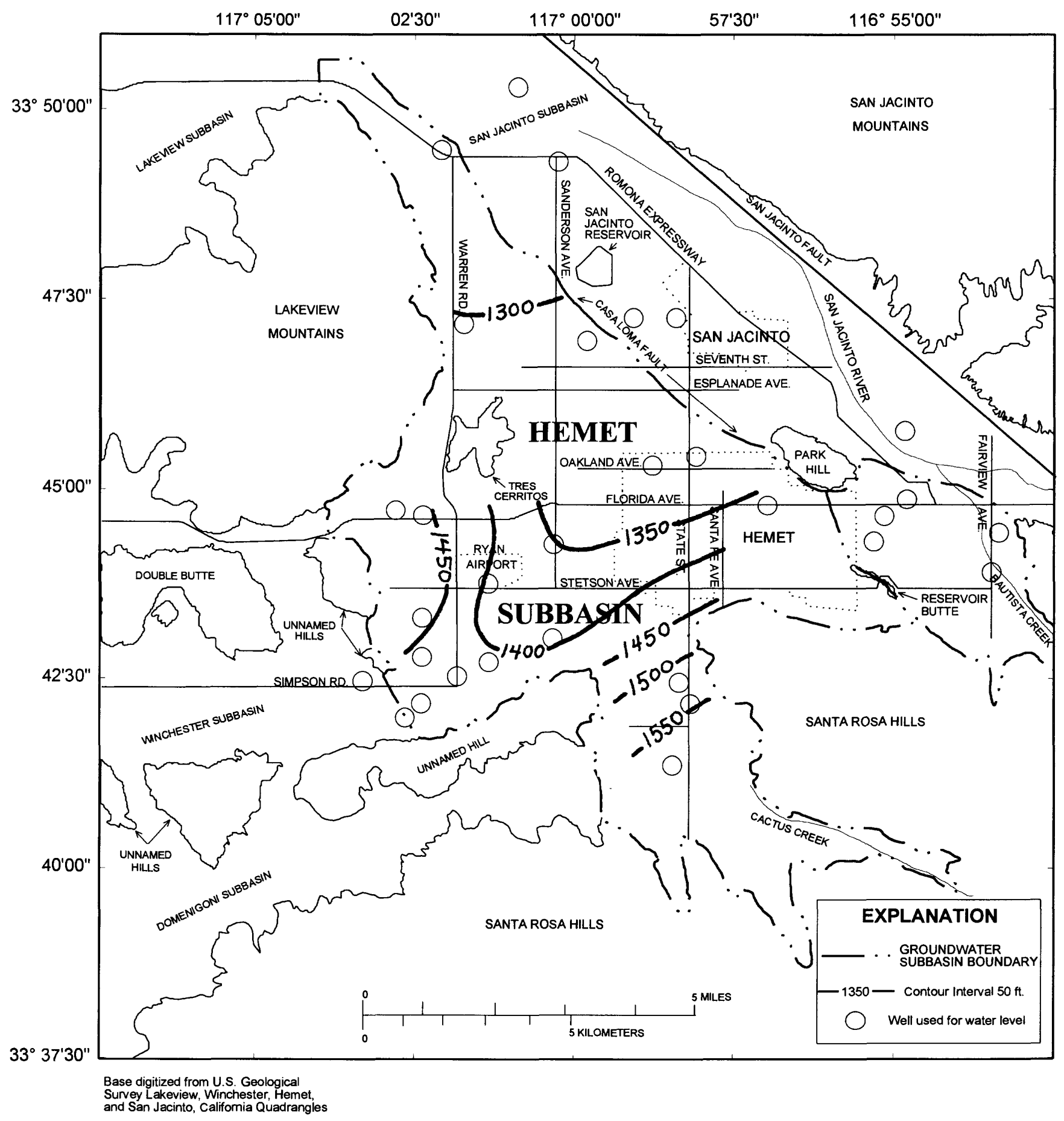

Figure 17. Water table elevations in the Hemet Subbasin and vicinity for Fall. 1992. 
8.35 in, fell in March; most months in 1991 had below normal precipitation. (At the time of this report, climatological data for 1992 have not been officially compiled.)

Ground-water flow in the subbasin is generally from the perimeters toward a large pumping depression underlying the city of Hemet. However, a ground-water divide exists in the area beneath Esplanade Avenue; north of this divide, groundwater flow is to the north. Most recharge is from Bautista Creek and from Cactus Creek in the Diamond Valley area. The water table in the Diamond Valley area rises quickly in response to rainfall, primarily because of the shallowness of alluvial fill in that area. Water seems to be moving from the Winchester subbasin into the Hemet subbasin, a reversal of historical conditions (Richard Morton, EMWD, oral commun., 1990). Although some ground water flows out of the northernmost part of the Hemet subbasin into the Lakeview subbasin, most of the discharge from the Hemet subbasin seems to be attributable to pumpage.

\section{Menifee Ground-Water Subbasin and Chino Ground-Water Basin}

The reclaimed-water site and the auxiliary dairy site were located in the Menifee subbasin and the Chino Basin, respectively. It is beyond the scope of this report to present a detailed description of these basins; therefore, only a brief summary is given.

The Menifee subbasin (fig. 2) is in southwestern Riverside County, California, $6 \mathrm{mi}$ west of the Hemet subbasin. The basement consists of crystalline metamorphic rocks, and outcrops of these rocks form most of the basin boundaries. Basin deposits consist of cemented sands at depth, and partly cemented sands nearer land surface. The deposits contain only small percentages of clay. A detailed stratigraphic description of the basin fill underlying the reclaimed-water site is given in the "Reclaimed-Water Site" section of this report.

Water-level measurements indicate that two vertically separated ground-water zones are present in the Menifee subbasin. The shallow zone has a potentiometric surface 8 to $10 \mathrm{ft}$ higher than that of the deep zone. The two zones seem to be separated by a silt and clay layer approximately $237 \mathrm{ft}$ below land surface at the reclaimed-water site. During the course of this study, the potentiometric surface rose $6.56 \mathrm{ft}$ in the shallow zone and $9.90 \mathrm{ft}$ in the deep zone.

The Chino Basin (fig. 2) is geologically distinct from the Hemet and Menifee subbasins. The Chino Basin abuts the San Gabriel Mountains on the north and slopes toward the Santa Ana River, the southern basin boundary, at a rate of $10 \mathrm{ft} / \mathrm{mi}$. Basin deposits consist of a complex series of sand, gravel, silt, and clay layers, but little is known about the areal extent and continuity of stratigraphic units. A detailed stratigraphic description of the basin fill underlying the auxiliary dairy site is given in the "Dairy Sites" section of this report.

Water-level measurements at the auxiliary dairy site indicated no change in head in the progressively deeper piezometers at the site. During the course of this study, the water table rose $2.68 \mathrm{ft}$.

\section{WATER-QUALITY OVERVIEW}

\section{Introduction}

The Hemet subbasin water-quality network (fig. 3 and table 1) consists of the 5 USGS multiple-well study sites (sites 2-6) in the Hemet subbasin; 20 wells in alluvium in the Hemet subbasin; 2 wells in alluvium in the San Jacinto subbasin; 1 well in alluvium in each of the Domenigoni and Winchester subbasins; 3 wells in fractured bedrock in the Lakeview Mountains; and 2 springs (in the Lakeview Mountains and in the Santa Rosa Hills). Water-quality data from the network, for 1990-92, are given in Supplmental Data 2 and 3 and illustrated in figures 18-27.

Stable isotopes in water samples were used to determine the general atmospheric conditions that existed when precipitation occurred, and the degree of evaporation prior to percolation to the water table. This is done by comparing the deviation of the ratios of deuterium to protium $(\delta \mathrm{D}$, in permil) and oxygen-18 to oxygen-16 $\left(\delta^{18} \mathrm{O}\right.$, in permil), in relation to standard mean ocean water (SMOW). Dansgaard (1964) showed that the $\delta^{18} \mathrm{O}$ of precipitation varies in a predictable way in relation to the average temperature conditions under which the atmospheric water condensed to form precipitation. A plot of his results is shown in figure 28. Craig (1961) prepared a $\delta \mathrm{D}-\delta^{18} \mathrm{O}$ diagram that is based on about 400 water samples from rivers, lakes, and precipitation from various countries. In Craig's diagram, reproduced in figure 29 , the data are clustered near a single line, which is called the meteoric-water line. It has been found that 


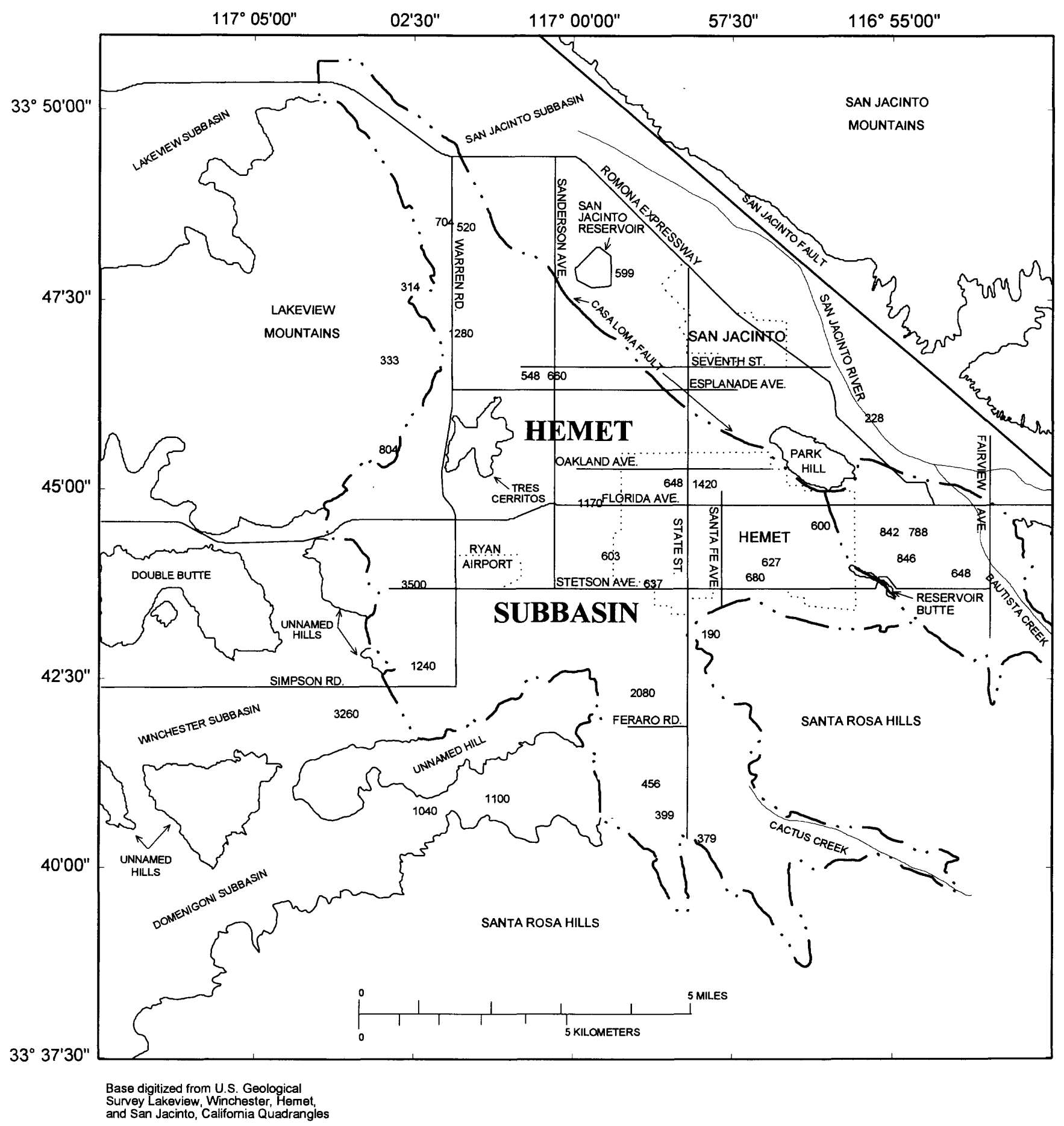

Figure 18. Distribution of dissolved-solids concentration, in milligrams per liter, in the Hemet Subbasin and vicinity. 


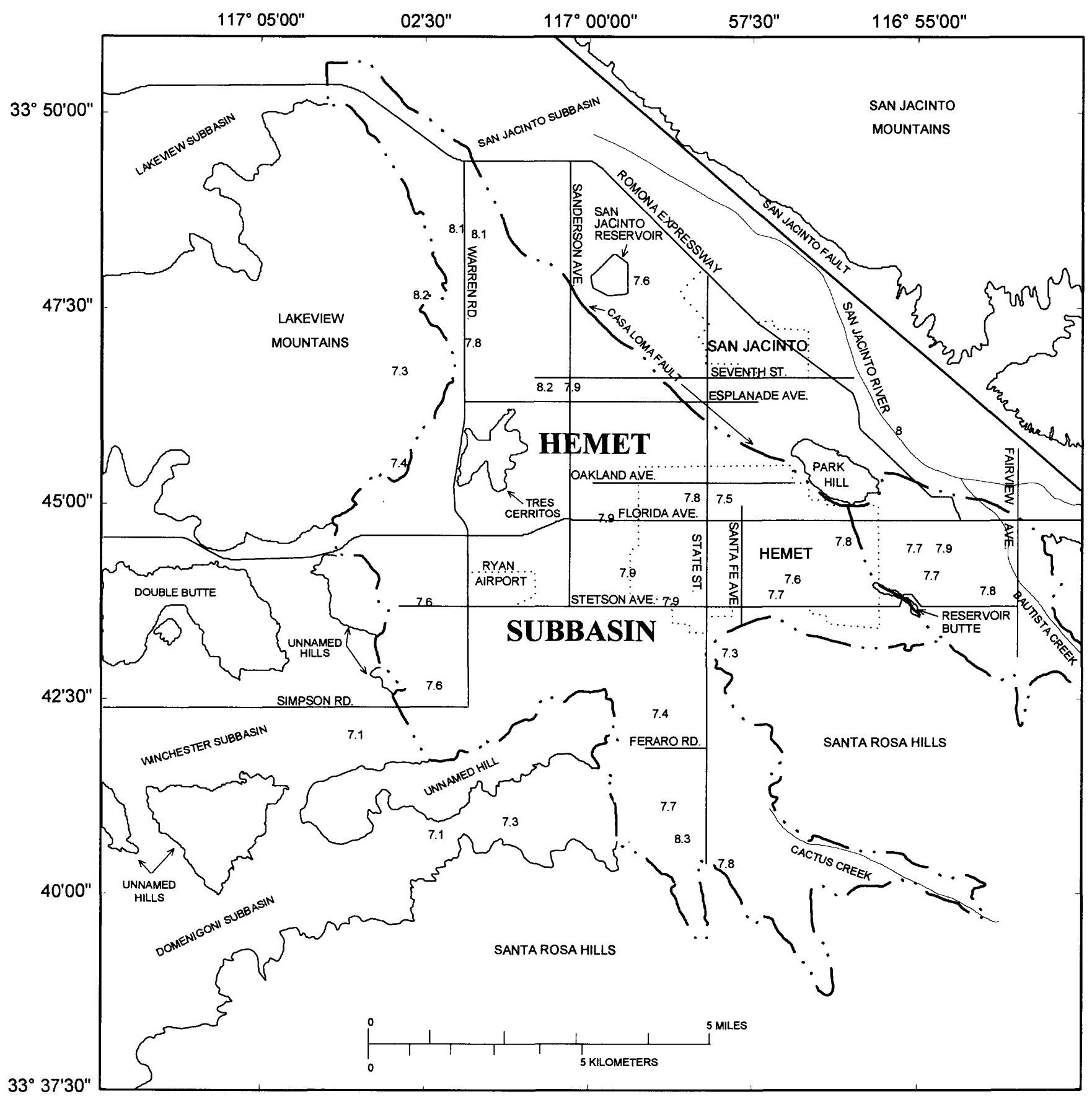

Base digitized from U.S. Geological

Survey Lakeview, Winchester, Hemet,

and San Jacinto, Califomia Quadrangles

Figure 19. Distribution of $\mathrm{pH}$, in standard units, in the Hemet Subbasin and vicinity. 


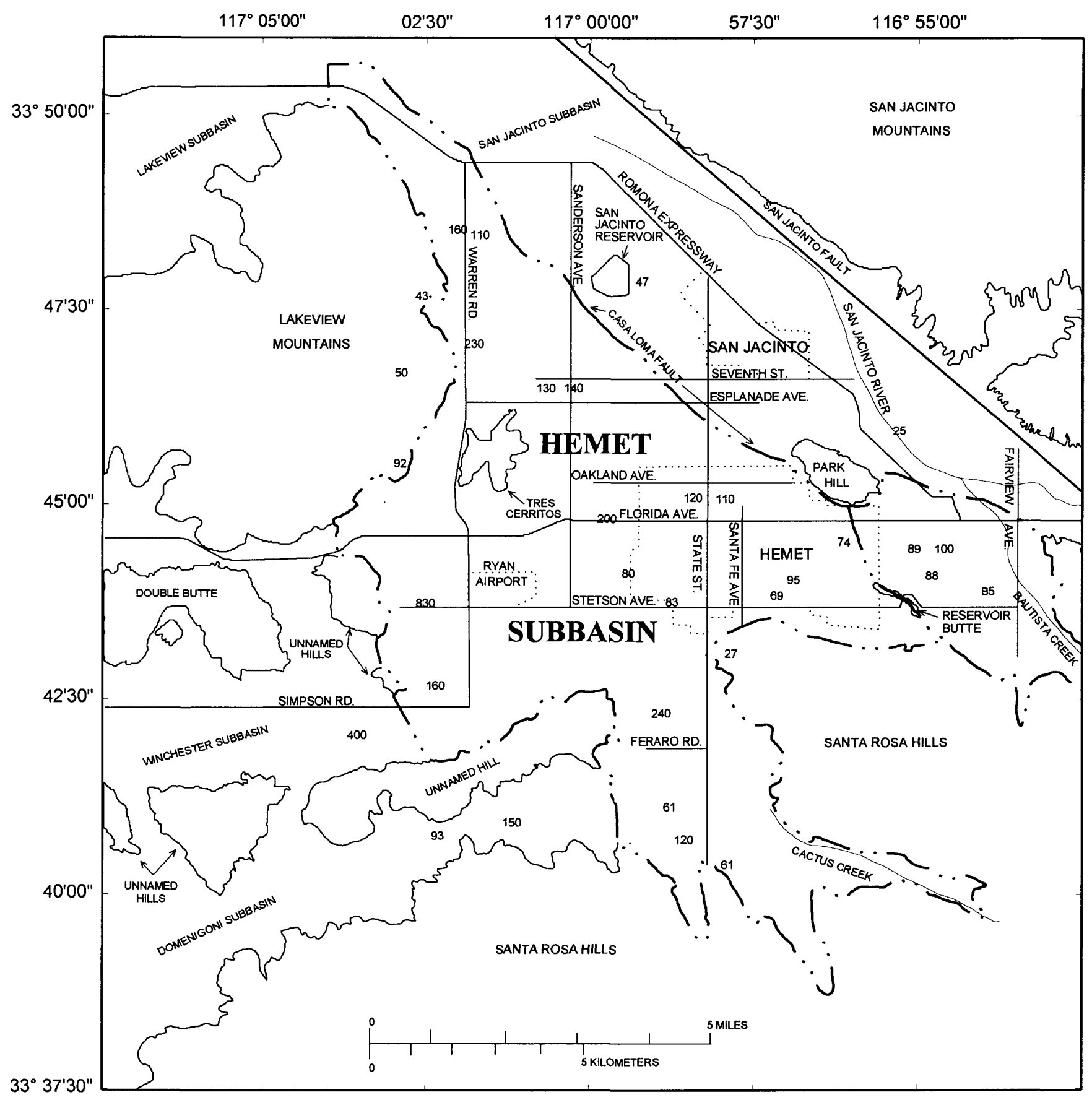

Base digitized from U.S. Geological Survey Lakeview, Winchester, Hemet,

Figure 20. Distribution of sodium concentration, in milligrams per liter, in the Hemet Subbasin and vicinity. 


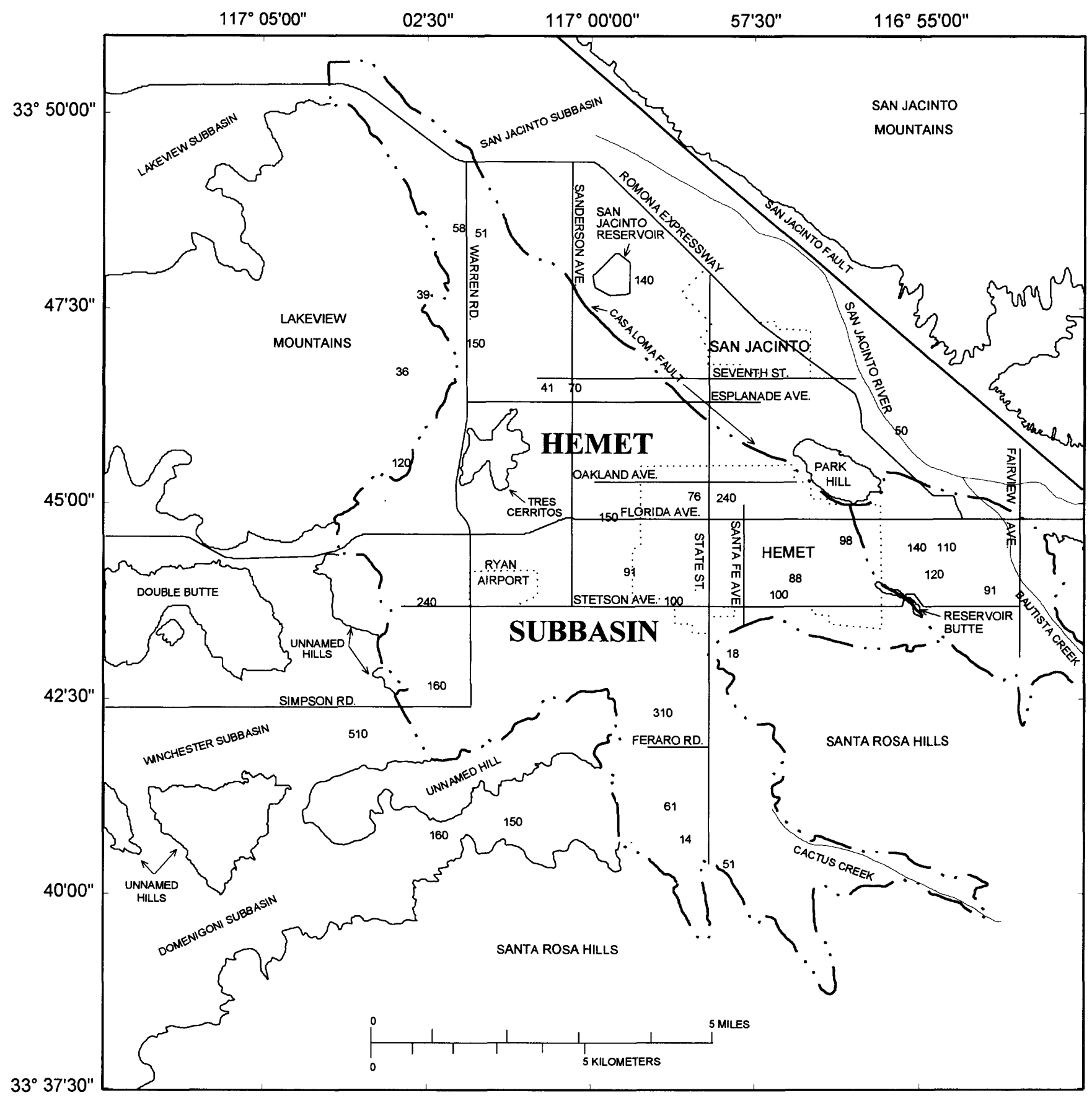

Base digitized from U.S. Geological

Survey Lakeview, Winchester, Hemet,

and San Jacinto, Califomia Quadrangles

Figure 21. Distribution of calcium concentration, in milligrams per liter, in the Hemet Subbasin and vicinity. 


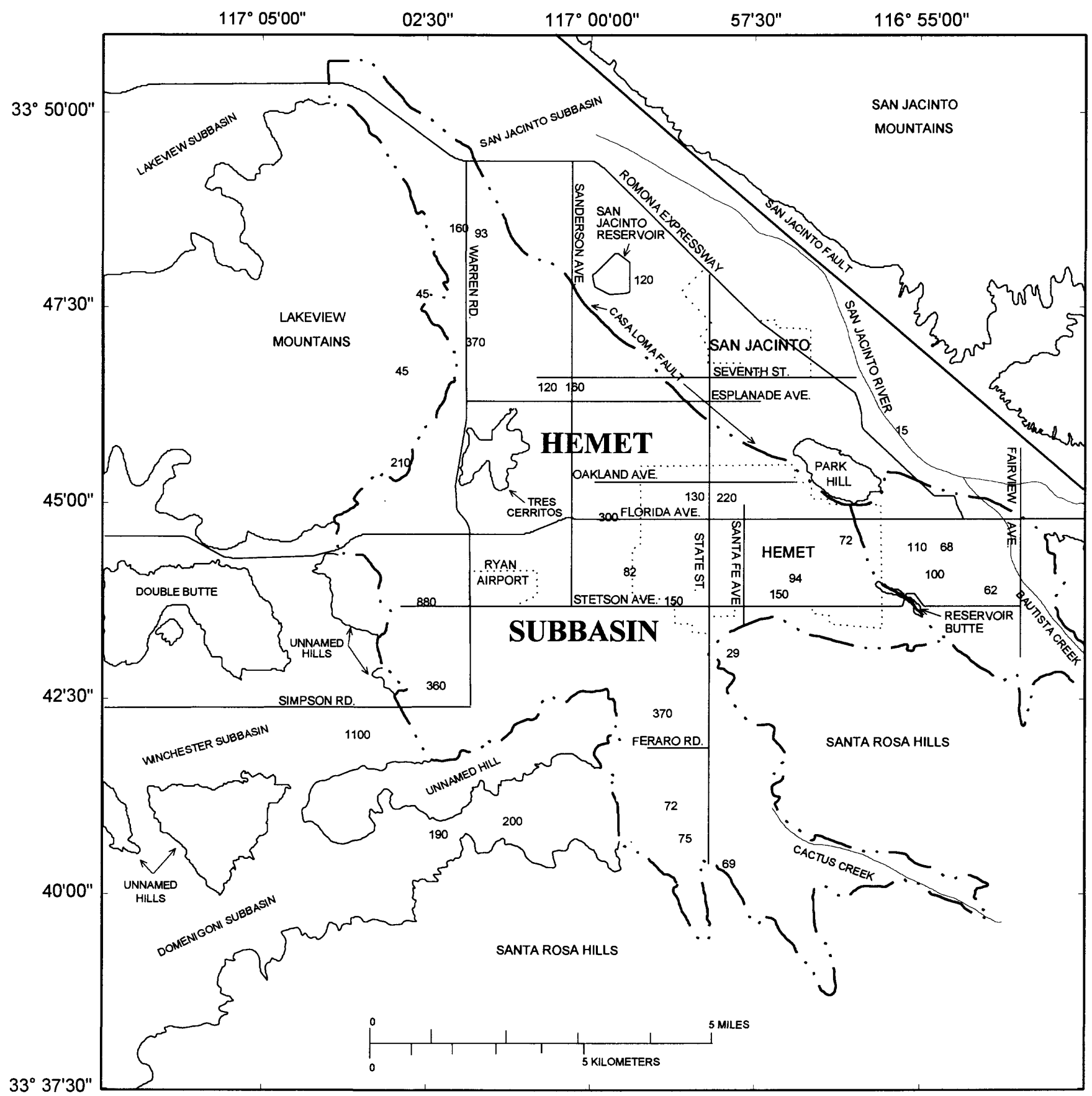

Base digitized from U.S. Geological

Survey Lakeview, Winchester, Hemet,

and San Jacinto, California Quadrangles

Figure 22. Distribution of chloride concentration, in milligrams per liter, in the Hemet Subbasin and vicinity. 


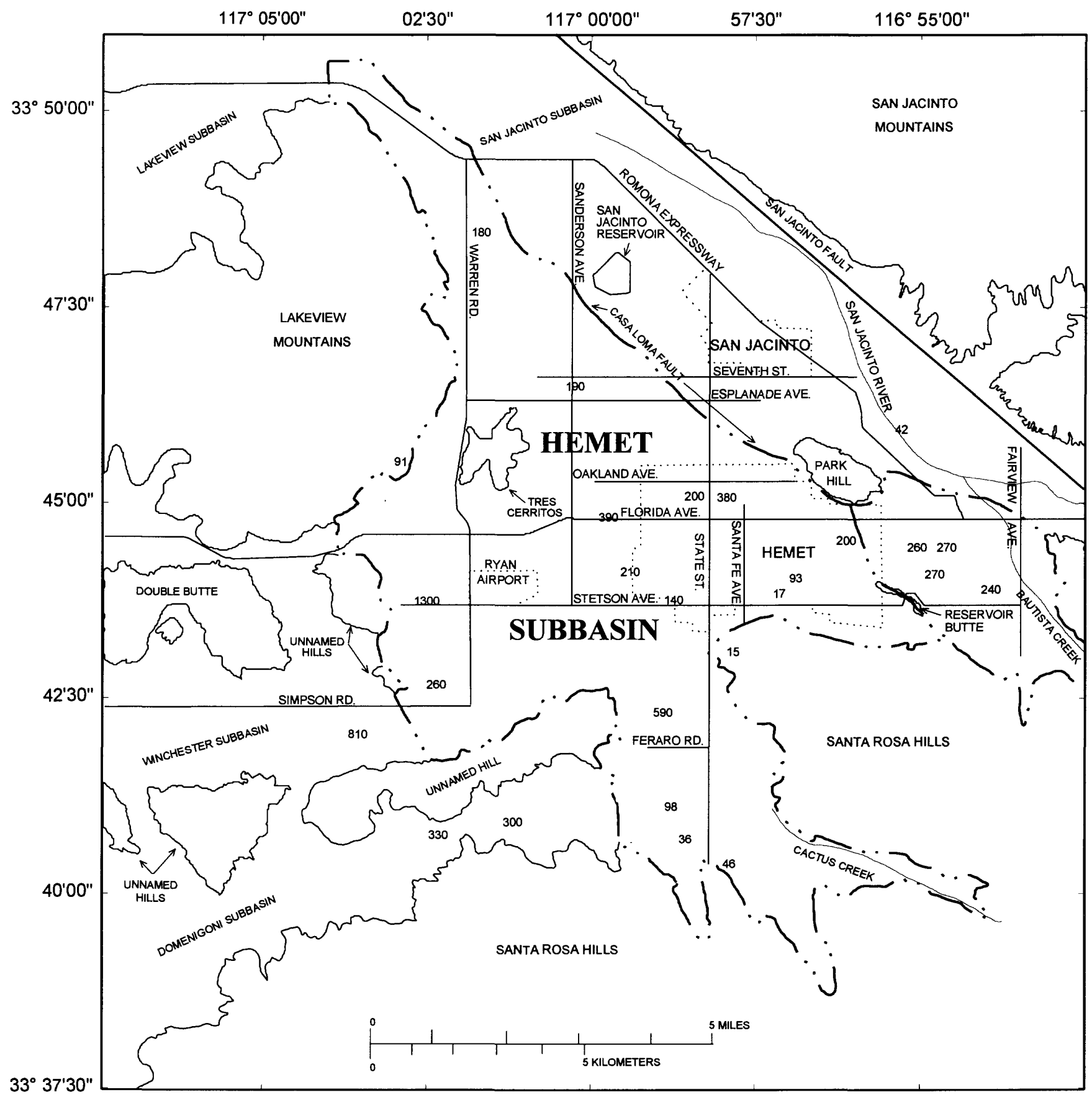

Base digitized from U.S. Geological

and San Jacinto, Califomia Quadrangles

Figure 23. Distribution of sulfate concentration, in milligrams per liter, in the Hemet Subbasin and vicinity. 


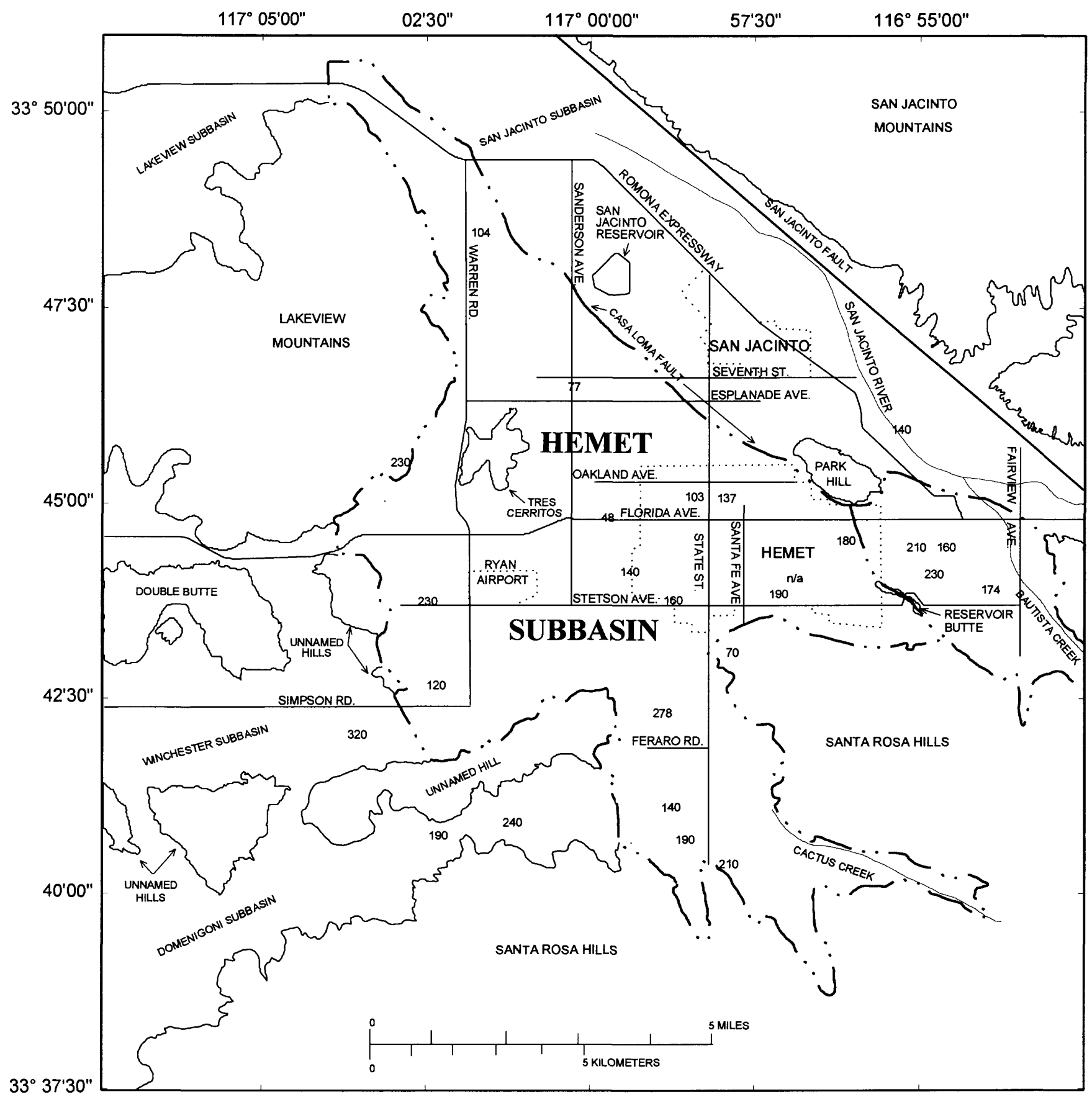

Base digitized from U.S. Geological

Survey Lakeview, Winchester, Hemet,

and San Jacinto, California Quadrangles

Figure 24. Distribution of total hardness, in milligrams per liter as $\mathrm{CaCO}_{3}$, in the Hemet Subbasin and vicinity. 


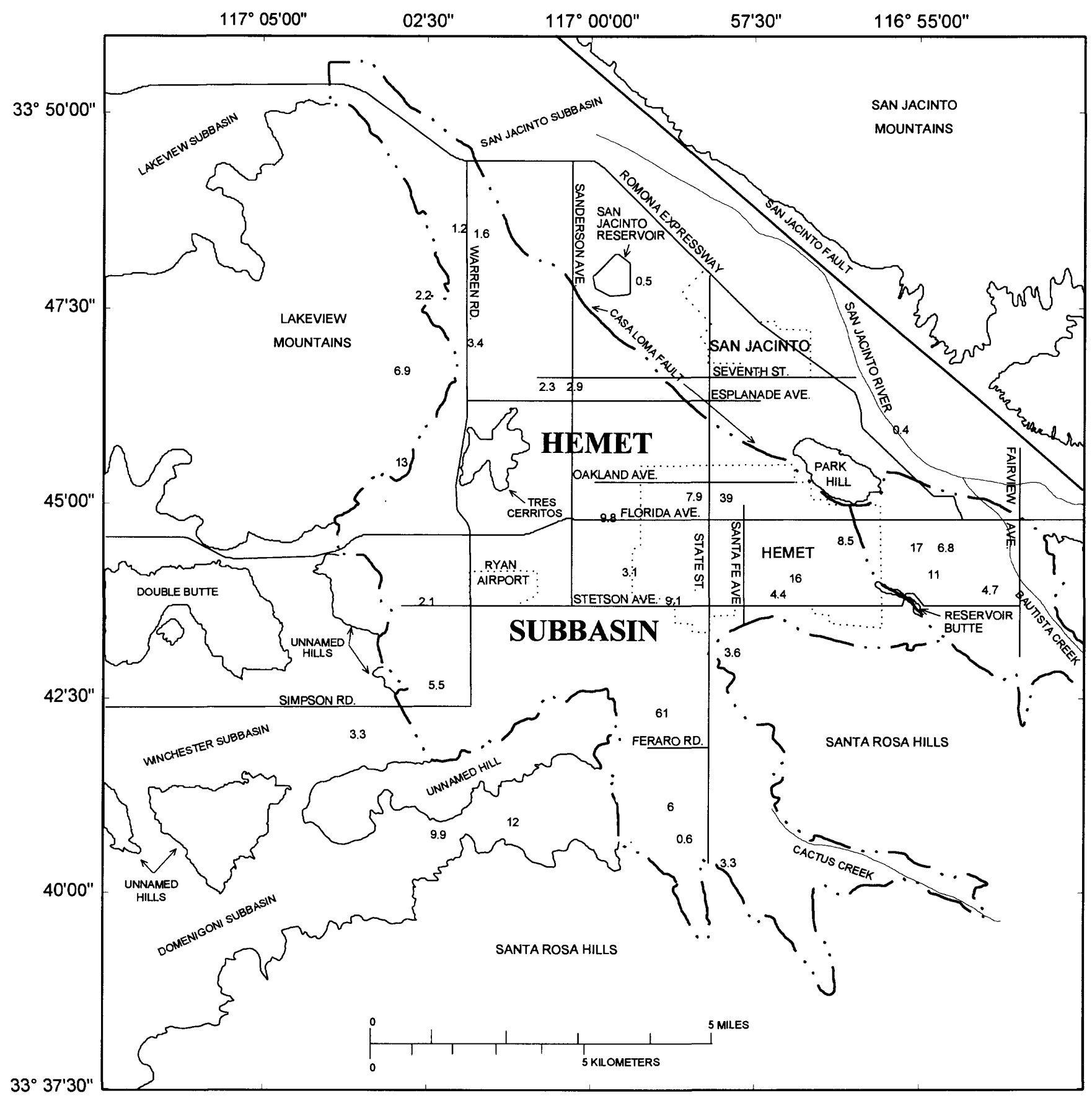

Base digitized from U.S. Geologıcal Survey Lakeview, Winchester, Hemet,

Figure 25. Distribution of nitrate concentration, in milligrams per liter as $\mathrm{N}$, in the Hemet Subbasin and vicinity. 


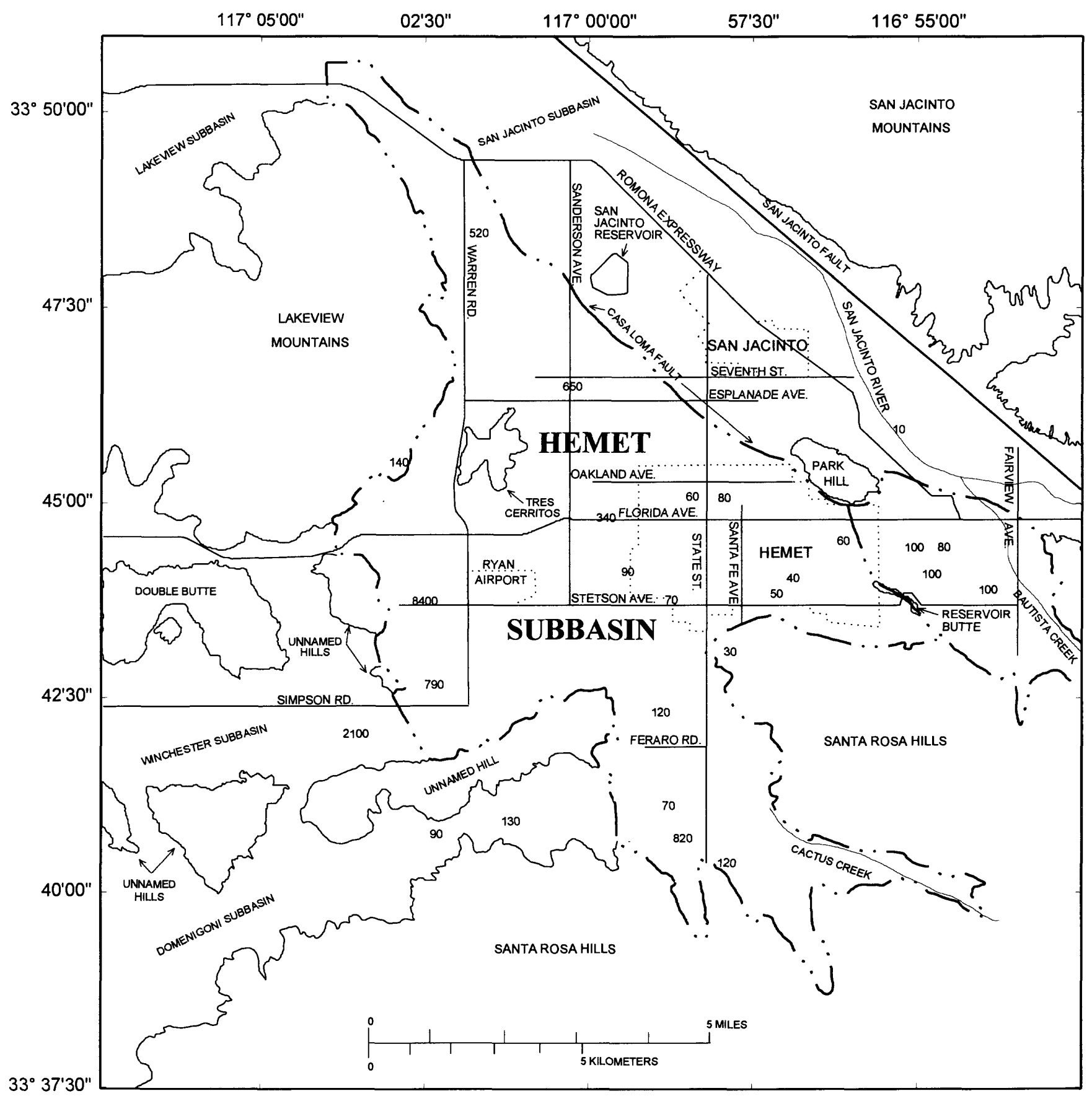

Base digitized from U.S. Geological

Survey Lakeview, Winchester, Hemet,

and San Jacinto, Califomia Quadrangles

Figure 26. Distribution of boron concentration, in milligrams per liter, in the Hemet Subbasin and vicinity. 


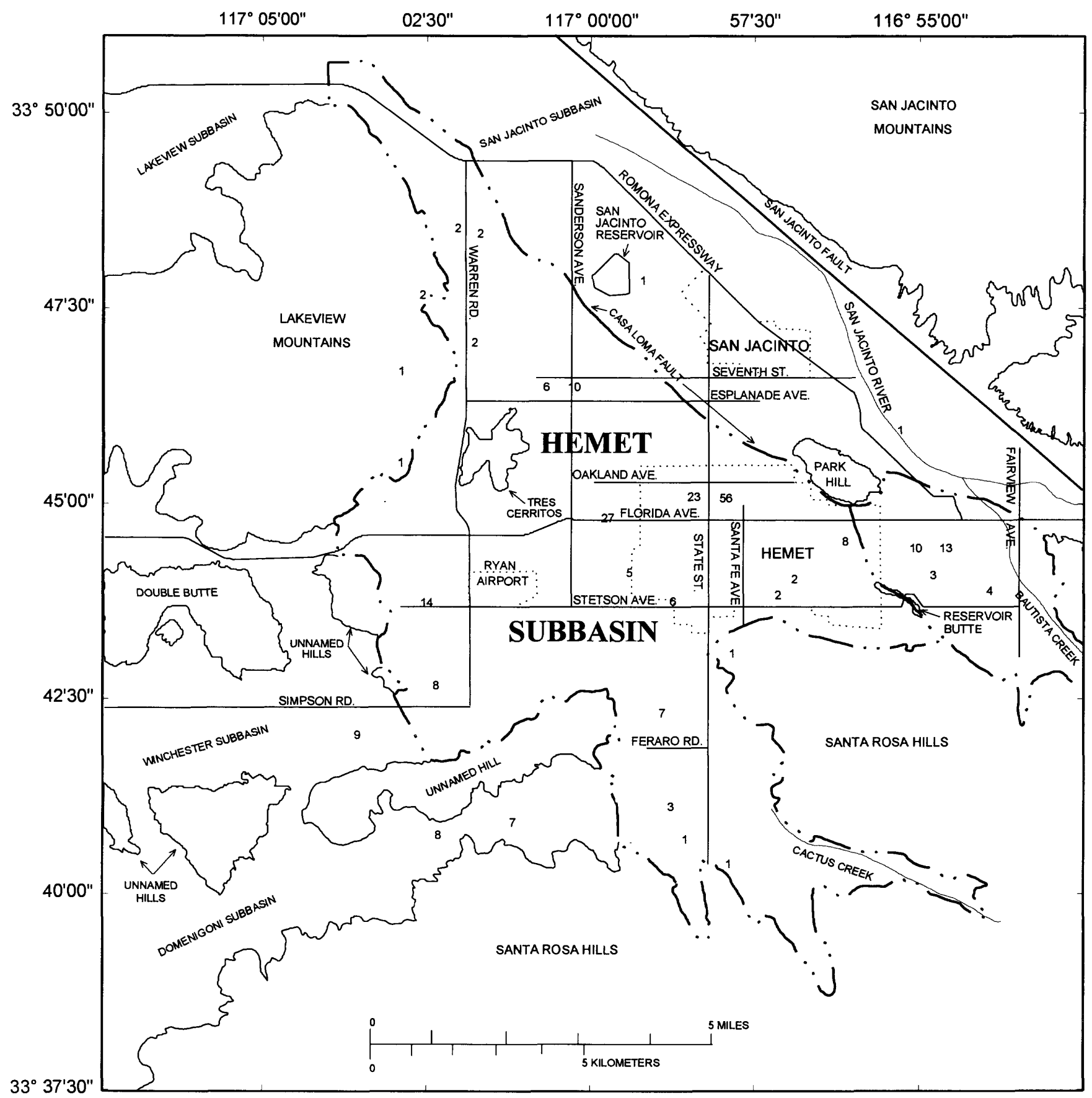

Base digitized from U.S. Geological

Survey Lakeview, Winchester, Hemet.

and San Jacinto, Califomia Quadrangles

Figure 27. Distribution of selenium concentration, in micrograms per liter, in the Hemet Subbasin and vicinity. 


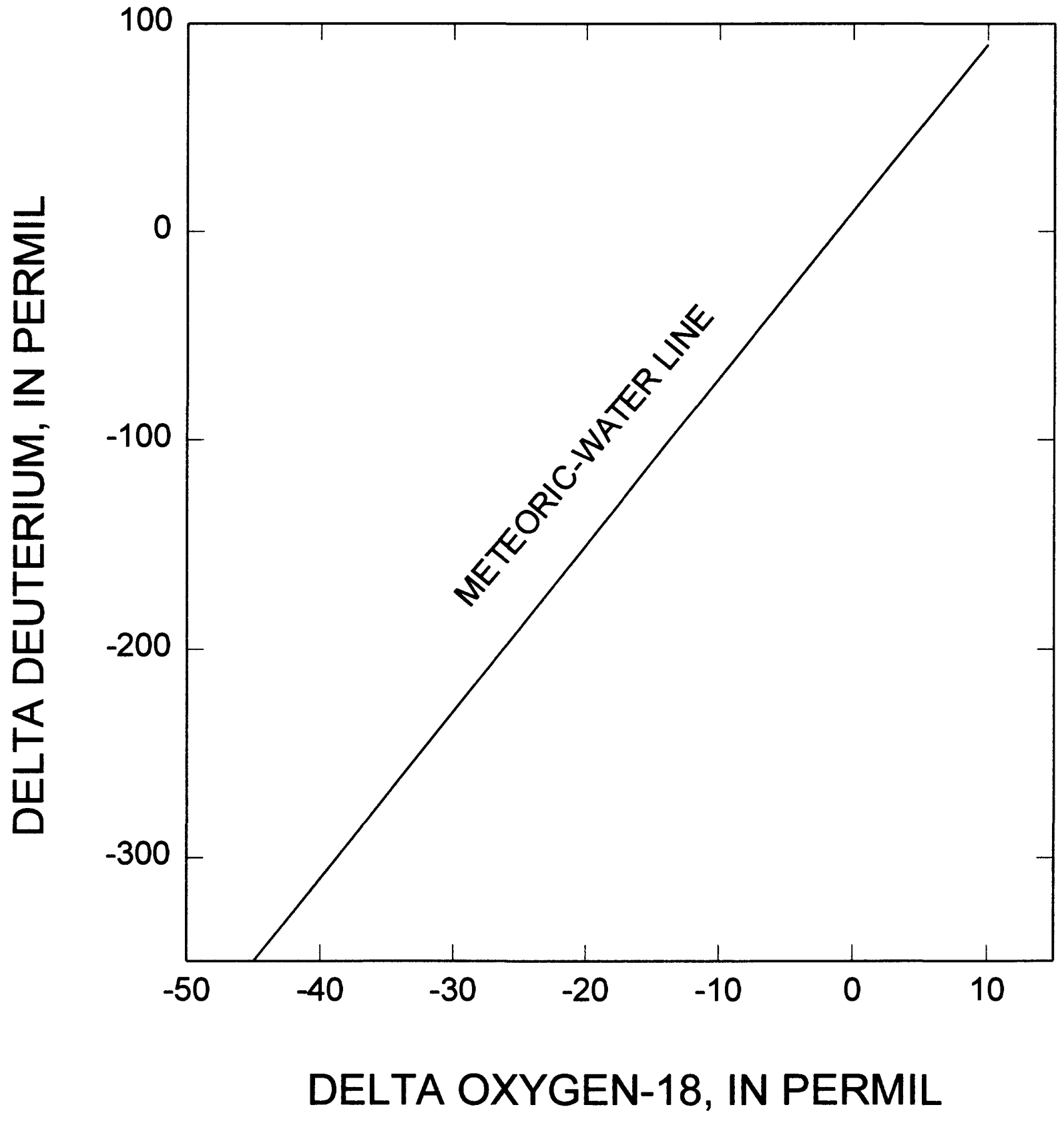

Figure 29. Relation of delta deuterium to delta oxygen-18 (after Craig, 1961). 
waters that have not undergone significant evaporation will plot near this meteoric-water line. Water that has been evaporated to a significant extent will plot below the line.

The deviations of ratios of nitrogen-15 to nitrogen-14 relative to atmospheric nitrogen $\left(8^{15} \mathrm{~N}\right)$ can give some information about the nitrogen source, and can indicate whether any biologically mediated nitrogen speciation changes have occurred. Typically, mineral forms of nitrogen have $8^{15} \mathrm{~N}$ values less than 2 , and animal forms (such as manures, septic wastes, and sewage) have $8^{15} \mathrm{~N}$ values greater than 10 . Microbial processes and incorporation of nitrogen into plant tissue cause the $\delta^{15} \mathrm{~N}$ value to increase, but seldom does this enrichment increase $\delta^{15} \mathrm{~N}$ to a value greater than 10 . Thus, a $8^{15} \mathrm{~N}$ value less than 10 suggests that the nitrogen had a mineral source, and a value greater than 10 suggests an animal source.

Tritium profiles were done for the unsaturated zone beneath each of the instrumented sites. Tritium $\left({ }^{3} \mathrm{H}\right)$ is the radioactive isotope of hydrogen, and it decays with a half-life of 12.3 years. Tritium is formed naturally in the upper atmosphere through cosmic ray interactions (neutrons) with nitrogen: ${ }^{14} \mathrm{~N}+\mathrm{n} \rightarrow{ }^{15} \mathrm{~N} \rightarrow{ }^{12} \mathrm{C}+{ }^{3} \mathrm{H}$. These tritium atoms can be oxidized to water and become mixed with precipitation. The natural production of tritium introduces varying quantities of tritium to precipitation and surface water depending on the latitude and longitude at which the precipitation falls. Michel (1989), who compiled precipitation tritium values for the United States, reported concentrations of about 15 picocuries per liter $(\mathrm{pCi} / \mathrm{L})$ for the southern California area and concentrations as high as $90 \mathrm{pCi} / \mathrm{L}$ for water from the Colorado River.

Nuclear weapons tests during the 1950's and 1960 's also introduced large quantities of tritium to the atmosphere. The peak concentrations occurred in 1963, when fallout tritium concentrations in precipitation in the United States were nearly 3,000 $\mathrm{pCi} / \mathrm{L}$. Since that time, human tritium inputs have greatly decreased, and tritium concentrations in fresh rainfall approximate natural concentrations.

A convenient way to estimate the age of ground water that has recharged since 1950 , or to estimate the rate of movement of water through the unsaturated zone, is to measure the tritium content of the water in a depth profile. In general terms, the following will be observed in the unsaturated zone, assuming that the percolation rates are sufficiently slow that transit time through the unsaturated zone is more than $\mathbf{5 0}$ years: first, a gradual increase in tritium concentration in the pore water with depth to a peak of about $600 \mathrm{pCi} / \mathrm{L}$, then a rapid decrease to less than $1 \mathrm{pCi} / \mathrm{L}$ at greater depths. The peak corresponds to the depth of percolation of 1963water, corrected for radioactive decay.

Water-quality samples were collected during spring and summer, 1991 and 1992. Specific conductance and $\mathrm{pH}$ were measured in the field using probes calibrated with appropriate standards. Alkalinity also was determined in the field by titration with dilute sulfuric acid to $\mathrm{pH} 4.5$. All other analyses were done at the U.S. Geological Survey National Water Quality Laboratory using techniques described by Fishman and Friedman (1989). Major anions were determined using liquid chromatography. Major cations were determined using either atomic absorption spectrophotometry or inductively coupled plasma emission spectrophotometry. Trace metals were determined using inductively coupled plasma mass spectrometry. Dissolved solids were determined by evaporation to constant mass at $180^{\circ} \mathrm{C}$.

\section{Diamond Valley Area}

The Diamond Valley area (fig. 3) is in the southeastern part of the Hemet subbasin east of the Domenigoni Hills. The Hemet dairy multiple-well site (5S/1W-28J), three network wells (5S/1W-33R1, 6S/1W-3M2, and 6S/1W-3R1), and a spring (5S/1W-22RS1) are in this part of the subbasin.

With the exception of water underlying the Hemet dairy site, (described in the "Dairy Sites" section of this report), ground water in alluvium in the Diamond Valley is of good quality. Dissolvedsolids concentration ranged from $379 \mathrm{mg} / \mathrm{L}$ at well $6 \mathrm{~S} / 1 \mathrm{~W}-3 \mathrm{R} 1$ in the southern part of the valley to $456 \mathrm{mg} / \mathrm{L}$ at well $5 \mathrm{~S} / 1 \mathrm{~W}-33 \mathrm{R} 1$ farther north. The predominant ions throughout this area are sodium, calcium, and bicarbonate; increasing percentages of chloride and sulfate are present in northern parts of the valley. The $\mathrm{pH}$ ranged from 7.8 to 8.3 . Nitrate concentrations, which increase from south to north, were below the MCL of $10 \mathrm{mg} / \mathrm{L}$ throughout the area. Boron concentrations ranged from $70 \mu \mathrm{g} / \mathrm{L}$ at well $5 \mathrm{~S} / 1 \mathrm{~W}-33 \mathrm{R} 1$ in the north to greater than 800 $\mu \mathrm{g} / \mathrm{L}$ at well $6 \mathrm{~S} / 1 \mathrm{~W}-3 \mathrm{M} 2$ farther south. Selenium concentrations were low throughout the area.

The Echo Hills Spring (5S/1W-22RS1) probably represents flow originating in fractured 
rocks in the Santa Rosa Hills. This water has a low dissolved-solids concentration $(190 \mathrm{mg} / \mathrm{L})$, and the predominant ions are sodium and bicarbonate. The $\mathrm{pH}$ is neutral (7.3), and boron and selenium concentrations were low. Nitrate concentration was about $4 \mathrm{mg} / \mathrm{L}$.

\section{Bautista Outwash Area}

The Bautista outwash area is in the southeastern part of the Hemet subbasin and consists of deposits of fluvial outwash from Bautista Creek canyon. The area (shown in fig. 3) is southwest of a line connecting Park Hill with the point separating the San Jacinto River canyon from the Bautista Creek canyon, and southeast of a line connecting Park Hill, Reservoir Butte, and the left canyon wall of Bautista Creek canyon. The citrus grove multiple-well site (5S/1E-17Q) and three network wells (5S/1E-18A1, $5 \mathrm{~S} / 1 \mathrm{E}-18 \mathrm{C} 1$, and $5 \mathrm{~S} / 1 \mathrm{E}-18 \mathrm{~K} 1)$ are in this part of the subbasin.

In ground water in this area, dissolved-solids concentration ranged from 650 to $850 \mathrm{mg} / \mathrm{L}$, and the predominant ions were calcium, sodium, bicarbonate, and sulfate. Hardness (as calcium carbonate) was relatively high, ranging from 350 to $500 \mathrm{mg} / \mathrm{L}$, and average $\mathrm{pH}$ was about 7.8. Nitrate concentration generally exceeded the MCL of $10 \mathrm{mg} / \mathrm{L}$. Nitrate concentrations were lowest in the southeastern part of the outwash area and highest along the Park Hill-Reservoir Butte line. Boron concentrations were about $100 \mu \mathrm{g} / \mathrm{L}$ throughout the area.

\section{Winchester Subbasin Area}

The Winchester subbasin area extends from the Hemet subbasin-Winchester subbasin boundary (the valley constriction 2 mi east of Winchester between the Lakeview and Domenigoni Mountains) eastward $1 \mathrm{mi}$ into the Hemet Basin. This area is southwest of Ryan Airport. There are two network wells $(5 \mathrm{~S} / 2 \mathrm{~W}-24 \mathrm{C} 2$ and $5 \mathrm{~S} / 2 \mathrm{~W}-25 \mathrm{Cl})$ in this area.

Ground water in this area is of poor quality. Dissolved-solids concentrations ranged from 1,240 to $3,860 \mathrm{mg} / \mathrm{L}$. The predominant cation was sodium, and anions consisted of approximately equal concentrations of chloride, sulfate, and bicarbonate. The composition of ground water in this area is distinctly different from that observed elsewhere in the basin. The $\mathrm{pH}$ was about 7.7. Nitrate concentrations were relatively low, less than $5 \mathrm{mg} / \mathrm{L}$, in this area. Alkalinity was high, greater than $500 \mathrm{mg} / \mathrm{L}$. Boron concentrations also were high, ranging from $790 \mu \mathrm{g} / \mathrm{L}$ at well $5 \mathrm{~S} / 2 \mathrm{~W}-25 \mathrm{Cl}$ to $8,000 \mu \mathrm{g} / \mathrm{L}$ at well $5 \mathrm{~S} / 2 \mathrm{~W}-24 \mathrm{C} 2$. Selenium concentrations throughout the area were relatively high, about $8 \mu \mathrm{g} / \mathrm{L}$, but less than the MCL.

\section{Main Basin Area}

The remaining parts of the Hemet subbasin will be considered together. The residential (5S/1W-10K), irrigated-farm (4S/1W-32Q), and poultry-farm (4S/1W-19N) multiple-well sites, along with the following network wells, are in the main basin area: $4 \mathrm{~S} / 2 \mathrm{~W}-24 \mathrm{~J} 2,4 \mathrm{~S} / 1 \mathrm{~W}-32 \mathrm{~N} 1$, 4S/2W-36M1, 5S/1W-8R1, 5S/1W-10E1, $5 \mathrm{~S} / 1 \mathrm{~W}-13 \mathrm{C} 1, \quad 5 \mathrm{~S} / 1 \mathrm{~W}-14 \mathrm{~K} 1, \quad 5 \mathrm{~S} / 1 \mathrm{~W}-14 \mathrm{P} 1$, 5S/1W-16L1, 5S/1W-20P2, 5S/1W-21A1.

Ground water in the main subbasin is of relatively good quality. Dissolved-solids concentrations ranged from 600 to $700 \mathrm{mg} / \mathrm{L}$. The predominant cation in ground water in the southern part of the subbasin was calcium, and the predominant anion was sulfate. Sodium and bicarbonate ions were present in smaller percentages. In the northern part of the subbasin, sodium was the predominant cation, and sulfate, bicarbonate, and chloride anions were present in approximately equal percentages. The $\mathrm{pH}$ ranged from 7.5 to 8.2. Nitrate concentrations were quite variable, ranging from 1.2 to $39 \mathrm{mg} / \mathrm{L}$. Nitrate concentrations were generally low in the northern parts of the subbasin, but approached or exceeded the MCL of $10 \mathrm{mg} / \mathrm{L}$ at the following wells: $5 \mathrm{~S} / 1 \mathrm{~W}-8 \mathrm{R} 1,5 \mathrm{~S} / 1 \mathrm{~W}-10 \mathrm{~K}, 5 \mathrm{~S} / 1 \mathrm{~W}-14 \mathrm{~K} 1$, and $5 \mathrm{~S} / 1 \mathrm{~W}-21 \mathrm{Al}$. Data from the residential site (discussed in "Residential Site" section) indicate that nitrate concentrations increased with depth at the residential site. Ground water in the main subbasin generally is hard; hardness (as calcium carbonate) was approximately $200 \mathrm{mg} / \mathrm{L}$ north of Florida Avenue, and greater than $300 \mathrm{mg} / \mathrm{L}$ south of Florida Avenue. Boron concentrations generally were less than $100 \mu \mathrm{g} / \mathrm{L}$ south of Esplanade Avenue (340 mg/L at well $5 \mathrm{~S} / 1 \mathrm{~W}-841$ is an exception) and greater than $500 \mu \mathrm{g} / \mathrm{L}$ north of Esplanade Avenue. Selenium concentrations were relatively high in ground water beneath Florida and Menlo Avenues between Sanderson Avenue and Sante Fe Avenue, and the concentration in water from the 380 -footdeep well at the residential site exceeded the MCL of $50 \mu \mathrm{g} / \mathrm{L}$.

\section{San Jacinto, Winchester, and Domenigoni Subbasins}

The San Jacinto subbasin is immediately 
northeast of the Hemet subbasin, between the Casa Loma and San Jacinto Faults (fig. 3). Two wells (4S/1W-28G1 and 5S/1E-6L2) in the San Jacinto subbasin were included in the network.

Water quality at well $5 \mathrm{~S} / 1 \mathrm{E}-6 \mathrm{~L} 2$ is good; dissolved-solids concentration was less than $250 \mathrm{mg} / \mathrm{L}$. The predominant ions were calcium and bicarbonate. The $\mathrm{pH}$ was about 8.0 , somewhat higher than that of water in the Hemet subbasin. The ground water is relatively soft; hardness (as calcium carbonate) was $140 \mathrm{mg} / \mathrm{L}$. Nitrate, boron, and selenium concentrations were low. The quality of water from well $4 \mathrm{~S} / 1 \mathrm{~W}-28 \mathrm{G} 1$ was similar to that of water in the adjacent Hemet subbasin. suggesting that there might be some cross-fault flow in that area. The dissolved-solids concentration was about $600 \mathrm{mg} / \mathrm{L}$, and the predominant ions were calcium and bicarbonate; smaller quantities of sodium, chloride, and sulfate were present. The $\mathrm{pH}$ was about 7.6. As at the other San Jacinto subbasin well, nitrate, boron, and selenium concentrations were low.

The Winchester subbasin is immediately west of the Hemet subbasin. One well from the Winchester subbasin, 5S/2W-26Pl, was included in the network. Ground water in the Winchester subbasin is of much poorer quality than ground water in the Hemet subbasin. Dissolved-solids concentrations exceeded 3,500 $\mathrm{mg} / \mathrm{L}$. Calcium, sodium, bicarbonate, and chloride ions dominated; sulfate was present in smaller quantities. The $\mathrm{pH}$ was 7.0, which is significantly lower than that in the Hemet subbasin. Hardness (as calcium carbonate) was $1,800 \mathrm{mg} / \mathrm{L}$, which is very high. Nitrate concentration was moderate, about $3 \mathrm{mg} / \mathrm{L}$, at well $5 \mathrm{~S} / 2 \mathrm{~W}-26 \mathrm{P} 1$. The boron concentration, $2,200 \mu \mathrm{g} / \mathrm{L}$, was high. The selenium concentration was $11 \mu \mathrm{g} / \mathrm{L}$.

The Domenigoni subbasin is south of the main part of the Hemet subbasin, and is separated from the Hemet subbasin by the Domenigoni Mountains. The Domenigoni subbasin is immediately west of the Diamond Valley area, and it contains two network wells, $6 \mathrm{~S} / 1 \mathrm{~W}-6 \mathrm{G} 1$ and $6 \mathrm{~S} / 2 \mathrm{~W}-1 \mathrm{~F} 1$.

In the Domenigoni subbasin, dissolved-solids concentration in ground water was approximately $1,100 \mathrm{mg} / \mathrm{L}$, and the dominant ions were calcium, sodium, and sulfate. The $\mathrm{pH}$ was about 7.0 , and hardness (as calcium carbonate) was 550 to $650 \mathrm{mg} / \mathrm{L}$. Nitrate concentration, about $11 \mathrm{mg} / \mathrm{L}$, exceeded the MCL throughout the subbasin. Boron concentrations, 80 and $140 \mu \mathrm{g} / \mathrm{L}$, were moderate. Selenium concentration was about $7 \mu \mathrm{g} / \mathrm{L}$.

\section{Lakeview Mountains}

The Lakeview Mountains form the western border of the Hemet subbasin. Ground water in this area is represented in the network by two fracturedrock wells (4S/2W-36Ml and 5S/2W-2Rl).

Well 4S/2W-36M1 produces water of relatively good quality; dissolved-solids concentration was about $330 \mathrm{mg} / \mathrm{L}$. The predominant ions were sodium and bicarbonate; smaller quantities of calcium and chloride were present. The $\mathrm{pH}$ was 7.3 , and hardness (as calcium carbonate), $150 \mathrm{mg} / \mathrm{L}$, was relatively low. The nitrate concentration, about 7 $\mathrm{mg} / \mathrm{L}$, was relatively high, but less than the MCL. Boron concentration, $130 \mu \mathrm{g} / \mathrm{L}$, was moderate. Selenium concentration was near the detection limit.

Water quality in well $5 \mathrm{~S} / 2 \mathrm{~W}-2 \mathrm{R} 1$ was marginal; dissolved-solids concentration was about $750 \mathrm{mg} / \mathrm{L}$. The predominant ions were calcium and bicarbonate; chloride also was present. The $\mathrm{pH}$ was about 7.4, and hardness (as calcium carbonate), $440 \mathrm{mg} / \mathrm{L}$, was high. The nitrate concentration, $15 \mathrm{mg} / \mathrm{L}$, exceeded the MCL. Boron concentration, $140 \mu \mathrm{g} / \mathrm{L}$, was moderate, and selenium was near the detection limit.

\section{GEOHYDROLOGY, WATER QUALITY, AND NITROGEN GEOCHEMISTRY AT THE STUDY SITES}

\section{Residential Site}

\section{Background}

Ragone and others (1980) reported that lawn fertilizers accounted for about 50 percent of nitrogen loading to the ground water in sewered areas of Nassau County, New York. For turf consisting of Kentucky Blue Grass, red fescue, and rye grass, Baier and Rykbost (1976) reported that removing turf-grass clippings eliminates 13 to 18 $\mathrm{lb} / \mathrm{acre}$ per year of nitrogen, and that this quantity varies little for nitrogen-fertilizer application rates of $0,8.9,17.8$, and $35.6 \mathrm{lb} /$ acre per year. Studies indicate that fertilizer applications exceeding 13 $\mathrm{lb} /$ acre per year could result in significant nitrogen loading to the unsaturated zone. Wellings and Bell (1980) reported that inorganic nitrogen fertilizers applied to a clay loam soil resulted in soil porewater nitrate concentrations greater than $12 \mathrm{mg} / \mathrm{L}$ in the near surface. The concentrations decreased to 
about $5 \mathrm{mg} / \mathrm{L}$ within $1.6 \mathrm{ft}$ of the land surface. Organic slurries applied at equivalent rates to the same soil, however, resulted in pore-water nitrate concentrations greater than $40 \mathrm{mg} / \mathrm{L}$, even at depths to $10 \mathrm{ft}$. Finally, Ryden (1983) reported that, for rye grass, denitrification closely correlated with moisture content of the soil, and that maximum denitrification rates occurred immediately after fertilizer application.

\section{Site Description}

The residential site (site 4 in fig. 3 ) is in the Hemet subbasin, two blocks north and two blocks east of the intersection of State Street and Florida Avenue in the city of Hemet. The area is sewered, and city-supplied water is used to irrigate the turf grass at the site.

Instrumentation of the site was completed in two phases. The saturated-zone multiple-depth wells were installed August 17-20, 1990, using the methods described in the "Site Instrumentation and Sample Collection" section. A single 10-inchdiameter bore hole was drilled to a depth of $385 \mathrm{ft}$ using the mud-rotary drilling technique. Wells were installed with screens at depths of $380,310,245$, and $215 \mathrm{ft}$ and developed using a high-volume air compressor to airlift water and surge the filter pack.

The unsaturated-zone instrumentation was installed November 8-10, 1990. The first hole was drilled to $115 \mathrm{ft}$, and continuous core was collected using the aseptic techniques described in the section mentioned above. A sealed 2-inch-diameter galvanized pipe was set in this bore hole at $105 \mathrm{ft}$ to serve as a neutron-probe access tube. Copper gassampling tubes $(0.25$-in.) were attached to the galvanized pipe at depths of $100,75,50$, and $25 \mathrm{ft}$. The bore hole was backfilled with native material to a depth of $14 \mathrm{ft}$ and a bentonite seal was installed to land surface. The second hole also was drilled to $115 \mathrm{ft}$, and lysimeters were installed in this bore hole at depths of $113,100,75$, and $50 \mathrm{ft}$. The third hole was drilled to $32 \mathrm{ft}$. The bore hole was backfilled with native material to $25.3 \mathrm{ft}$, and lysimeters were installed in this bore hole at depths of $25,15,10$, and $5 \mathrm{ft}$.

Illustrated in figure 30 are geophysical logs; the completion zones for the saturated-zone wells; and the lithology interpreted from the driller's and geologist's logs, the geophysical logs, and the core observations. As can be seen in the caliper log, significant caving occurred in only a few zones, notably the zones between 85 and $105 \mathrm{ft}$. and between 290 and $315 \mathrm{ft}$. The upper zone consists of fine to medium sands above a clay layer, and the lower zone consists of fine sand to coarse gravel above a cemented sand zone. In the gammaradioactivity $\log$, a characteristic increase in activity can be seen at the clay layers; the log indicates that even in zones consisting primarily of coarse material, there are layers containing significant quantities of silt and clay. The spontaneouspotential $\log$ is useful in locating the interface between dissimilar layers. The major deflection at $146 \mathrm{ft}$ is interpreted as the interface between the fine sand and the clay layer at that depth. The longnormal and short-normal resistivities are useful in identifying zones in which the drilling fluids have penetrated the surrounding formations, thus indicating zones of significantly greater hydraulic conductivity. Such zones commonly are interpreted to be zones that will yield the most water. The interpreted lithology indicates that the deposits beneath the residential site consist of interspersed layers of fine sand, gravel, and clay. Several of the clay layers are sufficiently thick to impede the percolation of water and thus the vertical migration of dissolved constituents.

Samples were collected from the cores at selected depths to determine the particle-size distributions in various lithologic units. These distributions are shown in figure 31 . The $3 \mathrm{ft}$. and $10 \mathrm{ft}$. samples have virtually identical distributions, and about 80 percent of the particles are between 62 and $500 \mu \mathrm{m}$ (fine sand). The $19.2 \mathrm{ft}$. and $39 \mathrm{ft}$. samples have relatively broad distributions; the clay is aggregated into a continuum of silt- and sandsized particles. The clay layers at 50 and $60 \mathrm{ft}$ show the same type of aggregation, but with a shift toward the fine-sand and silt sizes. The $50 \mathrm{ft}$. sample has a significant population of disaggregated particles in the colloid (clay) size. The samples from 80 and $90 \mathrm{ft}$ have characteristic distributions for fine and coarse sand, respectively, and the samples at 93.8 and $100 \mathrm{ft}$ are characteristic of medium sand.

\section{Saturated-Zone Results}

The water-table surface near the residential site was determined by measuring water levels at the multiple-well site $(5 \mathrm{~S} / 1 \mathrm{~W}-10 \mathrm{~K})$ and at wells $5 \mathrm{~S} / 1 \mathrm{~W}-9 \mathrm{~A} 1$, 5S/1W-10B2, and 5S/1W-10E1. These results (given in Supplemental Data 1 and Supplemental Data 3A), along with the configuration of the water-table surface (described in the "Ground-Water Storage and Ground-Water Flow, 1991-92" section), indicate that this site is 


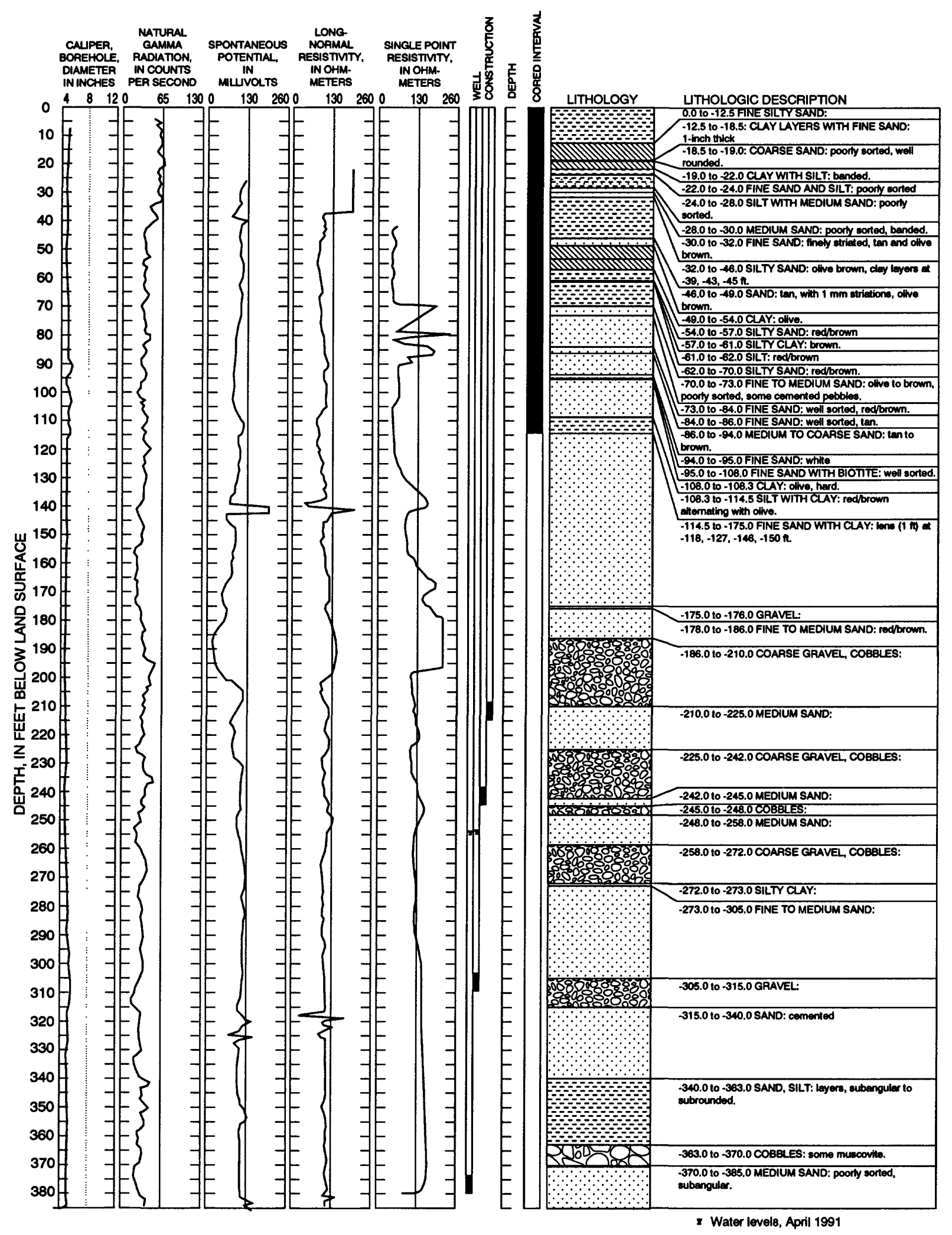

FIGURE 30. Geophysical logs, and diagram showing well construction, cored interval, and lithology for the residential site. 


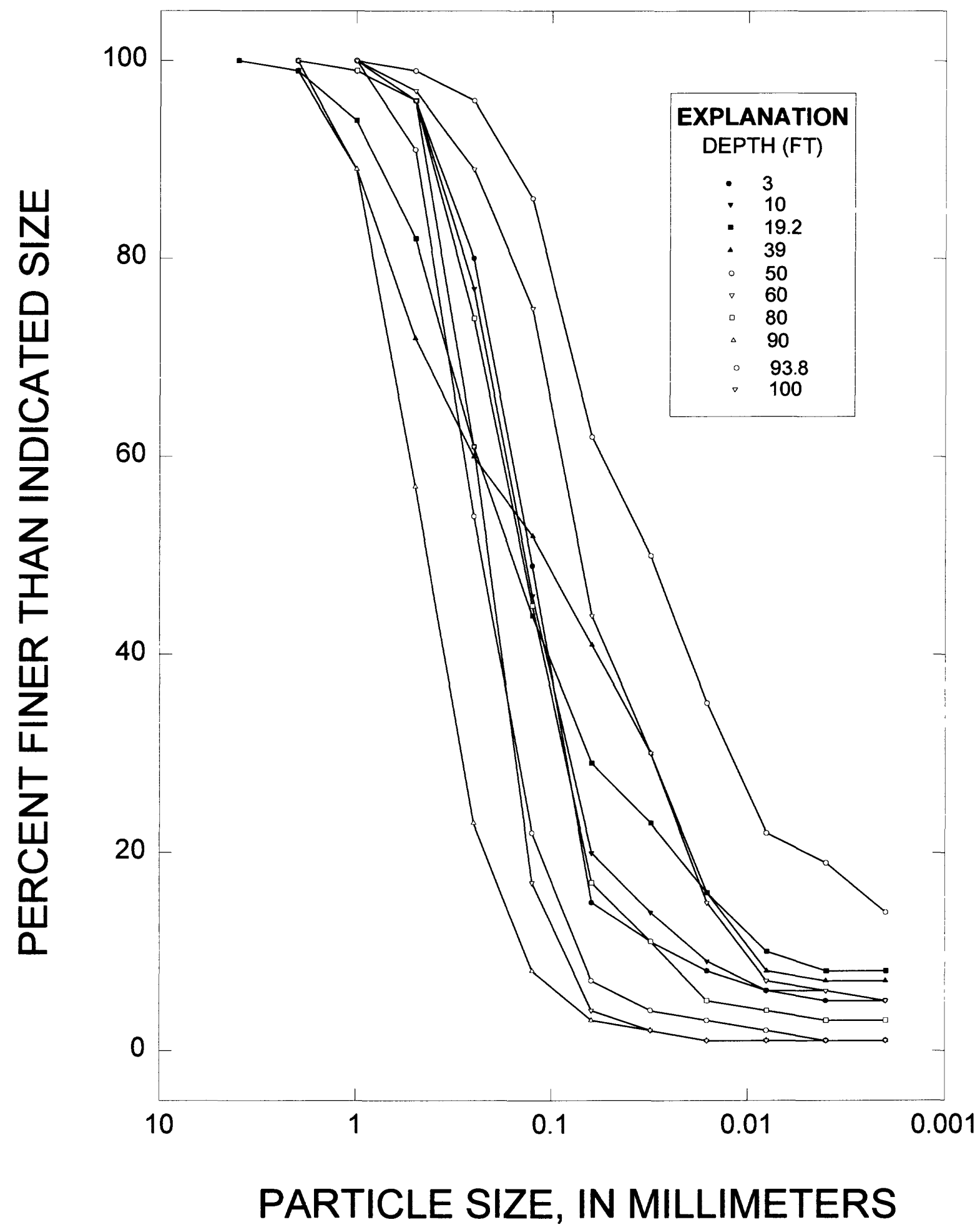

Figure 31. Particle-size distribution at selected depths for cores from the residential site. 
near the bottom of the pumping trough underlying the city of Hemet. Comparison of the potentiometric level in the two deepest wells at the site with the level in the shallow wells indicates that there is no vertical component of ground-water flow. During this study (1991-92), the water table in this area declined approximately $5 \mathrm{ft}$.

Water-quality samples were collected from the two deepest wells on the following dates: January 29, May 16, and August 16, 1991, and January 17 and August 7, 1992. Because of renewed pumping in a large-diameter municipal well about $200 \mathrm{ft}$ from the site, and the resulting cone of depression in the water table, the shallow wells were dry during most of the study period. Analytical results are given in Supplemental Data 3A.

\section{Water Quality at $\mathbf{3 1 0}$ feet}

The sample collected January 1991 from the 310-foot-deep well at the residential site had a dissolved-solids concentration of $1,030 \mathrm{mg} / \mathrm{L}$. The predominant ions were calcium and sulfate; present in smaller percentages were sodium, chloride, and bicarbonate ions. The $\mathrm{pH}$ was 7.8 . The nitrate concentration, $9.5 \mathrm{mg} / \mathrm{L}$, was near the MCL. Boron and selenium concentrations were low. The May 1991 sample had a dissolved-solids concentration of $850 \mathrm{mg} / \mathrm{L}$ and $\mathrm{a} \mathrm{pH}$ of 7.7. Calcium and sulfate ions were predominant. The nitrate concentration had decreased, in comparison with the January sample, to $1.5 \mathrm{mg} / \mathrm{L}$; boron remained low; and selenium increased to about $25 \mu \mathrm{g} / \mathrm{L}$, one-half the MCL. By August 1991, the dissolved-solids concentration had stabilized at $880 \mathrm{mg} / \mathrm{L}$, and calcium and sulfate ions were predominant. The $\mathrm{pH}$ was 7.7. Nitrate concentration had increased to $10 \mathrm{mg} / \mathrm{L}$, the MCL. Boron remained low, and selenium remained high, at $27 \mu \mathrm{g} / \mathrm{L}$. The January 1992 sample had a dissolved-solids concentration of $830 \mathrm{mg} / \mathrm{L}$; predominant ions were calcium and sulfate; and the $\mathrm{pH}$ was 7.7. Nitrate concentration remained high, at $9.8 \mathrm{mg} / \mathrm{L}$. Boron remained low, and selenium remained high, at $26 \mu \mathrm{g} / \mathrm{L}$. The August 1992 sample had a dissolved-solids concentration of $860 \mathrm{mg} / \mathrm{L}$; predominant ions were calcium and sulfate; and the $\mathrm{pH}$ was 7.7. Nitrate remained high, at $11 \mathrm{mg} / \mathrm{L}$; boron remained low; and selenium was $25 \mu \mathrm{g} / \mathrm{L}$.

With the exception of the first sample, collected in January 1991, the water quality in the 310-footdeep well remained relatively constant throughout the study. The high dissolved-solids concentration observed in the first sample may have been caused by residual drilling fluids in the bore hole, as evidenced by the elevated phosphorus concentration. The relative constancy of the remaining analyses gives confidence that those samples represent water in the formation at a depth of $310 \mathrm{ft}$.

On the basis of the Dansgaard plot discussed in the section, "Water Quality," the data for the 310foot-deep well $\left(8 \mathrm{D}=-56.5\right.$ permil and $8^{18} \mathrm{O}=-8.1$ permil) indicate that the water at this depth originated as rain that fell at the relatively warm temperature of $7^{\circ} \mathrm{C}$ rather than as snowfall at higher altitudes. The water from the $310 \mathrm{ft}$. depth plots on the meteoric water line of the Craig (1961) diagram (fig. 29), which indicates that the water percolated to the water table without undergoing significant evaporation. The $8^{15} \mathrm{~N}$ value for the sample from this well was 5.1. This value suggests that the source of the nitrogen is a mineral form, and that it has been subjected to some biological cycling. A less likely alternative interpretation is that there has been a mixing of nitrogen from mineral and animal sources.

\section{Water quality at 380 feet}

Water-quality data for the 380-foot-deep well at the residential site are given in Supplemental Data 3A. For the sample collected in January 1991, dissolved-solids concentration was $1,270 \mathrm{mg} / \mathrm{L}$; calcium, sulfate, and chloride were the dominant ions; and $\mathrm{pH}$ was 7.6. The concentrations of nitrate $(33 \mathrm{mg} / \mathrm{L})$ and selenium $(25 \mu \mathrm{g} / \mathrm{L})$ were high, and the concentration of boron was low. For the sample collected in May 1991, dissolved-solids concentration was $1,140 \mathrm{mg} / \mathrm{L}$; calcium, sulfate, and chloride again were the dominant ions; and $\mathrm{pH}$ was 7.6. The nitrate concentration remained high at $34 \mathrm{mg} / \mathrm{L}$, and the selenium concentration increased to $60 \mu \mathrm{g} / \mathrm{L}$, exceeding the MCL of $50 \mu \mathrm{g} / \mathrm{L}$. The boron concentration, $70 \mu \mathrm{g} / \mathrm{L}$, remained low. The sample collected in August 1991 had a dissolvedsolids concentration of $1,420 \mathrm{mg} / \mathrm{L}$, the same dominant ions, and a $\mathrm{pH}$ of 7.5. The concentrations of nitrate, $39 \mathrm{mg} / \mathrm{L}$, and selenium, $62 \mu \mathrm{g} / \mathrm{L}$, increased slightly. Boron remained at $70 \mu \mathrm{g} / \mathrm{L}$. The sample collected in January 1992 had a dissolvedsolids concentration of $1,210 \mathrm{mg} / \mathrm{L}$; the ionic relations and the $\mathrm{pH}$ remained the same. The nitrate concentrations decreased only slightly to $37 \mathrm{mg} / \mathrm{L}$, and the selenium concentration decreased to 50 $\mu \mathrm{g} / \mathrm{L}$. Boron remained at $70 \mu \mathrm{g} / \mathrm{L}$. The sample collected August 1992 had a dissolved-solids concentration of $1,420 \mathrm{mg} / \mathrm{L}$. The ionic relations and the $\mathrm{pH}$ remained the same. Nitrate concentrations remained high, at $39 \mathrm{mg} / \mathrm{L}$, and selenium concentration was $56 \mu \mathrm{g} / \mathrm{L}$. Boron 
concentration remained the same.

The relative constancy of these results once again gives confidence that the water being sampled is representative of the formation water. The water from this deeper zone has higher dissolved-solids, nitrate, and selenium concentrations than did water from the shallower zone. However, the source of this poorer quality water cannot be determined using the existing data set.

The $\delta \mathrm{D}$ and $\delta^{18} \mathrm{O}$ values $(-55.5$ and -8.1 , respectively) support the same conclusions given for the water at $310 \mathrm{ft}$. The water seems to have precipitated at a temperature of about $7^{\circ} \mathrm{C}$, and thus fell as rain at relatively low altitudes, rather than as snow at higher altitudes. The plotted values on the Craig diagram (fig. 29) suggest that the water did not undergo significant evaporation prior to percolation to the water table.

The $\delta^{15} \mathrm{~N}$ value of 5.2 indicates that the nitrate that is present came from a mineral source, and that some biological cycling of the nitrogen has occurred.

\section{Unsaturated-Zone Results}

\section{Pore-moisture profiles}

Pore-moisture saturation-index profiles were measured using a calibrated neutron-attenuation logging tool that was lowered into the neutron-probe access tube as described in the "Site Description" section. The pore-moisture saturation-index profiles are based on data collected at the residential site in May and July 1991; April, July, and October 1992; and January 1993 and are shown in figure 32. Vertical resolution is approximately $1 \mathrm{ft}$ and horizontal resolution is about 0.02 unit. The clay seal placed at the top of the bore hole extended to a depth of $14 \mathrm{ft}$, and that part of the profile has been excluded from the figure. The profiles, below the clay seal, indicate that the clay layers tend to have higher moisture-saturation indices than do the adjacent layers of sand and gravel. Moisture content ranges from 13 to 15 volume percent in the clay layers and from 7 to 10 volume percent in the sand and gravel layers. The clay layers at 39,43 , and $45 \mathrm{ft}$ are clearly indicated in the moisture saturationindex profiles. The sand layers between 65 and $75 \mathrm{ft}$ are exceptions to the general moisture-saturationindex profile, their indices being 0.1 higher than those for the other samples. The particle-size distributions discussed in the "Site Description" section indicate that sand layers from this $(65 \mathrm{ft}$. to $75 \mathrm{ft}$.) zone tend to have a higher percentage of fine material than do sand layers from the other zones.

The moisture saturation-index profiles show a temporal variation ranging from 0.07 unit in the shallow unsaturated zone to about 0.23 unit in the deep unsaturated zone. The saturation indices were lowest in May 1991 and highest in January 1993. The January 1993 measurements, however, were made immediately after a 13-day period during which more than 10 in of rain fell. The general trend seems to be that moisture-saturation indices are lowest in spring and highest in summer. This trend may be related to irrigation: During the summer months, irrigation increases the unsaturated-zone pore moisture, and when irrigation is stopped during the winter, the soil dries out.

The shape of the temporal profiles is virtually constant, and any change in moisture content is reflected in the entire profile, not just at a particular depth. The soil column seems to equilibrate rapidly to changes in precipitation and (or) irrigation. This rapid equilibration prevents using temporal changes in the moisture-saturation-index profiles to determine percolation rates in the unsaturated zone.

Unsaturated hydraulic conductivities for the various alluvial materials beneath the residential site ranged from $4.85 \times 10^{-7} \mathrm{ft} / \mathrm{s}$ (clay layer at $19 \mathrm{ft}$ ) to $1.60 \times 10^{-5} \mathrm{ft} / \mathrm{s}$ (sand layer at $100 \mathrm{ft}$ ). Using the appropriate unsaturated hydraulic conductivities and the corresponding moisture-saturation indices and integrating over the entire unsaturated zone, one obtains a transit time of about 7 years for water to percolate from land surface to the water table.

The unsaturated-zone pore-water tritiumconcentration profile (fig. 33) at the residential site was determined by compositing lysimeter-collected water during January 1992 until sufficient volume (1 L) was obtained for analysis. The tritium concentration of $13 \mathrm{pCi} / \mathrm{L}$, at $113 \mathrm{ft}$, is significantly lower than the expected 1963 concentration of 600 $\mathrm{pCi} / \mathrm{L}$, indicating that the unsaturated-zone transit time is less than 30 years. Also, the concentrations at shallow depths are considerably lower than what would be expected from fresh local rainfall (15 $\mathrm{pCi} / \mathrm{L}$ ). This is because most of the water used to irrigate the site is not local rainfall, but rather is municipally supplied water. This municipally supplied water is mostly pumped ground water that would be expected to have lower tritium concentrations. Therefore, the tritium concentrations observed are a consequence of mixing the lowtritium ground water with the higher tritium fresh rainfall. Pearson (1974) observed that the 


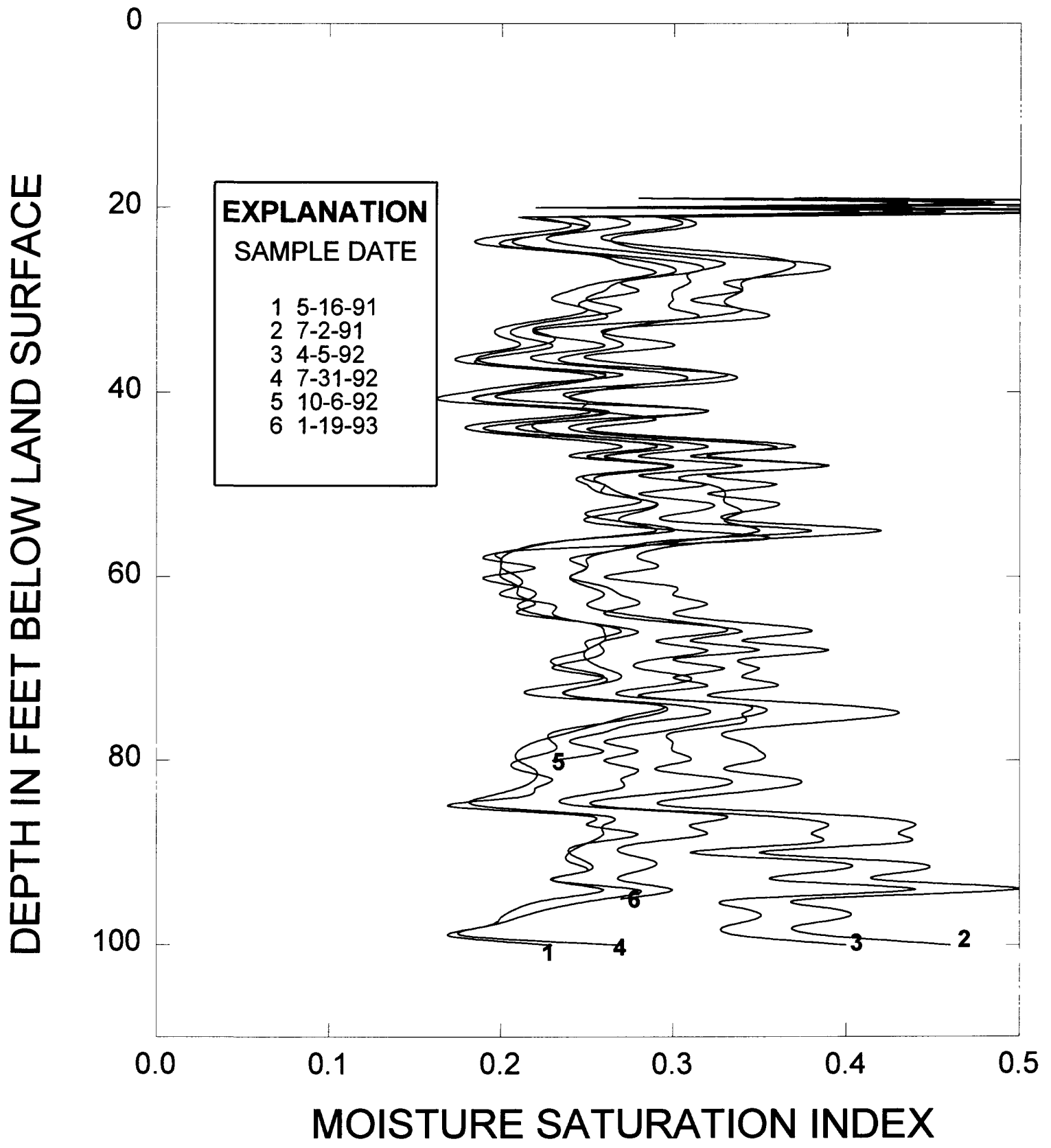

Figure 32. Unsaturated-zone pore-moisture profiles, for selected dates in 1991-93, for the residential site. 


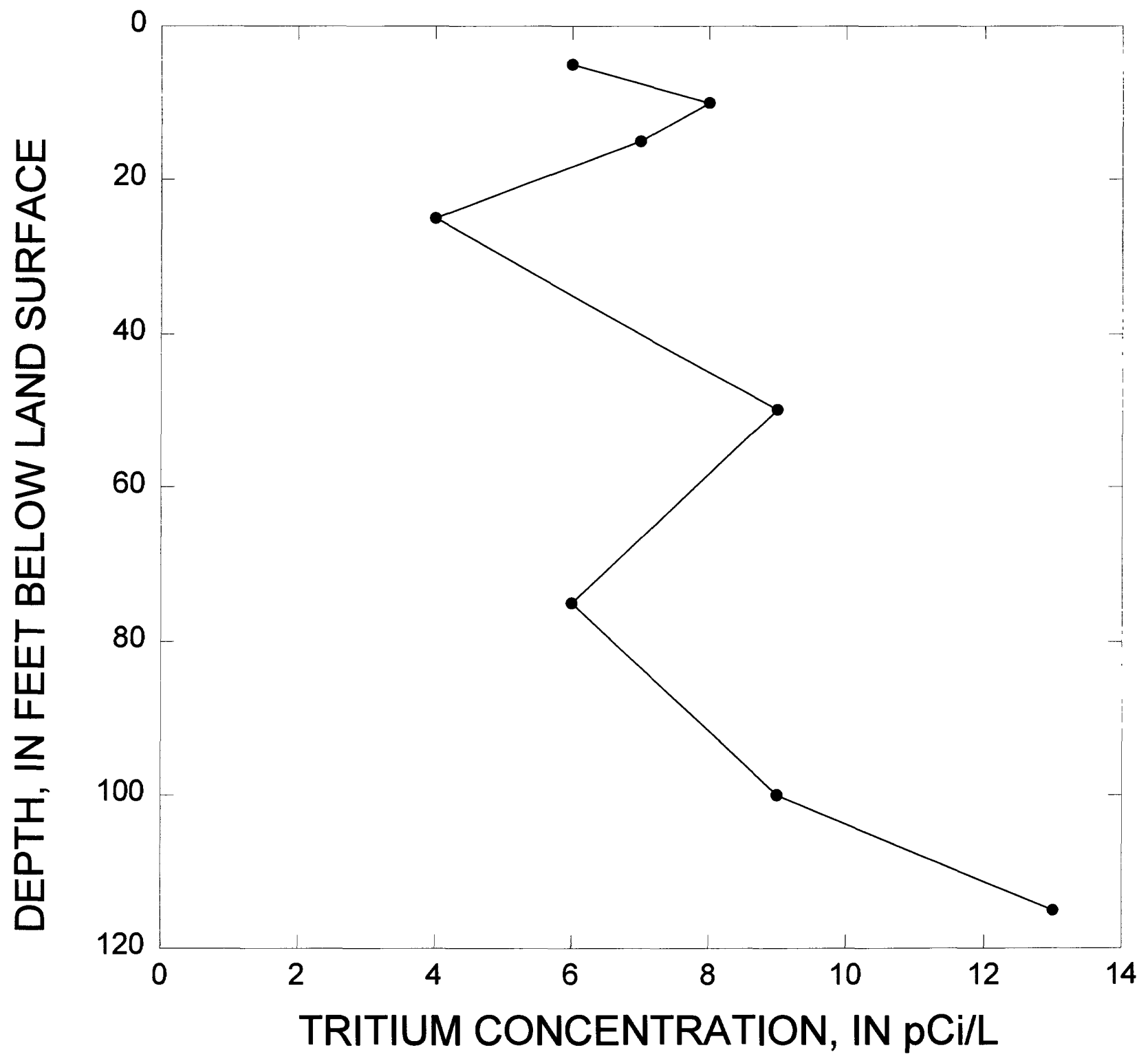

Figure 33. Tritium-concentration profile for pore water at the residential site. 
concentration of tritium in summer rainfall is as much as 5 times greater than the concentration in winter rainfall. The multiple peaks in the profile, at 10,50 , and $113 \mathrm{ft}$, likely are a reflection of this concentration trend, which repeats itself each year.

The peak in the tritium profile at $10 \mathrm{ft}$ may represent a mixture of precipitation that fell during the summer of 1991 and irrigation water. A twocomponent mixing model suggests that approximately equal contributions of fresh rainfall and irrigation water would result in the concentration measured at this depth. The minimum at $25 \mathrm{ft}$ can be interpreted as the winter minimum from the previous year, suggesting an unsaturatedzone percolation rate to that depth of about $25 \mathrm{ft} / \mathrm{yr}$. If one assumes that the peak at $50 \mathrm{ft}$ represents the summer tritium maximum of 1990 , an unsaturatedzone percolation rate of $40 \mathrm{ft} / \mathrm{yr}$ can be calculated for the zone between 10 and $50 \mathrm{ft}$ in the unsaturated zone. The minimum at $75 \mathrm{ft}$ can be interpreted as the winter tritium minimum for 1990 , yielding an unsaturated-zone percolation rate of about $50 \mathrm{ft} / \mathrm{yr}$ for the zone between 25 and $75 \mathrm{ft}$. Finally, the maximum at $113 \mathrm{ft}$ may represent summer precipitation during 1989 . If so, the unsaturatedzone percolation rate for the zone between 50 and $113 \mathrm{ft}$ would be $63 \mathrm{ft} / \mathrm{yr}$. Using these values, the estimated time for water to transit the approximately $250 \mathrm{ft}$ of unsaturated zone beneath the residential site would be at least 4 years and likely less than 10 years. These values are consistent with the moisturesaturation index/unsaturated hydraulic-conductivity estimate described earlier and with the lack of an observed 1963 tritium peak in the profile.

\section{Water quality}

Samples for determining unsaturated-zone porewater quality were collected, using the ceramic-cup suction lysimeters, during January, May, and August 1991, and April and August 1992. Analytical results are given in Supplemental Data 3A.

For the samples collected at a depth of $5 \mathrm{ft}$, the dissolved-solids concentration ranged from 2,400 to $3,000 \mathrm{mg} / \mathrm{L}$ during 1991 . The predominant ions were sodium and sulfate, with lesser concentrations of calcium, chloride, and bicarbonate ions. The $\mathrm{pH}$ was about 7.5. The dissolved-solids concentrations in the samples are considerably higher than the dissolved-solids concentrations in the water used to irrigate the site. The higher concentrations in the pore water probably can be attributed to evaporative concentration of salts, and to the addition of fertilizers to the site. Between August 1991 and
April 1992, the dissolved-solids concentration decreased by a factor of 2 to about $1,400 \mathrm{mg} / \mathrm{L}$. Precipitation in March 1992 was well above normal, and it is likely that this precipitation flushed the high-dissolved-solids pore water to greater depths in the unsaturated zone. The predominant ions in the water at the 5-ft depth remained sodium and sulfate, with lesser concentrations of calcium, chloride, and bicarbonate. The dissolved organic-carbon concentration in the pore water was $9.2 \mathrm{mg} / \mathrm{L}$.

The samples collected from a depth of $10 \mathrm{ft}$ show a temporal trend that is the opposite of the trend observed at $5 \mathrm{ft}$. In samples collected in 1991, dissolved-solids concentrations ranged from 1,100 to $2,400 \mathrm{mg} / \mathrm{L}$, and the concentration was highest in August. The $\mathrm{pH}$ and the ionic relations were the same as at $5 \mathrm{ft}$, except there was a larger contribution from bicarbonate. By August 1991, and through April and August 1992, there was a 2-fold increase in dissolved-solids concentration, probably a result of flushing of dissolved solids from shallower depths in the unsaturated zone. This percolating water had a chemical composition identical to that observed at $5 \mathrm{ft}$ the previous year. The dissolved organic-carbon concentration in the pore water was $4.5 \mathrm{mg} / \mathrm{L}$.

The samples collected from a depth of $15 \mathrm{ft}$ show the same trends as those observed at $10 \mathrm{ft}$. In the January and May 1991 samples, dissolvedsolids concentration ranged from 1,200 to $1,700 \mathrm{mg} / \mathrm{L}$, and the $\mathrm{pH}$ and the ionic relations were the same as at $10 \mathrm{ft}$. In the August 1991 and April and August 1992 samples, dissolved-solids concentration was higher, about $2,200 \mathrm{mg} / \mathrm{L}$. The increase was due to an increase in the concentrations of sodium, sulfate, and chloride ions. Thus, there was a continuous trend from January through August 1991 of increasing dissolved solids, and the trend leveled after August 1991. The dissolved organic-carbon concentration in the pore water was about $3.0 \mathrm{mg} / \mathrm{L}$.

The pore water collected from a depth of $25 \mathrm{ft}$ showed a trend opposite to that observed at the 10 $\mathrm{ft}$. and $15 \mathrm{ft}$. depths. The dissolved-solids concentration was highest in the January 1991 sample, decreasing thereafter to a nearly constant 1,000 to $1,200 \mathrm{mg} / \mathrm{L}$. The ionic relations also were different: Sodium and calcium ions were present in nearly equal concentrations, and sulfate and bicarbonate were present at lower, nearly equal concentrations. A tend was observed in which sodium replaced calcium, particularly in the April and August 1992 samples. The dissolved organic- 
carbon concentration in the pore water was $1.3 \mathrm{mg} / \mathrm{L}$.

Data from the deeper lysimeters are more sparse than from the shallow lysimeters. In general, the deeper lysimeters produced smaller volumes of water, thus limiting the number of constituents that could be determined at each sample date. Analysis of the January 1991 sample emphasized the anionic components, and sulfate was found to be the predominant anion. Analysis of the May 1991 sample emphasized the cations, and sodium was the dominant cation. The bicarbonate concentration was three times the concentration of chloride observed in January. The August 1991 sampling produced sufficient water to obtain a complete analysis. The dissolved-solids concentration was about $2,200 \mathrm{mg} / \mathrm{L}$. Sodium was the dominant cation, but the calcium concentration was about two-thirds that of sodium. Sulfate was the most prevalent anion, and the concentration of bicarbonate ions was half that of sulfate. Analysis of the April 1992 sample once again emphasized the cations. The results suggest little change in composition from the previously collected samples. The August 1992 sample allowed a complete analysis. The dissolvedsolids concentration was about $1,600 \mathrm{mg} / \mathrm{L}$, with decreased concentrations of both sulfate and bicarbonate. The organic-carbon concentration in the pore water was $2.1 \mathrm{mg} / \mathrm{L}$.

Because of low water production from the $75 \mathrm{ft}$. lysimeter, only very general comments can be made. The dissolved-solids concentration at this depth seemed to be about $5,000 \mathrm{mg} / \mathrm{L}$. The $\mathrm{pH}$ of 7.3 is somewhat lower than that observed at the shallower depths. The sodium and calcium concentrations were about equal, and sulfate was the dominant anion. Bicarbonate concentrations seemed to be about one-half the sulfate concentration. The chloride concentration was relatively low. The organic-carbon content in the pore water was $2.8 \mathrm{mg} / \mathrm{L}$.

The production of water from the 100-foot lysimeter also was low. The dissolved-solids concentration was about $6,100 \mathrm{mg} / \mathrm{L}$. Sodium concentrations were nearly twice those of calcium, and sulfate concentrations were nearly twice those of bicarbonate. The $\mathrm{pH}$ was 7.3. The organic carbon content in the pore water was $1.8 \mathrm{mg} / \mathrm{L}$.

The 113-foot lysimeter produced water containing dissolved-solids concentrations of about $5,700 \mathrm{mg} / \mathrm{L}$. The $\mathrm{pH}$ of 7.2 was slightly lower than that observed at the shallower depths. Calcium was the dominant cation, having a concentration approximately twice that of sodium. Sulfate remained the dominant anion, but there was relatively more bicarbonate. Chloride concentrations remained low. The organic-carbon concentration in the pore water was $3.6 \mathrm{mg} / \mathrm{L}$.

Several depth-related trends are apparent. Pore water in the shallow unsaturated zone had dissolvedsolids concentrations less than half those observed in the deep unsaturated zone. Pore water in the deeper zones does not show the temporal variations observed in the shallow zones. In the shallow unsaturated zone, to a depth of $25 \mathrm{ft}$, a monotonic trend of decreasing dissolved organic-carbon exists, and there seems to be active downward percolation of surface water. On the basis of observed dissolved-solids concentrations, it seems to take 4 to 8 months for water to percolate to a depth of $15 \mathrm{ft}$, a result consistent with the previous estimates of unsaturated-zone percolation rates.

\section{Nitrogen profiles}

Core results.--During site installation, cores were collected from the unsaturated zone, processed, and analyzed as described in the "Site Instrumentation and Sample Collection" section.

The organic-nitrogen-concentration profile for the residential site is shown in figure 34 . As will be discussed later, most of the nitrogen in the unsaturated zone at the site was present in the form of organic nitrogen. This indicates that virtually all the nitrogen introduced at the land surface as inorganic fertilizer is rapidly converted to an organic form. The highest concentration of organic nitrogen, $13 \mathrm{mg} / \mathrm{L}$, was at the top of the soil column; concentration decreased rapidly to less than $7 \mathrm{mg} / \mathrm{L}$ within $10 \mathrm{ft}$ of the surface. Organic-nitrogen concentrations do not correlate with moisture content, but there does seem to be some correlation with particle size. Organic-nitrogen concentrations tended to be somewhat higher in zones with fine to medium sand, and concentrations tended to be lower in zones containing more silt and clay. This correlation of organic-nitrogen concentration with particle size might be the result of microbiological control: Soil bacteria tend to sorb preferentially to clay-sized particles.

The data in Supplemental Data 3A indicate that concentrations of ammonia and ammonium in the core extracts were low, probably because ammonium tends to sorb strongly to soil particles. 


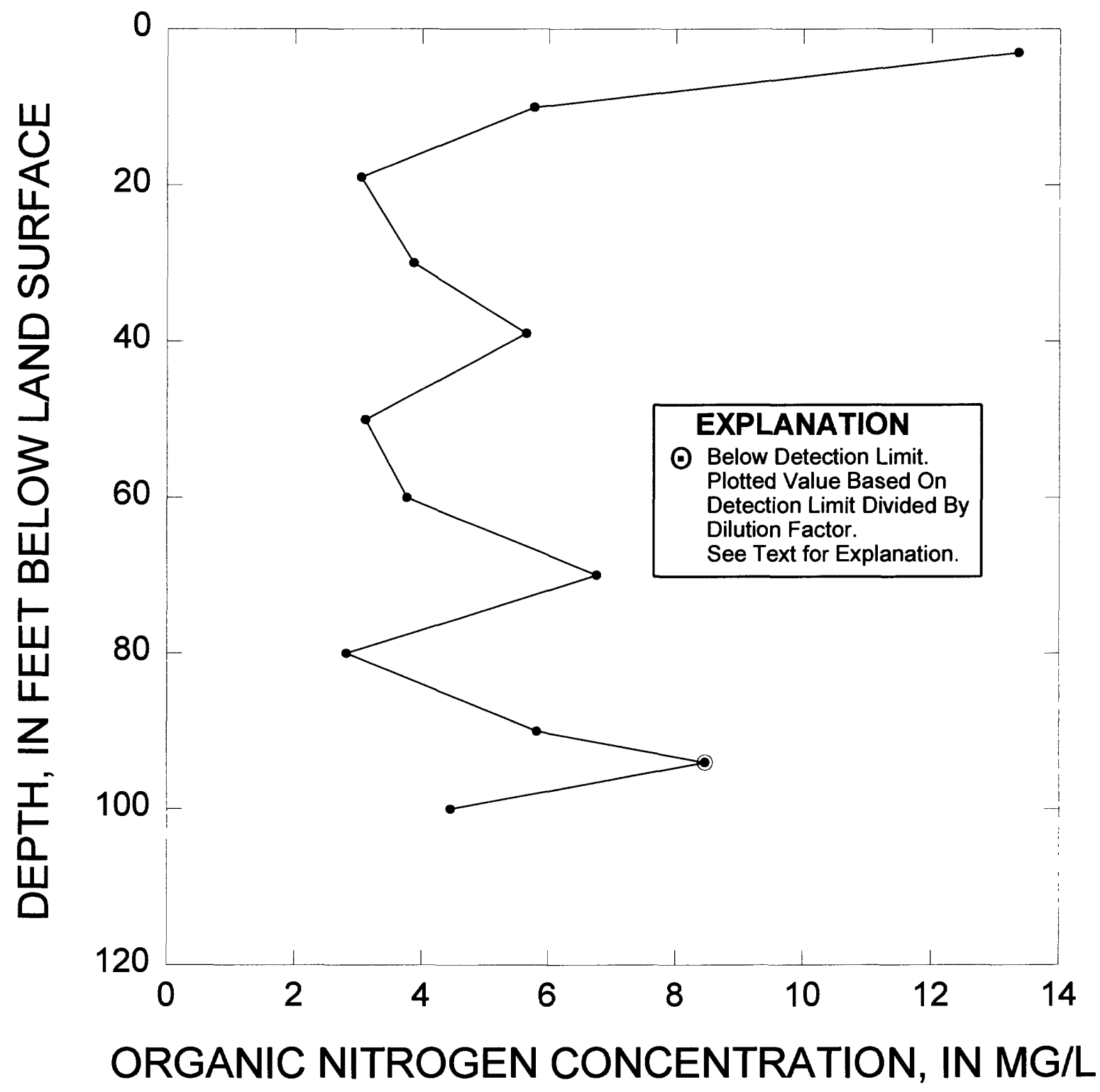

Figure 34. Organic-nitrogen-concentration profile, from core extracts, for the unsaturated zone at the residential site. 


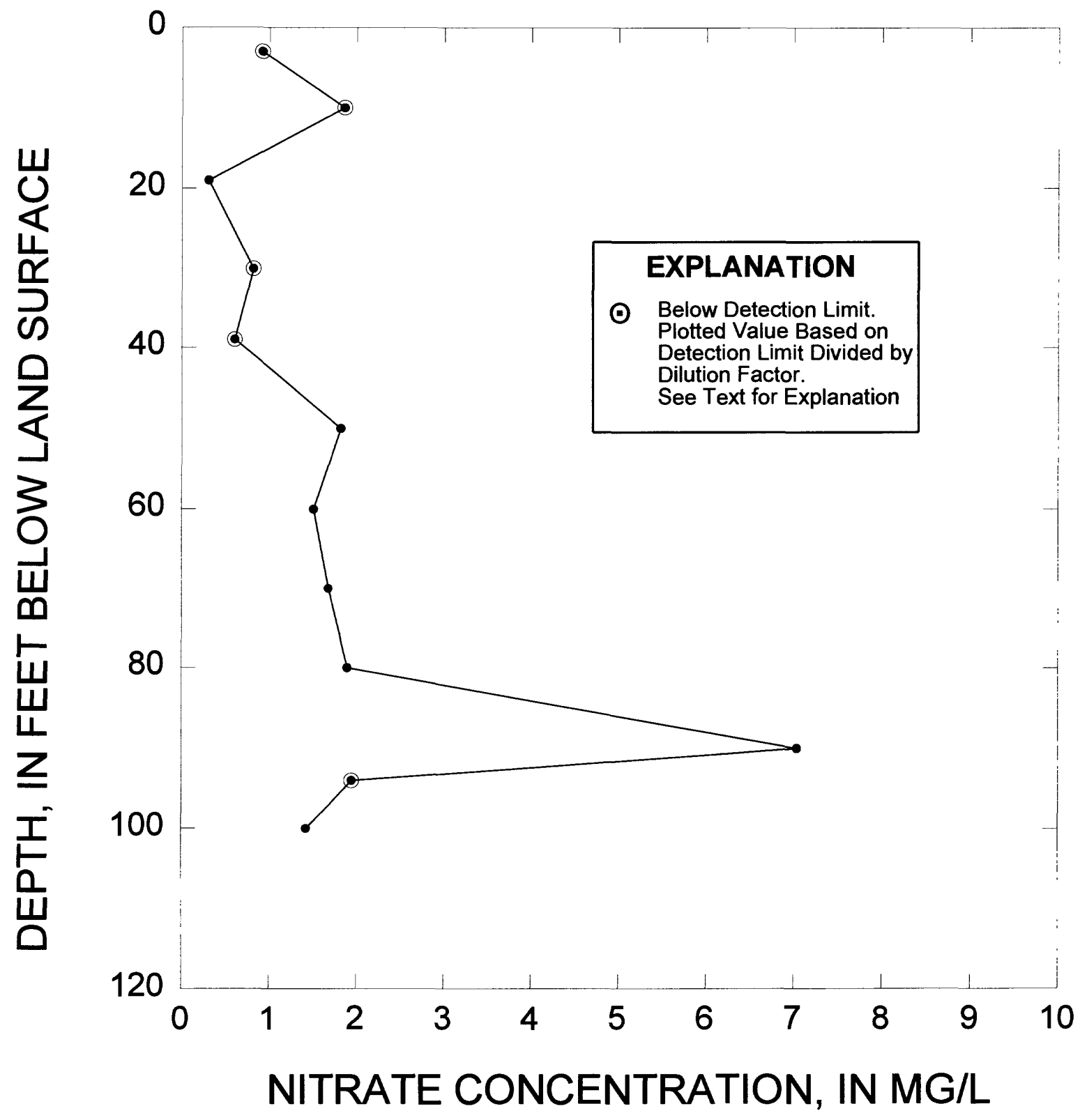

Figure 35. Nitrate-concentration profile, from core extracts, for the unsaturated zone at the residential site.

60 Residential Site 
The unsaturated-zone nitrate-concentration profile for the core extracts is shown in figure 35 . In the top $40 \mathrm{ft}$ of the soil column, nitrate concentrations were fairly constant at less than $2 \mathrm{mg} / \mathrm{L}$, about one-half the organic-nitrogen concentration at similar depths. These data, once again, indicate that nitrogen from the inorganicnitrogen fertilizers used on the turf does not reach the unsaturated zone beneath the turf, but is converted to organic nitrogen. The pore water contained appreciable concentrations of nitrate only at about $89 \mathrm{ft}$. This zone had the lowest moisture content and it yielded the largest dilution factor for the pore-water extraction used. On the basis of the analytical precision reported by Fishman and Friedman (Fishman and Friedman, 1989), and the dilution factor for this depth, the 95-percent confidence interval for the nitrate data is from 4.5 to $9.5 \mathrm{mg} / \mathrm{L}$. These values are significantly higher than for the rest of the profile. Basin fill at this depth consists of fine reddish-brown sand, indicating that reduced forms of iron eluting through the unsaturated zone become oxidized at this layer and precipitate. A similar elution of reduced forms of nitrogen, and oxidation to nitrate in this zone, could explain the high nitrate concentrations.

Lysimeter Results.--Samples of unsaturatedzone pore water were collected using the ceramic-cup suction lysimeters during January, May, and August 1991 and April and August 1992. Results are given in Supplemental Data 3A, and the nitrate results are illustrated in figure 36 . Organicnitrogen, ammonia, and nitrite concentrations were generally low; therefore, the discussion that follows focuses on the nitrate-concentration profiles.

For the most part, the samples collected from the suction lysimeters gave results similar to those obtained from the core pore-water extracts described in the preceding section. Pore water collected from $5 \mathrm{ft}$ had elevated nitrate concentrations, greater than the MCL of $10 \mathrm{mg} / \mathrm{L}$, during January and May 1991. In the samples collected after August 1991, however, nitrate concentrations were nondetectable. The nitrate concentrations in pore water collected from $10 \mathrm{ft}$ were more variable. In January 1991, the nitrate concentration was $5.8 \mathrm{mg} / \mathrm{L}$. By May 1991 , the concentration had increased to $20 \mathrm{mg} / \mathrm{L}$. By August 1991, however, the concentration had decreased considerably, remaining close to the detection limit of $0.1 \mathrm{mg} / \mathrm{L}$ for the duration of this study. The elevated nitrate concentration during May 1991 might have been caused by the flushing of higher nitrate shallow pore water through this deeper zone.
Analysis of the samples collected from $15 \mathrm{ft}$ also indicates that there might be some percolation of high-nitrate water through the shallow unsaturated zone. Nitrate concentration in the January 1991 sample was $4.0 \mathrm{mg} / \mathrm{L}$. By May 1991 , the concentration had increased to $34 \mathrm{mg} / \mathrm{L}$, and the concentration remained elevated at least through August 1991. By April 1992, the nitrate concentration had decreased considerably, and by July 1992 it had decreased to the detection limit in this zone.

A similar distribution of concentrations, although slightly attenuated, can be seen at $25 \mathrm{ft}$. The January 1991 concentration was $0.4 \mathrm{mg} / \mathrm{L}$. By May 1991, the concentration had increased to $5.1 \mathrm{mg} / \mathrm{L}$. The nitrate concentration peaked at 12 $\mathrm{mg} / \mathrm{L}$, above the $\mathrm{MCL}$, during August 1991. By April 1992, the concentration had decreased to 8.5 $\mathrm{mg} / \mathrm{L}$, and it continued to decrease through July 1992 to $3.3 \mathrm{mg} / \mathrm{L}$.

Analysis of unsaturated-zone samples from the intermediate depths of 50 and $75 \mathrm{ft}$ indicated that there was virtually no nitrate at those depths. All nitrate values were near or below the analytical detection limit.

Results from analysis of the deep unsaturatedzone pore water were more surprising. The samples collected from $100 \mathrm{ft}$ initially, during early 1991 , were well below the MCL. By August 1991, however, the nitrate concentrations had begun to increase dramatically, first to $21 \mathrm{mg} / \mathrm{L}$, then to $39 \mathrm{mg} / \mathrm{L}$ by April 1992. The nitrate concentration remained high through August 1992. The samples collected from $113 \mathrm{ft}$ followed a similar trend, starting at $2.0 \mathrm{mg} / \mathrm{L}$ in January 1991 , increasing to $23 \mathrm{mg} / \mathrm{L}$ by August 1991 and to greater than $60 \mathrm{mg} / \mathrm{L}$ in April and July 1992. These very high nitrate concentrations in the deep unsaturated zone are somewhat confusing because there is a broad intermediate zone above that contains virtually no nitrate.

\section{Microbial Processes}

Several techniques were applied to determine if microbial processes in the unsaturated zone were important in controlling nitrate concentrations. The most direct method involved quantifying the populations of bacteria present in the unsaturated zone that either could form nitrate from reduced forms of nitrogen (the nitrifying bacteria), or could utilize nitrate as a terminal electron acceptor during bacterial respiration (the denitrifying bacteria). The 


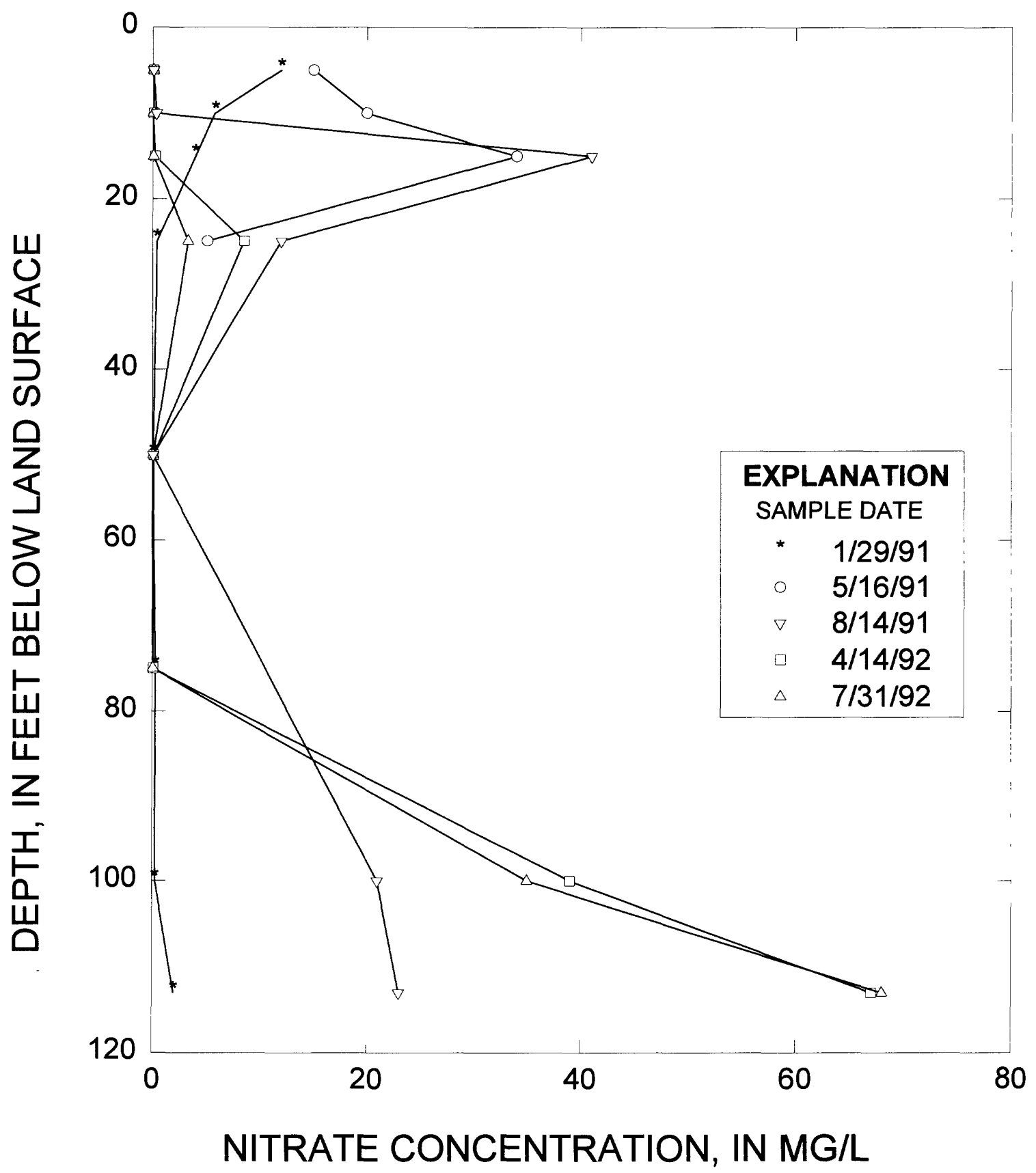

Figure 36. Nitrate concentration, for selected dates in 1991-92, in usaturated-zone pore water at the residential site. 
nitrifying bacteria include the Nitrosomonas group that oxidize ammonia to nitrite, and the Nitrobacter group that oxidize nitrite to nitrate. The denitrifying bacteria include Pseudomonas, Alcaligenes, Flavobacter, Bacillus, and Paracoccus. Bacterial populations were determined by culturing aliquots of the aseptically collected core material with appropriate media, incubating the inoculated cultures, and using the statistically based mostprobable-number (MPN) by three-tube series dilution method to determine probable numbers of viable bacteria. The procedures have been described in detail by Britton and Greeson (1987). The bacterial-population results for the residential site are given in table 2 . The number of nitrifying bacteria was below the detection limit of 30 for the procedure at each of the depths analyzed. No Nitrosomonas or Nitrobacter were detected. Significant populations of denitrifying bacteria were present, however. The highest concentration, 93,000 bacteria per gram of core, was observed in the $3 \mathrm{ft}$. sample. The number of bacteria rapidly decreases with depth, but even at a depth of $20 \mathrm{ft}$, there remained 2,100 viable denitrifying bacteria per gram of core material. Quantifiable numbers of denitrifiers were found to a depth of $50 \mathrm{ft}$.

The presence of assimilated denitrifying bacteria at the site suggests that denitrification might be occurring. The use of nitrogen-isotope ratios can give an indication of microbial denitrification. The $\delta^{15} \mathrm{~N}$ values for samples collected at the residential site are given in table 3 . The values are considerably less than 10 , suggesting a mineral rather than biological source of the nitrate. According to anecdotal reports, there was a fertilizer storage yard near this site; therefore, the nitrate observed here could be the result of fertilizer leaching into the soil column. The $8^{15} \mathrm{~N}$ values vary with depth: the shallower the zone from which the nitrate was obtained, the heavier the values. This presents a paradox: The $\delta^{15} \mathrm{~N}$ values are consistent with the distribution of observed denitrifying populations at the site, indicating that more microbially controlled denitrification occurs near the surface than at greater depths. However, nitrate percolation is assumed to be a downward process. Thus, the farther the nitrate percolates, the greater the cumulative denitrification should be and the heavier the $\delta^{15} \mathrm{~N}$ values should be. A possible explanation for this paradox is that evapotranspiration is cycling the nitrate in the shallow unsaturated zone, and little nitrate is moving to greater depths.

Concentrations of soil gases can provide additional information regarding microbial activity. When microbial denitrification occurs, one of the byproducts is gaseous $\mathrm{N}_{2} \mathrm{O}$ (Goreau and others, 1980; Firestone and others, 1980; Lipschultz and others, 1981; Johansson and Galbally, 1984; Poth and Focht, 1985; Anderson and Levine, 1986; Lloyd and others, 1987; Zafirion and Hanly, 1989; Smith and others, 1988; Amundson and Davidson, 1990). Therefore, zones in which active microbial denitrification is occurring may have measurable, and elevated, concentrations of $\mathrm{N}_{2} \mathrm{O}$. Microbial respiration also leads to increased concentrations of $\mathrm{CO}_{2}$. Atmospheric $\mathrm{CO}_{2}$ concentration is about 330 $\mu \mathrm{g} / \mathrm{g}$. Soil gas concentrations are perhaps 10 times higher as a result of root respiration. Concentrations greater than about $10,000 \mu \mathrm{g} / \mathrm{g}$ occur only when significant microbial activity is present. The soil gas profiles for the residential site are given in table 4. The absence of measurable $\mathrm{N}_{2} \mathrm{O}$ precludes the unequivocal conclusion that denitrification is occurring at the site. However, the elevated $\mathrm{CO}_{2}$ concentrations, ranging from 700 to $110,000 \mu \mathrm{g} / \mathrm{g}$, do suggest that significant microbial activity is occurring.

\section{Conclusions}

The residential site is located in a ground-water depression, probably caused by pumping in nearby wells. The water quality in the saturated zone is marginal, owing to high concentrations of dissolved solids, nitrate, and selenium (greater than the MCL). Water quality worsens with depth (concentrations of dissolved solids, nitrate, selenium, and boron increase). Ground water at this site probably is recharged at an altitude not much different from that of the site along the mountains to the west and south, from water draining the Diamond Valley, and from water moving from the San Jacinto subbasin across the Casa Loma fault. Areal recharge does not appear to be significant. The average temperature of recharging water is about $7^{\circ} \mathrm{C}$, and the water is subjected to only minimal evaporation prior to percolation to the water table. The nitrate in the saturated zone probably is from a mineral source.

Unsaturated-zone pore moisture is variable, and moisture contents are highest in the fine-grained materials. Moisture content ranged from 5 to 15 volume percent. The tritium profile suggests an unsaturated-zone percolation rate of $25 \mathrm{ft} / \mathrm{yr}$ in the shallow unsaturated zone, and $63 \mathrm{ft} / \mathrm{yr}$ in the coarsegrained material deeper in the unsaturated zone. On the basis of these rates, it would take at least 4 and probably less than 10 years for water to percolate 
Table 2. Bacteria populations in the unsaturated zone beneath the instrumented land-use sites

[Concentrations in most probable number per gram (wet). $\mathrm{ft}$, foot]

\begin{tabular}{|c|c|c|c|c|c|c|c|}
\hline \multirow{2}{*}{$\begin{array}{l}\text { Core } \\
\text { depth } \\
\text { (ft) }\end{array}$} & \multicolumn{2}{|c|}{ Nitrifying bacteria } & \multirow{2}{*}{$\begin{array}{l}\text { Denitrifying } \\
\text { and nitrate- } \\
\text { reducing } \\
\text { bacteria }\end{array}$} & \multirow{2}{*}{$\begin{array}{l}\text { Core } \\
\text { depth } \\
\text { (ft) }\end{array}$} & \multicolumn{2}{|c|}{ Nitrifying bacteria } & \multirow{2}{*}{$\begin{array}{l}\text { Denitrifyin } \\
\text { and nitrate } \\
\text { reducing } \\
\text { bacteria }\end{array}$} \\
\hline & Nitrosomonas & Nitrobacter & & & Nitrosomonas & Nitrobacter & \\
\hline \multicolumn{4}{|c|}{$\begin{array}{l}\text { Residential site } \\
\text { Sampled 11-9 to 11-10-90 }\end{array}$} & \multicolumn{4}{|c|}{$\begin{array}{c}\text { Poultry-farm site } \\
\text { Sampled 11-3 to 11-9-90 }\end{array}$} \\
\hline 3.3 & -- & $<30$ & 93,000 & 1.0 & 30 & 70 & 23,000 \\
\hline 10 & $<30$ & $<30$ & 2,100 & 3.3 & 280 & 80 & 9,300 \\
\hline 16 & $<30$ & $<30$ & 1,500 & 12.9 & $<30$ & $<30$ & 43,000 \\
\hline 19.2 & $<30$ & $<30$ & 2,100 & 33 & $<30$ & $<30$ & 90 \\
\hline 50 & $<30$ & $<30$ & 70 & 50 & $<30$ & $<30$ & 90 \\
\hline 100 & $<30$ & $<30$ & $<30$ & 101 & $<30$ & $<30$ & $<30$ \\
\hline
\end{tabular}

Reclaimed-water site Sampled 9-10 to 9-11-90

Hemet dairy site Sampled 9-12-90

$\begin{array}{rrrr}3.3 & <30 & <30 & 460,000 \\ 10 & <30 & <30 & 4,300 \\ 28 & <30 & <30 & 40 \\ 40 & <30 & <30 & 150 \\ 60 & <30 & <30 & 30 \\ 65 & <30 & <30 & 40\end{array}$

40

Citrus grove site Sampled 9-19-90

$\begin{array}{rrrr}3.3 & 4,300 & <30 & 23,000 \\ 20 & <30 & <30 & 140 \\ 30 & <30 & <30 & 90\end{array}$

Irrigated-farm site Sampled 9-20 to 9-21-90

$\begin{array}{lrrr}3.3 & 40 & <30 & 150,000 \\ 9.5 & <30 & <30 & 93,000 \\ 28 & <30 & <30 & <30 \\ 62 & <30 & <30 & <30 \\ 100 & <30 & <30 & <30 \\ 104 \text { (sand) } & <30 & <30 & <30 \\ 105 \text { (clay) } & <30 & <30 & 40 \\ 137 & <30 & <30 & <30 \\ 150 & <30 & <30 & 1,500\end{array}$

1.0

3.3

15

15.2

$\begin{array}{rrr}4,300 & 150 & 15,000 \\ <30 & <30 & 23,000 \\ <30 & <30 & <30 \\ <30 & <30 & <30\end{array}$

Chino dairy site Sampled 11-13 to 11-14-90

$\begin{array}{rrrr}1.0 & 4,300 & 290 & 1,100,000 \\ 3.3 & <30 & <30 & 15,000 \\ 10 & <30 & <30 & 4,300 \\ 30 & <30 & <30 & <30 \\ 36 & <30 & <30 & 430 \\ 50 & <30 & <30 & 70 \\ 80 & <30 & <30 & 40\end{array}$


Table 3. Nitrogen-isotope and nitrogen-to-chloride ratio data for unsaturated-zone pore water beneath the instrumented land-use sites [ft, foot; $\mu \mathrm{M} / \mathrm{L}$, micromoles per liter; --, no data]

Determined by:

\section{Sample depth}

(ft)

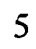

10

15

25

50

5

10

15

25

35

45

5

10

15

25

50

5

10

15

25

50

5

13.5

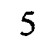

10

15

25

50
Date collected

(1992)

2-27

2-27

2-27

2-27

2-27

3-19

3-19

3-19

3-19

3-19

3-19

2-25

2-25

2-25

2-25

2-25

3-6

2-6

2-6

2-6

4-15

2-25

2-25

2-25

2-25

3-12

2-25

3-12

2-25 $\delta 15 \mathrm{~N}$

(permil)
Mass

spectrograph

$\mathrm{NO}_{3}$

$(\mu \mathrm{M} / \mathrm{L})$

\section{Residential site}

--
-
5.8
4.4
--

5.8

4.8

3.2

2.7

4.2

3.6

5.4

3.5

2.6

3.0

4.9

5.2

5.1

7.3

4.0

18.2

6.1

5.5

13.1

11.4

13.3

17.5

17.7

13.7

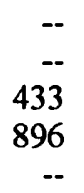

Reclaimed-water site

90
1,602
387
1,299
953
1,022

Citrus grove site

$$
\begin{array}{r}
15,396 \\
25,805 \\
10,047 \\
17,630 \\
3,035
\end{array}
$$

Irrigated-farm site

$$
\begin{array}{r}
460 \\
304 \\
187 \\
2,220
\end{array}
$$

Poultry-farm site

$$
254
$$

226

1,354

Hemet dairy site

$$
\begin{aligned}
& 7,798 \\
& 1,076 \\
& 1,225
\end{aligned}
$$

6,564

1,129

1,274

115,533

16,726

11,508

\section{Chino dairy site}
36,497
47,159
13,126
8,578
11,033

35,691
54,721
12,435
8,725
10,838

31,478

75,396

22,960

10,521

7,503

0.167

0.057

.067

.111

1.134

.542

1.439

2.735

3.758

551

.141

.133

.215

.829

1.444 
Table 4. Concentrations of selected gases in unsaturated-zone pore water beneath the instrumented land-use sites

[ft, foot; $\mu \mathrm{L}$, microliter; $\mu \mathrm{g} / \mathrm{g}$, micrograms per gram --, no data]

\begin{tabular}{|c|c|c|c|c|c|c|c|c|c|}
\hline $\begin{array}{l}\text { Core } \\
\text { depth } \\
\text { (ft) }\end{array}$ & $\begin{array}{c}\text { Sample } \\
\text { volume } \\
(\mu \mathrm{L})\end{array}$ & $\begin{array}{c}\text { Methane } \\
\left(\mathrm{CH}_{4}\right) \\
(\mu \mathrm{g} / \mathrm{g})\end{array}$ & $\begin{array}{c}\text { Carbon } \\
\text { dioxide } \\
\left(\mathrm{CO}_{2}\right) \\
(\mu \mathrm{g} / \mathrm{g})\end{array}$ & $\begin{array}{l}\text { Nitrous } \\
\text { oxide } \\
\left(\mathrm{N}_{2} \mathrm{O}\right) \\
(\mu \mathrm{g} / \mathrm{g})\end{array}$ & $\begin{array}{c}\text { Core } \\
\text { depth } \\
(f t)\end{array}$ & $\begin{array}{c}\text { Sample } \\
\text { volume } \\
(\mu \mathrm{L})\end{array}$ & $\begin{array}{c}\text { Methane } \\
\left(\mathrm{CH}_{4}\right) \\
(\mu \mathrm{g} / \mathrm{g})\end{array}$ & $\begin{array}{c}\text { Carbon } \\
\text { dioxide } \\
\left(\mathrm{CO}_{2}\right) \\
(\mu \mathrm{g} / \mathrm{g})\end{array}$ & $\begin{array}{c}\text { Nitrous } \\
\text { oxide } \\
\left(\mathrm{N}_{2} \mathrm{O}\right) \\
(\mu \mathrm{g} / \mathrm{g})\end{array}$ \\
\hline \multicolumn{5}{|c|}{ Residential site } & \multicolumn{5}{|c|}{ Irrigated-farm site } \\
\hline 25 & 900 & -- & 20,600 & -- & 25 & 900 & -- & 700 & -- \\
\hline 25 & 300 & -- & 17,000 & -- & 50 & 900 & -- & 18,300 & 200 \\
\hline 25 & 900 & -- & -- & -- & 50 & 900 & -- & 17,900 & 200 \\
\hline 50 & 300 & 30 & 22,200 & -- & 100 & 900 & -- & 48,500 & 0.0 \\
\hline 50 & 900 & -- & 22,400 & -- & 100 & 900 & 10 & 50,700 & 1.0 \\
\hline 50 & 300 & -- & 22,400 & -- & \multirow{2}{*}{\multicolumn{5}{|c|}{ Poultry-farm site }} \\
\hline 75 & 900 & -- & 21,300 & -- & & & & & \\
\hline 75 & 900 & -- & 19,700 & -- & & & & & \\
\hline 75 & 900 & - & 20,000 & -- & $\begin{array}{l}50 \\
75\end{array}$ & $\begin{array}{l}900 \\
900\end{array}$ & $\begin{array}{l}-- \\
--\end{array}$ & $\begin{array}{r}900 \\
3,600\end{array}$ & $\begin{array}{l}-- \\
--\end{array}$ \\
\hline \multicolumn{5}{|c|}{ Reclaimed-water site } & \multicolumn{5}{|c|}{ Hemet dairy site } \\
\hline 15 & 900 & - & 23,800 & -- & & & & & \\
\hline 15 & 300 & -- & 22,700 & -- & $\begin{array}{r}5 \\
10\end{array}$ & $\begin{array}{l}900 \\
900\end{array}$ & 20 & $\begin{array}{r}63,800 \\
900\end{array}$ & 150 \\
\hline 15 & 900 & -- & 23,500 & -- & 10 & $\begin{array}{l}900 \\
300\end{array}$ & $\begin{array}{l}-- \\
--\end{array}$ & $\begin{array}{r}900 \\
1,300\end{array}$ & - \\
\hline 30 & 300 & -- & 17,500 & -- & $\begin{array}{l}10 \\
10\end{array}$ & $\begin{array}{l}500 \\
900\end{array}$ & -- & 800 & - \\
\hline 30 & 900 & - & 17,800 & -- & $\begin{array}{l}10 \\
12\end{array}$ & 900 & - & 700 & - \\
\hline 45 & 900 & -- & 9,500 & -- & & & & & \\
\hline 45 & 900 & -- & 9,500 & -- & \multirow{2}{*}{\multicolumn{5}{|c|}{ Chino dairy site }} \\
\hline 63 & 900 & -- & 700 & -- & & & & & \\
\hline 63 & 300 & & 1,200 & -- & 10 & 900 & -- & 99,200 & 260 \\
\hline \multirow[t]{4}{*}{63} & 900 & - & 800 & -- & 25 & 900 & -- & 109,500 & 220 \\
\hline & & & & & 50 & 900 & -- & 94,300 & 240 \\
\hline & & & & & 50 & 900 & -- & 97,600 & 240 \\
\hline & \multicolumn{3}{|c|}{ Citrus grove site } & & 75 & 900 & - & 81,600 & 1.0 \\
\hline 10 & 900 & -- & 8,000 & -- & & & & & \\
\hline 25 & 900 & -- & 6,500 & -- & 75 & 900 & -- & 78,700 & 1.0 \\
\hline 25 & 300 & -- & 6,700 & -- & 75 & 900 & - & 81,400 & 1.0 \\
\hline 50 & 900 & -- & 9,100 & 160.0 & 90 & 900 & - & 70,800 & 1.0 \\
\hline 50 & 300 & - & 9,100 & 100.0 & & 900 & & 71,000 & \\
\hline 50 & 900 & - & 8,000 & - & & & & & \\
\hline
\end{tabular}


from the land surface to the water table. This estimate compares favorably with the estimate of 7 years obtained by using the unsaturated hydraulic conductivities.

Pore-water quality in the unsaturated zone is marginal to poor (dissolved-solids concentrations were 1,200 to more than $6,000 \mathrm{mg} / \mathrm{L}$ ). The predominant ions in the pore water were sodium and sulfate, and bicarbonate ions were present in smaller percentages. Nitrate is seasonally present in the shallow unsaturated zone, is absent in the middle unsaturated zone, and is present at high concentrations about $100 \mathrm{ft}$ below land surface. Microbial denitrification probably is occurring in the unsaturated zone, as evidenced by significant populations of denitrifying bacteria, decreasing dissolved organic carbon concentrations with depth, and elevated concentrations of $\mathrm{CO}_{2}$ in the soil gas. However, the absence of measurable $\mathrm{N}_{2} \mathrm{O}$ precludes an unequivocal conclusion that denitrification is occurring. The unsaturated-zone nitrate distribution suggests that the nitrate is not percolating from the surface at this time, but has a source that is deep within the unsaturated and (or) saturated zones. Because of this, it is not possible to determine the flux of nitrate reaching the water table at this site.

\section{Reclaimed-Water Site}

\section{Background}

Hughes and Robson (1974) reported that the use of reclaimed water to irrigate a golf course in Barstow, California, was the principal reason for increased dissolved-solids concentration in the underlying aquifer. Lund and others (1981) found that pore water in the unsaturated zone beneath a pasture irrigated with reclaimed water had nitrate concentrations of 15 to $32 \mathrm{mg} / \mathrm{L}$. Approximately 60 percent of the applied nitrogen was leached beneath the pasture root zone. Sylvester (1983) found that ground water underlying golf courses irrigated by reclaimed water in Livermore, California, had nitrate concentrations that exceeded the MCL. Ronen and Magaritz (1985) also found elevated nitrate concentrations in ground water underlying areas irrigated by reclaimed water.

\section{Site Description}

The reclaimed-water site is in the Menifee subbasin (fig. 2). The site is located near the 11th tee at the Cherry Hills Golf Club in Sun City,
California. The area is sewered, and reclaimed water from the Sun City Regional Water Reclamation Facility is used to irrigate the turf grass at the site.

Instrumentation of the site was completed in two phases using the techniques described in the "Site Instrumentation and Sample Collection" section of this report. The saturated-zone multipledepth wells were installed August 20-23, 1990, with screens at $430,370,242$, and $160 \mathrm{ft}$. The total borehole depth was $445 \mathrm{ft}$.

The unsaturated-zone instrumentation was installed in three holes September 10-17, 1990. The first hole was drilled to $67 \mathrm{ft}$, and continuous core was collected using the aseptic techniques described in the "Site Instrumentation and Sample Collection" section. A sealed 2-inch-diameter galvanized pipe was set in this bore hole at $65 \mathrm{ft}$ to serve as a neutron-probe access tube. Copper gas-sampling tubes $(0.25$-in.) were attached to the galvanized pipe at depths of $63,45,30$, and $15 \mathrm{ft}$. The bore hole was backfilled with native material to a depth of $2 \mathrm{ft}$ and a bentonite seal was installed to land surface. The second hole was drilled to $67 \mathrm{ft}$, and lysimeters were set in this bore hole at depths of 65,45 , and $35 \mathrm{ft}$. The third hole was drilled to $33 \mathrm{ft}$, and backfilled with native material to $28.5 \mathrm{ft}$, then with bentonite to $26 \mathrm{ft}$. Lysimeters were set in this bore hole at depths of $25,15,10$, and $5 \mathrm{ft}$.

Illustrated in figure 37 are the geophysical logs; the completion zones for the saturated zone wells; and the lithology interpreted from the driller's and geologist's logs, the geophysical logs, and the core observations. The caliper log indicates that several zones were prone to significant caving, notably the zones from 237 to $253 \mathrm{ft}, 265$ to $283 \mathrm{ft}$, and 355 to $390 \mathrm{ft}$. The $237-253 \mathrm{ft}$ zone consists of poorly cemented medium sand, silt, and uncemented sands; the $265-283 \mathrm{ft}$ zone consists of uncemented sands between two zones of poorly cemented material; and the 355-390 ft zone consists of silty sand, medium sand, and gravel. The gamma radioactivity log shows the characteristic increase in activity at the clay layers, and shows that zones that are relatively uniform have layers consisting of finer grained material. The spontaneous potential, single-point resistivity, and long-normal resistivity logs all are extremely flat, indicating that the permeability of the basin-fill materials is relatively constant, and that the formations are relatively uniform. The only significant spike was at $380 \mathrm{ft}$ between the layer of medium sand, gravel, and silt and the clay lens.

Samples were collected from the cores at 


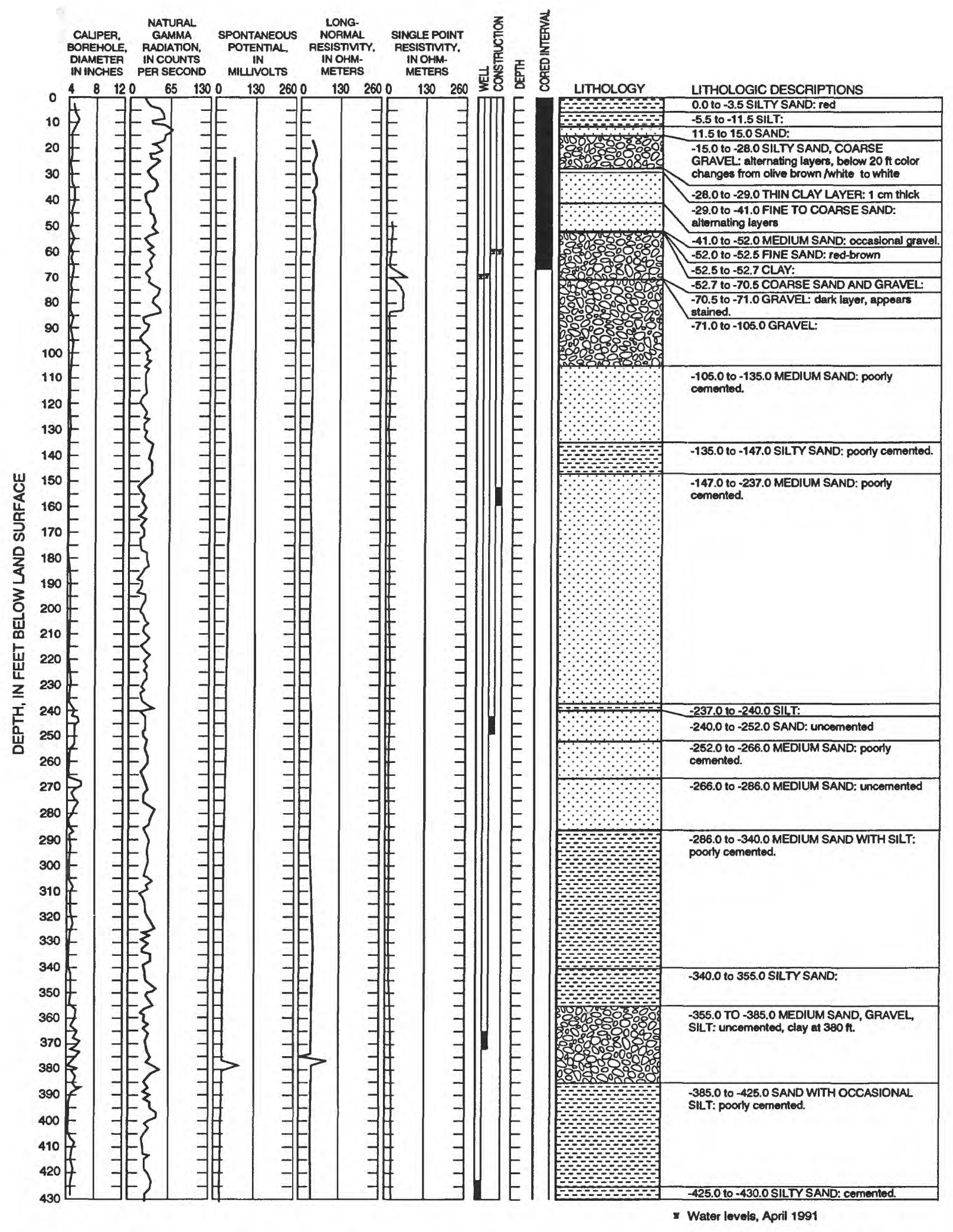

FIGURE 37. Geophysical logs, and diagram showing well construction, cored interval, and lithology for the reclaimed-water site. 


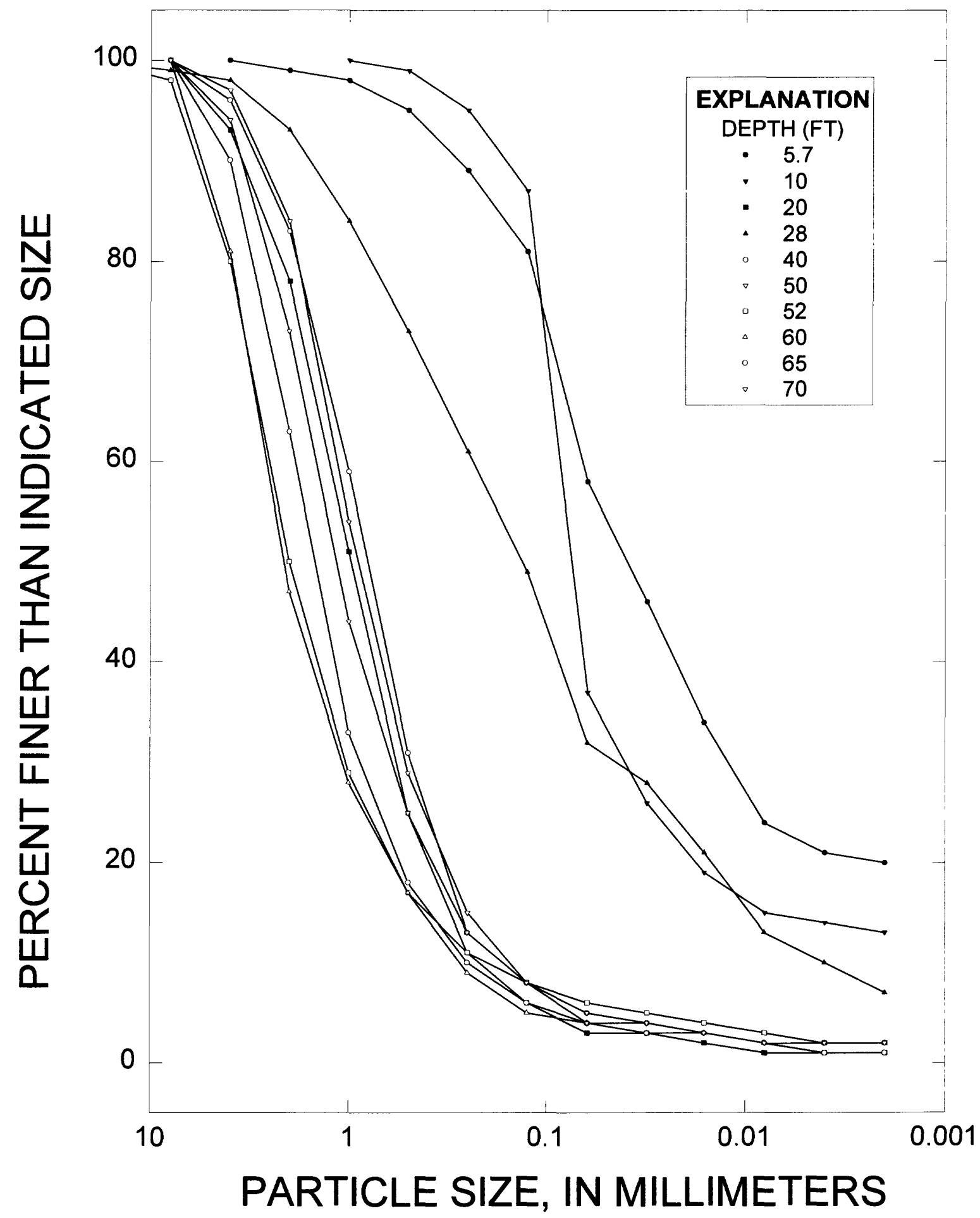

Figure 38. Particle-size distribution at selected depths for cores from the reclaimed water site. 
selected depths to determine the particle-size distributions in the different formations. These distributions are shown in figure 38. The sample from $5.7 \mathrm{ft}$ consists mostly of silt and clay, but it contains about 40 percent fine to medium sand. The sample from $10 \mathrm{ft}$ contains about 60 percent medium sand and 40 percent silt and clay. The sample from $20 \mathrm{ft}$ is primarily a coarser sand, and it contains only a small percentage of material smaller than $0.005 \mathrm{in}$. The sample from $28 \mathrm{ft}$ has the flattest distribution of the samples at the site, with significant percentages of particles in all size classes. All samples collected from zones deeper than $40 \mathrm{ft}$ were coarser than the shallower samples and had virtually identical particle-size distributions. More than 90 percent of the particles were larger than 0.01 in, and in samples from some depths, as much as 20 percent were larger than $0.16 \mathrm{in}$. None of the deeper samples had significant populations of particles smaller than 0.002 in.

\section{Saturated-Zone Results}

The reclaimed-water site was located in the Menifee ground-water basin because there were no sites available in the Hemet Basin that were utilizing reclaimed water. Although one of the objectives of the study was to develop a detailed understanding of the geohydrology of the Hemet Basin, it was not an objective to develop such an understanding of the other basins in which research sites were located. Therefore, no attempt was made to determine the horizontal component of ground-water flow at the reclaimed-water site.

The potentiometric levels in the four nested wells at this site $(5 \mathrm{~S} / 3 \mathrm{~W}-28 \mathrm{M})$ were measured five times during the course of this study, and the results are given in Supplemental Data 3B. The water table, as measured in the $160 \mathrm{ft}$. and $242 \mathrm{ft}$. shallow-zone wells, rose about $6.5 \mathrm{ft}$ during the course of the study (1991-92), and in August 1992 it was at $55.7 \mathrm{ft}$ below land surface. There was a slight upward gradient of about 0.2 to $0.4 \mathrm{ft}$ between these two depths. The water table, as measured in the 370 $\mathrm{ft}$ and $430 \mathrm{ft}$ deep-zone wells, rose about $10.0 \mathrm{ft}$ during the study, and it was $62.7 \mathrm{ft}$ below land surface in August 1992. There was a significant downward gradient from the shallow zones to the deep zones, ranging from $-10.4 \mathrm{ft}$ during January 1991 to $-7.0 \mathrm{ft}$ in August 1992. There was a slight dorvnward gradient of about $-0.3 \mathrm{ft}$ within the deep zone between the 370-foot depth and the 430-foot depth.

Water-quality samples were collected from the wells on January 31, June 13, and August 30, 1991, and on January 30 and August 19, 1992. Analytical results are given in Supplemental Data 3B. There is virtually no temporal variation in water quality at each of the sampled depths, suggesting that the samples collected are representative of water in the formation at the depths specified.

\section{Water quality in the shallow zone (160 and 242 feet)}

Water from a depth of $160 \mathrm{ft}$ had a dissolvedsolids concentration of about $3,300 \mathrm{mg} / \mathrm{L}$. Calcium, magnesium, chloride, and sulfate were the predominant ions; sodium and bicarbonate ions were present in smaller percentages. The $\mathrm{pH}$ was about 6.5 . The nitrate concentration, about $5 \mathrm{mg} / \mathrm{L}$, was below the MCL. The boron concentration, about $250 \mu \mathrm{g} / \mathrm{L}$, was moderate. The selenium concentration was about $12 \mu \mathrm{g} / \mathrm{L}$.

Water from a depth of the $242 \mathrm{ft}$ had a slightly higher dissolved-solids concentration, about $4,100 \mathrm{mg} / \mathrm{L}$. The ionic relations were similar to those at $160 \mathrm{ft}$, but with somewhat higher calcium, chloride, and bicarbonate concentrations, and somewhat lower sulfate concentrations. The $\mathrm{pH}$ was 6.4. The nitrate concentration, $1.7 \mathrm{mg} / \mathrm{L}$, was relatively low. The boron concentration was slightly lower than that at $160 \mathrm{ft}$, and the selenium concentration was about $8 \mathrm{mg} / \mathrm{L}$.

The stable-isotope values for the $160 \mathrm{ft}$ well were $\delta \mathrm{D}=-52.5$ permil and $\delta^{18} \mathrm{O}=-7.55$ permil, and $8 \mathrm{D}=-53.4$ permil and $8{ }^{18} \mathrm{O}=-7.55$ permil for the $242 \mathrm{ft}$ well. According to the Dansgaard (1964) diagram (fig. 28), the data for 160 and $242 \mathrm{ft}$ indicate that the water at these depths originated as rain that fell at the relatively warm temperature of $9^{\circ} \mathrm{C}$ rather than as snow at higher altitudes. The data for the water from both 160 and $242 \mathrm{ft}$ plot (fig. 29) on the meteoric-water line (Craig, 1961), suggesting that the water percolated to the water table without undergoing significant evaporation.

\section{Water quality in the deep zone ( 370 and 430 feet)}

Water collected from depths of 370 and $430 \mathrm{ft}$ was of much better quality than water from the shallow zone (described in the preceding section). The samples collected from $370 \mathrm{ft}$ had dissolvedsolids concentrations of about $1,500 \mathrm{mg} / \mathrm{L}$. The predominant ions were sodium and bicarbonate type; calcium and chloride ions were present in smaller percentages. The sulfate concentration was 
low; less than $20 \mathrm{mg} / \mathrm{L}$. The water had a $\mathrm{pH}$ of 7.1 . The nitrate concentrations were below the detection limit of $0.1 \mathrm{mg} / \mathrm{L}$, and the boron concentrations, about $220 \mu \mathrm{g} / \mathrm{L}$, are comparable to those in the water from the shallow zone. Selenium concentrations were below the detection limit of $1 \mu \mathrm{g} / \mathrm{L}$.

The water collected from $430 \mathrm{ft}$ had an even lower dissolved-solids concentration, about $1,070 \mathrm{mg} / \mathrm{L}$. The predominant ions were the same as those in the water from $370 \mathrm{ft}$. The sulfate, nitrate, and selenium concentrations all were low. The boron concentration, about $200 \mu \mathrm{g} / \mathrm{L}$, was slightly lower than concentrations in water from the other wells at the site. The water has a $\mathrm{pH}$ of 7.3 .

The $8 \mathrm{D}$ values $(-61.5$ permil for the $370 \mathrm{ft}$ water; -62.5 permil for the $430 \mathrm{ft}$ water) and $8^{18} \mathrm{O}$ values $(-8.95$ permil for the $370 \mathrm{ft}$ water; 9.15 permil for the $430 \mathrm{ft}$ water) suggest that both the $370 \mathrm{ft}$ water and the $430 \mathrm{ft}$ water were precipitated at an average temperature of about $8^{\circ} \mathrm{C}$. The data indicate that water at these depths originated as rain at relatively low altitudes, rather than as snow at higher altitudes. Plotting the values on the Craig (1961) diagram (fig. 29) reveals that the water may have undergone slight evaporation prior to percolation to the water table (the values plot slightly below the meteoric-water line).

\section{Unsaturated-Zone Results}

\section{Pore-moisture profiles}

Pore-moisture saturation-index profiles were measured using a calibrated neutron-attenuation logging tool that was lowered into the neutron-probe access tube. A description of how the neutron-attenuation logging tool operates, and how the saturation index is calculated, is given in the "Site Instrumentation" section.

The pore-moisture saturation-index profiles were measured in May, June, and November 1991, August and December 1992, and January 1993. The profiles are shown in figure 39 . Vertical resolution is approximately $1 \mathrm{ft}$ and horizontal resolution is about 0.02 unit. The clay seal placed at the top of the bore hole extended to a depth of $2 \mathrm{ft}$; moisture saturation-index profiles begin beneath this seal. Below the seal, to a depth of about $50 \mathrm{ft}$, the moisture saturation indices generally ranged from 0.2 to 0.5 . The highest moisture saturation indices correspond to the fine-grained sediments, and the lowest indices to the coarser sands. The clay layer at
$28 \mathrm{ft}$ is marked in the moisture profile by a decrease in moisture saturation index. The capillary fringe seems to begin at about $50 \mathrm{ft}$, about 5 to $10 \mathrm{ft}$ above the water table.

The moisture-saturation-index profile for January 1993 is similar in shape to that of the earlier profiles, but it is offset to higher saturation-index values. This January profile was measured after a 13-day period of intense rainfall (10 in. during the period).

The moisture saturation-index profiles show temporal variations of about 0.1 unit. The measured indices were lowest in August and October 1992 and highest in May 1991. The rapid change in profile between May and June 1991 suggests that the unsaturated zone is capable of draining very rapidly. There was an apparent drying of the unsaturated zone in that interval, and the zone stayed at the June 1991 moisture content through the rest of the summer and early fall (November 1991). The unsaturated zone continued to dry the next year (1992) through October. The seasonal variation is apparent in the drying trend.

The pore-moisture profiles indicate that there is no piston flow in the system, at least on the time scale of the measurements. The shape of the various profiles is virtually constant, and any change in moisture content is reflected in the entire profile, not just at a particular depth. The soil column seems to equilibrate rapidly to changes in precipitation and (or) irrigation.

Unsaturated hydraulic conductivities for the various alluvial materials beneath the reclaimedwater site ranged from $1.01 \times 10^{-8} \mathrm{ft} / \mathrm{s}$ (silt at $5 \mathrm{ft}$ ) to $1.75 \times 10^{-2} \mathrm{ft} / \mathrm{s}$ (gravel at $60 \mathrm{ft}$ ). Using the appropriate unsaturated hydraulic conductivities with the corresponding moisture saturation indices, and integrating over the entire unsaturated zone, one obtains a transit time of about 66 days for water to percolate from the land surface to the water table.

\section{Tritium profile}

The pore-water tritium-concentration profile in the unsaturated zone at the reclaimed-water site was determined by compositing lysimeter-collected water during July 1991 until sufficient volume $(1 \mathrm{~L})$ was obtained for analysis. The profile (fig. 40) shows that the tritium concentration was consistently less than $100 \mathrm{pCi} / \mathrm{L}$, significantly lower than the expected 1963 concentration of $600 \mathrm{pCi} / \mathrm{L}$; this indicates that the unsaturated-zone transit time 


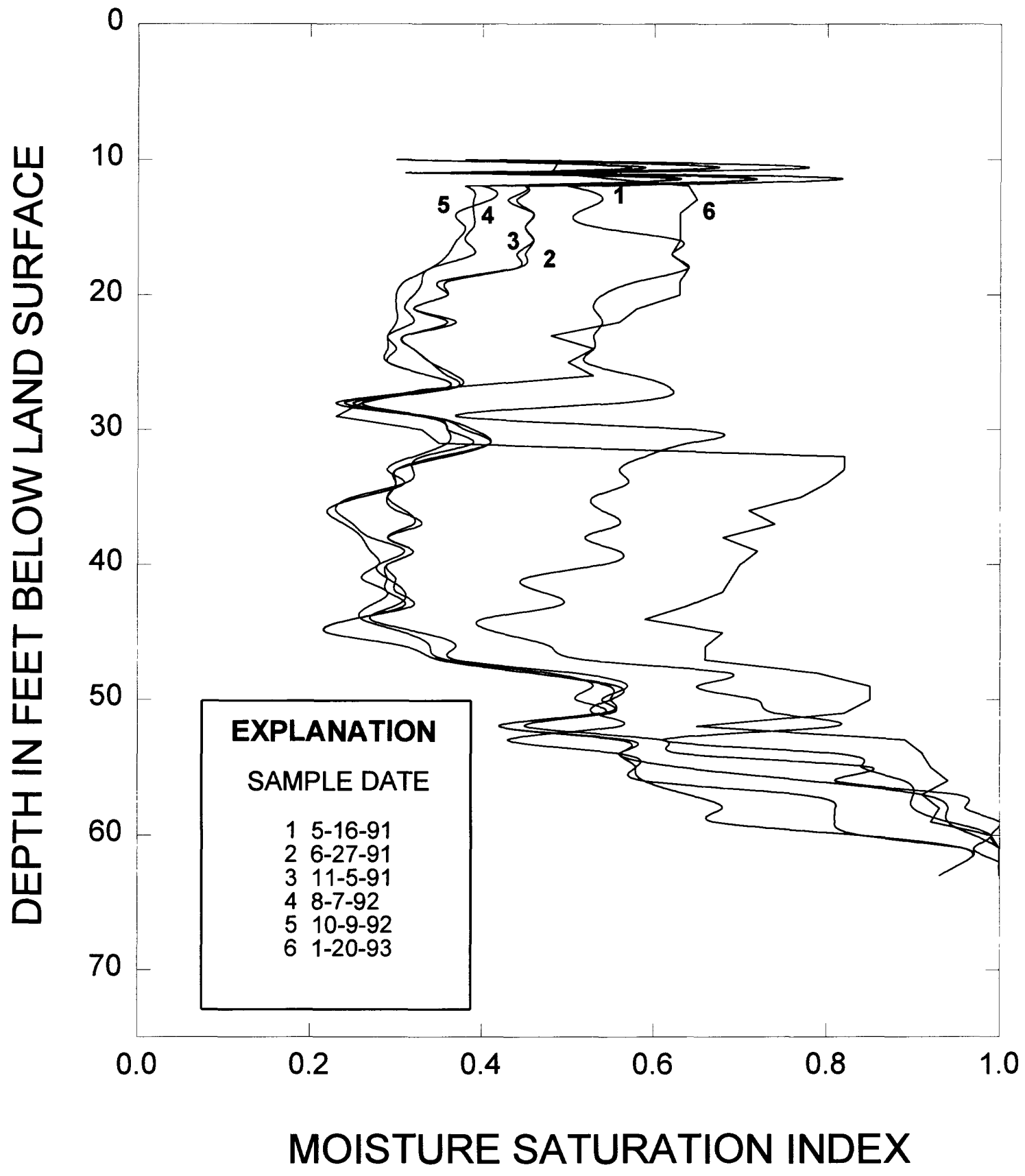

Figure 39. Unsaturated-zone pore-moisture profiles for selected dates in 1991-93 for the reclaimed-water site. 


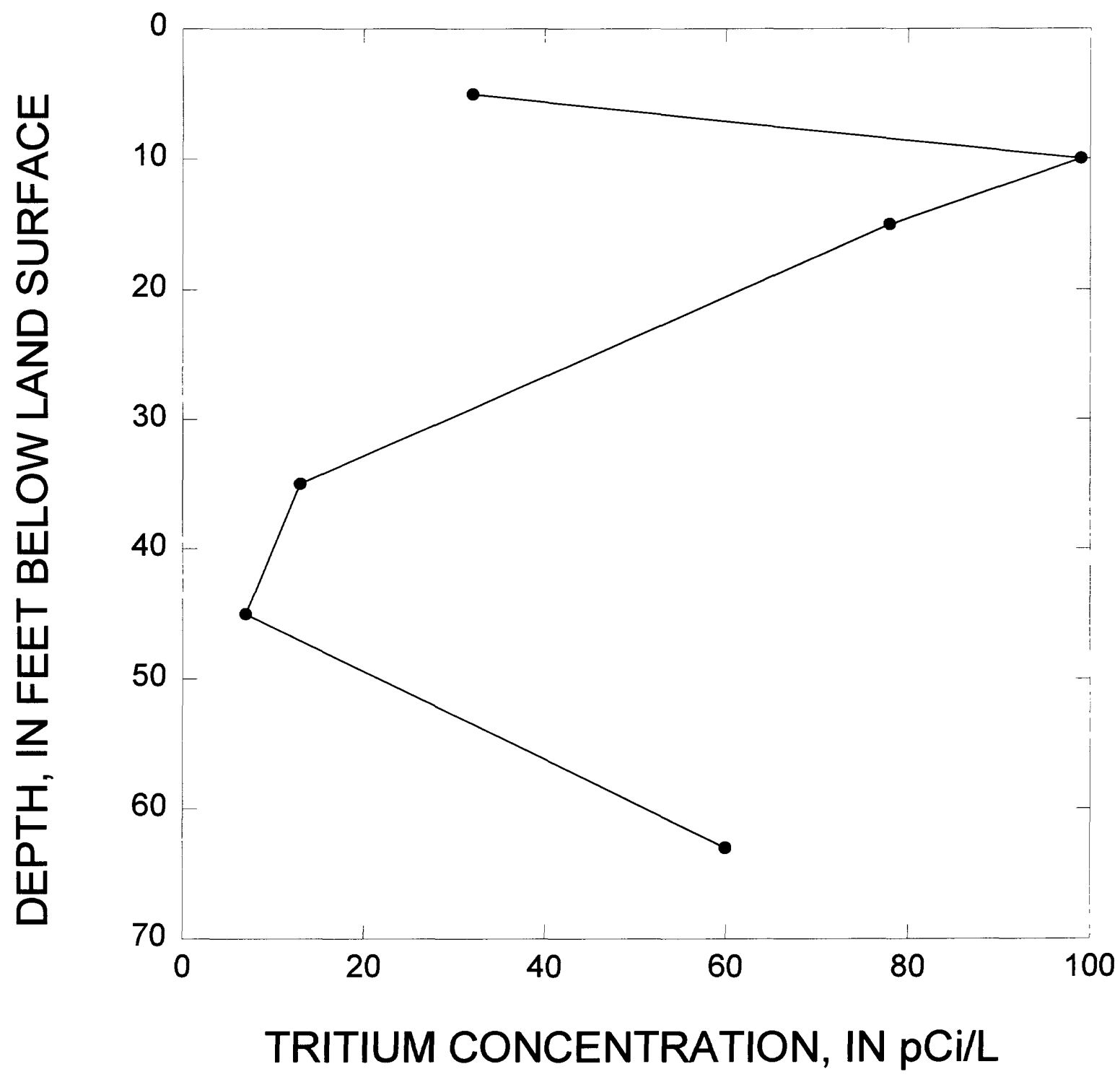

Figure 40. Tritium-concentration profile for pore water at the reclaimed-water site. 
is less than 30 years. The profile also shows that the observed maximum concentrations are considerably higher than the $15 \mathrm{pCi} / \mathrm{L}$ expected from fresh rainfall in southern California. The reclaimed-water site receives its irrigation water from the Sun City Regional Water Reclamation Facility. Most of the sewage treated at that facility comes from areas that receive for domestic supply imported Colorado River water, which has tritium concentrations of about $90 \mathrm{pCi} / \mathrm{L}$. The values observed are consistent with the source of the unsaturated-zone pore water being Colorado River water. The use of reclaimed water is highest during the summer and lowest during the winter. The maximums at 10 and $63 \mathrm{ft}$ probably represent reclaimed-water inputs from subsequent summers. Making this assumption gives an unsaturated-zone percolation rate of about $50 \mathrm{ft} / \mathrm{yr}$. This value suggests that it takes slightly more than 1 year for water to percolate from the land surface to the water table.

\section{Water quality}

Samples for determining unsaturated-zone porewater quality were collected using the ceramic-cup suction lysimeters in February, June, and August 1991 and February, May, and August 1992. Analytical results are given in Supplemental Data 3B.

In the samples collected at a depth of $5 \mathrm{ft}$, the dissolved-solids concentrations ranged from 6,300 to $9,520 \mathrm{mg} / \mathrm{L}$. There seems to be a trend of increasing concentration with time. The $\mathrm{pH}$ ranged from 7.1 to 7.6. The predominant ions were sodium, calcium, sulfate, and chloride. Bicarbonate was present only in very low concentrations. The dissolved-solids concentrations are considerably higher than the dissolved-solids concentrations in the reclaimed water used to irrigate the site (about $600 \mathrm{mg} / \mathrm{L}, \mathrm{M}$.W. Garner, Eastern Municipal Water District, written commun., 1990). The higher dissolved-solids concentrations in the pore water probably are due to evaporative concentration of salts, and to the addition of fertilizers to the site. The dissolved organic-carbon content in the pore water was $21 \mathrm{mg} / \mathrm{L}$.

The samples collected from a depth of $10 \mathrm{ft}$ had a relatively constant dissolved-solids concentration of about $6,400 \mathrm{mg} / \mathrm{L}$. The $\mathrm{pH}$ ranged from 6.9 to 7.6. The predominant ions were sodium, calcium, magnesium, sulfate, and chloride. Bicarbonate was not detected in the water from this depth. The dissolved-solids concentrations and ionic relations are consistent with water percolating from the shallow zone to this depth.

In the samples collected from a depth of $15 \mathrm{ft}$, dissolved-solids concentrations decreased from $5,500 \mathrm{mg} / \mathrm{L}$ in June 1991 to $4,670 \mathrm{mg} / \mathrm{L}$ in February 1992. This decrease was followed by an increase to $4,890 \mathrm{mg} / \mathrm{L}$ in August 1992. The $\mathrm{pH}$ ranged from 6.8 to 7.4 . The predominant ions were calcium, sulfate, sodium, and chloride--indicating a shift to calcium (perhaps as a result of calcium-sodium exchange with carbonates cementing the sand in the unsaturated zone). Bicarbonate concentrations again were negligible in comparison with the other anionic constituents. Dissolved organic-carbon concentration was $8.5 \mathrm{mg} / \mathrm{L}$.

Only two samples were collected from the lysimeter at $25 \mathrm{ft}$. Analyses indicated a continued high dissolved-solids concentration of about $5,700 \mathrm{mg} / \mathrm{L}$. The $\mathrm{pH}$ of the pore water was about 7.2. The predominant ions were calcium, chloride, sodium, and sulfate. Bicarbonate concentrations were relatively low. The dissolved organic-carbon concentration was $2.8 \mathrm{mg} / \mathrm{L}$.

Because the lysimeter at $35 \mathrm{ft}$ produced only small quantities of water, only anionic constituents were determined. These analyses suggest that the water chemistry is similar to that at $25 \mathrm{ft}$, being dominated by chloride. Sulfate concentrations were about $1,700 \mathrm{mg} / \mathrm{L}$. The organic-carbon concentration was $4.5 \mathrm{mg} / \mathrm{L}$.

The availability of samples from the $45 \mathrm{ft}$ lysimeter also was limited. The $\mathrm{pH}$ ranged from 6.7 to 7.6. The predominant ions were calcium and chloride; sodium and sulfate ions were present in smaller percentages. The organic-carbon concentration (16 mg/L) was relatively high.

The $63 \mathrm{ft}$ lysimeter is below the water table, and thus represents water from the shallow saturated zone. The water had a dissolved-solids concentration of about $2,900 \mathrm{mg} / \mathrm{L}$ and $\mathrm{a} \mathrm{pH}$ of about 7.2. The sodium and calcium concentrations were about equal, and magnesium was about half the calcium concentration. Chloride and sulfate concentrations were nearly identical at about $1,000 \mathrm{mg} / \mathrm{L}$. Bicarbonate concentrations were low. The dissolved organic-carbon concentration was $2.3 \mathrm{mg} / \mathrm{L}$. A comparison of these results with those from the $160 \mathrm{ft}$ well shows that the dissolved-solids concentrations in the shallow saturated zone were somewhat lower than the concentrations at greater depth; the sodium concentrations in the shallow saturated zone were higher, the calcium 
concentrations were lower, and the chloride and sulfate concentrations were about the same at both depths.

Several trends with depth in the unsaturated zone are notable. There is a general trend of decreasing dissolved-solids concentration with depth, but only by a factor of 17 percent. Pore-water concentrations do not show temporal variations, except in the $5 \mathrm{ft}$ zone. The general trend for dissolved organic carbon is decreasing concentrations with depth. Significant dissolved organic-carbon concentrations are present at all depths. The data do not indicate flushing of salts through the unsaturated zone to the water table. During the timeframe of this study (1991-92), the salts seem to have stayed in the same zone, migrating neither upward nor downward.

\section{Nitrogen profiles}

Core results.--Samples of core material were collected and processed using the procedures described in the "Site Instrumentation" section. The unsaturated-zone organic-nitrogen concentrations were relatively constant, ranging from 3 to $6 \mathrm{mg} / \mathrm{L}$ at all depths (fig. 41). There seems to be a weak correlation of higher pore-water organic-nitrogen concentrations with zones in which clay content is relatively high. Virtually no ammonia or ammonium was detected in the core extracts from the unsaturated zone beneath the reclaimed-water site.

Nitrate concentrations in the unsaturated zone are shown in figure 42 . There seems to be a linear increase in nitrate concentration with depth from about $3 \mathrm{ft}$ below land surface to about $63 \mathrm{ft}$, but only at $63 \mathrm{ft}$ does the pore-water nitrate concentration exceed the MCL of $10 \mathrm{mg} / \mathrm{L}$. The relatively low nitrate concentrations in the near surface indicate that both the nitrogen from the reclaimed water used for irrigation of the turf and the nitrogen from the inorganic nitrogen fertilizers are being used efficiently by the turf grass, and little nitrogen has leached beneath the root zone. The increase in nitrate with depth suggests that the nitrogen that does leach beneath the root zone is being oxidized to nitrate in the unsaturated zone.

Alternatively, the nitrate peak at $63 \mathrm{ft}$ may be the result of over-fertilizing at some time in the recent past and the movement of the excess nitrogen down through the unsaturated zone.

Lysimeter results.--Samples of unsaturatedzone pore water were collected using the ceramic- cup suction lysimeters in February, June, and August 1991 and in February, May, and August 1992. Results are given in Supplemental Data 3B and illustrated in figure 43. Organic-nitrogen, ammonia, and nitrite concentrations were generally low; therefore, the discussion that follows focuses on the nitrate-concentration profiles.

Pore-water samples collected from $5 \mathrm{ft}$ showed a cyclic trend in nitrate concentration. The concentration in the sample collected in February 1991 was $5 \mathrm{mg} / \mathrm{L}$. The concentration increased to 14 $\mathrm{mg} / \mathrm{L}$ in June and to $26 \mathrm{mg} / \mathrm{L}$ in August 1991. Both these concentrations are above the MCL of $10 \mathrm{mg} / \mathrm{L}$. The concentrations decreased over the winter, and by February 1992 the nitrate concentration was $3.5 \mathrm{mg} / \mathrm{L}$, well below the $\mathrm{MCL}$. The concentrations continued to decrease through the spring and summer and were below the detection limit in both May and August 1992.

The trend for pore water collected from $10 \mathrm{ft}$ was the same as that at $5 \mathrm{ft}$. The nitrate concentration increased from $8.7 \mathrm{mg} / \mathrm{L}$ in February 1991 to $19 \mathrm{mg} / \mathrm{L}$ in June 1991. The nitrate concentration continued to increase through August 1991 , and it stabilized at $27 \mathrm{mg} / \mathrm{L}$ in both the August 1991 and February 1992 samples. By April 1992, the nitrate concentration had decreased to $1.1 \mathrm{mg} / \mathrm{L}$, and by August 1992, the concentration was below the detection limit. The organic-carbon concentration in the pore water from $10 \mathrm{ft}$ was $13 \mathrm{mg} / \mathrm{L}$.

The nitrate data show a less definitive trend for unsaturated-zone pore water collected from $15 \mathrm{ft}$. In the June 1991 sample, nitrate concentration was $4.7 \mathrm{mg} / \mathrm{L}$. By August 1991, the concentration had decreased to $2.1 \mathrm{mg} / \mathrm{L}$. By February 1992, the concentration had increased again to $3.3 \mathrm{mg} / \mathrm{L}$. By May 1992, the nitrate concentration was $9.1 \mathrm{mg} / \mathrm{L}$, near the MCL of $10 \mathrm{mg} / \mathrm{L}$. By August 1992, the nitrate concentration was below the detection limit.

Only sparse data were obtained from the 25 foot depth; samples were collected only in May and August 1992. In both samples, the nitrate concentration in the pore water was about $18 \mathrm{mg} / \mathrm{L}$, well above the MCL.

In the pore water collected from the $35 \mathrm{ft}$ lysimeter, nitrate concentrations were high, ranging from 10 to $14 \mathrm{mg} / \mathrm{L}$ over the course of the study. The high nitrate concentrations persisted to the 45 . foot depth, with values ranging from 13 to $17 \mathrm{mg} / \mathrm{L}$. In water from the submerged lysimeter at $63 \mathrm{ft}$, the 


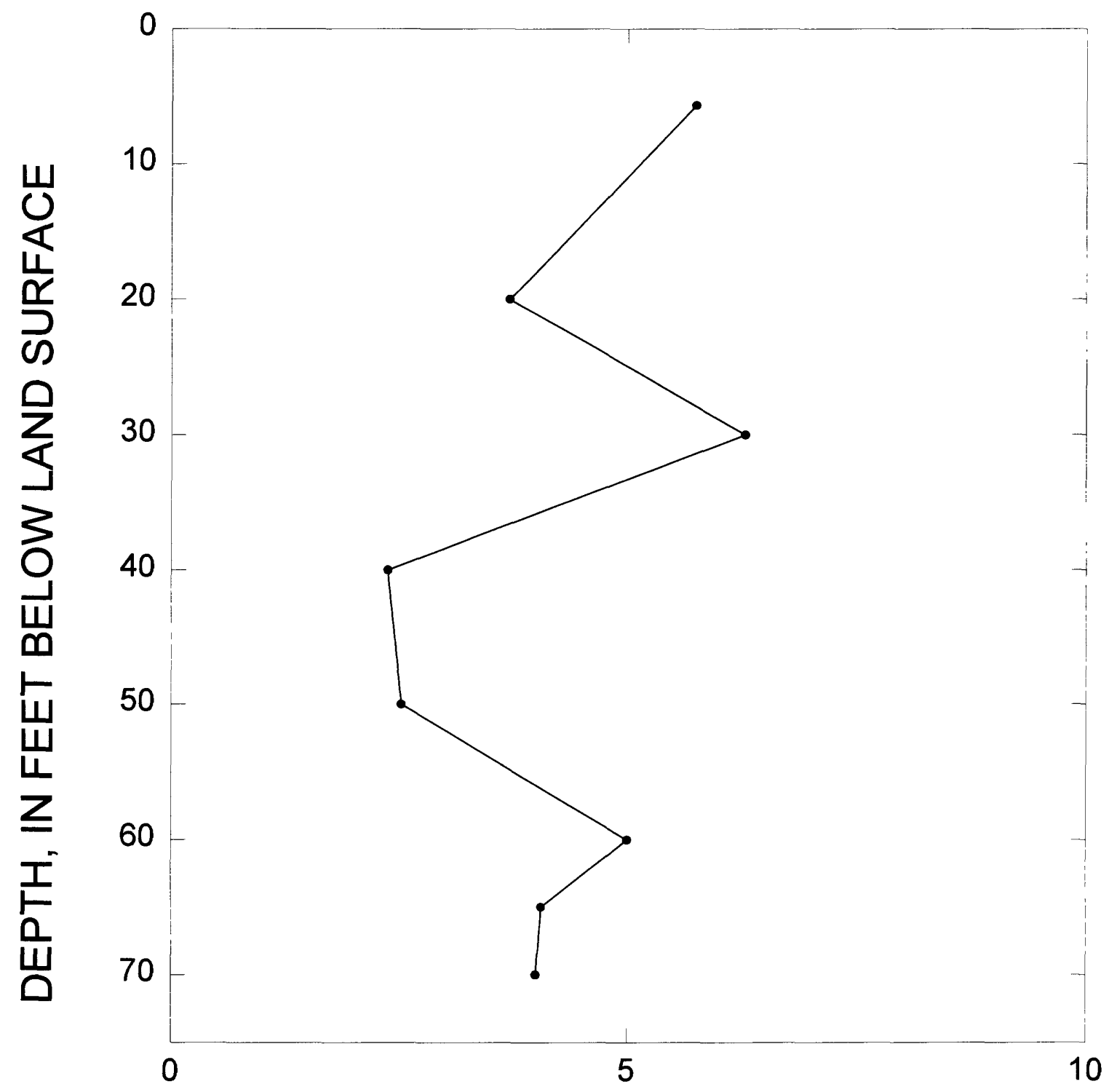

ORGANIC NITROGEN CONCENTRATION, IN MG/L

Figure 41. Organic-nitrogen-concentration profile, from core extracts, for the unsaturated zone at the reclaimed-water site. 


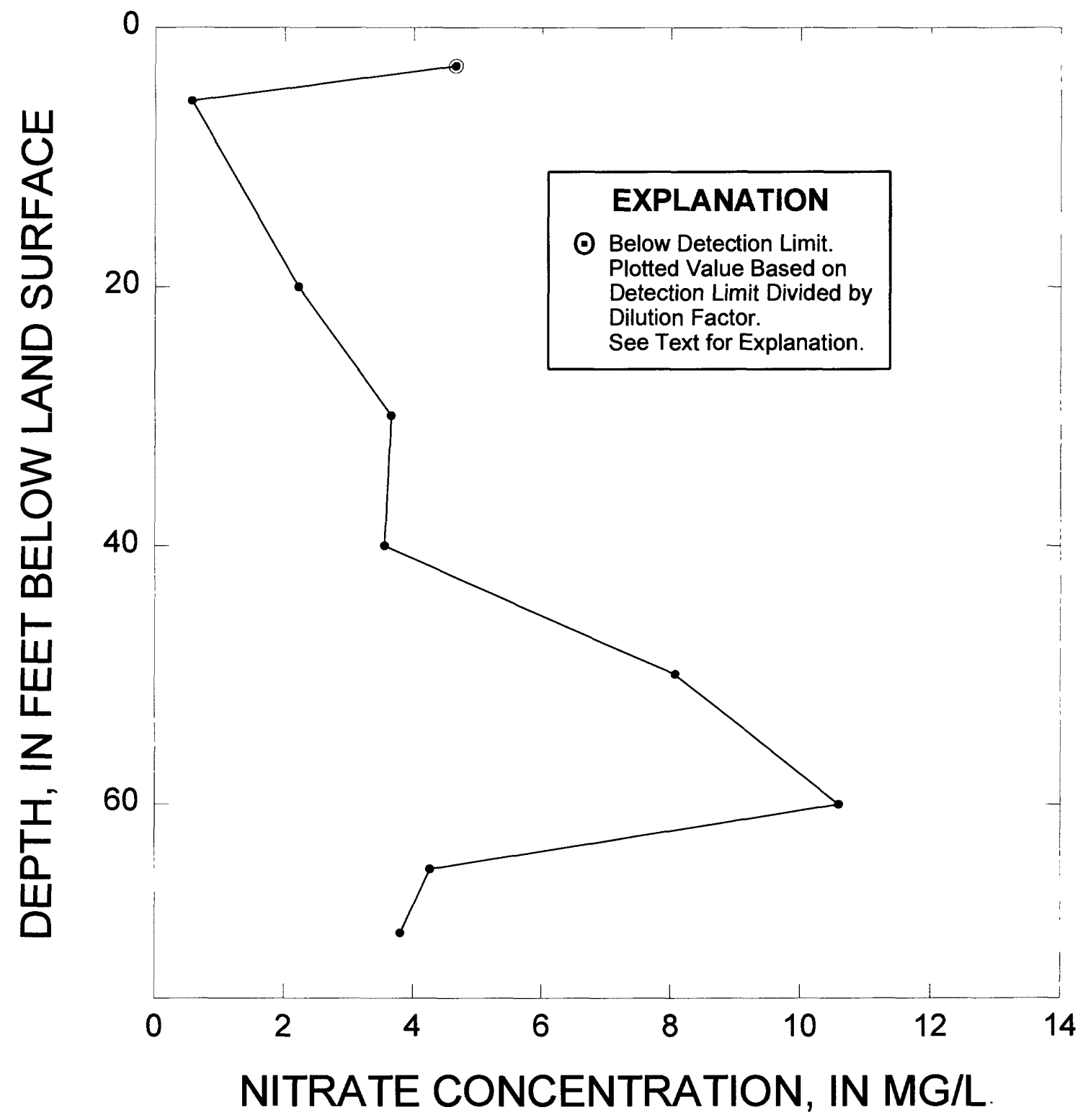

Figure 42. Nitrate-concentration profile, from core extracts, for the unsaturated zone at the reclaimed-water site. 


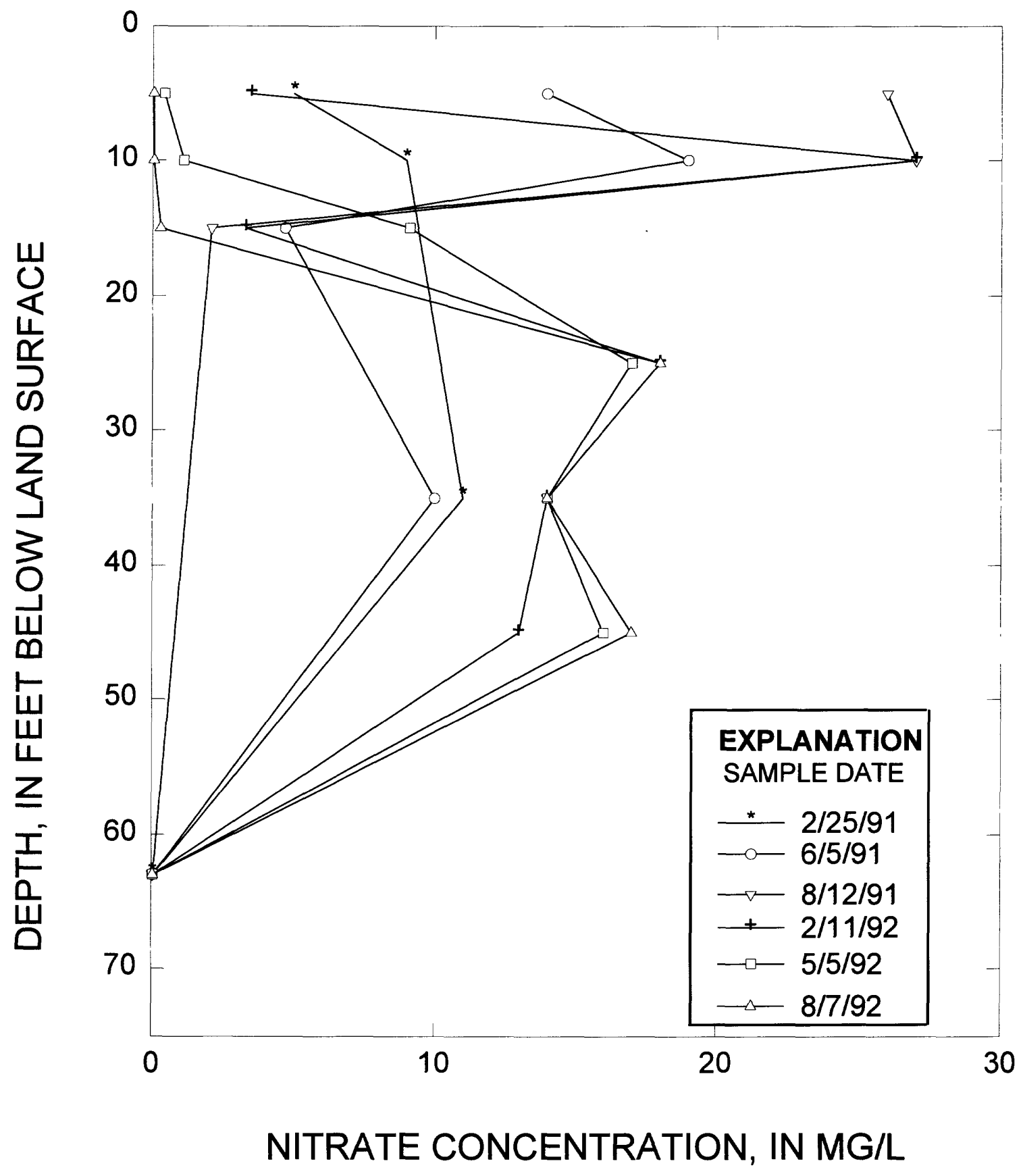

Figure 43. Nitrate concentration, for selected dates in 1991-92, in unsaturated-zone pore water at the reclaimed-water site. 
nitrate concentration was nondetectable.

The cyclic trend of nitrate concentration in the shallow unsaturated zone suggests an input of fertilizer in spring 1991 and repeated applications over the spring and summer of 1991 . The decrease during the late summer and autumn of 1991 suggests that the nitrate either (1) was washed out of the shallow unsaturated zone, (2) was incorporated into the turf biomass, (3) was consumed by nitratereducing bacteria--or was removed by some combination of the above. The elevated nitrate concentrations in the deeper unsaturated zone suggests percolation of high-nitrate pore water from the shallow zone to the deep zone. The low nitrate concentrations at $15 \mathrm{ft}$ suggest that this leaching must have occurred at some time in the past because there is a zone of low-nitrate pore water between the current inputs and the deeper water. The nondetectable nitrate concentrations in water from the $63 \mathrm{ft}$ lysimeter may be the result of additional denitrification in the capillary fringe above the water table (removing residual nitrate before it reaches the water table), or the result of simple dilution.

\section{Microbial Processes}

The results of microbial analyses for the reclaimed-water site are given in table 2 . The number of nitrifying bacteria was below the detection limit of 30 bacteria per gram of core material at each of the depths sampled. No Nitrosomonas or Nitrobacter were detected. Significant populations of denitrifying bacteria were present, however. The highest concentration, 460,000 bacteria per gram of core material, was in the $3 \mathrm{ft}$ sample. The number of bacteria rapidly decreased with depth, but even at a depth of $65 \mathrm{ft}$, there remained 40 viable denitrifying bacteria per gram of core.

The presence of assimilated denitrifying bacteria at the site suggests that denitrification might be occurring. The $\delta^{15} \mathrm{~N}$ values for the samples collected at the reclaimed-water site are given in table 3 . The values are considerably less than 10 , suggesting that the source of the nitrate is from mineral rather than biological sources. The $\delta^{15} \mathrm{~N}$ value of 5.8 at $5 \mathrm{ft}$ suggests considerable microbial cycling of the nitrate and is consistent with the large number of denitrifying bacteria at this depth. The $\delta^{15} \mathrm{~N}$ value of 4.8 at $10 \mathrm{ft}$ suggests that considerable microbial cycling of nitrate is occurring at this depth as well. The $\delta^{15} \mathrm{~N}$ values at 15,25 , and $35 \mathrm{ft}$ suggest that the microbial activity is less at 15 and $25 \mathrm{ft}$, but increases in the $35 \mathrm{ft}$ zone. The $8^{15} \mathrm{~N}$ value of 2.7 at $25 \mathrm{ft}$ is not much different from what would be expected from microbially untouched inorganic fertilizers.

The soil-gas profiles for the reclaimed-water site are given in table 4 . The absence of measurable $\mathrm{N}_{2} \mathrm{O}$ precludes the unequivocal conclusion that denitrification is occurring at the site. However, the elevated $\mathrm{CO}_{2}$ concentrations (ranging from 700 to $110,000 \mu \mathrm{g} / \mathrm{g}$ ) suggest the presence of significant microbial activity in the shallow unsaturated zone.

\section{Conclusions}

The reclaimed-water site is located over an aquifer consisting of two distinct zones. The uppermost zone has poor-quality (high dissolvedsolids concentration) water, but it does not have elevated nitrate concentrations. There is a slight upward gradient in the upper zone. The lower zone has better quality water, and the water quality improves with depth. There is a slight downward gradient within the lower zone, and a pronounced downward gradient between the upper and the lower zones. This would imply that poor-quality water from the upper zone is being drawn into the lower zone.

The unsaturated-zone pore moisture is variable, the fine-grained material having the highest moisture contents. The tritium profile suggests relatively rapid percolation of water from the land surface to the water table (percolation taking slightly more than 1 year) as do the unsaturated hydraulic conductivities (about 66 days). The porewater quality is poor throughout the unsaturated zone; dissolved-solids concentrations ranged from 3,000 to $9,000 \mathrm{mg} / \mathrm{L}$. Nitrate is seasonally present in the shallow unsaturated zone and perennially present in the deeper unsaturated zone. The nitrate concentrations in the unsaturated zone commonly exceeded the MCL. Significant microbial populations and elevated carbon-dioxide concentrations suggest that microbial denitrification may be occurring at the site, but the absence of measurable $\mathrm{N}_{2} \mathrm{O}$ precludes a definitive determination.

\section{Citrus Grove Site}

\section{Background}

Bingham and others (1970) studied a 960-acre watershed that was planted in citrus groves. They 
found that salts tended to accumulate in the top few feet of the soil column, and that the salts were primarily gypsum and lime. They found nitrate concentrations as high as $20 \mathrm{mg} / \mathrm{L}$ in the water draining the groves. This loss represented 45 percent of the applied fertilizer. Embleton and others (1980) also found significant nitrate losses in citrus groves, particularly where the fertilizer application rates exceeded $140 \mathrm{lb} / \mathrm{acre}$ per year. The soil conditions most suited to citrus production also seem to be conditions that allow significant quantities of nitrate to leach to the water table.

\section{Site Description}

The citrus grove site is in the Bautista Creek outwash area of the Hemet subbasin, about $0.5 \mathrm{mi}$ west of Fairview Avenue and several hundred feet north of Stetson Avenue (site 3 in fig. 3). The area has extensive citrus (orange and grapefruit) groves and is irrigated using both municipally supplied water and pumped ground water.

Instrumentation of the site was completed in two phases using the techniques described in the "Site Instrumentation and Sample Collection" section of this report. The saturated-zone multipledepth wells were installed during August 1-4, 1990, with screens at $435,385,335$, and $310 \mathrm{ft}$. Total depth of the hole was $465 \mathrm{ft}$.

The unsaturated-zone instrumentation was installed during September 19-November 29, 1990. The first attempt involved drilling a 9-inchdiameter bore hole using the dry auger drilling technique. Numerous cobbles were encountered, and usable core material was collected from only a few depths. The auger hole could be drilled only to a depth of $36 \mathrm{ft}$. Because of these difficulties, the remaining bore holes were drilled using the airrotary drilling technique. The first air-rotary bore hole was drilled to $151 \mathrm{ft}$. A sealed 2-inch-diameter galvanized pipe was set in this bore hole at $150 \mathrm{ft}$ to serve as a neutron-probe access tube. Copper gassampling tubes $(0.25$-in.) were attached to the galvanized pipe at depths of $100,50,25$, and $10 \mathrm{ft}$. The bore hole was backfilled with native material to a depth of $5 \mathrm{ft}$, and a bentonite seal was installed to land surface. The second air-rotary bore hole was drilled to $160 \mathrm{ft}$. Lysimeters were set in this bore hole at depths of 148, 100,75, and $49.9 \mathrm{ft}$. The third air-rotary bore hole was drilled to $33 \mathrm{ft}$. This bore hole was backfilled with native material to $25.2 \mathrm{ft}$, and lysimeters were set in this bore hole at depths of $25,15,10$, and $5 \mathrm{ft}$.
The geophysical logs; the completion zones for the saturated-zone wells; and the lithology interpreted from the driller's and geologist's logs, the geophysical logs, and the limited core observations are illustrated in figure 44 . The caliper log shows numerous zones where significant caving occurred, notably the $0-70,135-150$, and $205-240 \mathrm{ft}$ zones. The $0-70 \mathrm{ft}$ zone consists of alternating layers of unconsolidated sand, gravel, and cobbles. The 135150 foot zone consists of unconsolidated fine to medium sand and occasional layers of silt, clay, and gravel. The 205-240 $\mathrm{ft}$ zone also consists of unconsolidated fine to medium sand. The gamma radioactivity log indicates little clay underlying this site. The gamma peaks are more indicative of coarse-grained, poorly weathered granite, and correspond to zones with coarse gravels and cobbles. Several gamma peaks, however, probably do correspond to clay layers, particularly the peaks at 130 and $295 \mathrm{ft}$, and the multiple peaks between 355 and $450 \mathrm{ft}$. The spontaneous-potential and single-point resistivity logs indicate clay layers at 155 and $163 \mathrm{ft}$; these logs also clearly mark the sand/gravel interfaces at 180, 200 to 205 , and $335 \mathrm{ft}$. The spontaneous-potential log indicates a layer of more angular material at $215 \mathrm{ft}$, and the interface at $435 \mathrm{ft}$ between the cemented sand above and the uncemented sand below. Because the long and short normal resistivity tool did not function properly at this site, those logs have been omitted. The interpreted lithology indicates typical outwash deposits consisting of interspersed layers of sand, gravel, and cobbles. The presence of cobbles suggests periodic energetic deposition. No welldefined, extensive, thick clay layers are present in this area to impede water that percolates to the water table.

Samples were collected from the cores only at three shallow depths at this site because of the problems with the auger. The grain-size distributions of these samples are shown in figure 45. The $3 \mathrm{ft}$ and $30 \mathrm{ft}$ samples have virtually identical distributions, in which 90 percent of the particles are sand-sized or larger. The $3 \mathrm{ft}$ sample had more medium and fine sand, and the $30 \mathrm{ft}$ sample had more coarse sand and gravel. Neither sample had a significant percentage of clay-sized material. The $20 \mathrm{ft}$ sample consisted mostly of gravel and coarse sand: 80 percent of the material was larger than 0.01 in., and 20 percent was larger than 0.06 in.; the percentage of clay-sized material was negligible. 


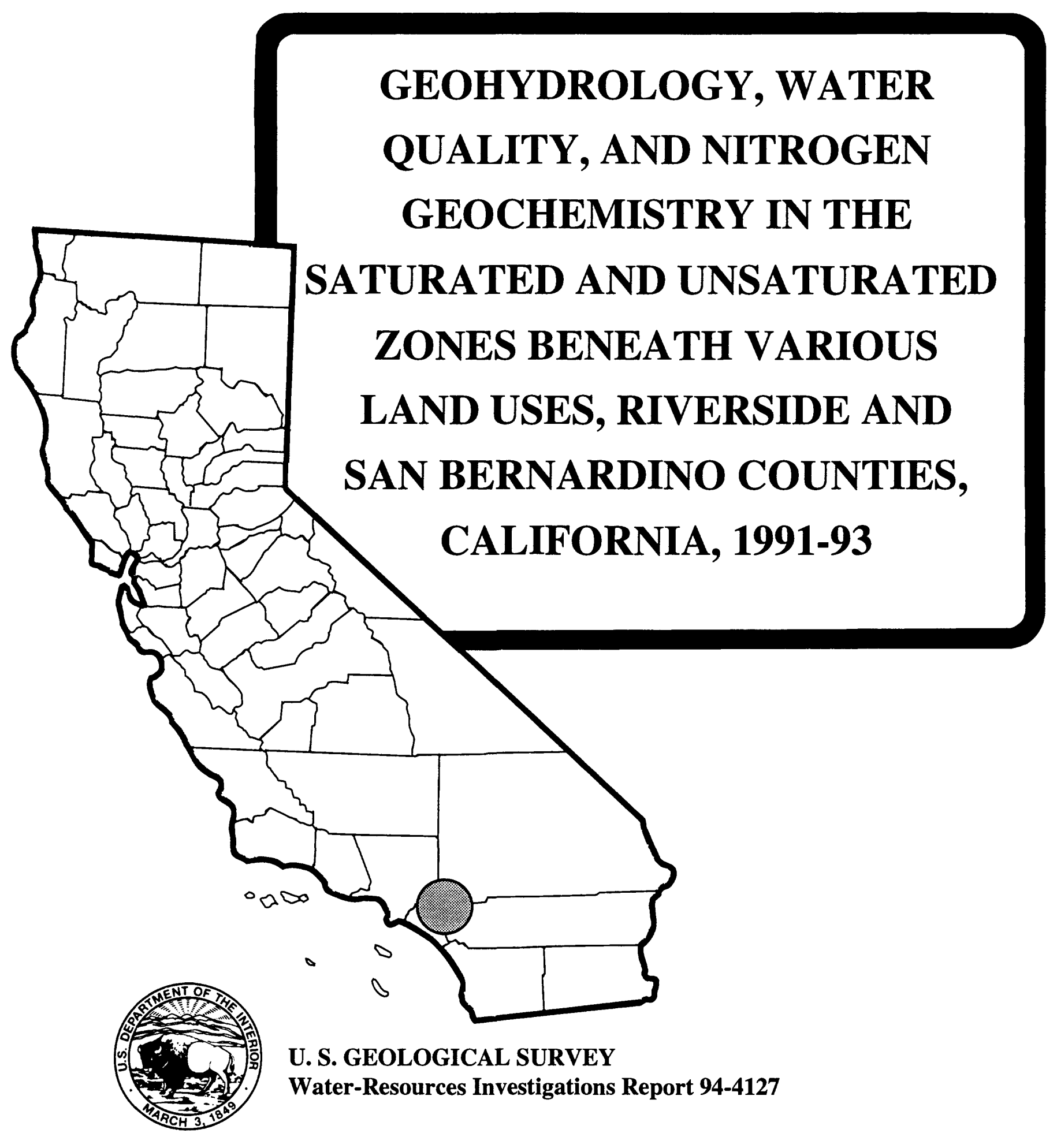

Prepared in cooperation with the

EASTERN MUNICIPAL WATER DISTRICT, the METROPOLITAN WATER DISTRICT OF SOUTHERN CALIFORNIA, and the ORANGE COUNTY WATER DISTRICT 


\section{U.S. DEPARTMENT OF THE INTERIOR \\ BRUCE BABBITT, Secretary}

U.S. GEOLOGICAL SURVEY

Gordon P. Eaton, Director

Any use of trade, product, or firm names in this publication is for descriptive purposes only and does not imply endorsement by the U.S. Government.

For sale by the

U.S. Geological Survey

Earth Science Information Center

Open-File Reports Section

Box 25286, MS 517

Denver Federal Center

Denver, CO 80225

For additional information write to:

District Chief

U.S. Geological Survey

Federal Building, Room W-2233

2800 Cottage Way

Sacramento, CA 95825 


\section{CONTENTS}

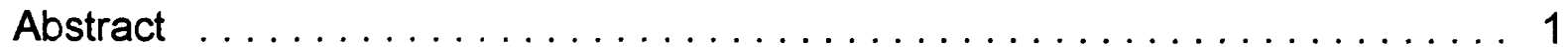

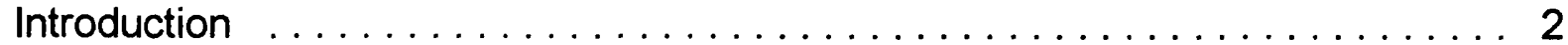

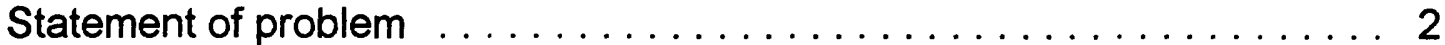

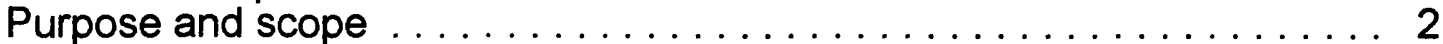

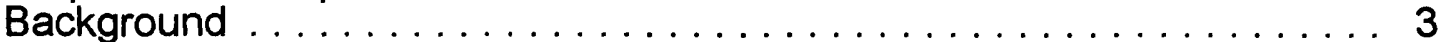

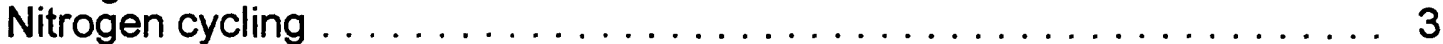

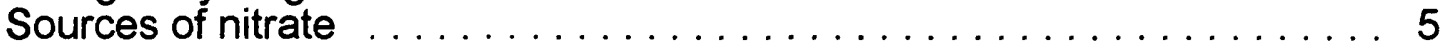

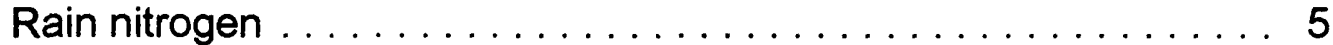

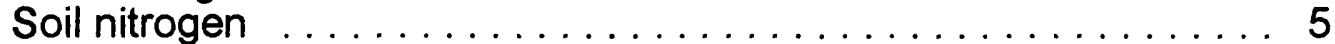

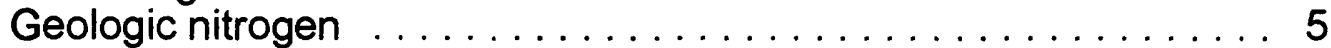

Row-crop agriculture ................... 5

Animal wastes and sewage $\ldots \ldots \ldots \ldots \ldots \ldots \ldots \ldots$

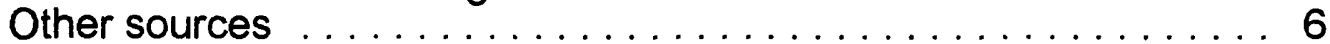

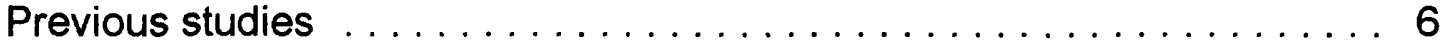

Saturated-zone studies $\ldots \ldots \ldots \ldots \ldots \ldots \ldots \ldots \ldots \ldots \ldots \ldots \ldots$

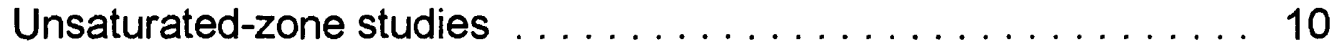

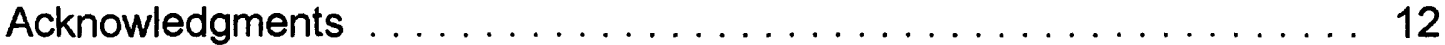

Site selection and instrumentation $\ldots \ldots \ldots \ldots \ldots \ldots \ldots \ldots \ldots \ldots \ldots \ldots \ldots$

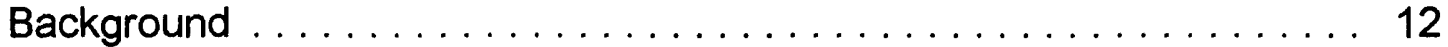

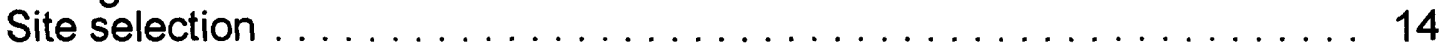

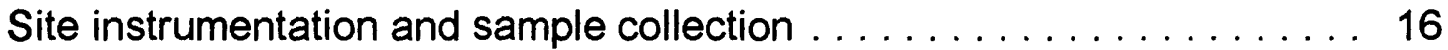

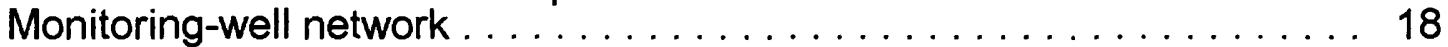

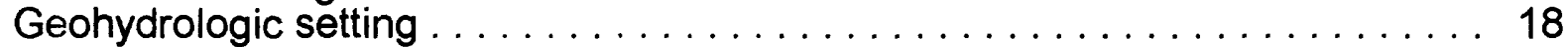

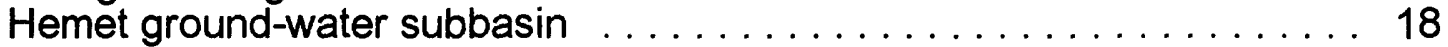

Distribution of alluvial deposits in the Hemet subbasin . . . . . . 18

Ground-water storage and ground-water ........... 31 flow, 1991-92

Menifee ground-water subbasin and Chino ground-water basin . . . . . . 34

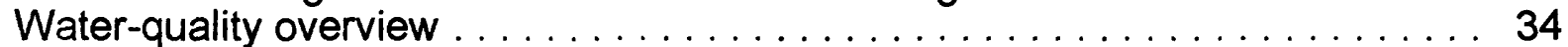

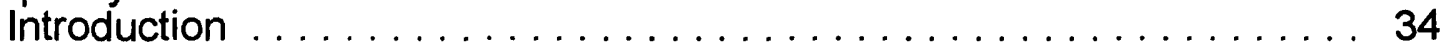

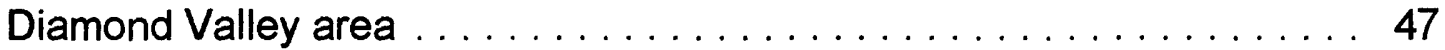

Bautista Outwash area ....................... 48

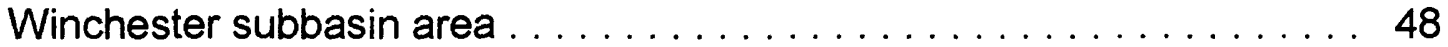

Main Basin area ........................... 48

San Jacinto, Winchester, and Domenigoni Basins . . . . . . . . . . 48

Lakeview Mountains . . . . . . . . . . . . . . . . . . . . . . . . . . . . . 49

Geohydrology, water quality, and nitrogen geochemistry at . . . . . . . . 49 the study sites

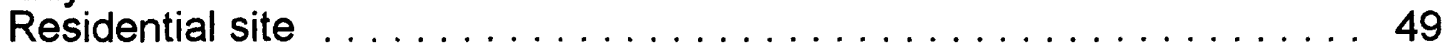

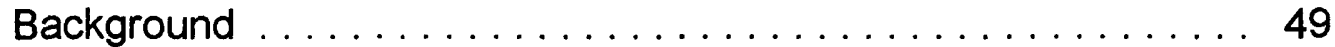

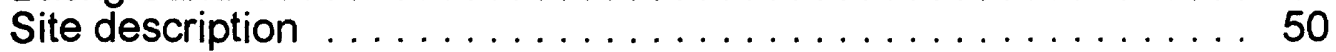

Saturated-zone results $\ldots \ldots \ldots \ldots \ldots \ldots \ldots \ldots \ldots \ldots$

Unsaturated-zone results $\ldots \ldots \ldots \ldots \ldots \ldots \ldots \ldots \ldots \ldots$

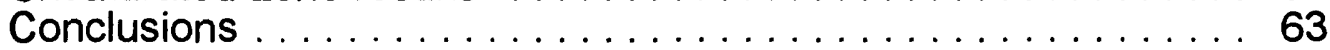

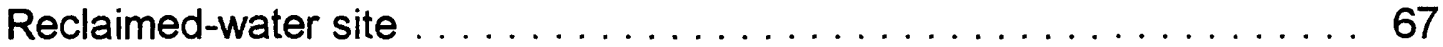

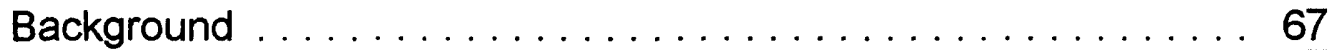

Site description ....................... 67

Saturated-zone results $\ldots \ldots \ldots \ldots \ldots \ldots \ldots \ldots \ldots \ldots \ldots$

Unsaturated-zone results $\ldots \ldots \ldots \ldots \ldots \ldots \ldots \ldots \ldots \ldots$

Conclusions .......................... 79 
Citrus Grove site . . . . . . . . . . . . . . . . . . . . . . . . . 79

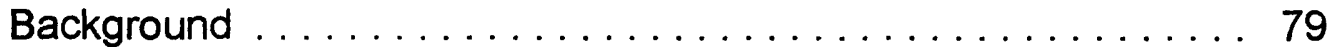

Site description ...................... 80

Saturated-zone results $\ldots \ldots \ldots \ldots \ldots \ldots \ldots \ldots \ldots \ldots \ldots . \ldots 3$

Unsaturated-zone results $\ldots \ldots \ldots \ldots \ldots \ldots \ldots \ldots \ldots \ldots 83$

Conclusions . . . . . . . . . . . . . . . . . . . . . 90

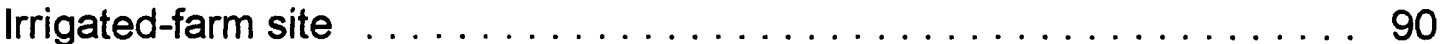

Background ........................ 90

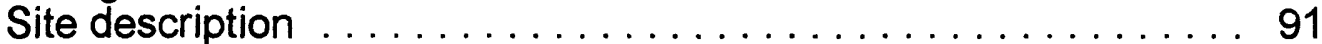

Saturated-zone results $\ldots \ldots \ldots \ldots \ldots \ldots \ldots \ldots \ldots \ldots \ldots 94$

Unsaturated-zone results $\ldots \ldots \ldots \ldots \ldots \ldots \ldots \ldots \ldots \ldots \ldots 94$

Conclusions . . . . . . . . . . . . . . . . . . . . . . . . . . . . 104

Poultry-farm site . . . . . . . . . . . . . . . . . . . . . . . . . . . 104

Site description .......................... 104

Saturated-zone results $\ldots \ldots \ldots \ldots \ldots \ldots \ldots \ldots \ldots \ldots$

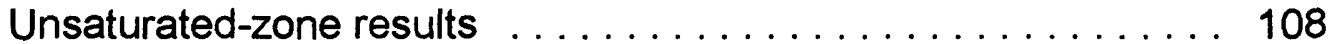

Conclusions . . . . . . . . . . . . . . . . . . . . . . . . 114

Dairy sites . . . . . . . . . . . . . . . . . . . . . . . . . 115

Site descriptions . . . . . . . . . . . . . . . . . . . 115

Saturated-zone results--Hemet dairy site $\ldots \ldots \ldots \ldots \ldots \ldots \ldots 118$

Saturated-zone results--Chino dairy site . . . . . . . . . . . . 118

Unsaturated-zone results . . . . . . . . . . . . . . . . . . 121

Conclusions . . . . . . . . . . . . . . . . . . . . . . . . . 137

Summary

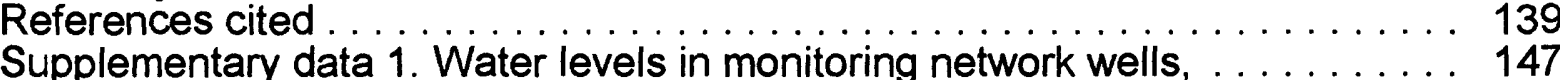
1990-92

Supplemental data 2. Analytical data for wells and springs in

the water-quality monitoring network

Supplemental data 3. Analytical data for wells and lysimeters at the instrumented land-use sites:

A. Residential site . . . . . . . . . . . . . . . . . . . . . . . . 160

B. Reclaimed-water site . . . . . . . . . . . . . . . . . . . . 178

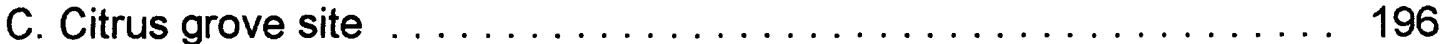

D. Irrigated-farm site $\ldots \ldots \ldots \ldots \ldots \ldots \ldots \ldots \ldots \ldots \ldots \ldots \ldots 214$

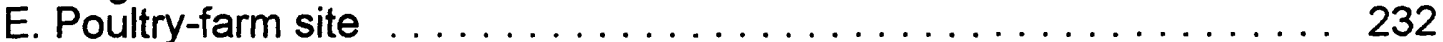

F. Hemet dairy site . . . . . . . . . . . . . . . . . . . . . 244

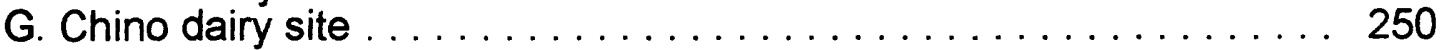

\section{ILLUSTRATIONS}

Figure 1. Diagram showing the nitrogen cycle $\ldots \ldots \ldots \ldots \ldots \ldots$

2-4. Maps showing:

2. Location of the study area . . . . . . . . . . . . . . . . 13

3. The Hemet subbasin and the monitoring-well network . . . . . 15

4. Altitude of bedrock surface in the Hemet subbasin . . . . . . . . 19

5-10. Maps showing texture, for selected depth intervals, of the alluvial deposits of the Hemet subbasin:

5. 0 to 100 feet ......................... 20

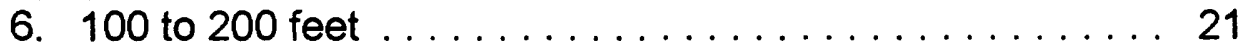

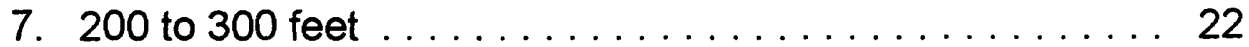

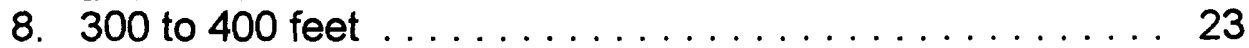

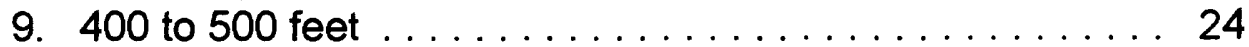

10. 0 to 500 feet ........................ 25

11. Map showing location of stratigraphic cross sections $\left(A-A^{\prime}, \ldots \ldots 26\right.$ $A-A^{\prime \prime}, B-B^{\prime}$, and $C-C^{\prime}$ ) shown in figures $12-15$ 
12. Lithologic profiles for stratigraphic cross section $A-A^{\prime} \ldots \ldots \ldots 27$

13. Lithologic profiles for stratigraphic cross section $A-A^{\prime \prime} \ldots \ldots \ldots 28$

14. Lithologic profiles for stratigraphic cross section $B-B^{\prime} \ldots \ldots \ldots .29$

15. Lithologic profiles for stratigraphic cross section $C-C^{\prime} \ldots \ldots \ldots 29$

16. Map showing water-table elevation in the Hemet subbasin and . . 32 vicinity, spring 1991

17. Map showing water-table elevation in the Hemet subbasin and . . 33 vicinity, autumn 1992

18-27. Maps showing areal distribution of selected constituents and properties in the Hemet subbasin and vicinity:

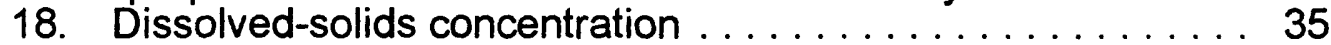

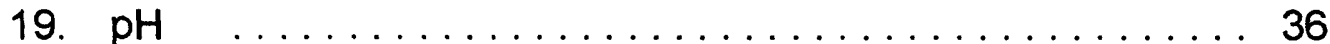

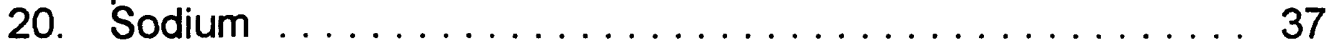

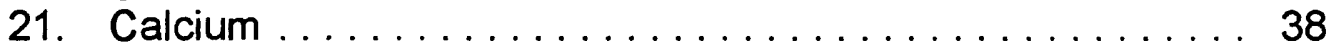

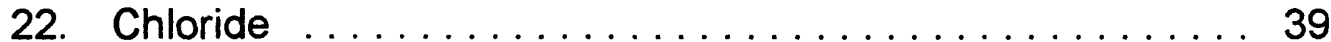

23. Sulfate ......................... 40

24. Total hardness $\ldots \ldots \ldots \ldots \ldots \ldots \ldots \ldots \ldots \ldots \ldots \ldots, 41$

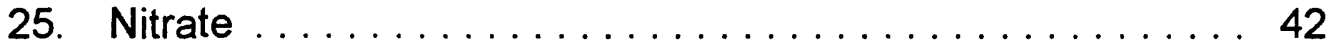

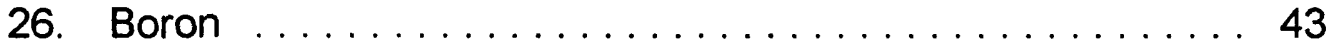

27. Selenium .................... 44

28. Graph showing relation of delta oxygen-18 to annual . . . . . . 45 mean air temperature

29. Graph showing relation of delta deuterium to delta . . . . . . . . . 46 oxygen-18

30. Geophysical logs, and diagram showing well construction, . . . . 51 cored interval, and lithology for the residential site

31. Graph showing particle-size distribution at selected depths . . . . 52 for cores from the residential site

32. Unsaturated-zone pore-moisture profiles, for selected dates . . . . 55 in 1991-93, for the residential site

33. Tritium-concentration profile for pore water at the $\ldots \ldots \ldots \ldots 56$ residential site

34. Organic-nitrogen-concentration profile, from core extracts, . . . . 59 for the unsaturated zone at the residential site

35. Nitrate-concentration profile, from core extracts, for the . . . . . . . 60 unsaturated zone at the residential site

36. Graph showing nitrate concentration, for selected dates in . . . . 62 1991-92, in unsaturated-zone pore water at the residential site

37. Geophysical logs, and diagram showing well construction, cored . 68 interval, and lithology for the reclaimed-water site

38. Graph showing particle-size distribution at selected depths . . . . . 69 for cores from the reclaimed-water site

39. Unsaturated-zone pore-moisture profiles for selected dates . . . . 72 in 1991-93 for the reclaimed-water site

40. Tritium-concentration profile for pore water at the . . . . . . . . 73 reclaimed-water site

41. Organic-nitrogen-concentration profile, from core extracts, . . . . 76 for the unsaturated zone at the reclaimed-water site

42. Nitrate-concentration profile, from core extracts, for the . . . . . . 77 unsaturated zone at the reclaimed-water site

43. Graph showing nitrate concentration, for selected dates in . . . . 78 1991-92, in unsaturated-zone pore water at the reclaimedwater site

44. Geophysical logs, and diagram showing well construction, cored interval, and lithology for the citrus grove site 
45. Graph showing particle-size distribution at selected depths . . . . 82 for cores from the citrus grove site

46. Unsaturated-zone pore-moisture profiles for selected dates . . . . . 84 in 1991-93 for the citrus grove site

47. Tritium-concentration profile for pore water at the citrus . . . . . . 86 grove site

48. Graph showing nitrate concentration, for selected dates in . . . . 89 1991-92, in unsaturated-zone pore water at the citrus grove site

49. Geophysical logs, and diagram showing well construction, cored . 92 interval, and lithology for the irrigated-farm site

50. Graph showing particle-size distribution for cores from ........ 93 the irrigated-farm site

51. Unsaturated-zone pore-moisture profiles, for selected dates . . . . 95 in 1991-93, for the irrigated-farm site

52. Tritium-concentration profile for unsaturated-zone pore water . . . 97 at the irrigated-farm site

53. Organic-nitrogen-concentration profile, from core extracts, . . . . .99 for the unsaturated zone at the irrigated-farm site

54. Ammonia-concentration profile for unsaturated-zone pore water . 100 at the irrigated-farm site

55. Nitrate-concentration profile, from core extracts, for the . . . . . 101 unsaturated zone at the irrigated-farm site

56. Graph showing nitrate concentration, for selected dates in . . . 102 1991-92, in unsaturated-zone pore water at the irrigated-farm site

57. Geophysical logs, and diagram showing well construction, . . . 105 cored interval, and lithology for the poultry-farm site

58. Graph showing particle-size distribution at selected . . . . . . . . 107 depths for cores from the poultry-farm site

59. Unsaturated-zone pore-moisture profiles for selected dates . . . . 109 in 1991-92 for the poultry-farm site

60. Organic-nitrogen-concentration profile, from core extracts, . . . . 110 for the unsaturated zone at the poultry-farm site

61. Ammonia-concentration profile, from core extracts, for the . . . . 111 unsaturated zone at the poultry-farm site

62. Nitrite-concentration profile, from core extracts, for . . . . . . . 112 the unsaturated zone at the poultry-farm site

63. Nitrate-concentration profile, from core extracts, for . . . . . . . . 113 the unsaturated zone at the poultry-farm site

64. Geophysical logs, and diagram showing well construction, . . . 116 cored interval, and lithology for the Hemet dairy site

65. Graph showing particle-size distribution at selected depths . . . . 117 for cores from the Hemet dairy site

66. Geophysical logs, and diagram showing well construction, . . . 119 cored interval, and lithology for the Chino dairy site

67. Graph showing particle-size distribution at selected depths . . . . 120 for cores from the Chino dairy site

68. Unsaturated-zone pore-moisture profiles for selected dates . . . . 122 in 1991-92 for the Hemet diary site

69. Unsaturated-zone pore-moisture profiles for selected dates . . . . 123 in 1991-92 for the Chino diary site 
70. Tritium-concentration profile for pore water at the Hemet . . . . 125 dairy site

71. Tritium-concentration profile for pore water at the Chino $\ldots \ldots 126$ diary site

72. Organic-nitrogen-concentration profile, from core extracts, . . . 128 for the unsaturated zone at the Hemet dairy site

73. Ammonia-concentration profile, from core extracts, for . . . . . . 129 the unsaturated zone at the Hemet dairy site

74. Nitrate-concentration profile, from core extracts, for . . . . . . 130 the unsaturated zone at the Hemet dairy site

75. Organic-nitrogen-concentration profile, from core extracts, . . . 131 for the unsaturated zone at the Chino dairy site

76. Ammonia-concentration profile, from core extracts, for . . . . . . 132 the unsaturated zone at the Chino dairy site

77. Nitrate-concentration profile, from core extracts, for . . . . . . . 133 the unsaturated zone at the Chino dairy site

78. Nitrate-concentration profile, for selected dates in 1991-92, . . . 135 in unsaturated-zone pore water at the Hemet dairy site

79. Nitrate-concentration profile, for selected dates in 1991-92, . . . 136 in unsaturated-zone pore water at the Chino dairy site

\section{TABLES}

Table 1. Water-quality and water-level monitoring network in the $\ldots \ldots \ldots$ 19a study area

2. Bacteria populations in the unsaturated zone beneath the . . . . . . 64 instrumented land-use sites

3. Nitrogen-isotope and nitrogen-to-chloride ratio data for . . . . . . . . 65 unsaturated-zone pore water beneath the instrumented land-use sites

4. Concentrations of selected gases in unsaturated-zone pore $\ldots \ldots 66$ water beneath the instrumented land-use sites 


\section{Conversion Factors, Water-Quality Information, Abbreviations, Vertical Datum, and Well-Numbering System}

$\begin{array}{rcl}\text { Multiply } & \text { By } & \text { To obtain } \\ & & \\ \text { acre-foot (acre-ft) } & 1,233 & \text { cubic meter } \\ \text { foot per mile (ft/mi) } & 0.1894 & \text { meter per kilometer } \\ \text { foot per second (ft/s) } & 0.3048 & \text { meter per second } \\ \text { foot per year }(\mathrm{ft} / \mathrm{yr}) & 0.3048 & \text { meter per year } \\ \text { gallon }(\mathrm{gal}) & 3.785 & \text { liter }(\mathrm{L}) \\ \text { inch (in.) } & 25.4 & \text { millimeter } \\ & 2.54 & \text { centimeter } \\ \text { inch per year (in/yr) } & 25.4 & \text { millimeter per year } \\ \text { mile (mi) } & 1.609 & \text { kilometer } \\ \left.\text { square mile (mi }{ }^{2}\right) & 2.590 & \text { square kilometer } \\ \text { pound per acre (lb/acre) } & 0.8922 & \text { kilogram per hectare } \\ \text { pound per acre per year } & & \\ {[(\mathrm{lb} / \mathrm{acre}) / \mathrm{yr}]} & 0.8922 & \text { kilogram per hectare } \\ & & \text { per year }\end{array}$

Temperature is given in degrees Celsius $\left({ }^{\circ} \mathrm{C}\right)$, which can be converted to degrees Fahrenheit $\left({ }^{\circ} \mathrm{F}\right)$ by the following equation:

$$
{ }^{\circ} \mathrm{F}=1.8\left({ }^{\circ} \mathrm{C}\right)+32 .
$$

\section{WATER-QUALITY (AND PARTICLE-SIZE) INFORMATION}

Metric units were used for chemical concentration and particle size. To convert metric units to inchpound units, multiply the metric unit by the reciprocal of the applicable conversion factor listed above.

Chemical concentrations are given in milligrams per liter $(\mathrm{mg} / \mathrm{L})$ or micrograms per liter $(\mu \mathrm{g} / \mathrm{L})$. Milligrams per liter is approximately equivalent to parts per million. Micrograms per liter is approximately equivalent to parts per billion. Tritium concentrations are expressed in picocuries per liter $(\mathrm{pCi} / \mathrm{L})$, which can be converted to tritium units (TU) by dividing by 3.2 .

\begin{aligned} & \multicolumn{1}{c}{ ABBREVIATIONS } \\ EMWD: & Eastern Municipal Water District \\ MWD: & Metropolitan Water District of Southern California \\ $\mathrm{MCL}: &$ Maximum Contaminant Level (U.S. Environmental Protection \\ & $\quad$ Agency, 1992) \\ $\mathrm{mg} / \mathrm{Kg} &$ milligram per kilogram \\ $\mathrm{mg} / \mathrm{L}: &$ milligram per liter \\ $\mathrm{pCi} / \mathrm{L}: &$ picocurie per liter \\ $\mu \mathrm{g} / \mathrm{L}: &$ microgram per liter \\ $\mu \mathrm{S} / \mathrm{cm}: &$ microsiemen per centimeter at $25^{\circ}$ Celsius \end{aligned}

\section{VERTICAL DATUM}

Sea Level: In this report, "sea level" refers to the National Geodetic Vertical Datum of 1929--a geodetic datum derived from a general adjustment of the first-order level nets of the United States and Canada, formerly called Sea Level Datum of 1929. 
Wells, lysimeters, and springs are identified and numbered according to their location in the rectangular system for subdivision of public lands in California. Identification consists of the township number, north or south; the range number, east or west; and the section number. Each section is divided into sixteen 40-acre tracts lettered consecutively (except I and O), beginning with "A" in the northeast corner of the section and progressing in a sinusoidal manner to " $\mathrm{R}$ " in the southeast corner. Within the 40-acre tract, wells are sequentially numbered in the order they are inventoried. The final letter refers to the base line and meridian. In California, there are three base lines and meridians: Humboldt $(\mathrm{H})$, Mount Diablo (M), and San Bernardino (S). All wells in the study area are referenced to the San Bernardino base line and meridian (S). Well numbers consist of 15 characters and follow the format $005 \mathrm{~N} 001 \mathrm{~W} 28 \mathrm{~J} 001 \mathrm{~S}$. The letters "LYS" following a sequence number indicate a lysimeter, and the letter "S" inserted before the sequence number indicates a spring. In this report, well numbers are abbreviated and written $5 \mathrm{~S} / 1 \mathrm{~W}-28 \mathrm{~J}$. Wells in the same township and range are referred to only by their section designation, $28 \mathrm{~J} 1$. The following diagram shows how the number for well $5 \mathrm{~S} / 1 \mathrm{~W}-28 \mathrm{~J} 1$ is derived.

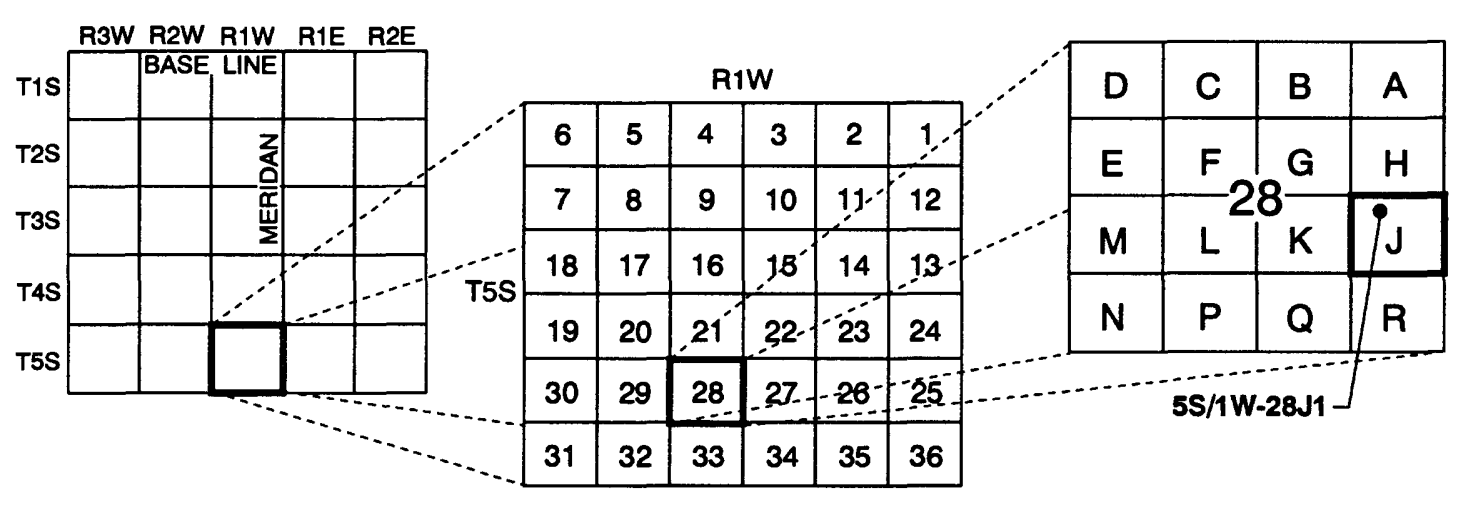




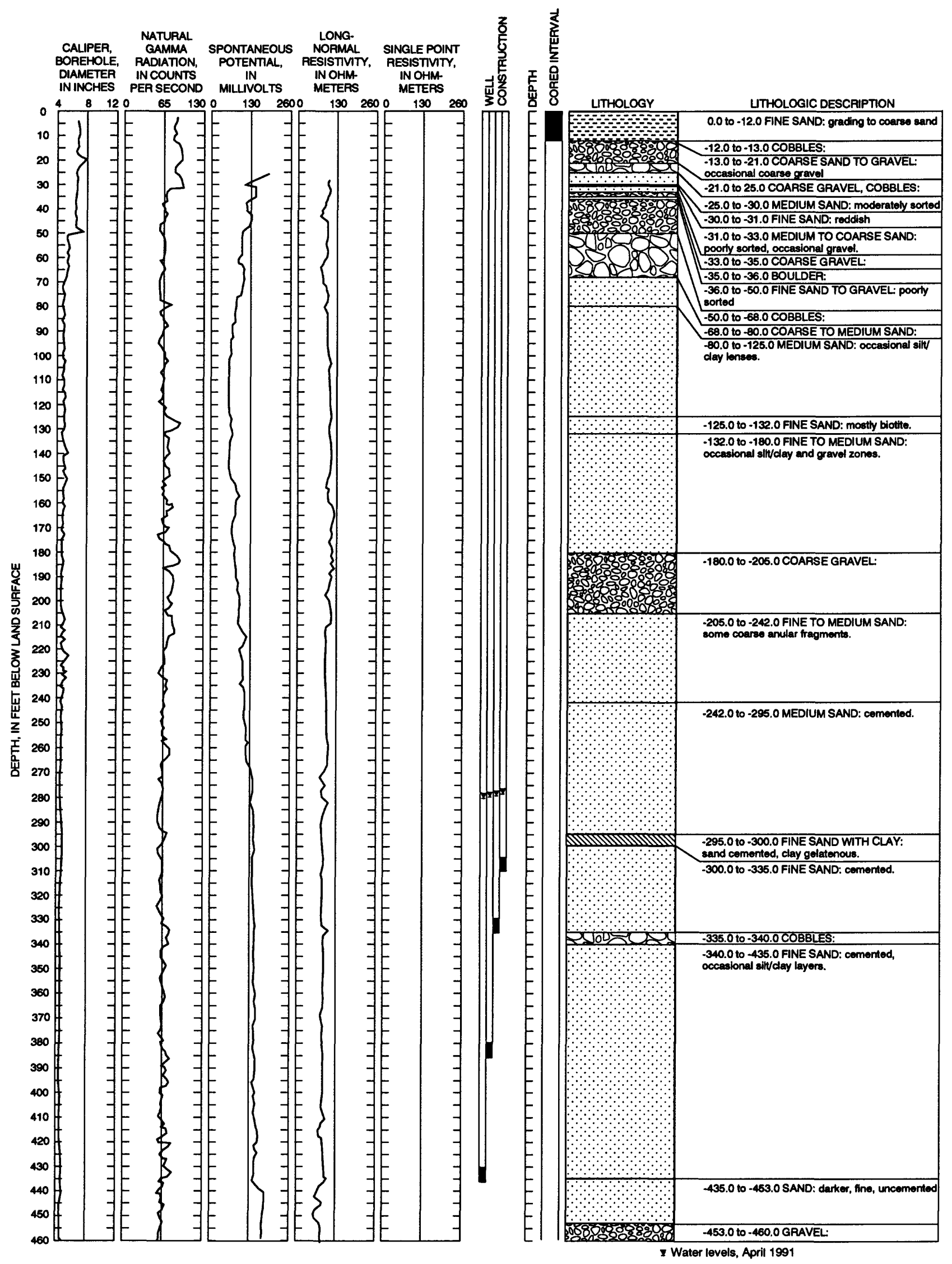

FIGURE 44. Geophysical logs, and diagram showing well construction, cored interval, and lithology for the citrus grove site. 


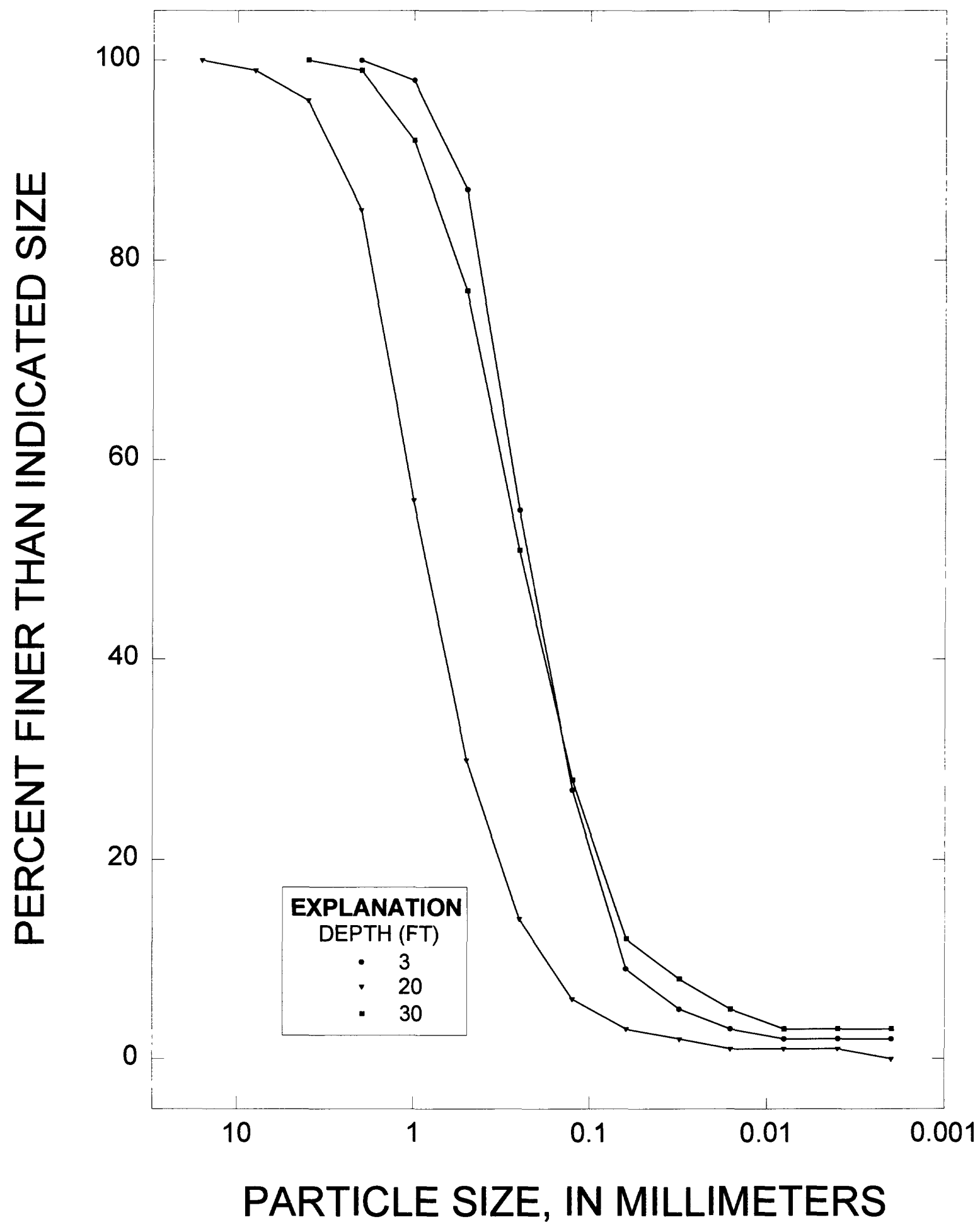

Figure 45. Particle-size distribution at selected depths for cores from the citrus grove site. 


\section{Saturated-Zone Results}

The water-table surface in the vicinity of the citrus grove site was determined by measuring water levels at the multiple-well site $(5 \mathrm{~S} / 1 \mathrm{E}-17 \mathrm{Q})$ and in wells 5S/1E-16D1, 5S/1E-16N1, 5S/1E-18C1, and $5 \mathrm{~S} / 1 \mathrm{E}-18 \mathrm{~F} 1$. These results, given in Supplemental Data 1, 2, and 3C, and the water-table surface described in the "Ground-Water Storage and Flow, 1991-92" section indicate a westward horizontal component of ground-water flow in this area. Comparison of the potentiometric levels in the four wells at the site indicates no vertical flow component. During the course of this study (1991-92), the water table declined approximately $13 \mathrm{ft}$.

Water-quality samples were collected from the four wells on the following dates: January 24, May 1, and September 5, 1991, and January 15 and August 18, 1992. Analytical results are given in Supplemental Data 3C. The data indicate virtually no temporal variation in water quality at each of the sampled depths and suggest that the samples collected are representative of water in the formation at the depths specified.

\section{Water quality in the shallow zone $(310,335$, and 385 feet $)$}

The quality of the ground water collected from the 310,335 , and $385 \mathrm{ft}$ wells is virtually identical. Dissolved-solids concentration was about $810 \mathrm{mg} / \mathrm{L}$ and $\mathrm{pH}$ was 7.7. The predominant ions were calcium, sodium, and sulfate. The nitrate concentration shows a slight increasing trend with depth, from about $15 \mathrm{mg} / \mathrm{L}$ at $310 \mathrm{ft}$ to $22 \mathrm{mg} / \mathrm{L}$ at $385 \mathrm{ft}$. These concentrations are considerably above the MCL of $10 \mathrm{mg} / \mathrm{L}$. Boron concentrations were moderate at about $120 \mu \mathrm{g} / \mathrm{L}$. The boron concentration at $385 \mathrm{ft}$ was about $105 \mu \mathrm{g} / \mathrm{L}$. Selenium concentrations, about $5 \mu \mathrm{g} / \mathrm{L}$ at all depths, were well below the MCL of $50 \mu \mathrm{g} / \mathrm{L}$.

The deuterium to hydrogen ratio deviation $(\delta D)$, and the oxygen $18 / 16$ ratio deviation $\left({ }^{18} \mathrm{O}\right)$ values for the $310 \mathrm{ft}$ well were $\delta \mathrm{D}=-66.8$ permil and $\delta^{18} \mathrm{O}=-8.98$ permil; for the $335 \mathrm{ft}$ well, $\delta \mathrm{D}=$ -64.5 permil and $\delta^{18} \mathrm{O}=-\mathbf{- 8 . 8 8}$ permil; and for the $385 \mathrm{ft}$ well, $8 \mathrm{D}=-71.0$ permil and $8^{18} \mathrm{O}=-9.52$ permil. According to the relation developed by Dansgaard (1964) that was discussed earlier and is illustrated in figure 28 , the $\delta^{18} \mathrm{O}$ values indicate that the water at all depths originated as rain that fell at the relatively high temperature of $7^{\circ} \mathrm{C}$ rather than as snow at high altitudes. The $\delta \mathrm{D}$ and $\delta^{18} \mathrm{O}$ values plotted on the Craig (1961) diagram (fig. 29) fall on the meteoric-water line. This suggests that the water percolated to the water table without undergoing significant evaporation.

The presence of elevated nitrate concentrations in this water also is of interest. The $\delta^{15} \mathrm{~N}$ values in water from the 310,335 , and $385 \mathrm{ft}$ wells were 5.9 , 5.3 , and 6.9 , respectively. These values suggest a mineral source that has had considerable microbial processing.

\section{Water quality in the deep zone (435 feet)}

Water quality in the deep zone is represented by water collected from the $435 \mathrm{ft}$ well. The waterquality results are given in Supplemental Data 3C. The dissolved-solids concentration of $632 \mathrm{mg} / \mathrm{L}$ was lower than the concentration $(810 \mathrm{mg} / \mathrm{L})$ the shallow zone. The predominant ions were sodium, calcium, and sulfate, and the $\mathrm{pH}$ was 7.9. The nitrate concentration was about $4.5 \mathrm{mg} / \mathrm{L}$, one-third of that in the shallow zone, and below the MCL. The boron concentration was moderate, $100 \mu \mathrm{g} / \mathrm{L}$, and selenium concentration was $3 \mu \mathrm{g} / \mathrm{L}$.

The $8 \mathrm{D}$ and $8^{18} \mathrm{O}$ values $(-63.8$ permil and 9.02 permil, respectively) support the same conclusions given for the water in the shallow zone. The water seems to have precipitated at a temperature of about $7^{\circ} \mathrm{C}$ as rain at relatively low altitudes rather than as snow at higher altitudes. The plotted values on the Craig diagram suggest that the water did not undergo significant evaporation prior to percolation to the water table.

The $\delta^{15} \mathrm{~N}$ value of 3.2 indicates that the nitrate came from a mineral source, and that slight biological cycling of the nitrogen has occurred.

\section{Unsaturated-Zone Results}

\section{Pore-moisture profiles}

Pore-moisture saturation-index profiles (fig. 46) were measured as described in the "Site Instrumentation and Sample Collection" section. The profiles were measured in May and July 1991, July and October 1992, and January 1993. Vertical resolution is approximately $1 \mathrm{ft}$, and horizontal resolution is about 0.02 unit. The clay seal placed at the top of the bore hole extended to a depth of $5 \mathrm{ft}$; moisture-saturation-index profiles begin beneath this seal. 


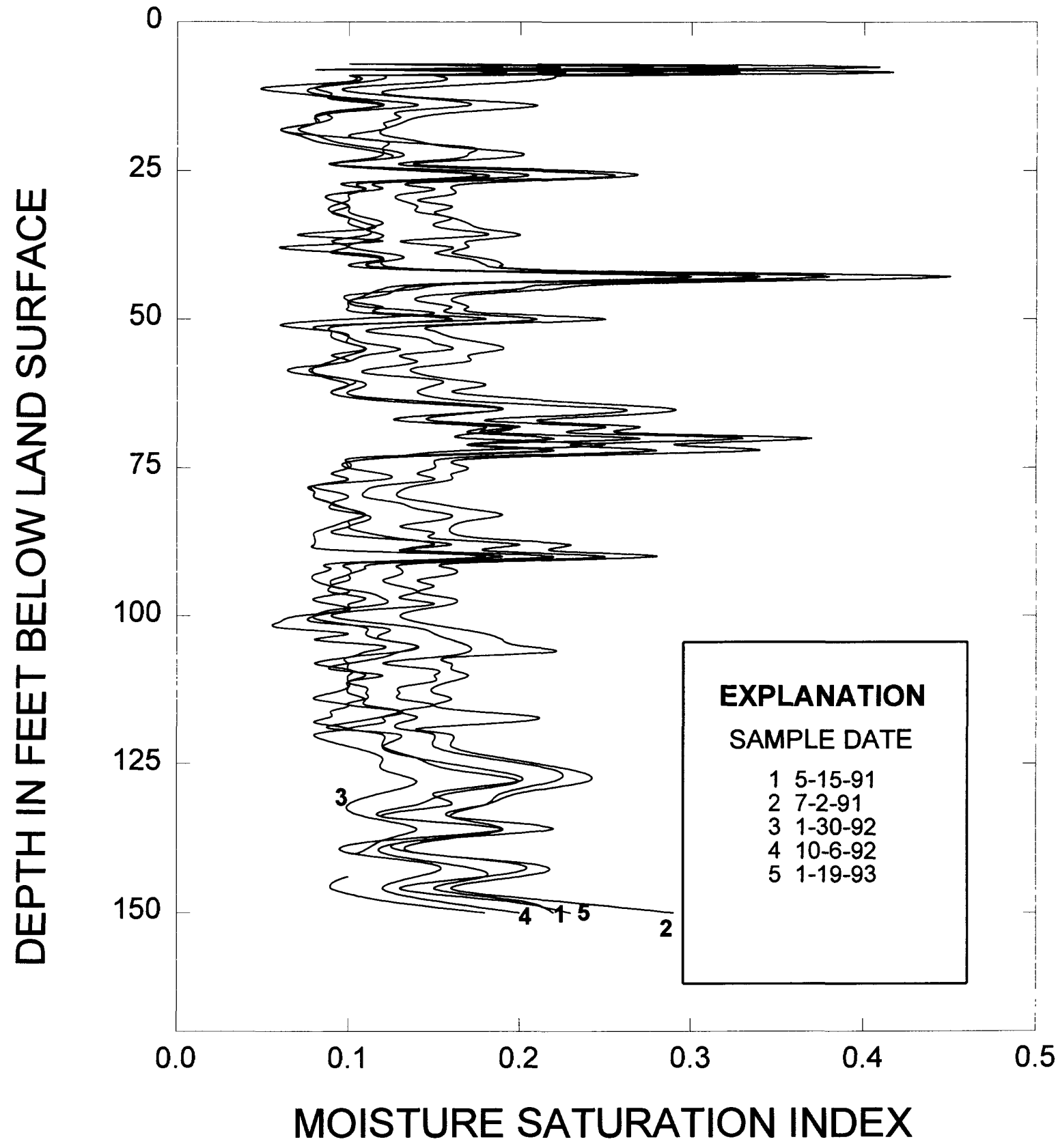

Figure 46. Unsaturated-zone pore-moisture profiles for selected dates in 1991-93 for the citrus grove site. 
The soil-moisture saturation-index profiles at the citrus grove site illustrate the effects of numerous capillary barriers that exist naturally in the soil column. A capillary barrier is a physical phenomenon whereby moisture accumulates in zones of fine material that are immediately adjacent to zones of coarse material. The reason the moisture stays in the fine material and does not move into the coarser material is that the fine material can hold water more tightly owing to capillary attraction. The index peak at $12 \mathrm{ft}$ is due to the capillary barrier at the interface between fine sand (above) and cobbles (below). The peak at $25 \mathrm{ft}$ is the bottom of the same cobble layer, which is resting on a layer of sand. At $36 \mathrm{ft}$ is another layer of fine sand directly beneath cobbles. The peak at $68 \mathrm{ft}$ is the interface of cobbles (above) and sand (below). At $80 \mathrm{ft}$, the interface is between coarse sand (above) and finer sand (below). The peak at $105 \mathrm{ft}$ is a thin clay lens. At $128 \mathrm{ft}$ there is an interface between medium sand (above) and fine sand (below). The peaks below $128 \mathrm{ft}$ are clay lenses.

At this site, the maximum pore-moisture saturation indices are about 0.4 unit, and most of the soil column has indices less than 0.2 unit. Temporal variation in the moisture-saturation indices is about 0.07 unit. The profiles indicate that there is no piston flow in the system, at least not on the time scale of these measurements. The shape of the profiles is virtually constant, and any change in moisture content is reflected in the entire profile, not just at a particular depth. The soil column seems to equilibrate rapidly to changes in precipitation and (or) irrigation.

Unsaturated hydraulic conductivities for the various alluvial materials beneath the citrus grove site ranged from $1.46 \times 10^{-4}$ to $8.06 \times 10^{-4} \mathrm{ft} / \mathrm{s}$ for the core samples collected. Using the appropriate unsaturated hydraulic conductivities and the corresponding moisture-saturation indices, and integrating over the entire unsaturated zone, one obtains an estimated transit time of about 5 years for water to percolate from the land surface to the water table.

\section{Tritium profile}

The pore-water tritium-concentration profile in the unsaturated zone at the citrus grove site was determined by compositing lysimeter-collected water during July 1991 until sufficient volume (1 L) was obtained for analysis. The profile is shown in figure 47. Note that the tritium concentration, consistently below $55 \mathrm{pCi} / \mathrm{L}$, is significantly lower than the expected 1963 concentration of $600 \mathrm{pCi} / \mathrm{L}$, indicating that the unsaturated-zone transit time is less than 30 years. Note also, that the observed concentrations are considerably higher than the 15 $\mathrm{pCi} / \mathrm{L}$ that would be expected if the soil moisture came from precipitation that fell locally. Groves in this area use both locally pumped ground water and municipally supplied water to irrigate the trees. The municipally supplied water is mostly imported Colorado River water that has tritium concentrations of about $90 \mathrm{pCi} / \mathrm{L}$. The tritium concentrations in the pore water are consistent with the mixing of this Colorado River water with the local supplies. The multiple peaks at 15,50 , and $100 \mathrm{ft}$ may result from seasonal variations in the relative proportion of local pumped water to imported Colorado River water used to irrigate the grove.

Percolation rates can be estimated on the basis of interpretations of the tritium profile for the citrus grove. The peak at $10 \mathrm{ft}$ may represent summer 1991 inputs of tritium from precipitation mixed with the irrigation water (composed of river water and ground water). The minimum at $25 \mathrm{ft}$ can be interpreted as the winter minimum from the previous year, suggesting an unsaturated-zone percolation rate of about $25 \mathrm{ft} / \mathrm{yr}$ to that depth in the unsaturated zone. If one assumes that the peak at $50 \mathrm{ft}$ represents the summer tritium maximum of 1990 , an unsaturated-zone percolation rate of $40 \mathrm{ft} / \mathrm{yr}$ can be calculated for that depth in the unsaturated zone. The minimum at $75 \mathrm{ft}$ can be interpreted as the winter tritium minimum for 1990 , yielding an unsaturated-zone percolation rate of about $50 \mathrm{ft} / \mathrm{yr}$. Finally, the value at $100 \mathrm{ft}$ may be a maximum representing the summer maximum of 1989. If so, the unsaturated-zone percolation rate to this depth in the unsaturated zone would be $63 \mathrm{ft} / \mathrm{yr}$. On the basis of these rates, the estimated time required for water to transit the approximately $300 \mathrm{ft}$ of unsaturated zone beneath the site is at least 5 years and likely much less than 30 years. These estimates are consistent with the lack of an observed 1963 tritium peak in the profile and are consistent with the estimate based on the moisture saturation indices presented earlier.

\section{Water quality}

Samples for determining unsaturated-zone porewater quality were collected using the ceramic-cup suction lysimeters during February, June, and August 1991 and April, July, and September 1992. Analytical results are given in Supplemental Data 3C. 


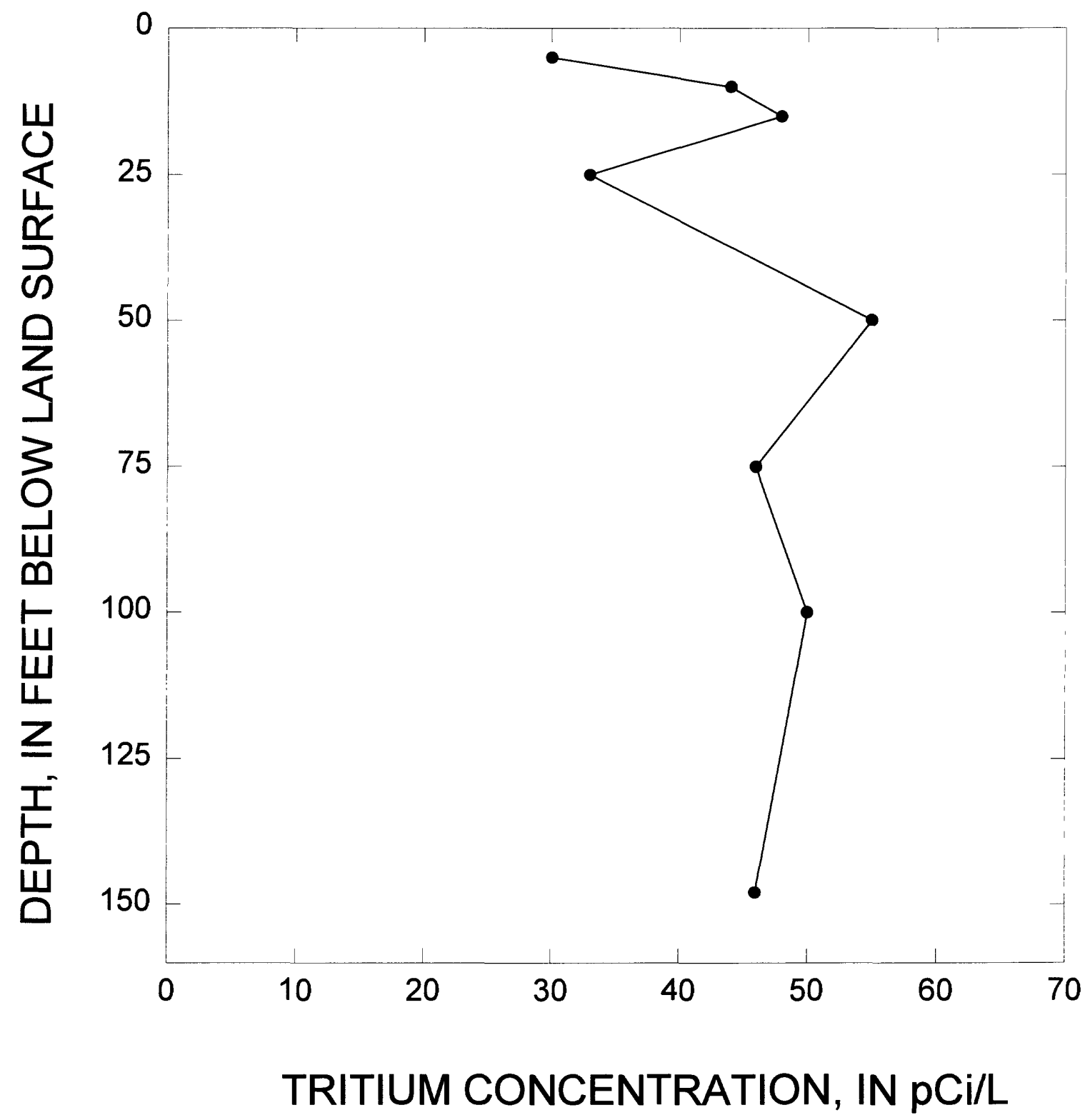

Figure 47. Tritium-concentration profile for pore water at the citrus grove site.

86 Citrus Grove Site 
The samples collected at a depth of $5 \mathrm{ft}$ indicate that the dissolved-solids concentration varies in a cyclic manner, being lowest during the late winter and early spring, increasing through the summer, then decreasing through the autumn and winter. The dissolved-solids concentration in the pore water varied by a factor of 2 , from $2,250 \mathrm{mg} / \mathrm{L}$ in February 1991 to $4,100 \mathrm{mg} / \mathrm{L}$ in August 1991. The $\mathrm{pH}$ of the pore water ranged from 7.3 to 8.0. Ion predominance also varied seasonally--from calcium, sodium, and sulfate in the spring to sodium, calcium, and sulfate in the summer. Chloride concentrations ranged from $220 \mathrm{mg} / \mathrm{L}$ in July 1992 to $620 \mathrm{mg} / \mathrm{L}$ in August 1991. The dissolved-solids concentrations were considerably higher than the dissolved-solids concentrations in the water used to irrigate the groves. The elevated concentrations probably are due, in part, to evaporative concentration as the water percolated through the top few feet of the soil column, but also to the addition of chemical fertilizers for the citrus trees. The very high nitrate concentrations in the pore water at this depth also are an indication of the addition of fertilizers (discussed in more detail in the following section). The organic-carbon concentration in the pore water was about $14 \mathrm{mg} / \mathrm{L}$.

The pore-water samples collected from a depth of $10 \mathrm{ft}$ showed the same seasonal trends observed at $5 \mathrm{ft}$. The dissolved-solids concentrations varied by a factor of 4 , from $1,170 \mathrm{mg} / \mathrm{L}$ in February 1991 to $4,130 \mathrm{mg} / \mathrm{L}$ in August 1991 . The predominant ions in the pore water at this depth were sodium and sulfate; calcium concentrations were about one-third those of sodium. The chloride concentrations were somewhat higher than those observed at $5 \mathrm{ft}$. The $\mathrm{pH}$ ranged from 7.5 to 8.0. The dissolved organiccarbon concentration in the pore water was $11 \mathrm{mg} / \mathrm{L}$.

The lysimeter at $15 \mathrm{ft}$ was not as productive as the two shallower lysimeters; therefore, the waterquality data set for pore water from this depth are somewhat sparse. The same seasonal variation in dissolved-solids concentration (lower during the winter and higher during the summer) seems to be present. In the February 1991 sample, dissolvedsolids concentration was $830 \mathrm{mg} / \mathrm{L}$; in the July 1991 sample, the concentration was $1,725 \mathrm{mg} / \mathrm{L}$. These concentrations are as much as 50 percent less than those observed in shallower samples. Ion predominance is the same as at $5 \mathrm{ft}$. Calcium concentrations were about one-half the sodium concentrations, and chloride about one-third the sulfate. The $\mathrm{pH}$ ranged from 7.6 to 8.0. The dissolved organic-carbon concentration in the pore water from $15 \mathrm{ft}$ was $4.5 \mathrm{mg} / \mathrm{L}$.

The 25-foot lysimeter also was not very productive, and thus the data are sparse. The dissolved-solids concentration in pore water collected from $25 \mathrm{ft}$ is higher than that observed at $15 \mathrm{ft}$. The concentration of $2,860 \mathrm{mg} / \mathrm{L}$ is comparable to that observed at 5 and $10 \mathrm{ft}$ during the same period. The predominant ions were sodium and sulfate. The concentration of calcium was, on the average, one-fifth to one-third that of sodium and chloride concentration was about one-tenth that of sulfate. The $\mathrm{pH}$ of the water ranged from 7.1 to 8.3 , and the dissolved organic-carbon concentration was $6.5 \mathrm{mg} / \mathrm{L}$.

The pore water collected from $50 \mathrm{ft}$ did not vary appreciably in quality during the course of the study. The dissolved-solids concentration ranged from $1,080 \mathrm{mg} / \mathrm{L}$ during July 1992 to $1,230 \mathrm{mg} / \mathrm{L}$ during June 1991. The predominant ions were sodium, calcium, and sulfate. Chloride concentration was about one-half that of sulfate. The $\mathrm{pH}$ ranged from 7.3 to 7.6 , and the dissolved organic-carbon concentration was $2.2 \mathrm{mg} / \mathrm{L}$.

The pore water collected from $75 \mathrm{ft}$ also did not vary significantly during the study. The dissolvedsolids concentration ranged from 640 to $970 \mathrm{mg} / \mathrm{L}$, and was lower than that observed at the shallower depths. The predominant ions were sodium, calcium, and sulfate. Chloride concentration was about onehalf that of sulfate. The $\mathrm{pH}$ ranged from 7.3 to 7.5, and the dissolved organic-carbon concentration was $3.0 \mathrm{mg} / \mathrm{L}$.

In the pore water collected from $100 \mathrm{ft}$, the trend of decreasing dissolved-solids concentration with increasing depth continued. The dissolvedsolids concentration was $730 \mathrm{mg} / \mathrm{L}$ in July 1991 and $890 \mathrm{mg} / \mathrm{L}$ in April 1992. The predominant ions were sodium, calcium, sulfate, and chloride. The sodium concentration was slightly higher than that of calcium, and the chloride and sulfate concentrations were about equal. The $\mathrm{pH}$ ranged from 7.3 to 7.9 , and the dissolved organic-carbon concentration was $1.9 \mathrm{mg} / \mathrm{L}$.

In the pore water collected from $148 \mathrm{ft}$, a reversal was observed in the dissolved-solidsconcentration trend. Also, a slight seasonality was apparent. In February 1991, the dissolved-solids concentration was $1,490 \mathrm{mg} / \mathrm{L}$. By June 1991 , the concentration had increased to $2,230 \mathrm{mg} / \mathrm{L}$. Then, by August, the concentration had decreased to $1,330 \mathrm{mg} / \mathrm{L}$. The predominant ions were sodium, 
calcium, chloride, and sulfate. The concentration of calcium was one-half that of sodium. The sulfate to chloride ratio varied: the concentration of sulfate ranged from eight-tenths to about equal that of chloride. The $\mathrm{pH}$ ranged from 7.0 to 7.6 , and the dissolved organic-carbon coneentration was $2.2 \mathrm{mg} / \mathrm{L}$.

Several trends with depth were observed. First, the dissolved-solids concentrations were highest, and tended to fluctuate seasonally, at the shallowest depths. These high dissolved-solids concentrations, which were greatest in late summer, correspond to the depth of the root zone of the citrus trees and seem to be linked to the application of fertilizers to the grove. Second, the dissolved-solidsconcentration profile has multiple peaks, suggesting that there are pulses of salts moving through the unsaturated zone, possibly the result of periodic flushing of the root zone with either increased irrigation or increased precipitation. If one assumes that these flushings occur once a year as a result of winter rains or periodic flooding of the grove, and that the peak concentrations at $5 \mathrm{ft}$ and $25 \mathrm{ft}$ represent subsequent-year pulses, then the unsaturated-zone percolation rate seems to be about $25 \mathrm{ft} / \mathrm{yr}$ in the shallow unsaturated zone. Under the same assumptions, but using only the peak concentrations at $25 \mathrm{ft}$ and $148 \mathrm{ft}$, the unsaturatedzone percolation rate seems to be about $120 \mathrm{ft} / \mathrm{yr}$ in the deep unsaturated zone. These values indicate that it would take from 3 to 14 years for water to percolate through the unsaturated zone to the water table. These values are similar to the rates (5 to much less than 30 years) estimated using tritium and moisture-saturation-indices values.

\section{Nitrogen profiles}

As stated earlier, because of the abundance of gravel and cobbles at the citrus grove site, it was not possible to obtain representative cores for nitrate analysis. The discussion that follows, therefore, is limited to the lysimeter results.

Lysimeter results.--Samples of the unsaturated-zone pore water were collected using the ceramic-cup suction lysimeters during February, June, and August 1991 and April and July 1992. Results are given in Supplemental Data $3 \mathrm{C}$ and illustrated in figure 48 . Because the organicnitrogen, ammonia, and nitrite concentrations were generally low, the discussion that follows focuses on the nitrate-concentration profiles.

Inspection of the data reveals extremely high nitrate concentrations in the shallow unsaturated zone. In pore water collected from $5 \mathrm{ft}$, nitrate concentration seems to fluctuate seasonally. During February 1991, the coneentration was $190 \mathrm{mg} / \mathrm{L}$, nearly 20 times the MCL of $10 \mathrm{mg} / \mathrm{L}$. The concentration increased to $260 \mathrm{mg} / \mathrm{L}$ in June and $320 \mathrm{mg} / \mathrm{L}$ in August. By April 1992, the concentration had decreased to $150 \mathrm{mg} / \mathrm{L}$, and it had decreased to $130 \mathrm{mg} / \mathrm{L}$ by July 1992 .

Nitrate concentration in pore water collected from $10 \mathrm{ft}$ also fluctuated seasonally. The sample collected during February 1991 had a concentration of $2.8 \mathrm{mg} / \mathrm{L}$. By June 1991, this concentration had increased to $440 \mathrm{mg} / \mathrm{L}$, and it remained high through the August 1991 sampling. By April 1992, the concentration had decreased to $300 \mathrm{mg} / \mathrm{L}$. By July 1992 , the nitrate concentration was below the detection limit. These extreme fluctuations in nitrate concentration suggest that there are pulses of highnitrate pore water moving through this zone, followed by water with relatively low nitrate concentrations. These data also suggest that denitrification may be occurring in this zone.

The nitrate concentrations in pore water collected from 15 and $25 \mathrm{ft}$ (about $150 \mathrm{mg} / \mathrm{L}$ ) indicate no seasonal variations at these depths; the water moving through this zone may have achieved a quasi-steady state, reflected by a smoothing of concentration spikes. These zones, apparently, do not support active denitrification.

A significant decrease in pore-water nitrate concentration occurs between 25 and $50 \mathrm{ft}$. During February 1991, nitrate concentrations at $50 \mathrm{ft}$ were $6.4 \mathrm{mg} / \mathrm{L}$, and they remained relatively low through June 1991. By August 1991, however, the nitrate concentrations had increased to $41 \mathrm{mg} / \mathrm{L}$, and they continued to increase--to $60 \mathrm{mg} / \mathrm{L}$ in April 1992 and $87 \mathrm{mg} / \mathrm{L}$ in July 1992. This increase, in which the concentration was beginning to approach that in the 25 -ft zone, may represent a pulse of high-nitrate water from the $25-\mathrm{ft}$ zone. Confirmation of the arrival of a nitrate front would require continued monitoring of the pore water at this depth.

The pore water collected from $75 \mathrm{ft}$ also shows a trend of increasing nitrate concentrations with time. Pore water collected during February 1991 had a concentration of $0.5 \mathrm{mg} / \mathrm{L}$. By June 1991, the coneentration had increased to $8.5 \mathrm{mg} / \mathrm{L}$, and it continued to increase, to $16 \mathrm{mg} / \mathrm{L}$ in August 1991 and $29 \mathrm{mg} / \mathrm{L}$ in April 1992, and then stabilized at $31 \mathrm{mg} / \mathrm{L}$ during July 1992. 


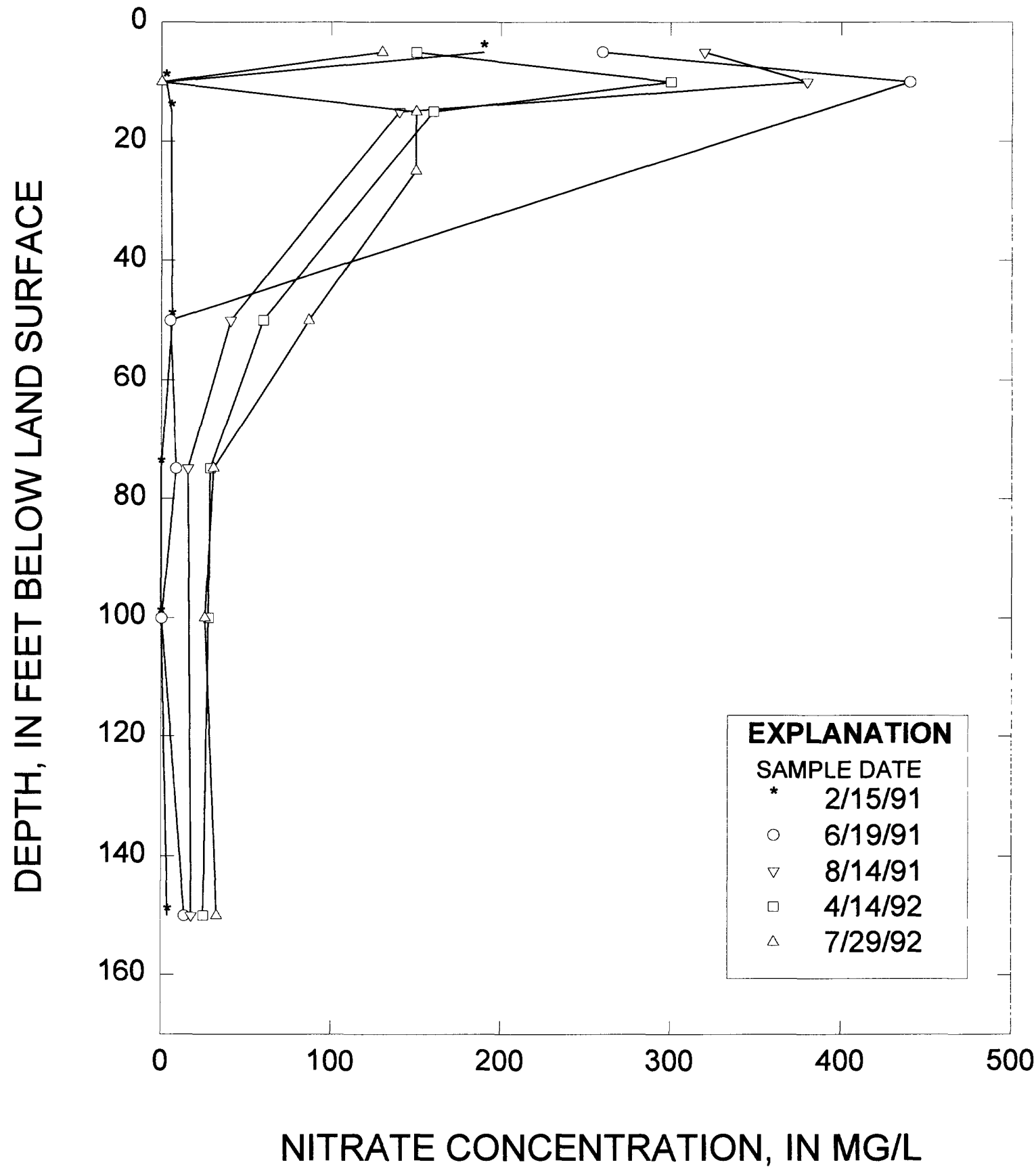

Figure 48. Nitrate concentration, for selected dates in 1991-92, in unsaturated-zone pore water at the citrus grove site. 
The same trend was observed at both 100 and $148 \mathrm{ft}$; concentrations were low in February 1991 and had become high by July 1992. Pore-water nitrate concentrations of 26 and $33 \mathrm{mg} / \mathrm{L}$ in later samples exceeded the MCL.

The dynamic nature of conditions at the citrus grove site, and the apparent trend of increasing nitrate concentrations in unsaturated-zone pore water, suggests that continued long-term monitoring is necessary to determine how much nitrate is reaching the water table at this site.

\section{Microbial Processes}

Several techniques were applied to determine if microbial processes in the unsaturated zone were important in controlling nitrate concentrations. The most direct method involved quantifying the populations of nitrifying and denitrifying bacteria. Unfortunately, the abundance of gravel and cobbles underlying the citrus grove site made it very difficult to collect undisturbed core samples for microbial enumeration, as described in the "Site Instrumentation and Sample Collection" section. Usable samples were obtained only from depths of 3,20 , and $30 \mathrm{ft}$. The results for these samples are given in table 2. No Nitrobacter were identified in the cores, but significant populations of Nitrosomonas were present in the $3 \mathrm{ft}$ sample. It is probable, therefore, that some nitrification (conversion of reduced forms of nitrogen to more oxidized forms is occurring in the shallow unsaturated zone. Significant populations of denitrifying bacteria also were found. The concentration at $3 \mathrm{ft}$ was 23,000 bacteria per gram of soil. The populations decreased with depth, yielding 140 bacteria per gram at $20 \mathrm{ft}$, and 90 bacteria per gram at $30 \mathrm{ft}$.

The presence of assimilated denitrifying bacteria at the site suggests that denitrification might be occurring. All the $8^{15} \mathrm{~N}$ values for the samples collected at the citrus grove site (given in table 3 ) are less than 10 , suggesting that the nitrate is from mineral rather than biological sources. A linear trend between depths of 5 and $25 \mathrm{ft}$ toward decreasing $8^{15} \mathrm{~N}$ values suggests a decrease in the degree of microbial cycling deeper in the unsaturated zone. The $8^{15} \mathrm{~N}$ value at $50 \mathrm{ft}$ implies increased microbial cycling in comparison with the shallower samples, once again suggesting a periodic flushing of salts through the unsaturated zone.

The soil-gas profiles for the citrus grove site are given in table 4. Significant concentrations of $\mathrm{N}_{2} \mathrm{O}$ are present at the $50 \mathrm{ft}$ depth, and $\mathrm{CO}_{2}$ concentrations are slightly elevated. These observations, along with the significant denitrifying bacteria population at $50 \mathrm{ft}$ and the decreased nitrate concentrations at this depth, confirms that microbial denitrification is occurring in the unsaturated zone beneath the citrus grove site.

\section{Conclusions}

The citrus grove site is located over an aquifer that has two distinct layers. In the uppermost layer, nitrate concentrations are high, but the water quality is good. In the lower zone, water quality is better, and nitrate concentrations are below the MCL. There seems to be no significant hydraulic gradient between the two zones, and appreciable mixing at this time is unlikely. Recharge to the aquifer is from stream-channel leakage along Bautista Creek.

The unsaturated-zone pore moisture is variable, and moisture contents are highest in natural capillary barriers at the interfaces between gravel and (or) cobbles and fine-grained materials. There are no extensive clay layers underlying this site, and it is likely, given enough time, that water can percolate from the land surface to the water table. The unsaturated-zone pore water has very high nitrate concentrations, and the nitrate seems to be migrating downward through the unsaturated zone. There are zones of active microbial denitrification, however. The estimated-unsaturated zone percolation rate is between 25 and $160 \mathrm{ft}$ per year, which would yield an unsaturated-zone transit time of 5 to 10 years.

\section{Irrigated-Farm Site}

\section{Background}

Numerous studies have demonstrated a positive correlation between increased nitrogen fertilizer application rates and increased nitrate concentrations in underlying aquifers. Considerably fewer studies have been done of nitrate concentrations in the unsaturated zone.

Schuman and others (1975) demonstrated that for corn, nitrogen application rates of $400 \mathrm{lb} / \mathrm{acre}$ per year over a 3-year period led to an increase of $640 \mathrm{lb} / \mathrm{acre}$ in the amount of nitrogen in the unsaturated zone (from the root zone to a depth of $10 \mathrm{ft}$ ). For vegetable row crops, nitrogen application rates of $16-280 \mathrm{lb} /$ acre per year yielded soil-poremoisture nitrate concentrations ranging from 8 to 
$120 \mathrm{mg} / \mathrm{L}$, even at depths to $50 \mathrm{ft}$ (Ayers, 1978).

Pratt and Adriano (1973) reported that with nitrogen loading of 100 to $1,300 \mathrm{lb} /$ acre per year, 22 to $800 \mathrm{lb} /$ acre per year is lost to leaching beneath the root zone. This leached nitrogen resulted in nitrate concentrations in the unsaturated-zone pore water of 12 to $120 \mathrm{mg} / \mathrm{L}$.

Adriano and others (1972), studying 50-ft cores beneath asparagus and celery fertilized at a rate of $500 \mathrm{lb} /$ acre per year, found that unsaturated-zone pore-water nitrate concentrations were higher where water application rates were higher. They reported nitrate concentrations in the unsaturated zone of 30 to $150 \mathrm{mg} / \mathrm{L}$.

Schmidt and Sherman (1987) reported nitrate concentrations in unsaturated-zone pore water of 37 to $86 \mathrm{mg} / \mathrm{L}$. Nitrate concentrations in pore water exceeded $10 \mathrm{mg} / \mathrm{L}$ at 90 percent of the irrigated sites, and concentrations exceeded $20 \mathrm{mg} / \mathrm{L}$ at 70 percent. Generally, concentrations in the saturated zone were less than those in the unsaturated zone. Also, concentrations were less in coastal valleys (higher percentage of sand and gravel) than in inland valleys (higher percentage of silt and clay).

Böhlke and others (1992), using nitrogen stable-isotope ratios, found that denitrification was more complete in areas of reducing aquifer sediments and shallow (less than $10 \mathrm{ft}$ ) confining units than in oxic aquifer sediments and deep (greater than $60 \mathrm{ft}$ ) confining units.

\section{Site Description}

The irrigated-farm site is in the main basin area of the Hemet Basin, near the intersection of Sanderson and Esplanade Avenues (site 2 in fig. 3). The area is sewered, and municipally supplied water is used to irrigate the crops grown on the farm. During the course of this study, crops of potatoes, squash, and potatoes (again) were grown.

Instrumentation of the site was completed in two phases. The saturated-zone multiple-depth wells were installed during August 5-8, 1990, using the methods described in the "Site Instrumentation and Sample Collection" section of this report. The total bore-hole depth was $321 \mathrm{ft}$. Wells were installed with screens at $300,255,233$, and $212 \mathrm{ft}$.

The unsaturated-zone instrumentation was installed during September 20- November 3, 1990. The first hole was drilled to $151 \mathrm{ft}$, and continuous core was collected using the aseptic techniques described in the "Site Instrumentation and Sample Collection" section. A sealed 2-inch-diameter galvanized pipe was set in this bore hole at $150 \mathrm{ft}$ to serve as a neutron-probe access tube. Copper gassampling tubes $(0.25$-in.) were attached to the galvanized pipe at depths of $150,100,50$, and $25 \mathrm{ft}$. The bore hole was backfilled with native material to a depth of $5 \mathrm{ft}$ and a bentonite seal was installed to land surface. The second hole was drilled to $116 \mathrm{ft}$, and lysimeters were set in this bore hole at depths of 98,75 , and $50 \mathrm{ft}$. The third bore hole was drilled to $26 \mathrm{ft}$. A 6-inch layer of bentonite was placed in the bottom of the hole, and lysimeters were set in this bore hole at depths of $25,15,10$, and $5 \mathrm{ft}$.

Illustrated in figure 49 are the geophysical logs; the completion zones for the saturated-zone wells; and the lithology interpreted from the driller's and geologist's logs, the geophysical logs, and the core observations. The caliper log indicated numerous zones that were prone to caving--notably from land surface to $7 \mathrm{ft}, 19$ to $23 \mathrm{ft}, 58$ to $62 \mathrm{ft}, 103$ to $106 \mathrm{ft}$, 113 to $118 \mathrm{ft}, 155$ to $193 \mathrm{ft}$, and 242 to $260 \mathrm{ft}$. The zone from land surface to $7 \mathrm{ft}$ is silty sandy loam, the zone from 19 to $23 \mathrm{ft}$ is silty sand, and the zone from 58 to $62 \mathrm{ft}$ is fine to coarse sand above a confining clay layer. The zones from 103 to $106 \mathrm{ft}$ and 113 to $118 \mathrm{ft}$ consist of fine uncemented sand above silt. The zone from 155 to $193 \mathrm{ft}$ is silty to medium sand directly below a thick confining clay layer and immediately above a poorly cemented sand zone. The zone from 242 to $260 \mathrm{ft}$ is uncemented coarse sand and gravel between two layers of cemented sand. The gamma radioactivity $\log$ clearly indicates clay layers at $28,62,66,90$, 148 , and $272 \mathrm{ft}$. The gamma log also indicates clay layers in the sand and gravel zones at other depths. The spontaneous-potential log shows the interface between the reduced sands above $46 \mathrm{ft}$ and the oxidized sands below. The log also indicates the interface at 116 feet between the reduced sands and the oxidized sands below. Neither the long nor short normal resistivity tools, nor the single-point resistivity tool, produced usable logs at the irrigated-farm site.

Samples were collected from the cores at selected depths to determine the particle-size distributions in the numerous formations. These distributions are shown in figure 50. In the sample from $3 \mathrm{ft}$, about 80 percent of the particles are in the fine and medium sand fractions $(0.062$ to $0.5 \mathrm{~mm})$. The remaining particles are in the silt-sized fraction. The sample from $20 \mathrm{ft}$ has a broader distribution. About 80 percent of the particles are between 0.008 


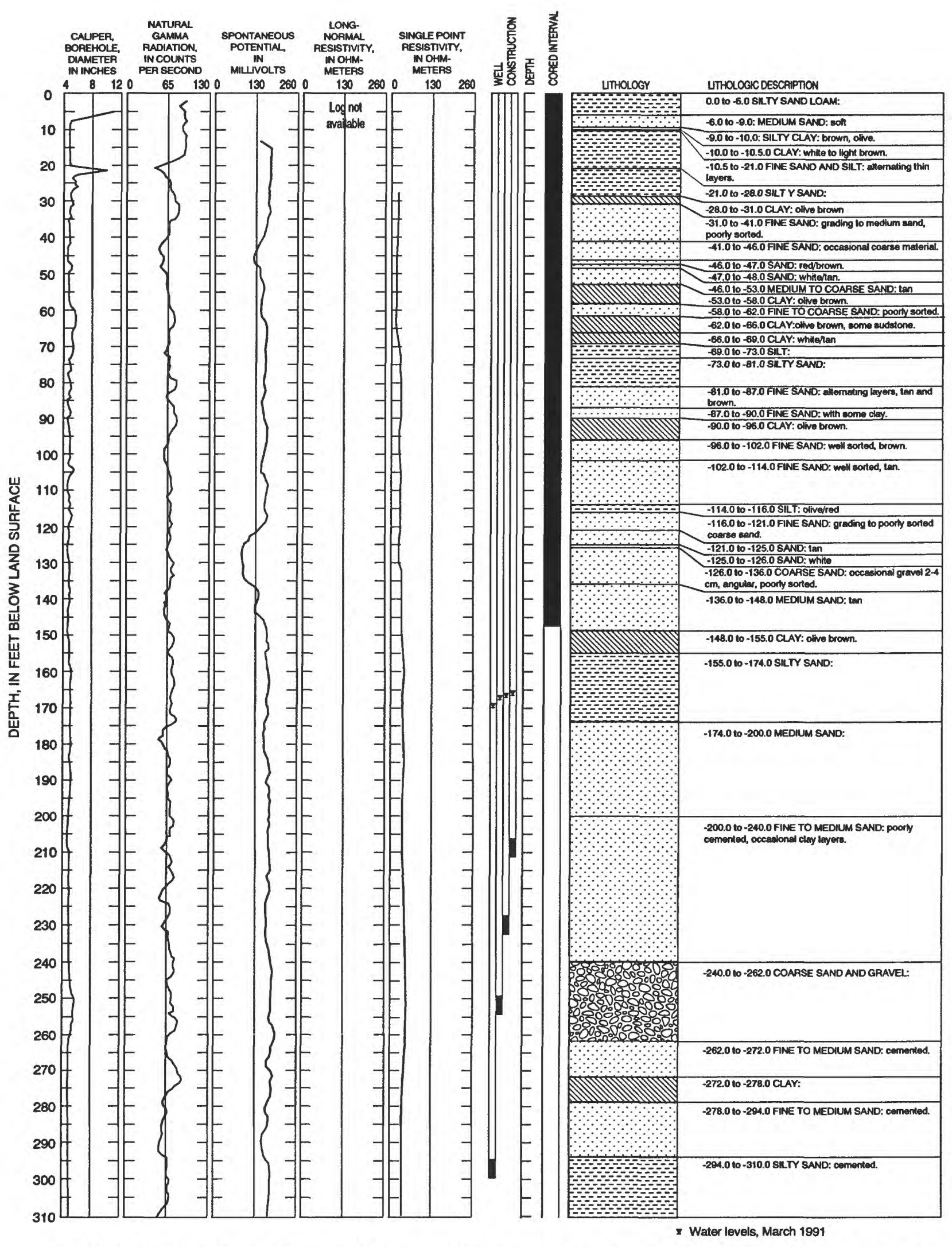

FIGURE 49. Geophysical logs, and diagram showing well construction, cored interval, and lithology for the irrigated-farm site. 


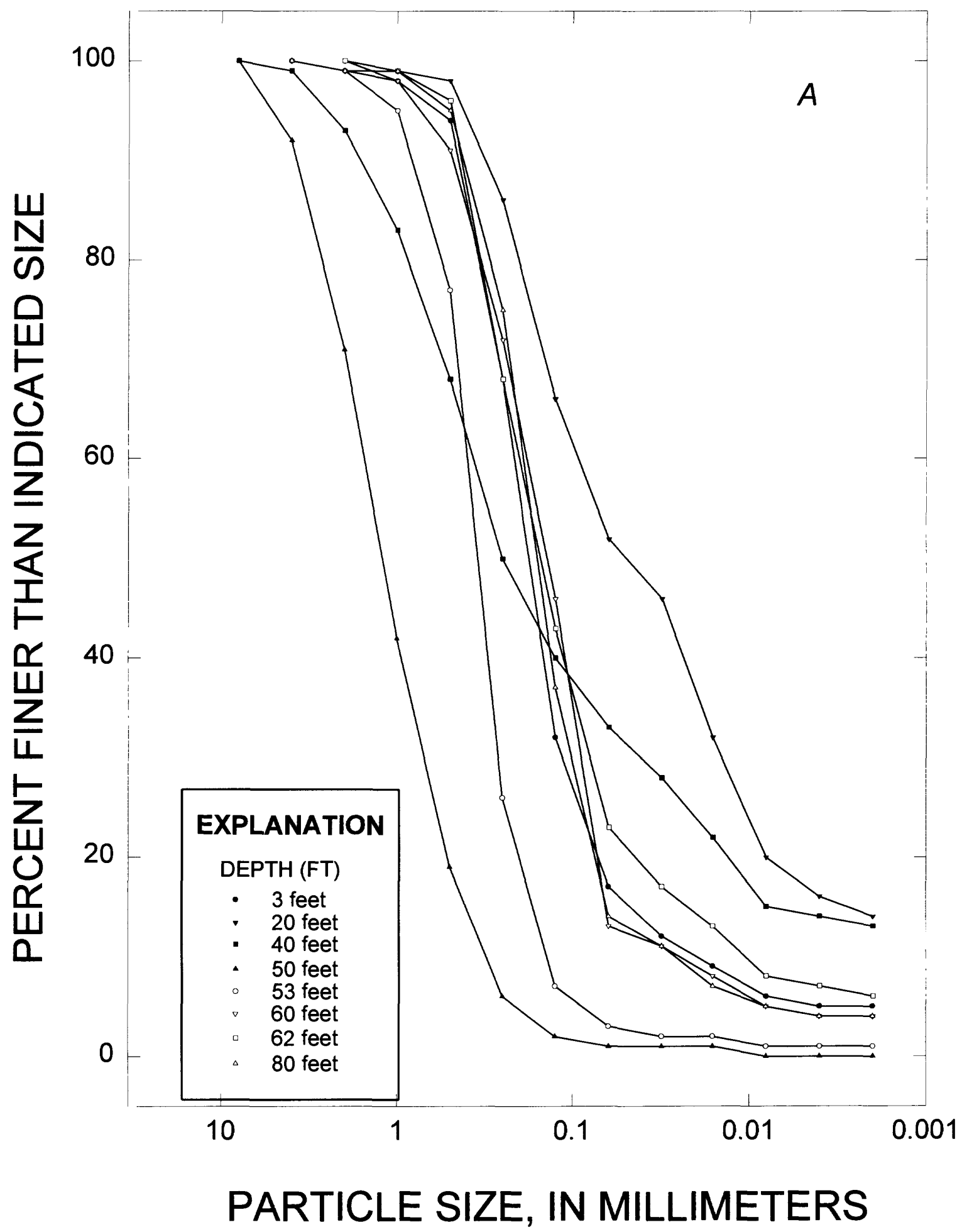

Figure 50. Particle-size distribution for cores from the irrigated-farm site. $A$, Depths of 3 to 80 feet. B, Depths of 100 to 150 feet. 


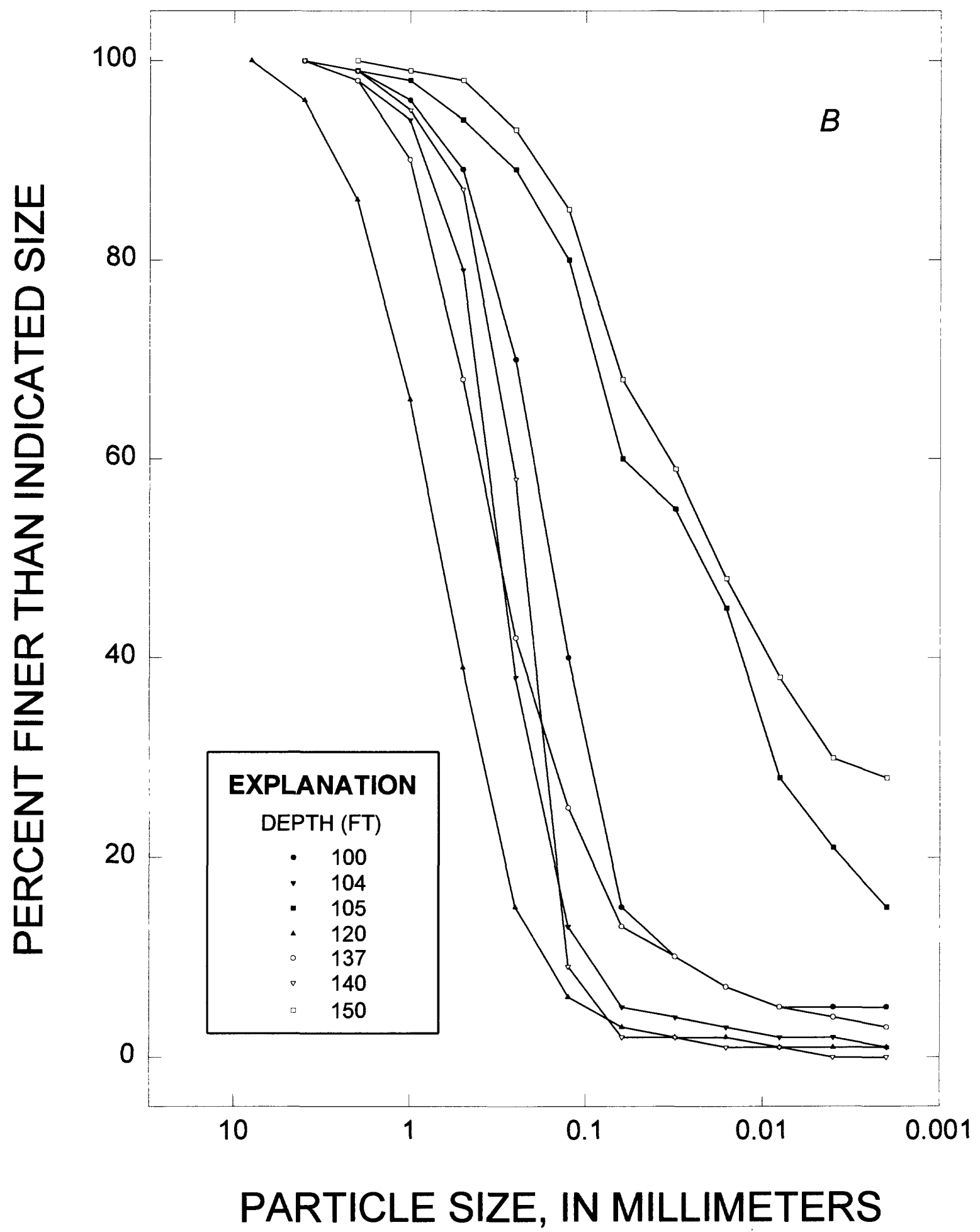

Figure 50--Continued.

Geohydrology, Water Quality, and Nitrogen Geochemistry in the Saturated and Unsaturated Zones 93 b 
and $0.5 \mathrm{~mm}$; the remaining 20 percent are clay sized. The sample from $40 \mathrm{ft}$ has an even flatter distribution, containing an appreciable population of particles in each size class. The sample from $50 \mathrm{ft}$ is coarse sand and gravel; it contains virtually no siltor clay-sized particles. The samples from 60 and 80 $\mathrm{ft}$, in comparison with that from $50 \mathrm{ft}$, contain more fine sand and slightly more silt-sized material. The samples from 100,104 , and $120 \mathrm{ft}$ grade downward from fine to coarse sand. The sample from $105 \mathrm{ft}$ indicates a thin clay layer within the fine sand. This sample has considerably more silt- and clay-sized particles than samples from the surrounding zones. The $137 \mathrm{ft}$ sample consists of medium sand that contains about 10 percent silt-sized particles. The sample from $140 \mathrm{ft}$ is a coarser, well-sorted sand. Finally, the sample from $150 \mathrm{ft}$ is from the confining clay at the bottom of the bore hole.

\section{Saturated-Zone Results}

The water-table surface near the irrigated-farm site was determined by measuring water levels at the multiple-well site $(4 \mathrm{~S} / 1 \mathrm{~W}-32 \mathrm{Q})$ and in wells $4 \mathrm{~S} / 1 \mathrm{~W}-31 \mathrm{G} 2,4 \mathrm{~S} / 1 \mathrm{~W}-32 \mathrm{H} 4,4 \mathrm{~S} / 1 \mathrm{~W}-32 \mathrm{~N} 1$, and $4 \mathrm{~S} / 1 \mathrm{~W}-33 \mathrm{Q} 1$. These results, given in Supplemental Data 1,2, and 3D, and the water-table surface described in the "Geohydrologic Setting" section, indicate that the irrigated-farm site lies above a ground-water ridge from which water flows to the north toward the San Jacinto Reservoir and to the southeast toward the pumping depression underlying the city of Hemet. The piezometric surface, measured in the four wells at the site, indicates that there is a downward gradient of about $8 \mathrm{ft}$ between the $212 \mathrm{ft}$ and $300 \mathrm{ft}$ wells. During the course of this study (1991-92), the water table declined about 4 to $7 \mathrm{ft}$.

Water-quality samples were collected from the four saturated-zone wells on the following dates: January 25, March 29, June 12, and August 23, 1991, and January 14 and August 14, 1992. Analytical results are given in Supplemental Data $3 D$. Inspection of these data shows that there is virtually no temporal variation in water quality at each of the sampled depths, an indication that the samples collected are representative of water in the formation at the depths specified.

There is a slight trend of increasing dissolvedsolids concentration with depth at the irrigated-farm site. The dissolved-solids concentration was about $500 \mathrm{mg} / \mathrm{L}$ at $212 \mathrm{ft} ; 510 \mathrm{mg} / \mathrm{L}$ at $233 \mathrm{ft} ; 570 \mathrm{mg} / \mathrm{L}$ at 255 ; and $590 \mathrm{mg} / \mathrm{L}$ at $300 \mathrm{ft}$. Although these concentrations are slightly above the U.S. EPA
Secondary Maximum Contaminant Level of $500 \mathrm{mg} / \mathrm{L}$, the water is considered to be of relatively good quality. The predominant ions are sodium and sulfate; the concentrations of both calcium and chloride are low. A trend of increasing calcium and chloride concentrations was observed in samples from the deeper wells. The $\mathrm{pH}$ of the ground water ranged from 8.4 in the $212 \mathrm{ft}$ well, to 8.0 in the 300 $\mathrm{ft}$ well. Nitrate concentrations were moderate at all depths. The ground water underlying the irrigatedfarm site had elevated boron concentrations: 770 $\mu \mathrm{g} / \mathrm{L}$ in the $212 \mathrm{ft}$ and $233 \mathrm{ft}$ wells; $400 \mu \mathrm{g} / \mathrm{L}$ in the $255 \mathrm{ft}$ well; and $660 \mu \mathrm{g} / \mathrm{L}$ in the $300 \mathrm{ft}$ well. Selenium concentrations were low at all depths except $300 \mathrm{ft}$, where the selenium concentration approached $10 \mu \mathrm{g} / \mathrm{L}$ (the MCL is $50 \mu \mathrm{g} / \mathrm{L}$ ).

The deuterium to hydrogen ratio deviation $(\delta D)$, and the oxygen $18 / 16$ ratio deviation $\left(\delta^{18} \mathrm{O}\right)$ values from all wells were nearly identical; average values were $\delta \mathrm{D}=-57.5$ permil and $\delta^{18} \mathrm{O}=-8.4$ permil. The Dansgaard plot (described in the "Water Quality Overview" section) indicates that ground water underlying the irrigated-farm site originated as rain that fell at the relatively warm temperature of about $7^{\circ} \mathrm{C}$, rather than as snow at high altitudes. Plots of the $8 \mathrm{D}$ and $8^{18} \mathrm{O}$ data on the Craig diagram (also described in the "Water Quality Overview" section) show that the ground water at the site did not undergo significant evaporation prior to percolating to the water table.

The $8^{15} \mathrm{~N}$ values $(11.5$ permil at $212 \mathrm{ft}, 10.2$ permil at $233 \mathrm{ft}, 7.6$ permil at $255 \mathrm{ft}$, and 9.4 permil at $300 \mathrm{ft}$ ) indicate that the nitrate in the ground water probably is a mixture derived from mineral and animal forms. (See the discussion of nitrogen isotopes in the "Introduction" subsection of the "Water Quality Overview" section.)

\section{Unsaturated-Zone Results}

\section{Pore-moisture profiles}

Pore-moisture saturation-index profiles were measured as described in the "Site Instrumentation and Sample Collection" section. The profiles were measured during May and November 1991; August and October 1992; and on January 20, 1993, and are shown in figure 51 . Vertical resolution is approximately $1 \mathrm{ft}$ and horizontal resolution is about 0.02 unit.

The profiles indicate that the materials underlying the irrigated-farm site contain much more moisture than the materials at the other 


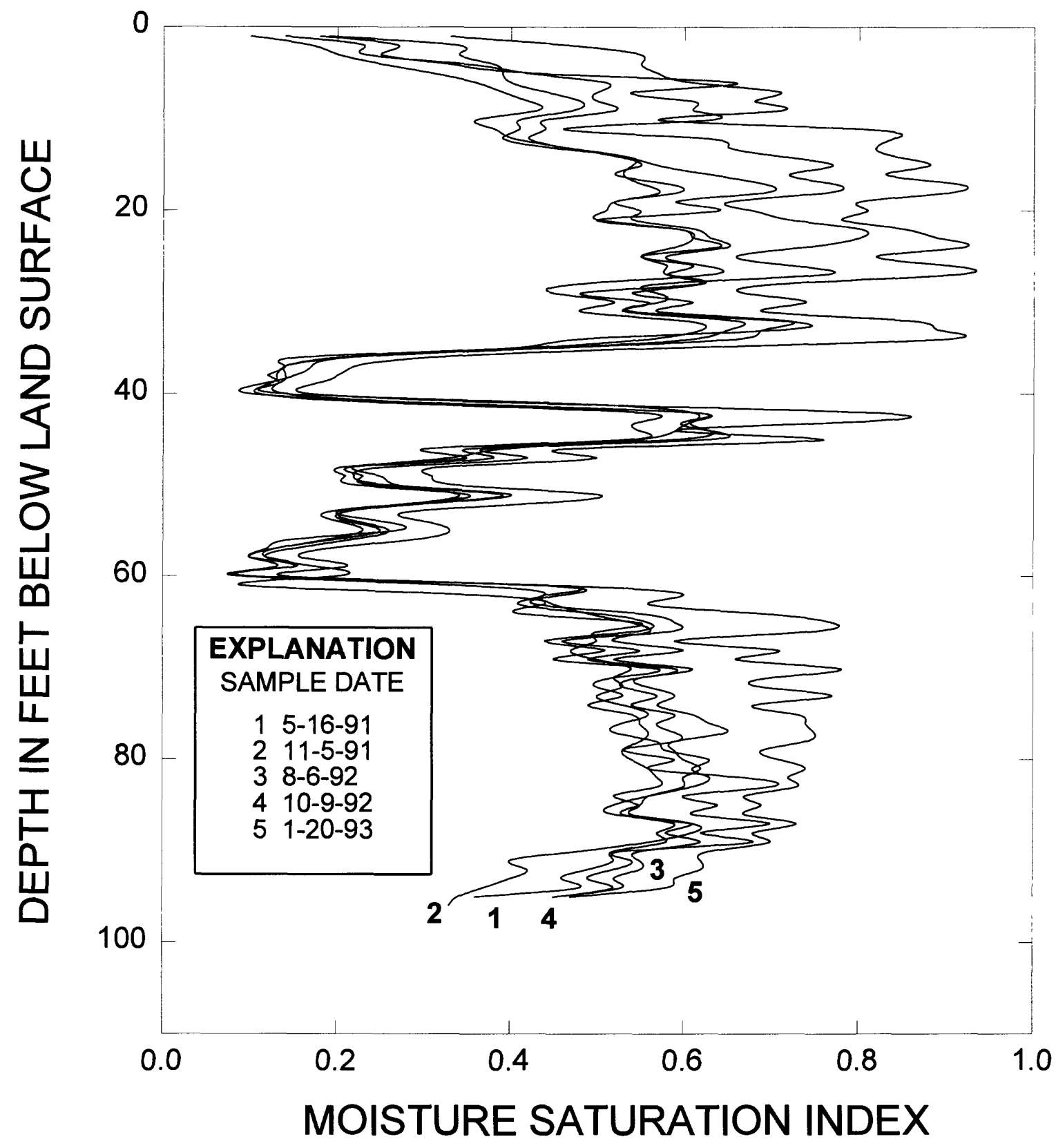

Figure 51. Unsaturated-zone pore-moisture profiles, for selected dates in 1991-93, for the irrigated farm site. 
research sites. The moisture saturation index in many zones is greater than 0.5 , and in a few zones it approaches 1.0. That is, some zones are either saturated or nearly saturated. Water is perched in the sand and silt above an extensive clay zone at about $28 \mathrm{ft}$. Immediately below this clay layer, the formations are very dry (saturation index less than 0.15 ). Another clay layer, at $53 \mathrm{ft}$, also causes the moisture content of the materials above it to increase, approaching saturation. The sand beneath this clay layer is relatively dry. The moisture content increases at and below a clay layer at $66 \mathrm{ft}$, and remains high through the clay layer at $90 \mathrm{ft}$. The pore moisture at this site remained relatively constant during the course of the study, varying by about 0.04 unit. Only the profile measured January 20,1993 , shows an appreciable increase in moisture content, probably associated with a period of intense precipitation in early January 1993 when large areas of the main part of the Hemet Basin were flooded.

These results indicate that unsaturated-zone pore water will percolate vertically until it reaches one of the perched saturated zones, where it then will move horizontally. Therefore, salts that leach from the surface probably will not be transported directly to the water table beneath the source, but rather will be transported some distance horizontally before resuming the vertical percolation to the water table.

The profiles seem to indicate that there is no piston flow in the system, at least on the time scale of the measurements made. The shape of the various profiles is virtually constant, and any change in moisture content is reflected in the entire profile, not at a particular depth only. The soil column seems to equilibrate rapidly to changes in precipitation and (or) irrigation.

Unsaturated hydraulic conductivities for the various alluvial materials beneath the irrigated-farm site ranged from $1.55 \times 10^{-8} \mathrm{ft} / \mathrm{s}$ for the dry sand at $40 \mathrm{ft}$ to $1.62 \times 10^{-3} \mathrm{ft} / \mathrm{s}$ for the coarse, relatively wet sand at $50 \mathrm{ft}$. Using the appropriate unsaturated hydraulic conductivities with the corresponding moisture saturation indices, and integrating over the entire unsaturated zone, one obtains an estimated transit time of about 1.3 years for water to percolate from the land surface to the first perched zone (the clay at $28 \mathrm{ft}$ ), and an additional 55 years to percolate to the water table.

\section{Tritium profile}

The unsaturated-zone pore-water tritium- concentration profile at the irrigated-farm site was determined by compositing lysimeter-collected water during July 1991 until sufficient volume $(1 \mathrm{~L})$ was obtained for analysis. The profile (fig. 52) shows that the tritium concentration never approaches the expected 1963 concentration of $600 \mathrm{pCi} / \mathrm{L}$; this indicates that the unsaturated zone transit time is less than 30 years. The observed concentrations are approximately what would be expected if the source of the tritium was local precipitation rather than imported Colorado River water.

\section{Water quality}

Unsaturated-zone pore-water samples were collected for analysis, using the ceramic-cup suction lysimeters, during February, June, and August 1991 and April and August 1992. Analytical results are given in Supplemental Data 3D.

For the samples collected at a depth of $5 \mathrm{ft}$, the dissolved-solids concentration was about $1,540 \mathrm{mg} / \mathrm{L}$. The predominant ions were calcium and sodium, and sulfate and chloride; the sodium and chloride concentrations were about two-thirds as great as the concentrations of calcium and chloride, respectively. The $\mathrm{pH}$ was about 7.3 , and the dissolved-organic-carbon concentration was 5.5 $\mathrm{mg} / \mathrm{L}$.

For the samples collected at a depth of $10 \mathrm{ft}$, the dissolved-solids concentration was about $1,940 \mathrm{mg} / \mathrm{L}$. The predominant ions were sodium and sulfate; in addition, calcium concentration was about one-fifth that of the sodium, and chloride about onethird that of sulfate. The $\mathrm{pH}$ in June was 7.3. Dissolved organic-carbon concentration was $2.9 \mathrm{mg} / \mathrm{L}$.

The samples collected at a depth of $14.9 \mathrm{ft}$ showed temporal variability in water quality. The samples collected in February and June 1991 had dissolved-solids concentrations of about $930 \mathrm{mg} / \mathrm{L}$. The predominant ions were sodium and sulfate; also, calcium concentration was about one-half that of sodium, and chloride about one-third that of sulfate. The $\mathrm{pH}$ of the water was 7.4. The samples collected in August 1991, April 1992, and August 1992 had much lower dissolved-solids concentrations--about $380 \mathrm{mg} / \mathrm{L}$. The predominant ions were sodium and sulfate; small quantities of calcium and chloride also were present. The $\mathrm{pH}$ of the water in August 1991 and April 1992 was 7.6. The dissolved-organic-carbon concentration was $1.5 \mathrm{mg} / \mathrm{L}$. 


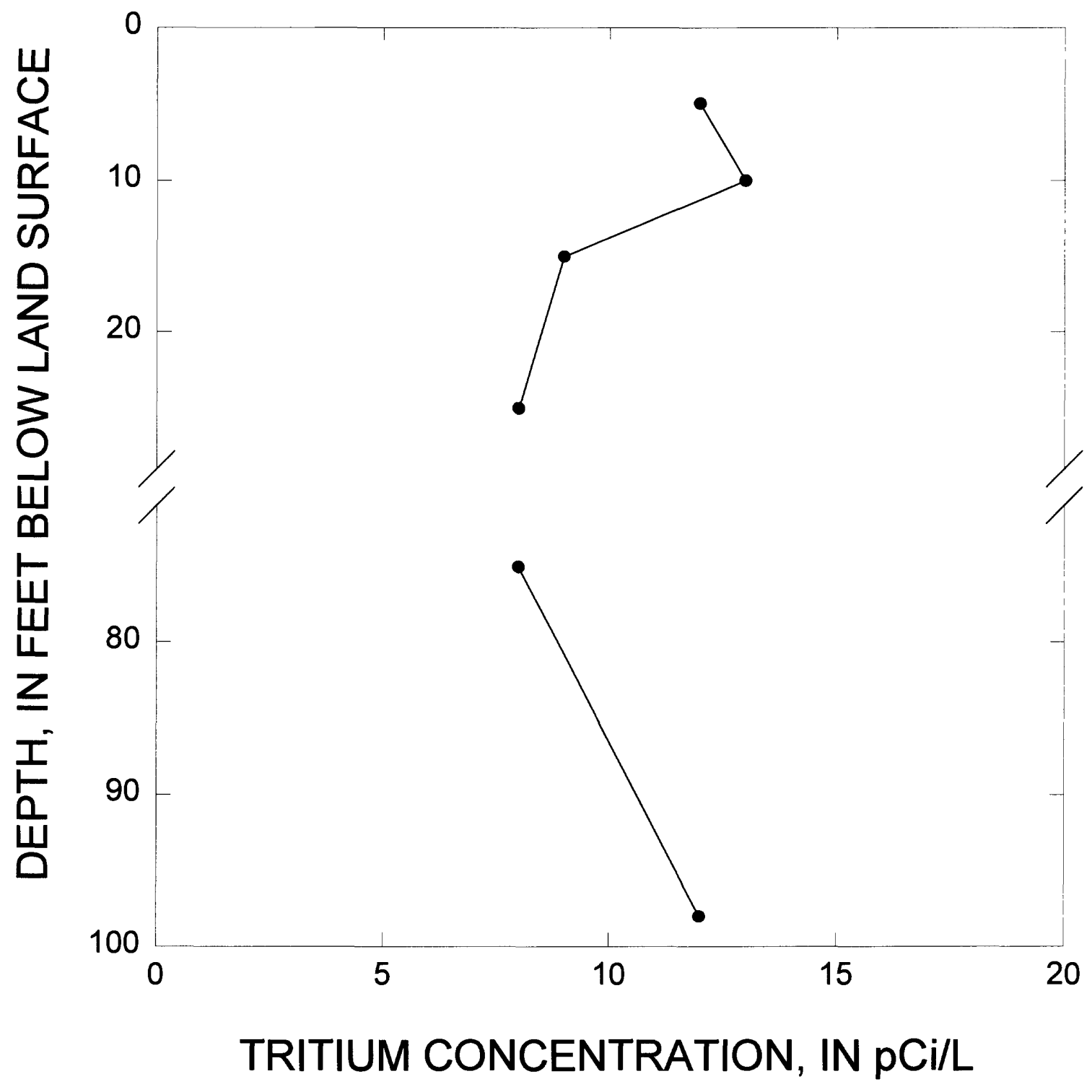

Figure 52. Tritium-concentration profile for unsaturated-zone pore water at the irrigated farm site. 
The samples collected at a depth of $25 \mathrm{ft}$ had a relatively constant dissolved-solids concentration of about $650 \mathrm{mg} / \mathrm{L}$. The predominant ions were sodium, sulfate, and chloride. The calcium concentration was very low. The $\mathrm{pH}$ of the pore water was about 8.1, and the dissolved-organiccarbon concentration was $1.4 \mathrm{mg} / \mathrm{L}$.

The lysimeter at $50 \mathrm{ft}$ did not function well, and only one sample was obtained. Because of the scant volume available, only anions were analyzed. Those results indicated a much higher dissolved-solids concentration than observed at other depths at this site. Chloride was the dominant anion. The $\mathrm{pH}$ of the pore water was 7.7. Dissolved organic carbon was not determined.

Unsaturated-zone pore water from $75 \mathrm{ft}$ had a dissolved-solids concentration of about $1,350 \mathrm{mg} / \mathrm{L}$. The predominant ions were sodium and sulfate. In addition, calcium concentration was about onefourth that of sodium, and chloride concentration was one-third that of sulfate. The $\mathrm{pH}$ was 7.3 , and the dissolved-organic-carbon concentration was $2.2 \mathrm{mg} / \mathrm{L}$.

The pore water collected from $98 \mathrm{ft}$ had a dissolved-solids concentration of about $990 \mathrm{mg} / \mathrm{L}$. The predominant ions were sodium and sulfate. In addition, calcium was one-fourth that of sodium, and chloride about one-half that of sulfate. The $\mathrm{pH}$ was 7.2, and the dissolved-organic-carbon concentration was $1.6 \mathrm{mg} / \mathrm{L}$.

The water quality of the unsaturated-zone pore water was relatively good. The dissolved-solids concentrations were fairly low, in comparison with concentrations at the other research sites. However, as will be discussed in the next section, there are some problems related to nitrate concentrations. Because of the complications of perched zones in the unsaturated zone, it is not possible to determine the percolation rates in the deposits underlying the irrigated-farm site using the water-quality results.

\section{Nitrogen profiles}

Core results.--Samples of core material were collected and processed using the procedures described in the "Site Instrumentation and Sample Collection" section. The organic-nitrogenconcentration profile for the irrigated-farm site is shown in figure 53. Most of the organic-nitrogen concentrations ranged from about 5 to $20 \mathrm{mg} / \mathrm{L}$, representing 35 to 50 percent of the total nitrogen (sum of organic nitrogen, ammonia, nitrite, and nitrate concentrations) at each depth. Organicnitrogen concentrations tended to be lowest in zones in which moisture contents were highest, suggesting that these high-moisture zones provide favorable sites for microbial consumption of organic nitrogen. Conversely, the maximum concentration observed, $46 \mathrm{mg} / \mathrm{L}$, was in a zone (at $140 \mathrm{ft}$ ) of coarse sand and gravel in which the moisture content was low (about 5 percent).

The ammonia-concentration profile (fig. 54) normally includes both free ammonia and ammonium concentrations. Because ammonium tends to sorb strongly to soil particles, however, it is unlikely that ammonium is present in appreciable concentrations in the pore water. The ammonia concentrations were generally low, ranging from less than the detection limit to about $7 \mathrm{mg} / \mathrm{L}$. Only in the clay layer at $53 \mathrm{ft}$ does the ammonia concentration become appreciable $(46 \mathrm{mg} / \mathrm{L}$, ammonia as nitrogen).

Nitrite concentrations were at or below the detection limit at all depths--except above the clay at $53 \mathrm{ft}$, where the nitrite concentration was about $27 \mathrm{mg} / \mathrm{L}$ (nitrite as nitrogen). This is among the highest nitrite concentrations that have been reported for field settings, strongly suggesting that significant microbial activity occurs in this zone.

Unsaturated-zone nitrate concentrations (profile shown in fig. 55) generally ranged from 5 to $20 \mathrm{mg} / \mathrm{L}$ and represent most of the nitrogen in the unsaturated zone. The trends for nitrate, nitrite, and ammonia are identical, and the highest nitrate concentrations occurred in the same zones that had the highest ammonia concentrations. The lowest nitrate concentrations occurred in the fine sands at depths of 23 and $104 \mathrm{ft}$; the highest nitrate concentrations were in and above the clay layer at $53 \mathrm{ft}$, and in a zone of silty sand stained with iron oxides at approximately $141 \mathrm{ft}$. Elevated nitrate concentrations in association with zones of ironoxide deposition in the unsaturated zone also were observed at the residential site (discussed earlier).

Lysimeter Results.--Samples of unsaturatedzone pore water were collected using the ceramic-cup suction lysimeters during February, June, and August 1991 and April and August 1992. Results are given in Supplemental Data 3D and illustrated in figure 56. Organic-nitrogen, ammonia, and nitrite concentrations were generally low; therefore, the discussion that follows focuses on the nitrate-concentration profiles. 


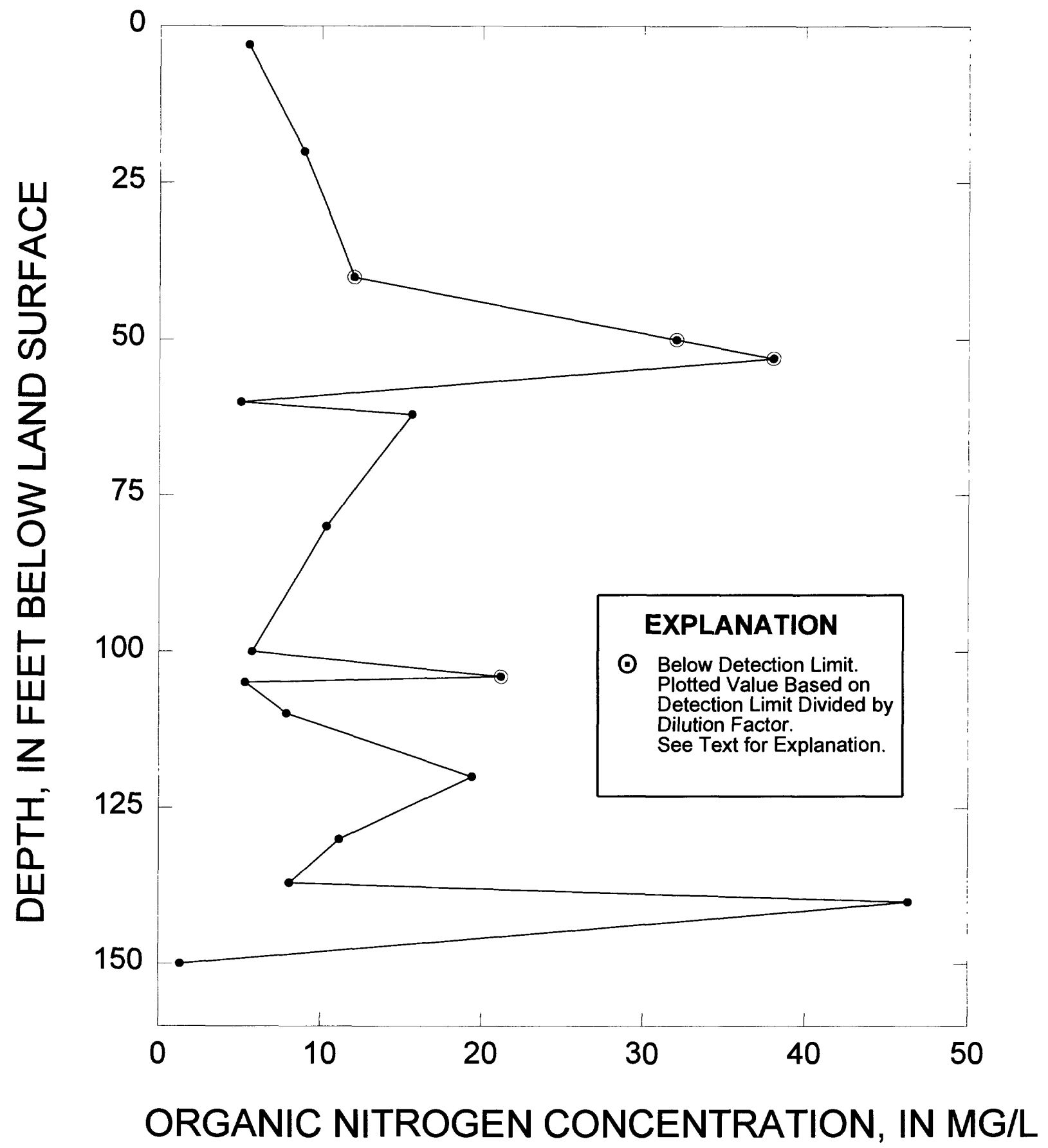

Figure 53. Organic-nitrogen-concentration profile, from core extracts, for the unsaturated zone at the irrigated farm site. 


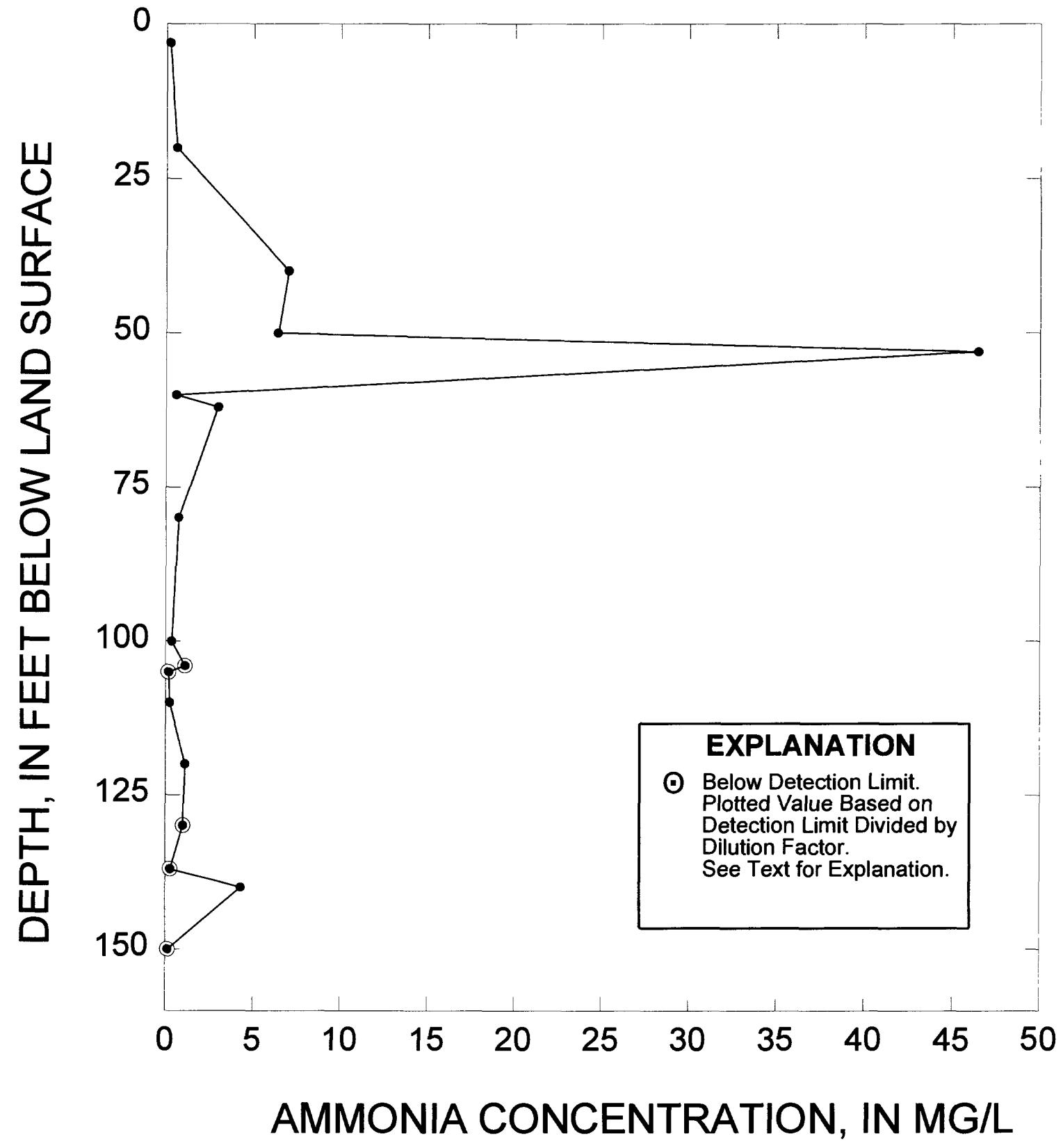

Figure 54. Ammonia-concentration profile for the unsaturated-zone pore water at the irrigated farm site. 


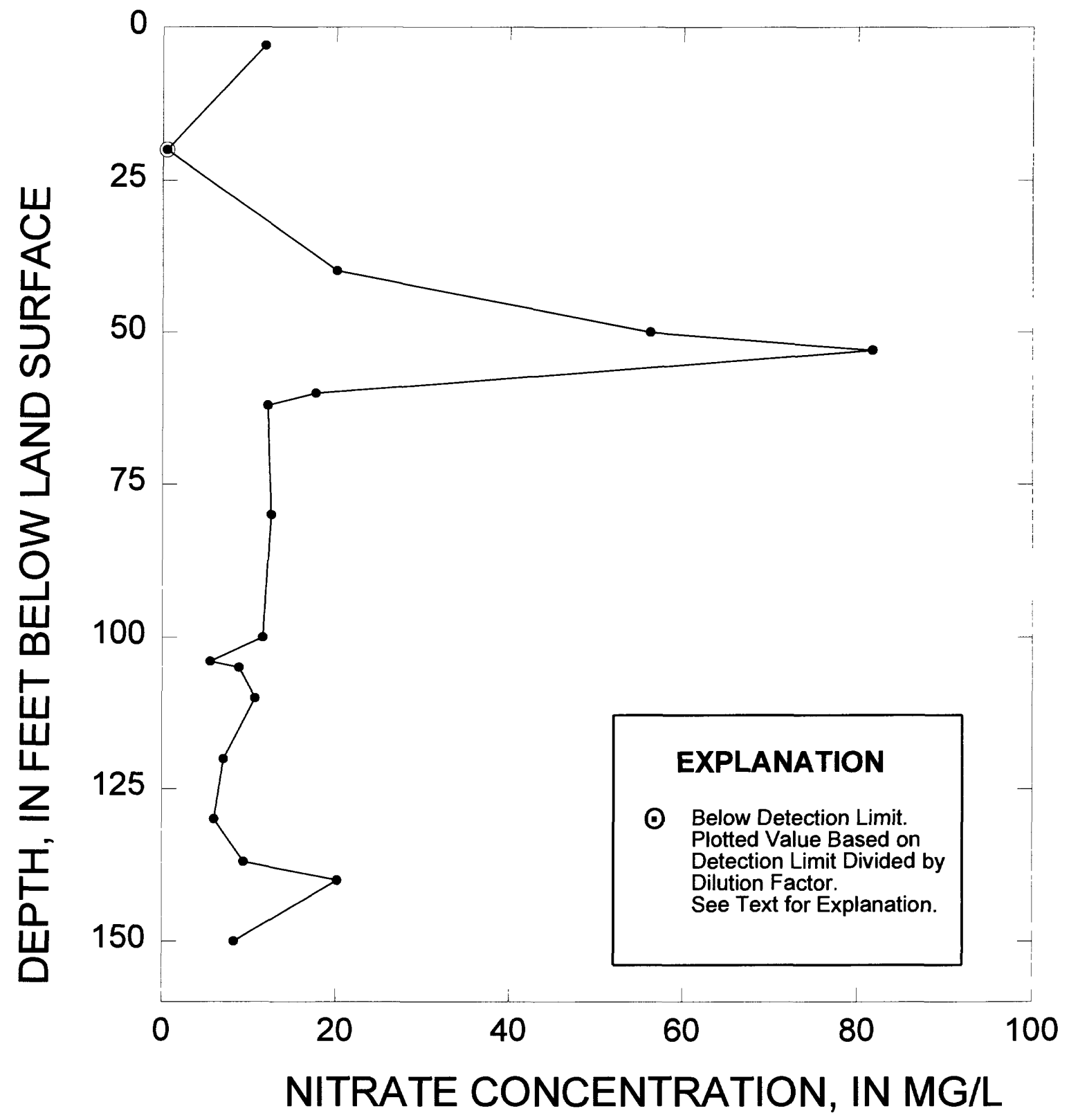

Figure 55. Nitrate-concentration profile, from core extracts, for the unsaturated zone at the irrigated-farm site. 


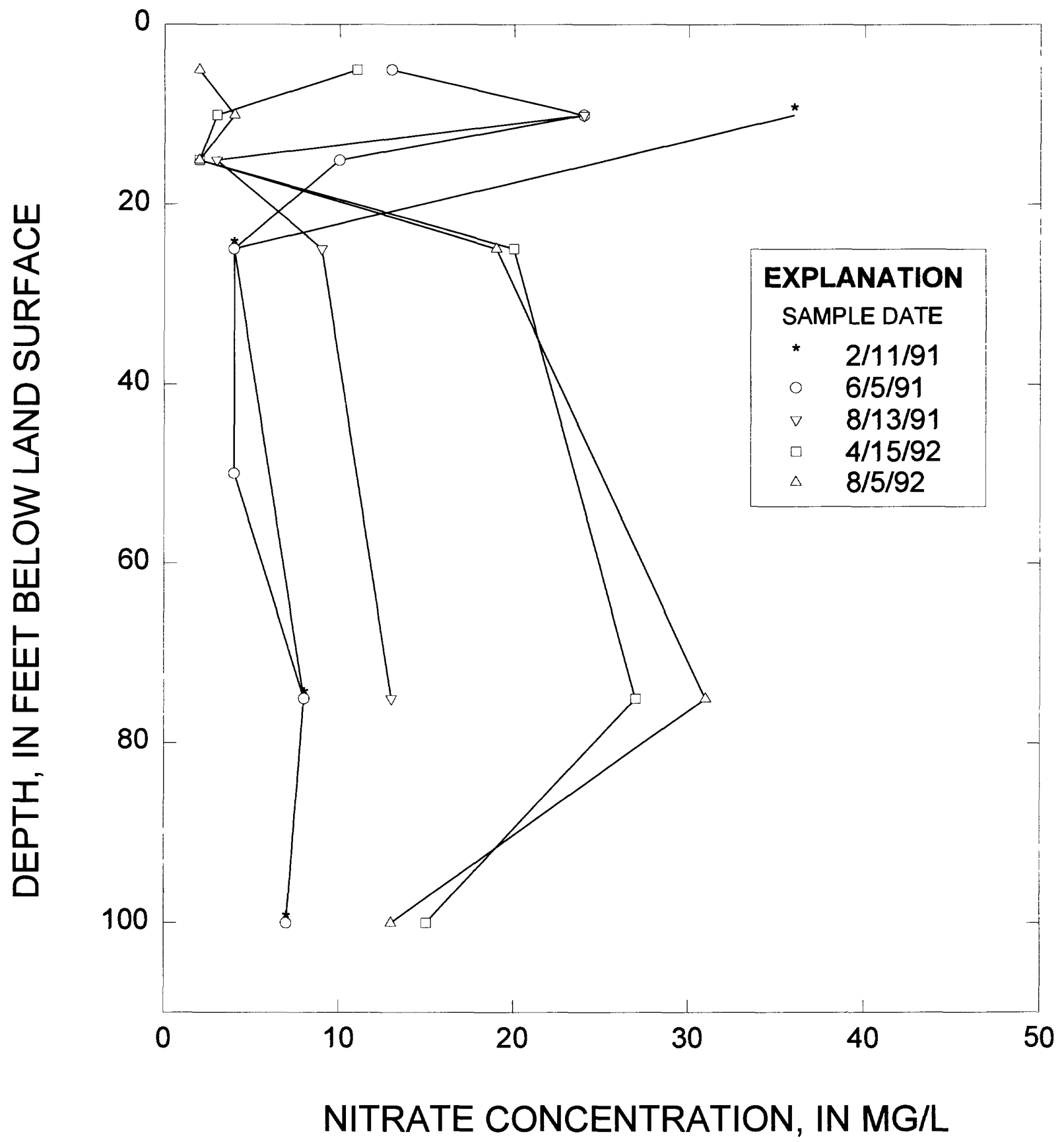

Figure 56. Nitrate concentration, for selected dates in 1991-92, in unsaturated-zone pore water at the irrigated-farm site. 
Nitrate concentrations varied in pore water collected from $5 \mathrm{ft}$. The sample collected during June 1991 had a nitrate concentration of $13 \mathrm{mg} / \mathrm{L}$. That concentration remained relatively constant through April 1992, when the concentration was $11 \mathrm{mg} / \mathrm{L}$. Both values are above the MCL. During summer 1992, the nitrate concentration decreased; the concentration was $2 \mathrm{mg} / \mathrm{L}$ in the pore water collected during August 1992. The organic-carbon concentration in the pore water was $5.5 \mathrm{mg} / \mathrm{L}$.

The trend for pore water collected from $10 \mathrm{ft}$ mimicked that observed at $5 \mathrm{ft}$. The nitrate concentration in pore water collected during February 1991 was $36 \mathrm{mg} / \mathrm{L}$. The concentration remained relatively high during June and August $1991(24 \mathrm{mg} / \mathrm{L})$. Over the winter, the nitrate concentration decreased, and in the April 1992 sampling, the nitrate concentration in the pore water was $3.1 \mathrm{mg} / \mathrm{L}$. The nitrate concentration remained low over the summer and was $4.0 \mathrm{mg} / \mathrm{L}$ during the August 1992 sampling. The organic-carbon concentration in the pore water was $2.9 \mathrm{mg} / \mathrm{L}$.

The nitrate concentration in the pore water collected from $14.9 \mathrm{ft}$ showed the same general pattern--of relatively high concentrations in the spring and summer 1991 samples, and decreased concentrations in the 1992 samples. The February 1991 concentration was $7.2 \mathrm{mg} / \mathrm{L}$, and the June 1991 concentration was 10.0. By August 1991, the nitrate concentration had decreased to $3.0 \mathrm{mg} / \mathrm{L}$, and it remained low through the April and August 1992 samples. Dissolved organic-carbon concentration was $1.5 \mathrm{mg} / \mathrm{L}$.

The pore-water samples from $25 \mathrm{ft}$ showed a trend opposite to that observed at the shallower depths. The nitrate concentration during February 1991 was $4.2 \mathrm{mg} / \mathrm{L}$, and it remained relatively constant through the June 1991 sampling (3.7 $\mathrm{mg} / \mathrm{L}$ ). By August 1991, however, the nitrate concentration had begun to increase, first to $8.9 \mathrm{mg} / \mathrm{L}$ (August 1991), then to $20 \mathrm{mg} / \mathrm{L}$ in the April 1992 sample. The nitrate concentration remained high through the August 1992 sampling (18 $\mathrm{mg} / \mathrm{L}$ ). Apparently, the high-nitrateconcentration pore water in the shallow part of the unsaturated zone in 1991 was flushed to a depth of $25 \mathrm{ft}$ during the winter, and because the downward flow of water at $25 \mathrm{ft}$ is impeded by the clay at $28 \mathrm{ft}$, the nitrate concentration remained high in this zone during summer 1992. The dissolved-organic-carbon concentration in the pore water was $1.4 \mathrm{mg} / \mathrm{L}$.

Because of poor lysimeter performance, only one sample was retrieved from $50 \mathrm{ft}$. That sample, collected during June 1991, had a nitrate concentration of $3.6 \mathrm{mg} / \mathrm{L}$.

The nitrate concentrations in the pore water collected from $75 \mathrm{ft}$ showed the same trends observed at $25 \mathrm{ft}$. The February 1991 sample had a concentration of $8.0 \mathrm{mg} / \mathrm{L}$, and the concentration remained relatively constant through the June 1991 sampling. The nitrate concentration then increased to $13 \mathrm{mg} / \mathrm{L}$ in August 1991, $27 \mathrm{mg} / \mathrm{L}$ in April 1992, and $31 \mathrm{mg} / \mathrm{L}$ in August 1992. It is unclear where this nitrate comes from because the clay at $28 \mathrm{ft}$ inhibits vertical movement of water from the shallow unsaturated zone directly above. The moisture profile (fig. 51) indicates relatively high moisture content in this zone, and some lateral movement of nitrate from nearby areas may be occurring. The dissolved-organic-carbon concentration in the pore water was $2.2 \mathrm{mg} / \mathrm{L}$.

The nitrate concentration in the pore water collected from $98 \mathrm{ft}$ showed the same trend observed in the 25- and 75-foot zones. The concentration was $7.4 \mathrm{mg} / \mathrm{L}$ in February 1991 and $7.7 \mathrm{mg} / \mathrm{L}$ in June 1991. But August 1991, the nitrate concentration had increased to $15 \mathrm{mg} / \mathrm{L}$ and remained near that level through April $1992(17 \mathrm{mg} / \mathrm{L})$ and August 1992 (13 mg/L). The dissolved-organic-carbon concentration was $1.6 \mathrm{mg} / \mathrm{L}$.

\section{Microbial processes}

Several techniques were applied to determine if microbial processes in the unsaturated zone were important in controlling nitrate concentrations. The most direct method involved quantifying the nitrifying and denitrifying bacteria present in the soil column. (Details of the enumeration procedure are given in the "Site Instrumentation and Sample Collection" section.) The results for the irrigatedfarm site are given in table 2.

Identifiable populations of nitrifying bacteria were found only at a depth of $3 \mathrm{ft}$. The results indicate 40 Nitrosomonas bacteria per gram of soil, and no Nitrobacter were present at this depth.

Significant populations of denitrifying and nitrate-reducing bacteria were found at several depths. Soil from $3 \mathrm{ft}$ hosted 150,000 bacteria per gram, and soil from $9.5 \mathrm{ft}$ had 93,000 bacteria per gram. No denitrifying bacteria were found in the zones between 28 and $104 \mathrm{ft}$. A small population, 40 bacteria per gram, was present in the clay at $105 \mathrm{ft}$, and the zone at $150 \mathrm{ft}$ had 1,500 bacteria per 
gram. The intermediate zones did not have quantifiable populations of denitrifying bacteria.

The fact that there were assimilated denitrifying bacteria at the site suggests that denitrification might be occurring. The $\delta^{15} \mathrm{~N}$ values for the samples collected at the irrigated-farm site are given in table 3 . The values are less than 10 , which suggests that the nitrate is from mineral rather than biological sources. The $\delta^{15} \mathrm{~N}$ values at 5 and $10 \mathrm{ft}(5.2$ and 5.1 permil, respectively), indicate considerable microbial cycling of nitrate at these depths. The $\delta^{15} \mathrm{~N}$ value at $15 \mathrm{ft}(7.3$ permil) indicates that this likely is the most biologically active zone; the zone at $25 \mathrm{ft}$ (4.0 permil) likely is the least biologically active.

The soil gas data for the irrigated-farm site are given in table 4 . The results confirm the conclusions that were made on the basis of the $\delta^{15} \mathrm{~N}$ values. The 25-foot zone had low concentrations of $\mathrm{CO}_{2}$ (similar to concentrations that would be expected if no microbial activity were occurring) and $\mathrm{N}_{2} \mathrm{O}$ was nondetectable. The concentrations of $\mathrm{N}_{2} \mathrm{O}$ and $\mathrm{CO}_{2}$ at the 50- and 100-foot depths, however, are elevated, suggesting that denitrification is occurring at these zones.

\section{Conclusions}

The irrigated-farm site is located on a groundwater divide, from which ground water flows to the north and to the southeast. There is an 8-foot downward gradient between the $212 \mathrm{ft}$ well and the $300 \mathrm{ft}$ well. Ground-water quality is fairly good, although boron concentrations are somewhat elevated. Water quality decreases slightly with depth.

Pore moisture in the unsaturated zone ranges from very high (above the confining clay layers) to very low (directly below the confining clay layers). Because of clay layers that effectively stop the downward movement of water, it was not possible to determine percolation rates in the unsaturatedzone. However, using the calculated unsaturated hydraulic conductivities gives estimated times of 1.3 and 55 years for water to percolate to the first perched zone and to the water table, respectively. Nitrate concentration in the unsaturated-zone pore water ranged from below the MCL to about four times the MCL. There is evidence of flushing of nitrate through the unsaturated zone and definitive proof that microbial denitrification is occurring in several zones beneath the site.

\section{Poultry-Farm Site}

\section{Site Description}

The poultry-farm site is in the northwest section of the Hemet Basin, $1 \mathrm{mi}$ north of Cottonwood Avenue, and one-quarter mi east of Warren Road (site 1 in fig. 3). The area is sewered, but several dairies are nearby. The site receives no supplemental irrigation, and it is located between three manurespreading areas. The manure-spreading areas are used to dry coop wastes prior to trucking them offsite.

Instrumentation of the site was completed in two phases. The saturated-zone multiple-depth wells were installed, using the methods described in the "Site Instrumentation and Sample Collection" section, during August 8-17, 1990. The total borehole depth was $365 \mathrm{ft}$, and wells were installed with screens at $344,310,265,210$, and $185 \mathrm{ft}$. Only the wells at 344,265 , and $210 \mathrm{ft}$, however, produced enough water to be adequately developed.

The unsaturated-zone instrumentation was installed during November 3-7, 1990. The first hole was drilled to $135 \mathrm{ft}$, and continuous core was collected using the aseptic techniques described in the "Site Instrumentation and Sample Collection" section. A sealed 2-inch-diameter galvanized pipe was set in this bore hole at $125 \mathrm{ft}$ to serve as a neutron-probe access tube. Copper gas-sampling tubes $(0.25$-in.) were attached to the galvanized pipe at depths of $125,100,75,50$, and $25 \mathrm{ft}$. The bore hole was backfilled with native material to a depth of $5 \mathrm{ft}$, and a bentonite seal was installed to land surface. The second hole was drilled to $155 \mathrm{ft}$, and lysimeters were set in this bore hole at depths of $150,100,75$, and $50 \mathrm{ft}$. The third bore hole was drilled to $27 \mathrm{ft}$ and backfilled with bentonite to 25.5 $\mathrm{ft}$. Lysimeters were set in this bore hole at depths of $25,15,10$, and $5 \mathrm{ft}$.

Illustrated in figure 57 are the geophysical logs; the completion zones for the saturated-zone wells; and the lithology interpreted from the driller's logs, the geophysical logs, and the core observations for this site. The caliper log indicates that several zones were susceptible to significant caving, notably the zones from land surface to $55 \mathrm{ft}, 160$ to $165 \mathrm{ft}$, and 185 to $192 \mathrm{ft}$. The zone from land surface to $55 \mathrm{ft}$ consists of complex interlayered beds of silt, clay, and fine sand. The zones from 160 to $165 \mathrm{ft}$ and from 185 to $192 \mathrm{ft}$ consist of coarse sand and gravel. The gamma radioactivity $\log$ indicates the numerous clay layers underlying this site. The layer at $212 \mathrm{ft}$ seems to be a confining unit that separates 


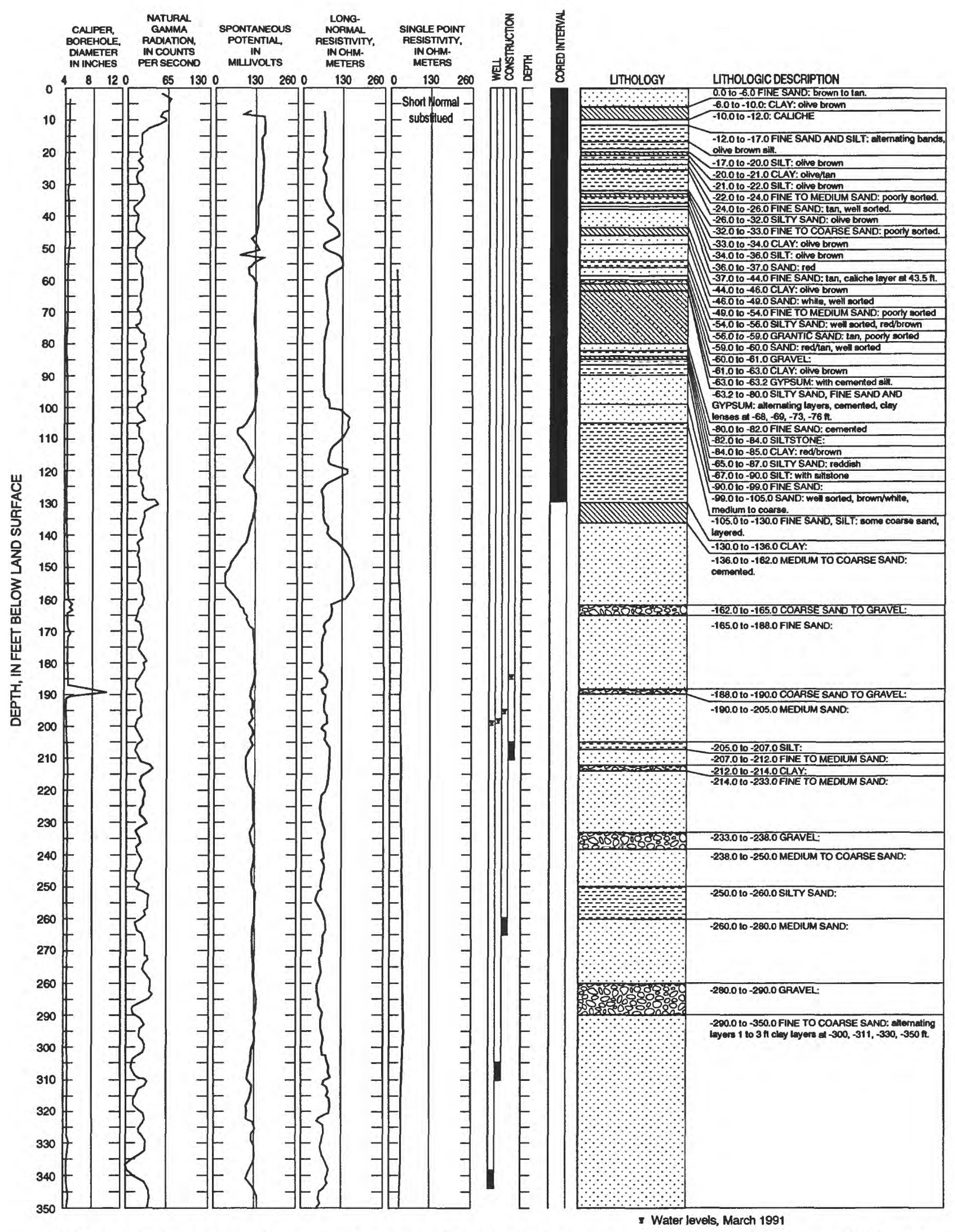

FIGURE 57. Geophysical logs, and diagram showing well construction, cored interval, and lithology for the poultry-farm site. 
the aquifer above from the aquifer below. The numerous clay layers below $290 \mathrm{ft}$ also are clearly reflected in the gamma log. The spontaneouspotential and single-point-resistivity logs seem to be sensitive to redox changes, thus indicating the interfaces between zones of oxidizing and reducing conditions.

Samples were collected from the cores at selected depths to determine the particle-size distributions in the different formations. These distributions are shown in figure 58 . The $3 \mathrm{ft}$ sample consists mostly of fine to medium sand, and a significant percentage of silt and clay. The $13 \mathrm{ft}$ and $20 \mathrm{ft}$ samples consist mostly of silt and clay, and contain only a small percentage of sand-sized material. More than 30 percent of the sample from $20 \mathrm{ft}$ consists of clay. The sample from $30 \mathrm{ft}$ consists of fine to medium sand and (about 22 percent) silt-sized particles. The $33 \mathrm{ft}$ sample, classified in the driller's and geologist's logs as a clay layer, actually consists of medium to fine sand, silt, and clay. The $40 \mathrm{ft}$ and $61 \mathrm{ft}$ samples consist mostly of fine sand and contain less than 10 percent silt and clay; the $50 \mathrm{ft}$ sample contains a greater percentage of silt and clay. The $70 \mathrm{ft}$ sample consists mostly of medium to fine sand, along with about 17 percent clay-sized materials. The $101 \mathrm{ft}$ sample consists mostly of coarser grained materials and contains very little silt or clay.

\section{Saturated-Zone Results}

The water-table surface near the poultry-farm site was determined by measuring water levels at the multiple-well site (4S/1W-19M) and at wells 4S/1W-31D2, 4S/1W-31G2, 4S/2W-13H1, and 4S/2W-24A1. These results (given in Supplemental Data 1 and $3 E$ ), along with the water-table surface described in the "Geohydrologic Setting" section, indicate that the horizontal component of groundwater flow in this area is to the north. Comparison of the potentiometric levels in the four wells at the site indicates that there are two distinct zones in the underlying aquifer, probably separated by the clay at $212 \mathrm{ft}$. During the study (1991-92), the potentiometric level of the upper zone, which is tapped by the $210 \mathrm{ft}$ well, ranged from 1,293 to $1,296 \mathrm{ft}$ above sea level. During the course of this study, a net decline of $0.5 \mathrm{ft}$ was recorded in the potentiometric level in this upper zone. For the lower zone, the potentiometric level ranged from 1,274 to $1,288 \mathrm{ft}$ above sea level during the study, and the piezometric surface showed a net decline of 14.3 to $19.6 \mathrm{ft}$. The downward gradient between the two zones increased from $5.9 \mathrm{ft}$ in spring 1991 to
19.7 ft in August 1992. There also seems to be a downward gradient within the lower zone of about 1.2 to $2.3 \mathrm{ft}$.

Water-quality samples were collected from the four wells on the following dates: January 30, May 15, August 15, 1991, and January 29 and August 12, 1992. Analytical results are given in Supplemental Data 3E. There was virtually no temporal variation in water quality at each of the sampled depths, which indicates that the samples collected are representative of water in the formation at the depths specified.

\section{Water quality in the upper zone (210 feet)}

The sample collected during May 1991 apparently contained residual drilling fluids, as indicated by the elevated dissolved-solids concentration and the high $\mathrm{pH}$. The well was redeveloped, and the subsequent samples were used in the following discussion. The ground water from this depth had a dissolved-solids concentration of about $410 \mathrm{mg} / \mathrm{L}$ and a $\mathrm{pH}$ of about 8.3. The predominant ions were sodium and sulfate; also present were calcium ions (percentage was about one-half that of sodium) and chloride ions (percentage was about one-third that of sulfate). The nitrate concentration, $1.4 \mathrm{mg} / \mathrm{L}$, was low. Concentrations of boron, $140 \mu \mathrm{g} / \mathrm{L}$, and selenium (about $2 \mu \mathrm{g} / \mathrm{L}$ ) were moderate.

Stable-isotope values for ground water from the $210 \mathrm{ft}$ well were $8 \mathrm{D}=-59.0$ permil and $8^{18} \mathrm{O}=$ 8.75 permil. On the basis of the Dansgaard (1964) relation illustrated in figure 28 , this $8^{18} \mathrm{O}$ value suggests that the ground water in this zone originated as rain that fell at the relatively warm temperature of $7^{\circ} \mathrm{C}$ rather than as snow at high altitudes. Plots of the $8 \mathrm{D}$ and $8^{18} \mathrm{O}$ values on the Craig diagram (fig. 29) show that the water falls on the meteoric-water line, suggesting that the water percolated to the water table without undergoing significant evaporation.

Even though the nitrate concentrations were low, an effort was made to determine the likely source of nitrate in the ground water. The $8^{15} \mathrm{~N}$ value for the $210 \mathrm{ft}$ water sample was 13.1 permil. This value suggests that animal wastes are the source for the nitrate observed. 


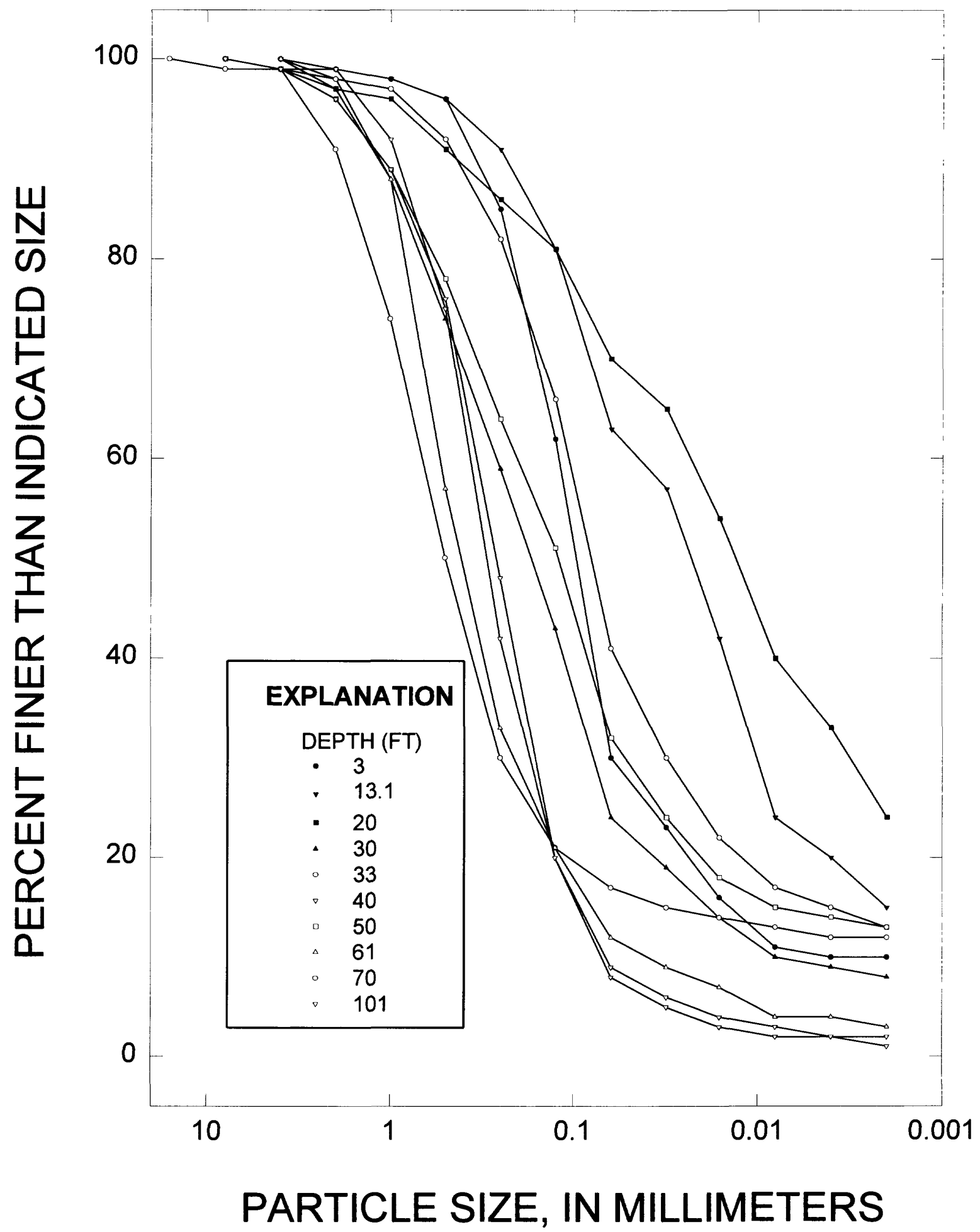

Figure 58. Particle-size distribution at selected depths for cores from the poultry farm site. 


\section{Water quality in the lower zone}

$(265,310$, and 344 feet)

The ground-water quality in the lower zone is similar to that in the upper zone. The dissolvedsolids concentrations were comparable to those in the upper zone and increased with depth: from 410 $\mathrm{mg} / \mathrm{L}$ at $265 \mathrm{ft}$ to $491 \mathrm{mg} / \mathrm{L}$ at $310 \mathrm{ft}$; and $526 \mathrm{mg} / \mathrm{L}$ at $344 \mathrm{ft}$. The predominant ions in the lower zone were sodium and sulfate; also present were calcium ions (percentage was about one-fourth that of sodium) and chloride ions (percentage was about one-third that of sulfate). Nitrate concentrations were low at all depths, ranging from 1.1 to 1.6 $\mathrm{mg} / \mathrm{L}$. The $\mathrm{pH}$ was about 8.5 . Nitrate concentrations were low at all depths, ranging from 1.1 to 1.6 $\mathrm{mg} / \mathrm{L}$. The main chemical difference between the upper zone and the lower zone is the difference in boron concentration. The boron concentration in the lower zone was about $480 \mu \mathrm{g} / \mathrm{L}$, nearly four times as high as that in the upper zone.

The $\delta \mathrm{D}$ values ranged from -57.5 to -59.0 permil, and the $\delta^{18} \mathrm{O}$ values ranged from -8.40 to 8.65 permil. These values translate to average precipitation temperatures of about $7^{\circ} \mathrm{C}$ and imply that virtually no evaporation occurred prior to percolation to the water table.

The $\delta^{15} \mathrm{~N}$ values ranged from 12.6 to 14.4 permil, and indicate, as in the upper zone, that nitrate in the ground water of the lower zone probably comes from animal wastes rather than mineral fertilizers

\section{Unsaturated-Zone Results}

\section{Pore-moisture profiles}

Pore-moisture saturation-index profiles were measured as described in the "Site Instrumentation and Sample Collection" section. The profiles, which are shown in figure 59, were measured during June and November 1991 and July and September 1992. Vertical resolution is approximately $1 \mathrm{ft}$ and horizontal resolution is about 0.02 unit. The moisture-saturation indices ranged from 0.12 to 0.7 unit. The indices measured at the poultry-farm site generally are the lowest of the study. Only the zone from 45 to $60 \mathrm{ft}$, which consists of sand and gravel sandwiched between clay layers, shows any temporal variation. It is probable that this zone receives recharge from another location, rather than through vertical percolation at the site. The poremoisture profiles give no indication of piston flow in the system, at least not on the time scale of these measurements.

Sand and gravel zones, with the exception of the zones between 45 to $60 \mathrm{ft}$, had the lowest moisture contents in the profile, and clay layers had the highest moisture contents. In fact, the moisture profile is an excellent tool for locating the numerous clay layers underlying the poultry-farm site.

Unsaturated hydraulic conductivities for the various alluvial materials beneath the poultry-farm site ranged from $5.58 \times 10^{-10} \mathrm{ft} / \mathrm{s}$ in the clay at $20 \mathrm{ft}$ to $1.28 \times 10^{-6} \mathrm{ft} / \mathrm{s}$ in the coarse sand at $32 \mathrm{ft}$. Using the appropriate unsaturated hydraulic conductivities with the corresponding moisture saturation indices, and integrating over the entire unsaturated zone, one obtains an estimated transit time of about 27 years for water to percolate from the land surface to the water table.

\section{Nitrogen profiles}

Core results.--Samples of core material were collected and processed using the procedures described in the "Site Instrumentation and Sample Collection" section. The results for organic-nitrogen, ammonia, nitrite, and nitrate concentrations are shown in figures 60-63.

Significant concentrations of organic nitrogen were present in pore- water samples collected from nearly all depths except 13.1 and $80 \mathrm{ft}$ (fig. 60). The surface concentration approached $400 \mathrm{mg} / \mathrm{L}$, but the concentration rapidly decreased to less than $20 \mathrm{mg} / \mathrm{L}$ within the top $10 \mathrm{ft}$. From 20 to $100 \mathrm{ft}$, the organic-nitrogen concentration ranged from nondetectable to about $20 \mathrm{mg} / \mathrm{L}$. The highest concentrations were associated with layers of fine sand, and the lowest with layers of reducing clay.

Ammonia concentrations were much lower than the organic-nitrogen concentrations (fig. 61). The highest ammonia concentration, which was near land surface, was a little less than $5 \mathrm{mg} / \mathrm{L}$. The concentration rapidly decreased to less than $2 \mathrm{mg} / \mathrm{L}$ at most depths. In a manner similar to that for organic nitrogen, the highest concentrations for ammonia (about 2 to $3 \mathrm{mg} / \mathrm{L}$ ) were associated with fine sand, and the lowest concentrations (less than 1 $\mathrm{mg} / \mathrm{L}$ ) with reducing clay.

The poultry-farm site is one of the few locations where appreciable nitrite concentrations were found in pore water. The profile, shown in figure 62 , indicates that the nitrite concentration increased at 


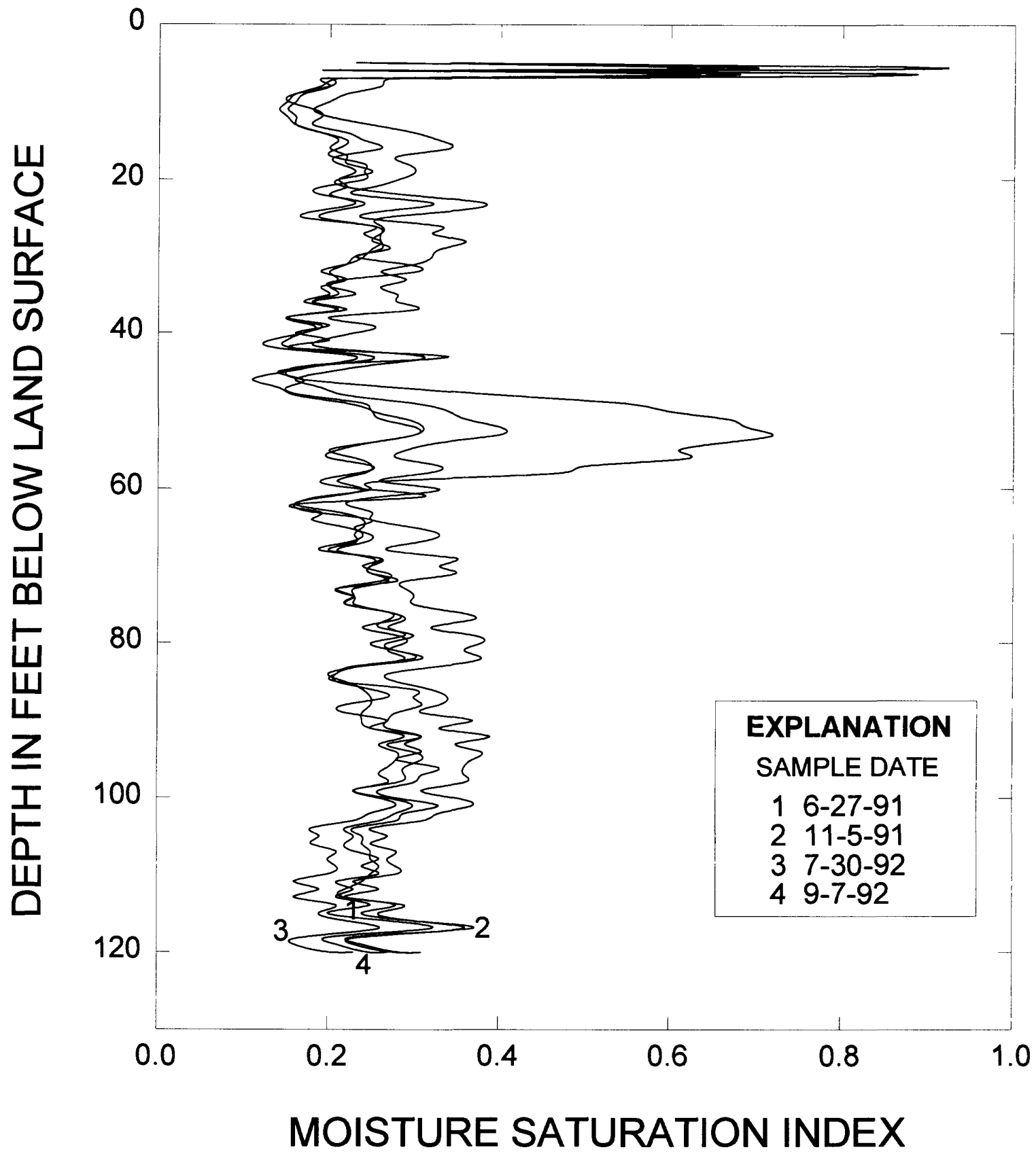

Figure 59. Unsaturated-zone pore-moisture profiles for selected dates in 1991-92 for the poultry farm site. 


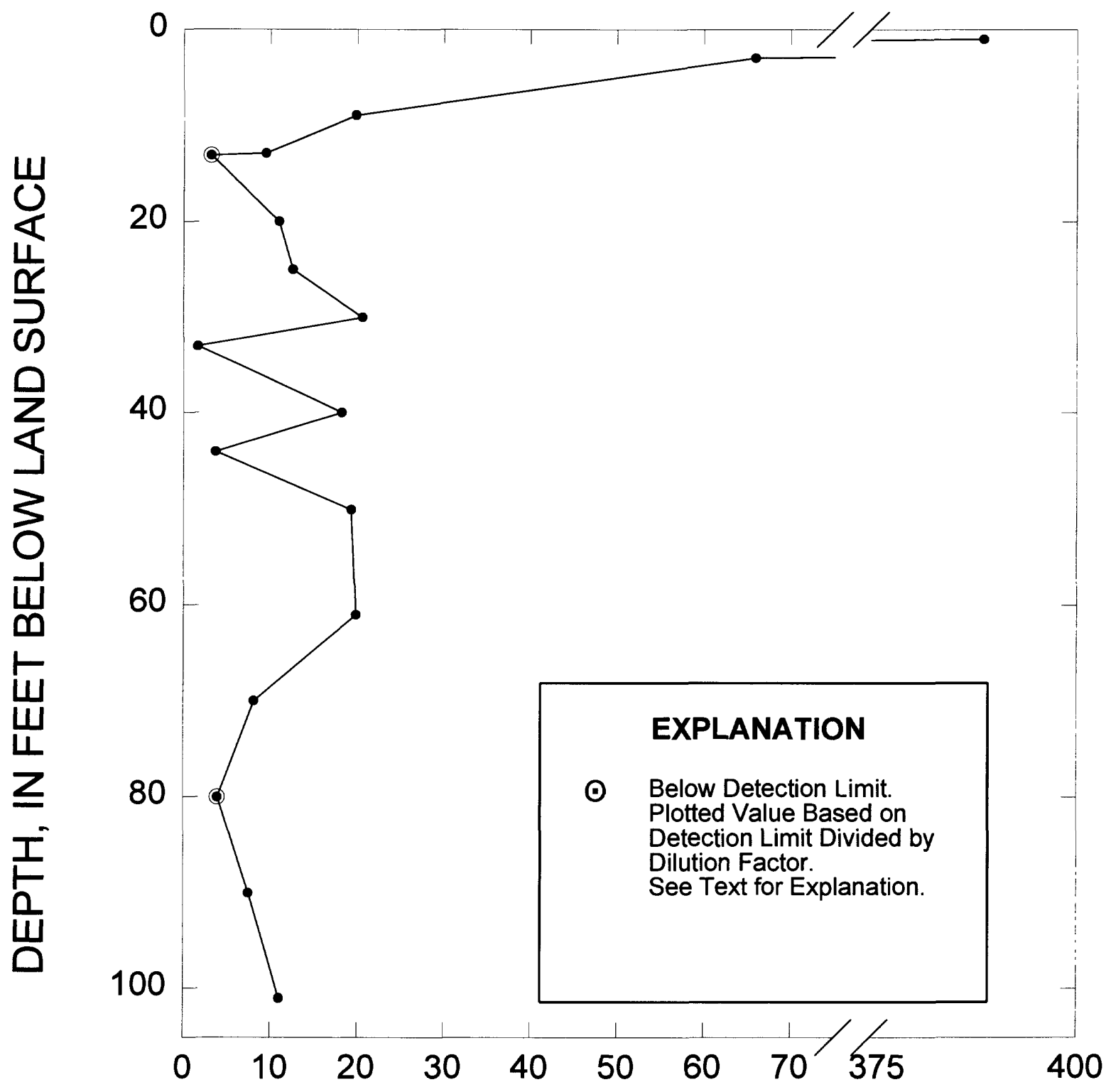

\section{ORGANIC NITROGEN CONCENTRATION, IN MG/L}

Figure 60. Organic-nitrogen-concentration profile, from core extracts, for the unsaturated zone at the poultry farm site. 


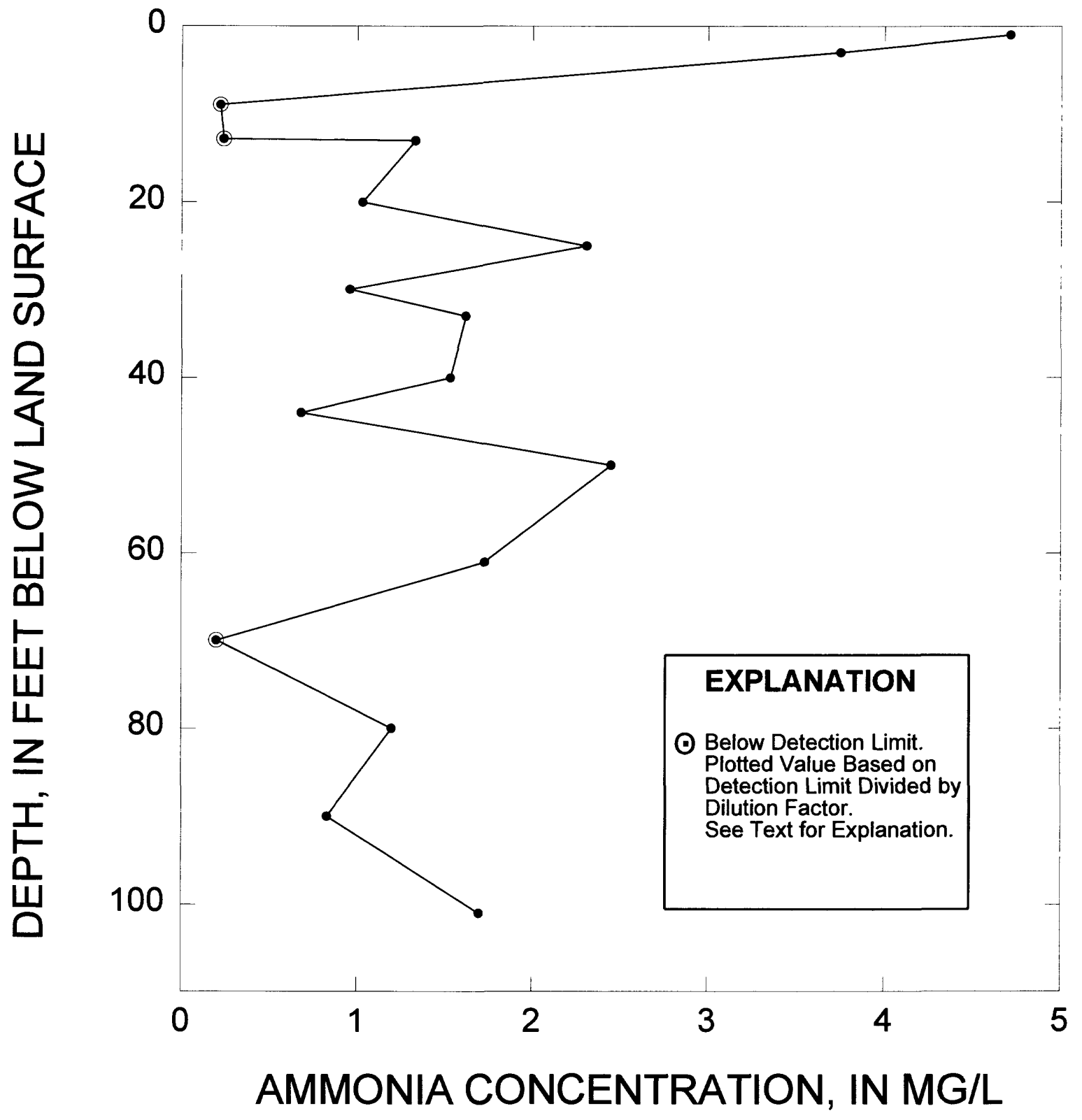

Figure 61. Ammonia-concentration profile, from core extracts, for the unsaturated zone at the poultry farm site. 


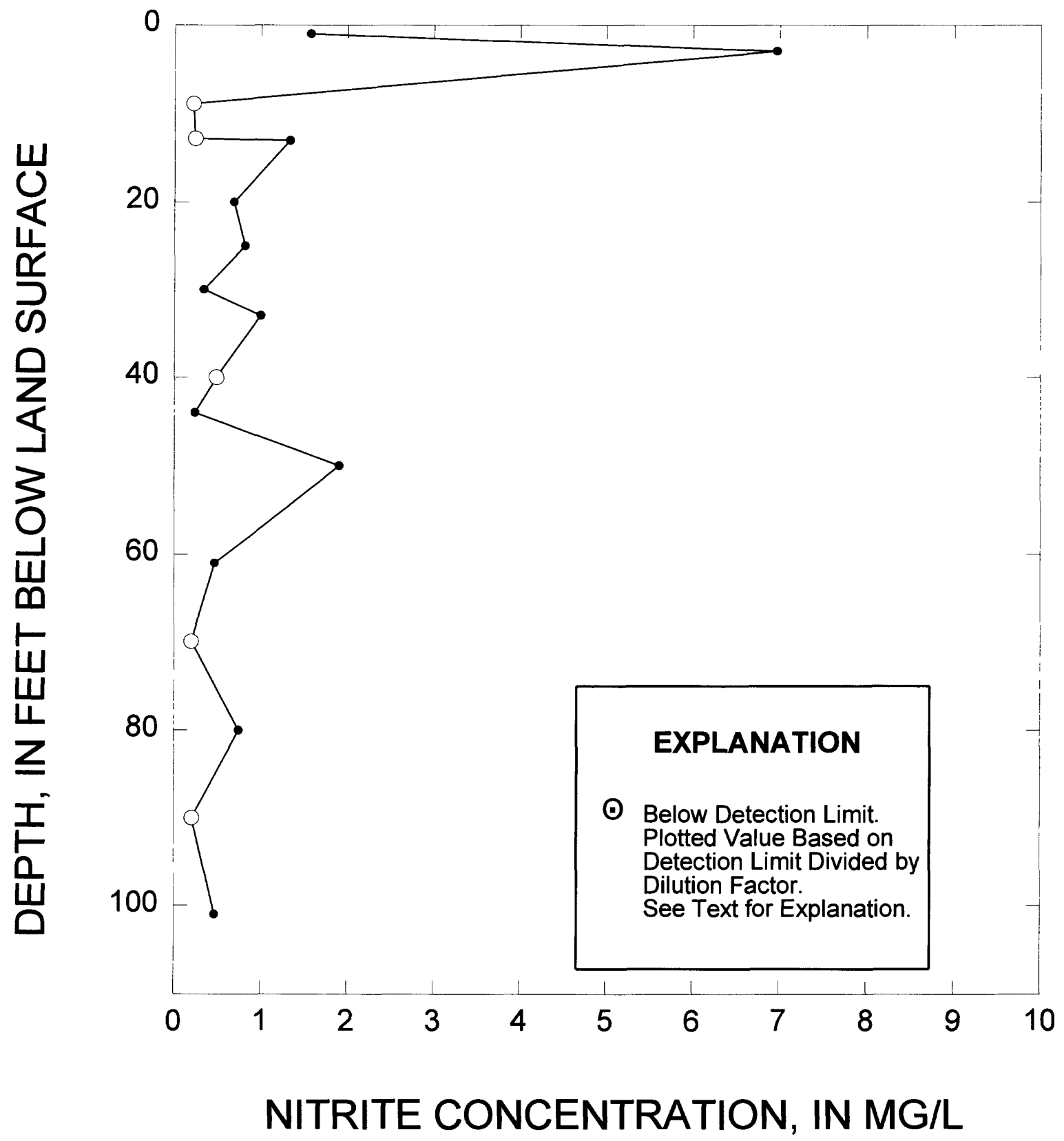

Figure 62. Nitrite-concentration profile, from core extracts, for the unsaturated zone at the poultry farm site. 


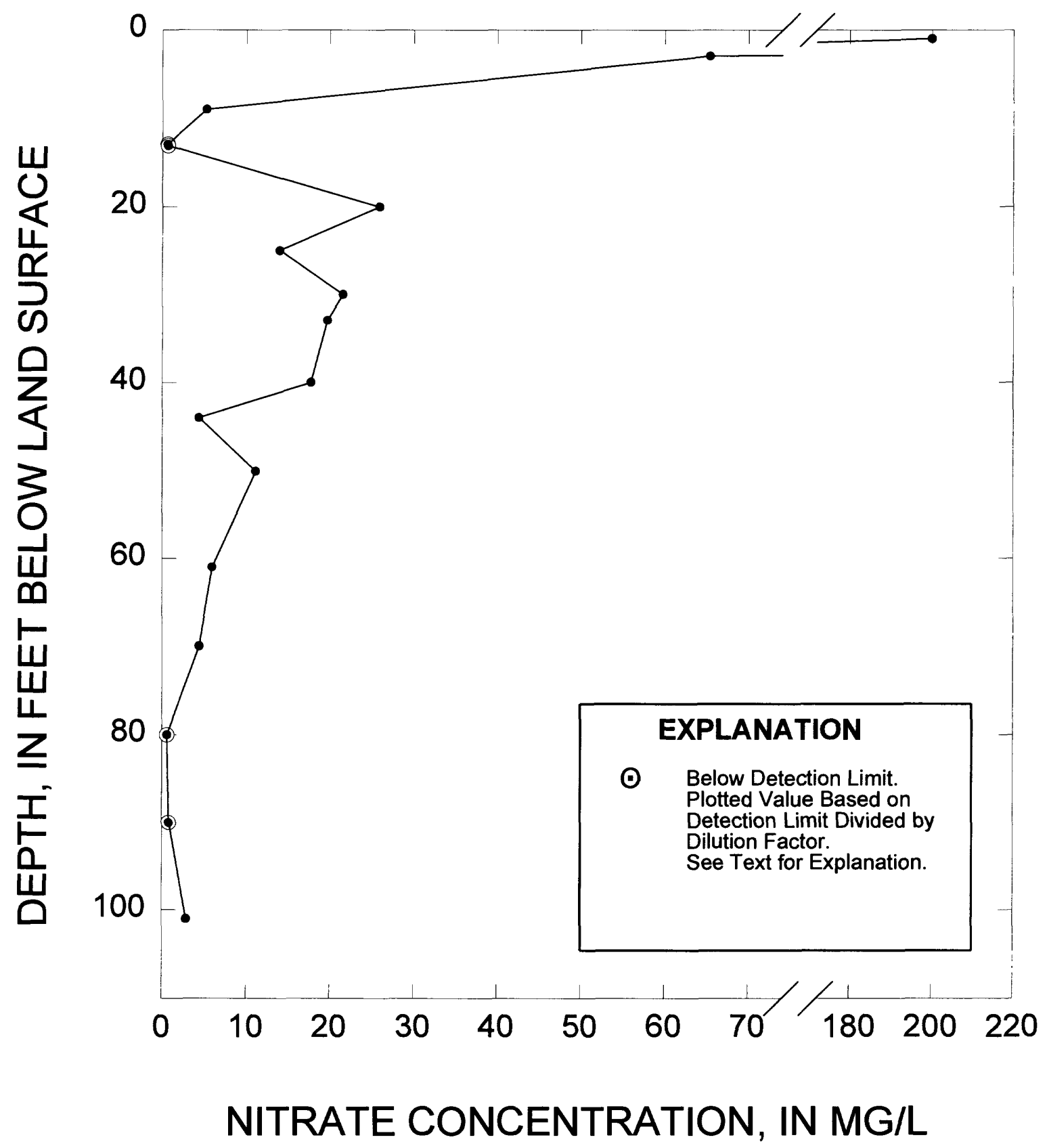

Figure 63. Nitrate-concentration profile, from core extracts, for the unsaturated zone at the poultry farm site. 
a depth of $3 \mathrm{ft}$ to a concentration of about $7 \mathrm{mg} / \mathrm{L}$. The concentration then decreased to below the detection limit. The presence of nitrite in unsaturated-zone pore water is a good indication that microbial denitrification is occurring at that depth.

The nitrate-concentration profiles (fig. 63) resemble the profiles for organic nitrogen. At a depth of $1 \mathrm{ft}$, the nitrate concentration was about $200 \mathrm{mg} / \mathrm{L}$. The concentration rapidly decreased to less than $10 \mathrm{mg} / \mathrm{L}$ at $10 \mathrm{ft}$. At $25 \mathrm{ft}$, the pore water had a nitrate concentration of about $25 \mathrm{mg} / \mathrm{L}$. Below $25 \mathrm{ft}$, there is a trend toward decreasing nitrate concentration until, at $80 \mathrm{ft}$, the nitrate was no longer detectable.

Lysimeter results.--Samples of unsaturatedzone pore water were collected using the ceramic-cup suction lysimeters during January, June, and October 1991 and May and July 1992. Results are given in Supplemental Data 2E. Because of the very dry conditions in the unsaturated zone underlying the poultry-farm site, the lysimeters were not very efficient at collecting pore-water samples. As a result, the lysimeter data for this site are sparser than for the other sites.

Nitrate concentrations in pore water collected from $50 \mathrm{ft}$ ranged from $3.9 \mathrm{mg} / \mathrm{L}$ during May 1992 to $8.7 \mathrm{mg} / \mathrm{L}$ during June 1991 . The lysimeter at $75 \mathrm{ft}$ produced only one usable pore-water sample, during January 1991. The nitrate concentration was $16 \mathrm{mg} / \mathrm{L}$. Some temporal variation was observed in nitrate concentration in the pore water collected from $150 \mathrm{ft}$. The samples collected during January and June 1991 had a nitrate concentration of $12 \mathrm{mg} / \mathrm{L}$. By May 1992, the nitrate concentration had decreased to $3.9 \mathrm{mg} / \mathrm{L}$, and it continued to decrease to $1.3 \mathrm{mg} / \mathrm{L}$ in August 1992.

\section{Microbial processes}

Several techniques were applied, as described earlier, to determine if microbial processes in the unsaturated zone are important in controlling nitrate concentrations.

Nitrifying bacteria were detected at the poultryfarm site at several depths. (The bacterialenumeration results are given in table 2.) Nitrosomonas concentrations were 30 bacteria per gram at $1 \mathrm{ft}$, and 280 bacteria per gram at $3 \mathrm{ft}$. Nitrosomonas were not found at other depths. Nitrobacter also were present in the $1 \mathrm{ft}$ and $3 \mathrm{ft}$ samples, at 70 and 80 bacteria per gram, respectively. Denitrifying bacteria were present in all samples at depths less than $100 \mathrm{ft}$. Concentrations were 23,000 bacteria per gram at 1 $\mathrm{ft}$, and 9,300 at $3 \mathrm{ft}$. The largest population, 43,000 bacteria per gram, was found at $12.9 \mathrm{ft}$. The number of bacteria decreased with increasing depth, and concentrations were 90 bacteria per gram in the samples from 33 and $50 \mathrm{ft}$.

The presence of assimilated denitrifying bacteria at the site, and an observed decrease in nitrate concentration with depth, suggests that microbial denitrification might be occurring at the poultry-farm site. The $8^{15} \mathrm{~N}$ value of 18.2 permil (table 3) for the samples collected from the 50-foot depth indicates that the source of nitrogen in the unsaturated zone under the poultry-farm site is animal wastes; also, because the value is significantly higher than 10 permil, it is likely that the nitrate has undergone microbial cycling.

Soil gas profiles also can be used as an aid in evaluating microbial processes. Samples of soil gas were collected from depths of 50 and $75 \mathrm{ft}$. The 50 ft sample had no detectable $\mathrm{N}_{2} \mathrm{O}$, and $\mathrm{CO}_{2}$ concentrations were about what would be expected if there were no microbial activity. Similarly, the 75 ft sample also had no detectable $\mathrm{N}_{2} \mathrm{O}$. The $\mathrm{CO}_{2}$ concentration was slightly elevated. On the basis of the gas analyses, we cannot conclude that denitrification was occurring at these depths. Thus, the nitrogen-isotope results and the soil gas analysis seem to support contradictory conclusions.

\section{Conclusions}

The poultry-farm site is located above an aquifer that has two distinct layers or zones. Water in the upper zone is of good quality and contains low concentrations of nitrate and boron. Water in the lower zone also is of good quality and contains low nitrate concentrations, but the boron concentrations are somewhat elevated. Because of numerous clay layers under the site, it is unlikely that significant areal recharge occurs. There is a pronounced downward potentiometric gradient between the upper and lower zones.

The quality of unsaturated-zone pore water could not be adequately addressed because of the dry conditions in the unsaturated zone beneath the site. However, core extracts indicate the presence of significant nitrate concentrations in the pore water, and there is some (uncorroborated) evidence that microbial denitrification is occurring in the unsaturated zone. The section of the unsaturated 
zone between 45 and $60 \mathrm{ft}$ below land surface apparently is being recharged from offsite, and unsaturated-zone pore moisture contents in this zone increased dramatically during the course of this study.

\section{Dairy Sites}

\section{Site Descriptions}

Two dairy sites were used in this study, one in the Diamond Valley area of the Hemet Basin $(0.75$ mi west of State Street and 0.25 mi north of Ferraro Road; site 5 in fig. 3) and the other in the San Bernardino County Dairy Preserve near Ontario, California, in the Chino Basin (near the intersection of Eucalyptus Avenue and Cleveland Avenue; fig. 2). Both sites are unsewered. The Hemet dairy site is located in a feedlot devoid of plant-cover crops, and municipally supplied water is used for watering the cattle and for other dairy operations. The Chino dairy site is located in a pasture area adjacent to the feedlots, and dairy wastewater is used for irrigation.

Instrumentation of the Hemet dairy site was completed in two phases. The saturated-zone well was installed during July 31-August 1, 1990, using the methods described in the "Site Instrumentation and Sample Collection" section. Total bore-hole depth was $52 \mathrm{ft}$. Drill cuttings were collected and described, and driller's and geologist's logs were prepared onsite. Single-point resistivity, spontaneous potential, gamma radioactivity, and caliper geophysical logs were done immediately after pulling the drill stem from the hole. The driller's log and the geophysical logs indicate that granitic bedrock was reached at a depth of $42 \mathrm{ft}$. A 2-inch-diameter well casing was prepared with a 5 foot screen at the bottom and $a$ well was installed at $39 \mathrm{ft}$.

The unsaturated-zone instrumentation was installed September 18, 1990. The first hole was drilled to $26 \mathrm{ft}$, and continuous core was collected using the aseptic techniques described in the "Site Instrumentation and Sample Collection" section. A sealed 2-inch-diameter galvanized pipe was set in this bore hole at $25 \mathrm{ft}$ to serve as a neutron access tube. Copper-gas sampling tubes $(0.25$-in.) were attached to the galvanized pipe at depths of 15,12 , 10 , and $5 \mathrm{ft}$. The bore hole was backfilled with native material to a depth of $1 \mathrm{ft}$, and a bentonite seal was installed to land surface. The second bore hole was drilled to $17 \mathrm{ft}$, and lysimeters were set at depths of $13.5,10$, and $5 \mathrm{ft}$.
The geophysical logs; the completion zone for the saturated-zone well; and the lithology interpreted from the drill cuttings, the geophysical logs, and the core observations are illustrated in figure 64 . The caliper log indicates that the entire lithologic column above bedrock is subject to caving. The gamma radioactivity log is relatively flat, the small peaks corresponding to zones of poorly sorted sand. Underlying the Hemet dairy site are clay and manure near the surface, a well defined "B" soil horizon of leach deposits at $4 \mathrm{ft}$, a clay layer from 4 to $9 \mathrm{ft}$, and then alternating layers of silt and sand. A thick zone of gravel, from 26 to $42 \mathrm{ft}$, is present just above the bedrock.

Samples were collected from the cores at selected depths to determine the particle-size distributions in the numerous formations. These distributions are shown in figure 65. More than 50 percent of the particles in the sample from $1 \mathrm{ft}$ are silt sized or smaller, and 21 percent are clay sized or smaller. The sample from $3 \mathrm{ft}$ has slightly more large particles, about 31 percent being silt sized or smaller. Only 9 percent of the particles in this sample were clay sized. The 9-foot sample has 40 percent silt-sized or smaller particles, 20 percent of the particles being in the clay-size fraction. The sample from $15 \mathrm{ft}$ has much coarser material, less than 4 percent of the particles being smaller than silt sized. More than 50 percent of the mass is from particles greater than $0.5 \mathrm{~mm}$. The sample from $15.2 \mathrm{ft}$ has more than 25 percent silt-sized or smaller material, the clay content being about 13 percent. The $18 \mathrm{ft}$ sample reverts to larger particles, about 47 percent of the mass being from particles larger than $0.5 \mathrm{~mm}$, and about 12 percent from siltsized or smaller particles. In the sample from $25.5 \mathrm{ft}, 42$ percent of the mass is from particles smaller than silt size, and 19 percent of the mass is from clay-sized particles.

Instrumentation at the Chino dairy site also was completed in two phases. The saturated-zone multiple-depth wells were installed during December 1-4, 1990. The total bore-hole depth was $455 \mathrm{ft}$, and wells were installed with screens at 450 , $370,320,255,215$, and $187 \mathrm{ft}$. Only the wells at 450,370 , and $320 \mathrm{ft}$ produced sufficient water to develop properly, and only those wells were used in this study.

The unsaturated-zone instrumentation was installed during November 13-15, 1990. The first hole was drilled to $92 \mathrm{ft}$, and continuous core was collected to a depth of $85 \mathrm{ft}$ using the aseptic techniques described in the "Site Instrumentation 

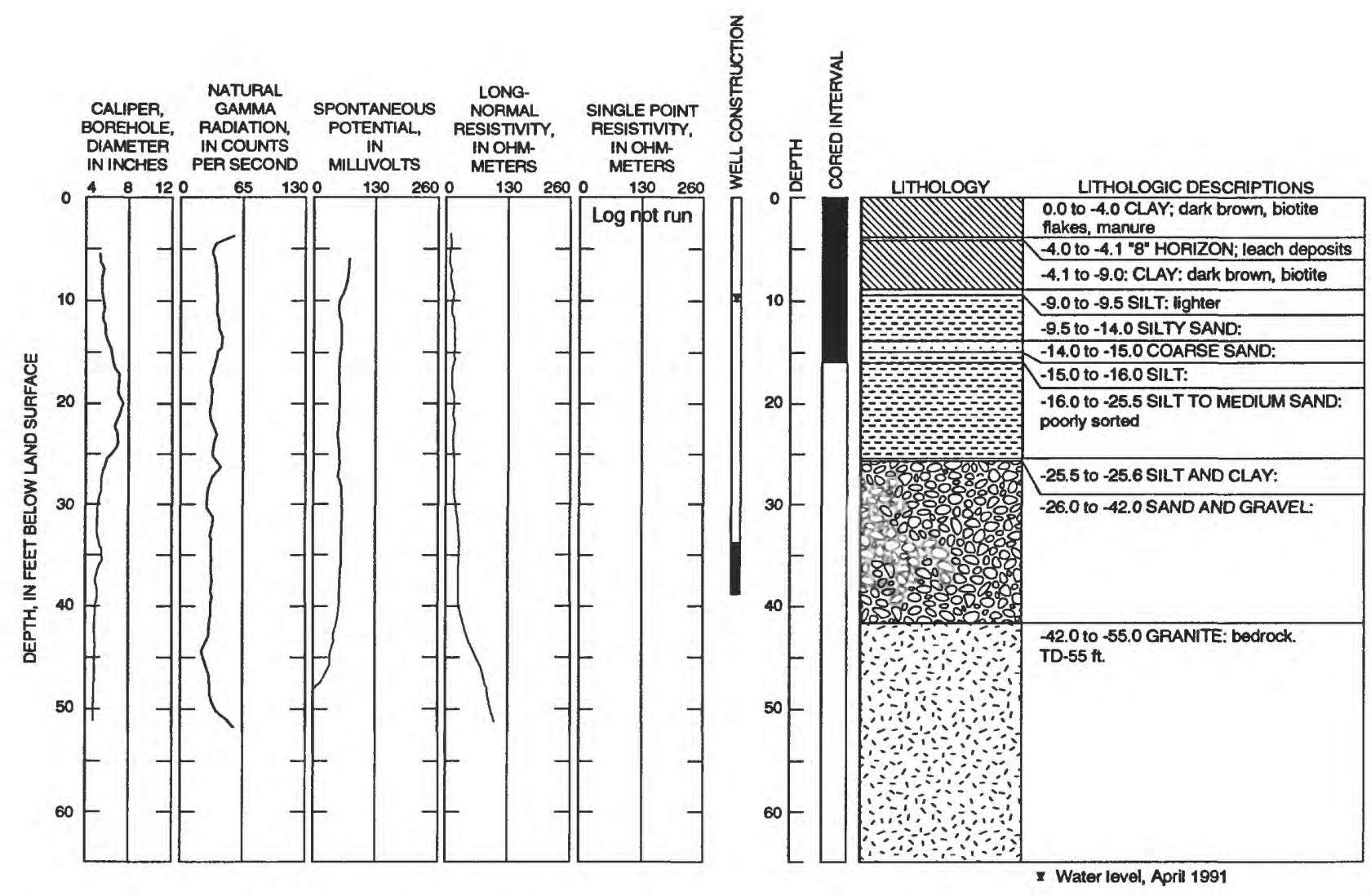

FIGURE 64. Geophysical logs, and diagram showing well construction, cored interval, and lithology for the Hemet dairy site. 


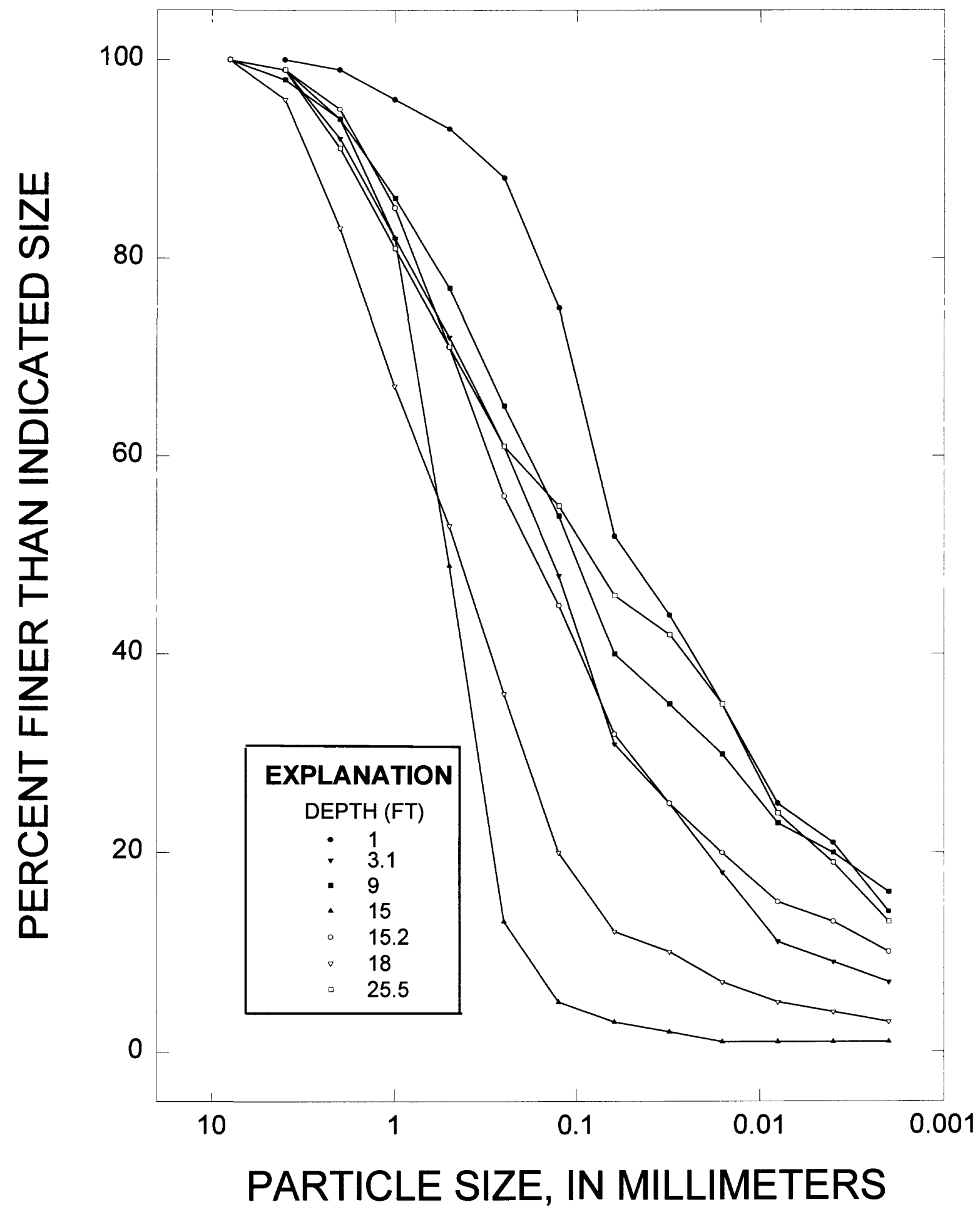

Figure 65. Particle-size distribution at selected depths for cores from the Hemet dairy site. 
and Sample Collection" section. A sealed 2-inchdiameter galvanized pipe was set in this bore hole at $90 \mathrm{ft}$ to serve as a neutron-probe access tube. Copper gas-sampling tubes $(0.25$ in.) were attached to the galvanized pipe at depths of $90,75,50,25$, and $10 \mathrm{ft}$. The bore hole was backfilled with native material to a depth of $6 \mathrm{ft}$, and a bentonite seal was installed to land surface. The second hole was drilled to $102 \mathrm{ft}$. Ceramic-cup suction lysimeters were installed, using the procedures described for the Hemet dairy site, at depths of 100,75 , and $50 \mathrm{ft}$. The third bore hole was drilled to $26.7 \mathrm{ft}$. The bore hole was backfilled with native material to $25.6 \mathrm{ft}$, and lysimeters were installed at depths of 25,15 , 10 , and $5 \mathrm{ft}$.

The geophysical logs; the completion zones for the saturated-zone wells; and the lithology interpreted from the driller's logs, the geophysical logs, and the core observations are illustrated in figure 66 . The caliper $\log$ indicates that numerous zones are subject to caving, notably from 28 to $90 \mathrm{ft}, 110$ to $150 \mathrm{ft}$, and 280 to $420 \mathrm{ft}$. The zone from 28 to $90 \mathrm{ft}$ consists of clay, silty sand, and sand, all beneath a 2 -foot-thick clay layer. The zone from 110 to $150 \mathrm{ft}$ consists of a thick clay layer, fine sand, and gravel. The zone from 280 to $420 \mathrm{ft}$ consists of cobbles, coarse gravel, fine sand, and clay. The gamma radioactivity log is very complex and indicates numerous thin to thick clay layers interspersed with layers of coarser material. The resistivity and potential logs are featureless, except for indications of zones of increased permeability from 185 to $215 \mathrm{ft}, 245$ to $325 \mathrm{ft}$, and 345 to $375 \mathrm{ft}$.

Samples were collected from the cores at selected depths to determine the particle-size distributions in the numerous formations. These distributions are shown in figure 67. The $1 \mathrm{ft}$ sample has a broad distribution. About 75 percent of the mass is from sand-sized particles, and 10 percent is from clay-sized particles. The $10 \mathrm{ft}$ sample has an even broader distribution: about 45 percent sand and gravel, 30 percent silt, and 25 percent clay. The 20 $\mathrm{ft}$ sample has a narrower distribution: about 60 percent sand, 30 percent silt, and 10 percent clay. The distribution for the samples at 30,50 , and 60 feet is about 80 percent fine to medium sand, 10 percent silt, and less than 10 percent clay. The distribution in samples from 36 and $41.5 \mathrm{ft}$ is very broad: 30 to 40 percent gravel, 45 to 50 percent sand, 10 to 15 percent silt, and no appreciable claysize fraction. The sample from $70 \mathrm{ft}$ has a narrow distribution, virtually all particles being in the finesand fraction. The $80 \mathrm{ft}$ sample includes 80 percent sand and about 10 percent silt.

\section{Saturated-Zone Results-Hemet Dairy Site}

The water-table surface in the vicinity of the Hemet dairy site was determined by measuring water levels at the multiple-well site $(5 \mathrm{~S} / 1 \mathrm{~W}-28 \mathrm{~J})$ and in wells $5 \mathrm{~S} / 1 \mathrm{~W}-27 \mathrm{~F} 1,5 \mathrm{~S} / 1 \mathrm{~W}-27 \mathrm{Q} 2$, $5 \mathrm{~S} / 1 \mathrm{~W}-34 \mathrm{~N} 2$, and $5 \mathrm{~S} / 1 \mathrm{~W}-21 \mathrm{A1}$. These results, given in Supplemental Data 1, 2, and 3E, and the water-table surface described in the "Geohydrologic Setting" section, indicate that the horizontal component of ground-water flow in this area is to the north. During the course of this study, the water table rose $1.3 \mathrm{ft}$.

Water-quality samples from the saturated zone at the Hemet dairy site were collected September 18, 1990; April 2 and September 6, 1991; and February 4 and August 28, 1992. Analytical results are given in Supplemental Data 3F. With the exception of nitrate, virtually no temporal variation in water quality was found in the single saturatedzone well. The dissolved-solids concentration ranged from 1,630 to $2,080 \mathrm{mg} / \mathrm{L}$, and the $\mathrm{pH}$ was about 7.5. The predominant ions were calcium, sodium, and sulfate. The concentration of chloride was about one-half that of sulfate. The nitrate concentration increased from $24 \mathrm{mg} / \mathrm{L}$ in May 1991 to $61 \mathrm{mg} / \mathrm{L}$ in August 1992. These concentrations are considerably above the MCL of $10 \mathrm{mg} / \mathrm{L}$. Boron concentrations were moderate, about $100 \mu \mathrm{g} / \mathrm{L}$, and selenium concentrations were about $7 \mu \mathrm{g} / \mathrm{L}$.

The stable-isotope values for the Hemet dairy site were $8 D=-57.7$ permil and $\delta^{18} \mathrm{O}=-8.15$ permil. On the basis of the relation developed by Dansgaard (1964) and illustrated in figure 28, the $8^{18} \mathrm{O}$ values suggest that the water at all depths originated as rain that fell at the relatively warm temperature of $8^{\circ} \mathrm{C}$ rather than as snow at high altitudes. Plotting the $8 \mathrm{D}$ and $8^{18} \mathrm{O}$ values on the Craig (1961) diagram (fig. 29) shows that the sample falls on the meteoric-water line. This suggests that the water percolated to the water table without undergoing significant evaporation.

Nitrate concentrations in this water were elevated; the $8^{15} \mathrm{~N}$ values determined for water (at $13.5 \mathrm{ft}$ ) at the Hemet dairy sitewas 13.1 permil. This value suggests that the nitrate is from animal wastes, and that significant microbial cycling of the nitrate has occurred.

\section{Saturated-Zone Results-Chino Dairy Site}

The Chino dairy site is located in the Chino Basin. Although one of the objectives of the study 


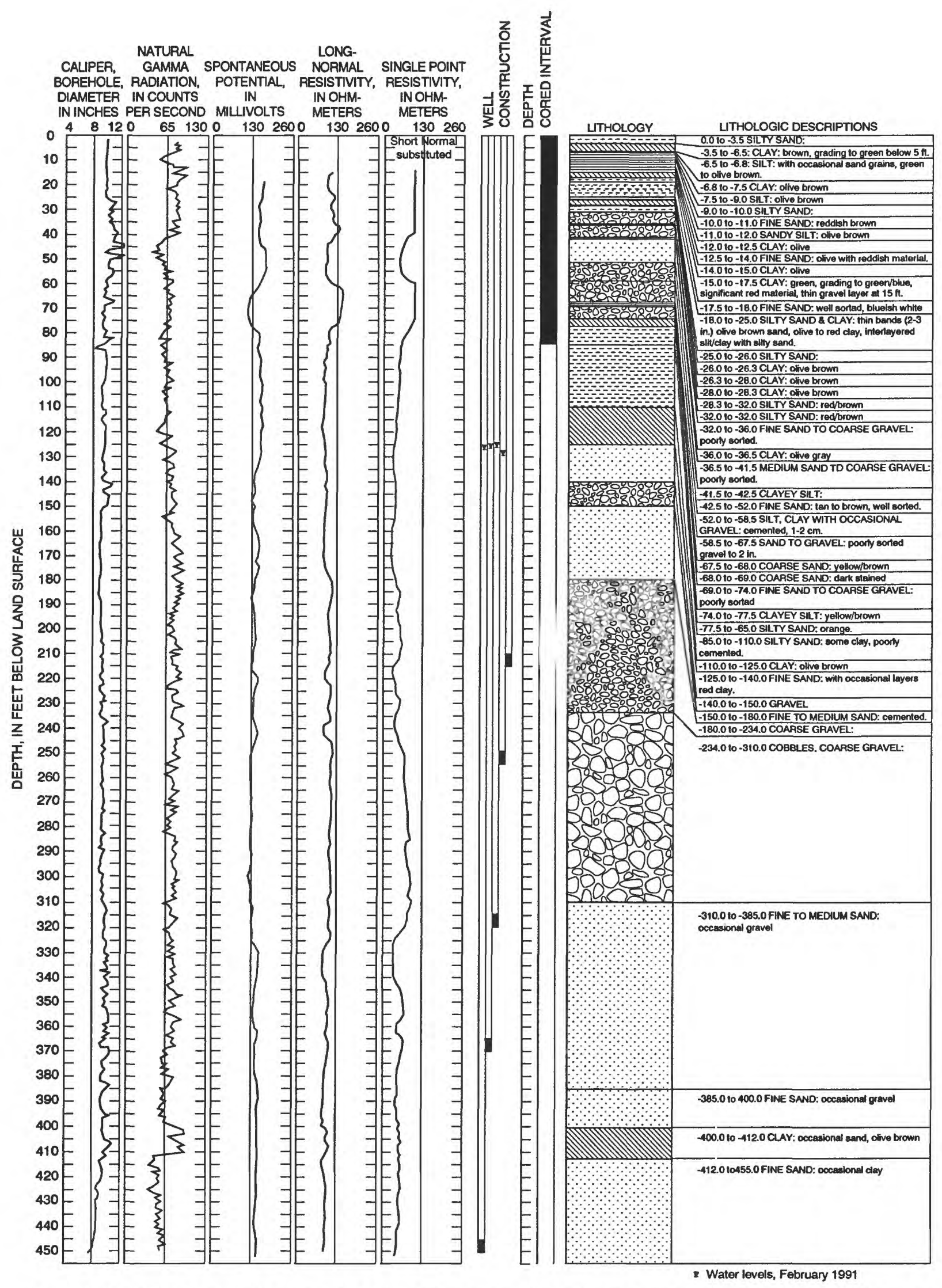

FIGURE 66. Geophysical logs, and diagram showing well construction, cored interval, and lithology for the Chino dairy site. 


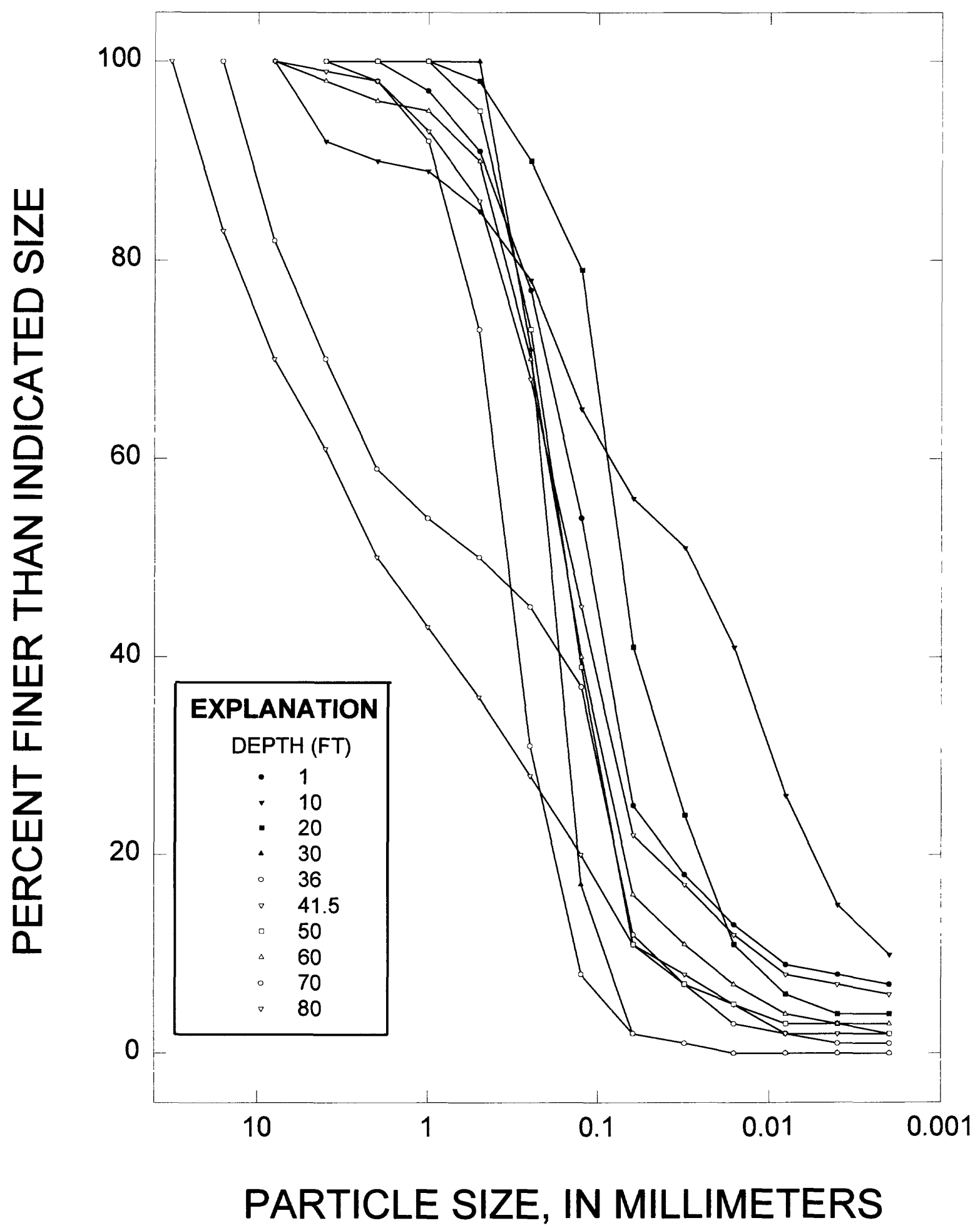

Figure 67. Particle-size distribution at selected depths for cores from the Chino dairy site. 
was to develop a detailed understanding of the geohydrology of the Hemet Basin, it was not an objective to develop such an understanding of the other basins in which research sites were located. Therefore, no attempt was made to determine the horizontal component of ground-water flow at the Chino dairy site.

The potentiometric levels in the three wells were measured five times during the course of this study. The results, given in Supplemental Data 3G, suggest the presence of two distinct zones in the aquifer underlying the Chino dairy site. The potentiometric surface of the upper zone (represented by the $320 \mathrm{ft}$ and $370 \mathrm{ft}$ wells) rose about $2.7 \mathrm{ft}$ during the course of this study; during August 1992, the level was about $123.7 \mathrm{ft}$ below land surface. There is no appreciable vertical ground-water gradient within this upper zone. The potentiometric level of the lower zone, represented by the $450 \mathrm{ft}$ well, rose about $1.1 \mathrm{ft}$, and during August 1992 it was about $124.9 \mathrm{ft}$ below land surface. There is an apparent 1.2- $\mathrm{ft}$ downward gradient between the upper and lower zones.

Water-quality samples were collected from the wells February 22, June 19, and September 4, 1991; and February 19 and August 11, 1992. Analytical results are given in table 3 . Because of the virtual absence of temporal variation in water quality at each of the sampled depths, the samples are assumed to be representative of water in the formation at the depths specified.

\section{Water Quality in the Shallow Zone (320 and 370 feet)}

Water from the 320-foot depth had a dissolvedsolids concentration of about $233 \mathrm{mg} / \mathrm{L}$. The predominant ions were calcium, sodium, and bicarbonate; present at smaller percentages were chloride and sulfate ions. The $\mathrm{pH}$ was about 7.8. The nitrate concentration of about $2 \mathrm{mg} / \mathrm{L}$ is well below the MCL of $10 \mathrm{mg} / \mathrm{L}$, and boron and selenium concentrations also were low.

Water from the 350-foot depth had a dissolvedsolids concentration of about $210 \mathrm{mg} / \mathrm{L}$, and the ionic composition was the same as that at $320 \mathrm{ft}$. The $\mathrm{pH}$ was about 8.0. The nitrate concentration was about $1.5 \mathrm{mg} / \mathrm{L}$, suggesting a trend of decreasing nitrate concentration with depth. Boron and selenium concentrations were low.

The stable-isotope values were $8 D=-49.0$ permil and $\delta^{18} \mathrm{O}=-7.65$ permil for the $320 \mathrm{ft}$ well, and $8 D=-48.2$ permil and $8^{18} \mathrm{O}=-7.80$ permil for the $350 \mathrm{ft}$ well. On the basis of the Dansgaard diagram shown in figure 28 , these values indicate that the water at these depths originated as rain that fell at the relatively warm temperature of about $9^{\circ} \mathrm{C}$ rather than as snow at high altitudes. Plots of the values on the Craig (1961) diagram (fig. 29) suggest that the water percolated to the water table without undergoing significant evaporation.

The $8^{15} \mathrm{~N}$ values determined for water at the Chino dairy site were $4.9(320 \mathrm{ft})$ and $1.7(370 \mathrm{ft})$ permil. The value at $370 \mathrm{ft}$ indicates that the nitrate at that depth is from a mixed source. The heavier value at $320 \mathrm{ft}$ indicates that the nitrate has a mixed origin of both mineral and animal wastes.

\section{Water quality in the deep zone (450 feet)}

Water from the 450-foot depth had a dissolvedsolids concentration of about $144 \mathrm{mg} / \mathrm{L}$. The predominant ions were sodium and bicarbonate; present at smaller percentages were calcium, chloride, and sulfate ions. The $\mathrm{pH}$ was about 8.8 . The nitrate concentration was less than $1 \mathrm{mg} / \mathrm{L}$, and boron and selenium concentrations also were low. The values of $8 D\left(-52.0\right.$ permil) and $8^{18} \mathrm{O}(-8.25$ permil) indicate that the water at this depth originated as rain that fell at the relatively warm temperature of about $8^{\circ} \mathrm{C}$, and that the water did not undergo significant evaporation prior to percolation to the water table.

\section{Unsaturated-Zone Results}

\section{Pore-moisture profiles}

The pore-moisture saturation-index profiles for the Hemet dairy site (fig. 68) indicate temporal variations of about 0.1 unit. Moisture content is relatively high near the top of a clay layer that extends from 4.1 to $9.0 \mathrm{ft}$ below land surface. The high moisture content probably is due to perching of water that percolates from the surface. The clay is relatively dry in the center, and then becomes wet again near the bottom. The profiles show that the capillary fringe starts at about 10 to $11 \mathrm{ft}$ below land surface, and the water table ranges from 10.3 to $13.6 \mathrm{ft}$ below land surface. The profiles indicate that there is no piston flow in the system, at least not on the time scale of the measurements. The shape of the several profiles is virtually identical, and any changes in moisture content is reflected in the entire profile, not just at one depth. The soil column seems 


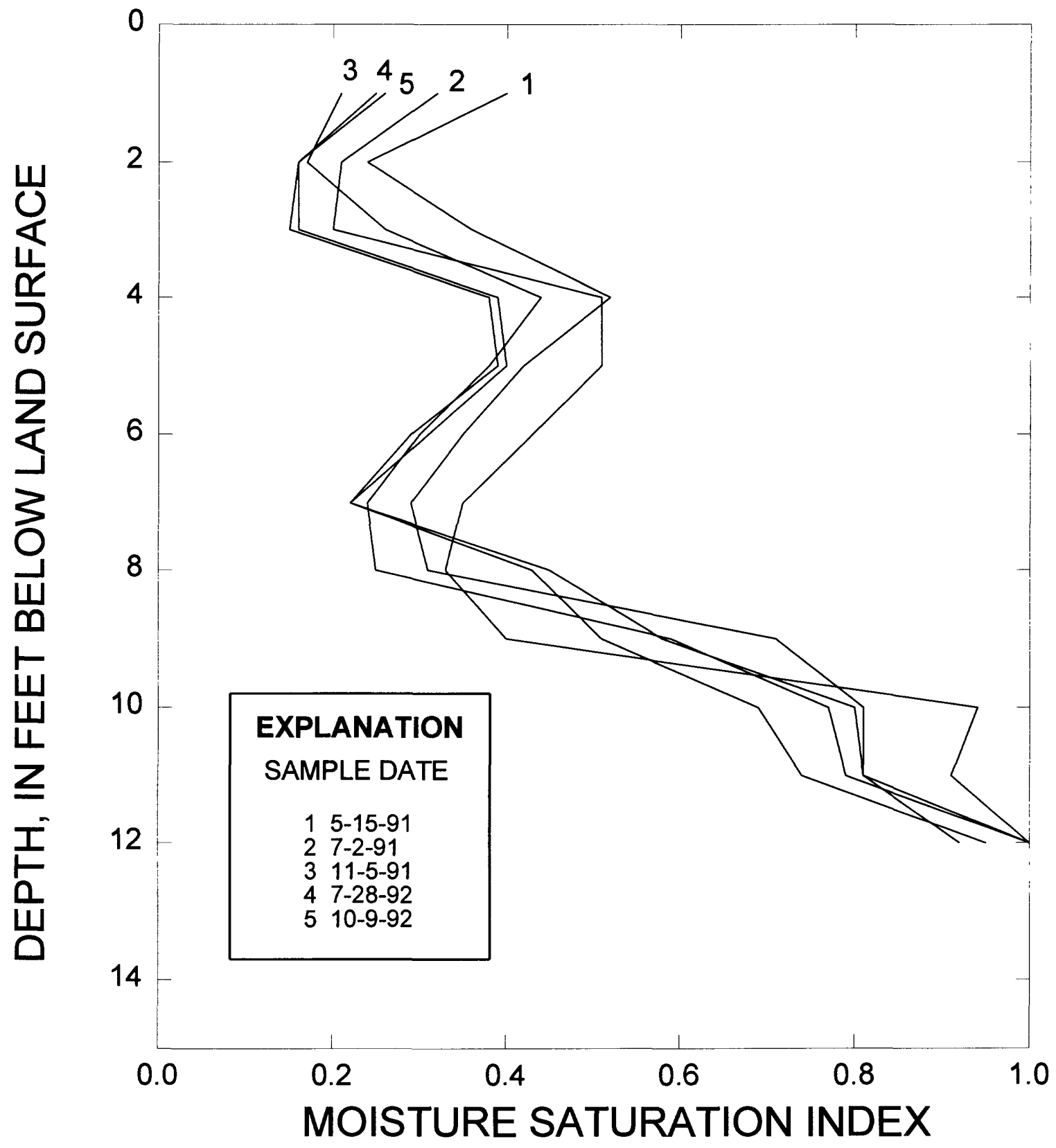

Figure 68. Unsaturated-zone pore-moisture profiles for selected dates in 1991-92 for the Hemet dairy site. 


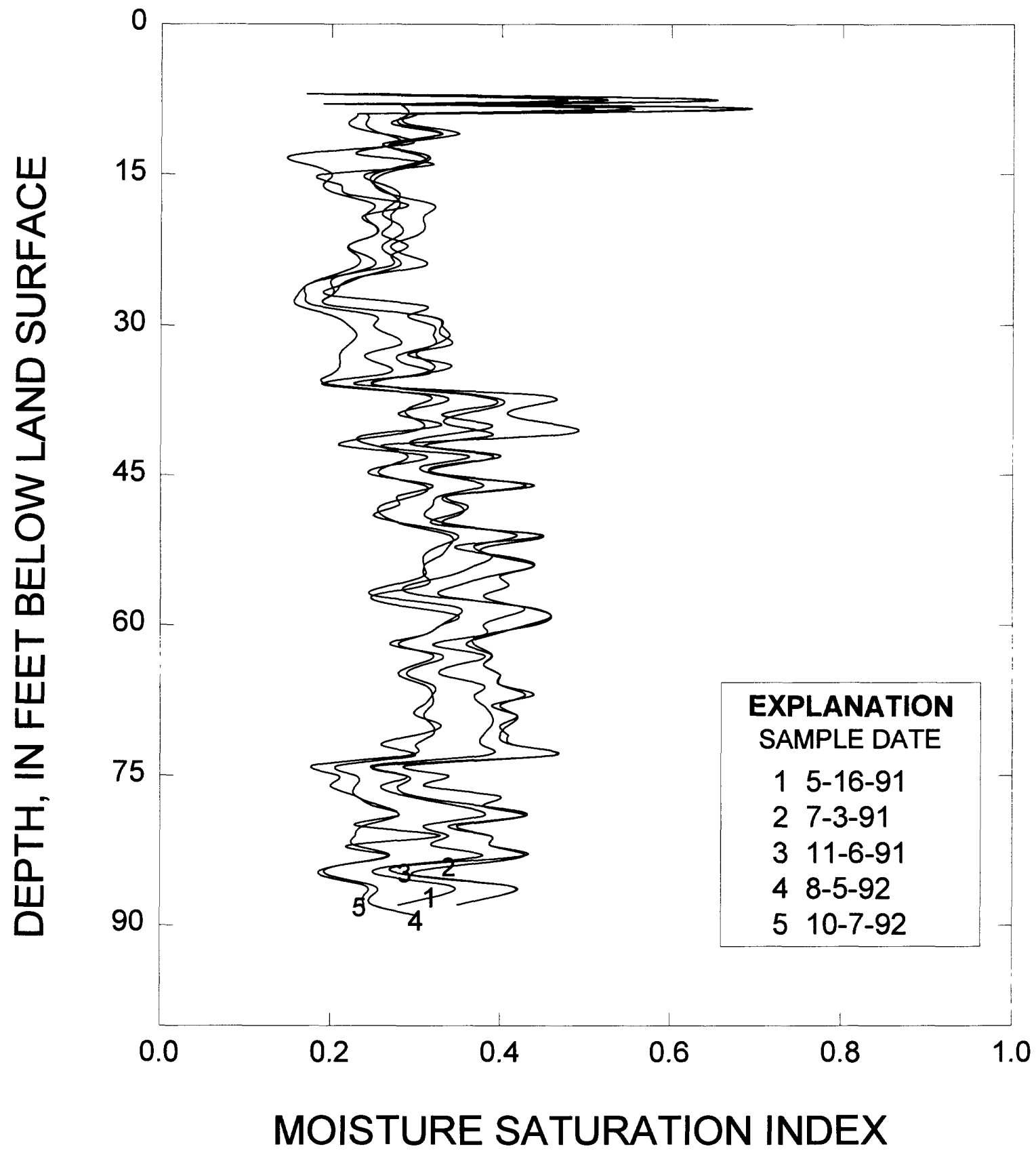

Figure 69. Unsaturated-zone pore-moisture profiles for selected dates in 1991-92 for the Chino dairy site. 
to equilibrate rapidly in response to changes in precipitation.

The pore-moisture saturation-index profiles for the Chino dairy site (fig. 69) are very complex, reflecting the complex stratigraphy underlying the site. The saturation indices ranged from 0.15 and 0.50 , the highest moisture contents being in the clay between 52 and $58 \mathrm{ft}$ below land surface. Generally, the saturation indices were highest in the fine-grained materials and lowest in sand and gravel. As at the Hemet dairy site, temporal variations were about 0.10 unit; the shape of the profiles are virtually identical, indicating no piston flow at the site on the time scale of the measurements; and any change in moisture content is reflected in the entire profile, not just at a particular depth.

Unsaturated hydraulic conductivities for the various alluvial materials beneath the Hemet dairy site ranged from $3.12 \times 10^{-9} \mathrm{ft} / \mathrm{s}$ in the clay at $1 \mathrm{ft}$ to $3.84 \times 10^{-3} \mathrm{ft} / \mathrm{s}$ in the sand at $18 \mathrm{ft}$. The unsaturated hydraulic conductivities beneath the Chino dairy site ranged from $8.17 \times 10^{-8} \mathrm{ft} / \mathrm{s}$ in the oxidized sand at $10 \mathrm{ft}$ to $2.32 \times 10^{-3} \mathrm{ft} / \mathrm{s}$ in the gravel at $41 \mathrm{ft}$. Using the appropriate unsaturated hydraulic conductivities with the corresponding moisture saturation indices, and integrating over the entire unsaturated zone, one obtains an estimated transit time of 120 days for the Hemet dairy site and 4.2 years for the Chino dairy site for water to percolate from the land surface to the water table.

\section{Tritium profiles}

The tritium-concentration profile for the unsaturated-zone pore water at the Hemet dairy site was determined by compositing lysimeter-collected water during July 1991 until sufficient volume (1 L) was obtained for analysis. The profile (fig. 70) indicates that the tritium concentration never approaches the expected 1963 concentration of $600 \mathrm{pCi} / \mathrm{L}$; thus, the unsaturated zone transit time is less than 30 years. The profile also shows that the concentrations at $5 \mathrm{ft}$ and $13.5 \mathrm{ft}$ were considerably higher than what would be expected from fresh rainwater in southern California $(15 \mathrm{pCi} / \mathrm{L})$, but the concentration at $10 \mathrm{ft}$ was considerably lower (than $15 \mathrm{pCi} / \mathrm{L}$ ). These results indicate that there is a mixture of sources of unsaturated pore water: some comes from the Colorado River, and some comes from locally pumped ground water (tritium concentrations less than $2 \mathrm{pCi} / \mathrm{L}$ ). The profile also indicates that it takes less than 1 year for water to percolate from the land surface to the water table.
The tritium-concentration profile for pore water in the unsaturated zone at the Chino dairy site (fig. 71) was determined in the same way as at the Hemet dairy site. The tritium concentrations at the Chino dairy site are consistent with local precipitation as the source and seem to indicate seasonal pulses. If one assumes that the peak at $5 \mathrm{ft}$ represents the summer 1991 maximum, and the peak at $25 \mathrm{ft}$ the summer 1990 maximum, then the unsaturated-zone percolation rate through this zone is $20 \mathrm{ft} / \mathrm{yr}$. (See discussion of assumptions in the introductory part of the "Water-Quality Overview" section that follows the "Geohydrologic Setting" section.) If one assumes, further, that the minimum at $15 \mathrm{ft}$ represents winter 1990 water, and that the minimum at $50 \mathrm{ft}$ represents winter 1989 water, then the percolation rate through this part of the unsaturated zone is approximately $35 \mathrm{ft} / \mathrm{yr}$. Similarly, the maximums at 25 and $75 \mathrm{ft}$ yield a rate of approximately $50 \mathrm{ft} / \mathrm{yr}$, and the minimums at 50 and $100 \mathrm{ft}$ also yield a rate of about $50 \mathrm{ft} / \mathrm{yr}$. On the basis of these rates, the time required for water to percolate from land surface to the water table would be 3 to 5 years.

\section{Water quality}

Water-quality samples of unsaturated-zone pore water were collected using the ceramic-cup suction lysimeters. Samples at the Hemet dairy site were collected during January, June, and August 1991 and April and September 1992. Samples at the Chino dairy site were collected during June and August 1991, and April and September 1992. Analytical results are given in Supplemental Data $3 F, G$.

Hemet dairy site.--At the Hemet dairy site, samples collected from $5 \mathrm{ft}$ below land surface had dissolved-solids concentrations of about $19,300 \mathrm{mg} / \mathrm{L}$. The $\mathrm{pH}$ was about 7.2 , and the predominant ions were sodium and sulfate. Other ions present were calcium, whose concentration was about one-tenth that of sodium, and chloride, whose concentration was about one-half that of sulfate. The bicarbonate concentration was less than $300 \mathrm{mg} / \mathrm{L}$, and the organic-carbon concentration was $44 \mathrm{mg} / \mathrm{L}$.

The samples collected from $10 \mathrm{ft}$ had much lower dissolved-solids concentrations, about $2,600 \mathrm{mg} / \mathrm{L}$. The $\mathrm{pH}$ ranged from 7.1 to 8.0. The predominant ions were sodium and chloride, and calcium and sulfate were present--at concentrations about one-half those of sodium and chloride, 


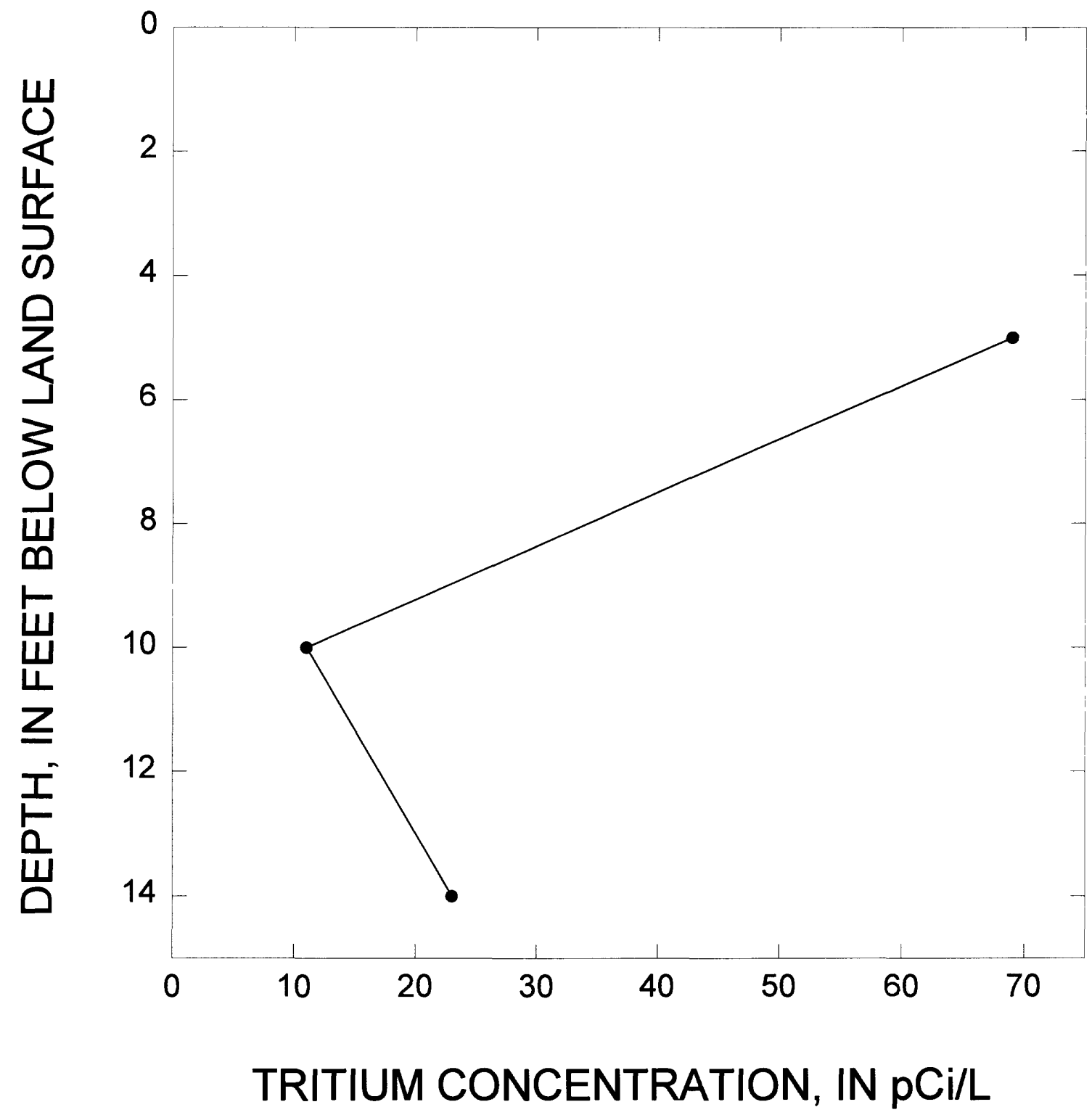

Figure 70. Tritium-concentration profile for pore water at the Hemet dairy site. 


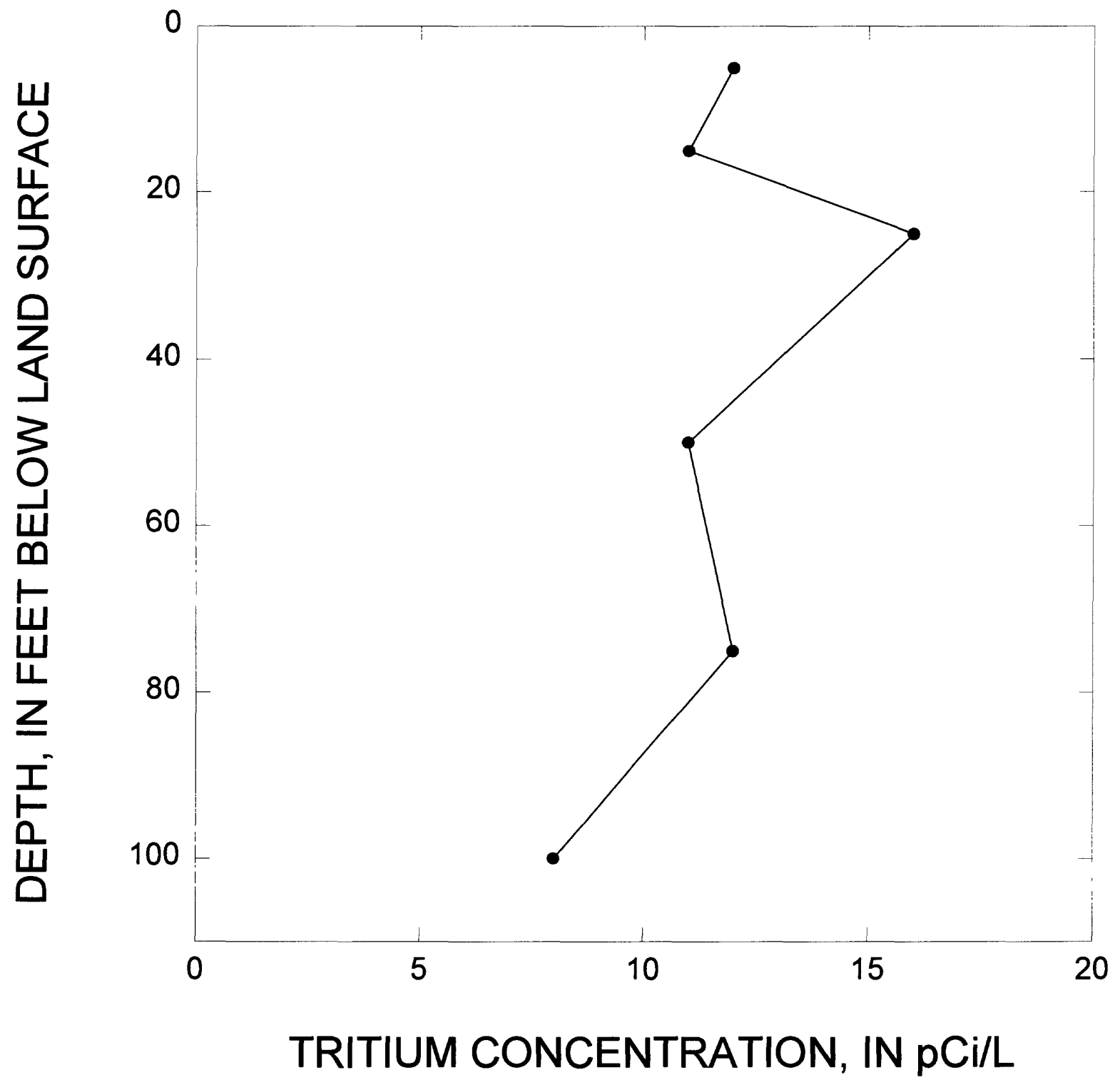

Figure 71. Tritium-concentration profile for pore water at the Chino Dairy site. 
respectively. The alkalinity was about $400 \mathrm{mg} / \mathrm{L}$, and the organic-carbon concentration was $1.6 \mathrm{mg} / \mathrm{L}$. The relative constancy of the analytical results for the $5 \mathrm{ft}$ and $10 \mathrm{ft}$ samples indicates that the clay layer between 5 and $10 \mathrm{ft}$ effectively impedes the downward movement of highly contaminated water from the surface.

The samples collected at $13.5 \mathrm{ft}$ had dissolvedsolids concentrations of about $1,600 \mathrm{mg} / \mathrm{L}$. The $\mathrm{pH}$ ranged from 7.2 to 7.9 . The predominant ions were sodium, calcium, and sulfate. The calcium concentration was two-thirds that of sodium. Chloride also was present--at a concentration about one-half that of sulfate. Alkalinity was about $300 \mathrm{mg} / \mathrm{L}$, and the organic-carbon concentration was $2.9 \mathrm{mg} / \mathrm{L}$.

Chino dairy site.--At the Chino dairy site, the dissolved-solids concentrations in the unsaturatedzone pore water tended to decrease with increasing depth. At $5 \mathrm{ft}$, the dissolved-solids concentration was about $10,400 \mathrm{mg} / \mathrm{L}$, comparable to that observed at the Hemet dairy site at the same depth. The concentration decreased to $6,020 \mathrm{mg} / \mathrm{L}$ at $10 \mathrm{ft}$, $3,980 \mathrm{mg} / \mathrm{L}$ at $15 \mathrm{ft}$, and $1,390 \mathrm{mg} / \mathrm{L}$ at $25 \mathrm{ft}$. The concentration remained relatively constant, at about $1,350 \mathrm{mg} / \mathrm{L}$, below $25 \mathrm{ft}$. The predominant ions at all depths were sodium, calcium, chloride, and sulfate. The sodium concentration was slightly higher than that of calcium, and the chloride and sulfate concentrations were about equal. The organic-carbon concentration decreased from $69 \mathrm{mg} / \mathrm{L}$ at $10 \mathrm{ft}$ to $3.6 \mathrm{mg} / \mathrm{L}$ at $100 \mathrm{ft}$.

\section{Nitrogen profiles}

Core results.--Samples of core material were collected and processed using the procedures described in the "Site Instrumentation and Sample Collection" section. The analytical results for the Hemet and Chino dairy sites are given in Supplemental Data 3F,G and illustrated in figures 72-77.

Most of the nitrogen introduced into the environment from animal wastes is initially in the form of organic nitrogen and ammonia, and organic nitrogen can be readily hydrolyzed to yield additional ammonia (Bouldin and others, 1984). Depth profiles for these constituents for the Hemet dairy site are shown in figures 72 and 73 . Organicnitrogen concentrations decreased rapidly with depth, from $66 \mathrm{mg} / \mathrm{L}$ at $1 \mathrm{ft}$ to below detection at $10 \mathrm{ft}$. Ammonia concentrations were less than $1 \mathrm{mg} / \mathrm{L}$ at all depths except $15 \mathrm{ft}(1.3 \mathrm{mg} / \mathrm{L})$, which corresponds to the top of a silt layer directly beneath coarse sand. Lauer and others (1976) found, at other dairies, that 60 to 100 percent of ammonia in the wastes was volatilized, and the loss followed a first order reaction rate with $\mathrm{t}_{1 / 2}=1.8$ to 3.4 days. $\left(\mathrm{t}_{1} / 2\right.$ is the time required for one-half of a reactant to react.) Beauchamp and others (1982) found ammonia losses of 24 to 33 percent in the first 6 to 7 days after application. In both studies, it was assumed that ammonia loss was due to volatilization. Ammonia also can be lost by ion exchange onto clays, and by oxidation to nitrate.

Under oxic conditions, the organic nitrogen and non-volatilized ammonia in animal wastes are converted rapidly to nitrate. The nitrateconcentration profile for the Hemet dairy site (fig. 74) indicates that nitrate concentration decreases about 1 order of magnitude in the top $10 \mathrm{ft}$ : from $300 \mathrm{mg} / \mathrm{L}$ near the surface to about $25 \mathrm{mg} / \mathrm{L}$ at $10 \mathrm{ft}$. The nitrate concentrations remain relatively constant at about $30 \mathrm{mg} / \mathrm{L}$ at all other depths except at $15 \mathrm{ft}$ (less than $7 \mathrm{mg} / \mathrm{L}$ ). Interpretation of this profile is complicated because the soil column is saturated below $12 \mathrm{ft}$, allowing both horizontal and vertical transport.

If one assumes that the concentrations in the near-surface samples represent the loading of nitrogen to the system, and that only vertical movement of water is occurring, then the core data can be used to calculate the instantaneous flux of nitrogen moving through the unsaturated zone at the Hemet dairy site at the time of core collection. Using a 0.3-foot-thick layer at each depth, and the volumepercent moisture from figure 69 , one obtains a value for the total amount of nitrogen entering the system of about $37 \mathrm{lb} / \mathrm{acre}$. The flux of nitrogen decreases to $15 \mathrm{lb} /$ acre at a depth of $3 \mathrm{ft}$, and to $9.8 \mathrm{lb} /$ acre at $15 \mathrm{ft}$. This flux remains relatively constant through $25 \mathrm{ft}$.

The organic-nitrogen concentration profile for the Chino dairy site (fig. 75) shows that the organicnitrogen concentration decreases rapidly from $150 \mathrm{mg} / \mathrm{L}$ near the surface to about $15 \mathrm{mg} / \mathrm{L}$ below $10 \mathrm{ft}$. Ammonia concentration (fig. 76) follows a similar pattern, decreasing from $2.3 \mathrm{mg} / \mathrm{L}$ near the surface to less than $1 \mathrm{mg} / \mathrm{L}$ below $10 \mathrm{ft}$, except beneath the clay layer at 26.0 to $26.3 \mathrm{ft}(1.5 \mathrm{mg} / \mathrm{L})$ and the clayey silt layer at $41.5 \mathrm{ft}(2.0 \mathrm{mg} / \mathrm{L})$.

The depth profile for nitrate in the pore-water extracts from the Chino dairy site (fig. 77) shows that nitrate concentrations are very high, greater than $7,000 \mathrm{mg} / \mathrm{L}$, near the surface. This suggests 


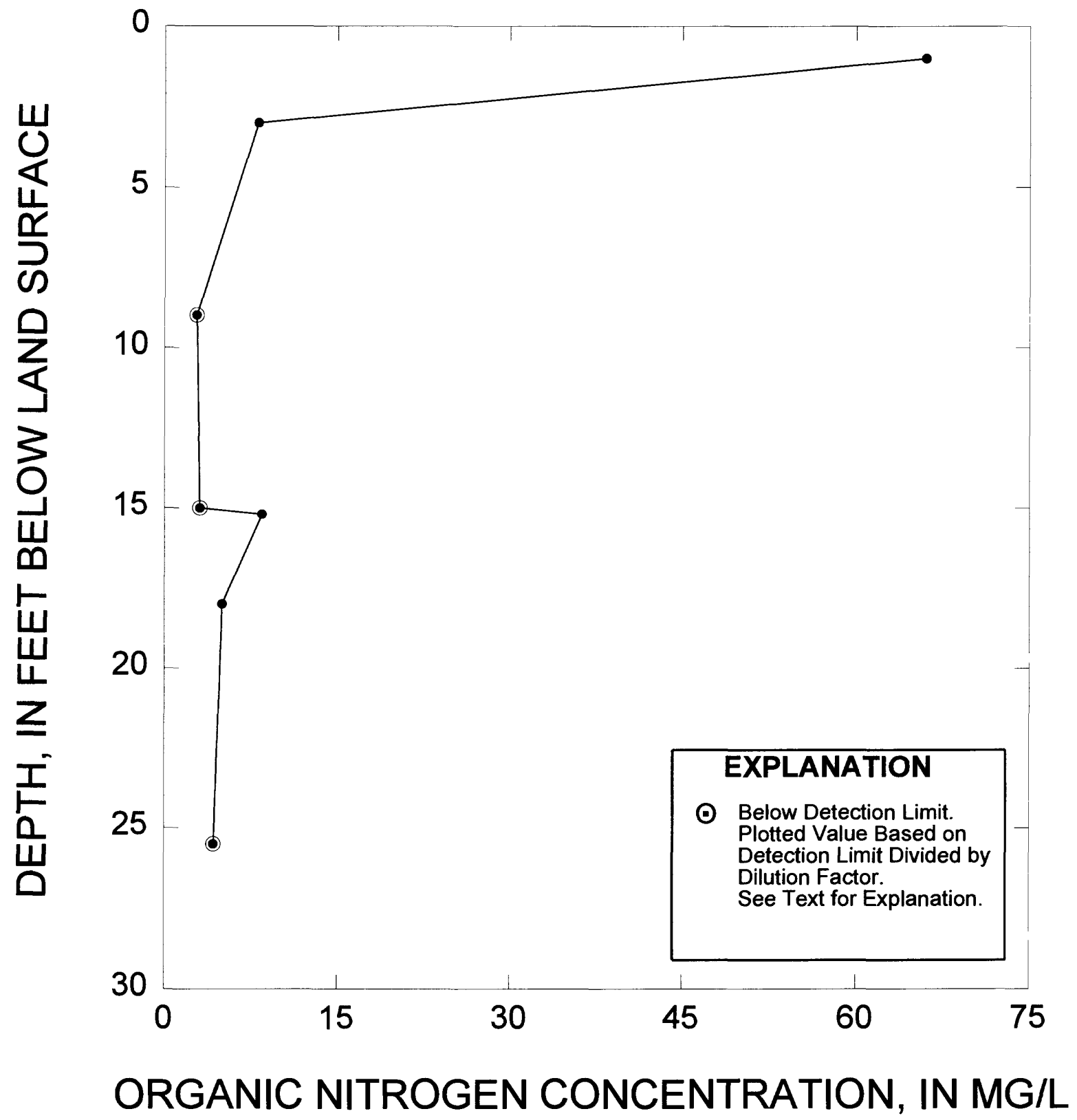

Figure 72. Organic-nitrogen-concentration profile, from core extracts, for the unsaturated zone at the Hemet dairy site. 


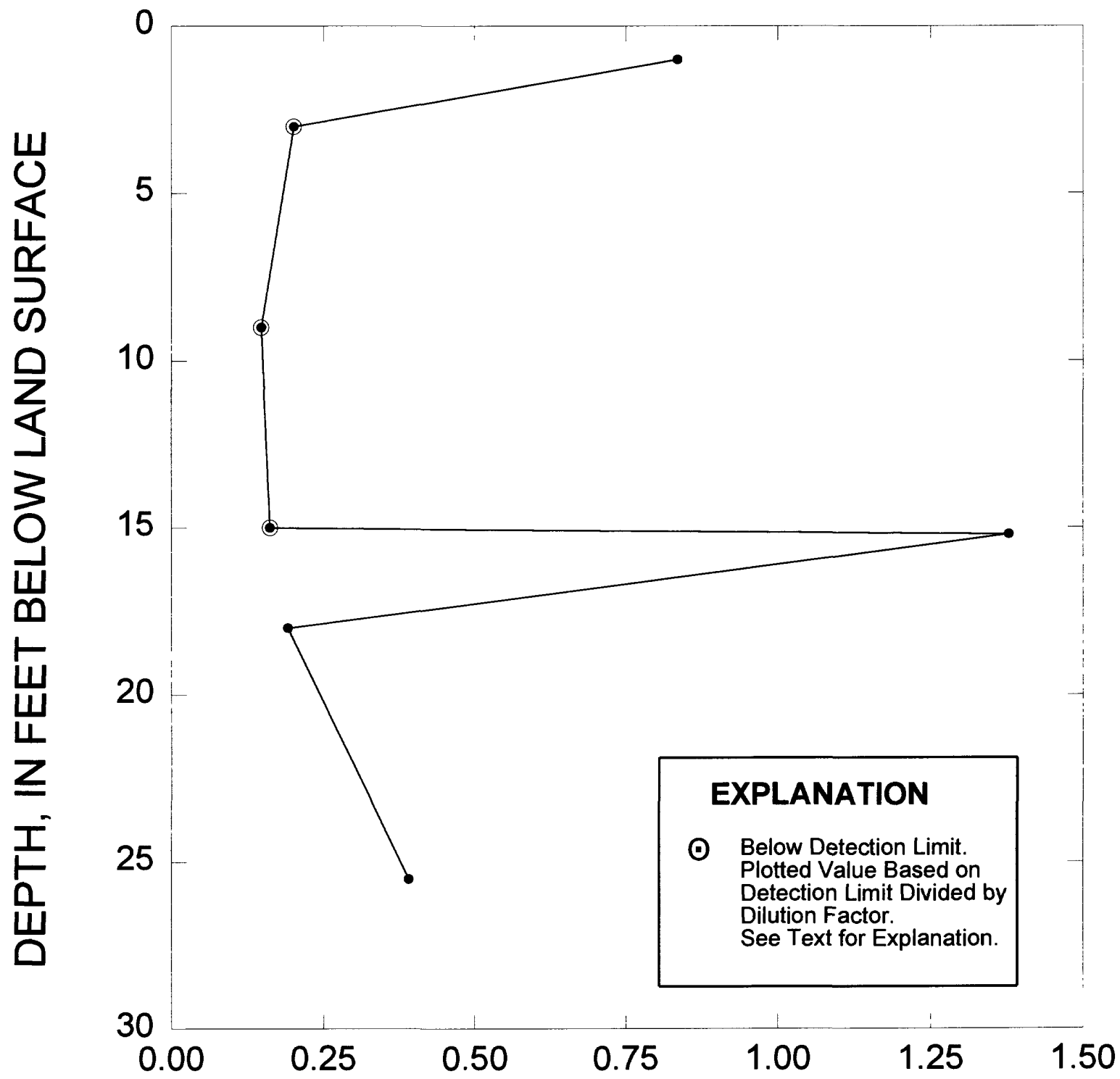

AMMONIA CONCENTRATION, IN MG/L

Figure 73. Ammonia-concentration profile, from core extracts, for the unsaturated zone at the Hemet dairy site. 


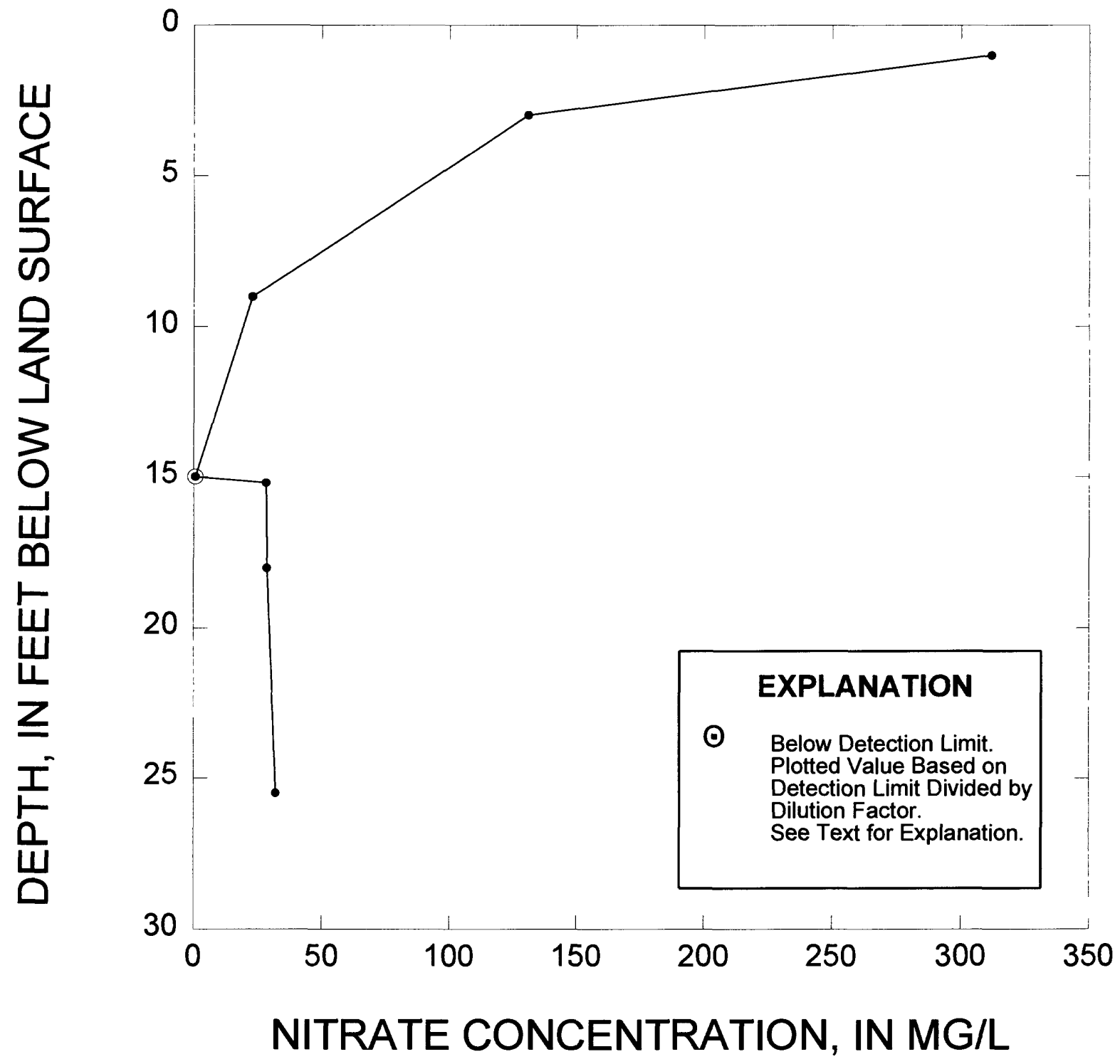

Figure 74. Nitrate-concentration profile, from core extracts, for the unsaturated zone at the Hemet Dairy site. 


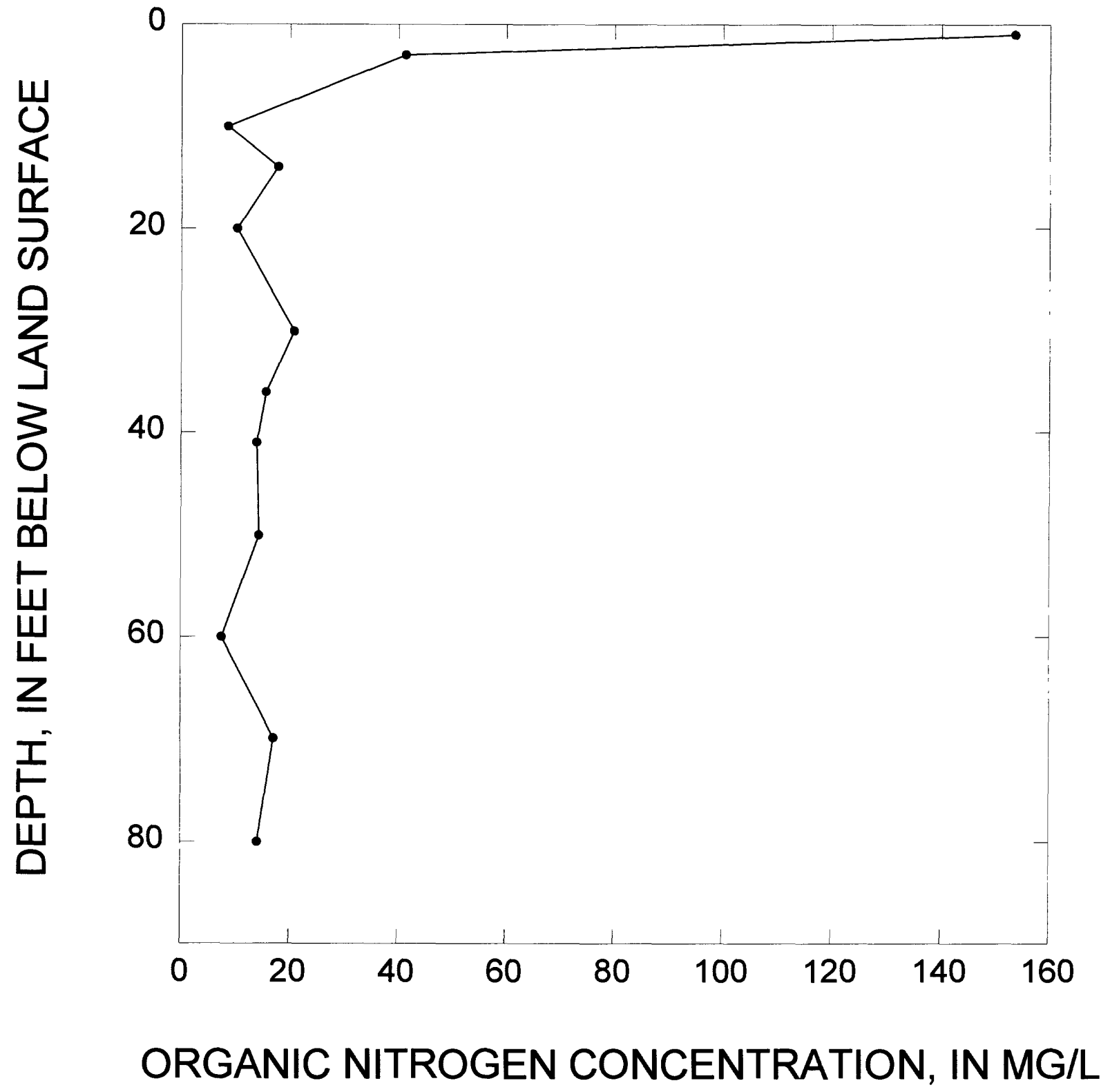

Figure 75. Organic-nitrogen-concentration profile, from core extracts, for the unsaturated zone at the Chino dairy site. 


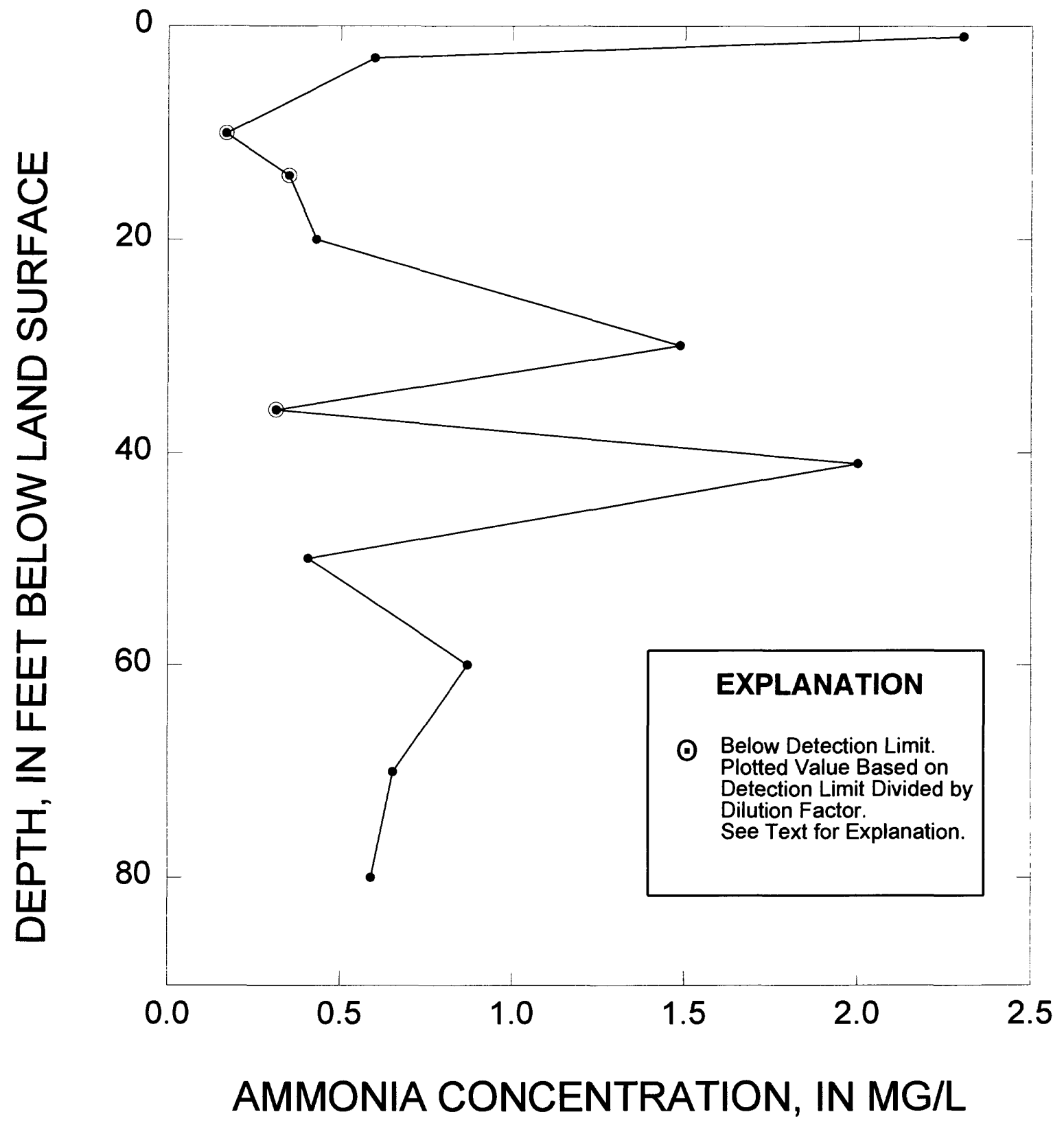

Figure 76. Ammonia-concentration profile, from core extracts, for the unsaturated zone at the Chino dairy site. 


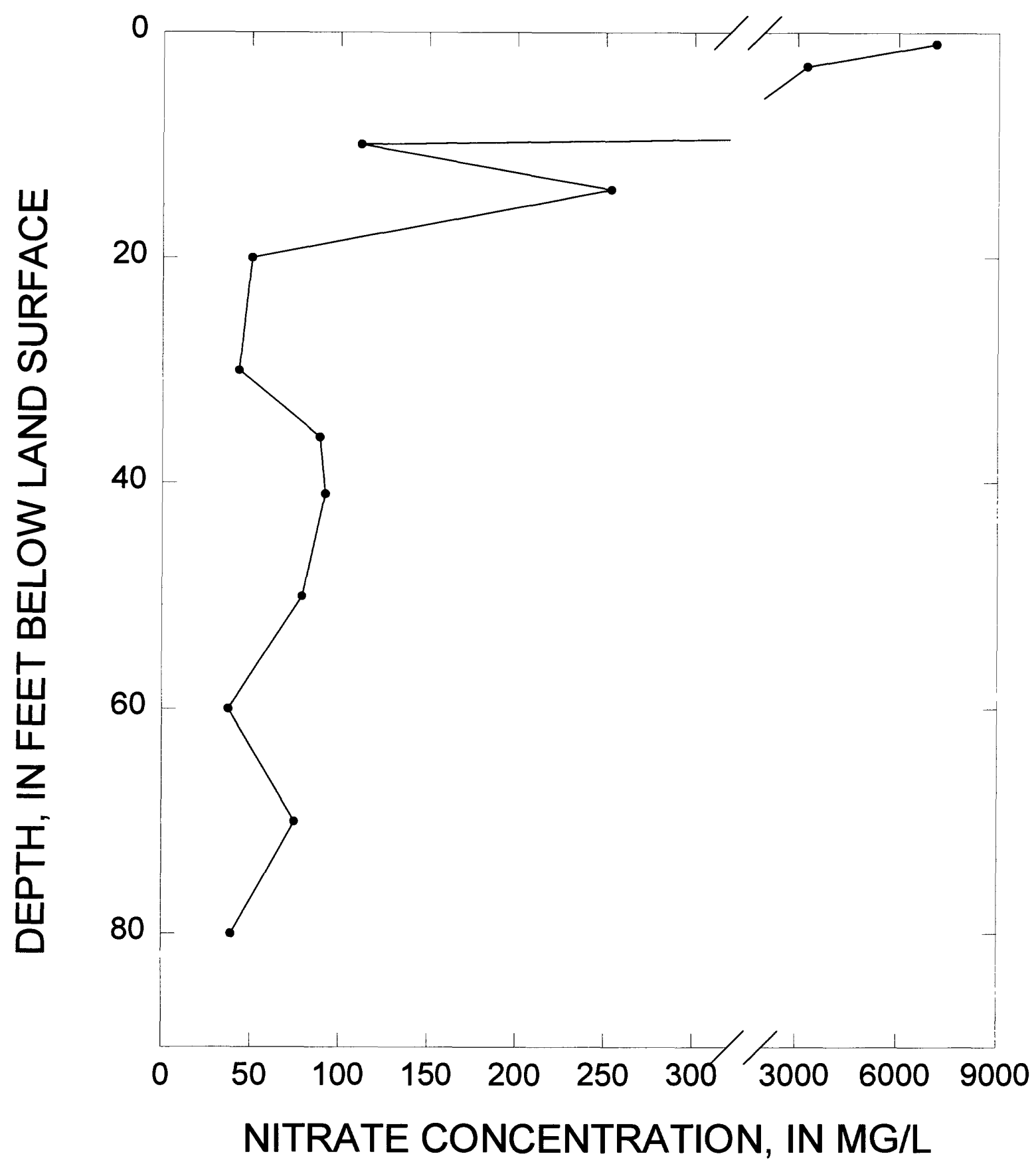

Figure 77. Nitrate-concentration profile, from core extracts, for the unsaturated zone at the Chino dairy site. 
that almost all the nitrogen is oxidized to nitrate before it is used to irrigate the pasture. Nitrate concentration decreases nearly 2 orders of magnitude (to $110 \mathrm{mg} / \mathrm{L}$ ) at a depth of $10 \mathrm{ft}$. Except for perturbation at the clay layer at $14 \mathrm{ft}$, the nitrate concentration becomes relatively constant (ranging from 40 to $100 \mathrm{mg} / \mathrm{L}$ ) to a depth of $75 \mathrm{ft}$.

Using the same assumption used at the Hemet dairy site--that the nitrogen concentrations near the surface represent the loading of nitrogen to the system, and that only vertical movement of water occurs--one can make the following conclusions: The total amount of nitrogen entering the system is about $310 \mathrm{lb} / \mathrm{acre}$, and the instantaneous flux of nitrogen below $30 \mathrm{ft}$ is about $31 \mathrm{lb} /$ acre Comparison of these values indicates that about 280 $\mathrm{lb} /$ acre of nitrogen is removed from the pore water in the top $10 \mathrm{ft}$ of the soil column. The flux of nitrogen below $20 \mathrm{ft}$ is about $7.6 \mathrm{lb} / \mathrm{acre}$, and it decreases to about $5.3 \mathrm{lb} /$ acre below $75 \mathrm{ft}$.

Stewart and others (1967) reported an average nitrogen loading of $1,146 \mathrm{lb} /$ acre for feedlots in the South Platte Valley of Colorado. They also reported that average nitrate concentrations decreased from $70 \mathrm{mg} / \mathrm{kg}$ (dry soil) near the surface to less than $5 \mathrm{mg} / \mathrm{kg}$ (dry soil) at the bottom of $20-\mathrm{ft}$ cores. Adriano and others (1973) studied cores from the Chino Basin at a time when the dairy-related animal population was 122,000 (about one-third the present population). Cores were collected to a depth of $20 \mathrm{ft}$. Nitrogen loading was $316 \mathrm{lb} /$ acre. Nitrate concentrations decreased from $120 \mathrm{mg} / \mathrm{kg}$ (dry soil) at the surface to $13 \mathrm{mg} / \mathrm{kg}$ (dry soil) at $20 \mathrm{ft}$. Results of these two studies are not directly comparable to the results reported herein because the analyses in those studies were done on dried soil rather than pore water. Qualitatively, however, the results of these earlier studies are consistent with the results reported here. Mielke and Ellis (1976) studied abandoned feedlots, also along the Platte River Valley, and found average nitrogen loading of 6,400 $\mathrm{lb} /$ acre. Nitrate concentrations ranged from $300 \mathrm{mg} / \mathrm{kg}$ (dry soil) near the surface to less than $10 \mathrm{mg} / \mathrm{kg}$ (dry soil) at $30 \mathrm{ft}$ (bottom of the core). Soil-moisture profiles showed an average moisture content of about 25 percent. Calculations of the nitrate concentrations in the pore water, using this value, range from $1,000 \mathrm{mg} / \mathrm{L}$ to less than $40 \mathrm{mg} / \mathrm{L}$. These results are comparable to those reported herein for this study.

Lysimeter results.--Samples of unsaturatedzone pore water from the Hemet dairy site were collected using the ceramic-cup suction lysimeters during June and August 1991 and April and August 1992. Samples from the Chino dairy site were collected during June and August 1991 and May and August 1992. Results are given in Supplemental Data 3F, G and illustrated in figures 78-79. Because organic-nitrogen, ammonia, and nitrite concentrations were generally low, the discussion that follows focuses on the nitrate-concentration profiles.

At the Hemet dairy site, the nitrate concentration in pore water collected from $5 \mathrm{ft}$ was relatively constant, at about $120 \mathrm{mg} / \mathrm{L}$, during the study. At $10 \mathrm{ft}$, the concentration decreased to 14 $\mathrm{mg} / \mathrm{L}$, and this concentration remained constant to $13.5 \mathrm{ft}$.

At the Chino dairy site, the nitrate concentration in pore water at $5 \mathrm{ft}$ was about $1,000 \mathrm{mg} / \mathrm{L}$. Pore water from $10 \mathrm{ft}$ had nitrate concentrations of about $400 \mathrm{mg} / \mathrm{L}$, and the concentrations decreased to $200 \mathrm{mg} / \mathrm{L}$ at $15 \mathrm{ft}$ and to $120 \mathrm{mg} / \mathrm{L}$ at $25 \mathrm{ft}$. The concentrations remained relatively constant, at 120 to $150 \mathrm{mg} / \mathrm{L}$, from a depth of $25 \mathrm{ft}$ to $100 \mathrm{ft}$ below land surface.

The nitrate-concentration trends in pore water at the two sites were similar: high concentrations at shallow depths, decreasing by an order of magnitude within the top 10 to $25 \mathrm{ft}$ of the soil column. Below this initial zone, the nitrate concentrations remained relatively constant until reaching the water table (at the Hemet dairy site) or the deepest lysimeter (at the Chino dairy site).

\section{Microbial processes}

Both nitrifying and denitrifying bacteria were found at the Hemet dairy site (table 2). Nitrosomonas and Nitrobacter were present in the $1 \mathrm{ft}$ sample, at 4,300 and 150 bacteria per gram soil, respectively. Neither was present in the deeper samples. Significant populations (greater than 15,000 bacteria per gram soil) of denitrifying bacteria were found at the shallow depths above the clay at $4.1 \mathrm{ft}$; none were found below that clay.

Similarly, the nitrifying bacteria were present in the 1-foot sample at the Chino dairy site. The Nitrosomonas concentration was 4,300 bacteria per gram soil, and the Nitrobacter concentration was 290 bacteria per gram soil. Nitrifying bacteria were absent in the deeper samples. Denitrifying bacteria were present at all depths except $30 \mathrm{ft}$. There was an orderly decrease in bacteria numbers from 


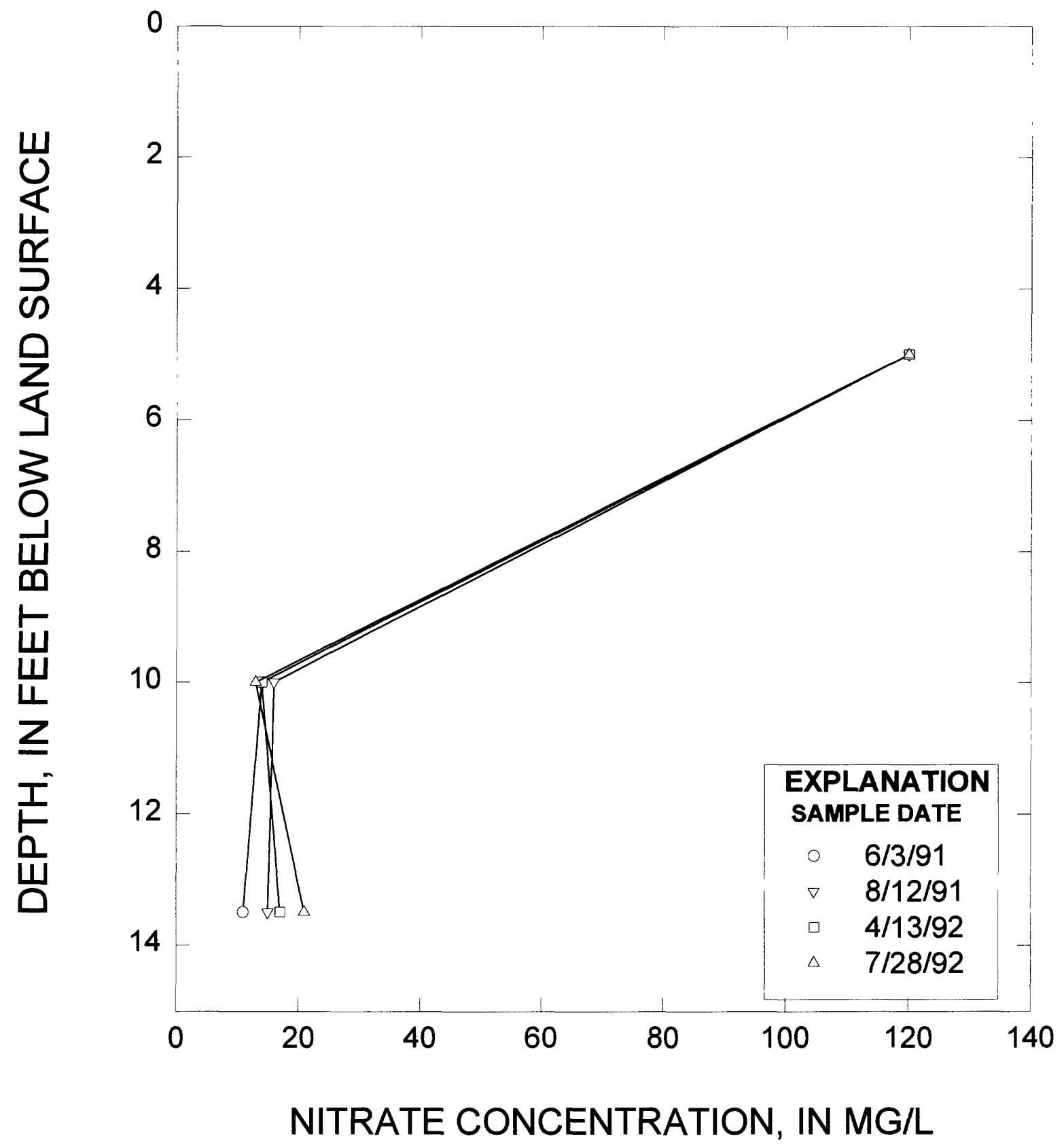

Figure 78. Nitrate-concentration profile, for selected dates in 1991-92 in unsaturated-zone pore water at the Hemet dairy site. 


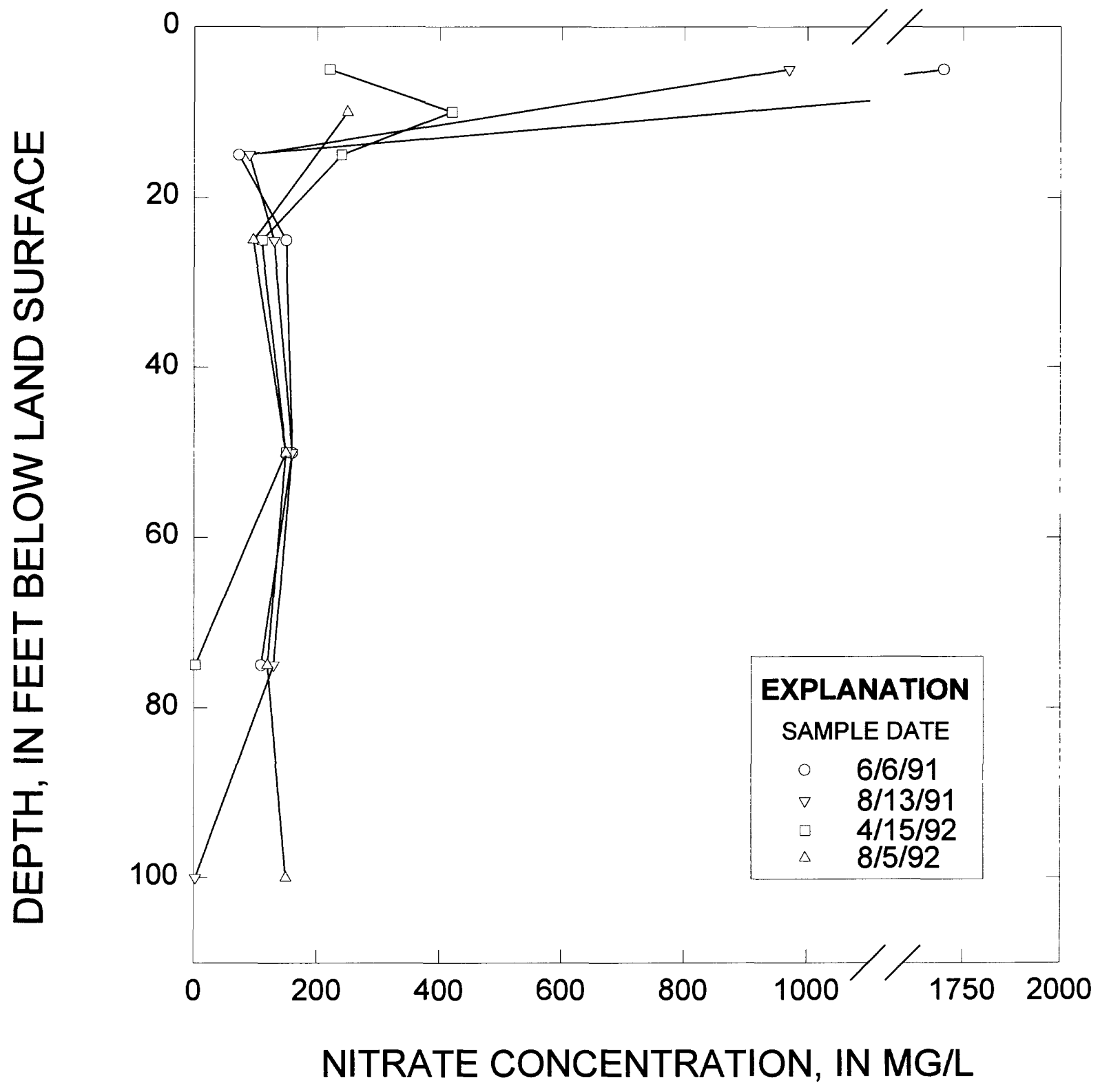

Figure 79. Nitrate-concentration profile, for selected dates in 1991-92, in unsaturated-zone pore water at the Chino dairy site. 
$1,100,000$ bacteria per gram soil at $1 \mathrm{ft}$ to about 40 bacteria per gram soil at $80 \mathrm{ft}$.

The presence of assimilated denitrifying bacteria at the sites indicates that denitrification might be occurring. As stated in an earlier section, the $\delta^{15} \mathrm{~N}$ value can provide information about whether the nitrate is from a mineral or a biological source, and it also can provide information about whether the nitrate has been altered through microbial processing. The $\delta^{15} \mathrm{~N}$ value for the samples collected from the Hemet dairy site, 13.1 permil (table 5), is consistent with an animal-waste source. The value is significantly higher than 10 permil, suggesting that microbial processing of the nitrate has occurred. The $\delta^{15} \mathrm{~N}$ values for the samples collected from the Chino dairy site (also given in table 5) indicate a trend of increasing $\delta^{15} \mathrm{~N}$ values with depth: 11.4 permil at $5 \mathrm{ft} ; 13.3$ permil at $10 \mathrm{ft}$; and 17.5 permil at all depths greater than $15 \mathrm{ft}$. All the $\delta^{15} \mathrm{~N}$ values are greater than 10 permil, indicating an animal-waste source for the nitrate. The increase in $\delta^{15} \mathrm{~N}$ with depth suggests that as the nitrate moves downward through the unsaturated zone, the nitrate is subjected to more and more microbial processing, until the processing is virtually finished at $15 \mathrm{ft}$. Below this depth, the nitrate concentration stabilized at about $130 \mathrm{mg} / \mathrm{L}$.

The $\mathrm{CO}_{2}$ concentration in the pore gas at the Hemet dairy site (table 4) was $63,800 \mu \mathrm{g} / \mathrm{g}$, considerably higher than would be expected if microbial activity were not occurring. Measurable concentrations of $\mathrm{N}_{2} \mathrm{O}(150 \mu \mathrm{g} / \mathrm{g})$ also were found at this site. These data support the conclusion that microbial denitrification is occurring in the unsaturated zone beneath the Hemet dairy site. The $\mathrm{CO}_{2}$ concentrations at the Chino dairy site ranged from 71,000 to $109,500 \mu \mathrm{g} / \mathrm{g}$, and the $\mathrm{N}_{2} \mathrm{O}$ concentrations were about $240 \mu \mathrm{g} / \mathrm{g}$ at depths less than $50 \mathrm{ft}$. These data support the conclusion that microbial denitrification is occurring in the unsaturated zone beneath the Chino dairy site, as well.

\section{Conclusions}

The aquifer underlying the Hemet dairy site is shallow: The water table is about 10 to $13 \mathrm{ft}$ below land surface, and bedrock is at $42 \mathrm{ft}$. Water quality is poor: Dissolved-solids concentrations exceeded $1,500 \mathrm{mg} / \mathrm{L}$., and nitrate concentrations exceeded $50 \mathrm{mg} / \mathrm{L}$. Because the unsaturated zone is thin, it takes less than 1 year for water to percolate from the land surface to the water table. The presence of a thick clay layer provides most of the retardation to downward flow. Nitrate concentrations in the unsaturated-zone pore water ranged from $300 \mathrm{mg} / \mathrm{L}$ near the surface to about $25 \mathrm{mg} / \mathrm{L}$ below $10 \mathrm{ft}$. On the basis of the presence of suitable bacteria, the alteration in $8^{15} \mathrm{~N}$ values, and the presence of elevated $\mathrm{CO}_{2}$ and $\mathrm{N}_{2} \mathrm{O}$ concentrations, this decrease in nitrate concentration can be attributed to microbial denitrification.

The aquifer underlying the Chino dairy site consists of at least two zones. The shallow zone has good-quality water, in which dissolved-solids concentrations were about $230 \mathrm{mg} / \mathrm{L}$. Nitrate concentrations, at $1.5 \mathrm{mg} / \mathrm{L}$, were relatively low. The deep zone has water of even better quality: Dissolved-solids concentrations were less than $150 \mathrm{mg} / \mathrm{L}$ and nitrate concentrations were less than $1 \mathrm{mg} / \mathrm{L}$. The nitrate from both zones can be attributed to an inorganic source, rather than to animal wastes. The unsaturated-zone percolation rates ranged from 20 to $50 \mathrm{ft} / \mathrm{yr}$, and the time required for water to percolate from the land surface to the water table is estimated to be 3 to 5 years. Nitrate concentrations in the unsaturated-zone pore water were very high, ranging from $7,000 \mathrm{mg} / \mathrm{L}$ near the surface to about $100 \mathrm{mg} / \mathrm{L}$ below $10 \mathrm{ft}$. The decrease in nitrate concentration is attributed to microbial denitrification on the basis of populations of suitable bacteria, the alteration of $\delta^{15} \mathrm{~N}$ values, and the presence of elevated concentrations of $\mathrm{CO}_{2}$ and $\mathrm{N}_{2} \mathrm{O}$ in the soil gas.

\section{SUMMARY}

The residential site is located in a ground-water depression, probably caused by pumping in nearby wells. The water quality in the saturated zone is marginal because of high dissolved-solids concentrations, high nitrate concentrations, and selenium concentrations that exceed the U.S. Environmental Protection Agency Maximum Contaminant Level (MCL). Water quality deteriorates with depth as a result of increases in the concentrations of dissolved solids, nitrate, selenium, and boron. Delta deuterium $(\delta \mathrm{D})$ and delta oxygen$18\left(8^{18} \mathrm{O}\right)$ values suggest that ground water at this site probably is recharged at an altitude not much different from that of the site (the average temperature of recharging water being about $7^{\circ} \mathrm{C}$ ), and that the water is subjected to only minimal evaporation prior to percolation to the water table. Delta nitrogen-15 $\left(\delta^{15} \mathrm{~N}\right)$ data suggest that the nitrate in the saturated zone is from a mineral source, and that the nitrate has undergone some 
microbial cycling prior to reaching the water table.

Unsaturated-zone pore-moisture contents varied and were highest in the fine-grained materials. Moisture content in the unsaturated zone ranged from as low as $\mathbf{5}$ volume percent to as high as 15 volume percent. The tritium profile suggests a percolation rate of about $25 \mathrm{ft} / \mathrm{yr}$ in the shallow unsaturated zone and $63 \mathrm{ft} / \mathrm{yr}$ in the coarse-grained material deeper in the unsaturated zone. On the basis of these rates, and the fact that tritium concentrations were much less than $600 \mathrm{pCi} / \mathrm{L}$, it would take more than 4 and less than 10 years for water to percolate from the ground surface to the water table. A percolation period of 7 years was calculated from the moisture-saturation-index profiles.

Water quality in the pore water in the unsaturated zone is marginal to poor, the dissolvedsolids concentrations ranging from $1,200 \mathrm{mg} / \mathrm{L}$ to more than $6,000 \mathrm{mg} / \mathrm{L}$. The predominant ions in the pore water are sodium and sulfate, and bicarbonate is present in significant concentrations. Nitrate is seasonally present in the shallow unsaturated zone, is absent in the middle unsaturated zone, and is present at high concentrations at about $100 \mathrm{ft}$ below land surface.

Microbial denitrification probably is occurring in the unsaturated zone on the basis of significant populations of denitrifying bacteria, decreasing dissolved organic carbon concentrations with depth, and significantly elevated concentrations of $\mathrm{CO}_{2}$ in the soil gas.

The unsaturated-zone nitrate distribution suggests that the nitrate is not percolating from the surface, but rather has a source that is deep within the unsaturated and (or) saturated zones. Because of this, it is not possible to determine the flux of nitrate reaching the water table at this site.

The reclaimed-water site is located over an aquifer that has two distinct zones. The uppermost zone has poor-quality water, but nitrate concentrations were not elevated. There is a slight upward gradient in the upper zone. The lower zone had water of better quality, and the quality improved with depth. There is a slight downward gradient within the lower zone, and a pronounced downward gradient between the upper and the lower zones. This would imply that poor-quality water from the upper zone is being drawn into the lower zone.

The unsaturated-zone pore-moisture contents varied and were highest in the fine-grained material The tritium profile suggests relatively rapid percolation of water from the land surface to the water table, a transit time of slightly more than 1 year. The transit time estimated from the moisturesaturation-index profiles is 66 days.

The quality of the pore water is poor throughout the unsaturated zone, the dissolved-solids concentrations ranging from 3,000 to $9,000 \mathrm{mg} / \mathrm{L}$. Nitrate is seasonally present in the shallow unsaturated zone and perennially present in the deeper unsaturated zone. A few of the nitrate concentrations exceeded the MCL.

Significant microbial populations and elevated carbon dioxide concentrations suggest that microbial denitrification may be occurring at the site, but the absence of measurable $\mathrm{N}_{2} \mathrm{O}$ precludes a definitive determination. Denitrification seems to be occurring in the capillary fringe, and this denitrification is preventing significant quantities of nitrate from reaching the water table.

The citrus grove site is located over an aquifer that has two distinct zones. The uppermost zone has relatively good-quality water, but nitrate concentrations were high. The lower zone has better quality water, and nitrate concentrations were below the MCL. There seems to be no significant hydraulic gradient between the two zones, and it is unlikely that water from the two zones is mixing appreciably at this time.

The unsaturated-zone pore-moisture contents varied and were highest in natural capillary barriers at the interfaces of coarse-grained materials (gravels and cobbles) and fine-grained materials. There are no extensive clay layers underlying this site, and it is likely, given enough time, that water can percolate from the land surface to the water table. The unsaturated-zone pore water has very high nitrate concentrations, and nitrate seems to be migrating downward through the unsaturated zone. Active microbial denitrification is occurring, however, in some zones. The tritium data indicate an estimated unsaturated-zone percolation rate between 25 and $160 \mathrm{ft} / \mathrm{yr}$. These rates would yield an unsaturatedzone transit time of 5 to 10 years. The moisturesaturation-index profiles suggest a transit time of 5 years.

The irrigated-farm site is located on a groundwater divide, and ground water flows to the north and the southeast. There is an 8-foot downward gradient between the $212 \mathrm{ft}$ well and the $300 \mathrm{ft}$ well. 
Ground-water quality is fairly good, although boron concentrations are elevated. Water quality deteriorates slightly with depth.

The unsaturated-zone pore moisture varied and was high (nearly saturated) above the confining clay layers and very low directly below the confining clay layers. Because of the perching clays, it was not possible to use the tritium data to determine the unsaturated-zone percolation rates to the water table. Nitrate concentrations in the unsaturated-zone pore water ranged from less than the MCL to about four times the MCL. There is evidence of flushing of nitrate through the unsaturated zone, and ofmicrobial denitrification in several zones beneath the site.

The poultry-farm site is located over an aquifer consisting of two distinct zones. The upper zone has good-quality water and low concentrations of nitrate and boron. The lower zone also has good-quality water and low nitrate concentrations, but the boron concentrations are elevated. There is a pronounced downward gradient between the upper and lower zones.

The unsaturated-zone pore-water quality and tritium profiles could not be adequately addressed because of the very dry conditions in the unsaturated zone beneath the site. However, the pore water contains significant concentrations of nitrate, and there is contradictory evidence regarding microbial denitrification in the unsaturated zone. There seems to be a subzone within the unsaturated zone that is being recharged from offsite, and unsaturated-zone moisture contents have increased dramatically in that smaller zone during the course of this study. On the basis of the moisture-saturation-index profiles, it is estimated that the time required for water to percolate from land surface to the water table is 27 years.

The aquifer underlying the Hemet dairy site is shallow: The water table is about 10 to $13 \mathrm{ft}$ below land surface, and bedrock is at $42 \mathrm{ft}$. Water quality is poor; dissolved-solids concentrations exceeded $1,500 \mathrm{mg} / \mathrm{L}$, and nitrate concentrations exceeded $50 \mathrm{mg} / \mathrm{L}$. Because the unsaturated zone is thin, it takes less than 1 year for water to percolate from the land surface to the water table. A thick clay layer provides most of the retardation of downward flow. Nitrate concentrations in the unsaturated-zone pore water ranged from $300 \mathrm{mg} / \mathrm{L}$ near the surface to about $25 \mathrm{mg} / \mathrm{L}$ below $10 \mathrm{ft}$. This decrease in nitrate concentration is attributed to microbial denitrification, on the basis of the presence of suitable bacteria, the alteration in $8^{15} \mathrm{~N}$ values, and the presence of elevated $\mathrm{CO}_{2}$ and $\mathrm{N}_{2} \mathrm{O}$ concentrations.

The aquifer underlying the Chino dairy site consists of at least two zones. The shallow zone has good-quality water, in which dissolved-solids concentrations were about $230 \mathrm{mg} / \mathrm{L}$. Nitrate concentrations, at $1.5 \mathrm{mg} / \mathrm{L}$, were relatively low. The deep zone has water of even better quality: dissolved-solids concentrations were less than $150 \mathrm{mg} / \mathrm{L}$ and nitrate concentration was less than $1 \mathrm{mg} / \mathrm{L}$. The nitrate from both zones can be attributed to an inorganic source, rather than to animal wastes. The unsaturated-zone percolation rates ranged from 20 to $50 \mathrm{ft} / \mathrm{yr}$, and the time required for water to percolate from the land surface to the water table is estimated, on the basis of the tritium profiles, to be 3 to 5 years. The moisturesaturation-index profiles yield an estimate of 4.2 years. The unsaturated-zone pore water has very high nitrate concentrations, ranging from $7,000 \mathrm{mg} / \mathrm{L}$ near the surface to about $100 \mathrm{mg} / \mathrm{L}$ below $10 \mathrm{ft}$. The nitrate concentration diminution is attributed to microbial denitrification on the basis of the presence of populations of suitable bacteria, the alteration of $8^{15} \mathrm{~N}$ values, and the presence of elevated concentrations of $\mathrm{CO}_{2}$ and $\mathrm{N}_{2} \mathrm{O}$ in the soil gas.

\section{REFERENCES CITED}

Adams, J.A., Campbell, A.S., McKeegan, W.R., McPherson, R.J., and Tonkin, P.H., 1979, Nitrate and chloride in ground-water, surface water and deep soil profiles of central Canterbury, New Zealand: Progress in Water Technology, v. 11, p. 351-360.

Adelman, D.D., Schroeder, W.J., Smaus, R.J., and Wallin, G.P., 1985, Overview of nitrate in Nebraska's ground water: Transaction of the Nebraska Academy of Sciences, v. 13, p. 75-81.

Adriano, D.C., Pratt, P.F., Bishop, S.E., 1971, Fate of inorganic forms of $\mathrm{N}$ and salt from land-disposed manures from dairies, in Livestock Waste Management and Pollution Abatement, Proceedings International Symposium on Livestock Wastes, April 19-22, 1977, St. Joseph, Missouri: American Society of Agricultural Engineers, p. 243-246. 
Adriano, D.C., Pratt, P.F. Takatori, F.H., 1972, Nitrate in unsaturated zone of an alluvial soil in relation to fertilizer nitrogen rate and irrigation level: Journal of Environmental Quality. v. 1, p. 418-422.

Amundson, R.G., and Davidson, E.A., 1990, Carbon dioxide and nitrogenous gases in the soil atmosphere: Journal of Geochemical Exploration, v. 38, p. $13-41$.

Anderson, I.C., and Levine, J.S., 1986, Relative rates of nitric oxide and nitrous oxide production by nitrifiers, denitrifiers, and nitrate respirers: Applied and Environmental Microbiology, v. 51, p. 938-945.

Anton, E.C., Barnickol, J.L., and Schnalble, D.R., 1988, Nitrate in drinking water--Report to the Legislature: Report No. 88-11WQ, Sacramento, California, Division of Water Quality, State Water Resources Control Board, $148 \mathrm{p}$.

Arya, L.M., and Paris, J.F., 1981, A physicoempirical model to predict the soil moisture characteristics from particle-size distribution and bulk density data: Soil Science Society of America Journal, v. 45, p. 1023-1030.

Ayers, R.S., 1978, A case study--Nitrates in the upper Santa Ana River basin in relation to groundwater pollution, in Proceedings of the National Conference on Management of Nitrogen in Irrigated Agriculture, May 15-18, 1978, Sacramento, California: Washington, D.C., U.S. Environmental Protection Agency, National Science Foundation, and University of California, p. 355-367.

Ayers, R.S., and Branson, R.L., eds., 1973, Nitrates in the upper Santa Ana River basin in relation to groundwater pollution: California Agricultural Experiment Station Bulletin 861, University of California, $60 \mathrm{p}$.

Bachman, L.J., 1984, Nitrate in the Columbia aquifer, central Delmarva Peninsula, Maryland: U.S. Geological Survey Water-Resources Investigations Report 84-4322, $51 \mathrm{p}$.

Baier, J.H., and Rykbost, K.A., 1976, The contribution of fertilizer to the ground water of Long Island: Ground Water v. 14, p. 439-448.
Barton, C., Vowinkel, E.F., and Nawyn, J.P., 1987, Preliminary assessment of water quality and its relation to hydrogeology and land use: Potomac-Raritan-Magothy Aquifer system, New Jersey, U.S. Geological Survey Water-Resources Investigations Report 87-4023, $79 \mathrm{p}$

Biehler, S., and Lee, T.C., 1993, Subsurface structure of the Hemet Basin, Riverside County, California, a geophysical study: Department of Earth Sciences, University of California, Riverside, California, $41 \mathrm{p}$.

Bingham, F.T., Davis, S., and Shade, E.,1970, Water relations, salt balance, and nitrate leaching losses of a 960-acre citrus watershed: Soil Science, v. 112, p. $410-418$.

Bohlke, J.K., Denver, J.M., Phillips, P.J. Gwinn, C.J. Plummer, L.N., Busenberg, E., Dunkle, S.A., 1992, Combined use of nitrogen isotopes and ground water dating to document nitrate fluxes and transformations in small agricultural watersheds, Delmarva Peninsula, Maryland: Proceedings of the 1992 American Geophysical Union meeting

Bouton, D., and Froment, P., 1985, Mise en evidence de zones aquiferes a faibles teneurs en nitrates en Champagne crayeuse Vallees de l'Aube et de la Seine--Etat de la situation, hypoteses de travail, methodolgie d'etude: Hydrogeologie, v. 4, p. 285291.

Britton, L.J., and Greeson, P.E., 1987, Methods for collection and analysis of aquatic biological and microbiological samples: Techniques for WaterResources Investigations of the United States Geological Survey, Book 5, Chapter A4, p. 61-67.

Bulgar, P.R., Kehew, A.E., and Nelson, R.A., 1989, Dissimilatory nitrate reduction in a waste-water contaminated aquifer: Ground Water, v. 27, p. 664671.

Chen, H.H., and Druliner, A.D., 1987, Nonpoint-source agricultural chemicals in ground water in Nebraska-Preliminary results for six areas of the High Plains Aquifer: U.S. Geological Survey Water-Resources Investigations Report 86-4338, $68 \mathrm{p}$.

Cohenour, D.H., and Knox, R.C., 1990, Nitrate contamination in the central Oklahoma aquifer system: Ground Water Management, v. 1, p. 33-49. 
Comly, H.R., 1945, Cyanosis in infants caused by nitrates in well water: Journal of the American Medical Association, v. 129 , p. $112-116$

Craig, Harmon, 1961, Isotopic variations in meteoric waters: Science, v. 133, p. 1702-1703.

Dansgaard, W., 1964, Stable isotopes in precipitation: Tellus, v. 16, p. 436-469.

Detroy, M.G., Clark, M.L., Holub, M.A., and Hunt, P.K.B., 1990, Water quality of the alluvial aquifers, Carroll and Guthrie Counties, Iowa, with emphasis on the occurrence of nitrate and pesticides, 1986-87: U.S. Geological Survey Water-Resources Investigations Report 89-4186, 52 p.

Detroy, M.G., Hunt, P.K.B., and Holum, M.A., 1988, Ground water quality monitoring program in Iowa: Nitrate and pesticides in shallow aquifers: U.S. Geological Survey Water-Resources Investigations Report 88-4123, 31 p.

Duell, L.F.W., and Schroeder, R.A., 1989, Appraisal of ground-water quality in the Bunker Hill Basin of San Bernardino Valley, California: U.S. Geological Survey Water-Resources Investigations Report 884203, 69 p.

Eastern Municipal Water District, 1988, Alternate "B" San Jacinto Basin Plan Update Brief Task Report Update Planning Area Data (3.1): San Jacinto, California, Eastern Municipal Water District.

Eccles, L.A., 1979, Ground-water quality in the upper Santa Ana River basin, southern California: U.S. Geological Survey Water-Resources Investigations Report 79-113, California, 51 p.

Eccles, L.A., and Bradford, W.L., 1977, Distribution of nitrate in ground water, Redlands, California: U.S. Geological Survey Water Resources Investigations Report 76-117, 38 p.

Eccles, L.A., and Klein, J.M., 1978, Distribution of dissolved nitrate and fluoride in ground water, Highland-East Highlands, San Bernardino County, California: U.S. Geological Survey Water-Resources Investigations Report 78-14, 42 p.

Eccles, L.A., Klein, J.M., and Hardt, W.F., 1976, Abatement of nitrate pollution in a public-supply well by analysis of hydrologic characteristics: Ground Water, v. 14, p. 449-454.
Eckhardt, D.A.V., Flipse, W.J., and Oaksford, E.T., 1989, Relation between land use and ground water quality in the upper glacial aquifer in Nassau and Suffolk Counties, Long Island, New York: U.S. Geological Survey Water-Resources Investigations Report 86-4142, 35 p

Edwards, D.D., Bartholomay, R.C., and Bennet, C.M., 1990 , Nutrients, pesticides, surfactants, and trace metals in ground water from the Howe and Mud Lake areas upgradient from the Idaho National Engineering Laboratory, Idaho: U.S. Geological Survey Open-file Report 90-565, 19 p.

Embleton, T.W., Pallares, C.O., Jones, W.W., Summers, L.L., and Matsumura, M., 1980, Nitrogen fertilizer management of vigorous lemons and nitratepollution potential of groundwater: California Water Resources Center Contribution No. 182, University of California, Davis.

Englund, J.O., and Haldorsen, S., 1986, Profiles of nitrogen species in a sand-silt aquifer at Haslemoen, Solor, South Norway: Nordic Hydrology, p. $295-$ 403.

Feder, G.L., 1986, Hydrogeologic controls on nitrogen species in ground and surface waters, in Gorelick, S.M., ed., Conjunctive Water Use: Proceedings of the Budapest Symposium, July 1986, IAHS Publication No. 156, p. 211-215.

Firestone, M.K., Firestone, R.B., and Tiedje, J.M., 1980, Nitrous oxide from soil denitrication: Factors controlling its biological production: Science, v. 208 , p. $749-751$.

Foster, S.S.D., and Bath, A.H., 1986, The distribution of agricultural soil leachates in the unsaturated zone of the British Chalk: International Contributions to Hydrogeology, v. 5, p. 271-295.

Geake A.K., and Foster, S.S.D., 1989, Sequential isotope and solute profiling in the unsaturated zone of British Chalk: Journal of Hydrological Sciences, v. 34, p. $79-95$.

Gilliam, J.W., Dasberg, S., Lund, L.J., and Focht D.D., 1978, Denitrification in four California soils: Effect of soil profile characteristics: Journal of the Soil Science Society of America, v. 42, p. 61-66. 
Goreau, T.J., Kaplan, W.A., Wofsy, S.C., McElroy, M.B., Valois, F.W., and Watson, S.W., 1980, Production of $\mathrm{NO}_{2}{ }^{-}$and $\mathrm{N}_{2} \mathrm{O}$ by nitrifying bacteria at reduced concentrations of oxygen: Applied and Environmental Microbiology, v. 40, p. 526-532

Gosselin, D.C., 1991, Bazile Triangle groundwater quality study: Nebraska Water Survey Paper No. 68, University of Nebraska, Lincoln, 27 p.

Guy, H.P., 1969, Laboratory theory and methods for sediment analysis: Techniques for Water Resources Investigations of the United States Geological Survey, Book 5, Chapter Cl, $58 \mathrm{p}$.

Hagebro, C., Bang, S., and Somer, E., 1983, Nitrate load/discharge relationships and nitrate load trends in Danish rivers, in Dissolved Loads of Rivers and Surface Water Quantity/Quality Relationships: Proceedings of the Hamburg Symposium, August 1983, IAHS Publication No. 141, p. 377-386.

Hallberg, G.R., 1990, Nitrates in Iowa groundwater: in Rural Ground Water Contamination, p. 23-68.

Hamilton, P.A., Shedlock, R.J., and Phillips, P.J., 1991, Water quality assessment of the DelMarVa Peninsula, Delaware, Maryland, and Virginia-Analysis of available ground water quality data through 1987: U.S. Geological Survey WaterSupply Paper 2355, $65 \mathrm{p}$

Heaton, T.H.E., 1984, Sources of the nitrate in phreatic groundwater in the western Kalahari: Journal of Hydrology, v. 67, p. 249-259.

Hill, A.R., 1982, Nitrate distribution in the ground water of the Alliston region of Ontario, Canada: Ground Water, v. 120 , p. 696-702.

Ho, G.E., Mathew, K., Newman, P.W.G., 1991, Modeling of nitrogen removal in the vadose zone, in Durham, N.N., Redelfs, A.E., Eds., Second International Conference on Ground Water Quality Research: University Center for Water Research, Stillwater, Oklahoma, Oklahoma State University, p. 112-114.

Howard, K.W.F., 1985, Denitrification in a major limestone aquifer: Journal of Hydrology, v. 76, p. 265-280.
Hughes, J.L., and Robson, S.G., 1974, Effects of waste percolation on groundwater in alluvium near Barstow California, in Brounstein, J., Ed., Underground Waste Management and Artificial Recharge: Washington, D.C., The American Association of Petroleum Geologists, United States Geological Survey, International Association of Hydrological Sciences, v. 1, p. 91-129.

Jacobs, H.S., 1990, Fiscal Year 1989 Program Report Grant No. 14-08-0001-G1563 for U.S. Department of the Interior Geological Survey: Kansas Water Resource Research Institute, Manhattan, Kansas, $5 \mathrm{p}$.

Johansson, C., and Galbally, I.E., 1984, Production of nitric oxide in loam under aerobic and anaerobic conditions: Applied and Environmental Microbiology, v. 47, p. 1284-1289.

Jones, D.C., 1973, An investigation of the nitrate problem in Runnels County, Texas: Environmental Protection Agency Report EPA-R2-73-267, Washington, D.C., 214 p.

Kanfi, Y., Ronen, D., and Magaritz, M., 1983, Nitrate trends in the coastal plain aquifer of Israel: Journal of Hydrology, v. 66, p. 331-341.

Kastrinos, J.R., and White, W.B., 1989, Seasonal, hydrogeologic, and land use controls on nitrate contamination of carbonate ground waters, in Procedings of the Environmental Problems in Karst Terrains and their Solutions Conference, October 28-30, 1986: Bowling Green, Kentucky, p. 88-114.

Keeley, G.M., and Quin, B.F.,1979, The effects of irrigation with meatworks-fellmongery effluent on water quality in the unsaturated zone and shallow aquifer: Progress in Water Technology, v. 11, p. $369-386$.

Keeney, D., 1990, Sources of nitrate to ground water: Critical Reviews in Environmental Control, v. 16, p. 257-304.

Kimmell, G.E., 1984, Nonpoint contamination of groundwater on Long Island, New York, in Groundwater Contamination: National Research Council, Washington, D.C., p. 120-126.

Klein, J.M., and Bradford, W.L., 1980, Distribution of nitrate in the unsaturated zone, Highland-East Highlands area, San Bernardino County, California: U.S. Geological Survey Water-Resources Investigations Report 80-48, 70 p. 
Klein, J.M., and Bradford, W.L., 1979, Distribution of nitrate and related nitrogen species in the unsaturated zone, Redlands and vicinity, San Bernardino County, California: U.S. Geological Survey Water-Resources Investigations Report 79$60,81 \mathrm{p}$.

Kolle, W., Werner, P., Strebel O., and Bottcher, J., 1983, Denitrifikation in einem reduzierenden: Grundwasserleiter Vom Wasser, 61 Band, p. 125147.

Kosmas, C., Moustakas, N., Kallianou, C., and Yassoglou, N., 1991, Cracking patterns, bypass flow and nitrate leaching in Greek irrigated soils: Geoderma, v. 49 p. 139-152.

Kreitler, C.W., and Jones, D.C., 1975, Natural soil nitrate: The cause of the nitrate contamination of ground water in Runnels County, Texas: Ground Water, v. 13, p. 53-61.

Ku, H.F.H., and Sulam, D.J., 1976, Distribution and trend of nitrate, chloride, and total solids in water in the Magothy aquifer in southeast Nassau County, New York, from the 1950's through 1973: U.S. Geological Survey Water-Resources Investigations Report 76-44, $47 \mathrm{p}$.

Lahl, U., Zeschmar, B., Gabel, B., Kozicki, R., Podbielski, A., Stachel, B., and Struss, S., 1983, Ground water pollution by nitrate, in Proceedings of the Ground Water in Water Resources Planning Conference, Koblenz, Federal Republic of Germany, 28 August-3 September 1983: p. 1159-1184.

Langdale, G.W., Leonard, R.A., Fleming, W.G., and Jackson, W.A., 1979, Nitrogen and chloride movement in small upland Piedmont watersheds: I. Nitrate and chloride distribution in soil profiles: Journal of Environmental Quality, v. 8, p. 49-57.

Lawrence, A.R, and Foster, S.S.D., 1986, Denitrification in a limestone aquifer in relation to the security of low-nitrate ground water supplies: Journal of the Institution of Water Engineers and Scientist, v. 40, p. 159-172.

Lewis, B.D, Custer, S.G., and Miller, M.R., 1979, Saline-seep development in the hailstone basin, northern Stillwater County, Montana: U.S. Geological Survey Water-Resources Investigations Report 79-107, 32 p.
Lipschultz, F., Zafiriou O.C., Wofsy, S.C., McElroy, M.B., Valois, F.W., and Watson, S.W., 1981, Production of $\mathrm{NO}$ and $\mathrm{N}_{2} \mathrm{O}$ by soil nitrifying bacteria: Nature, v. 294, p. 641-643

Lloyd, D., Boddy, L., and Davies, K.J.P., 1987, Persistence of bacterial denitrification capacity under aerobic conditions: the rule rather than the exception: Microbiology Ecology, v. 45, p. 185-190.

Lund, L.J., Adriano, D.C., and Pratt, P.F., 1974, Nitrate concentrations in deep soil cores as related to soil profile characteristics: Journal of Environmental Quality, v. 3, p. 78-82.

Lund, L.J., Page, A.L., Nelson, C.O., and Elliott, R.A., 1981, Nitrogen balances for an effluent irrigation area: Journal of Environmental Quality, v. 10, p. 349-352.

Metropolitan Water District of Southern California, 1987, Groundwater quality and its impact on water supply in the Metropolitan Water District service area: Report No. 969, Los Angeles, Metropolitan Water District of Southern California, $45 \mathrm{p}$.

Metropolitan Water District of Southern California, 1990, Metropolitan's role in the development of groundwater in Southern California: Los Angeles, Metropolitan Water District Of Southern California.

Miller, J.C., 1972, Nitrate contamination of the water table aquifer in Delaware: Delaware Geological Survey Report of Investigations No. 20, 47 p.

Morris, J.T., Whiting, G.J., and Chapelle, F.H., 1988, Potential denitrification rates in deep sediments from the southeastern coastal plain: Environmental Science and Technology, v. 22, p. 832-836.

Moyle, W.R., Jr., 1976, Geohydrology of the AnzaTerwilliger area, Riverside County, California: U.S. Geological Survey Water-Resources Investigations Report 76-10, 25 p.

Mualem, Y., 1976, A new model for predicting the hydraulic conductivity of unsaturated porous media: Water Resources Research, v. 12, p. 513-522.

National Oceanic and Atmospheric Administration, 1991, Climatological Data annual summary, California, 1991: v. 95, p. 12-13. 
National Pesticide Survey, 1992, National Pesticide Survey: Phase II Report, Environmental Protection Agency Report No. EPAV09-91-020, Washington, D.C., $166 \mathrm{p}$

National Pesticide Survey, 1990, National Pesticide Survey: Phase I Report, Environmental Protection Agency Report EPA570/9-90-015, Washington, D.C., 235 p.

National Research Council, 1978, Nitrates: An environmental assessment: Washington, D.C. National Academy of Sciences, 723 p.

Parkhurst, D.L., Christenson, S.C., and Schlottmann, J.L., 1989, Ground water quality assessment of the central Oklahoma aquifer, Oklahoma--Analysis of available water quality data through 1987: U.S. Geological Survey Open-File Report 88-728, 80 p.

Patt, R.O., and Hess, J.W., 1976, Characterization of nitrogen sources contaminating shallow ground water in an arid basin, Las Vegas area, Nevada: Technical Report Series H-W, Hydrology and Water Resources Publication No. 26, Desert Research Institute, Nevada, 44 p.

Pedersen, J.K., Bjerg, P.L., and Christensen T.H., 1991, Correlation of nitrate profiles with groundwater and sediment characteristics in a shallow sandy aquifer: Journal of Hydrology, v. 124, p. 263-277.

Pekny, V., Skorepa, J, and Vrba, J., 1989, Impact of nitrogen fertilizers on groundwater quality--some examples from Czechoslovakia: Journal of Contaminant Hydrology, v. 4, p. 51-67.

Pimir, S.M., 1989, NPS pollution impact of agricultural chemicals, in Proceedings of the Non-Point Source Pollution Control Workshop, Irvine, California, July 25-28, 1989: Midvale, Utah, Western States Water Council, p. 1-D-1 to 1-D-5.

Piskin, R., 1973, Evaluation of nitrate content of ground water in Hall County, Nebraska: Ground Water, v. 11 , p. $4-13$.

Poth, M., Focht, D.D., $1985,{ }^{15} \mathrm{~N}$ Kinetic analysis of $\mathrm{N}_{2} \mathrm{O}$ production by Nitrosomonas europea: An examination of nitrifier denitrification: Applied and Environmental Microbiology, v. 49, p. 1134-1141.

Pratt, P.F., and Adriano, D.C., 1973, Nitrate concentrations in the unsaturated zone benath irrigated fields in southern California: Soil Science Society of America, Proceedings, v. 37, p. 321-322.
Pratt, P.F., Broadbent, F.E., McLaren, A.D., Nielsen, D.R., Stolzy, L.H., and Stout, P.R., 1976, Nitrate in effluents from irrigated lands: Annual Report to the National Science Foundation for Grant Nos. GI34733X, GI43664, and AEN74-11136 A01, University of California, 280 p.

Pratt, P.F., Jones, W.W., and Hunsaker, V.E., 1972 , Nitrate in deep soil profiles in relation to fertilizer rates and leaching volume: Journal of Environmental Quality, v. 1, p. 97-102.

Ragone, S.E., Katz, B.G., Kimmel, G.E., and Lindner, J.B., 1980, Nitrogen in ground water and surface water from sewered and unsewered areas, Nassau County, Long Island, New York: U.S. Geological Survey Water-Resources Investigations Report 8021,72 p.

Reeves, C.C., and Miller, W.D., 1978, Nitrate, chloride, and dissolved solids, Ogallala aquifer, west Texas: Ground Water, v. 16, p. 167-173.

Rima, D.R., Moran, M.S., and Woods, E.J., 1978, Ground water supplies in the Murfreesboro area, Tennessee: U.S. Geological Survey WaterResources Investigations Report 77-86, 76 p.

Rodelsperger, M., 1989, Natural denitrification process in the aquifer, in Kobus, H.E., and Kinzelbach, W. eds., Contaminant Transport in Groundwater: Rotterdam, A.A. Balkema, p 159-161.

Ronen, D., and Margaritz, M., 1985, High concentration of solutes at the upper part of the saturated zone (water table) of a deep aquifer under sewage irrigated land: Journal of Hydrology, v. 80, p. 311 323.

Ryden, J.C., 1983, Denitrification loss from a grassland soil in the field receiving different rates of nitrogen as ammonium nitrate: Journal of Soil Science, v. 34, p. 355-365.

Schaller, F., and Bailey, G., eds., 1983, Agricultural Management and Water Quality: Ames, Iowa, Iowa State University Press, p. 261.

Schmidt, K.D., 1974, Nitrates in ground water management in the Fresno urban area: Journal of the American Water Works Association, March 1974, p. 146-148.

Schmidt, K.D., 1972, Nitrate in ground water of the Fresno-Clovis metropolitan area, California: Ground Water, v. 10, p. 50-61. 
Schmidt, K.D., and Sherman, I., 1987, Effect of irrigation on groundwater quality in California: Journal of Irrigation and Drainage Engineering, v. 113, p. 1629.

Schuman, G.E., McCalla, T.M., Saxton, K.E., and Knox, H.T., 1975, Nitrate movement and its distribution in the soil profile of differentially fertilized corn watersheds: Soil Science Society of America Proceedings, v. 39, p. 1192-1197.

Shevah, Y., and Waldman, M., 1989, Advances in management of fertilizer application and the resulting effect on the pollutant load in soil, in Bar-Yosef, B., Barrow, N.J., and Goldshmid J., Eds., Inorganic Contaminants in the vadose zone: New York, Springer-Verlag, p. 179-189.

Silver, B.A., and Fielden, J.R., 1980, Distribution and probable source of nitrate in ground water at Paradise Valley, Arizona: Ground Water, v. 18, p. 244.

Singh, B., and Sekhon, G.S., 1976, Some measures of reducing leaching loss of nitrates beyond potential rooting zone. Proper co-ordination of nitrogen splitting with water management: Plant and Soil, v. 44, p. $193-200$.

Slater, J.M., and Capone, D.G., 1987, Denitrification in aquifer soil and nearshore marine sediments influenced by groundwater nitrate: Applied and Environmental Microbiology, v. 53, p. 1292-1297.

Smith, K.A., and Arah, J.R.M., 1990, Losses of nitrogen by denitrification and emissions of nitrogen oxides from soils: Proceedings of the Fertiliser Society in London, v. 299, p. 3-34.

Smith, R.L., and Duff, J.H., 1988, Denitrification in a sand and gravel aquifer: Applied and Environmental Microbiology, v. 54, p. 1071-1078.

Smith, R.L., Howes, B.L., and Duff, J.H., Denitrification in nitrate-contaminated groundwater: Occurrence in steep vertical geochemical gradients: Geochimica et Cosmochimica Acta, v. 55, p. 1815-1825.

Soren, J., 1978, Hydrogeologic conditions in the town of Shelter Island, Suffolk County, Long Island, New York: U.S. Geological Survey Water-Resources Investigations Report 77-77, 28 p.
Spalding, ME., 1984, Implication of temporal variations and vertical stratification of groundwater nitratenitrogen in the Hall County Special Use Area: Nebraska Water Resources Center Report No. G854-06, University of Nebraska, $33 \mathrm{p}$

Spalding, R.F., and Kitchen, L.A., 1988, Nitrate in the intermediate vadose zone beneath irrigated cropland: Ground Water Monitoring Review, v. VIII, no. 2, p. 89-95.

Spencer, H.A., McGuire, J., Morton, R.K., 1990, Eastern Municipal Water District report on groundwater basins in the San Jacinto River and Santa Margarita River areas: Eastern Municipal Water District, San Jacinto, California, 68 p.

Starr, R.C., and Gillham, R.W., 1989, Controls on denitrification in shallow unconfined aquifers, in Kobus, H.E., Zinzenbach, W., eds., Contaminant Transport in Groundwater: Rotterdam, Balkema, p. 51-56.

Stewart, B.H., ed., Control of water pollution from cropland: A manual for guideline development, Volume 1: U.S. Environmental Protection Agency, Department of Agriculture, Washington, D.C., 27 p.

Stullken, L.E., Stamer, J.K., and Carr, J.E., 1987, Reconnaissance of water quality in the High Plains Aquifer beneath agricultural lands, south-central Kansas: U.S. Geological Survey Water-Resources Investigations Report 87-4003, 25 p.

Sylvester, M.A., 1983, Land application of wastewater and its effect on ground water quality in the Livermore-Amador Valley, California: U.S. Geological Survey Water Resources Investigations Report, 58 p.

Taghavi, S.A., Marino, M.A., and Howitt, R.E., 1988, Conjunctive use study of ground water and surface water in the Chino Basin, California: 15th Annual National Specialty Conference, Water Resources Planning and Management Division, American Society of Civil Engineers, Norfolk, Virginia, extended abstract, $2 \mathrm{p}$.

Trudell, M.R., Gillham, R.W., and Cherry, J.A., 1986, An in-situ study of the occurrence and rate of denitrification in a shallow unconfined sand aquifer: Journal of Hydrology, v. 83, p. 251-268. 
U.S. Environmental Protection Agency, 1990, Drinking Water Regulations and Health Advisories: Washington, D.C., Office of Drinking Water: U.S. Environmental Protection Agency.

Verstraete, W., Nitrification, in Clark, F.E., and Rosswall, T., eds., Terrestrial Nitrogen Cycles, Processes, Ecosystem Strategies, and Management Impacts: Ecological Bulletin, v. 33, Stockholm, Swedish Natural Science Research Council, p. 303.

Waller, B.G., 1983, Effects of land use on ground water quality in the east Everglades, Dade County, Florida: U.S. Geological Survey Water-Resources Investigations Report 82-4093, 67 p.

Wehmeyer, L.K., 1988, Denitrification and nitrate movement in the shallow alluvial aquifer of the West Des Moines River, Palo Alto County, Iowa: Geological Society of America Abstracts, 1988, p. 394.

Wehmeyer, L.K., 1988, Denitrification and nitrate movement in the shallow alluvial aquifer of the West Des Moines River, Palo Alto County, Iowa: M.S. thesis, University of Iowa, $129 \mathrm{p}$.

Wellings, S.R., and Bell, J.P., 1980, Movement of water and nitrate in the unsaturated zone of upper chalk near Winchester, Hants., England: Journal of Hydrology, v. 48, p. 119-136.

Whitelaw, K., and Rees, J.F., 1980, Nitrate reducing and ammonium oxidizing bacteria in the vadose zone of the Chalk Aquifer of England: Journal of Geomicrobiology, v. 2, p. 179-187.

Young, C.P., 1981, The distribution and movement of solutes derived from agricultural land in the principal aquifers of the United Kingdom, with particular reference to nitrate: Water Science and Technology, v. 13, p. 1137-1152.

Young, C.P., and Morgan-Jones, M., 1980, A hydrogeochemical survey of the chalk groundwater of the Banstead area, Surrey, with particular reference to nitrite: Journal of the Institution of Water Engineers and Scientists, v. 34, p. 213-236.

Zafiriou, O.C., Hanley, Q.S., and Snyder, G., 1989, Nitric oxide and nitrous oxide production and cycling during dissimilatory nitrite reduction by Pseudomonas perfectomarina: The Journal of Biological Chemistry, v. 264, p. 5694-5699.
Zakosek, H., and Zepp, H., 1988, Water and solute movement in the soil and underground, in Maltby, E., and Wollersen, T., Eds., Soils and their Management: A Sino-European Perspective: New York, Elsevier Applied Science, p. 183-200

Zwirnmann, K.H., 1982, Nonpoint nitrate pollution of municipal water supply sources: Issues of analysis and control: IIASA Collaborative Proceedings Series CP-82-S4, International Institute for Applied Systems Analysis, Laxenburg, Austria, 303 p. 
Supplemental Data 1. Water levels in monitoring network wells, 1990-92

[Water level: altitude, in feet above sea level. Location of sites shown in figure 3]

\begin{tabular}{|c|c|c|c|c|c|c|c|c|c|c|c|}
\hline $\begin{array}{l}\text { Site } \\
\text { No. }\end{array}$ & $\begin{array}{l}\text { State } \\
\text { well } \\
\text { No. }\end{array}$ & Date & $\begin{array}{c}\text { Water } \\
\text { level }\end{array}$ & $\begin{array}{l}\text { Site } \\
\text { No. }\end{array}$ & $\begin{array}{c}\text { State } \\
\text { well } \\
\text { No. }\end{array}$ & Date & $\begin{array}{l}\text { Water } \\
\text { level }\end{array}$ & $\begin{array}{l}\text { Site } \\
\text { No. }\end{array}$ & $\begin{array}{c}\text { State } \\
\text { well } \\
\text { No. }\end{array}$ & Date & $\begin{array}{c}\text { Water } \\
\text { level }\end{array}$ \\
\hline \multirow[t]{4}{*}{35} & $4 \mathrm{~S} .1 \mathrm{~W}-7 \mathrm{H} 1$ & $06-27-91$ & 1,356 & 55 & $5 S / 1 W-17 F 2$ & $04-19-91$ & 1,359 & 67 & $5 \mathrm{~S} / 2 \mathrm{~W}-25 \mathrm{C} 2$ & $05-09-91$ & 1,436 \\
\hline & & $12-24-91$ & 1,364 & & & $12-24-91$ & 1,353 & & & $12-23-91$ & 1,435 \\
\hline & & $04-29-92$ & 1,370 & & & $04-30-92$ & 1,349 & & & $07-08-92$ & 1,437 \\
\hline & & $07-06-92$ & 1,367 & & & $05-15-92$ & 1,357 & 68 & $5 \mathrm{~S} / 2 \mathrm{~W}-25 \mathrm{~J} 1$ & $05-09-91$ & 1,428 \\
\hline \multirow[t]{2}{*}{36} & $4 \mathrm{~S} / 1 \mathrm{~W}-17 \mathrm{~K} 3$ & $06-27-91$ & 1,393 & & & $07-08-92$ & 1,352 & & & $12-24-91$ & 1,423 \\
\hline & & $07-06-92$ & 1,397 & 56 & 5S/1W-18P1 & $05-09-91$ & 1,401 & & & $07-08-92$ & 1,431 \\
\hline \multirow[t]{2}{*}{37} & 4S/1W-27P5 & $03-07-91$ & 1,352 & & & $07-08-92$ & 1,399 & 69 & $5 \mathrm{~S} / 2 \mathrm{~W}-25 \mathrm{P} 2$ & $12-23-91$ & 1,436 \\
\hline & & $07-08-92$ & 1,354 & 57 & $5 \mathrm{~S} / 1 \mathrm{~W}-20 \mathrm{P} 2$ & $04-19-91$ & 1,377 & & & $04-29-92$ & 1,436 \\
\hline \multirow[t]{3}{*}{38} & $4 \mathrm{~S} / 1 \mathrm{~W}-28 \mathrm{~N} 3$ & $03-07-91$ & 1,337 & & & $02-21-92$ & 1,377 & & & $07-08-92$ & 1,432 \\
\hline & & $12-24-91$ & 1,342 & & & $05-13-92$ & 1,376 & & & & \\
\hline & & $07-07-92$ & 1,331 & & & $07-08-92$ & 1,376 & 70 & $5 \mathrm{~S} / 2 \mathrm{~W}-26 \mathrm{G} 3$ & $06-20-91$ & 1,445 \\
\hline \multirow[t]{2}{*}{39} & $4 \mathrm{~S} / 1 \mathrm{~W}-31 \mathrm{D} 2$ & $03-08-91$ & 1,324 & & & & & & & $12-23-91$ & 1,445 \\
\hline & & $07-06-92$ & 1,320 & 58 & $5 \mathrm{~S} / 1 \mathrm{~W}-27 \mathrm{~F} 1$ & $01-17-91$ & 1,540 & & & $07-08-92$ & 1,446 \\
\hline 40 & $4 \mathrm{~S} / 1 \mathrm{~W}-31 \mathrm{G} 2$ & $06-12-90$ & 1,330 & & & $04-17-92$ & 1,539 & 71 & $5 \mathrm{~S} / 2 \mathrm{~W}-26 \mathrm{~N} 1$ & $06-21-91$ & 1,448 \\
\hline 41 & $4 \mathrm{~S}_{i} 1 \mathrm{~W}-32 \mathrm{C} 3$ & 03-07-91 & 1,335 & & & $07-07-92$ & 1,540 & & & $12-23-91$ & 1,448 \\
\hline 42 & $4 \mathrm{~S} / 1 \mathrm{~W}-32 \mathrm{H} 4$ & $03-07-91$ & 1,335 & 59 & 5S/1W-27Q1 & $01-18-91$ & 1,548 & & & $04-29-92$ & 1,456 \\
\hline 43 & $4 S / 1 W-33 Q 1$ & $06-12-92$ & 1,322 & & & $12-23-91$ & 1,547 & & & $07-08-92$ & 1,452 \\
\hline \multirow[t]{3}{*}{44} & $4 \mathrm{~S} / 2 \mathrm{~W}-13 \mathrm{H} 1$ & $06-12-91$ & 1,223 & & & $04-17-92$ & 1,548 & & & & \\
\hline & & $07-09-92$ & $\left({ }^{1}\right)$ & & & $07-07-92$ & 1,548 & 72 & $5 \mathrm{~S} / 2 \mathrm{~W}-35 \mathrm{D} 1$ & $06-21-91$ & 1,446 \\
\hline & & & & 60 & 5S/1W-27Q2 & $01-18-91$ & 1,548 & & & $12-23-91$ & 1,445 \\
\hline \multirow[t]{4}{*}{45} & $4 \mathrm{~S} / 2 \mathrm{~W}-24 \mathrm{Al}$ & $06-12-90$ & 1,266 & & & $12-22-91$ & 1,548 & & & $07-08-92$ & 1,446 \\
\hline & & $12-24-91$ & 1,264 & & & $04-17-92$ & 1,548 & 73 & $5 \mathrm{~S} / 2 \mathrm{~W}-36 \mathrm{D} 4$ & $06-21-91$ & 1,441 \\
\hline & & $05-15-92$ & 1,266 & & & $07-07-92$ & 1,548 & & & $12-23-91$ & 1,440 \\
\hline & & $07-07-92$ & $\left({ }^{2}\right)$ & & & & & & & $04-29-92$ & 1,441 \\
\hline 46 & $5 \mathrm{~S} / 1 \mathrm{E}-06 \mathrm{~K} 2$ & $03-08-91$ & 1,371 & 61 & $5 \mathrm{~S} / 1 \mathrm{~W}-30 \mathrm{C} 1$ & $05-09-91$ & 1,421 & & & $07-08-92$ & 1,446 \\
\hline \multirow[t]{4}{*}{47} & $5 \mathrm{~S} / 1 \mathrm{E}-07 \mathrm{~K} 1$ & $03-08-91$ & 1,397 & & & $12-23-91$ & 1,421 & & & & \\
\hline & & $12-23-91$ & 1,388 & & & $04-29-92$ & 1,423 & 74 & $6 \mathrm{~S} / 1 \mathrm{~W}-3 \mathrm{M} 1$ & $04-19-91$ & 1,587 \\
\hline & & $05-13-92$ & 1,386 & & & $07-08-92$ & 1,423 & & & $12-19-91$ & 1,584 \\
\hline & & $07-06-92$ & 1,385 & 62 & $5 \mathrm{~S} / 1 \mathrm{~W}-30 \mathrm{E} 2$ & $05-09-91$ & 1,426 & & & $12-23-91$ & 1,584 \\
\hline \multirow[t]{2}{*}{48} & 5S/1E-07Q2 & $03-05-91$ & 1,523 & & & $02-04-92$ & 1,426 & & & $04-17-92$ & 1,586 \\
\hline & & & & & & $04-30-92$ & 1,427 & & & $07-07-92$ & 1,584 \\
\hline \multirow[t]{4}{*}{49} & $5 \mathrm{~S} / 1 \mathrm{E}-16 \mathrm{D} 1$ & $03-06-91$ & 1,559 & & & $07-07-92$ & 1,428 & 75 & $6 \mathrm{~S} / 1 \mathrm{~W}-4 \mathrm{Gl}$ & $04-18-91$ & 1,574 \\
\hline & & $12-23-91$ & 1,561 & & & & & & & $12-31-91$ & 1,569 \\
\hline & & $05-13-92$ & 1,565 & 63 & $5 \mathrm{~S} / 1 \mathrm{~W}-34 \mathrm{~N} 2$ & $04-26-91$ & 1,589 & & & $07-17-92$ & $\left(^{2}\right)$ \\
\hline & & $07-06-92$ & 1,563 & & & $12-23-91$ & 1,587 & & & & \\
\hline \multirow[t]{5}{*}{50} & $5 \mathrm{~S} / 1 \mathrm{E}-16 \mathrm{~N} 1$ & $03-08-91$ & 1,534 & & & $04-17-92$ & 1,587 & 76 & $6 \mathrm{~S} / 2 \mathrm{~W}-1 \mathrm{Ml}$ & $01-16-91$ & 1,428 \\
\hline & & $12-23-91$ & 1,507 & & & $07-07-92$ & 1,587 & & & $04-16-92$ & 1,428 \\
\hline & & $02-19-92$ & 1,476 & 64 & $5 \mathrm{~S} / 2 \mathrm{~W}-12 \mathrm{~N} 2$ & $07-03-91$ & 1,474 & & & $07-07-92$ & 1,427 \\
\hline & & $05-13-92$ & 1,503 & & & $12-23-91$ & 1,473 & 77 & $6 \mathrm{~S} / 2 \mathrm{~W}-2 \mathrm{~J} 2$ & $01-16-91$ & 1,428 \\
\hline & & $07-06-92$ & 1,494 & & & $04-29-92$ & 1,474 & & & $12-19-91$ & 1,425 \\
\hline 51 & $5 \mathrm{~S} / 1 \mathrm{E}-18 \mathrm{~F} 1$ & $04-26-91$ & 1,526 & & & $07-07-92$ & 1,473 & & & $04-16-92$ & 1,428 \\
\hline 52 & $5 \mathrm{~S} / 1 \mathrm{~W}-9 \mathrm{~A} 1$ & $06-12-91$ & 1,340 & 65 & $5 S / 2 W-12 Q 2$ & $07-03-91$ & 1,462 & & & $07-07-92$ & 1,427 \\
\hline 53 & $5 \mathrm{~S} / 1 \mathrm{~W}-10 \mathrm{~B} 2$ & $06-28-91$ & 1,341 & & & $12-23-91$ & 1,461 & & & & \\
\hline \multirow{7}{*}{54} & $5 \mathrm{~S} / 1 \mathrm{~W}-11 \mathrm{Q} 1$ & $03-07-91$ & 1,354 & & & $04-29-92$ & 1,462 & & & & \\
\hline & & $12-30-91$ & 1,352 & & & $07-07-92$ & 1,460 & & & & \\
\hline & & $07-09-92$ & 1,351 & 66 & $5 \mathrm{~S} / 2 \mathrm{~W}-24 \mathrm{Gl}$ & $04-26-91$ & 1,479 & & & & \\
\hline & & & & & & $12-23-91$ & $\left({ }^{3}\right)$ & & & & \\
\hline & & & & & & $04-29-92$ & 1,481 & & & & \\
\hline & & & & & & $05-15-92$ & 1,480 & & & & \\
\hline & & & & & & $07-07-92$ & 1,478 & & & & \\
\hline
\end{tabular}

${ }^{1}$ Oil in casing. Unable to determine water level ${ }^{2}$ Well being pumped. No measurement taken. ${ }^{3}$ Dry well. 


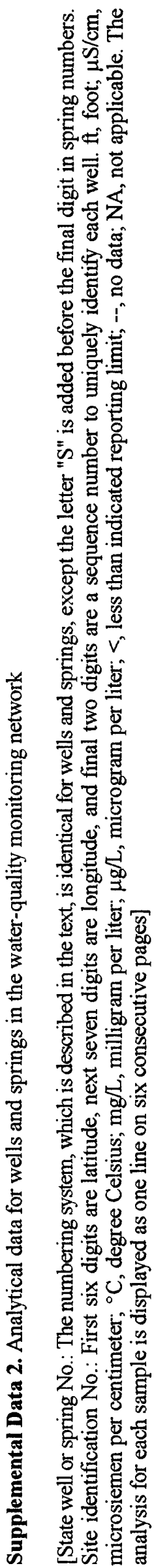

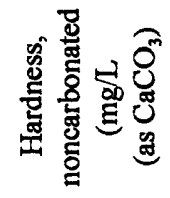

总

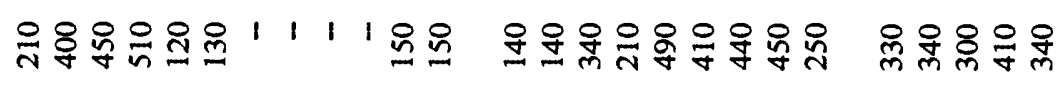

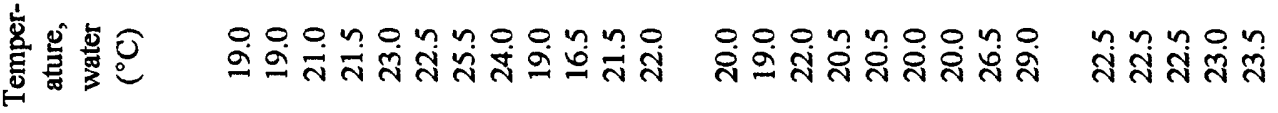

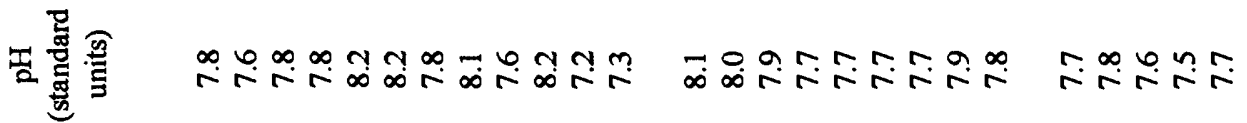

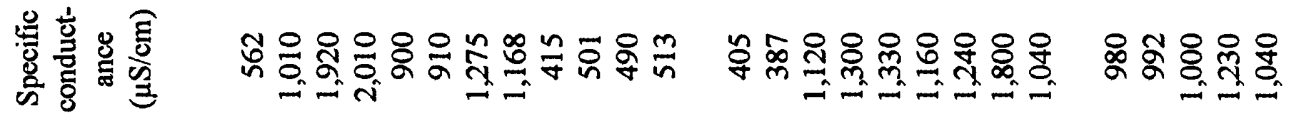

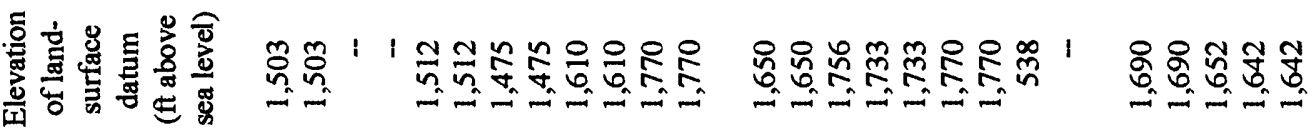

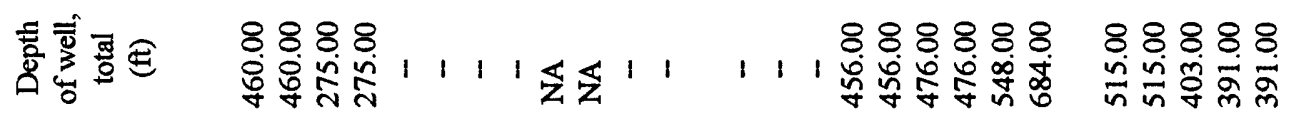

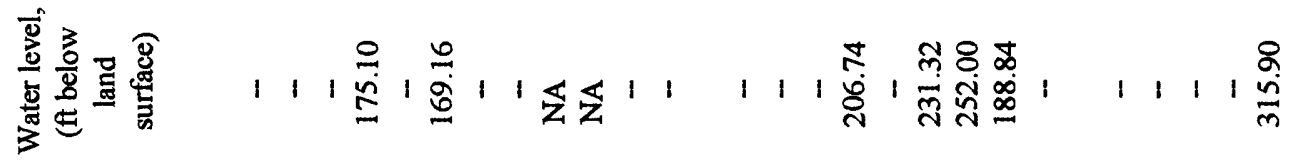

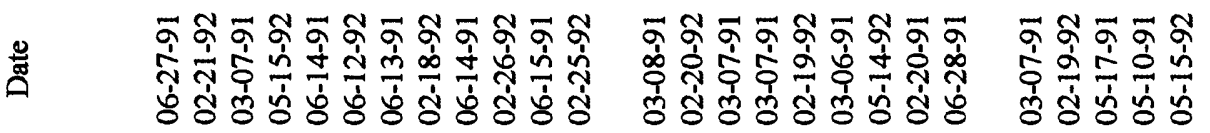

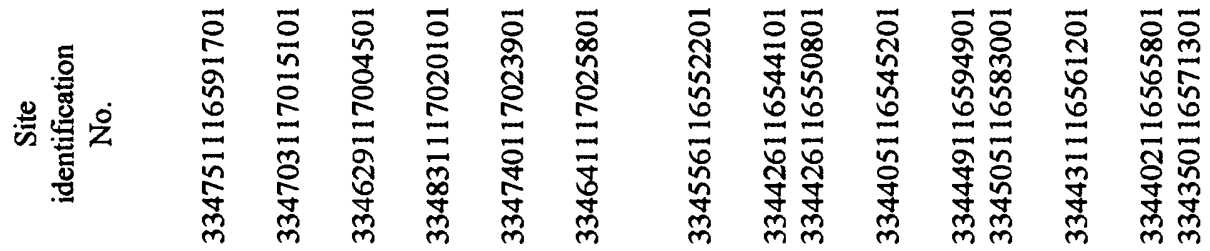

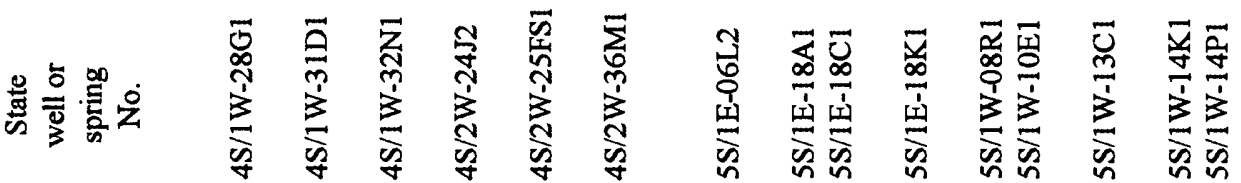




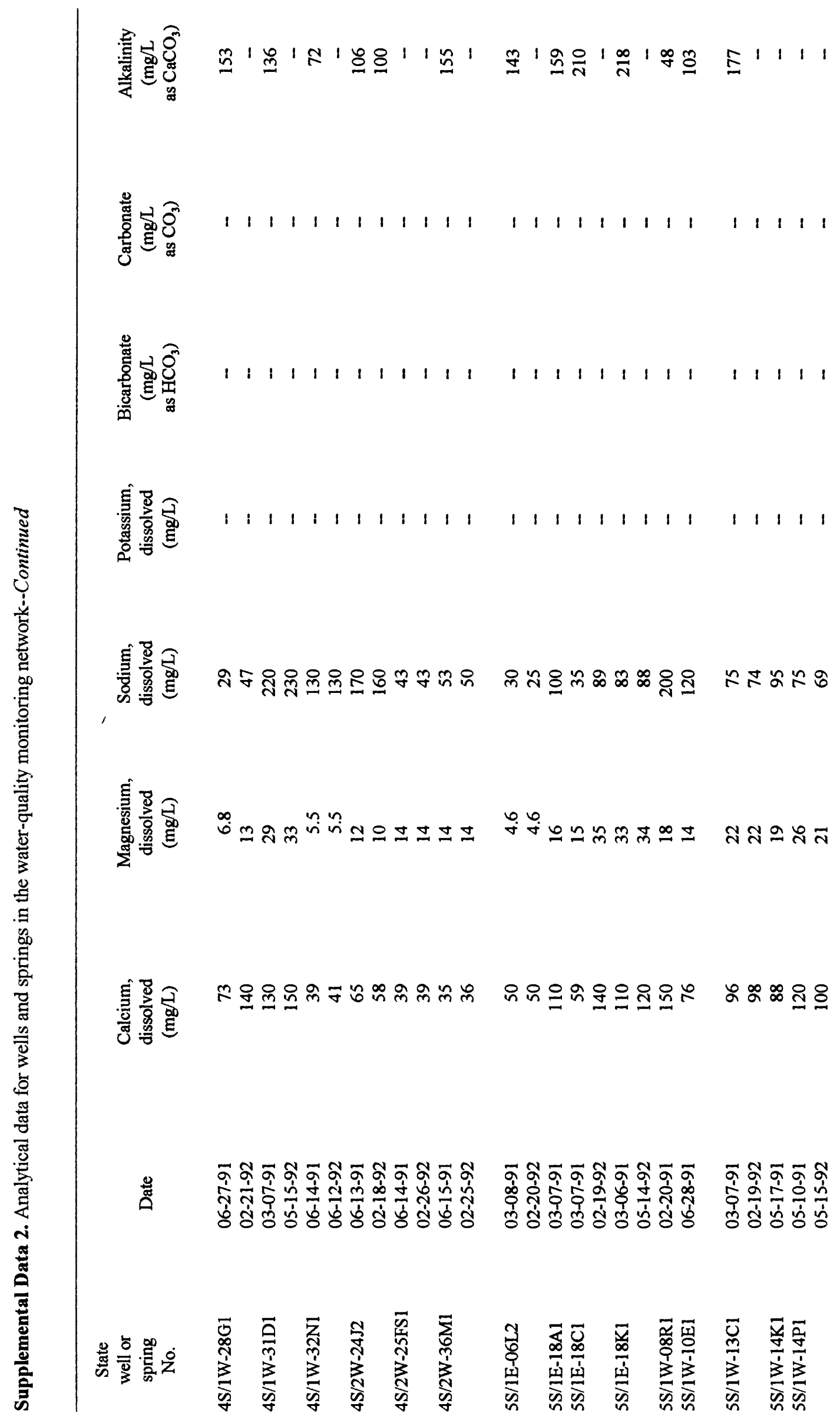




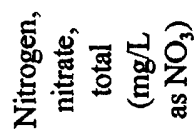

$\stackrel{-\pi}{N} 1$

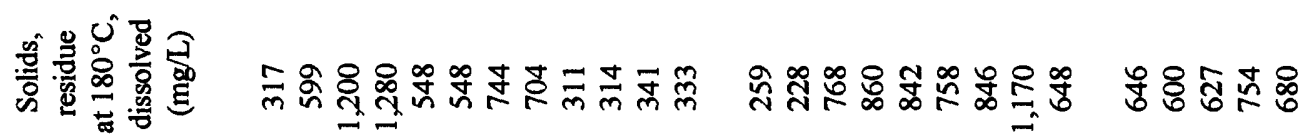

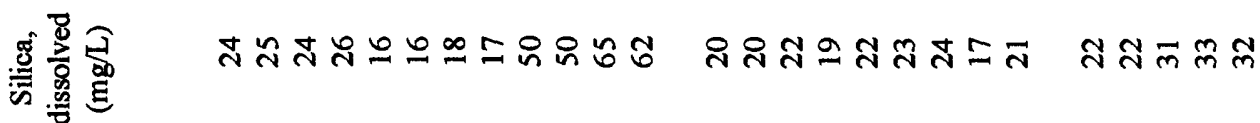

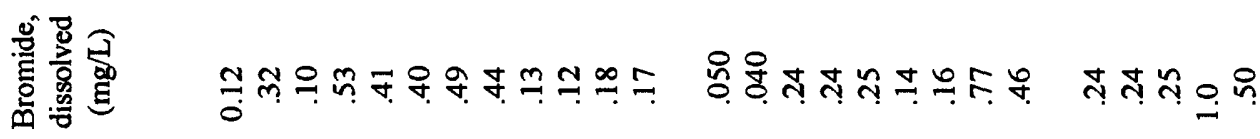

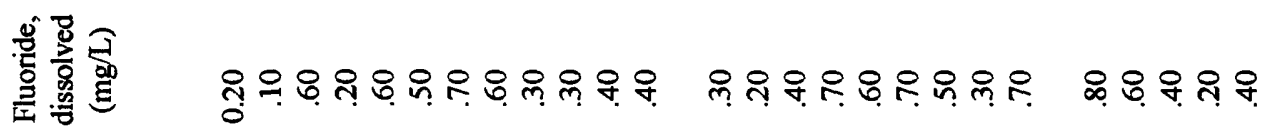

突总总

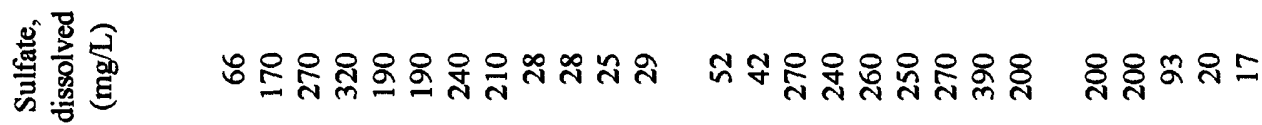

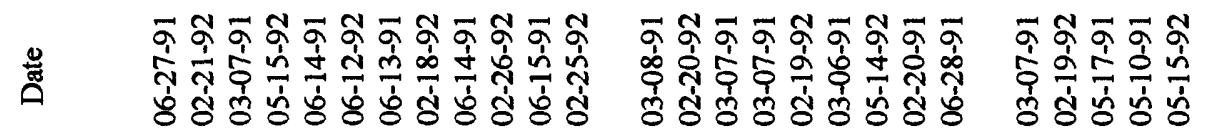

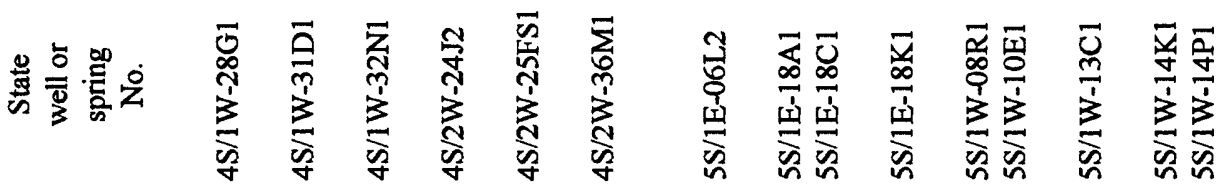




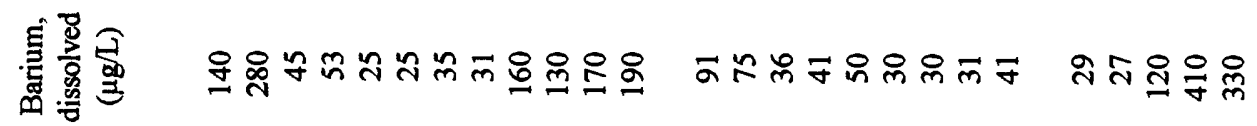

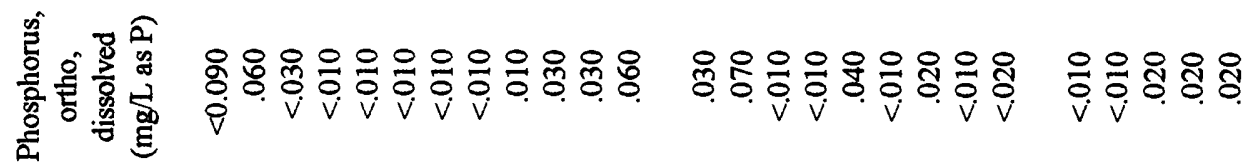

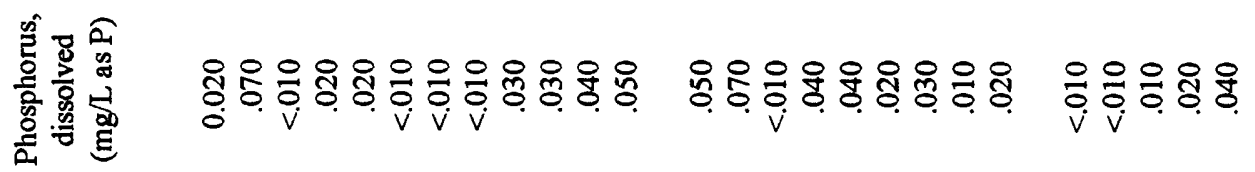

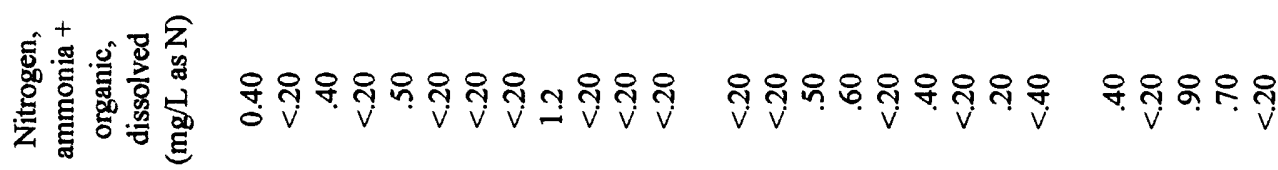

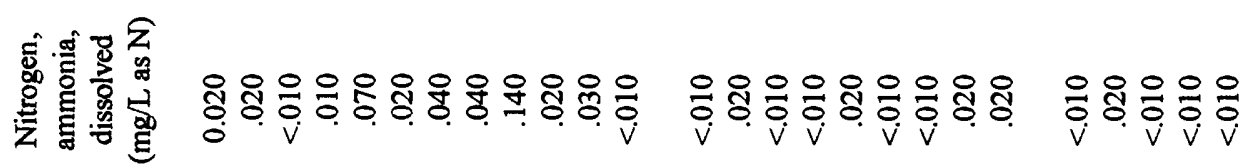

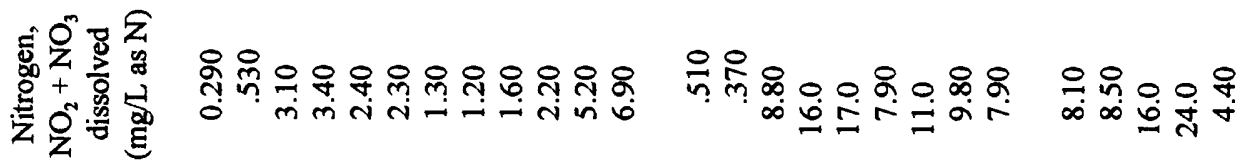

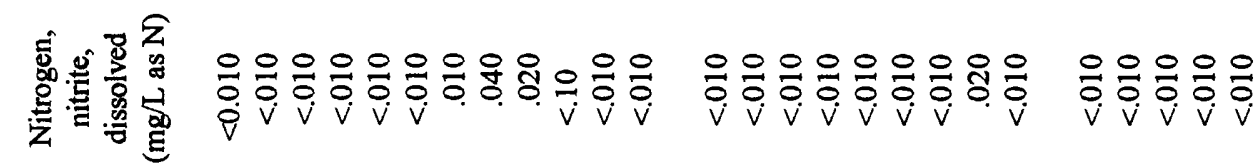

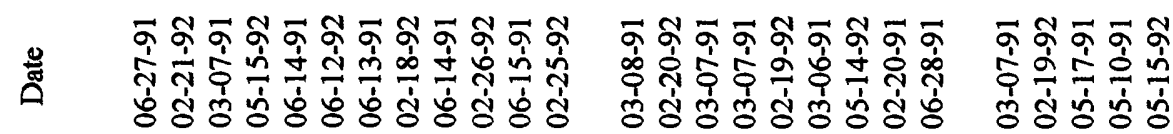

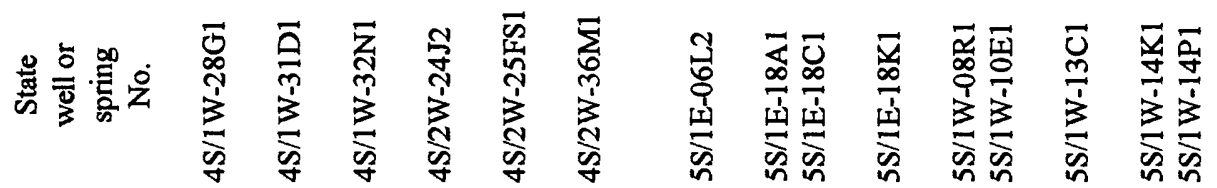




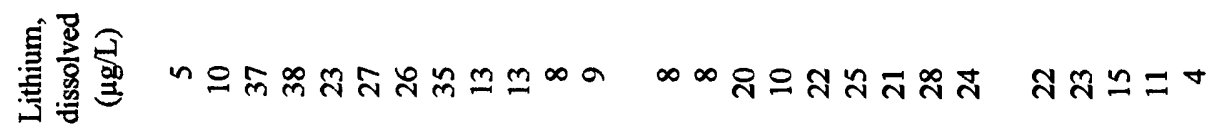

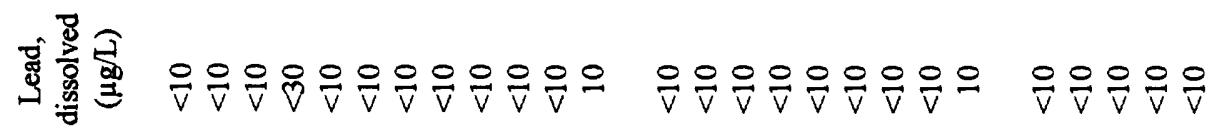

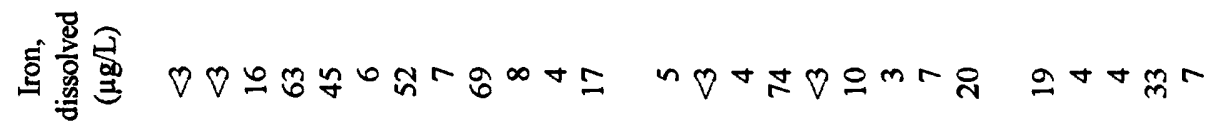

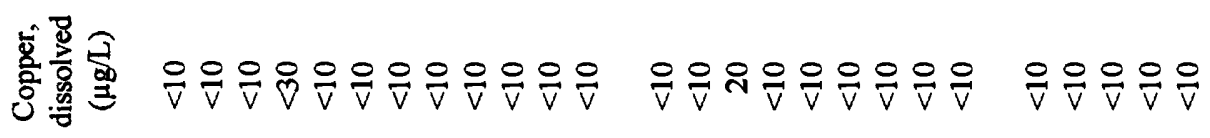

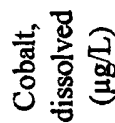
DORO

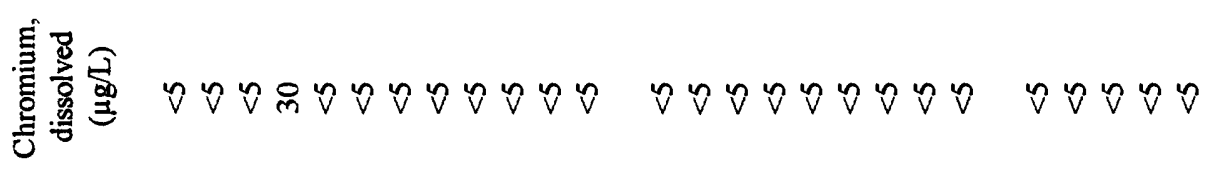

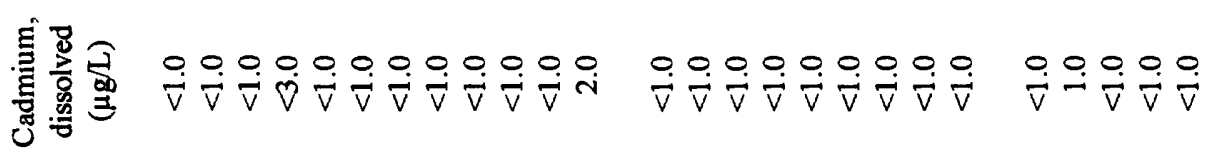

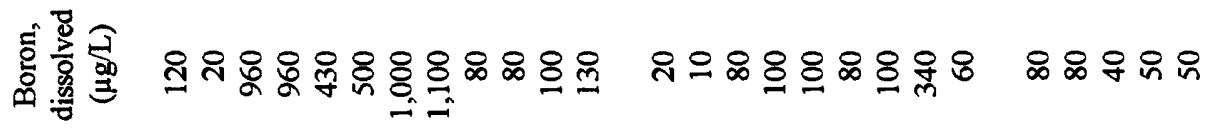

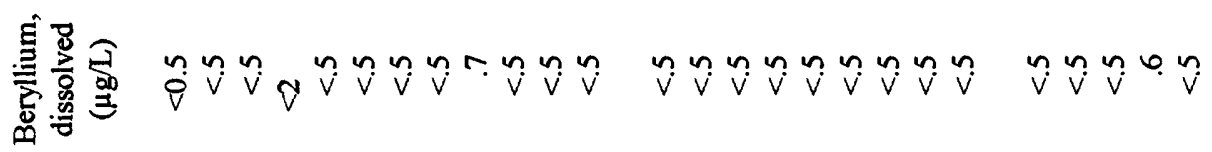

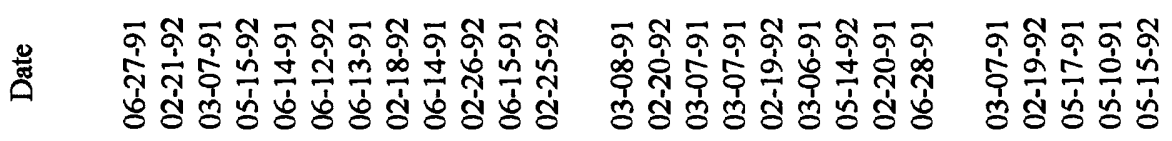

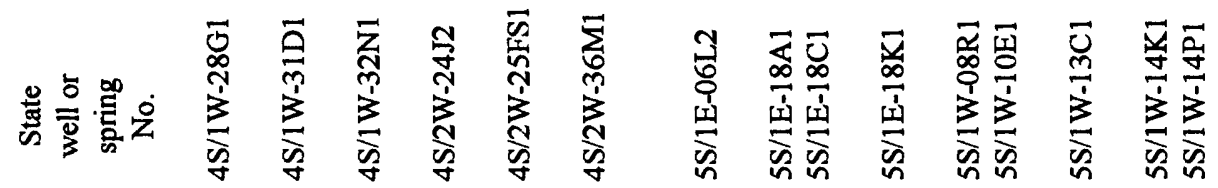




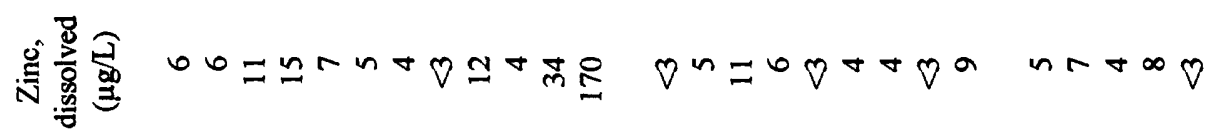

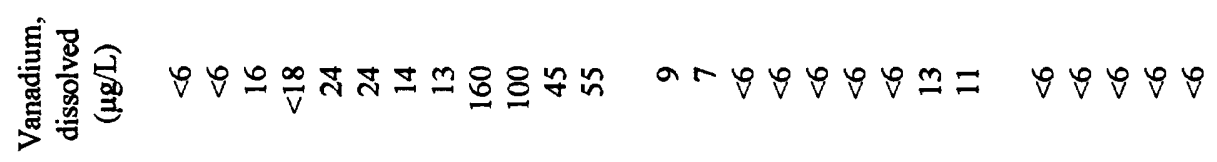

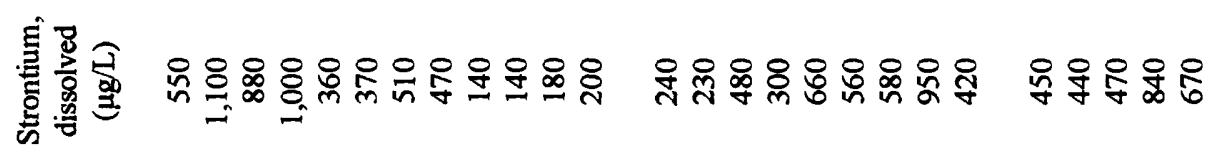
竞崽兽

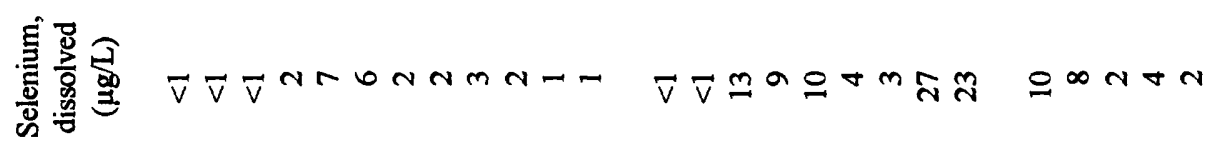
竞尊总

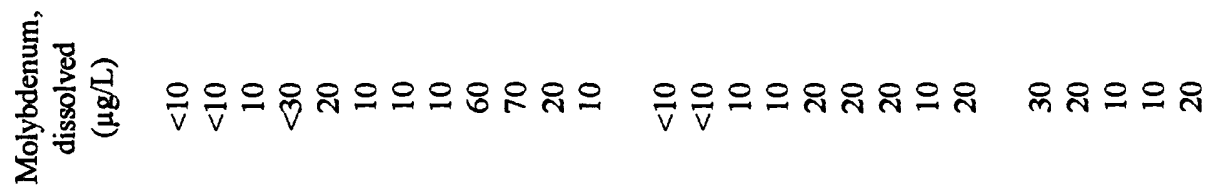

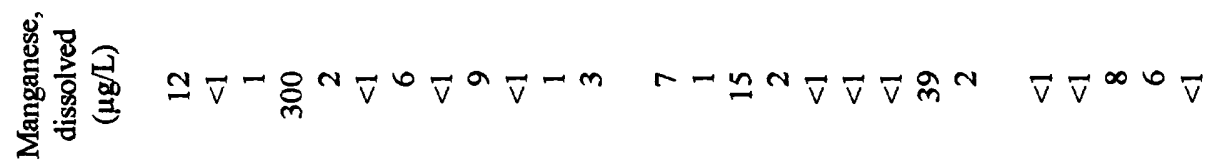

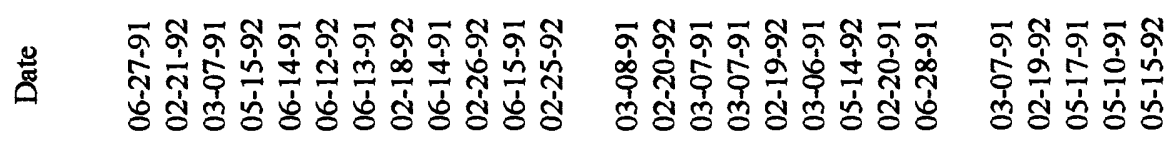

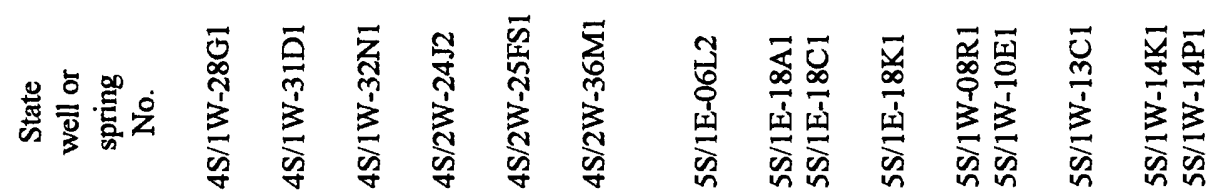


焉

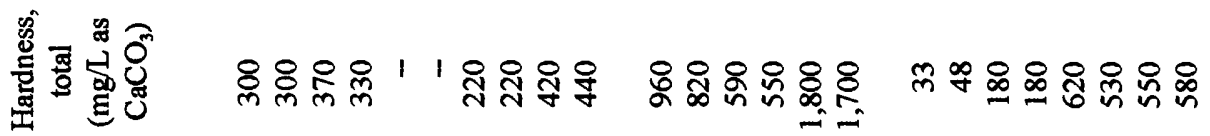

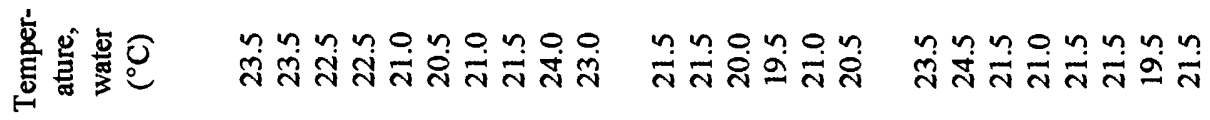

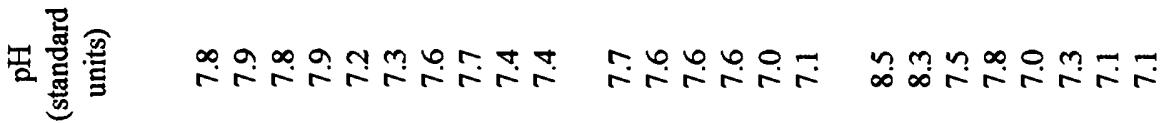

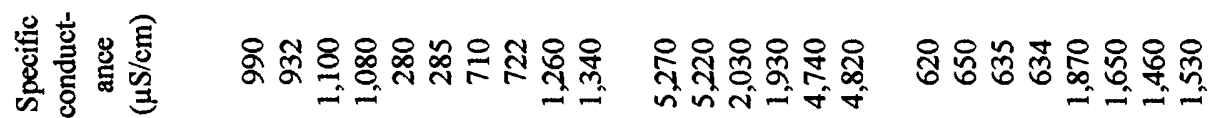

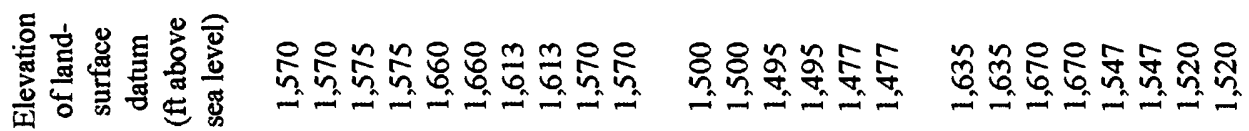

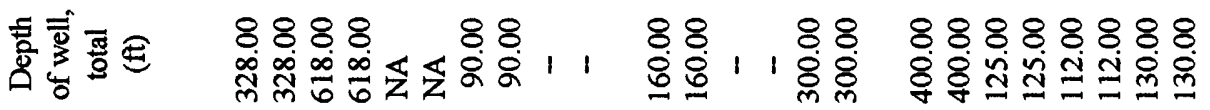

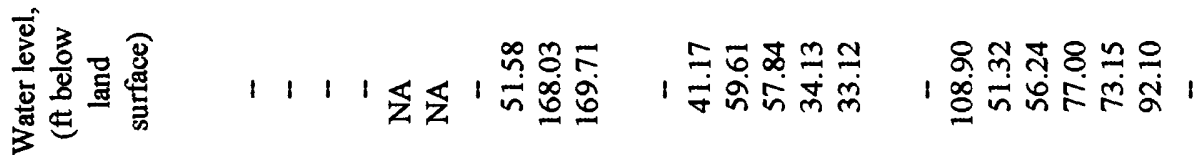

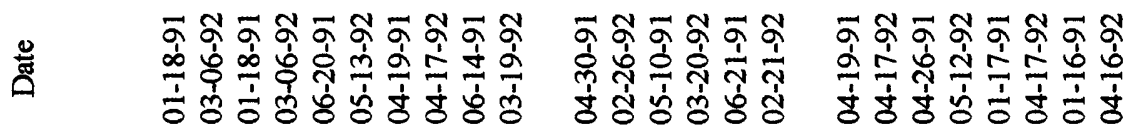

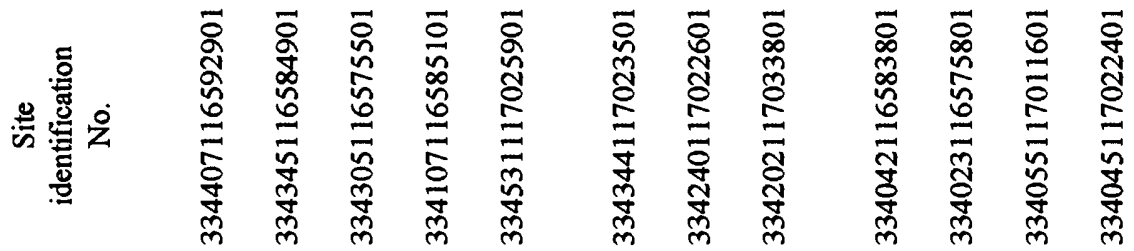

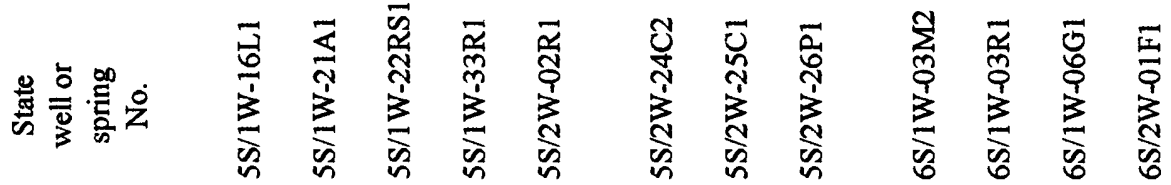




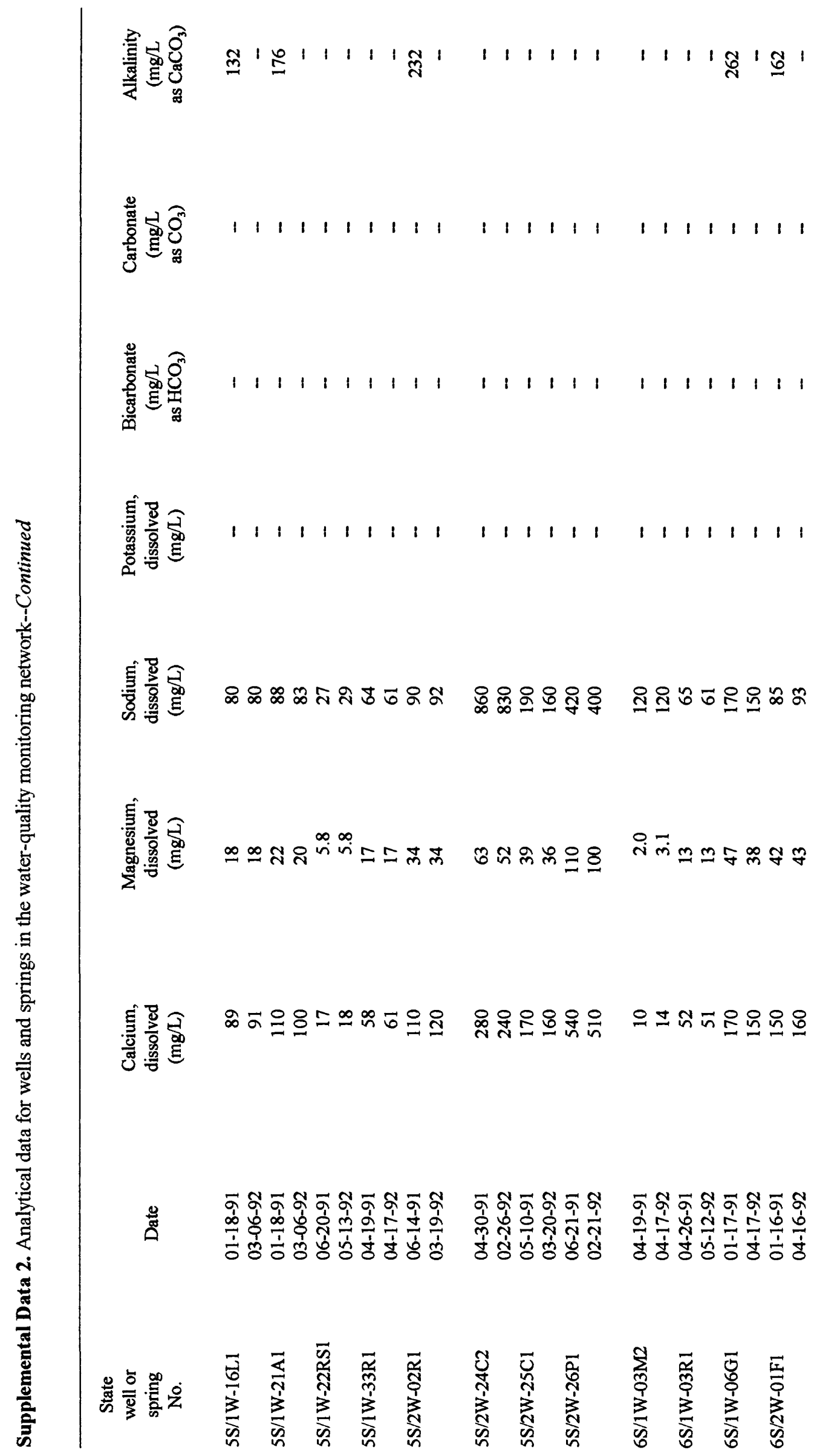




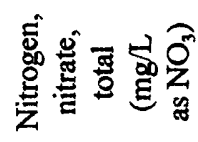

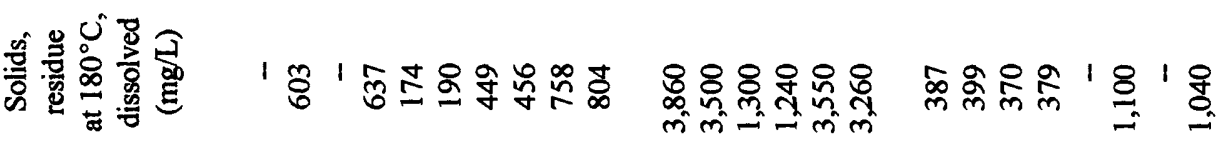

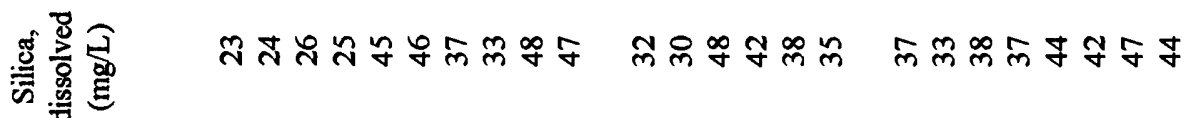

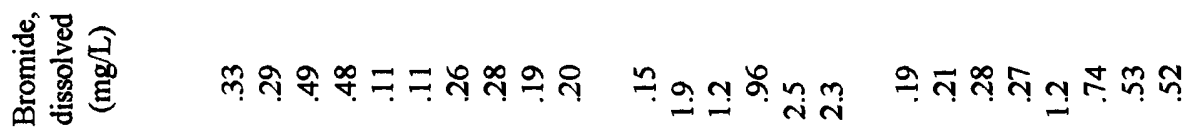

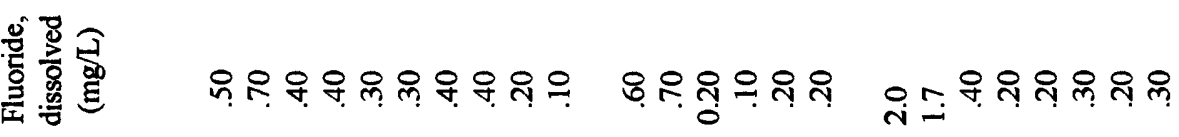

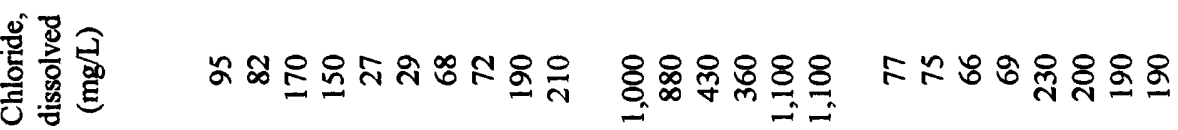

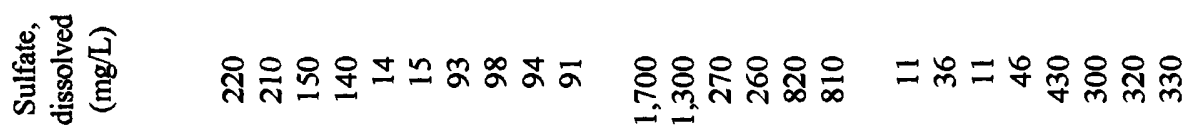

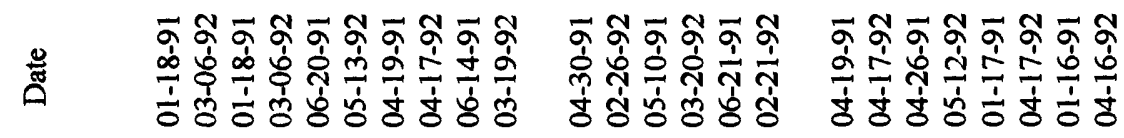

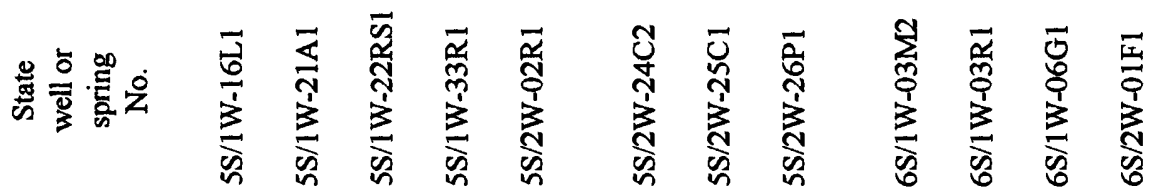




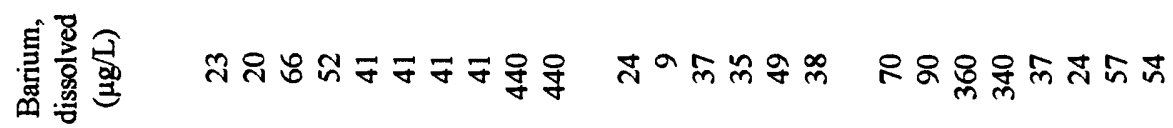

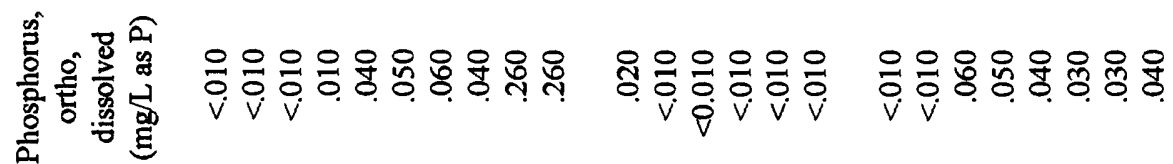

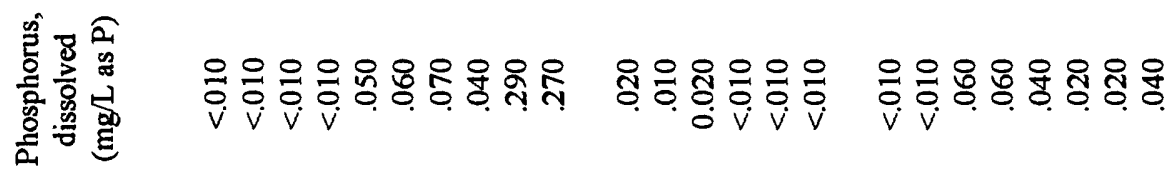

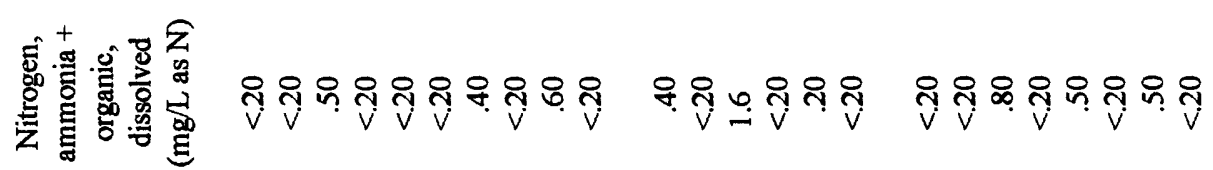

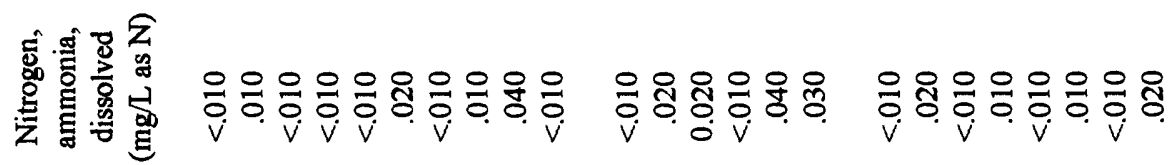

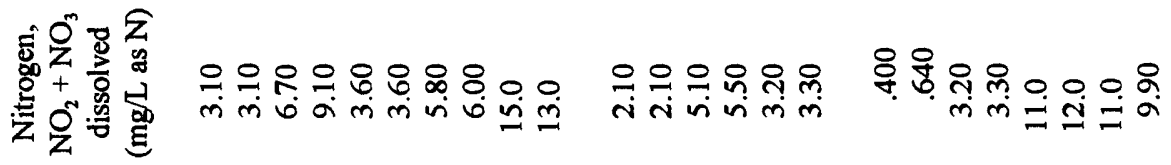

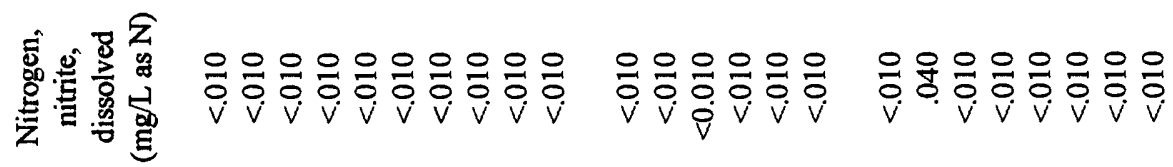

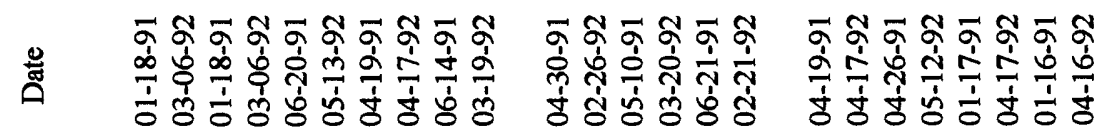

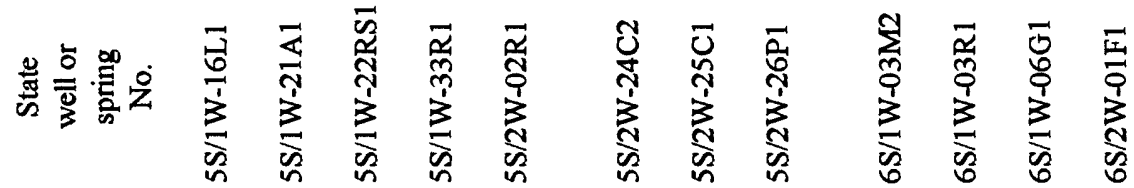




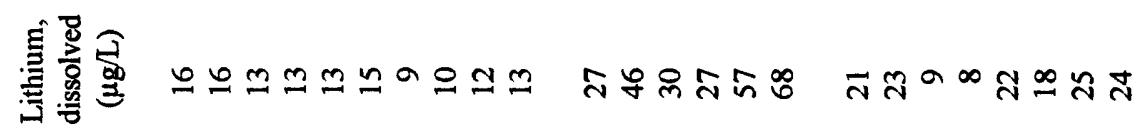

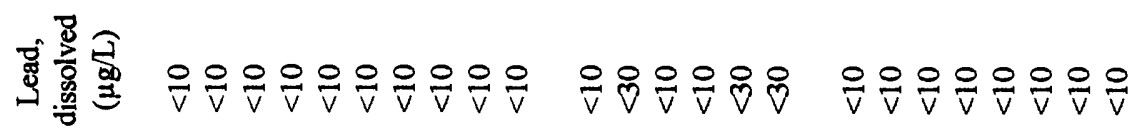

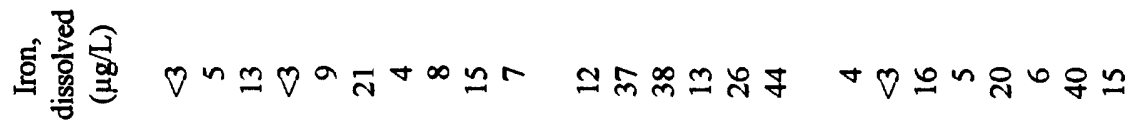

崖离

兽总

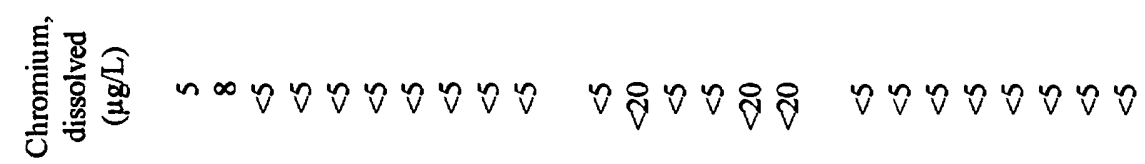

音惫兽

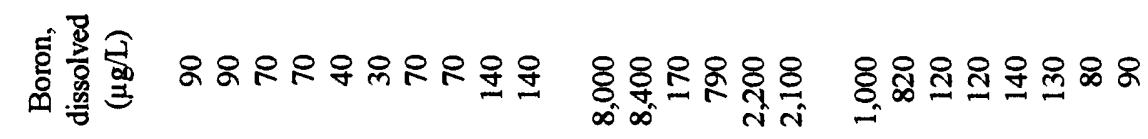

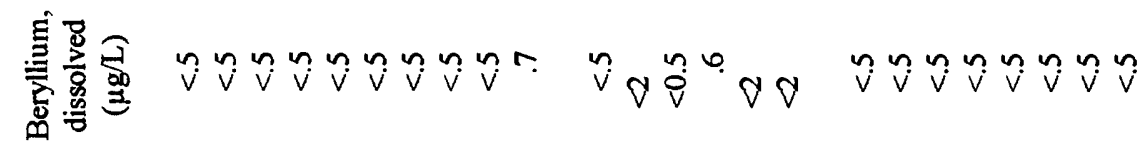

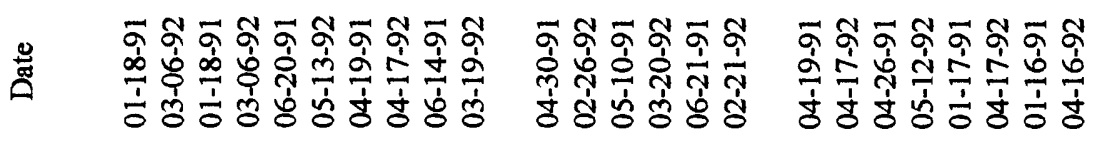

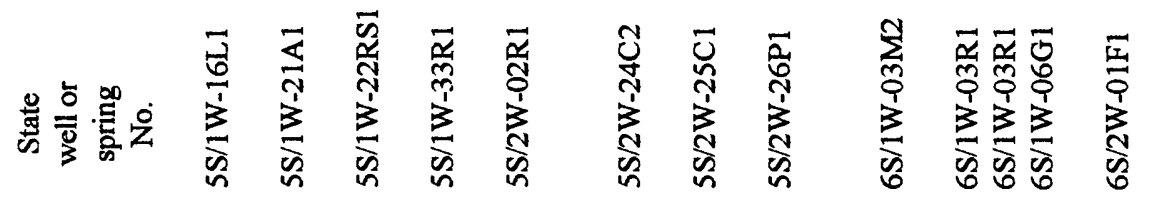




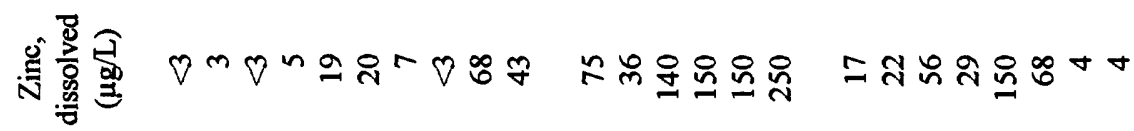

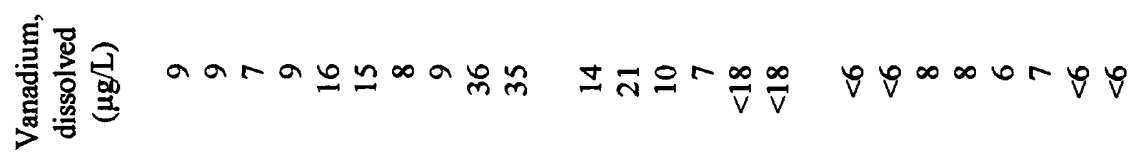

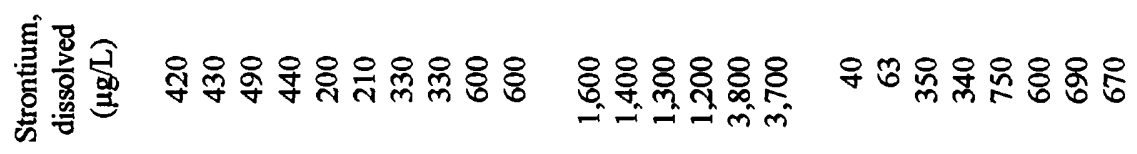
悹兽兽

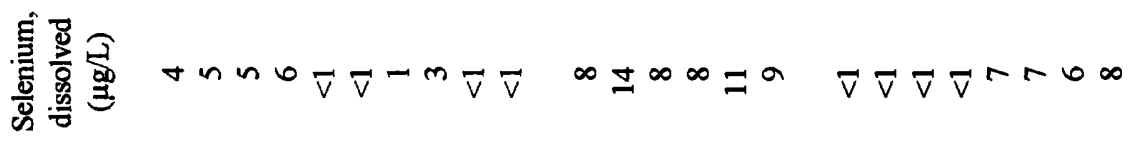

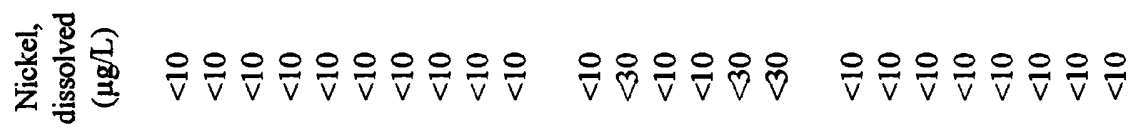

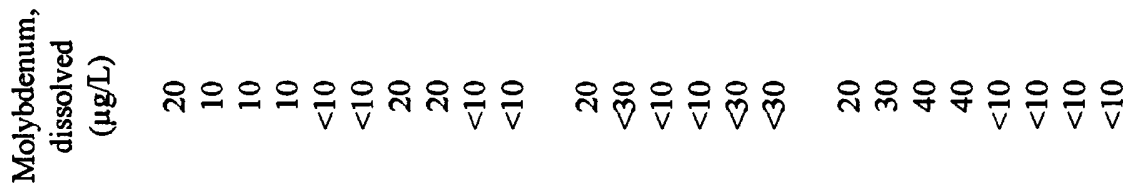

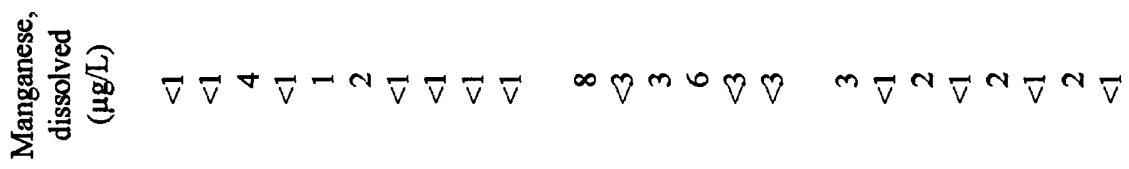

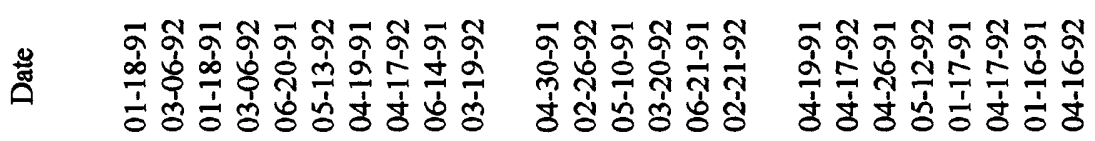

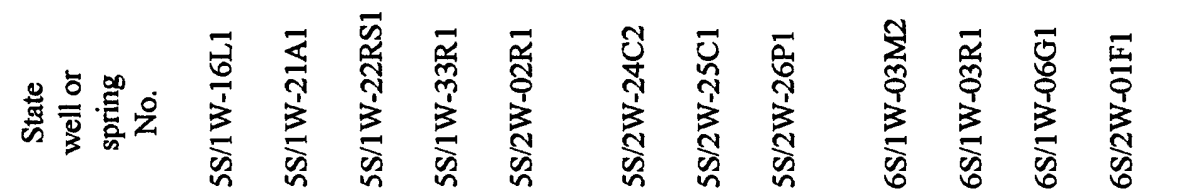




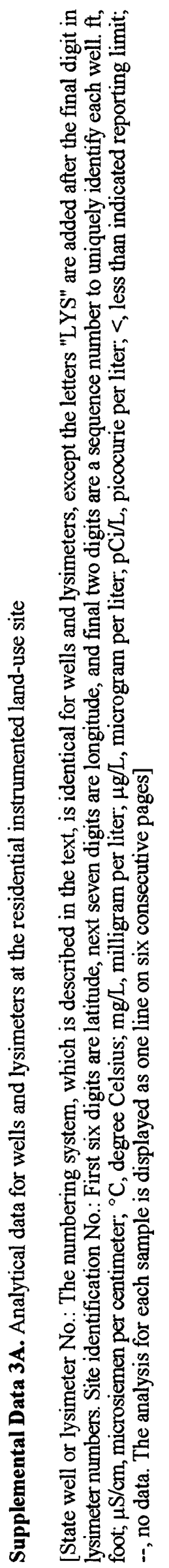

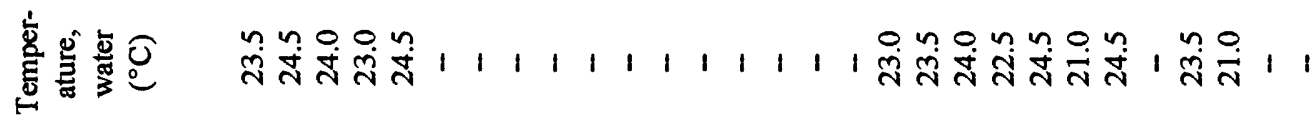

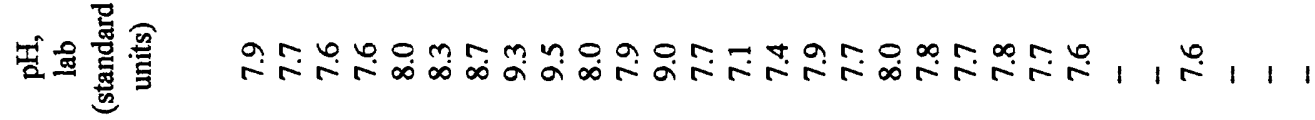

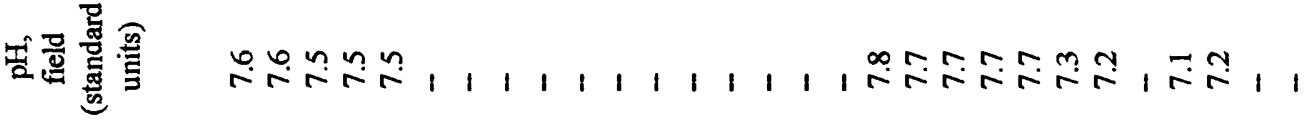

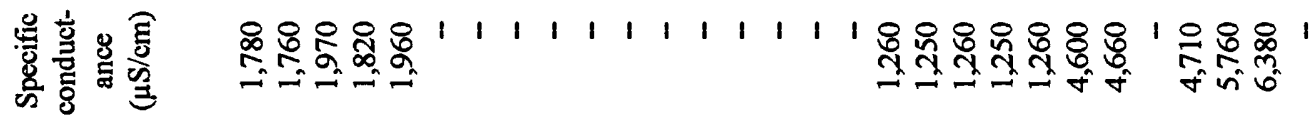

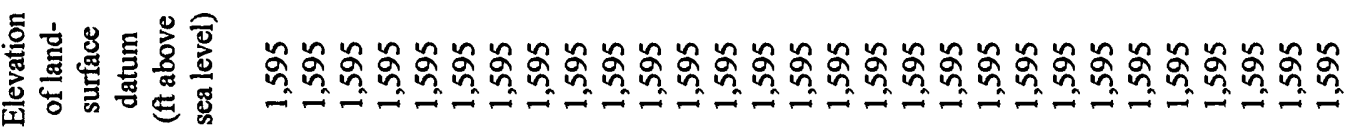

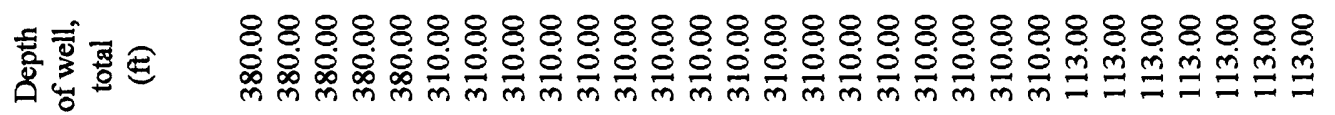

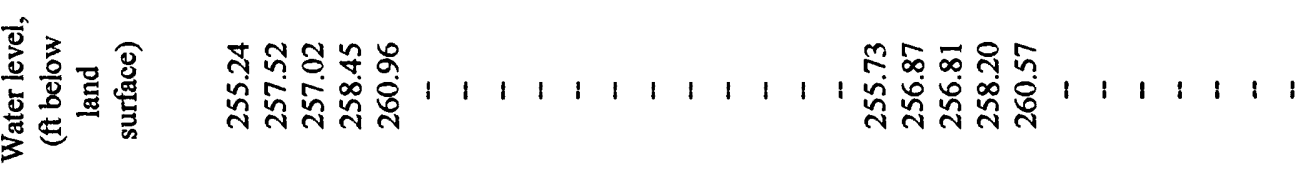

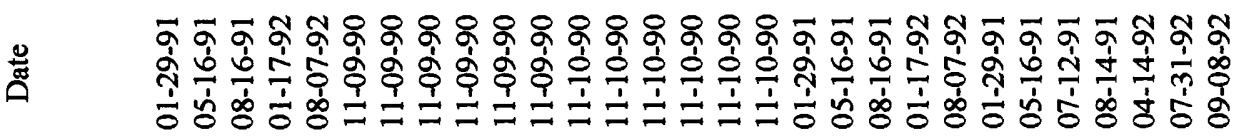

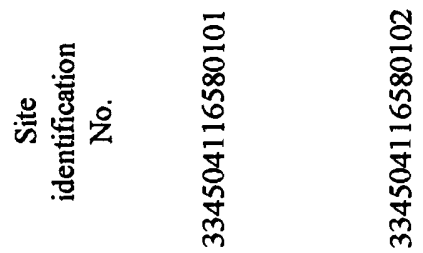

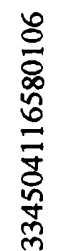

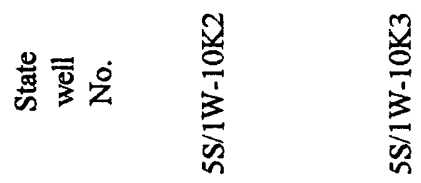

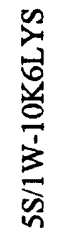




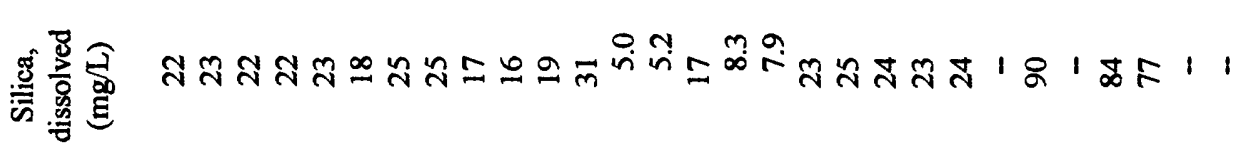

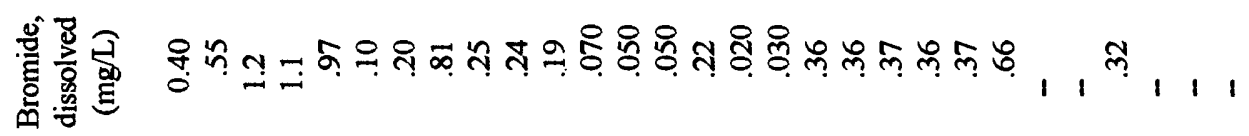

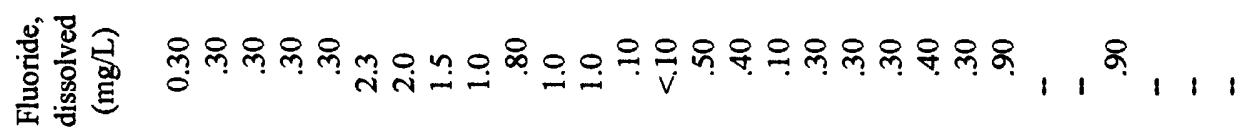

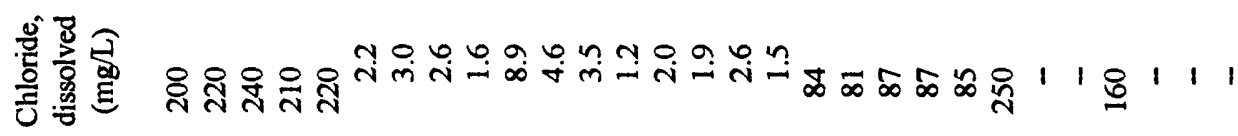

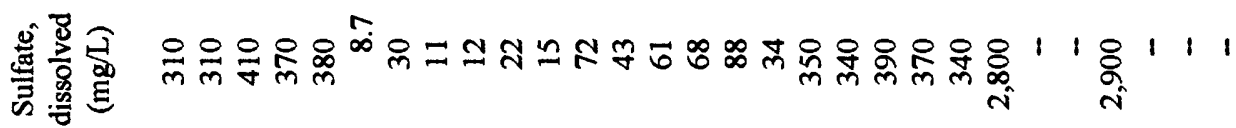

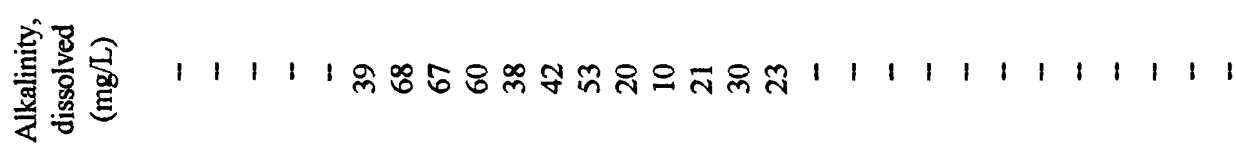

产总总

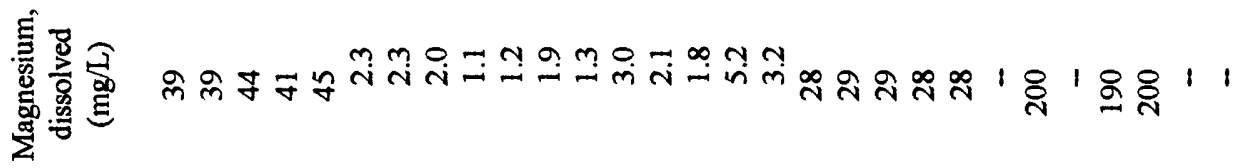

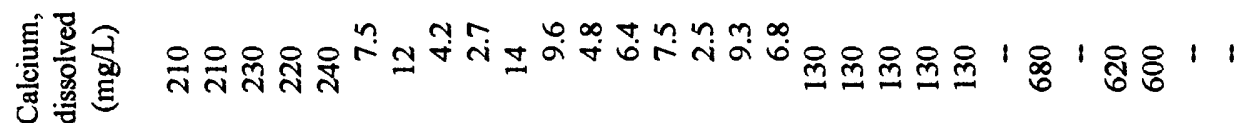

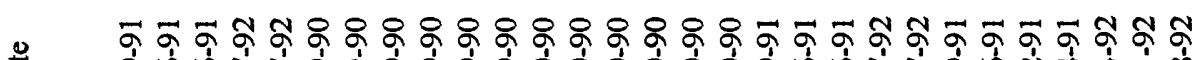

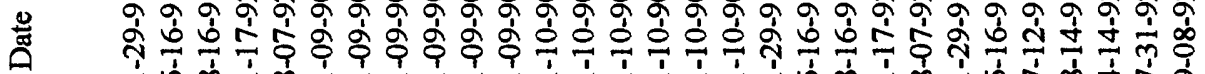

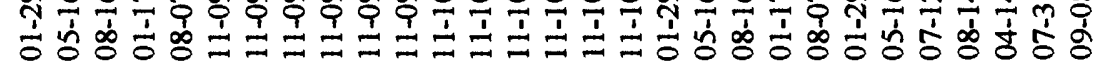

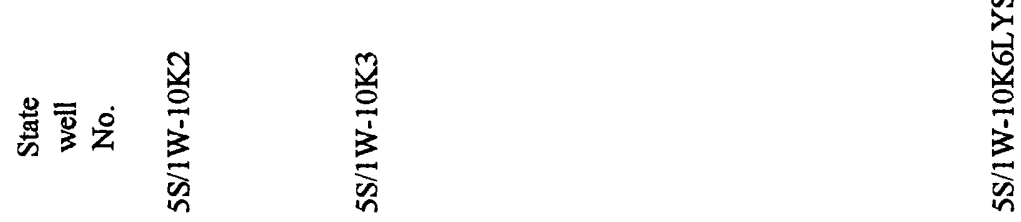

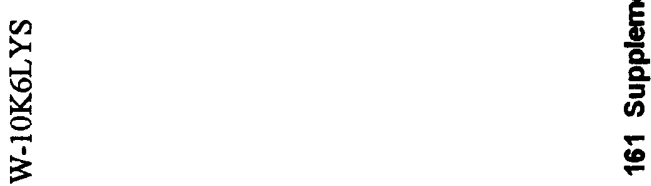




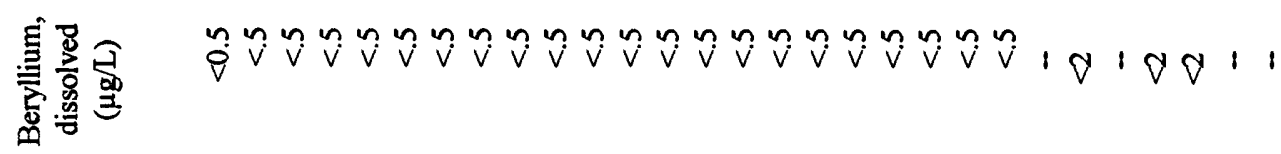

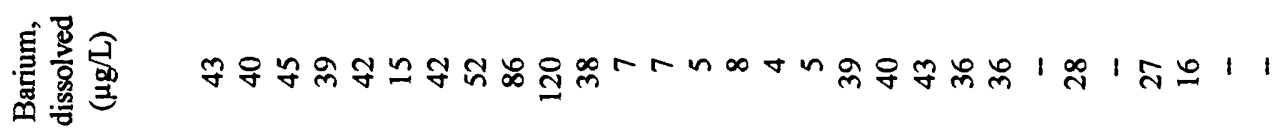

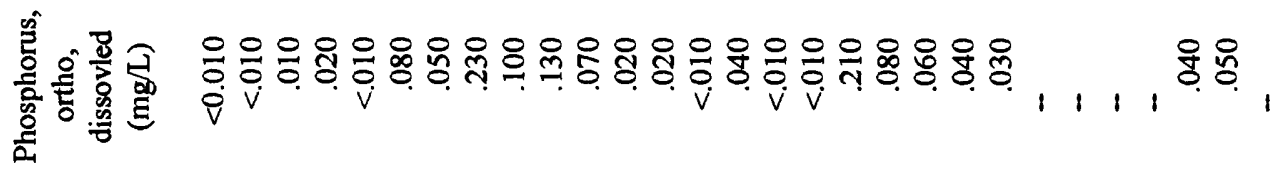

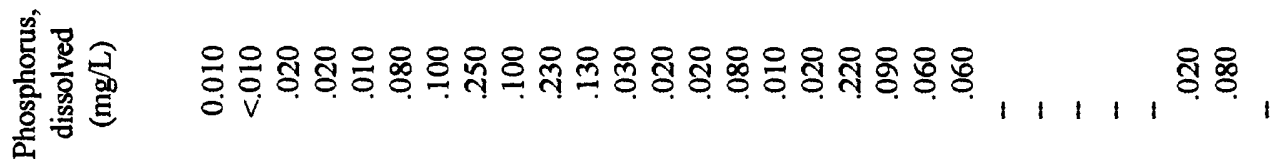

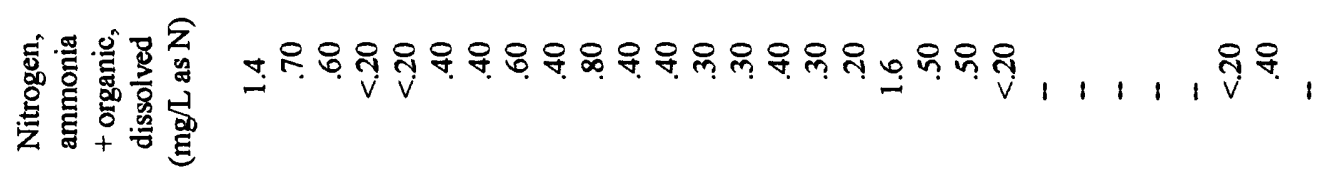

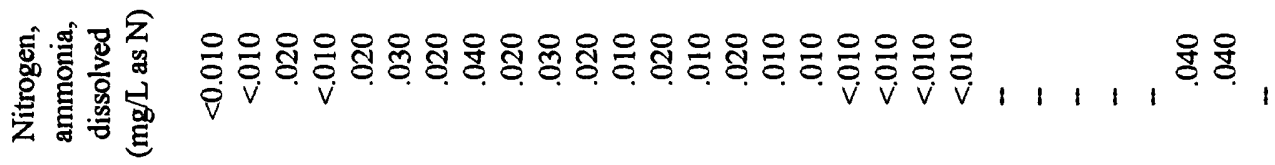

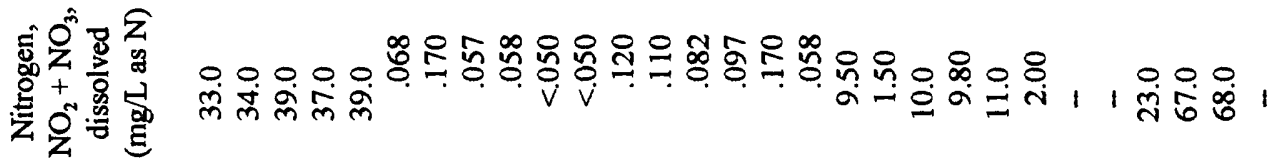

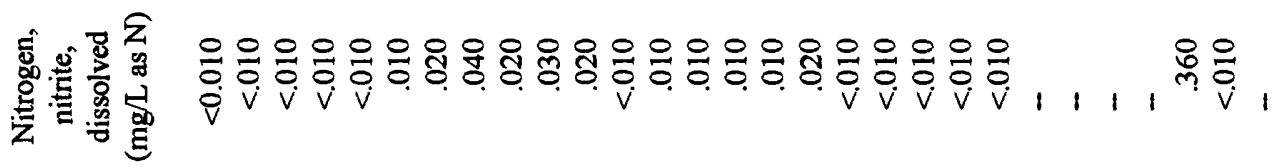

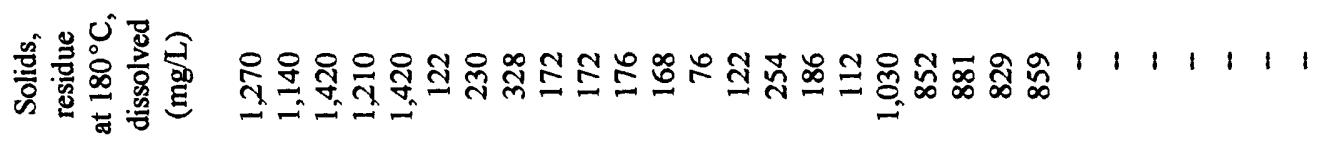

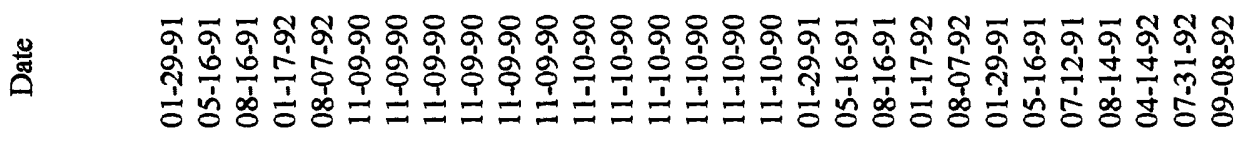

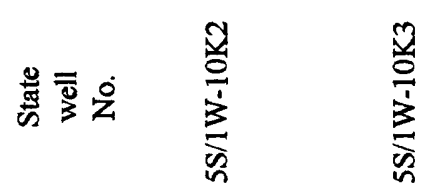




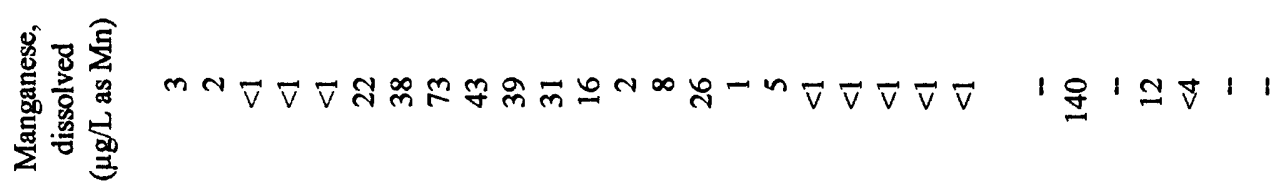

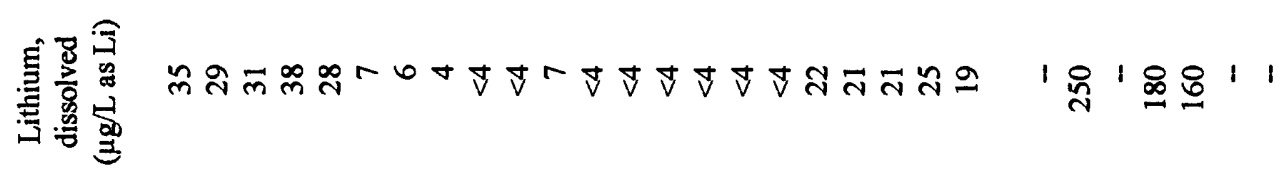

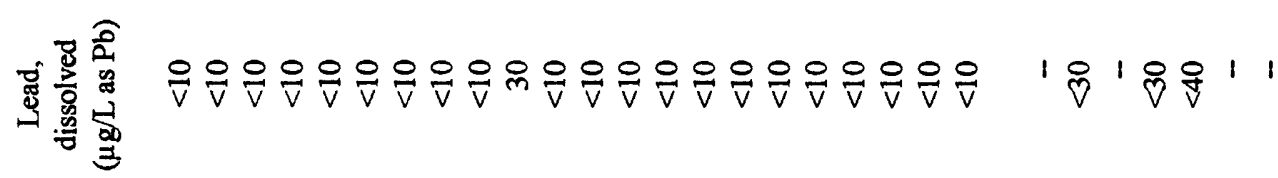
造总要 崖离 官参宓 矛要总

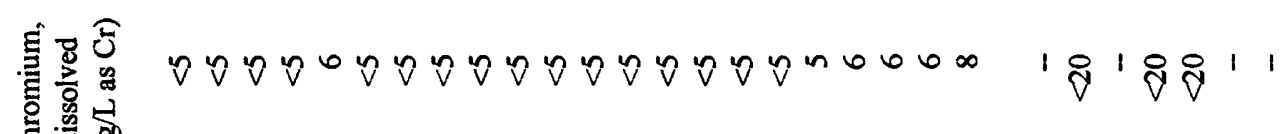

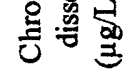

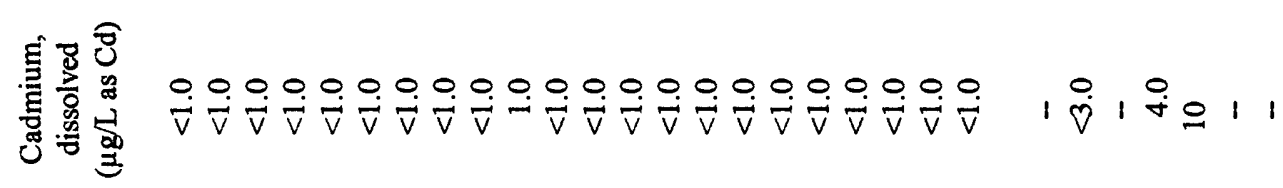

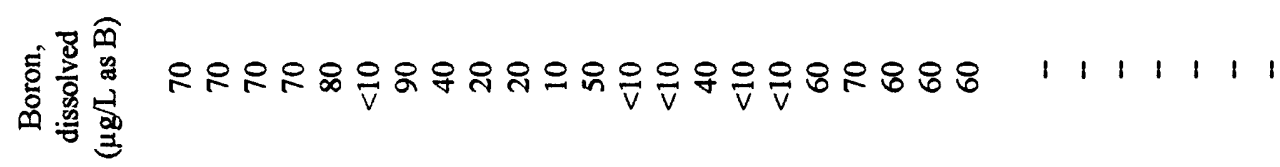

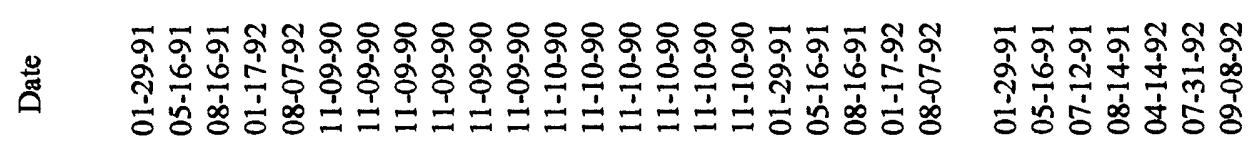

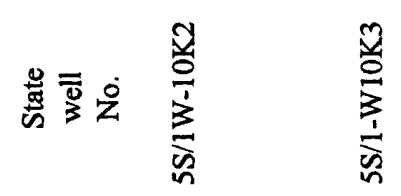




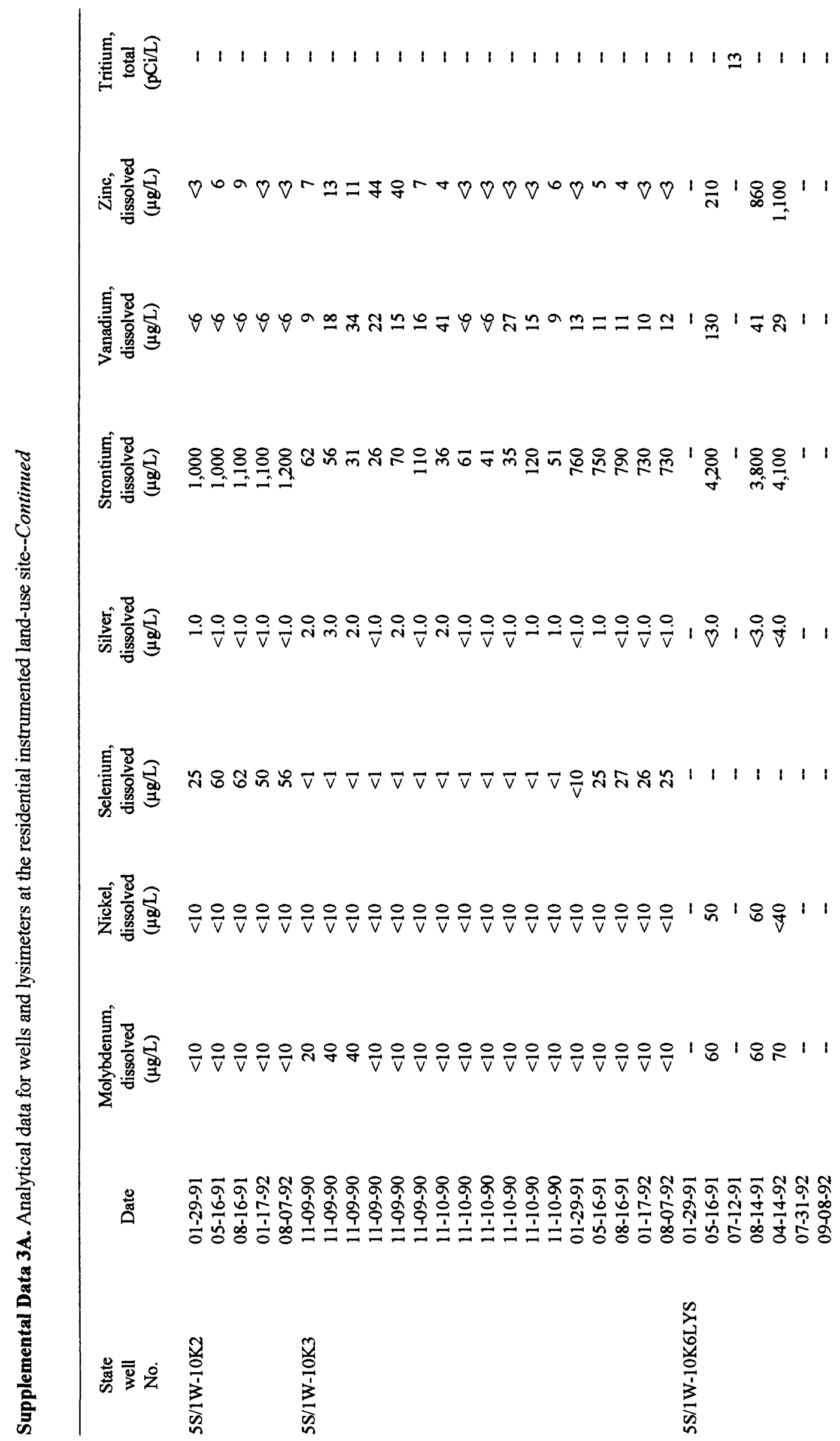




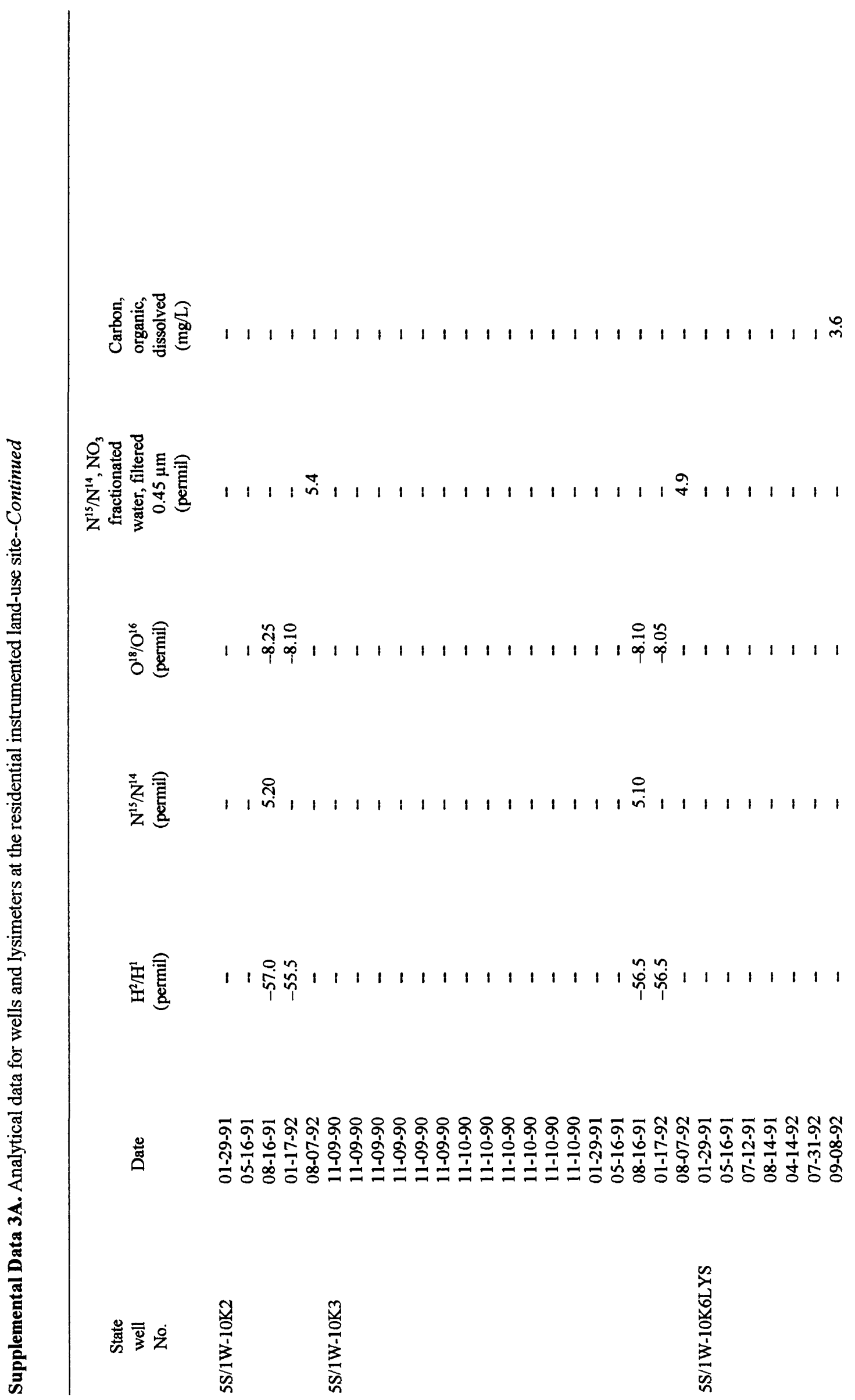




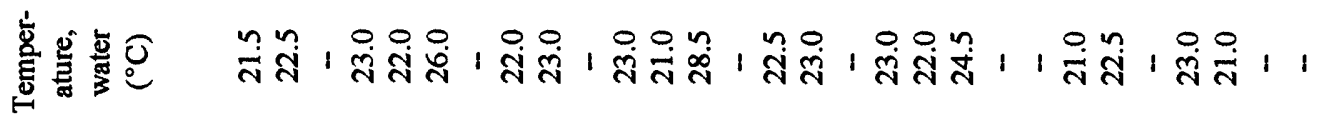

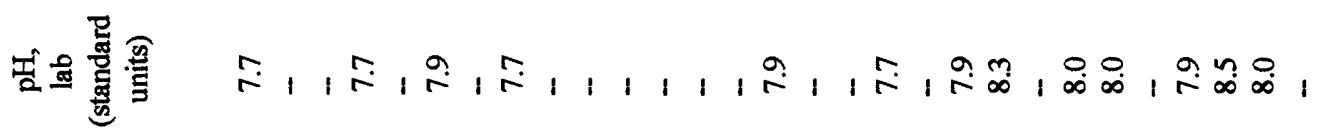

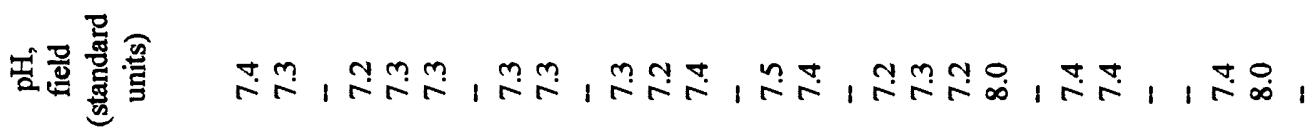

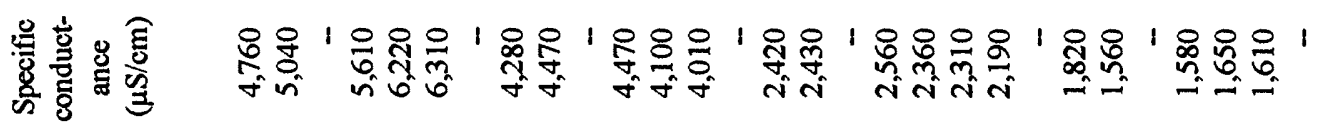

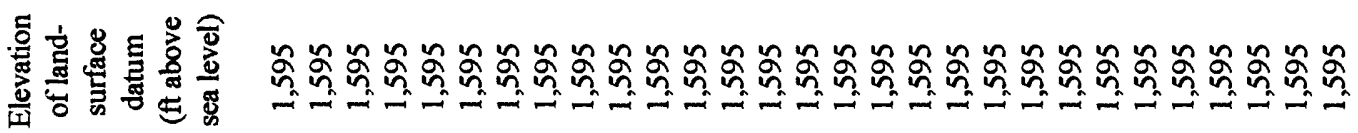

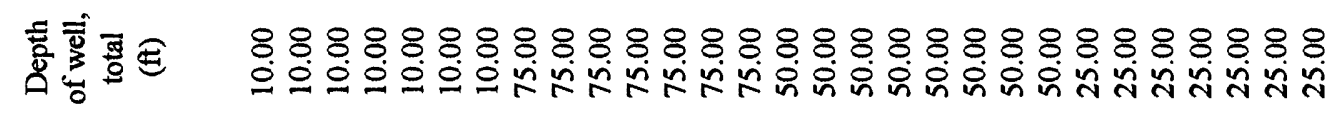

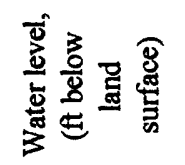

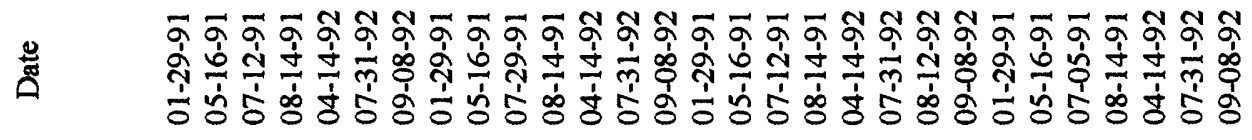

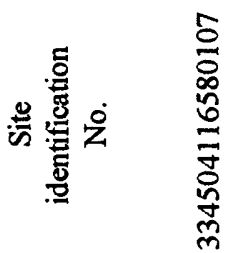

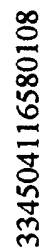

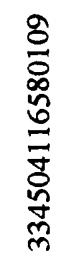

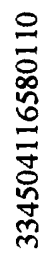

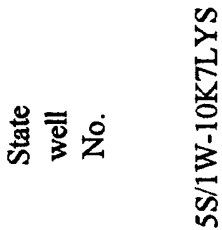




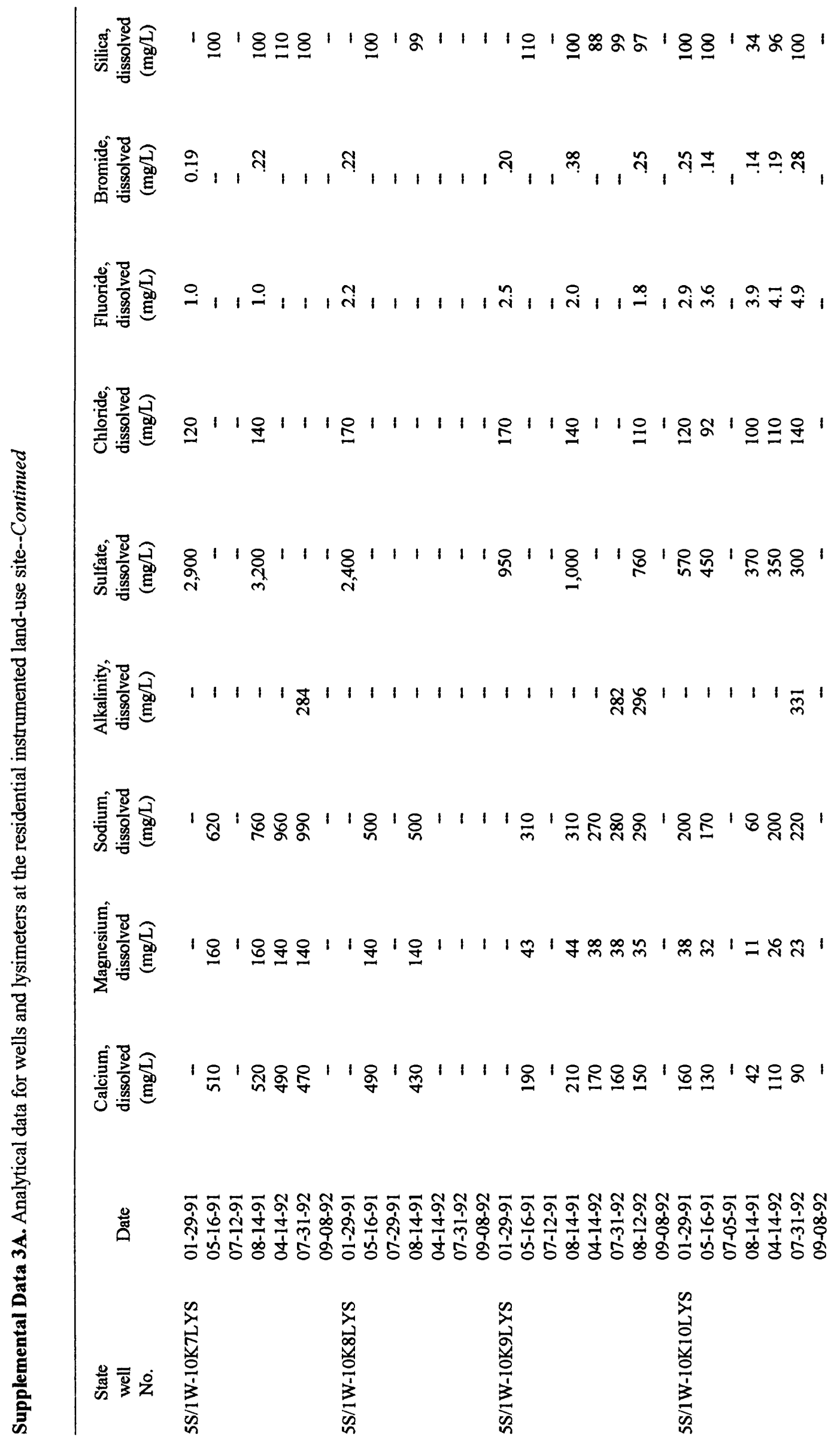




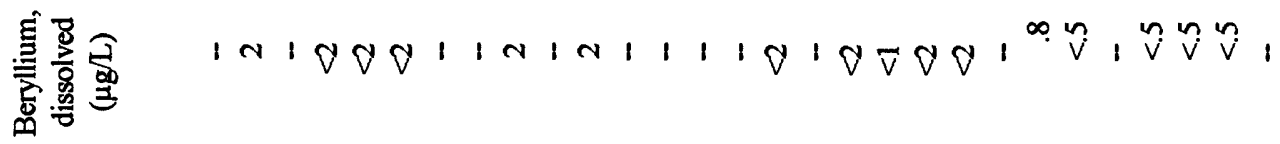

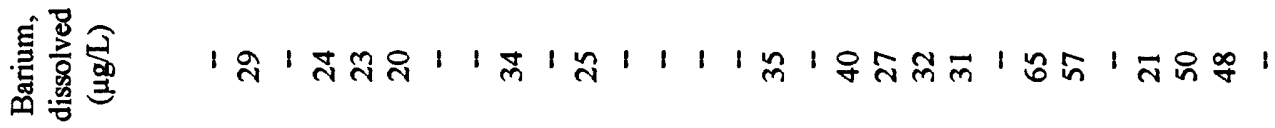

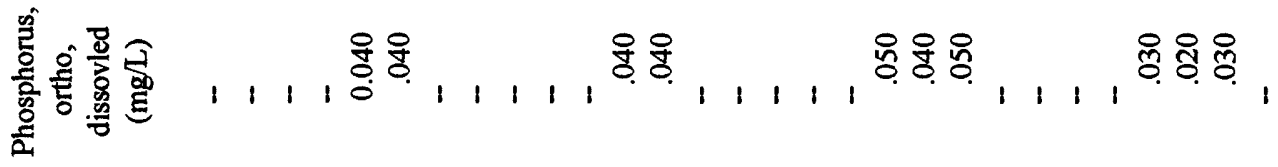

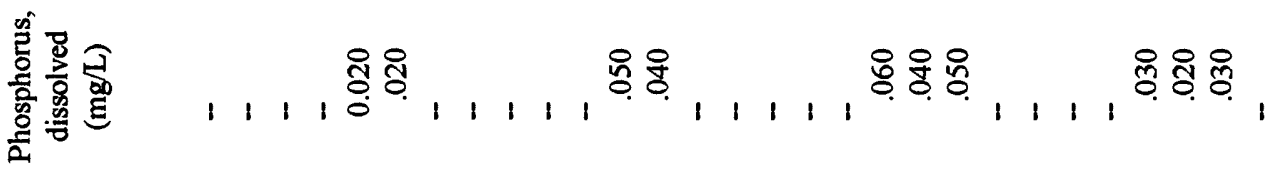

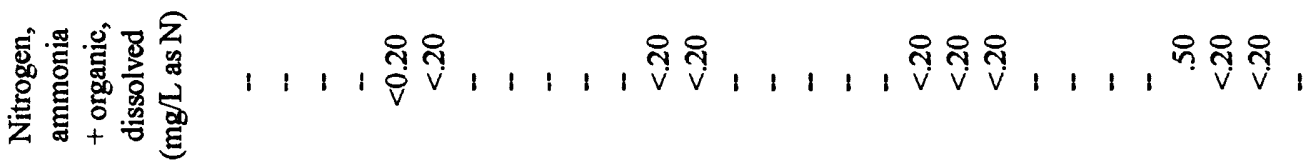

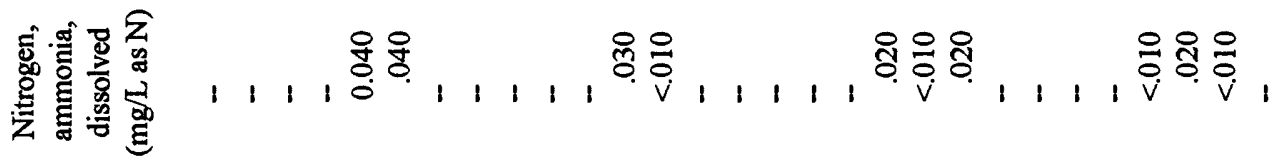

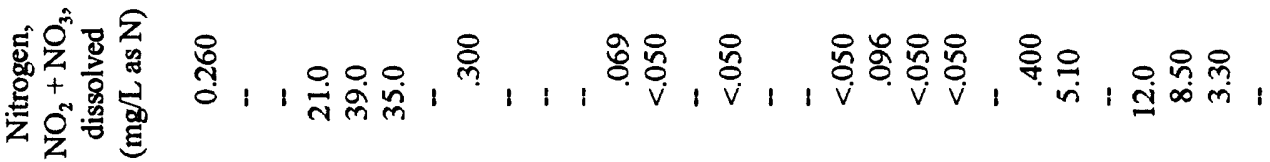

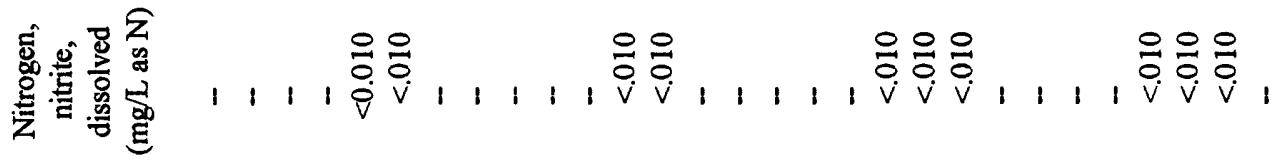

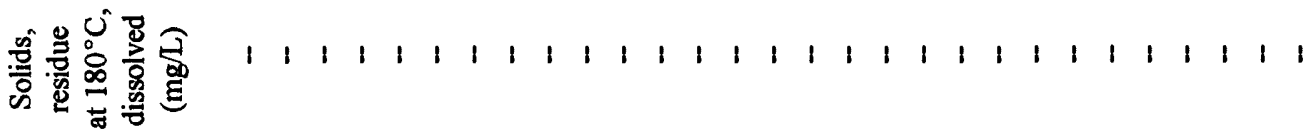

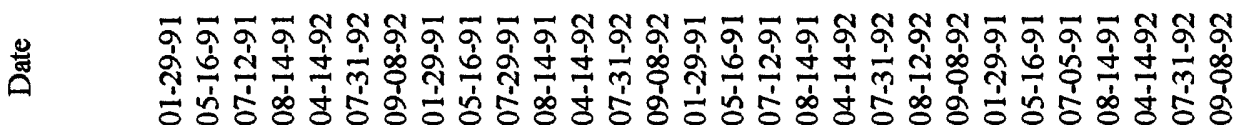

焉要完 


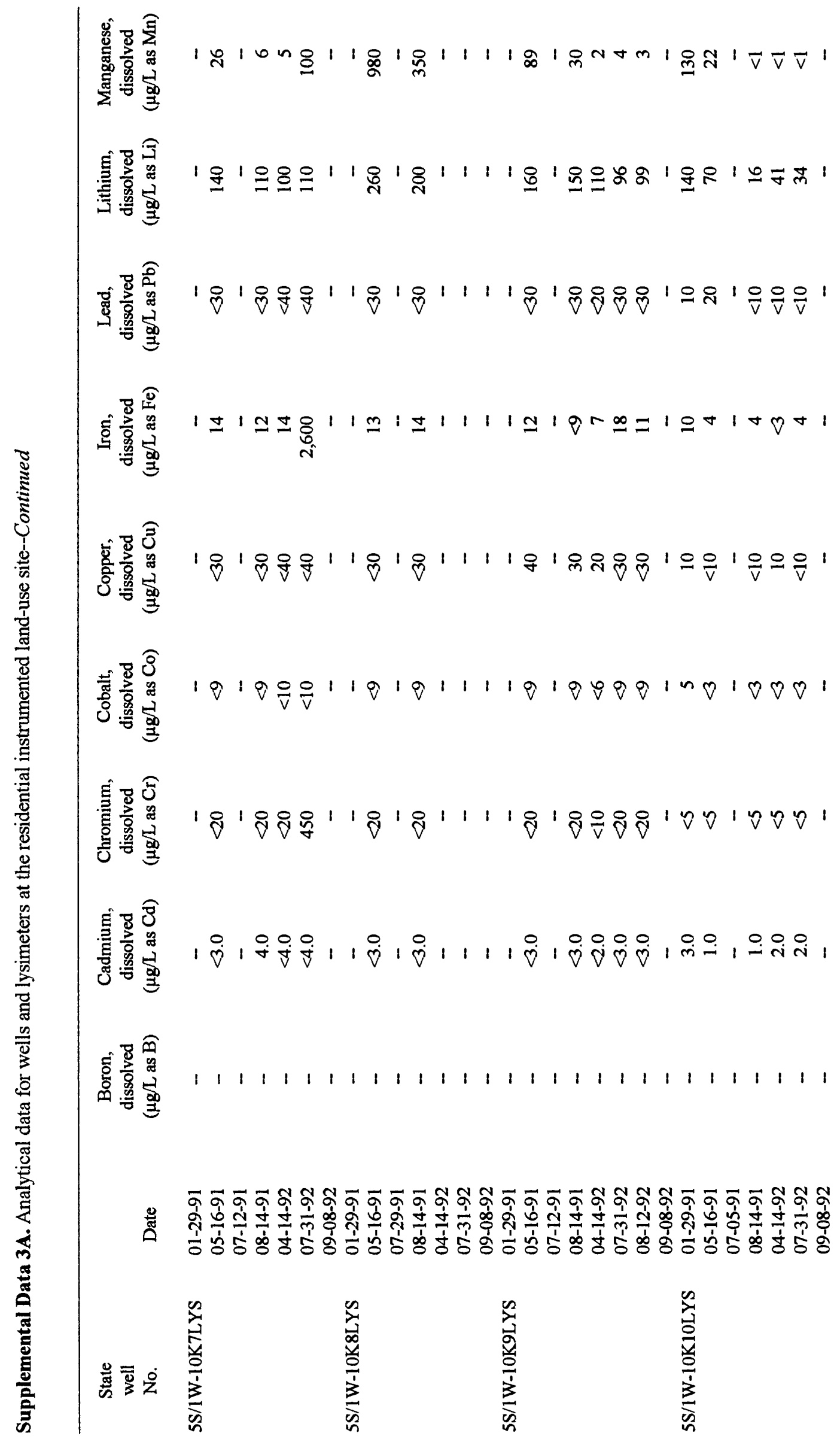




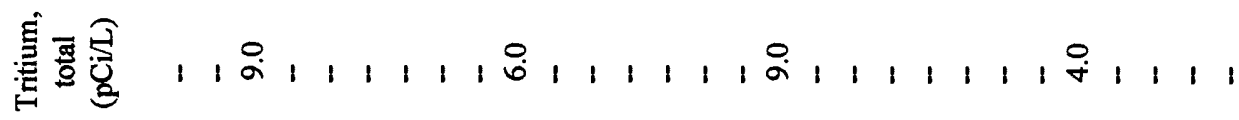

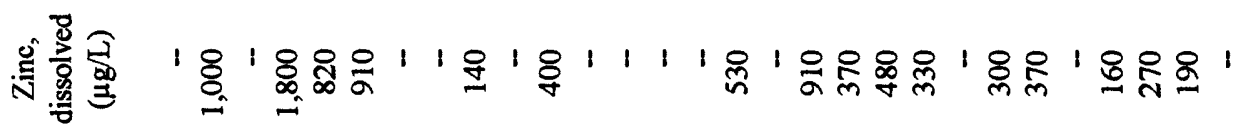

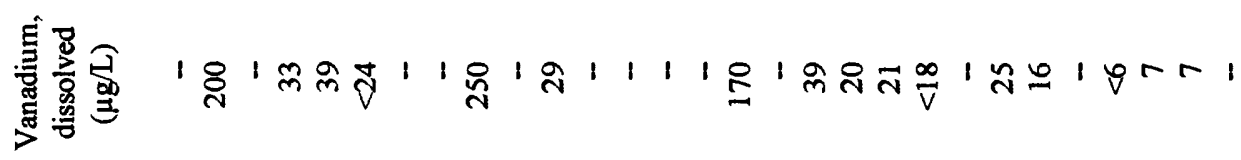

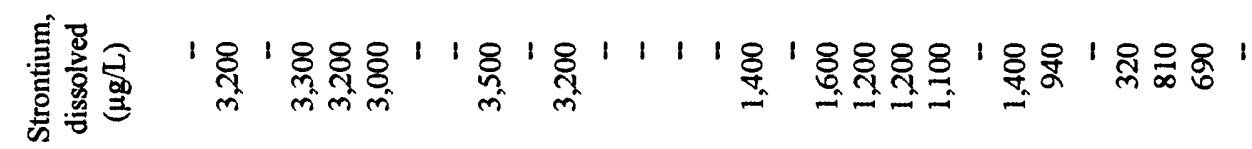

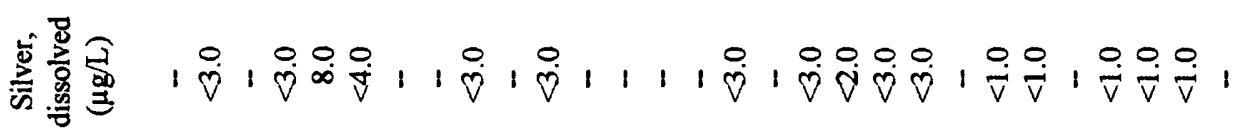

恶惫导

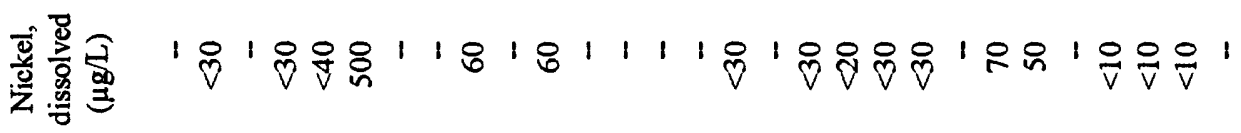

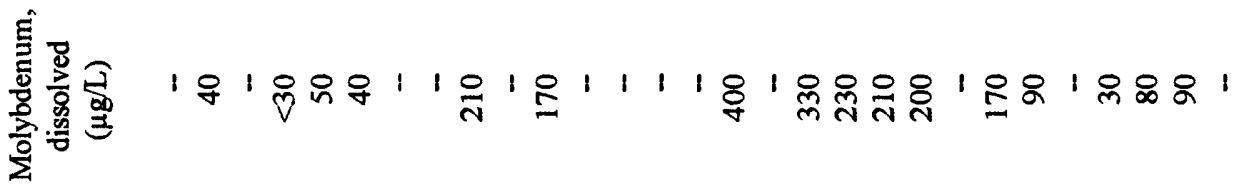

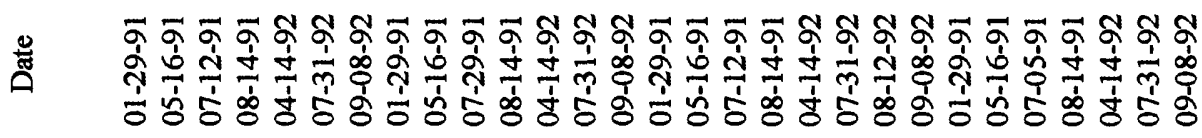

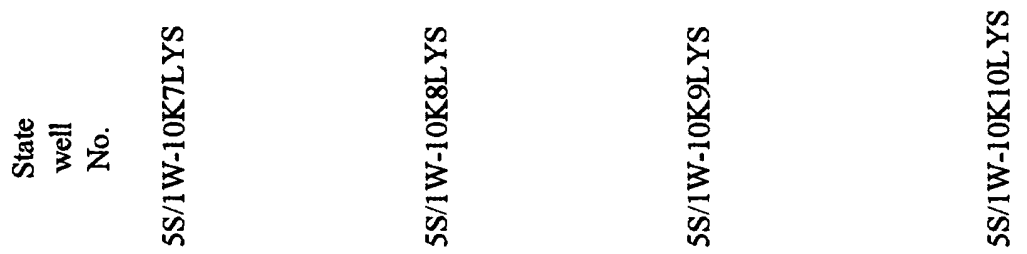

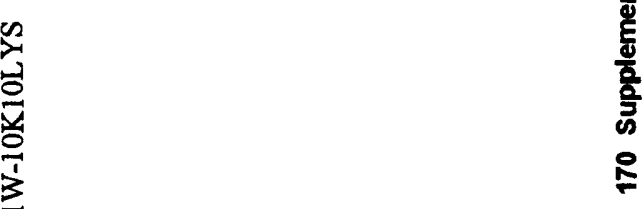




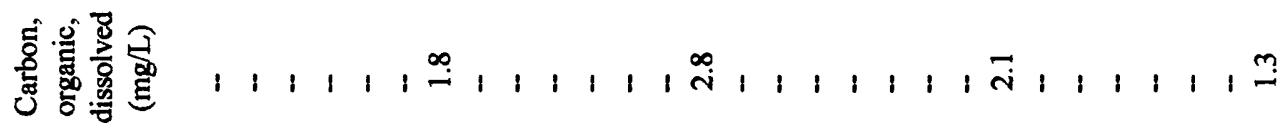

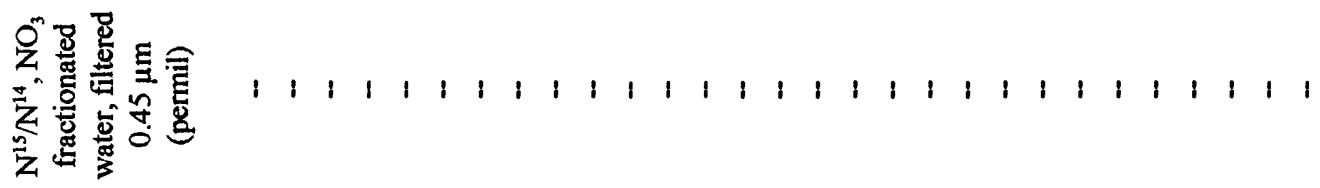

○串

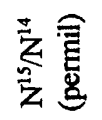

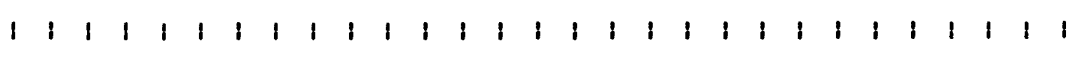

衰产

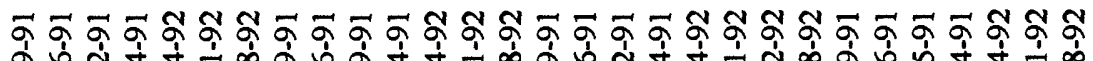

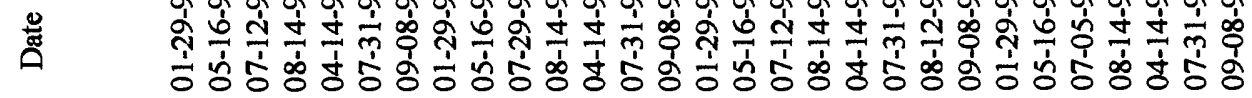

$\dot{4}$

:

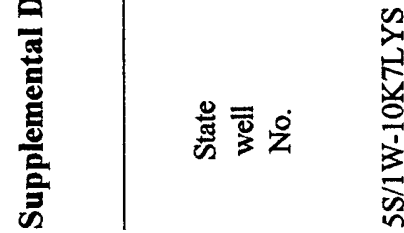

离

离

资 


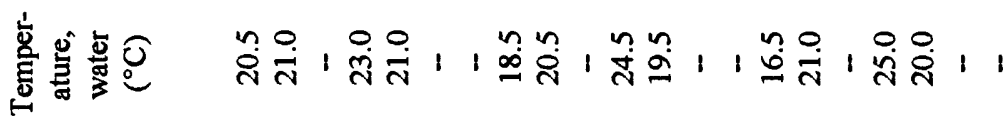

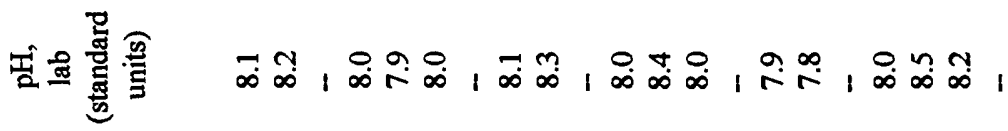

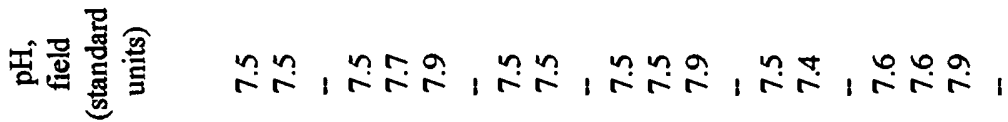

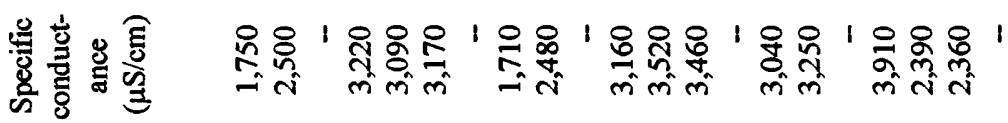

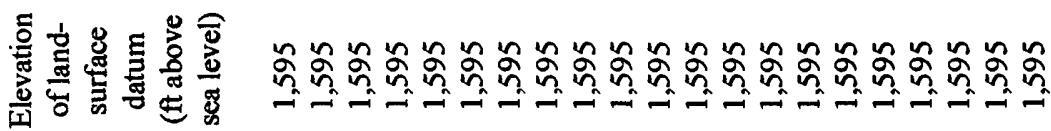

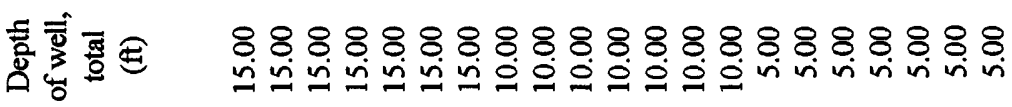

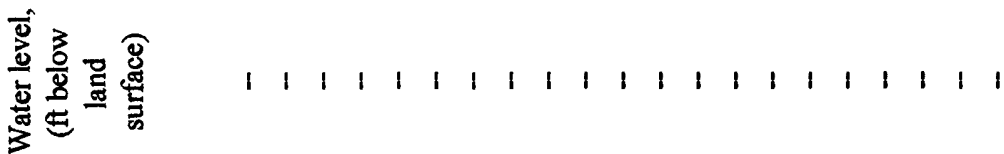

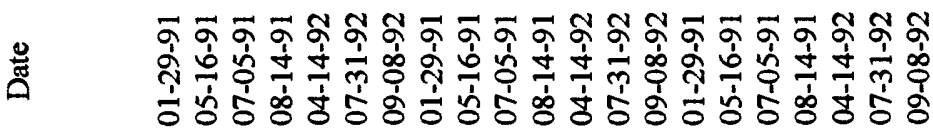

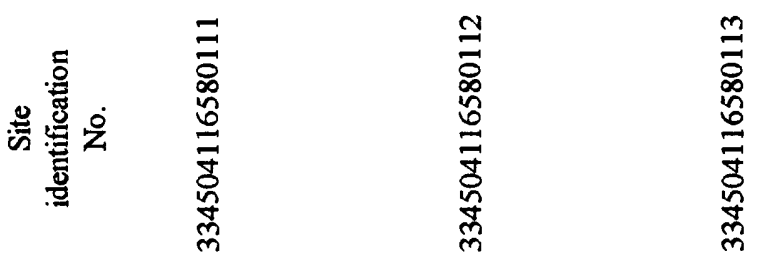

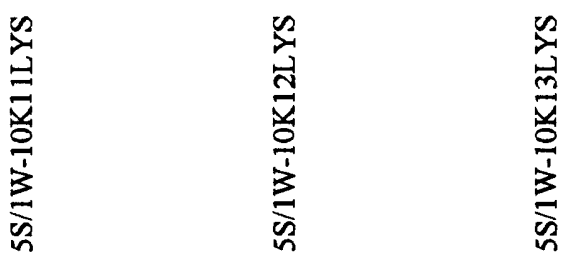




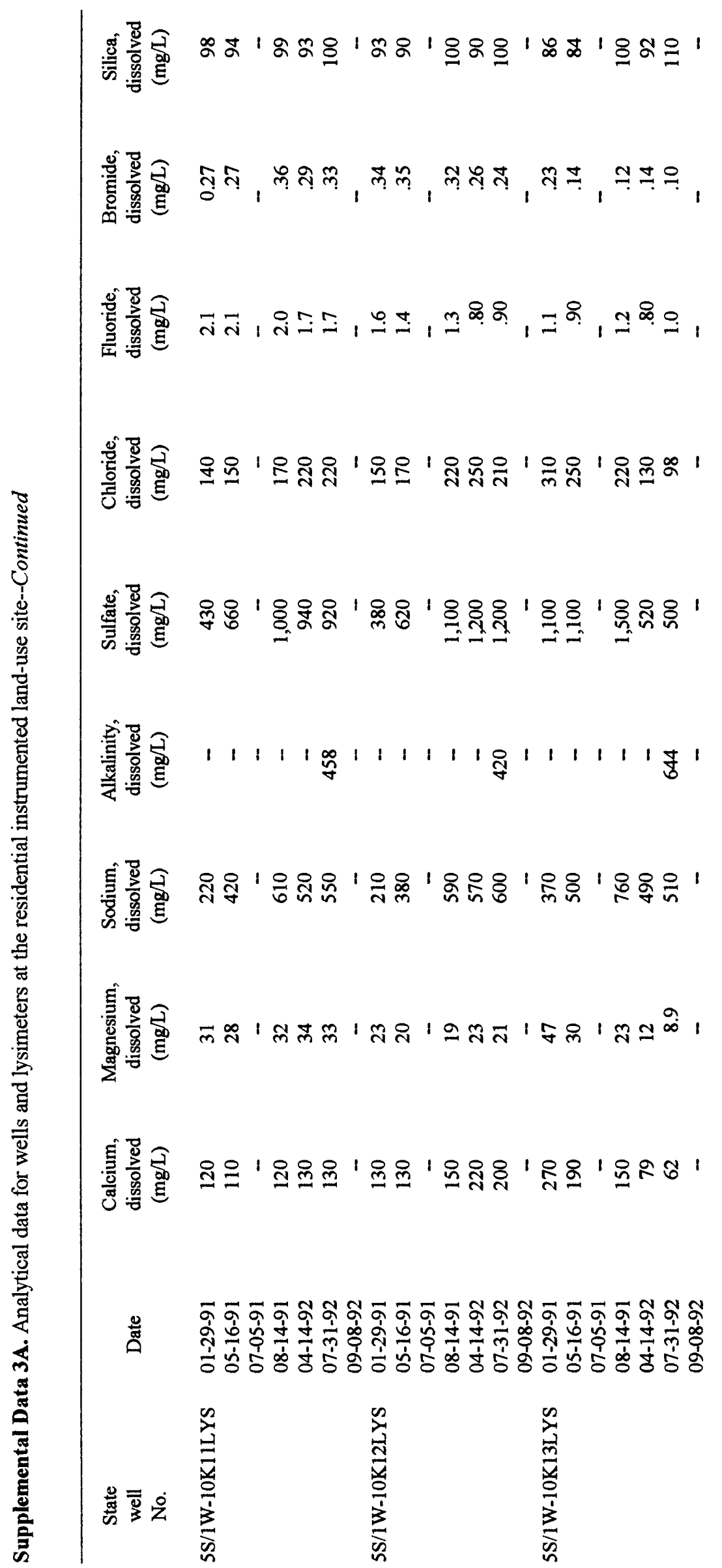




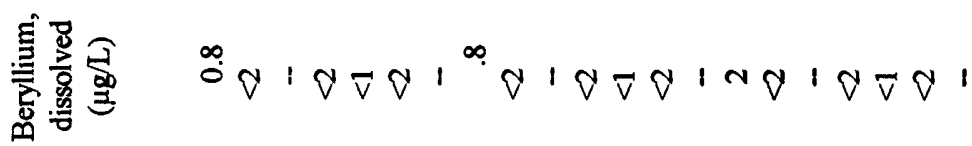

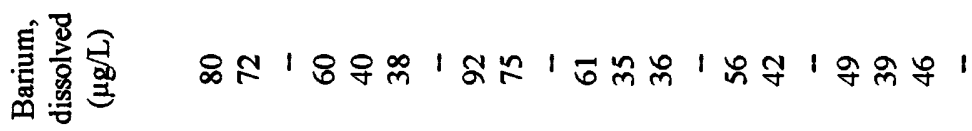

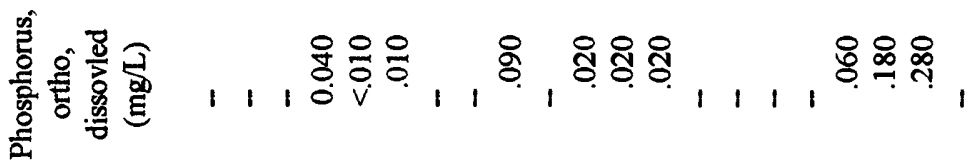

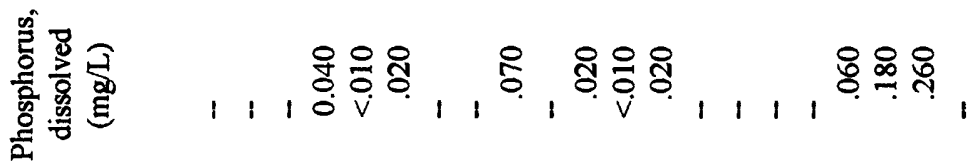

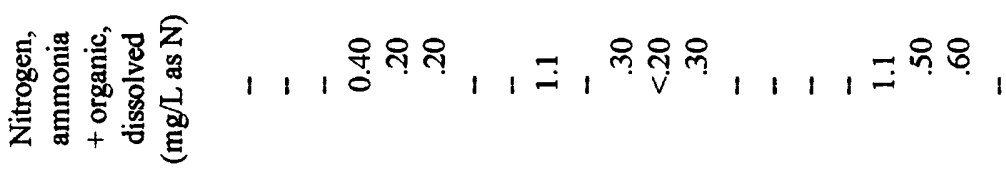

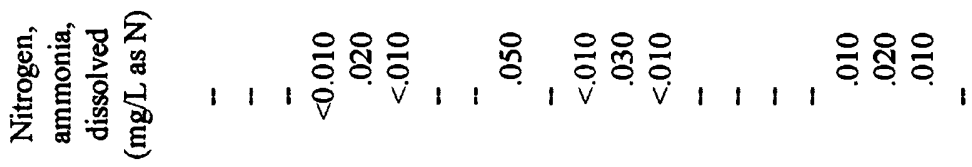

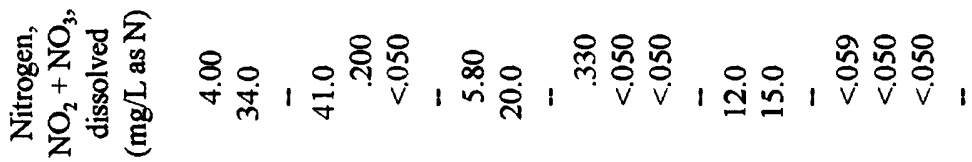

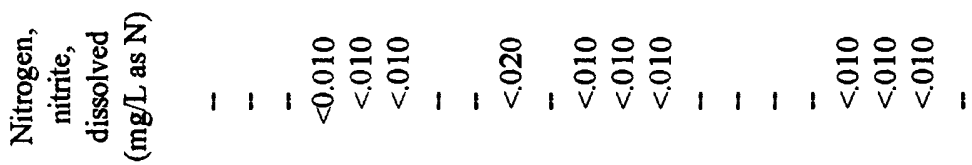

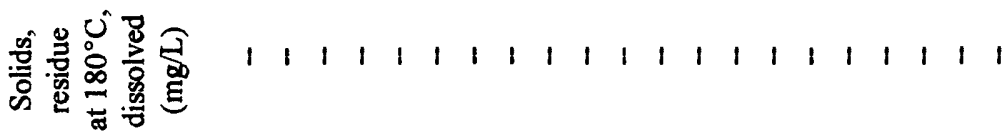

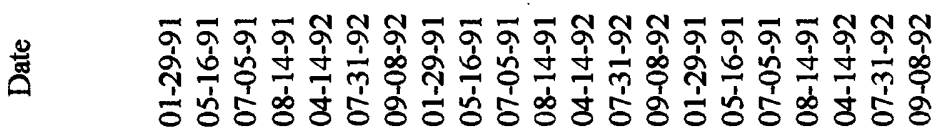

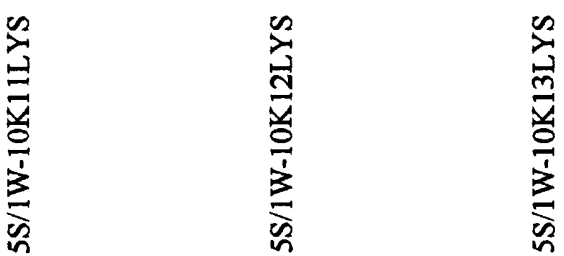




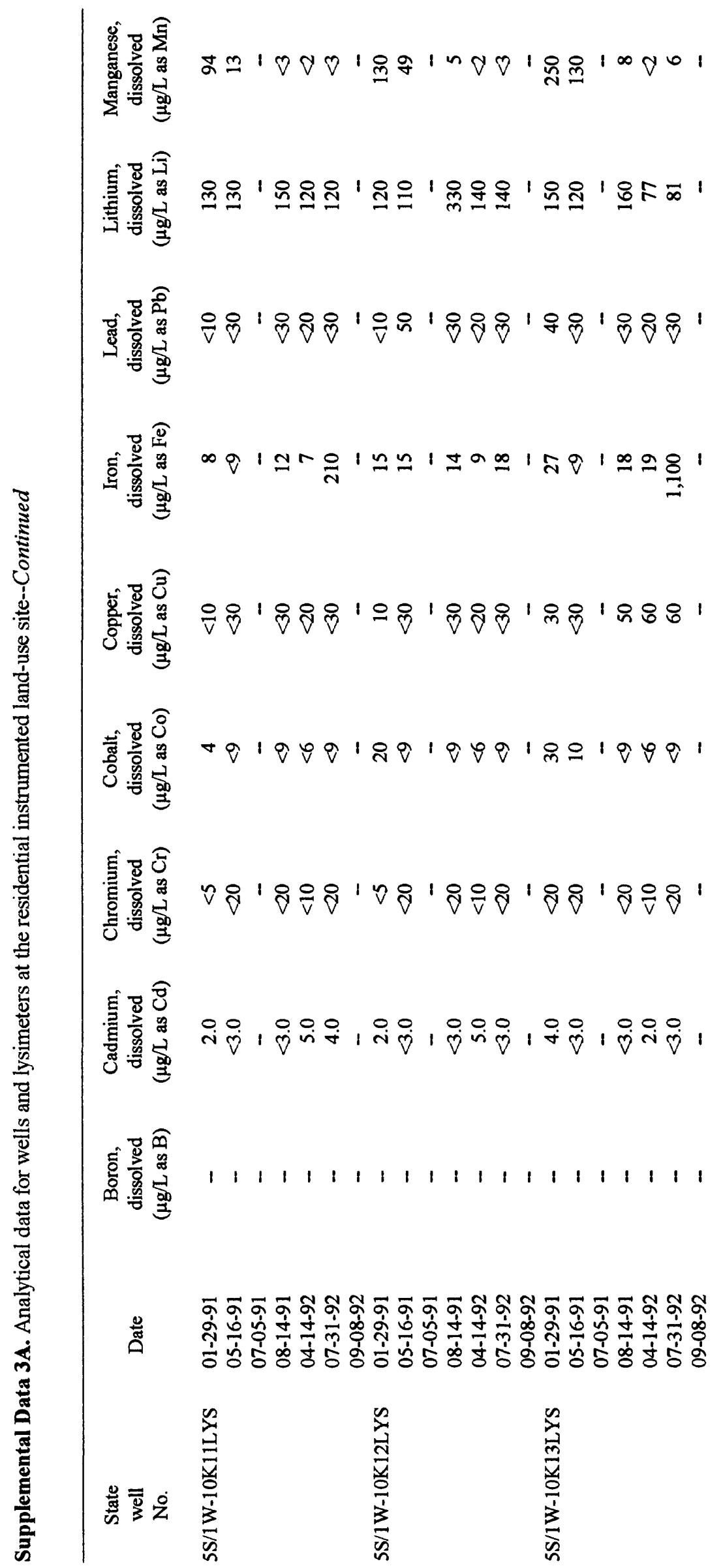




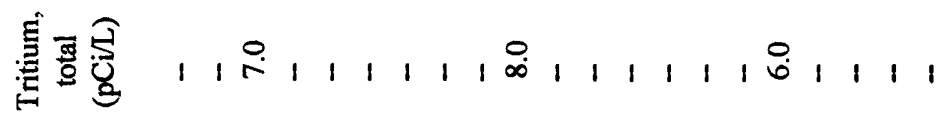

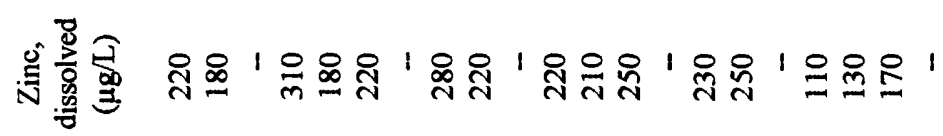

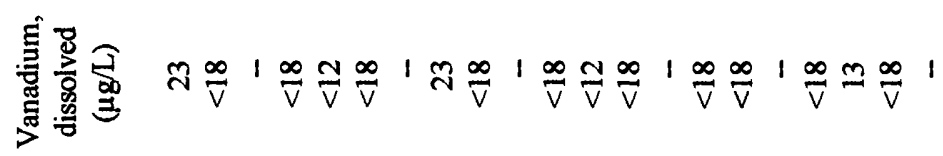

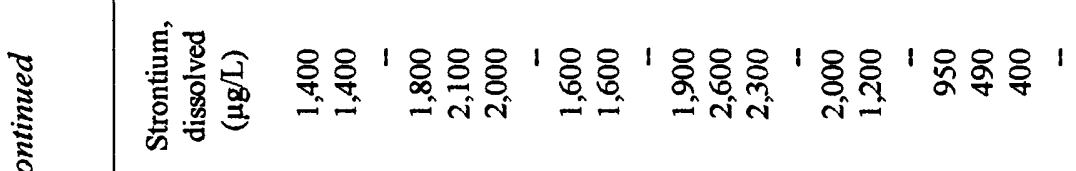

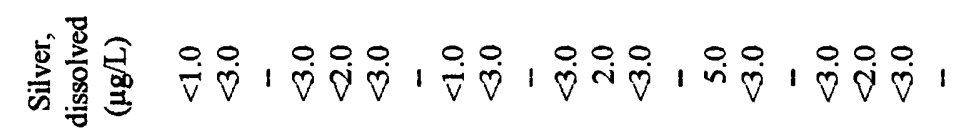

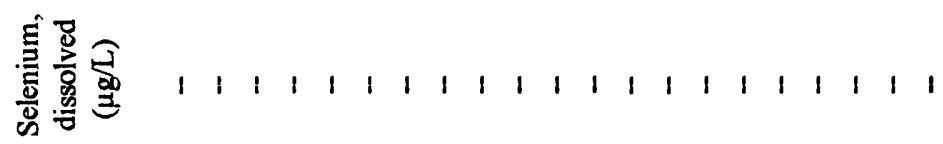

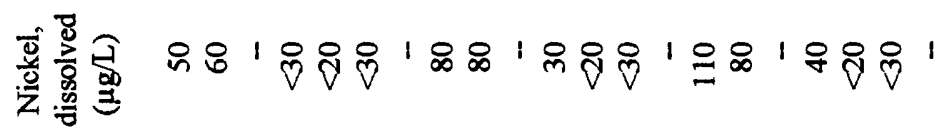

产兽兽

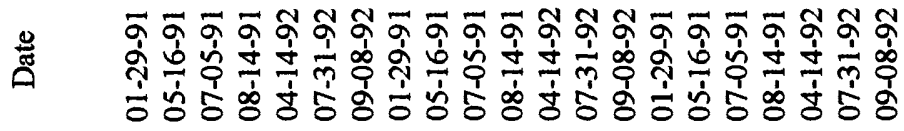

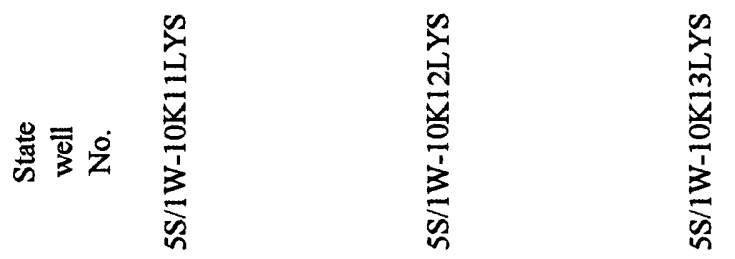




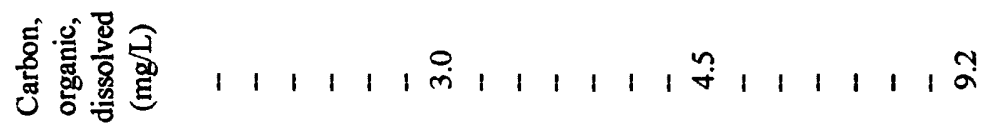

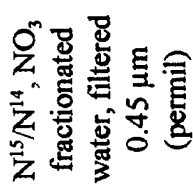

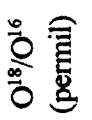

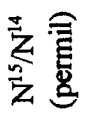

$\begin{array}{lllllllllllllllllllll}1 & 1 & 1 & 1 & 1 & 1 & 1 & 1 & 1 & 1 & 1 & 1 & 1 & 1 & 1 & 1 & 1 & 1 & 1 & 1 & 1\end{array}$

密高

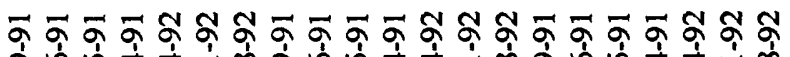

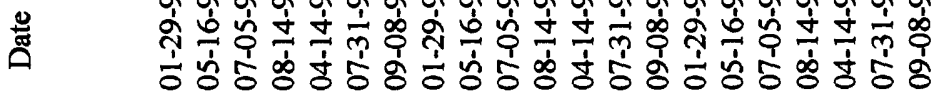

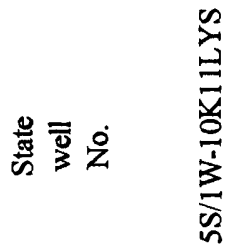

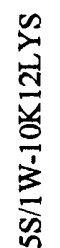

$\frac{2}{\frac{2}{2}}$ 


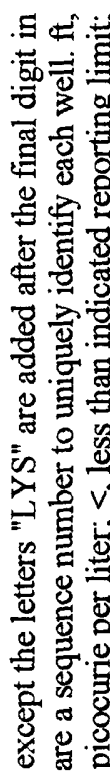

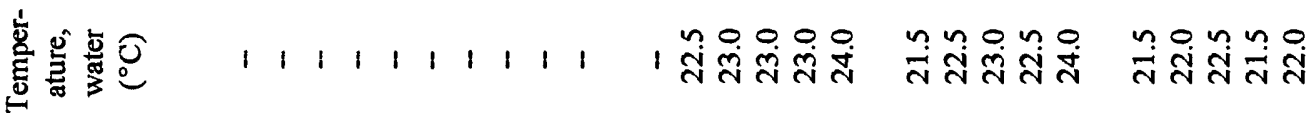

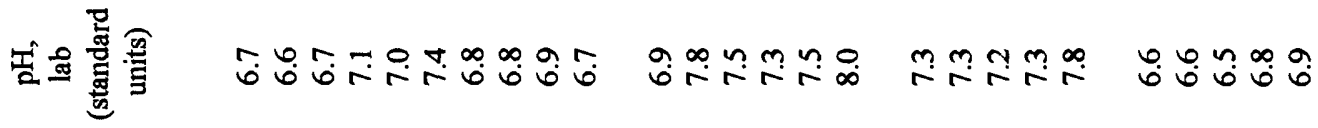

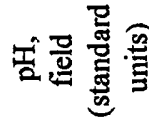

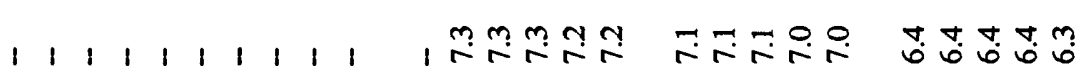

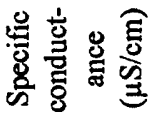

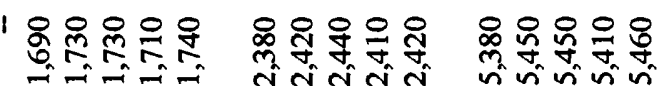
की :

. $\frac{0}{0}$ 需岁 䆑察

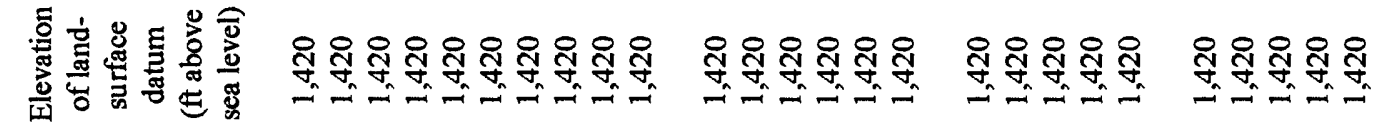
बi 을

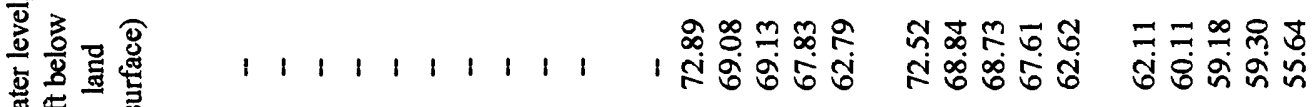

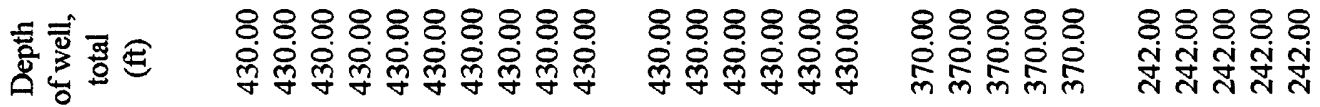
马 


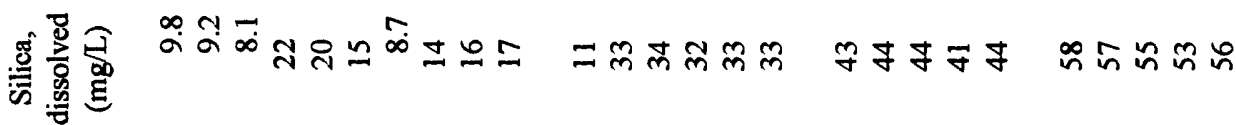

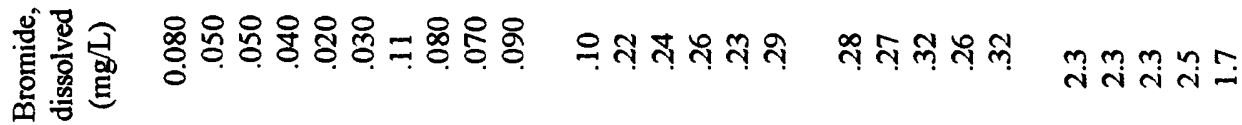

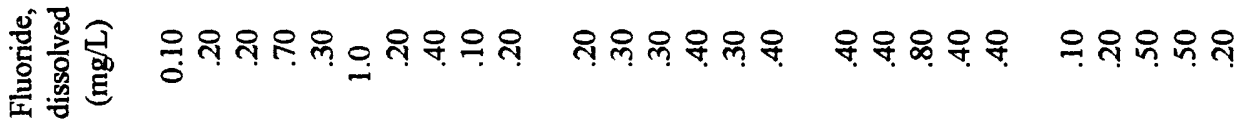

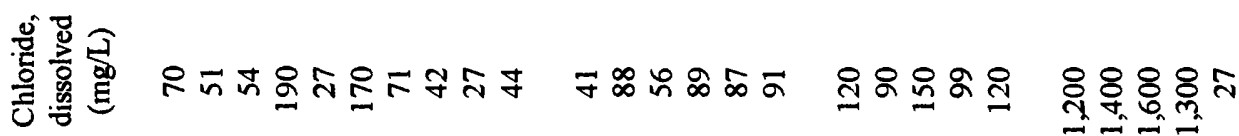

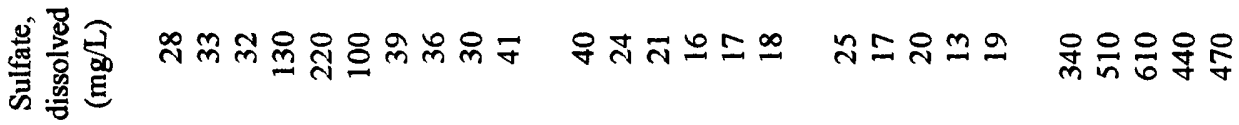

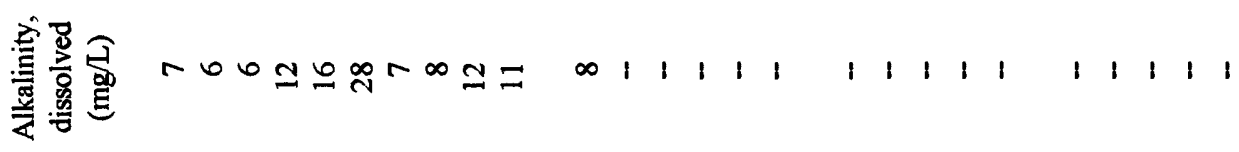

言总总

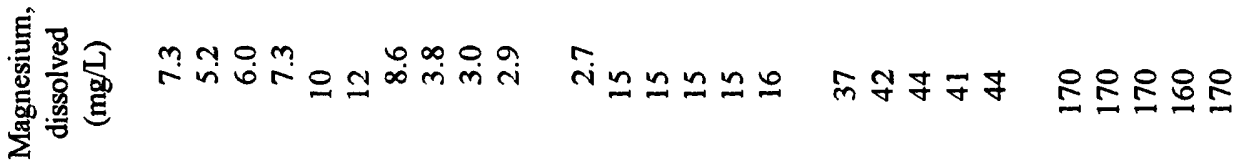

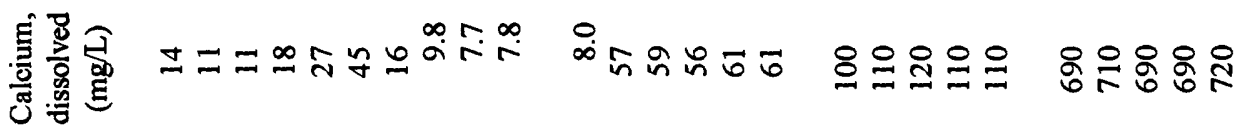

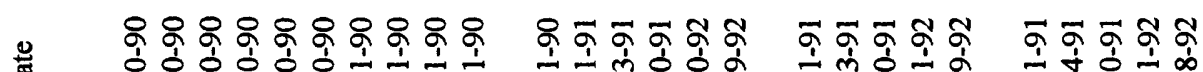

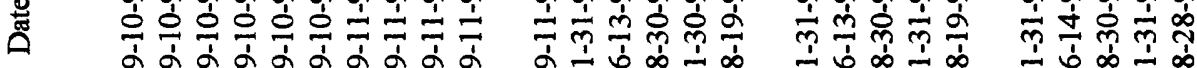

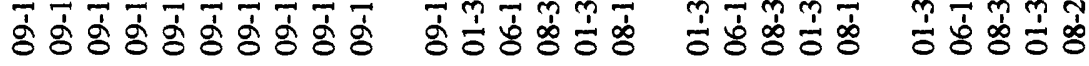

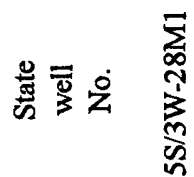

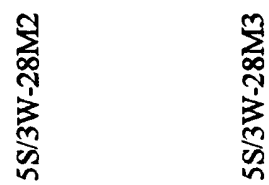




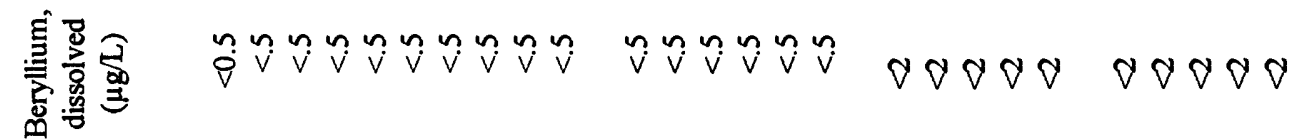

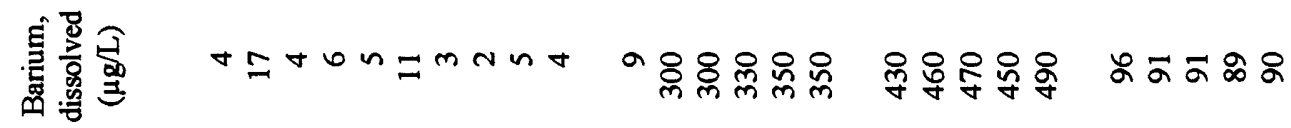

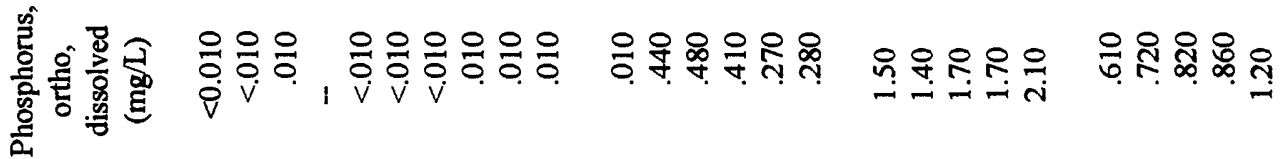

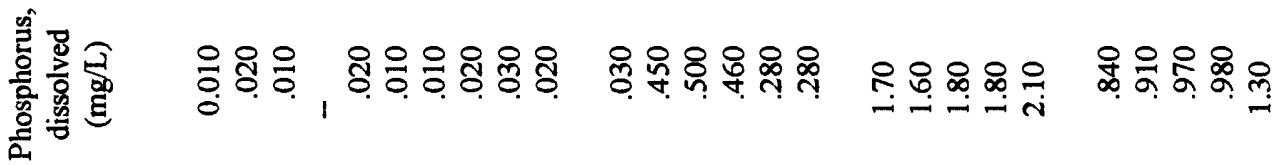

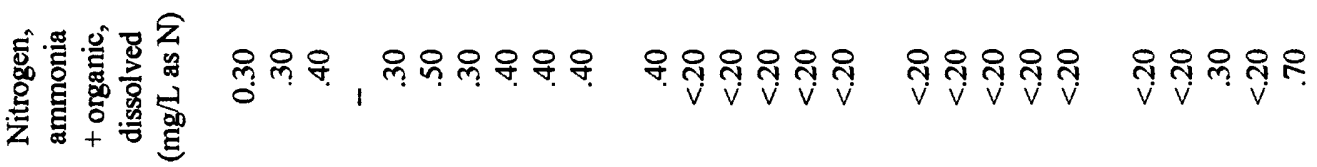

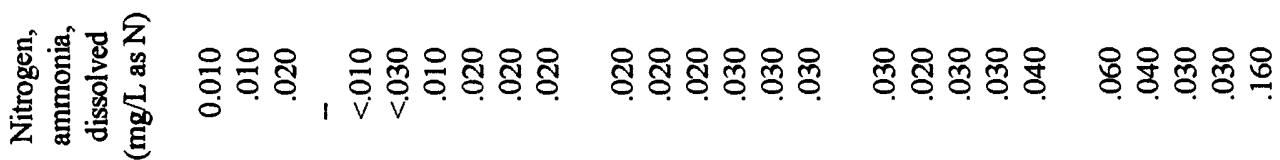

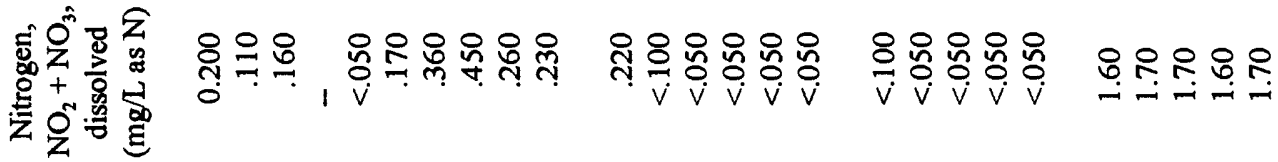

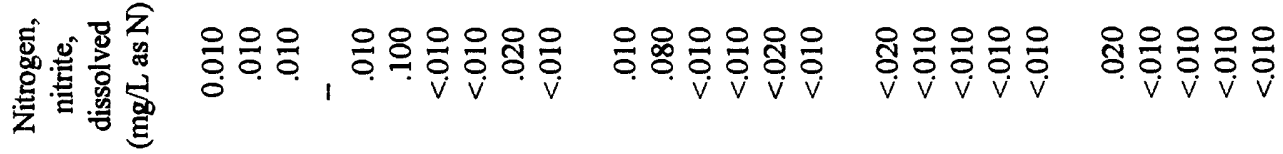

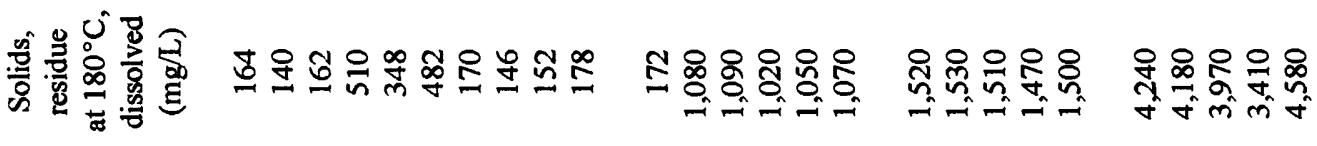

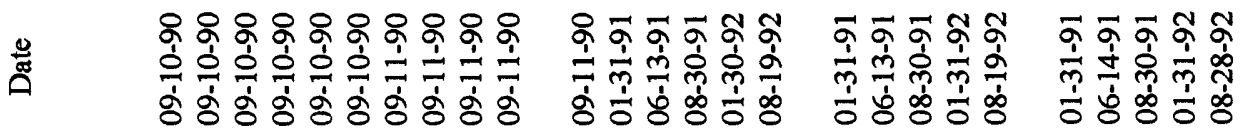

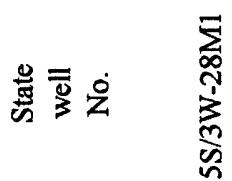

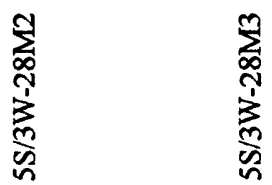




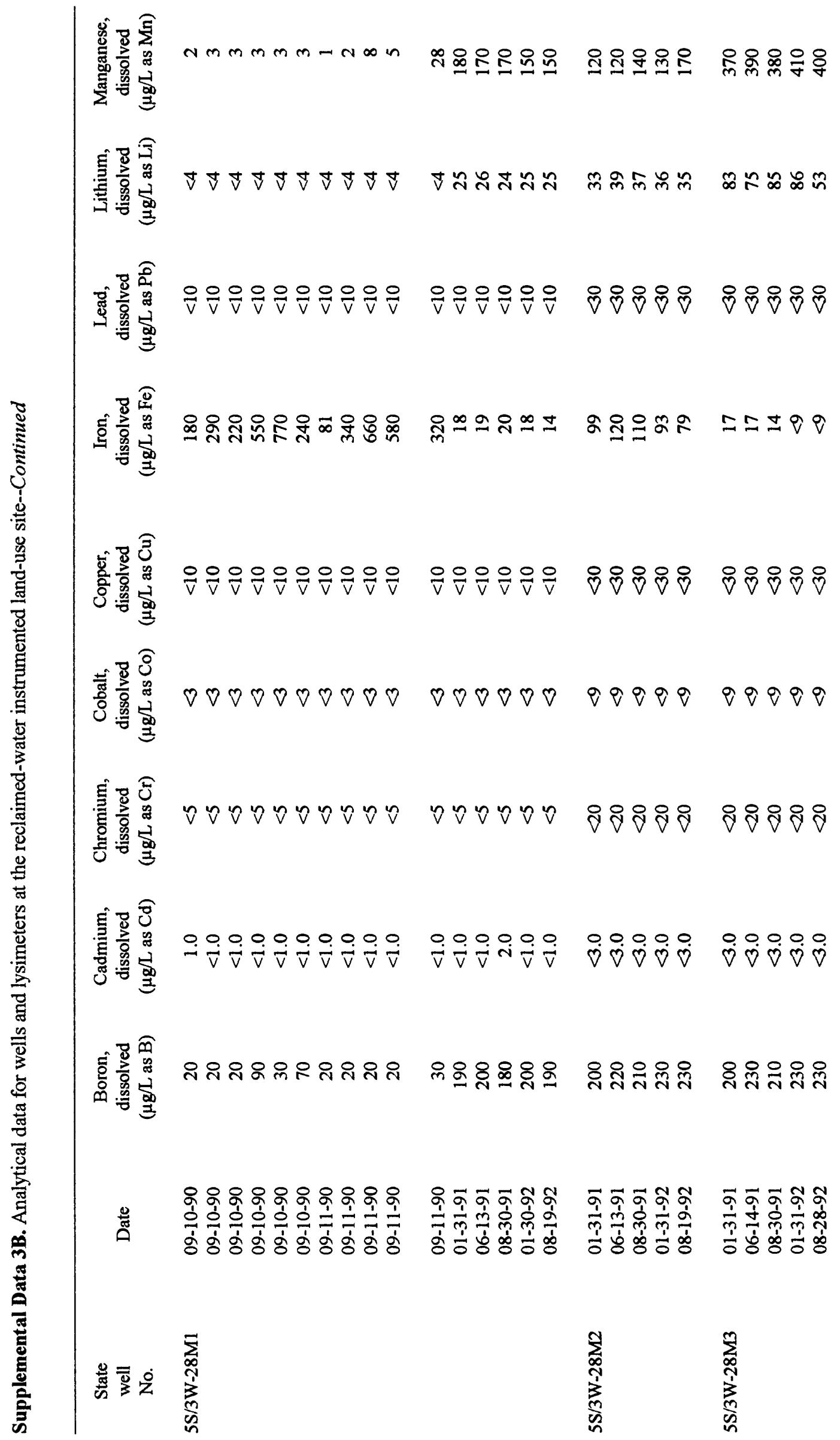


nng

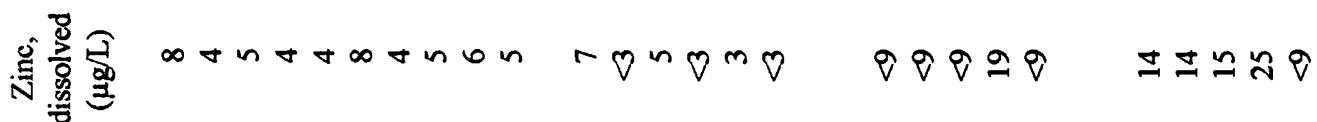

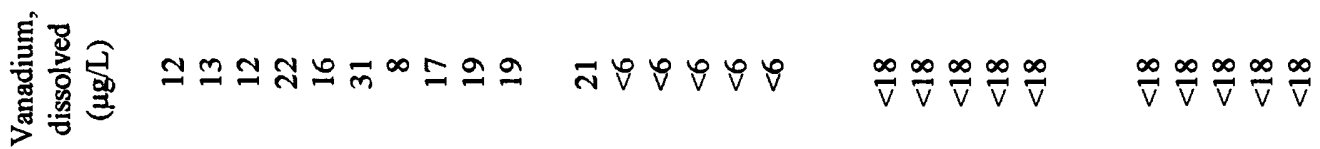

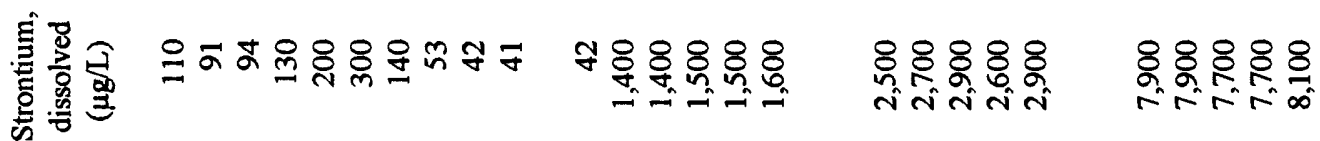

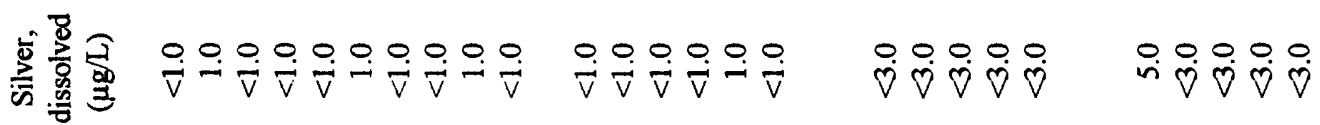

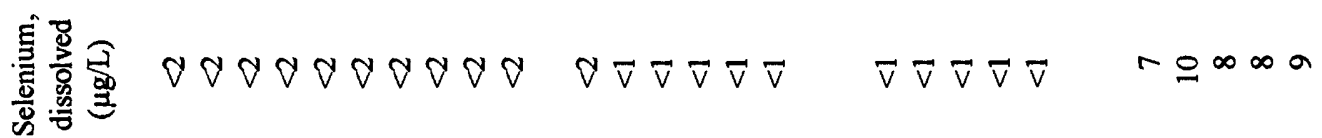

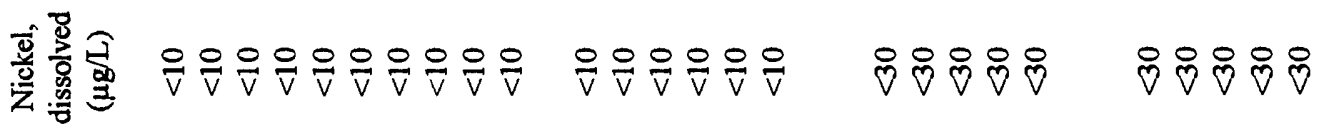

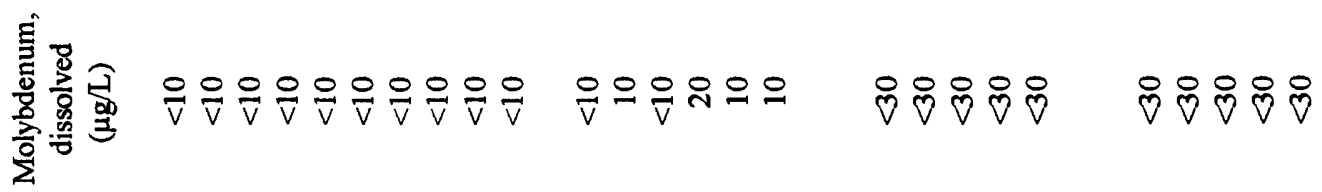

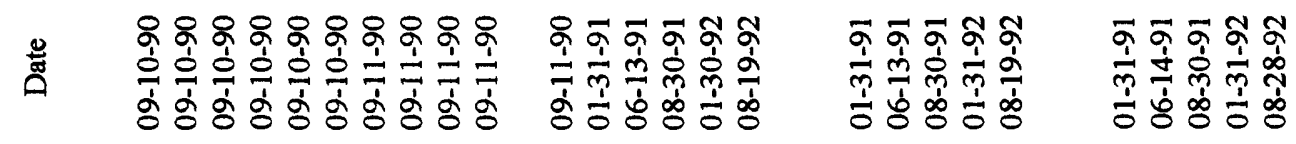

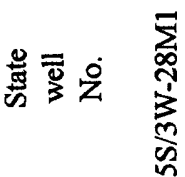

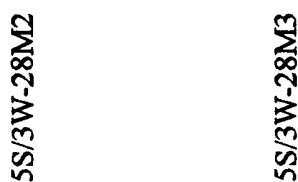




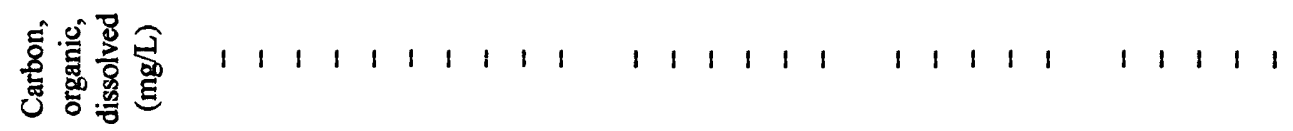

응

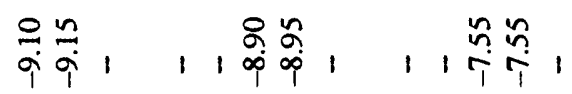
学余 11111111111 111111 11111 $\begin{array}{lllll}1 & 1 & 1 & 1 & 1\end{array}$

武䑐 111111111 111 กู่

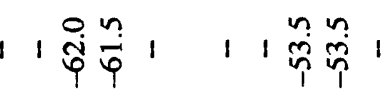

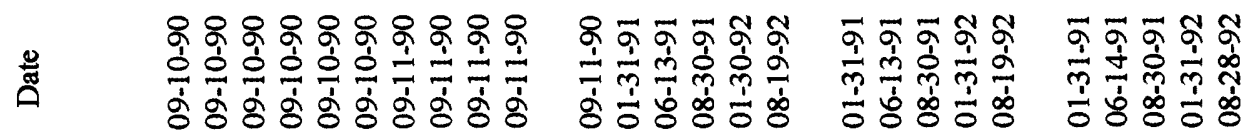




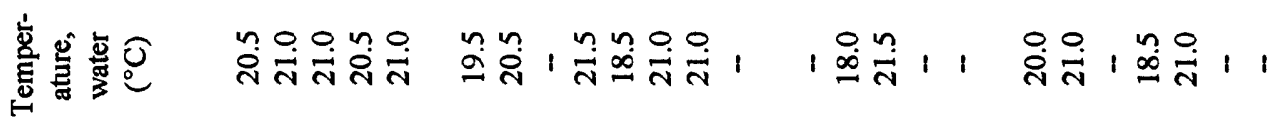

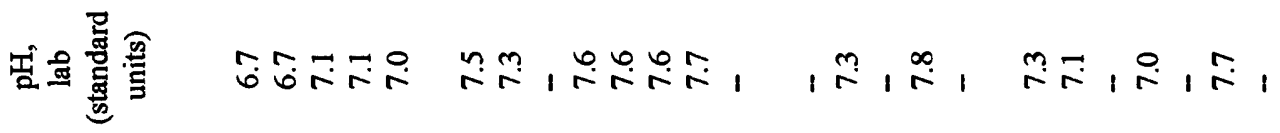

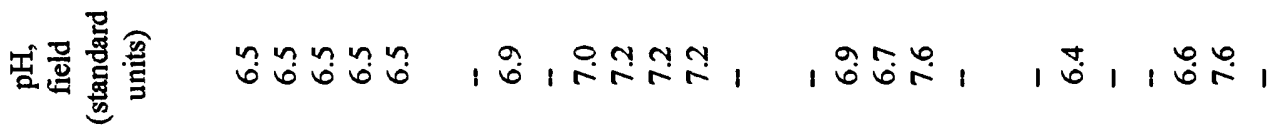

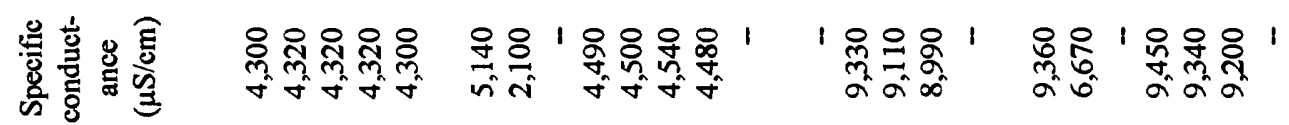

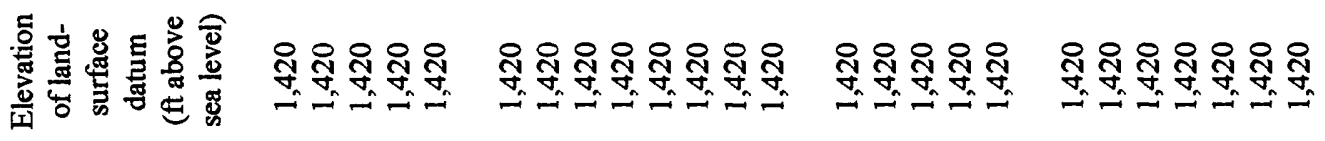

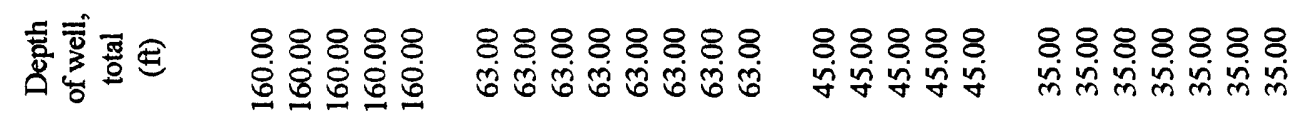

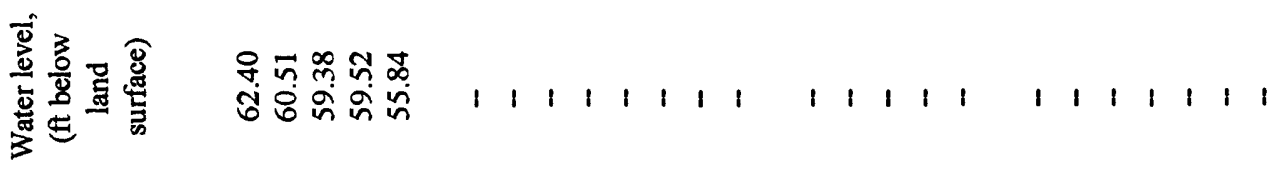

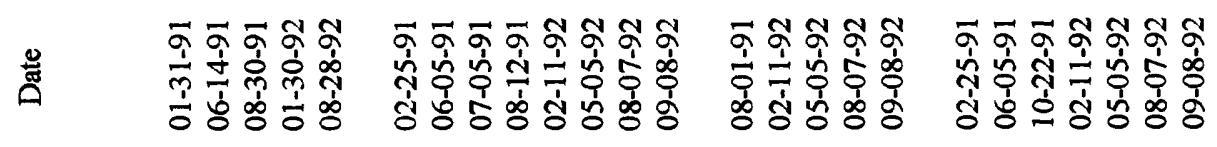

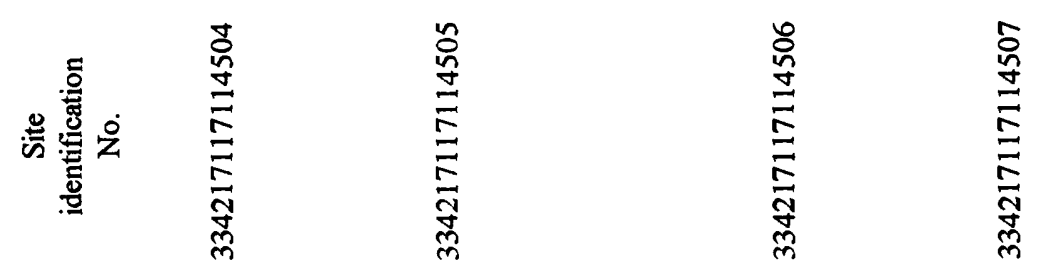

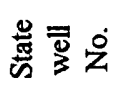




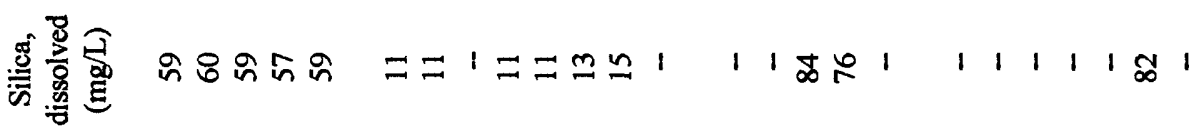

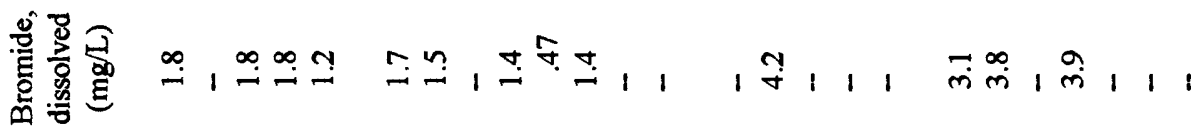

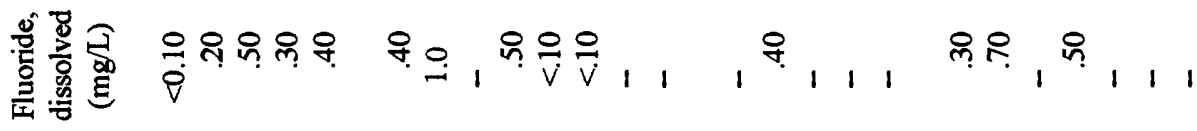

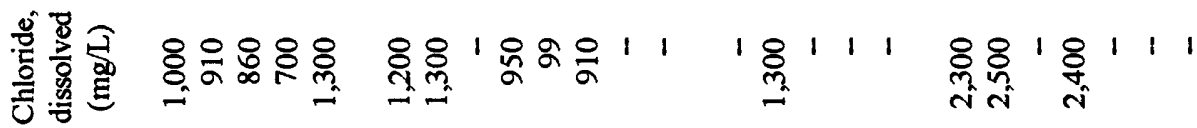

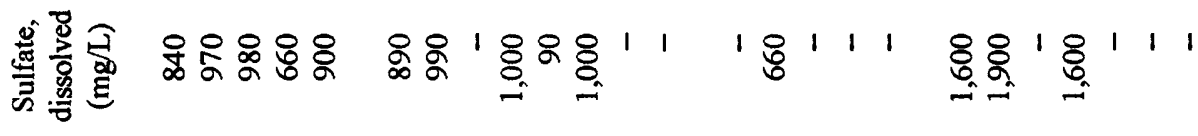

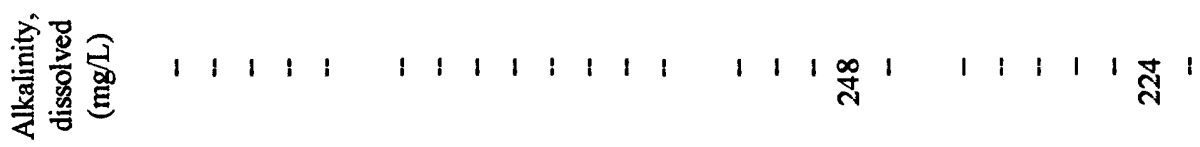

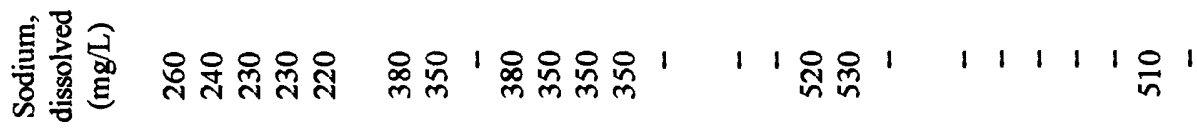

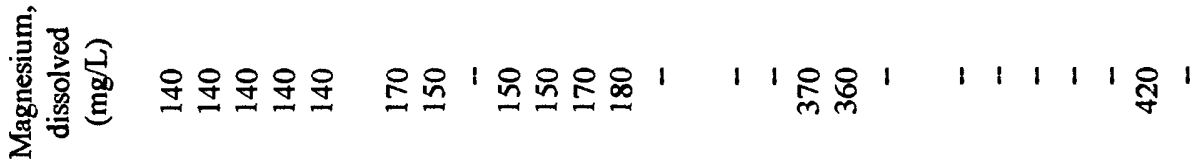

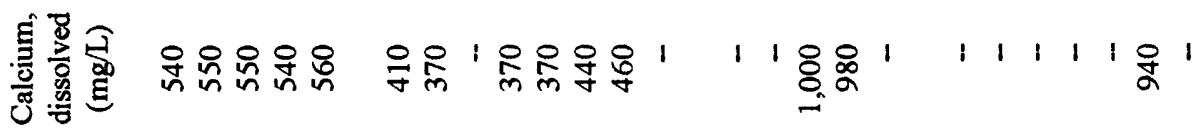


緊量

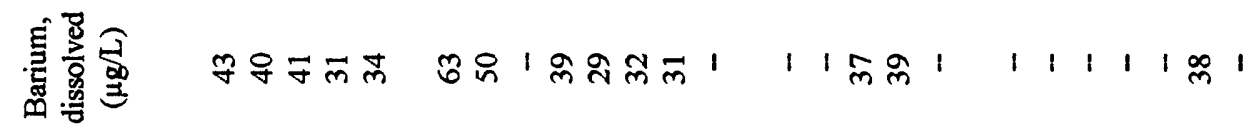
1ำ

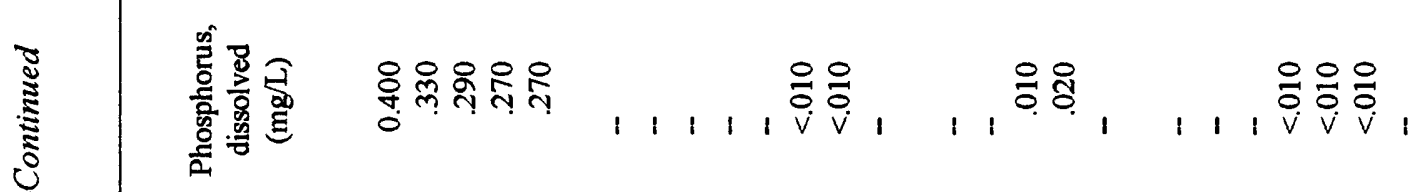
प111

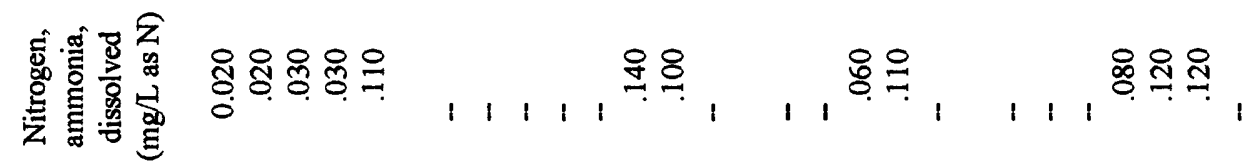

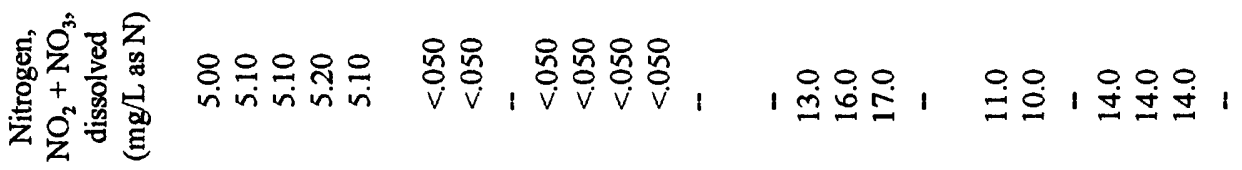

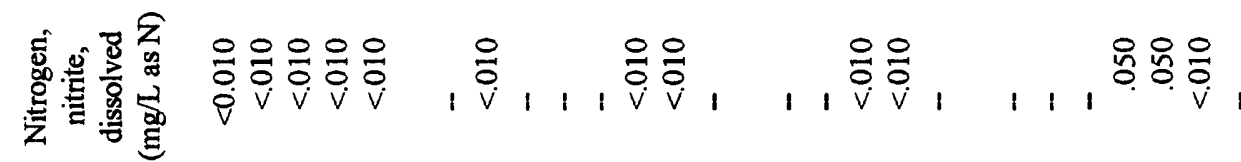

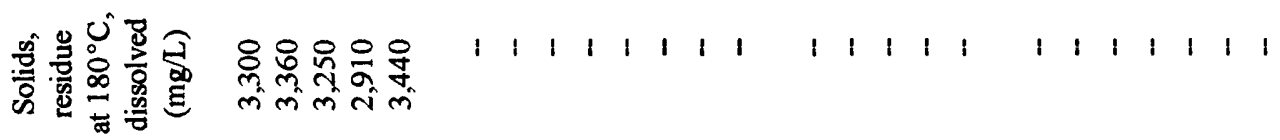

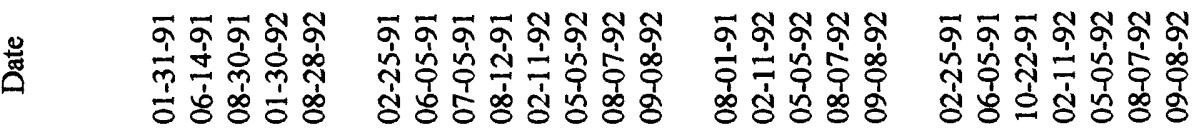

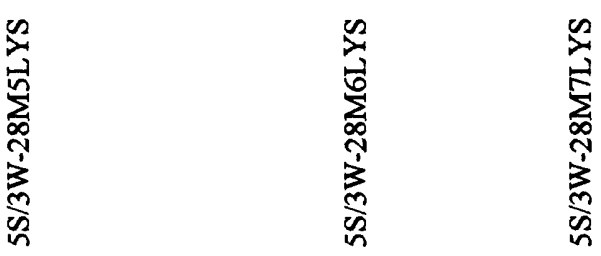




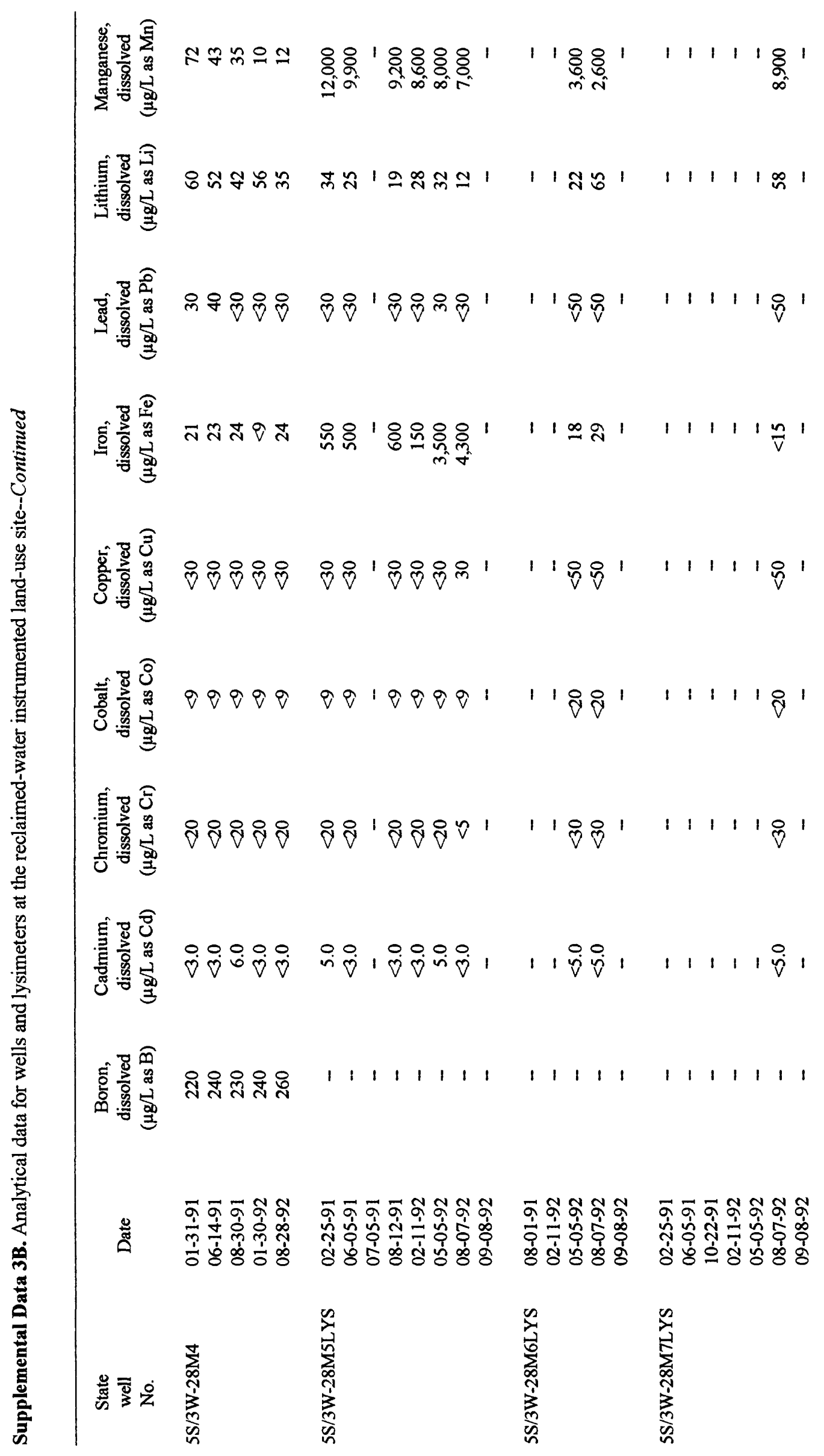




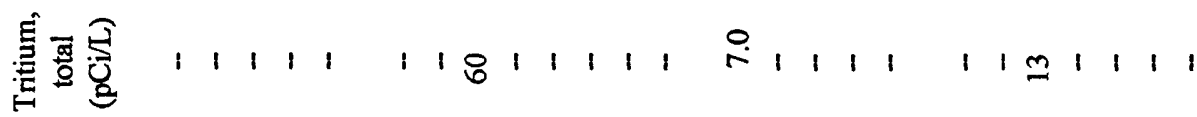

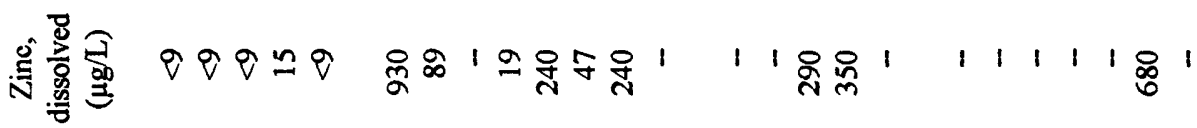

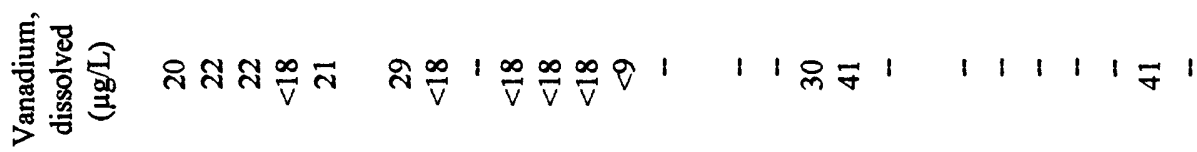

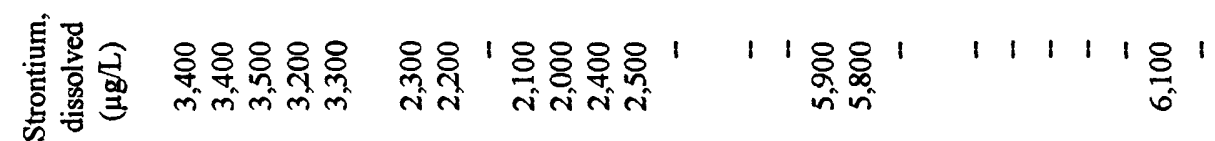

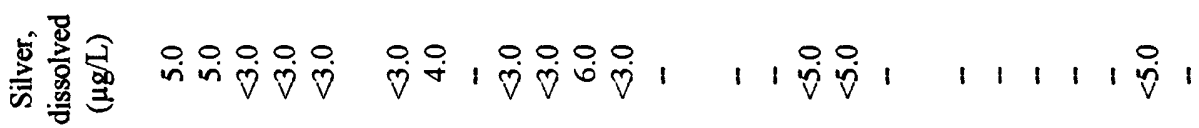

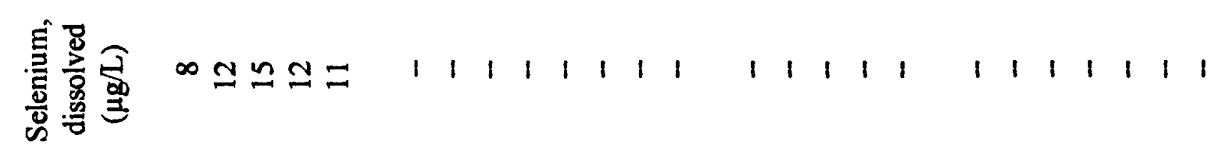

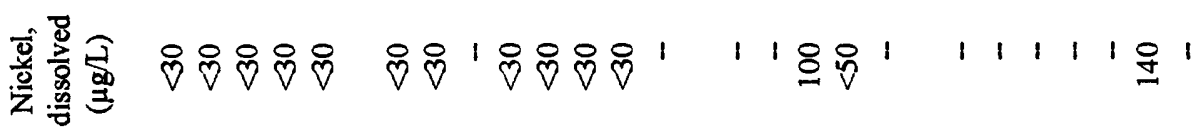

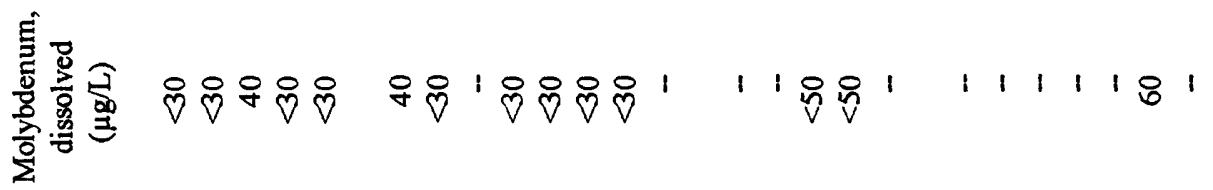

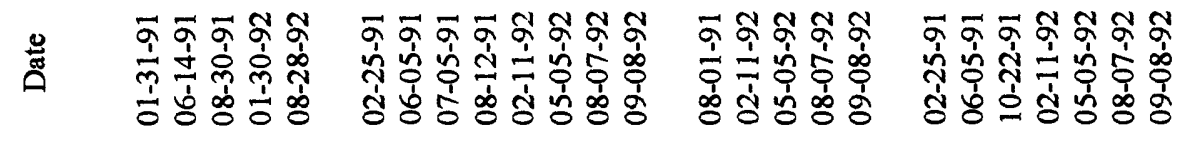




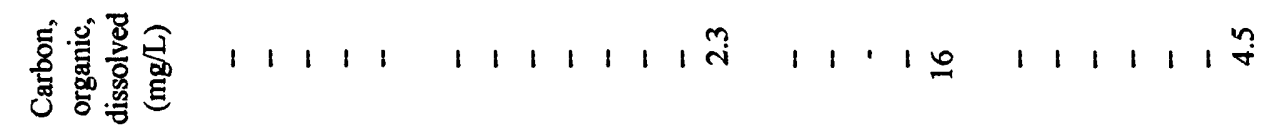

$\bigcirc^{m} \ddot{Z}$

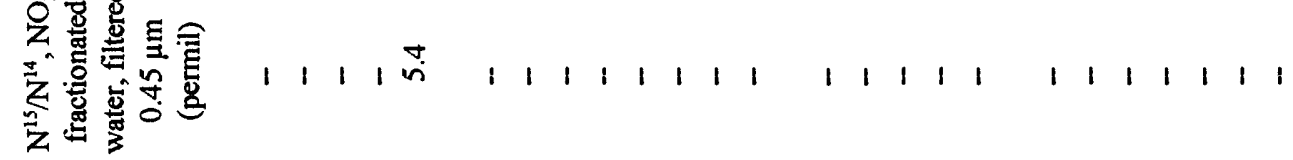

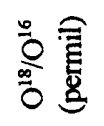
$1: \frac{1}{n} n$

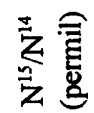
1 1 รัँ 1

焉 总 1 i⿱ñ in 1 1111111 $\begin{array}{lllll}1 & 1 & 1 & 1 & 1\end{array}$ $\begin{array}{lllllll}1 & 1 & 1 & 1 & 1 & 1 & 1\end{array}$

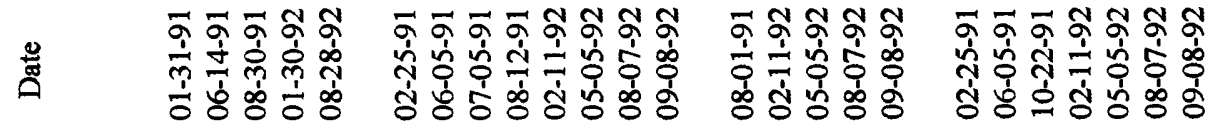




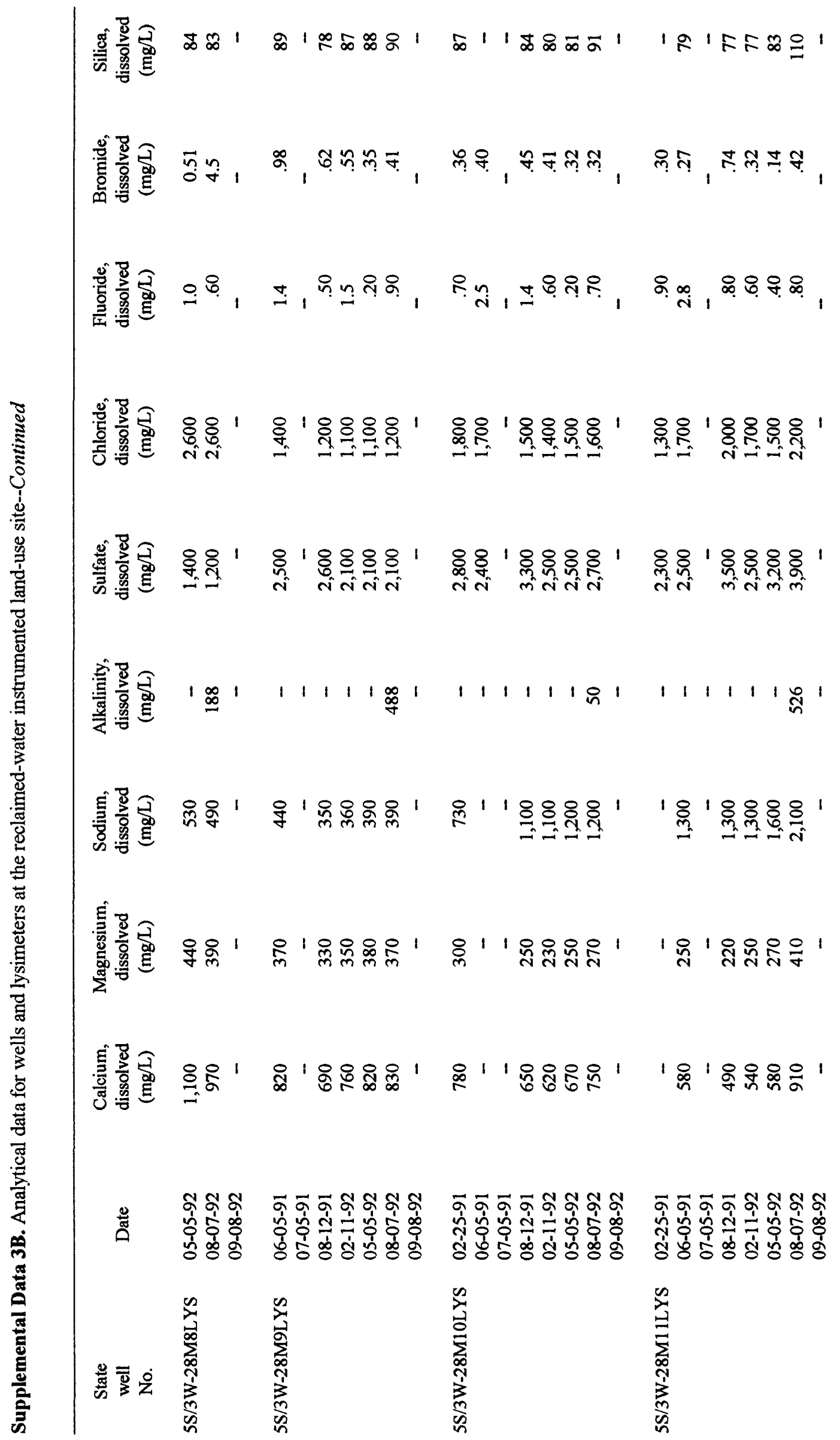




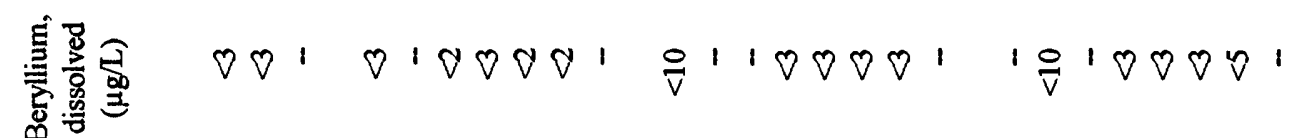

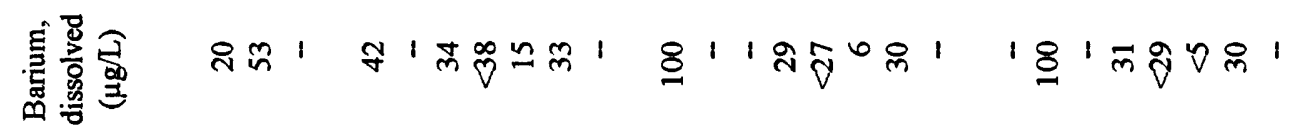

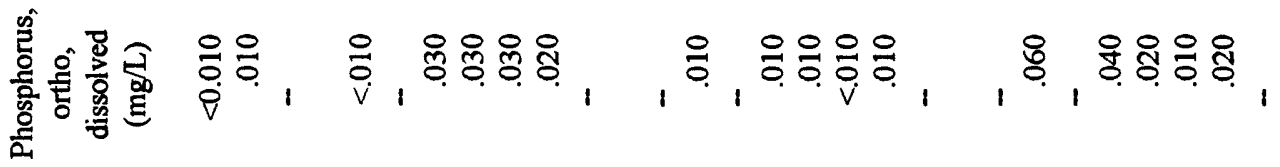

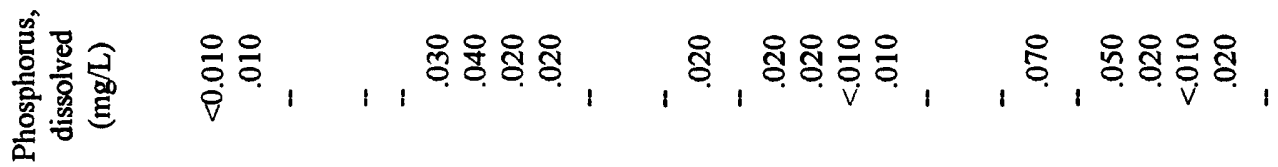

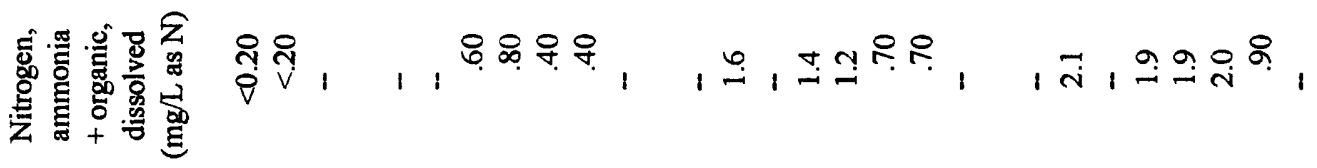

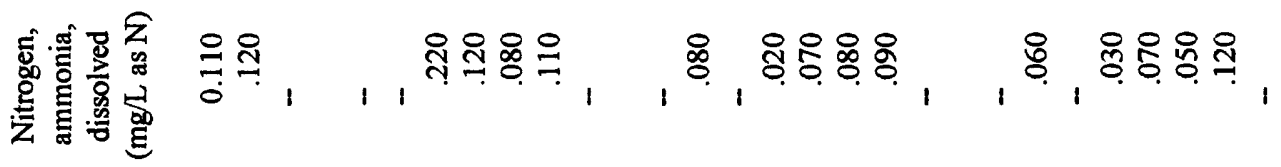

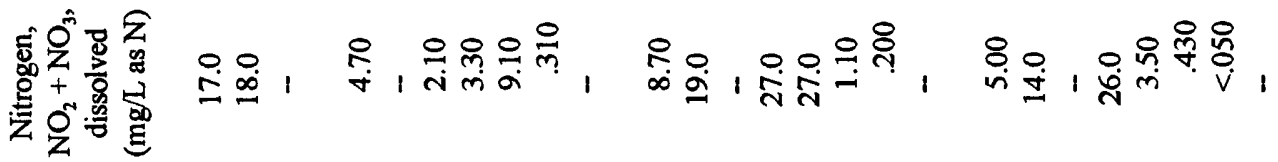

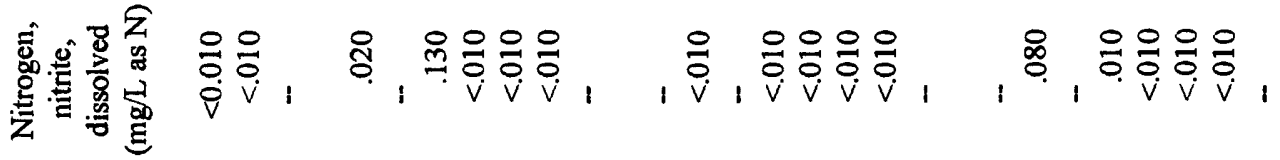

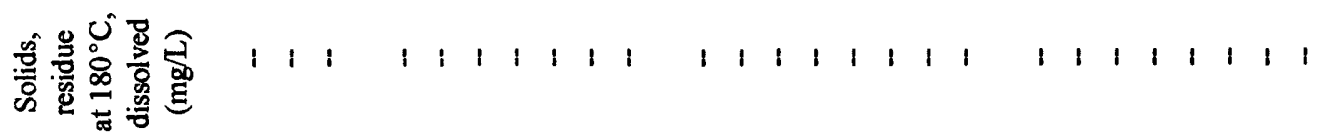

空




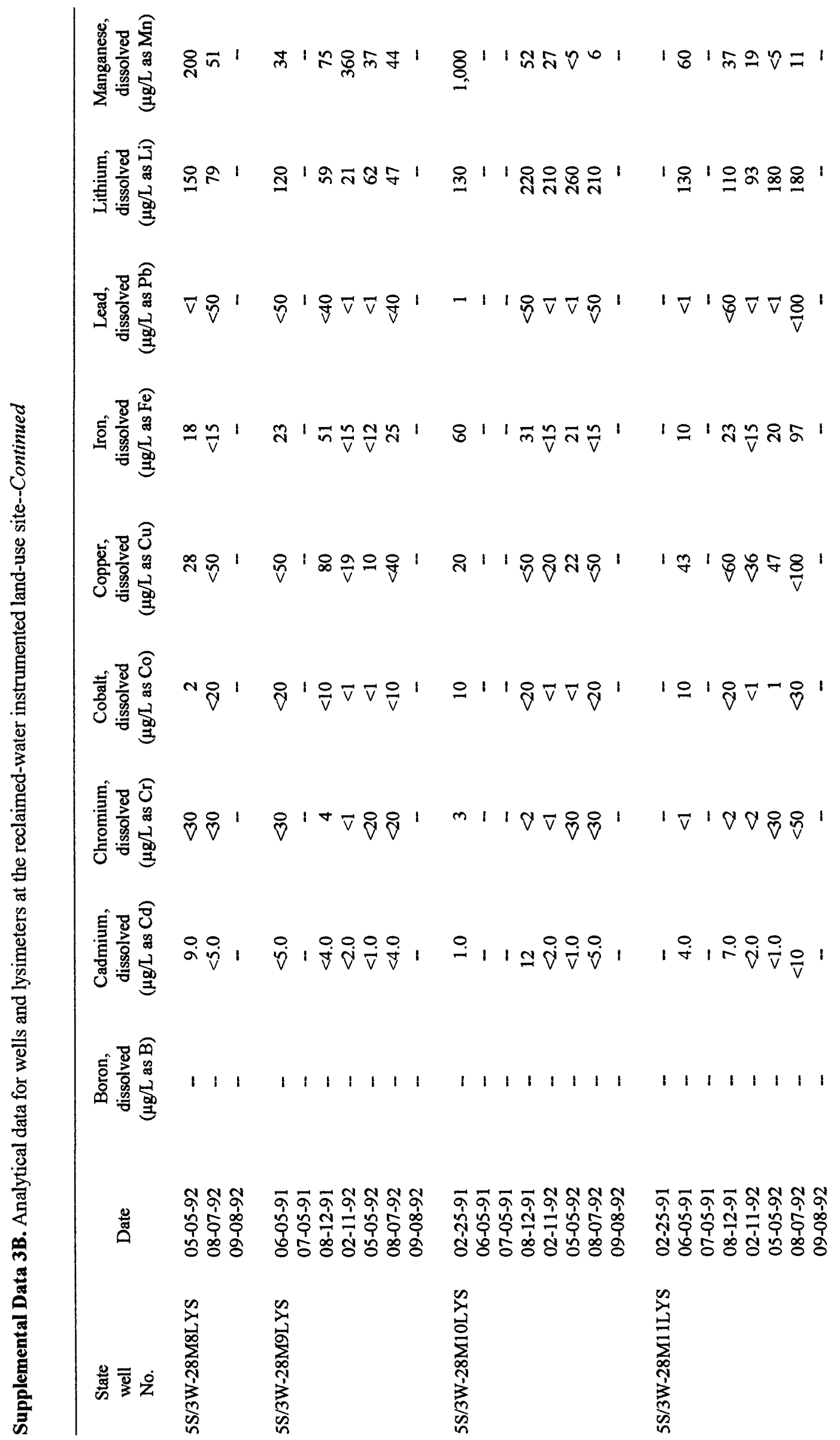




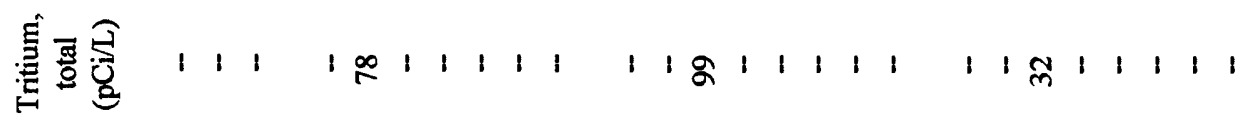

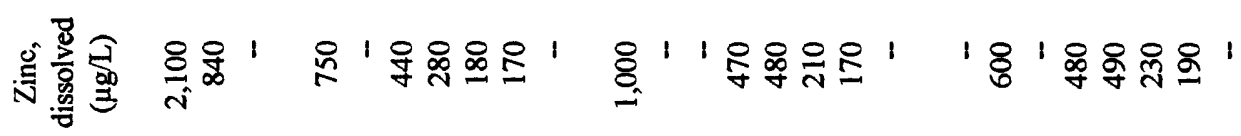

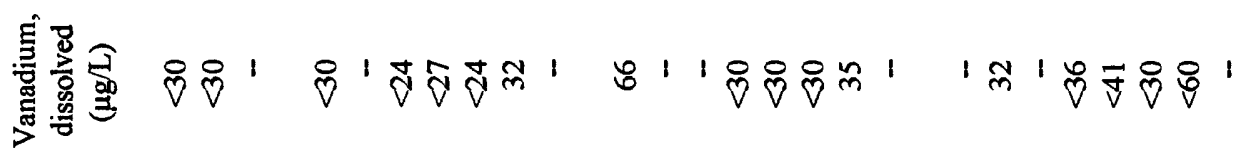

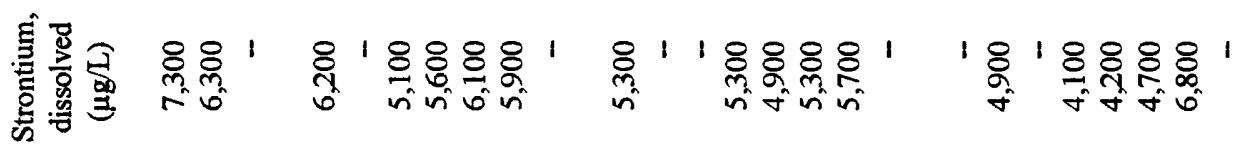

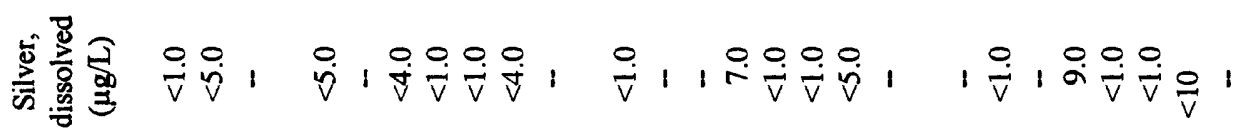

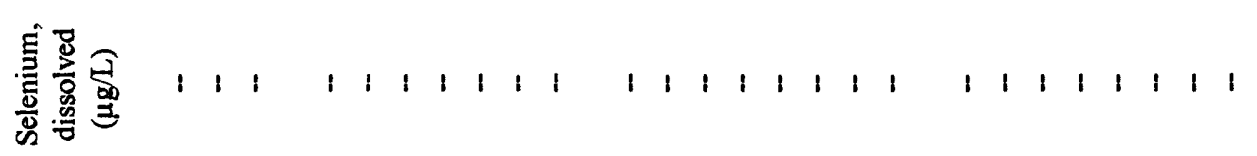

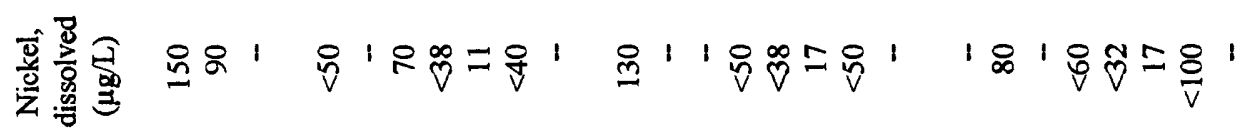

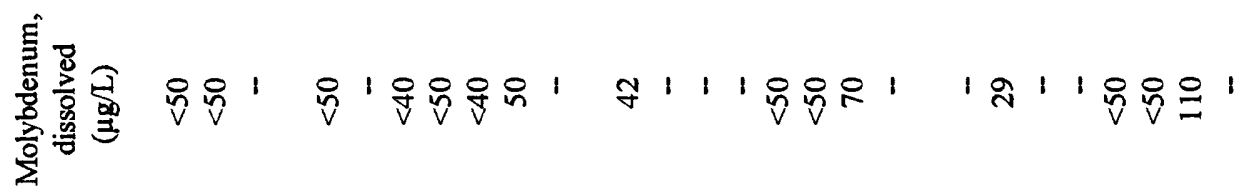

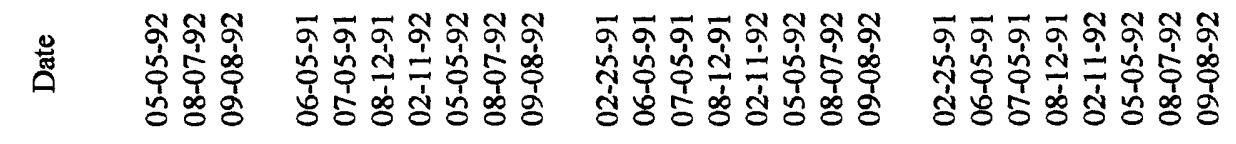

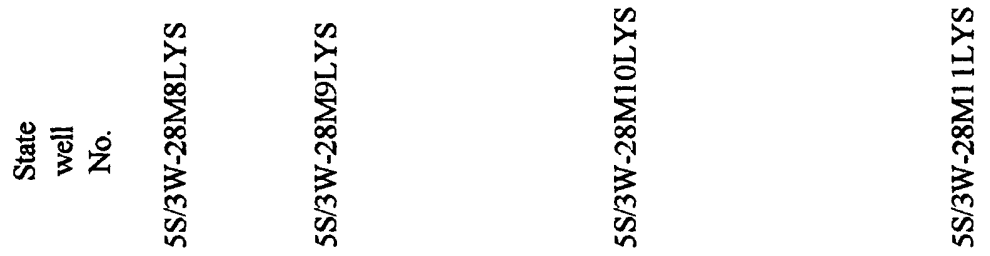




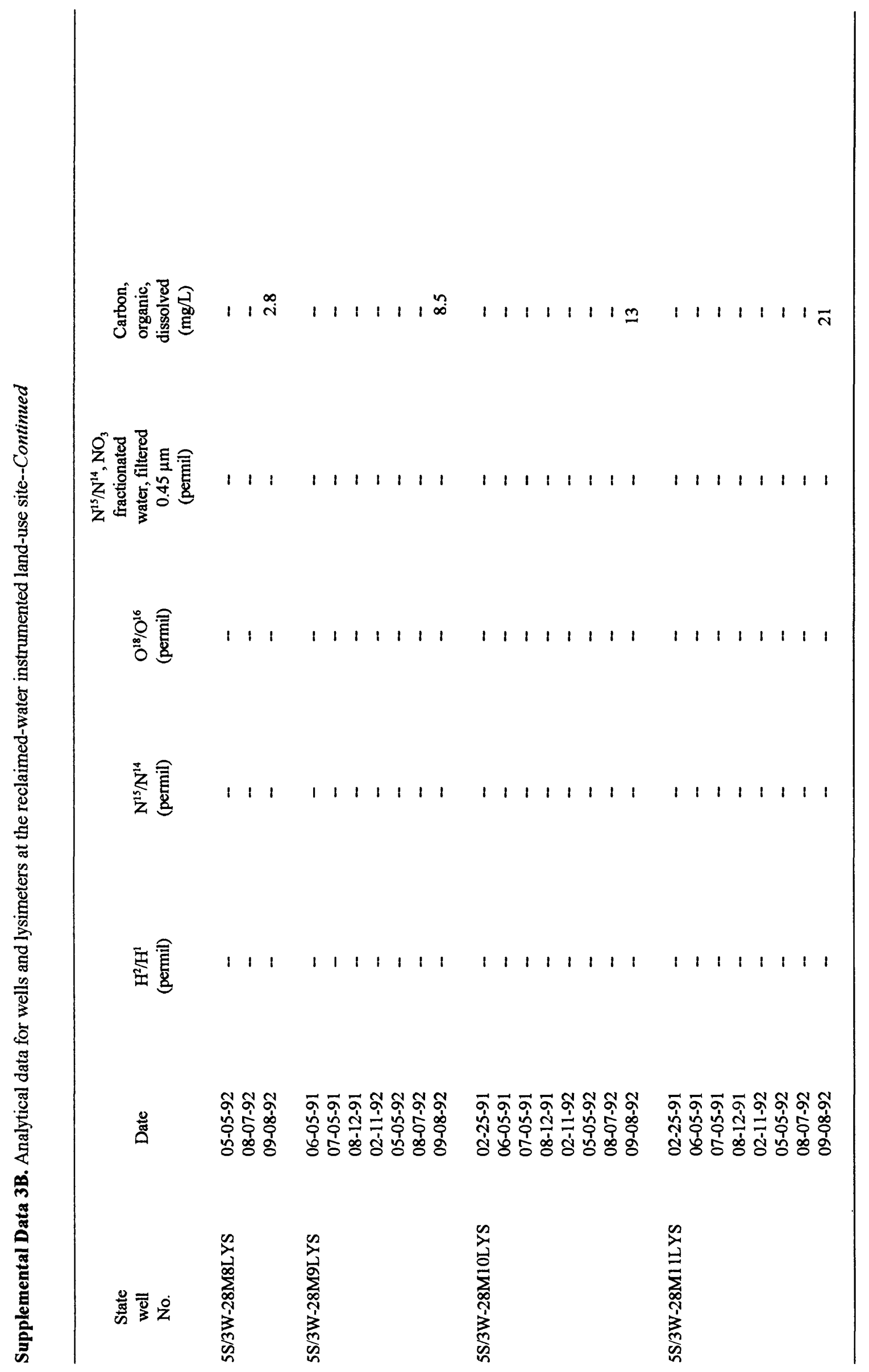




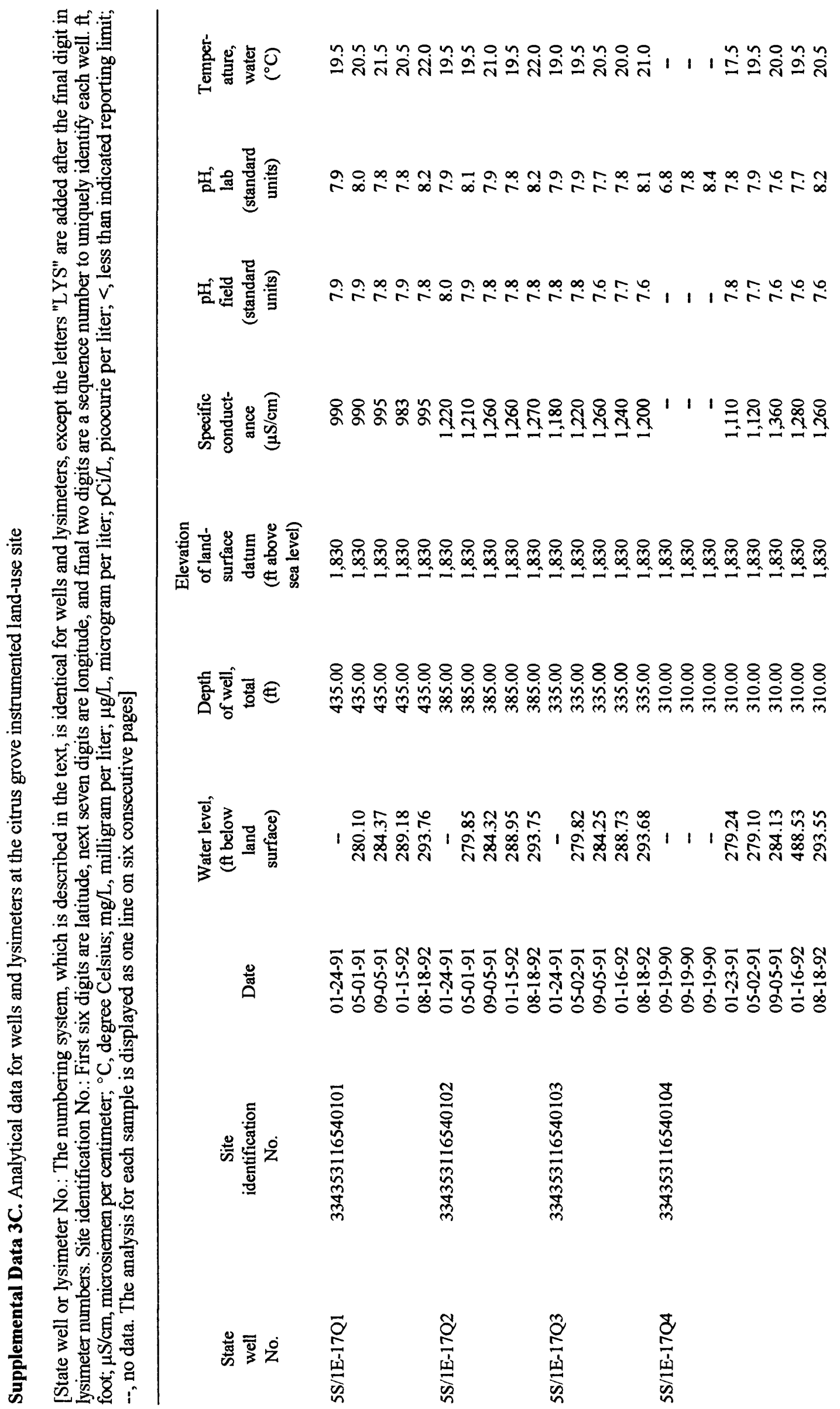




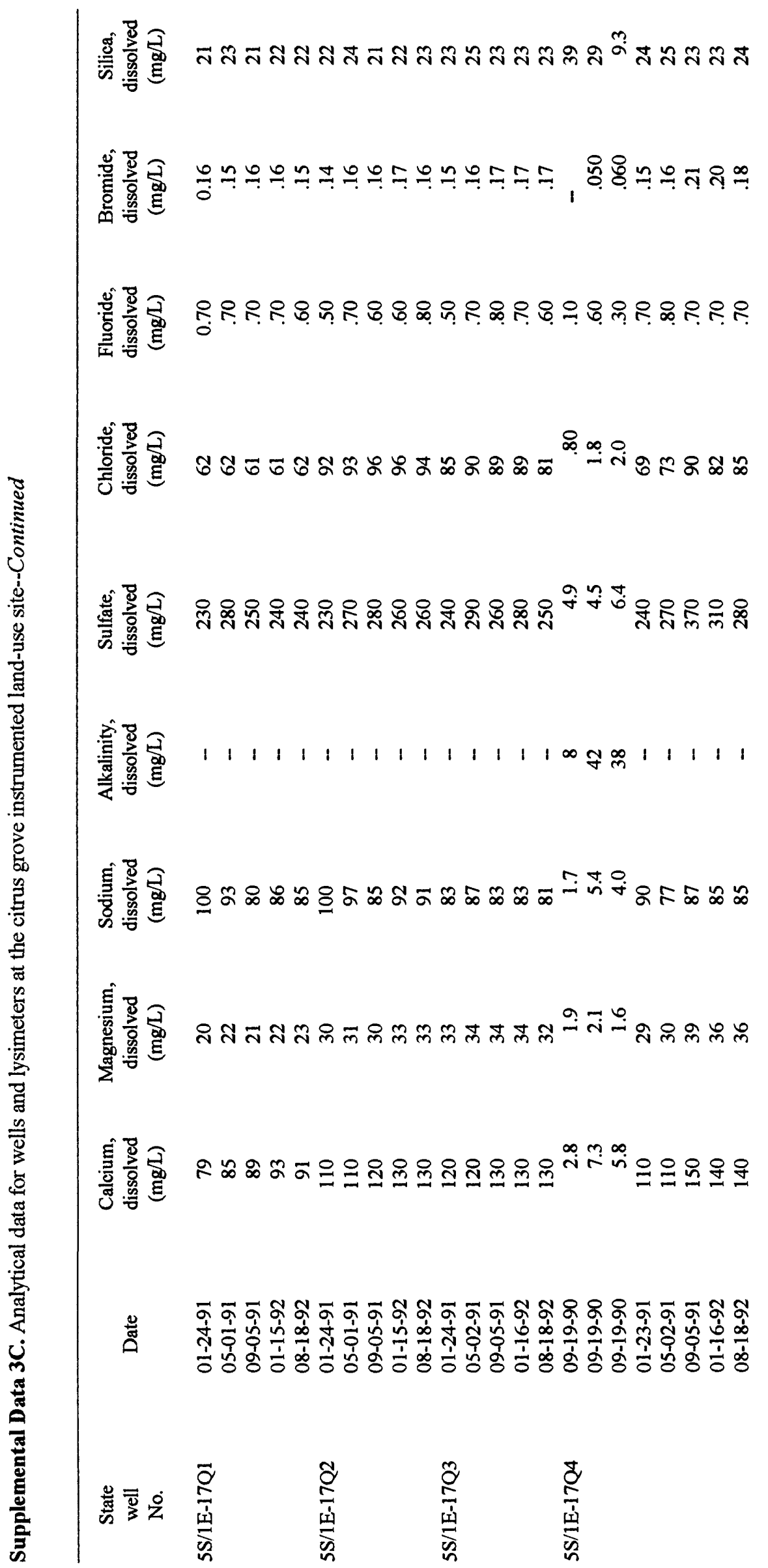




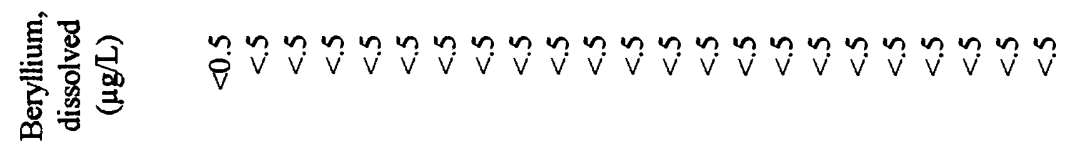

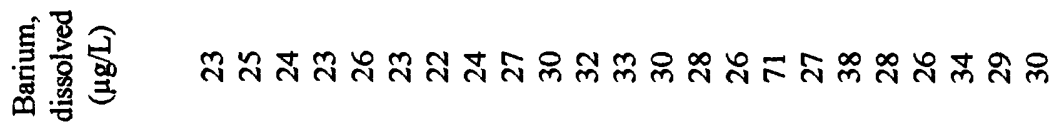

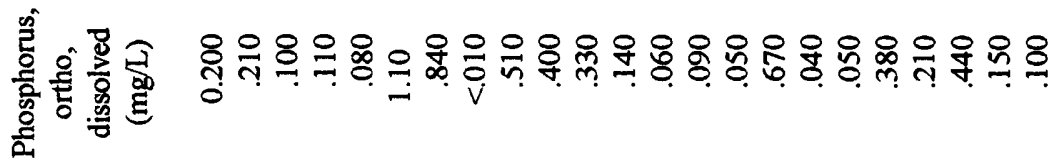

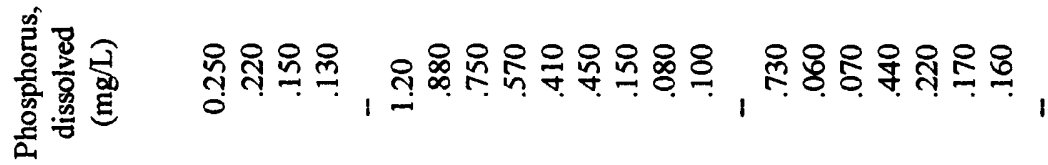

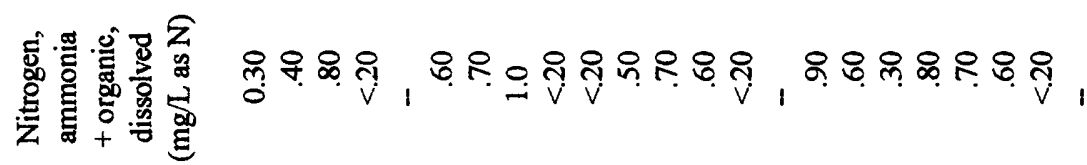

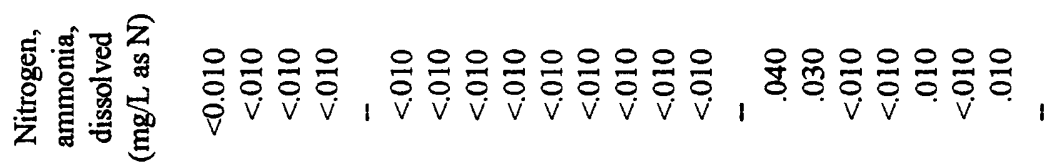

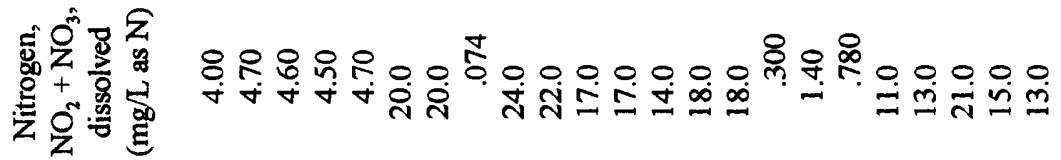

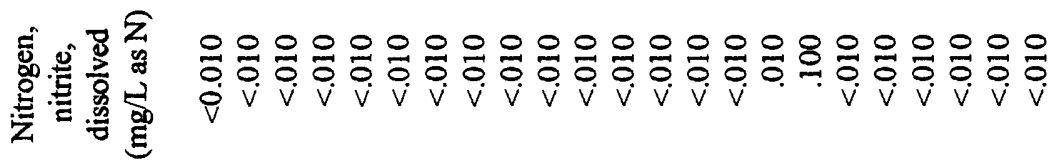

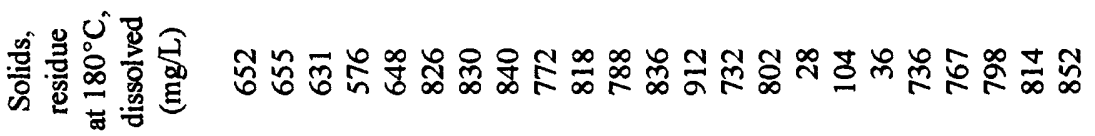

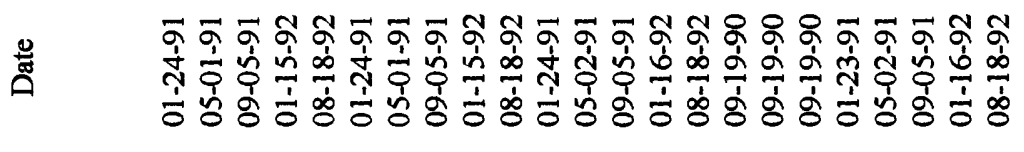

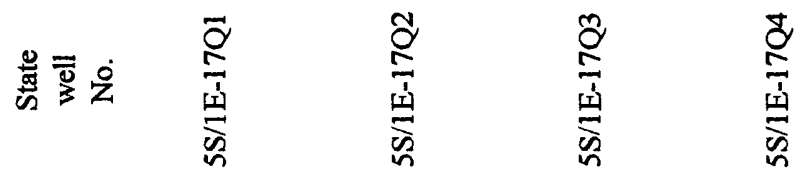




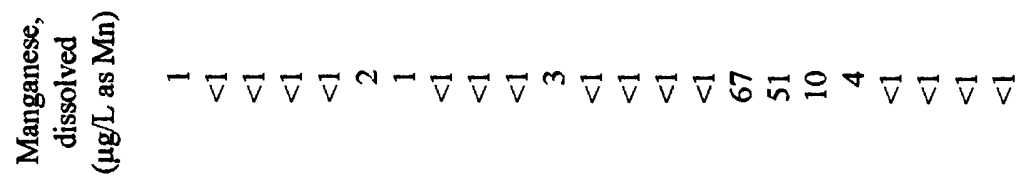

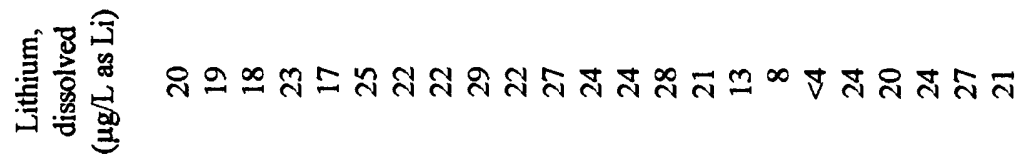

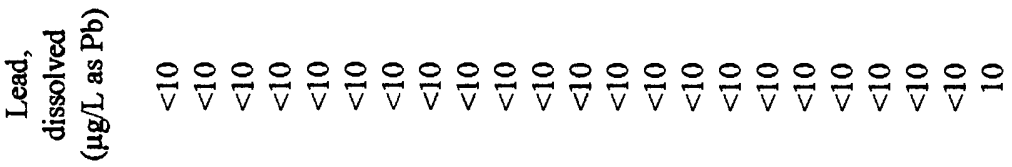

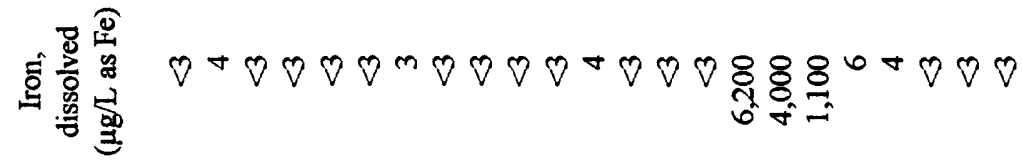

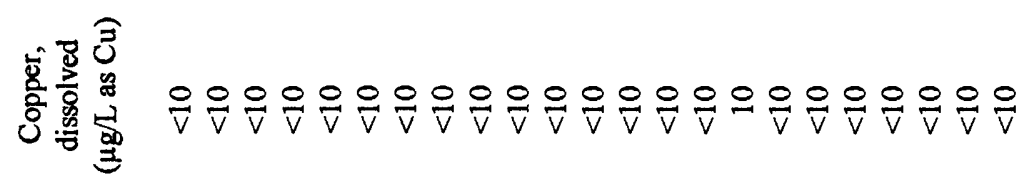

$$
\begin{aligned}
& \text { 产离兽 }
\end{aligned}
$$

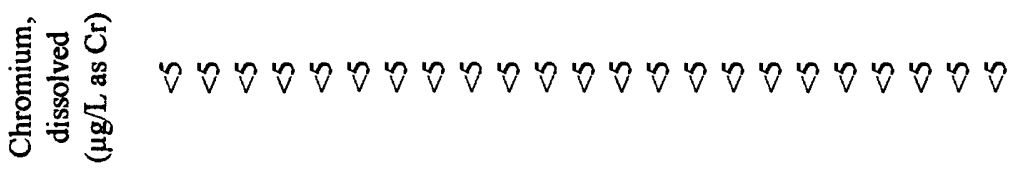

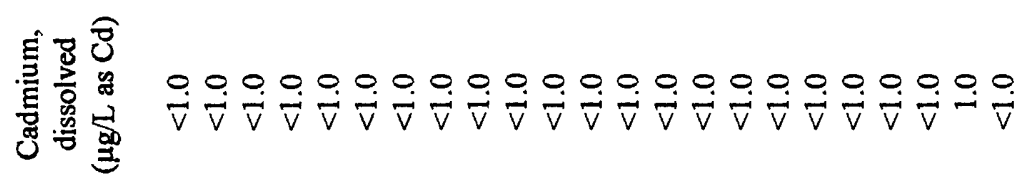

$$
\begin{aligned}
& \text { 言离总兽 }
\end{aligned}
$$

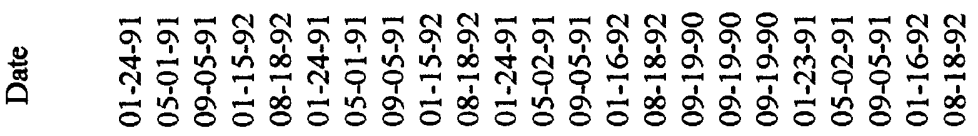

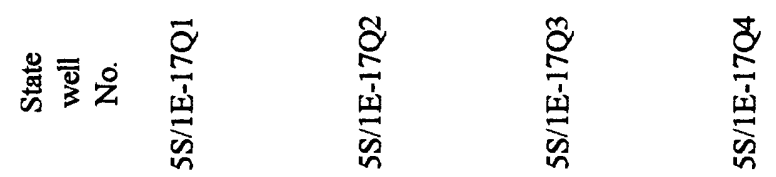




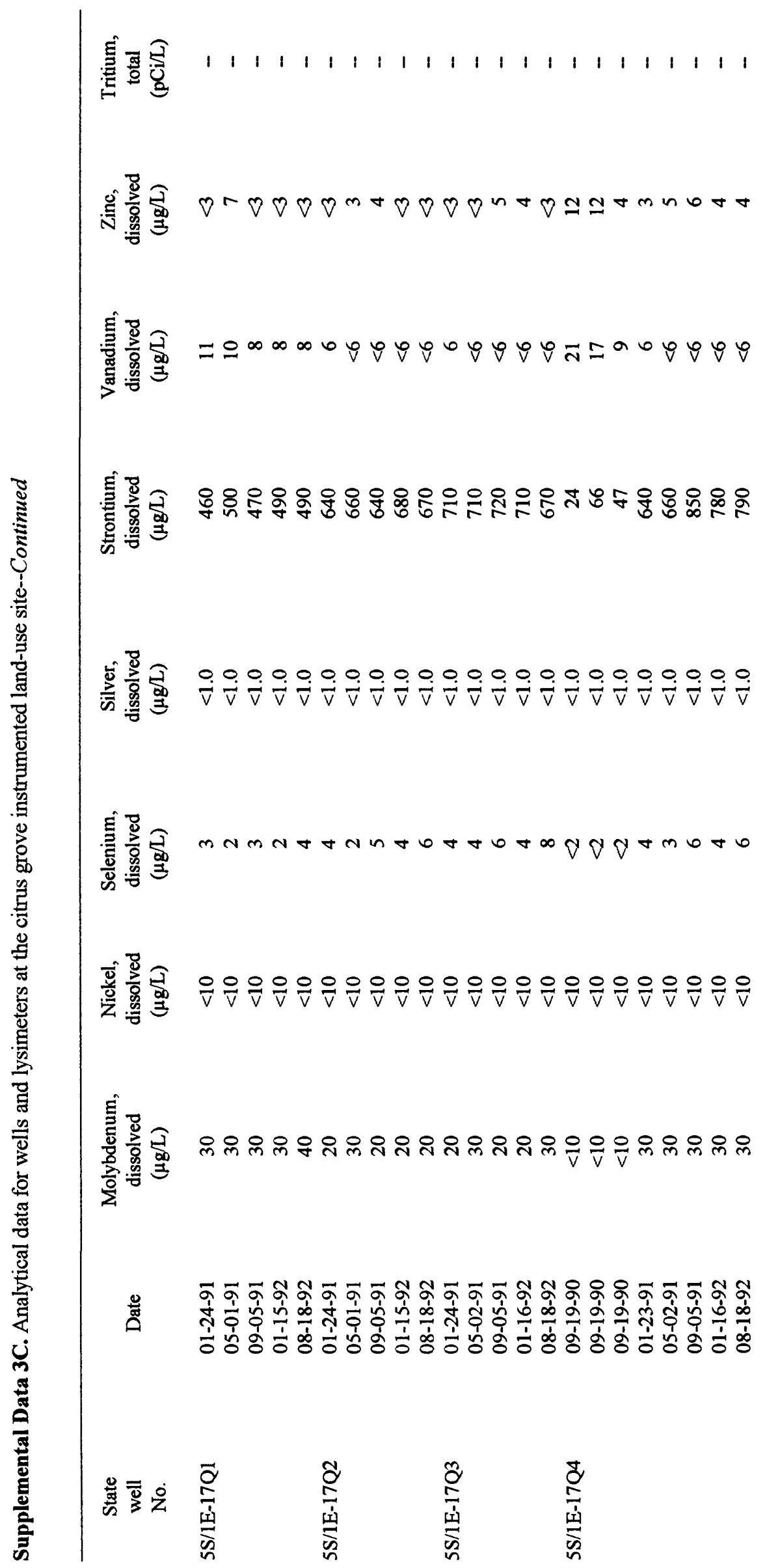




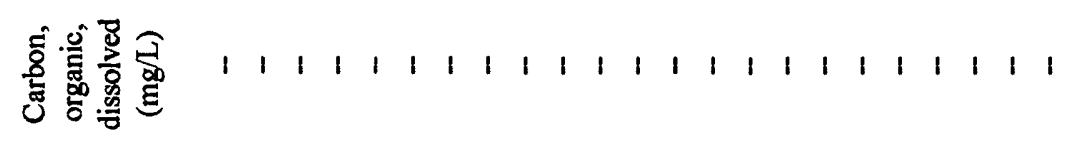

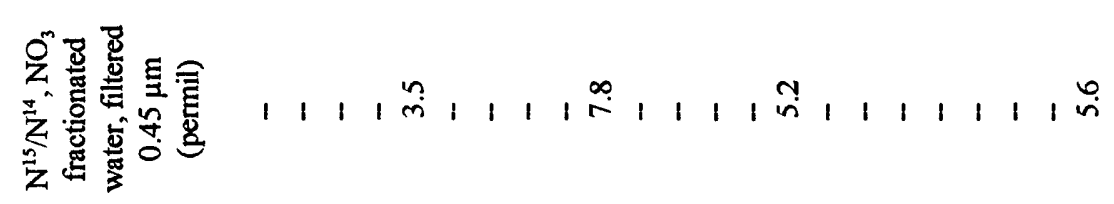

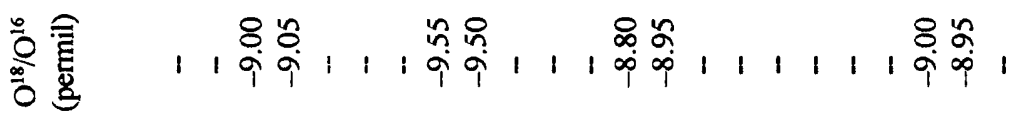

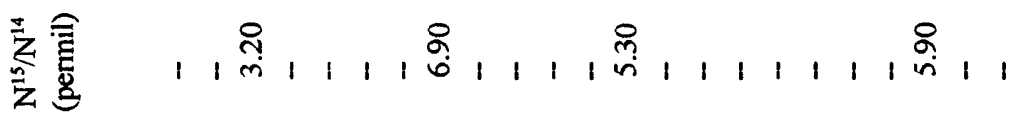

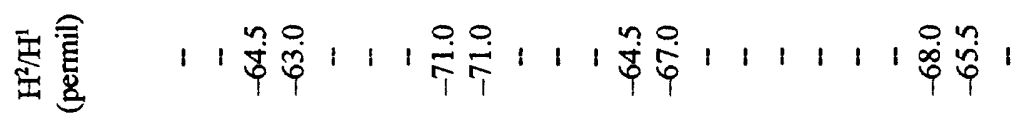

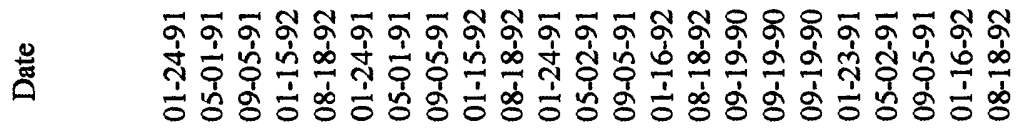

| 


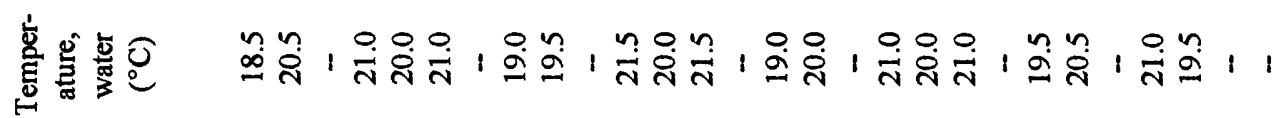

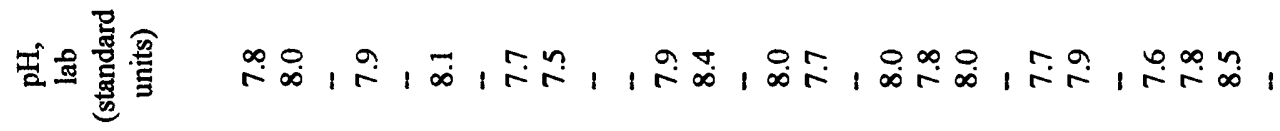

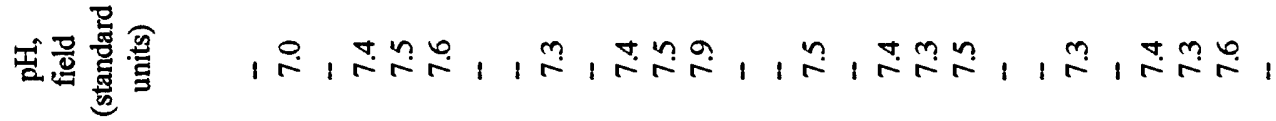

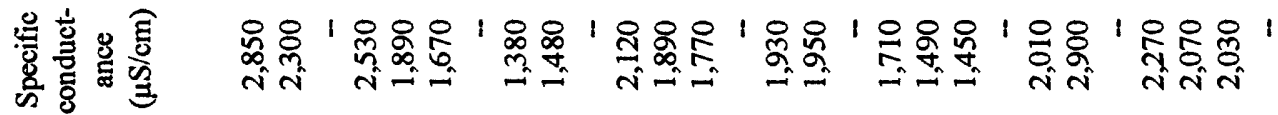

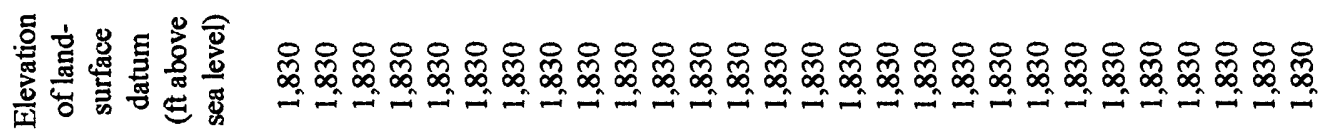

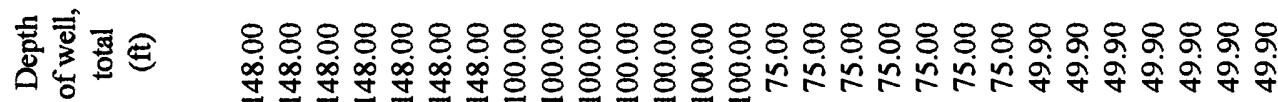

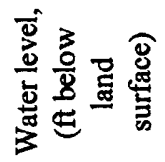

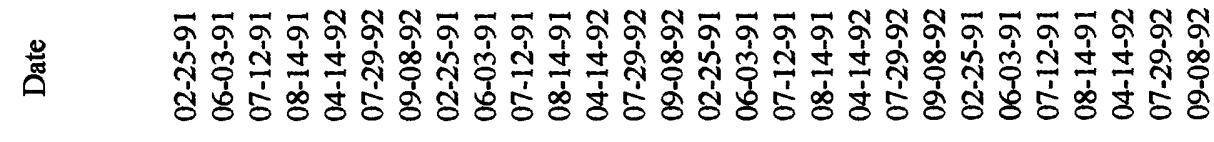

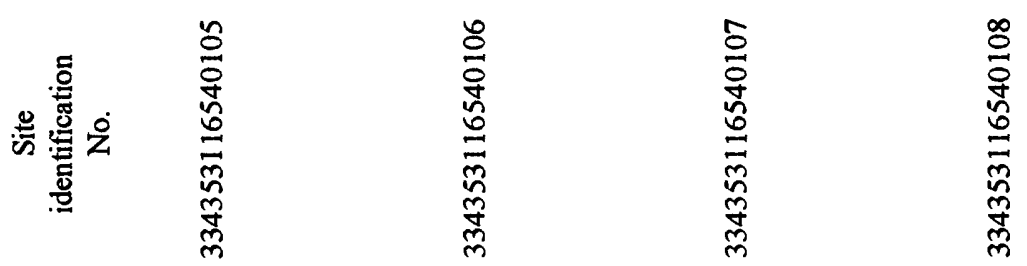

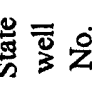

离

$\frac{\sqrt{2}}{8}$

雚

窝 


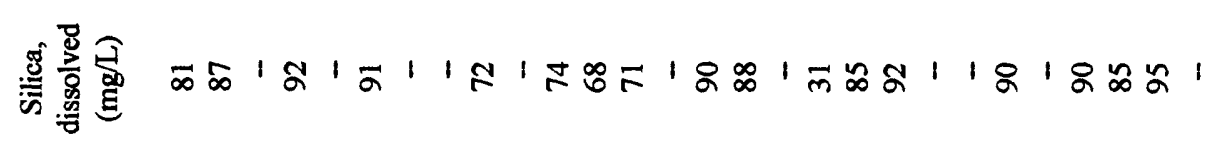

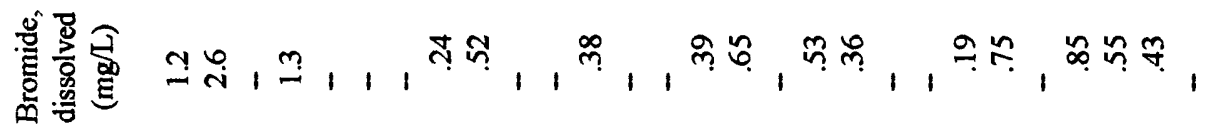

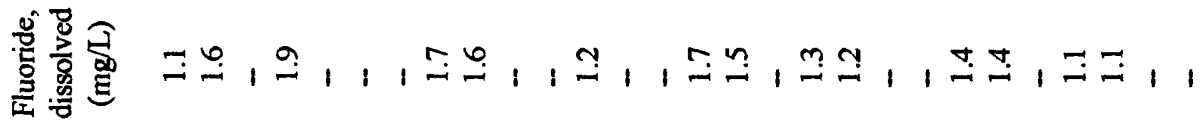

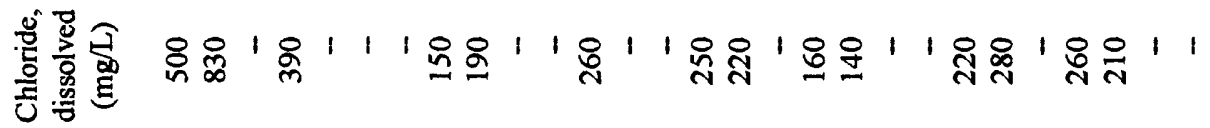

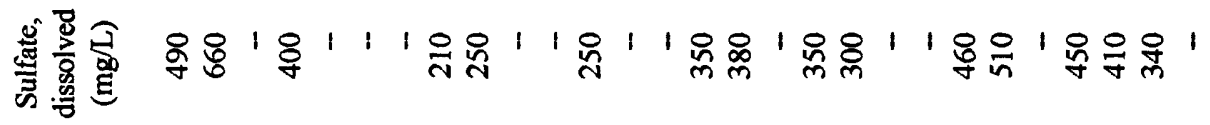

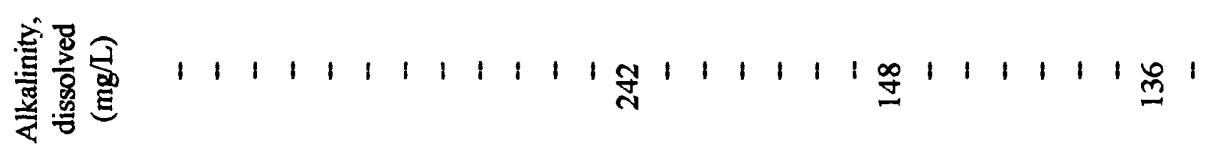

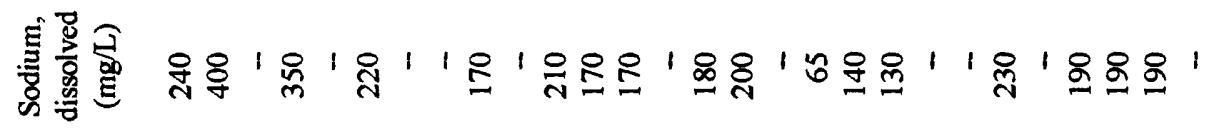

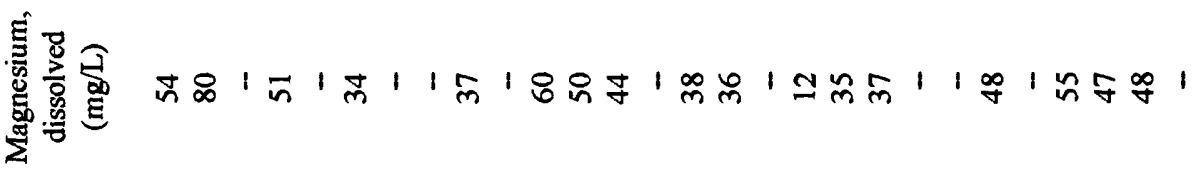

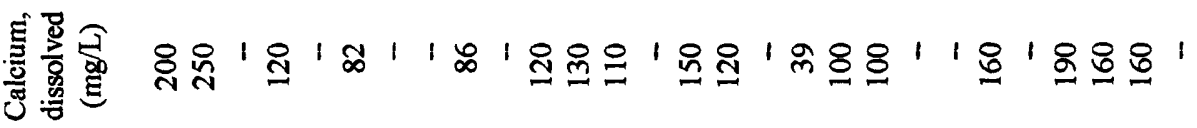

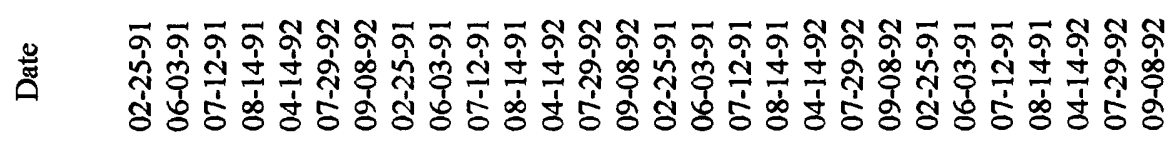

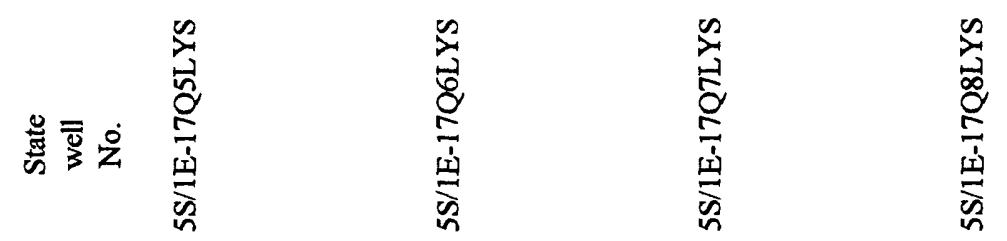




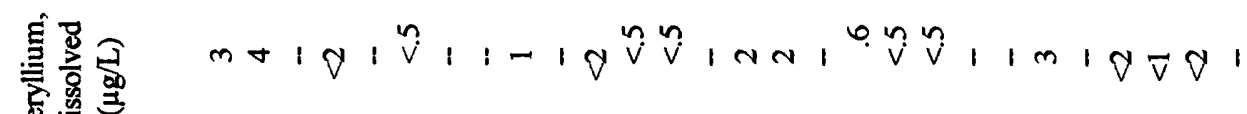

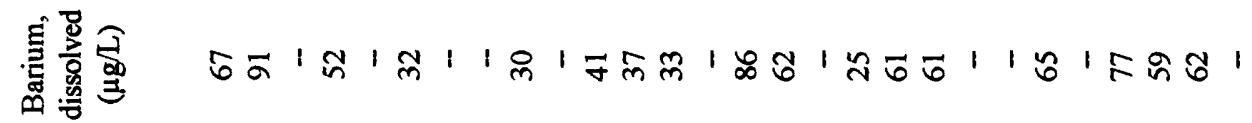

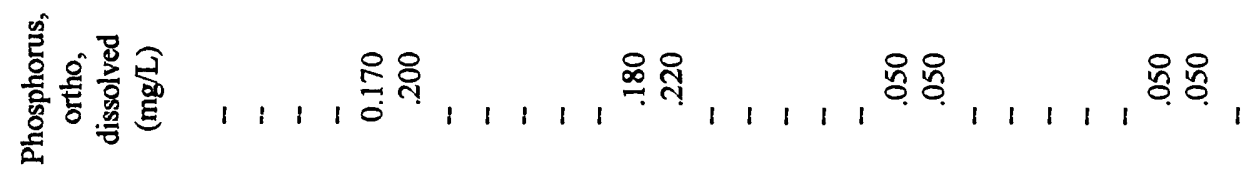

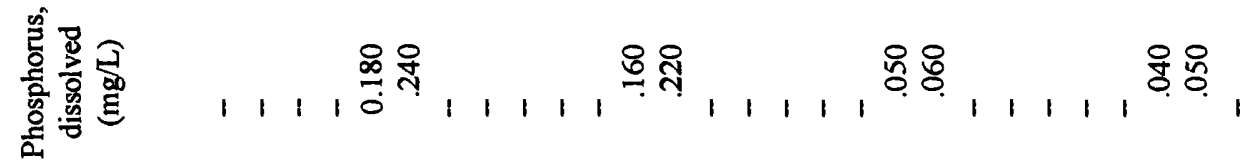

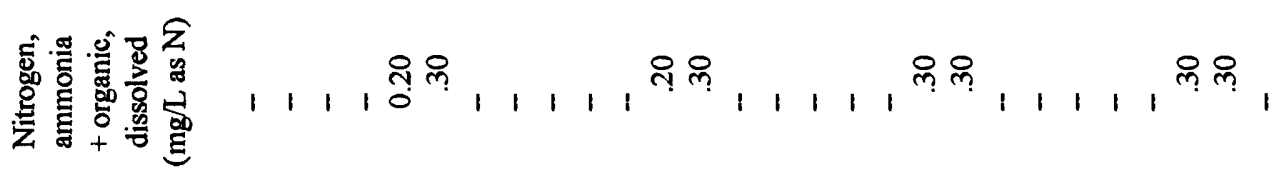

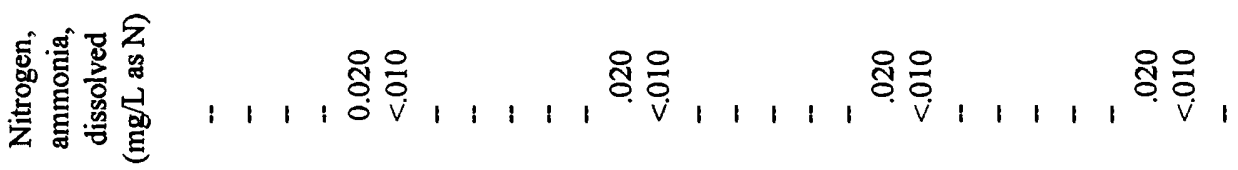

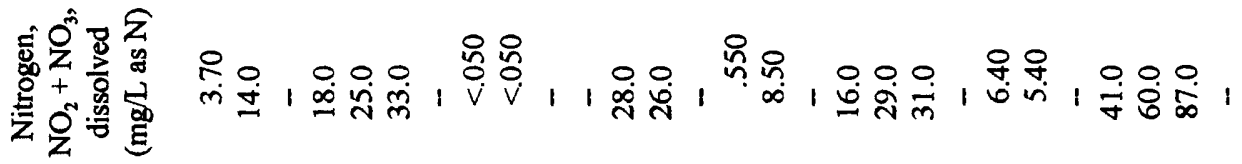

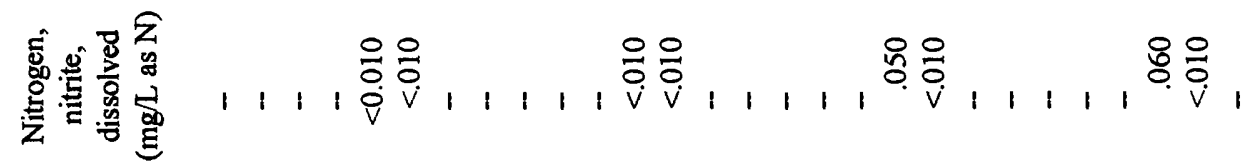

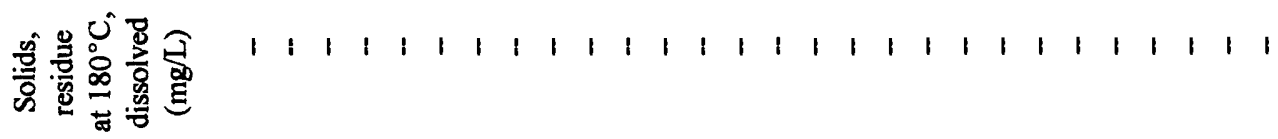

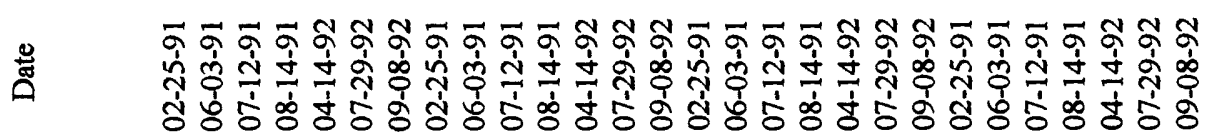

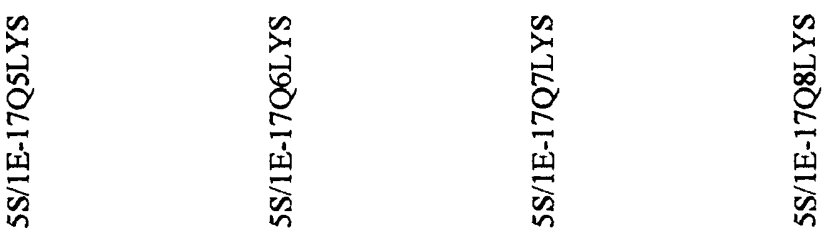




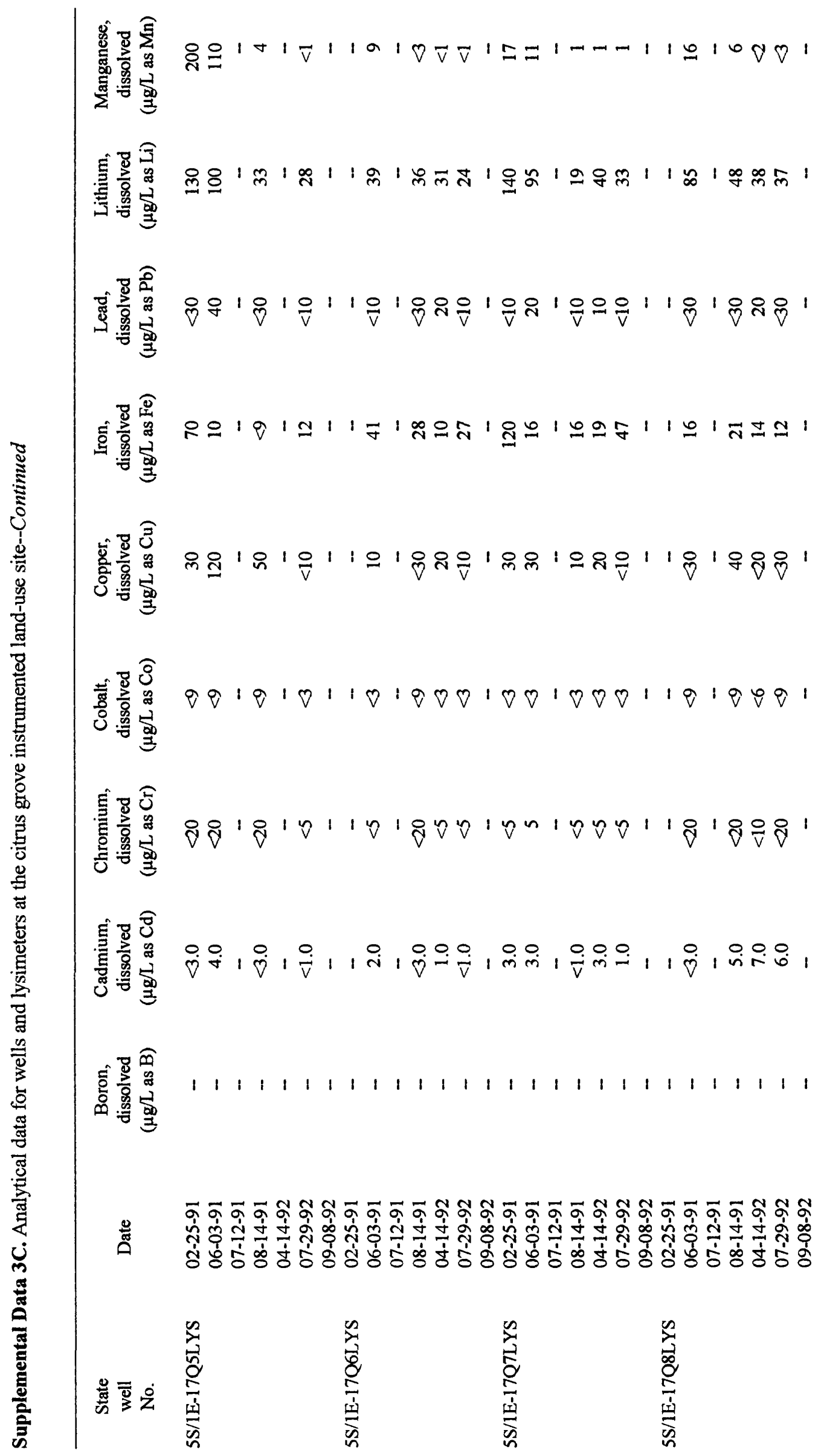




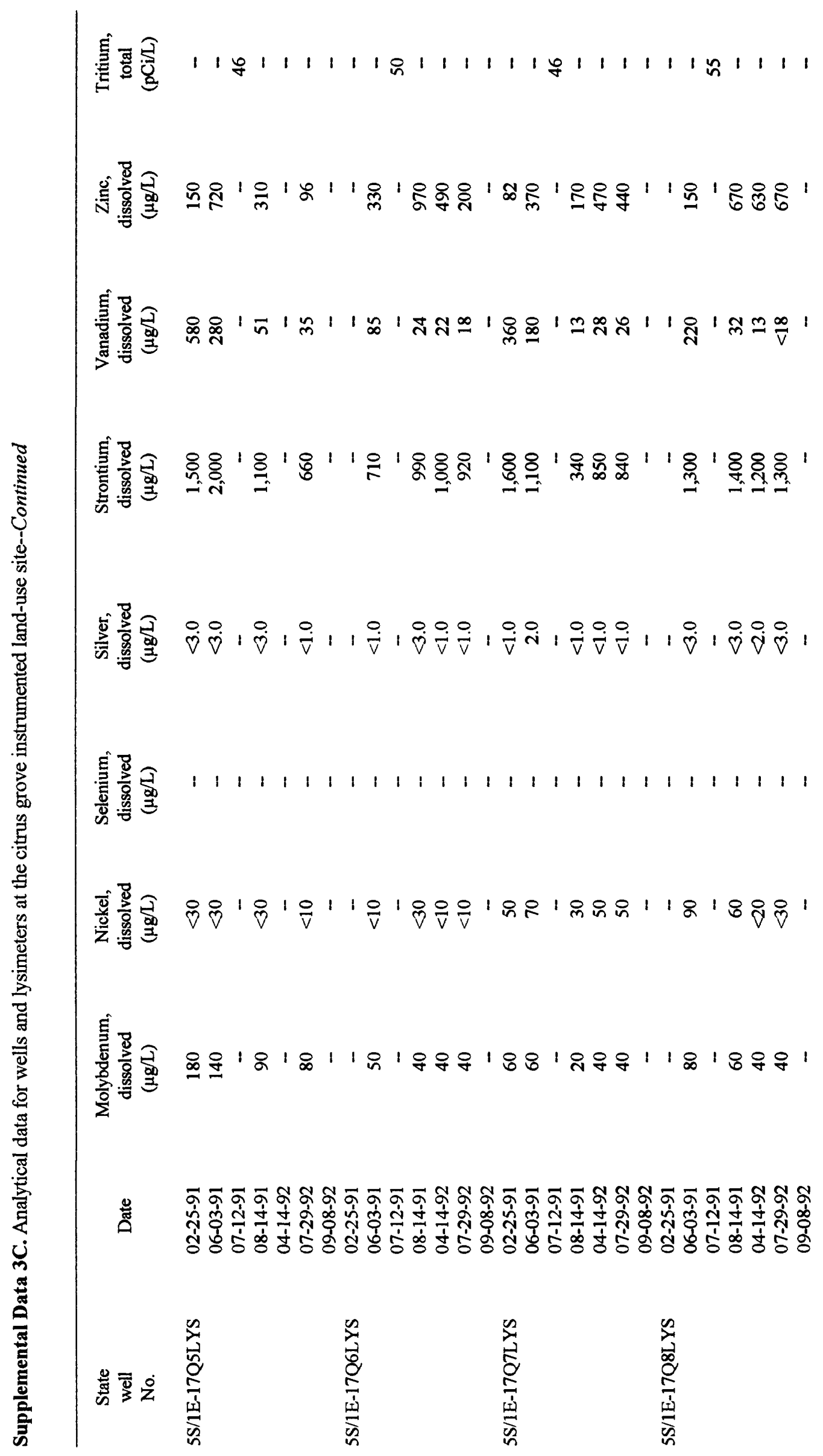




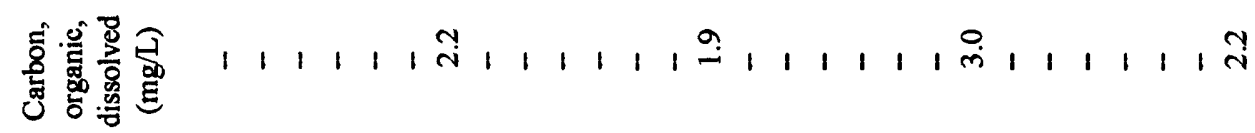

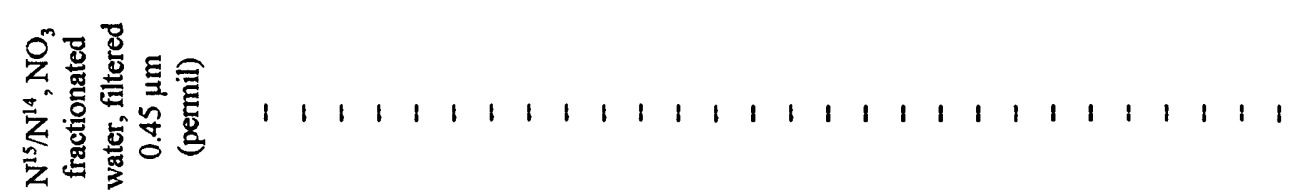

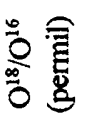

艺产

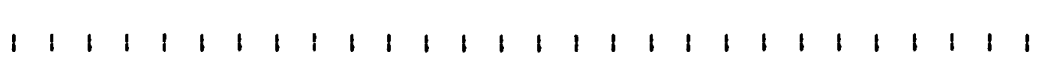

善鱼

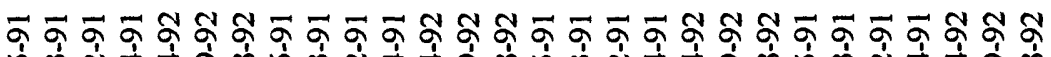

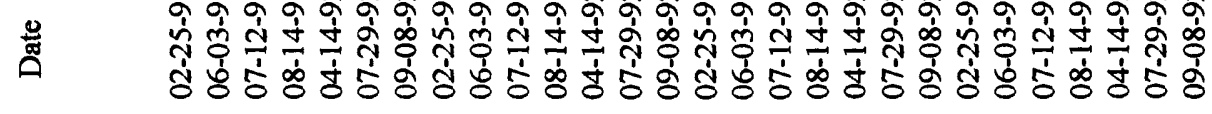

安

政

:

苛

先 


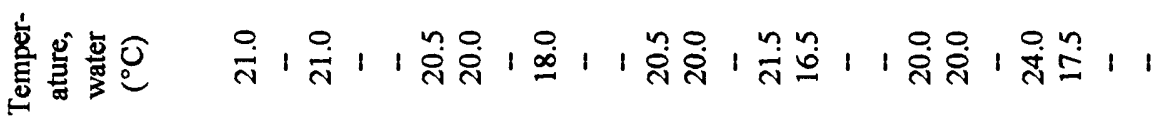

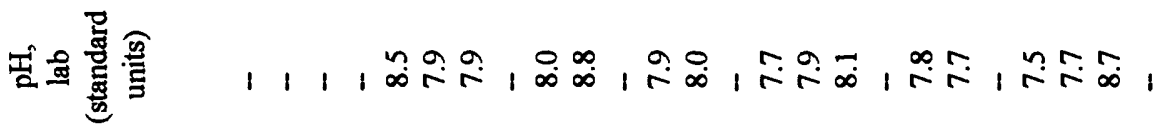

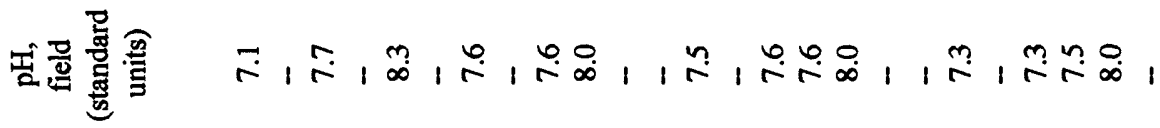

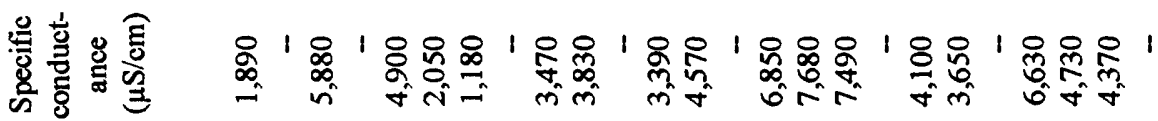

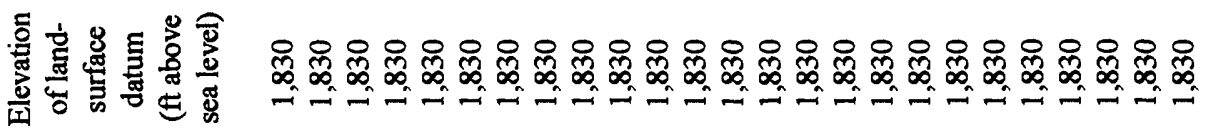

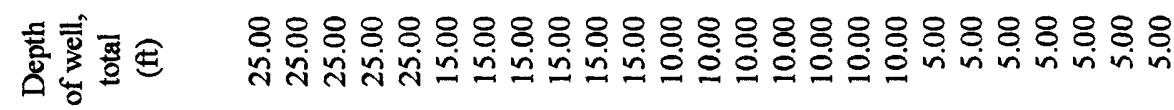

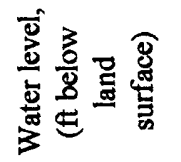

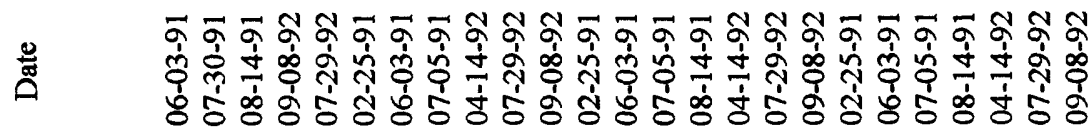

$\frac{3}{3}$

은

莺

हृ

点

站旁宽

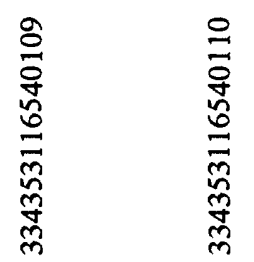

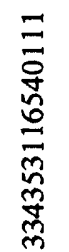

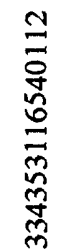

$\frac{2}{\frac{2}{2}}$

祘

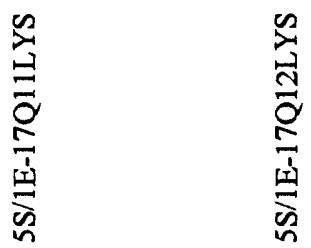




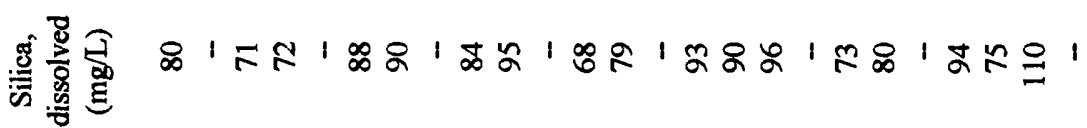

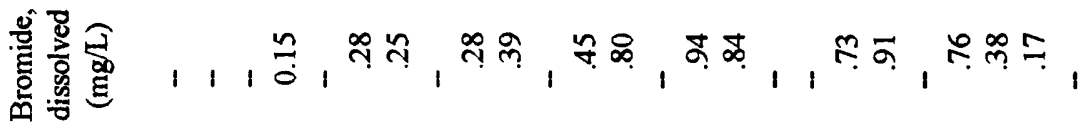

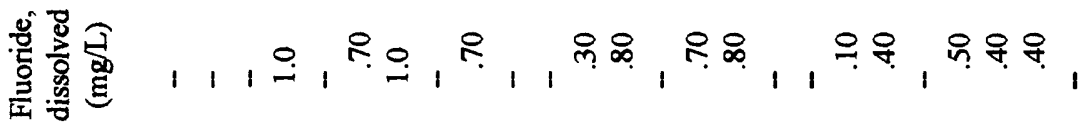

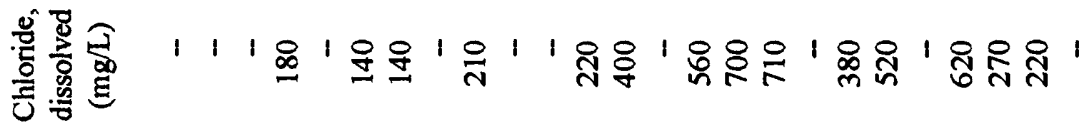

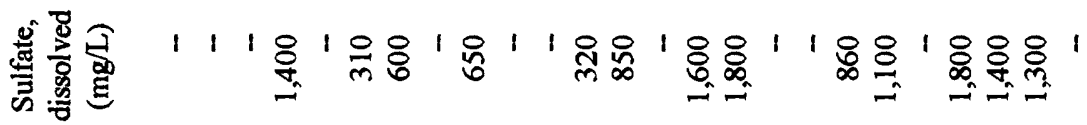

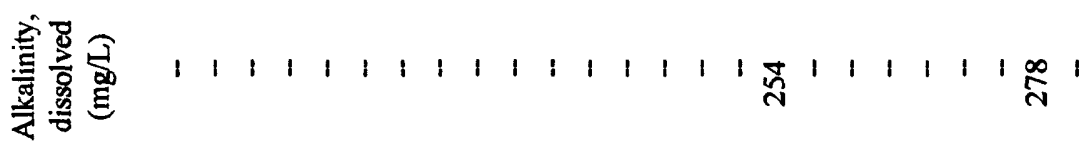

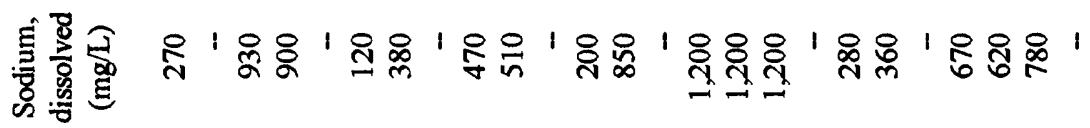

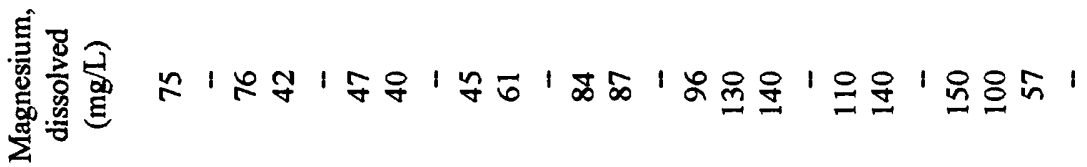

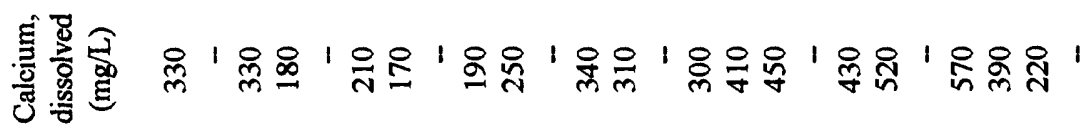

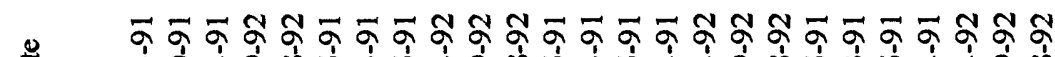

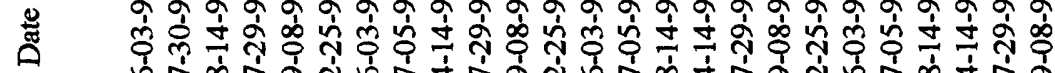

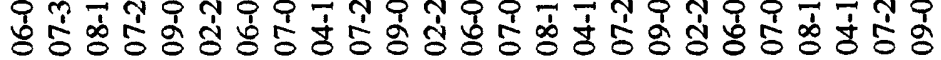




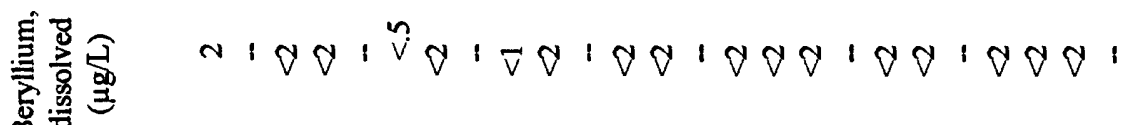

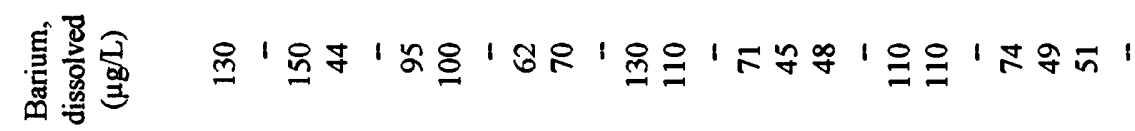

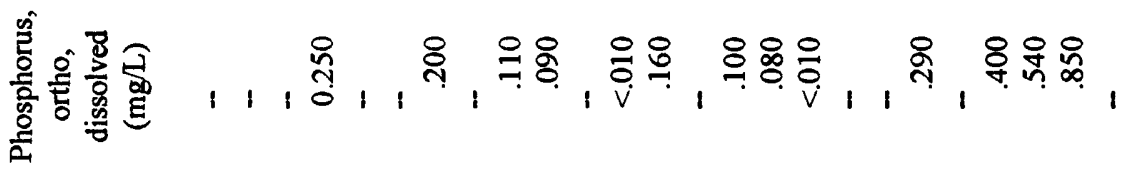

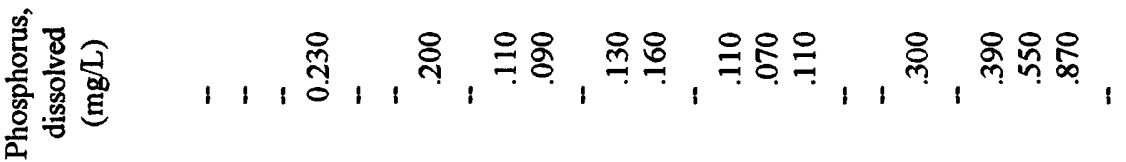

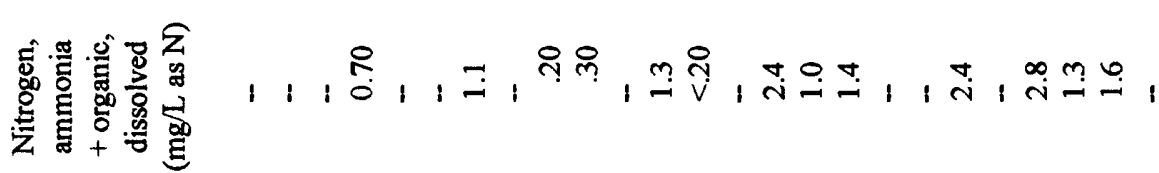

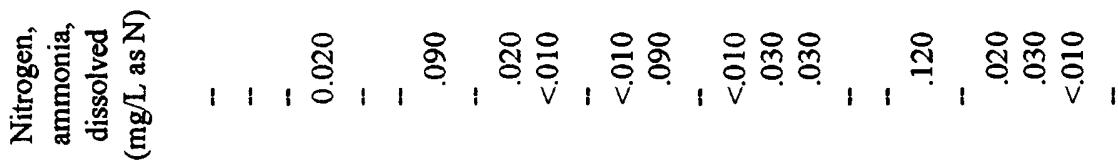

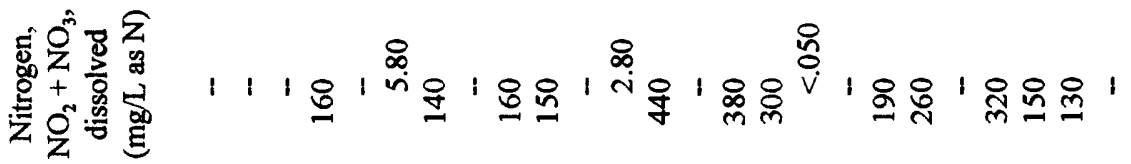

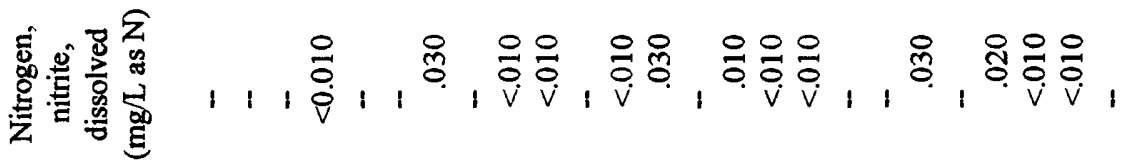

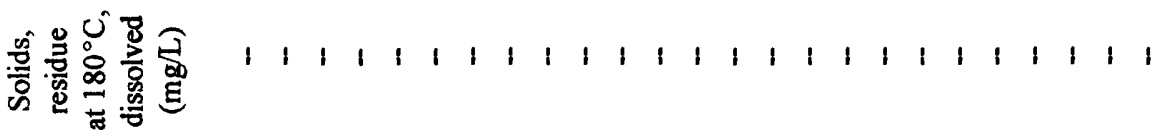

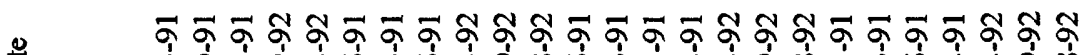

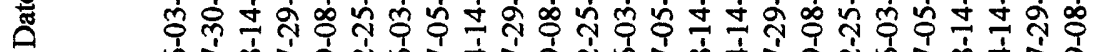

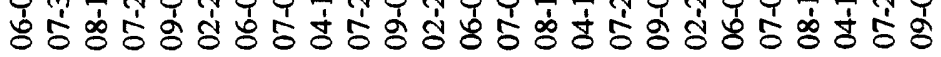

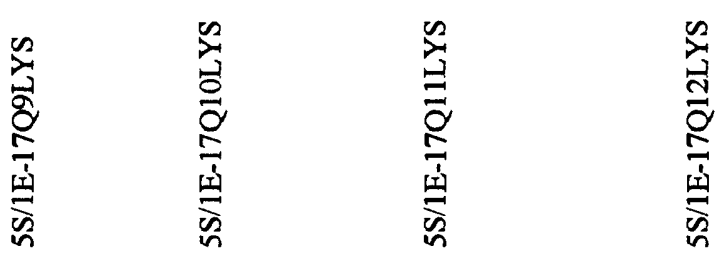




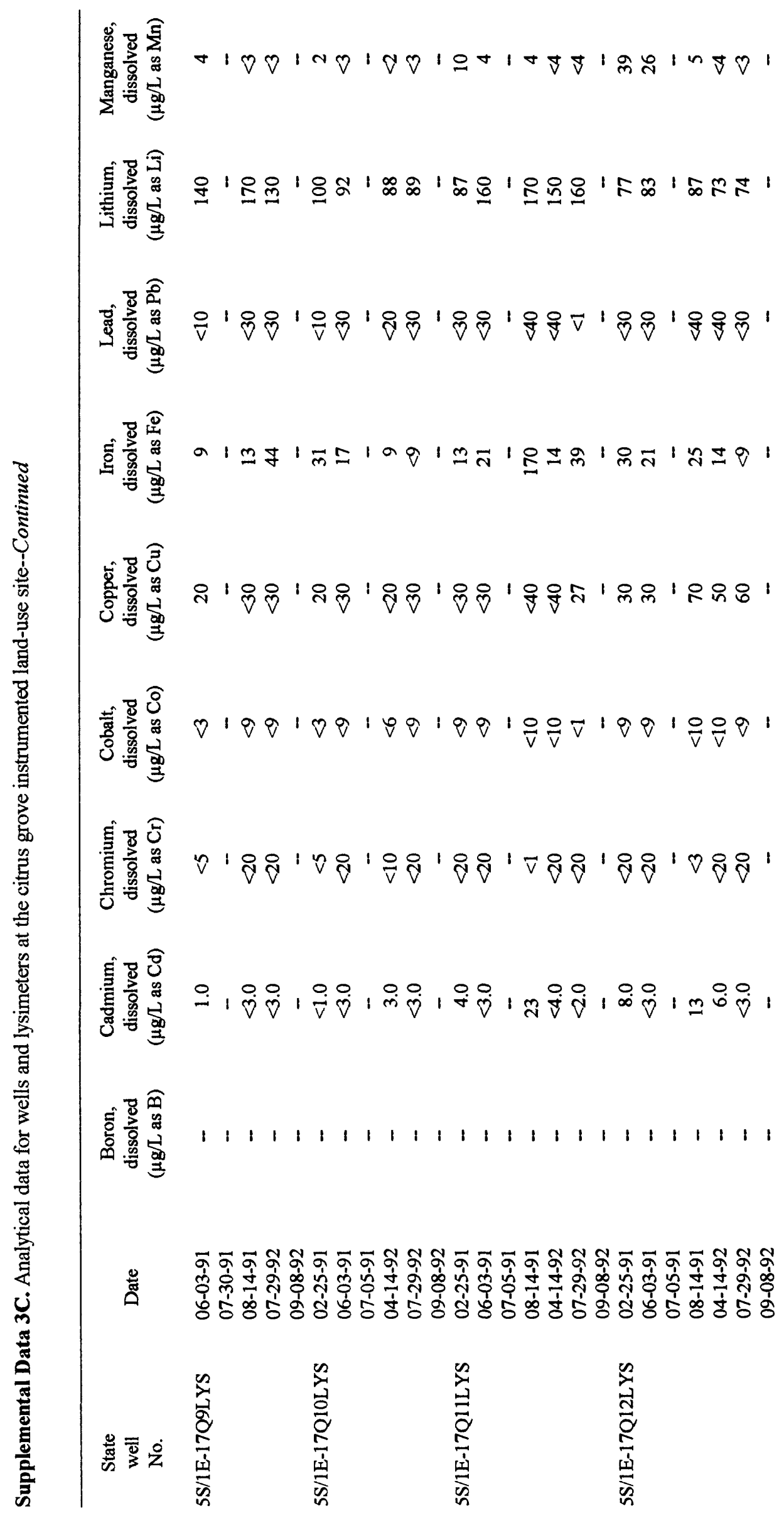




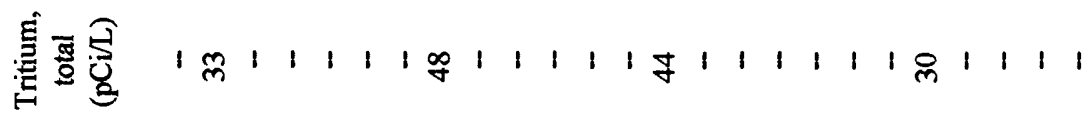

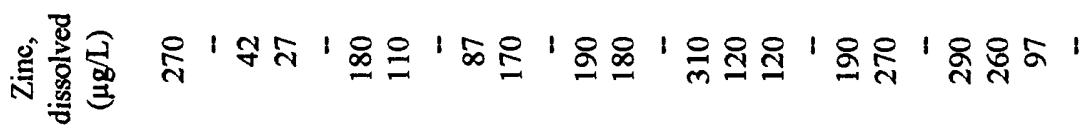

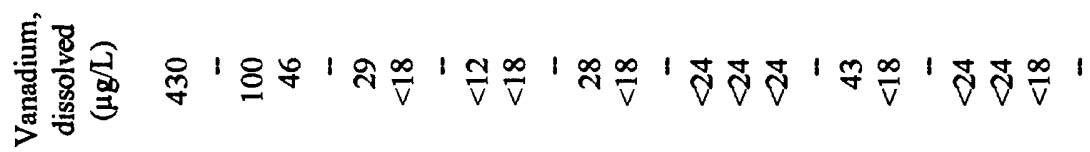

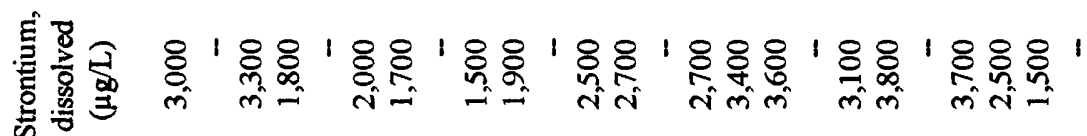

离产兽兽

寻兽兽

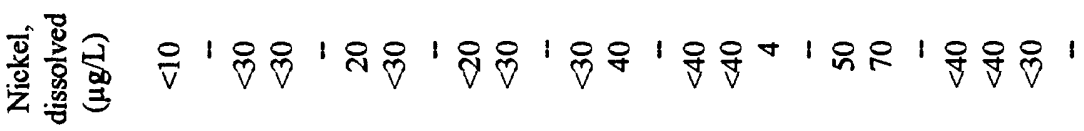

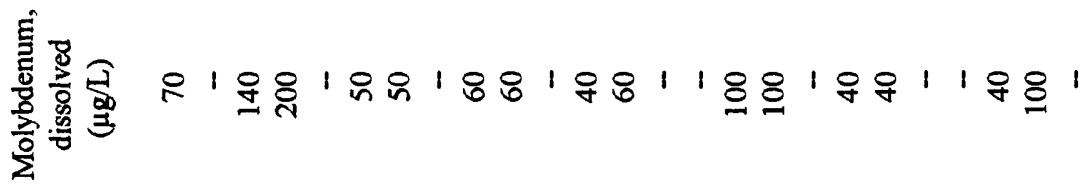

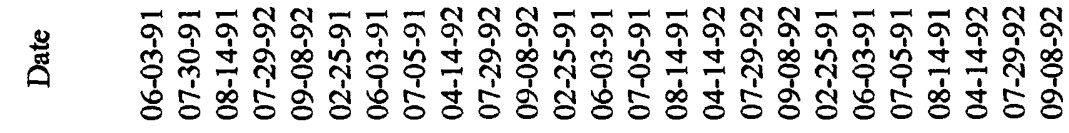

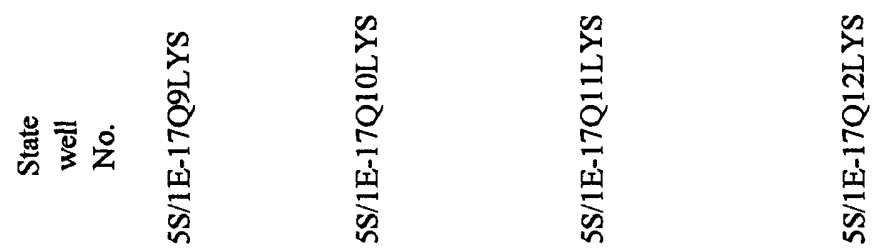




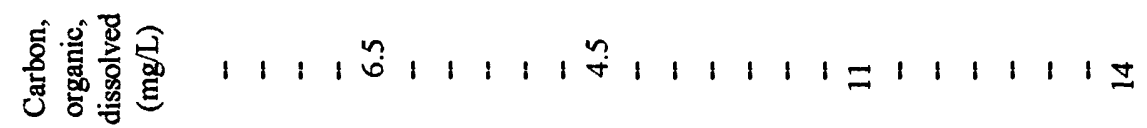

艺言

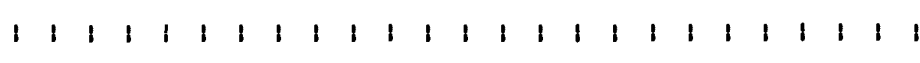

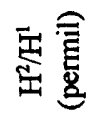

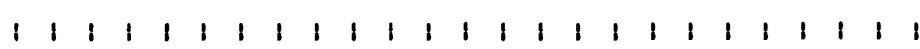

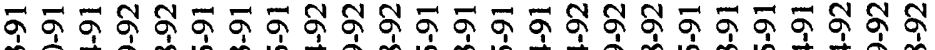

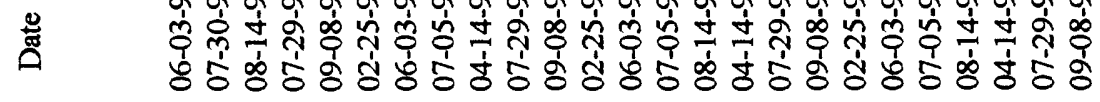

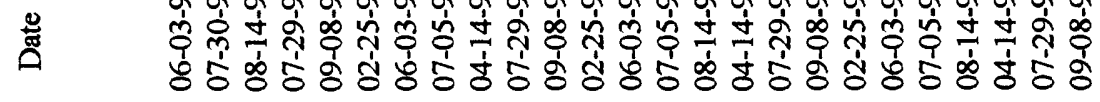




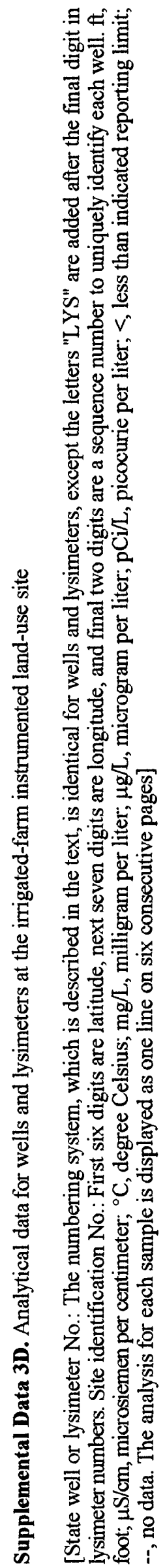

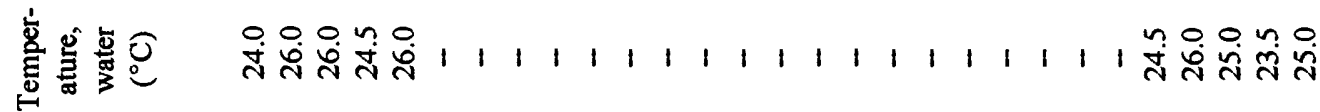

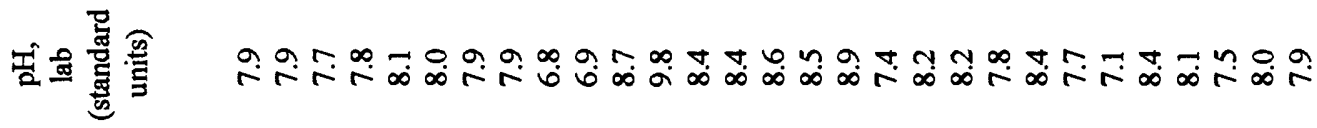

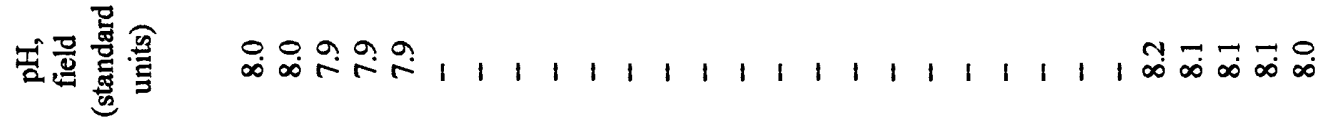

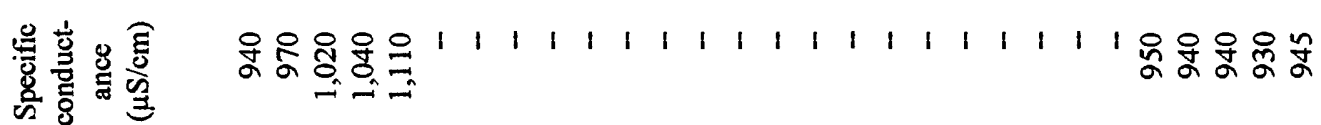

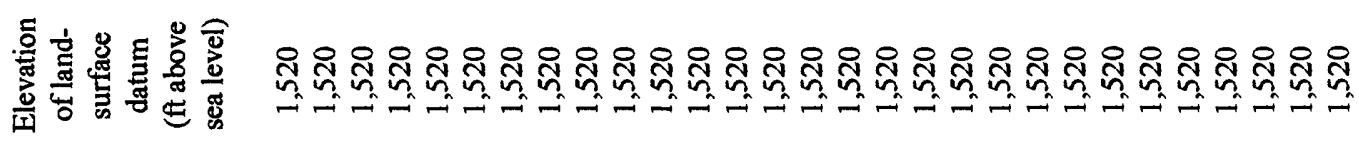

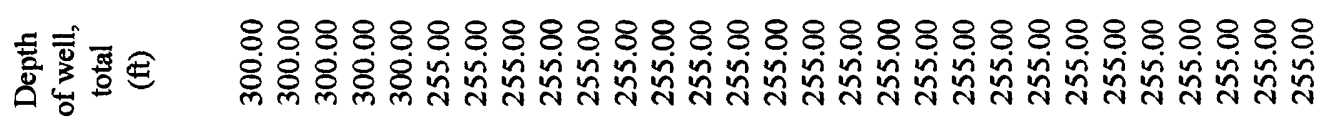

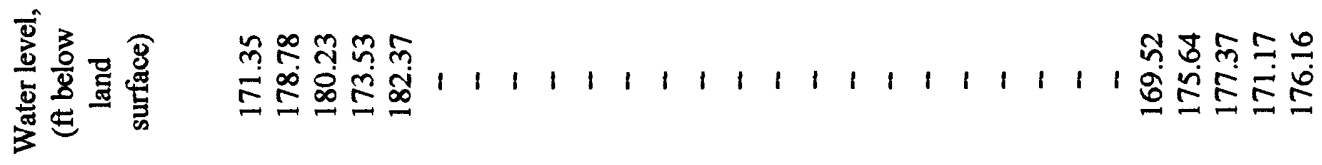

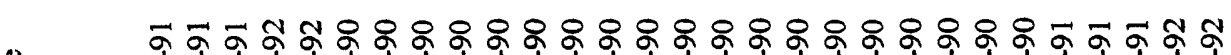

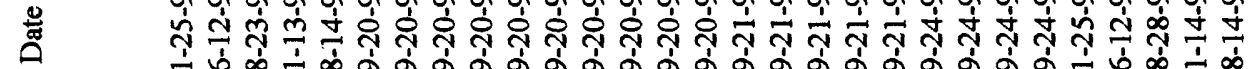

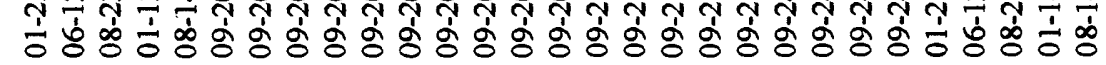

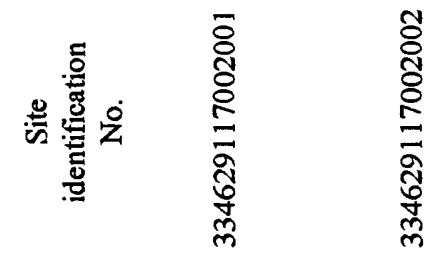

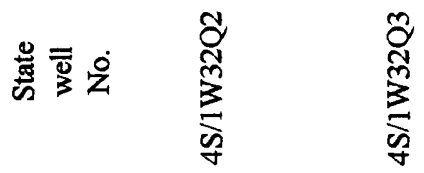




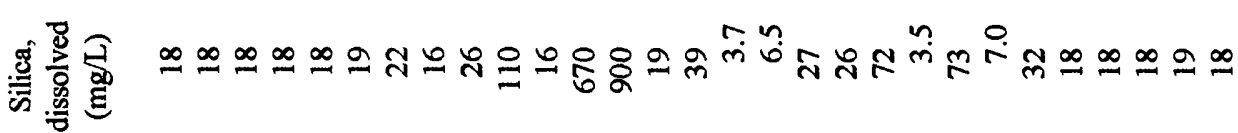

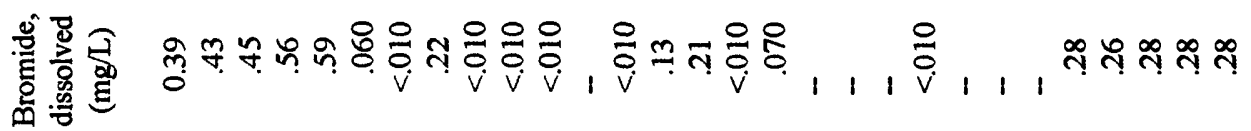

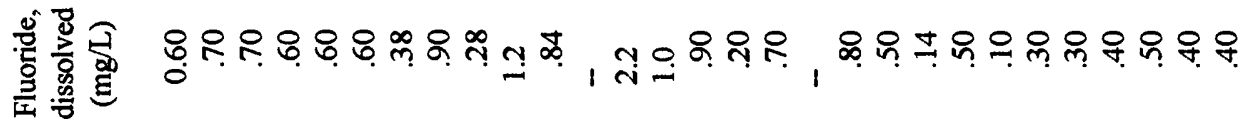

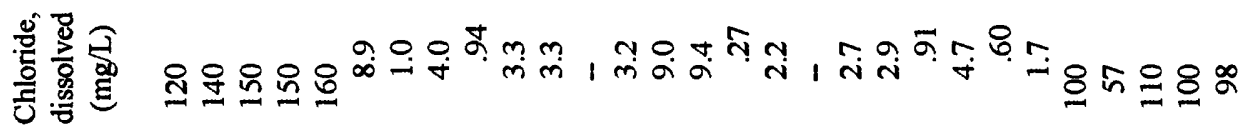

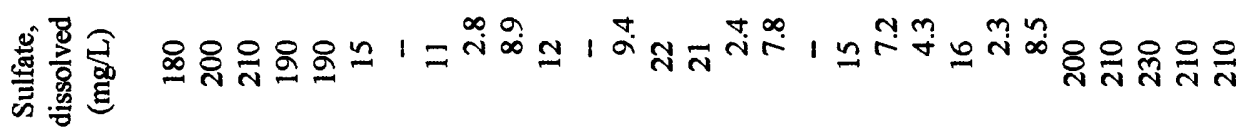

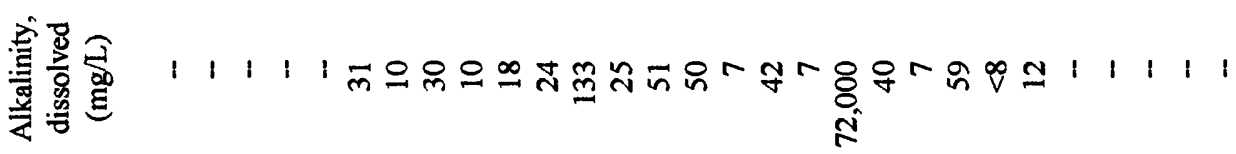

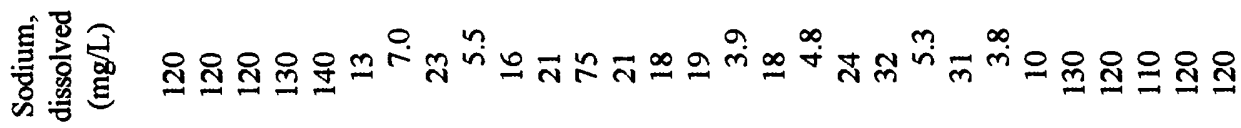

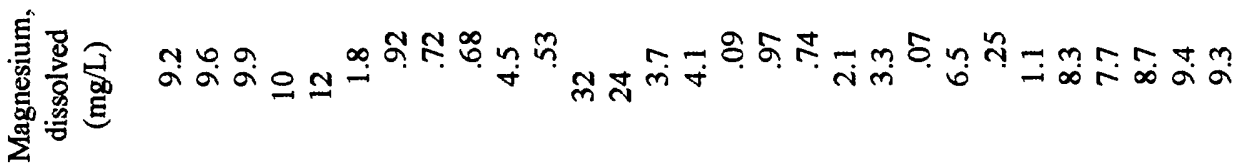

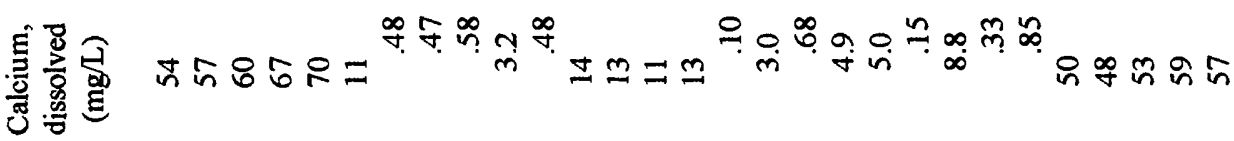

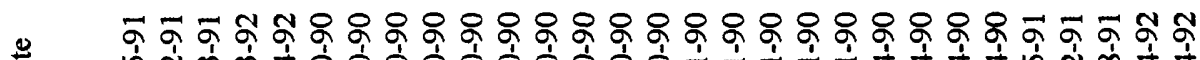

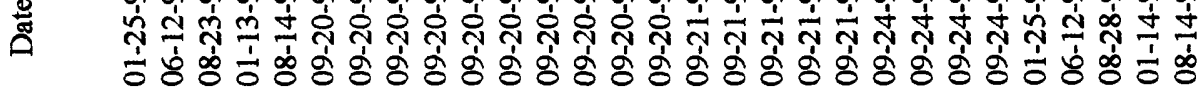




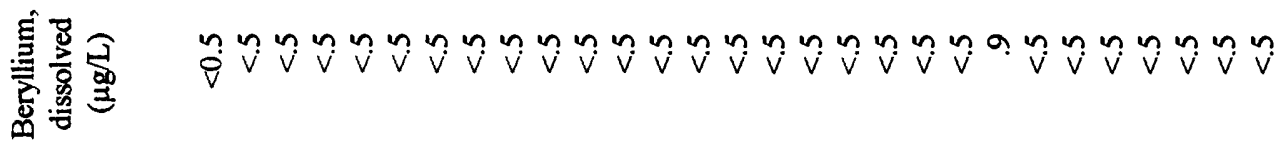

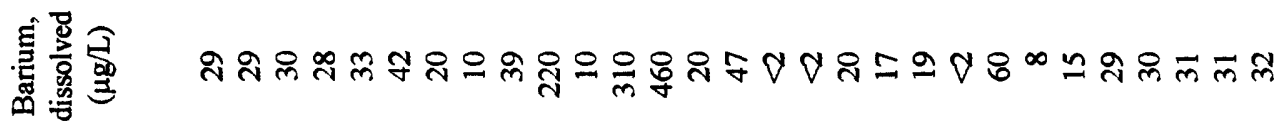

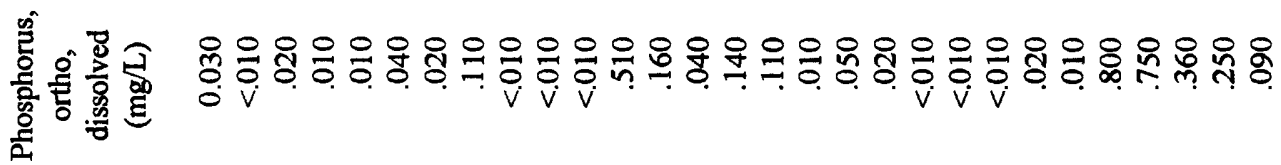

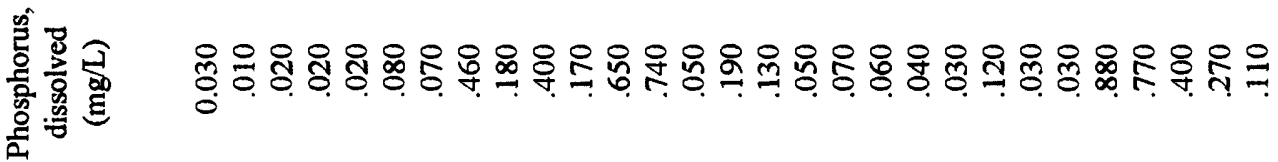

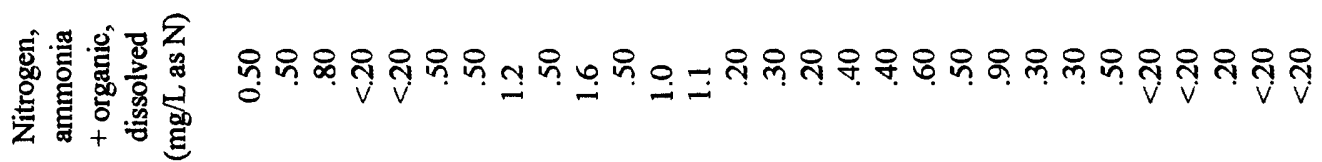

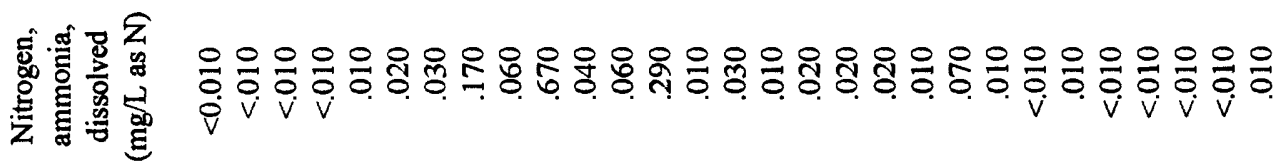

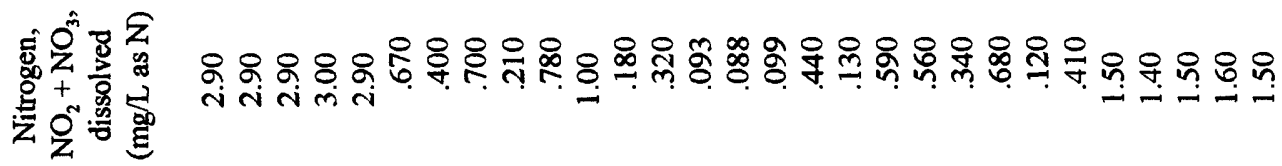

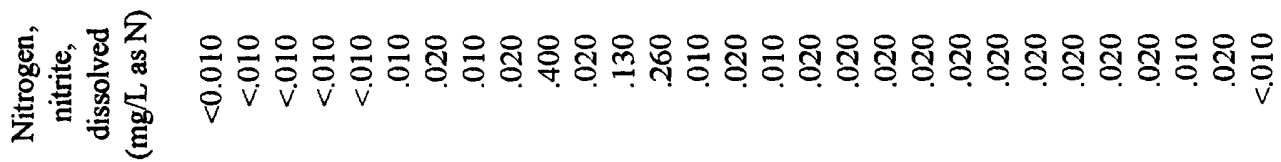

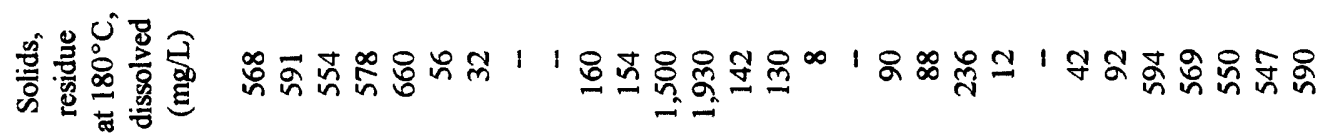

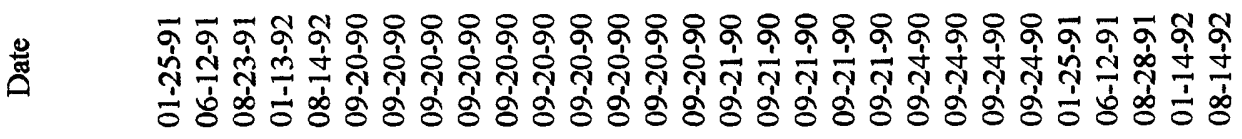

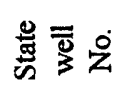

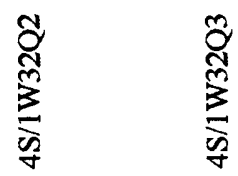




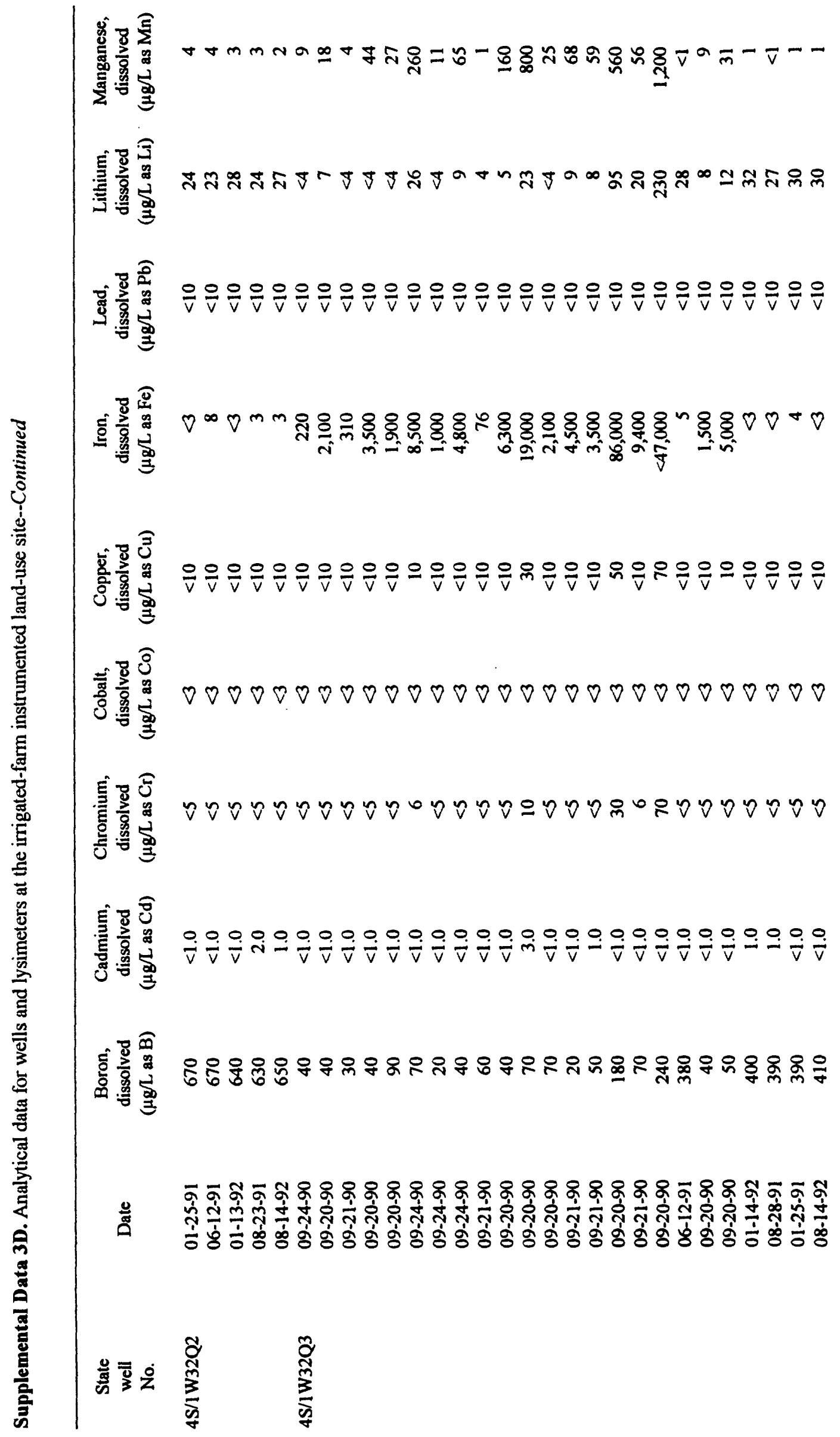




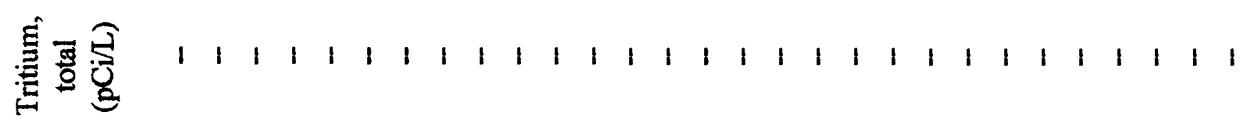

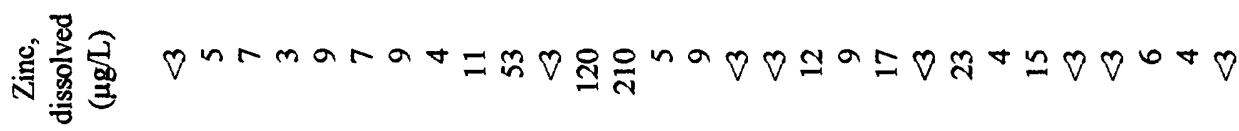

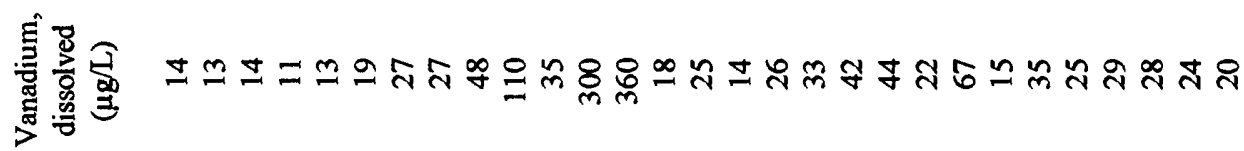

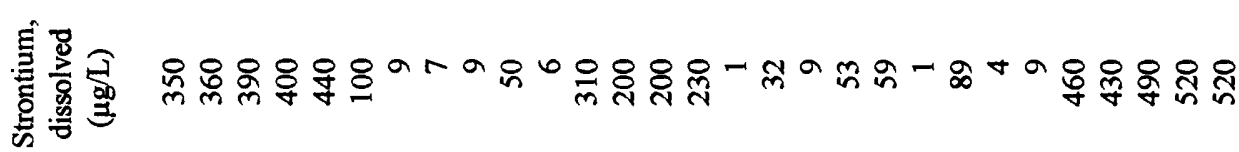

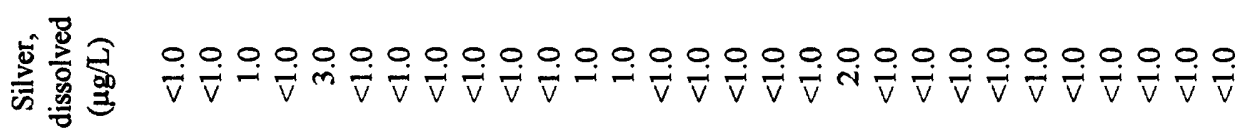

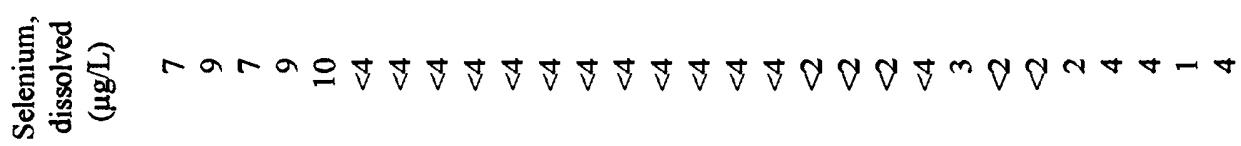

兽旁兽

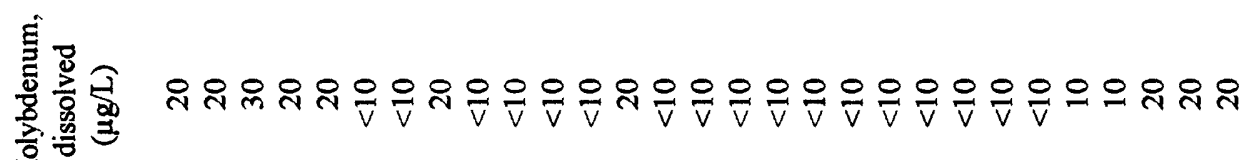
$\sum$

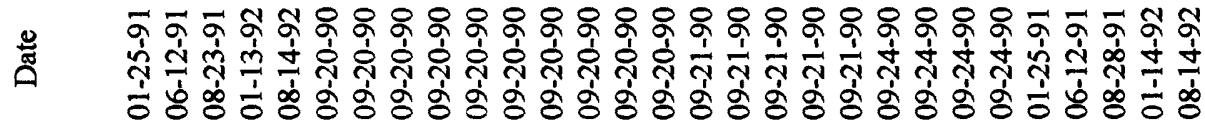

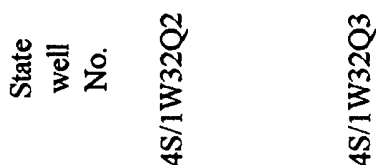

\section{$\sum_{\substack{\infty \\ \infty}}^{\infty}$}




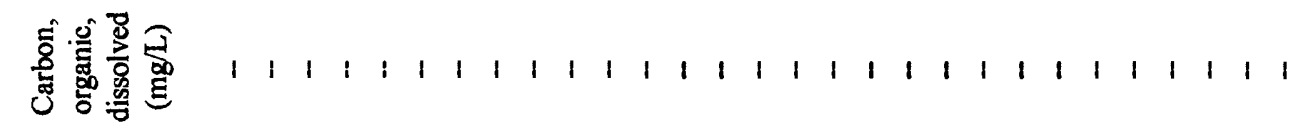

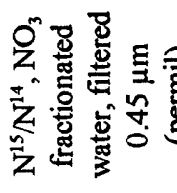

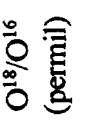

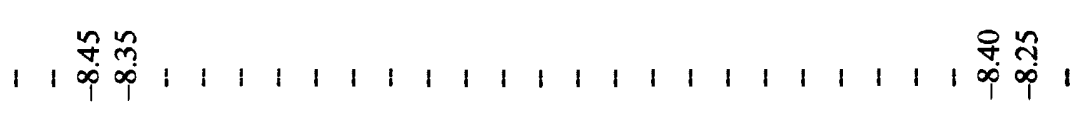

艺高

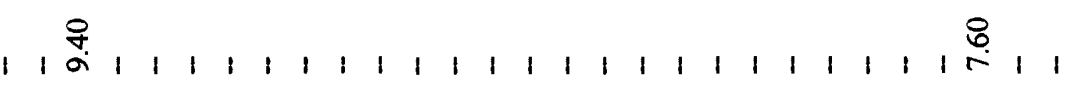

蛋高

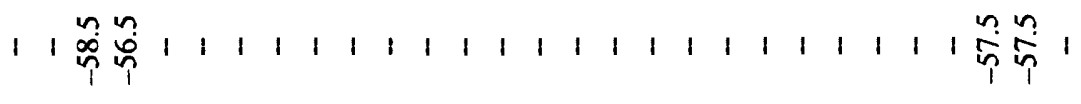

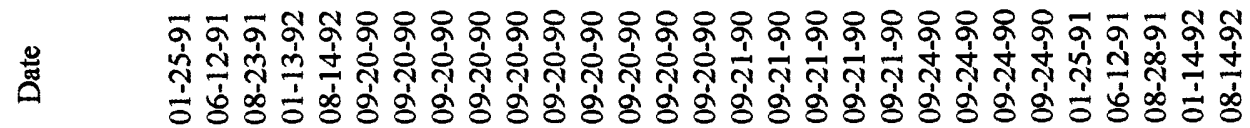




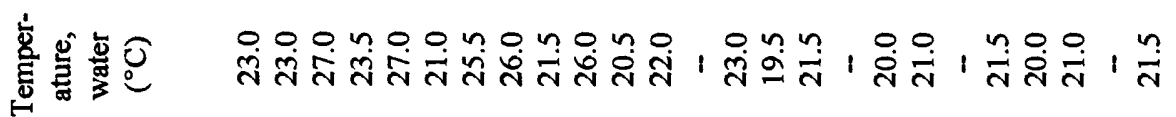

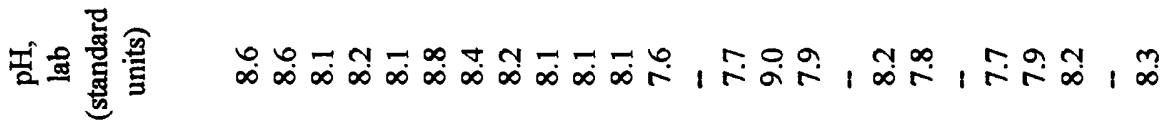

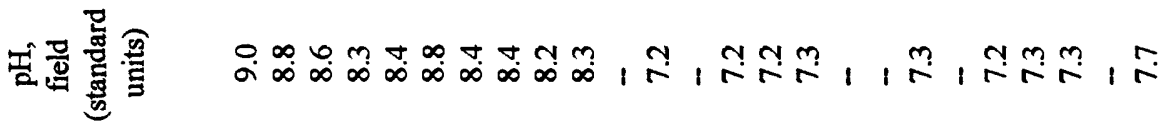

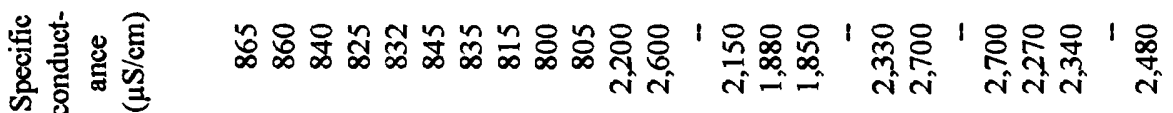

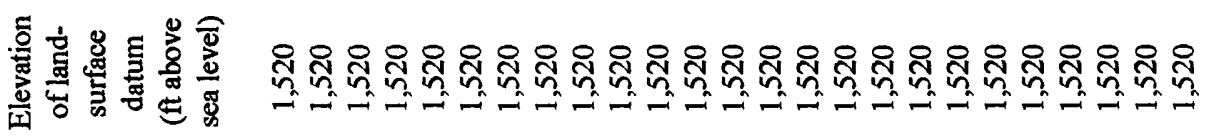

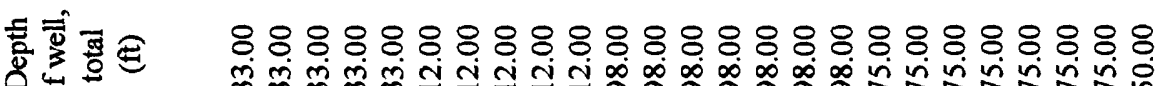

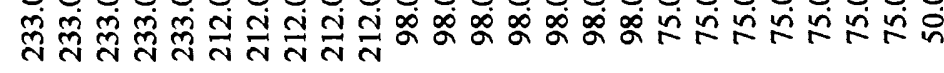

焉

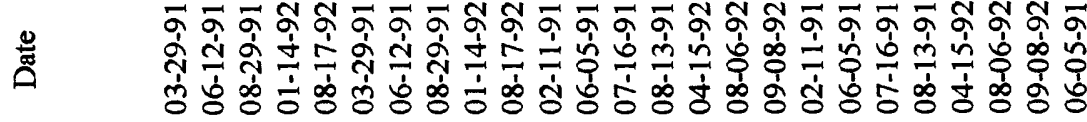

\begin{tabular}{|c|c|c|}
\hline 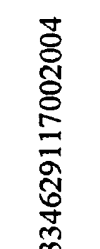 & 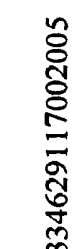 & 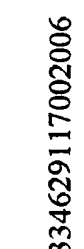 \\
\hline
\end{tabular}

密異完 


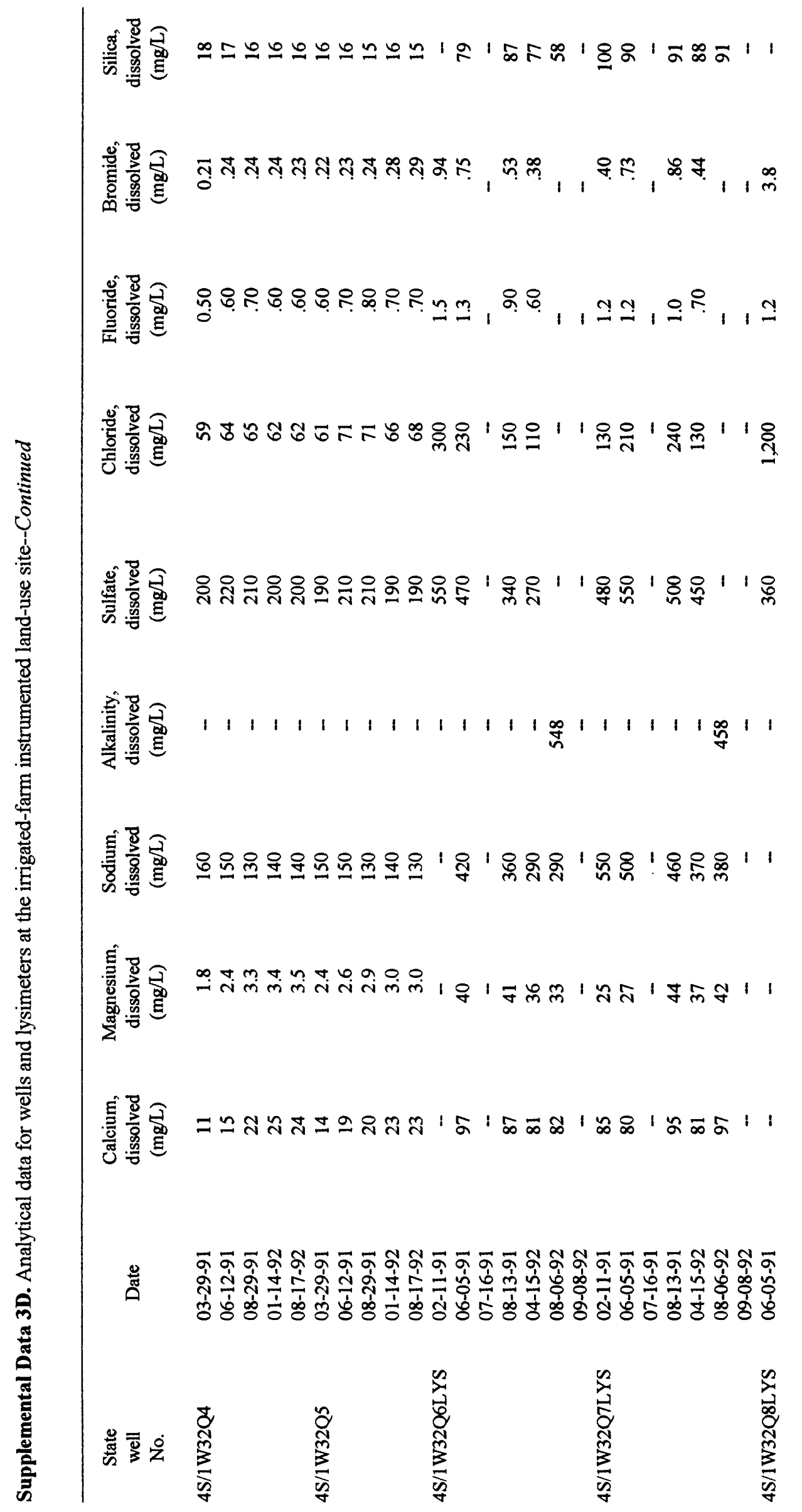




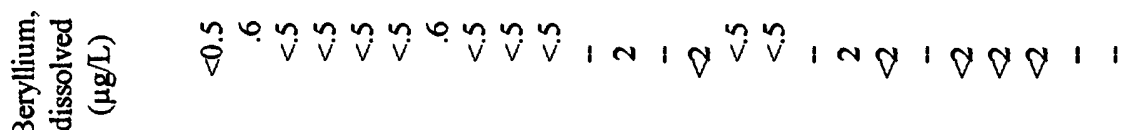

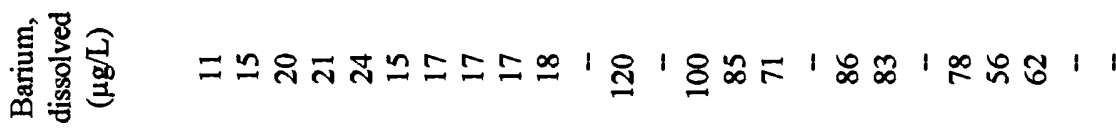

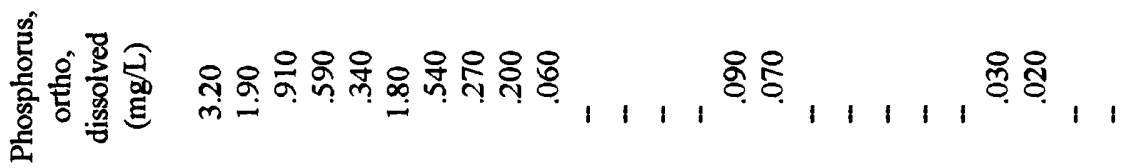

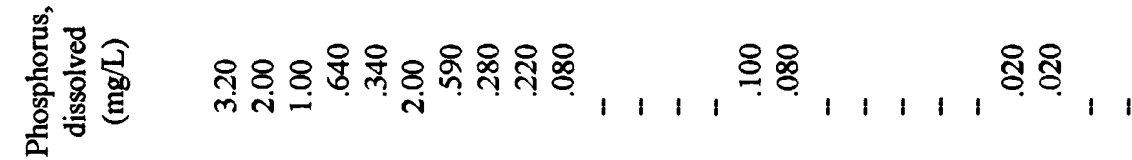

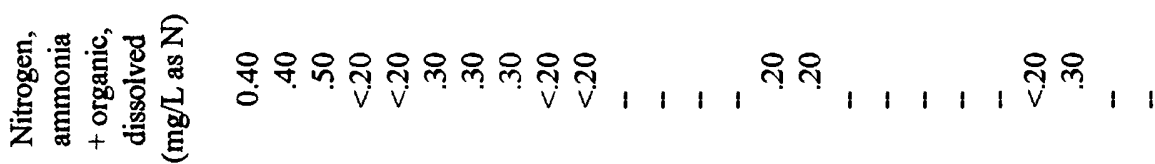

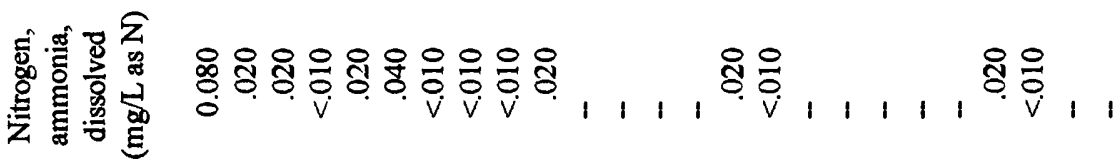

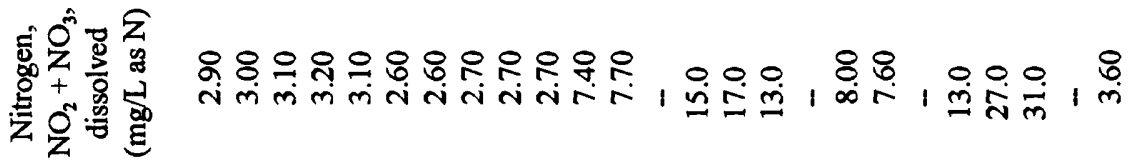

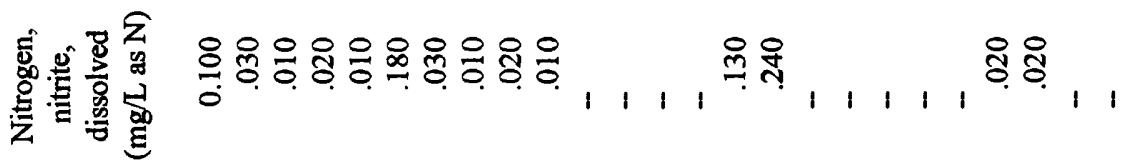

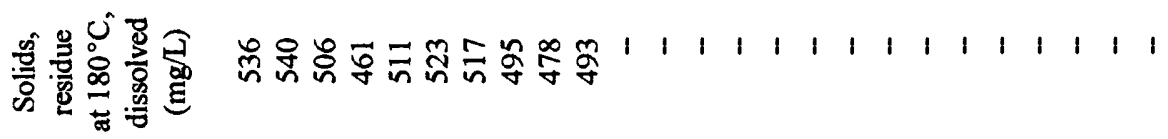

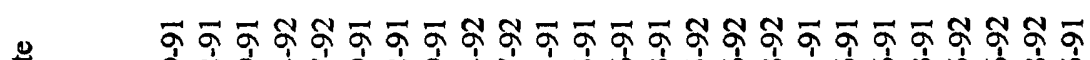
สิ่

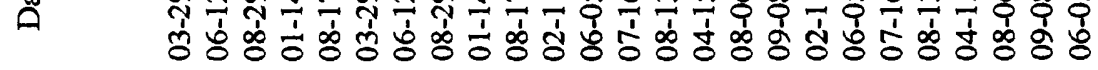
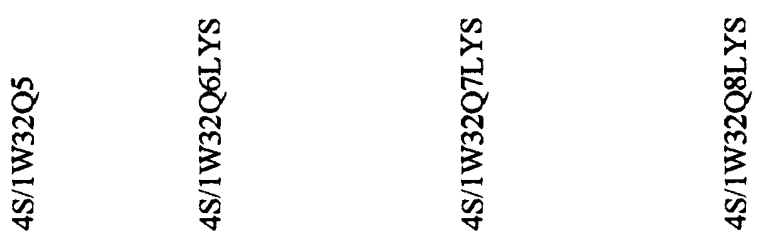


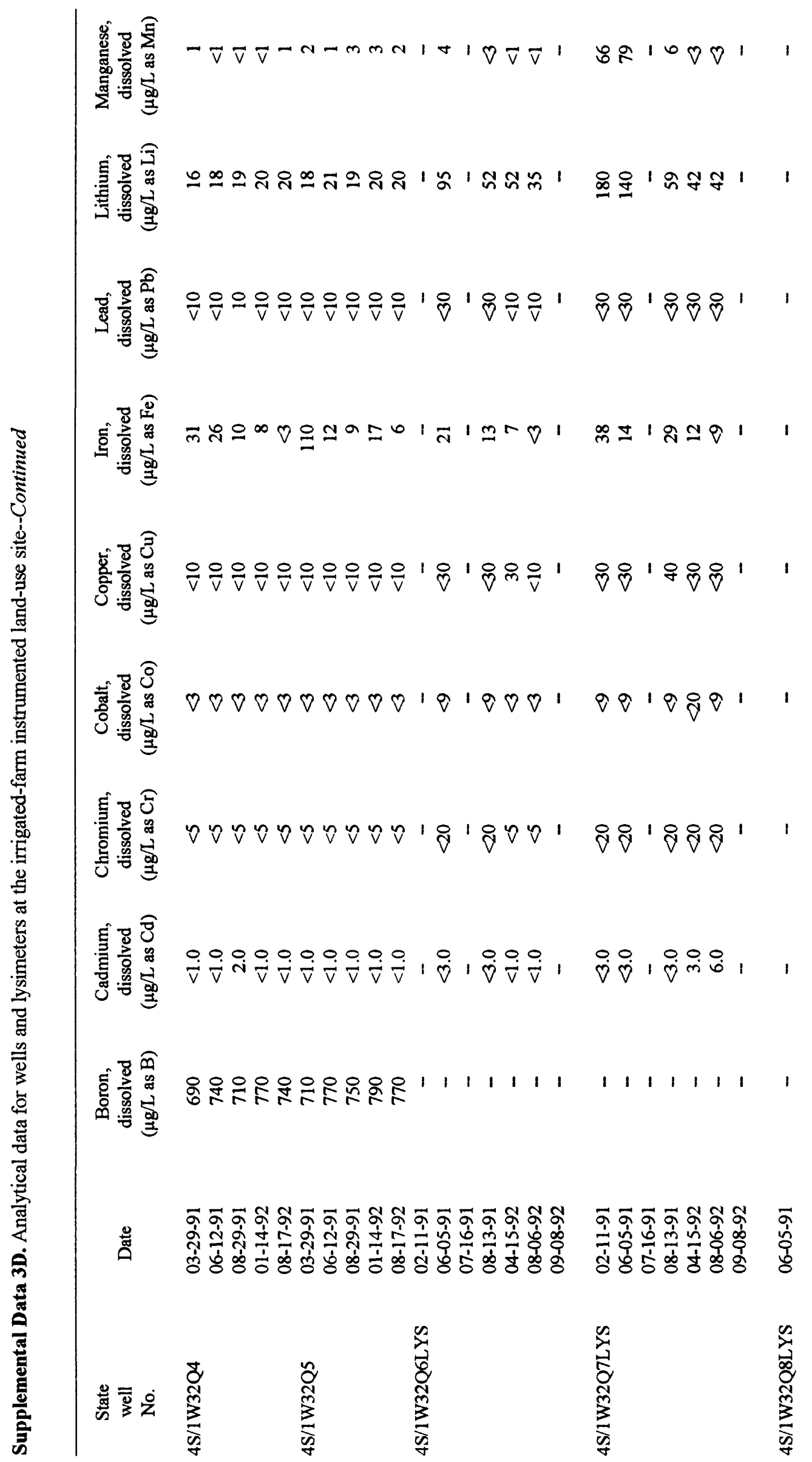




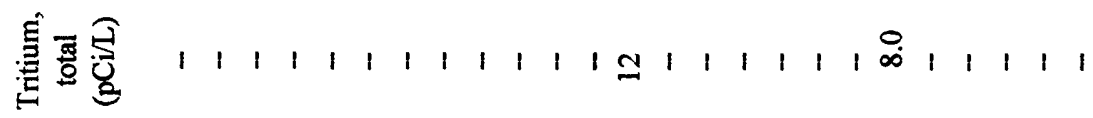

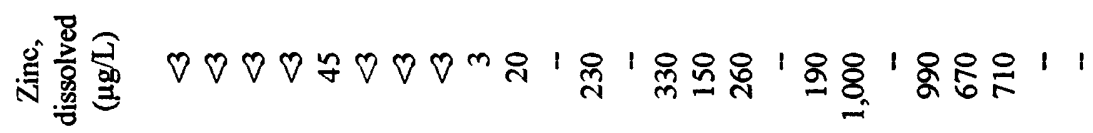

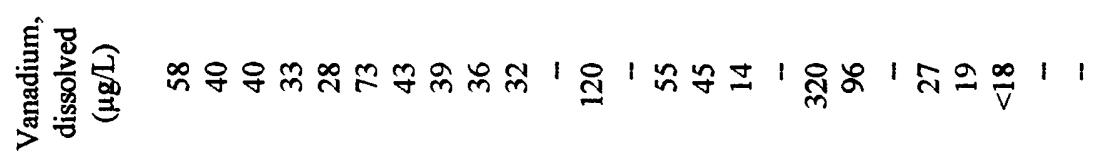

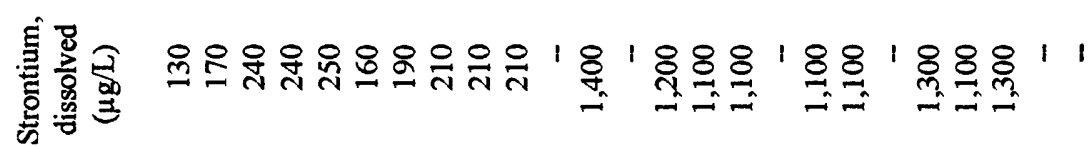

离崽忽

竧总总

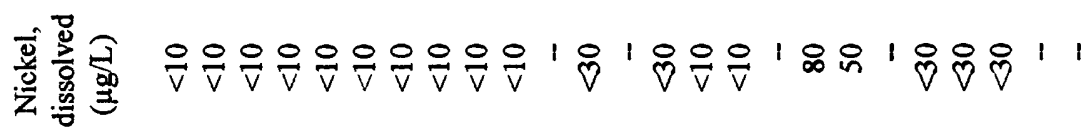

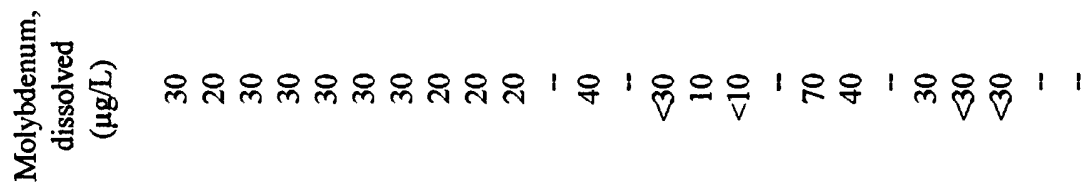

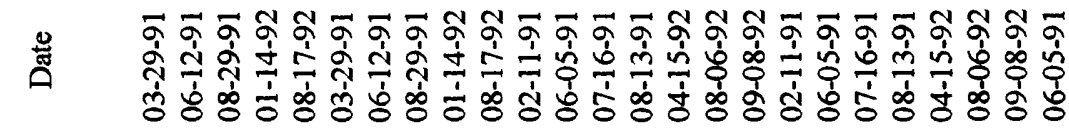

คิ

气ี 


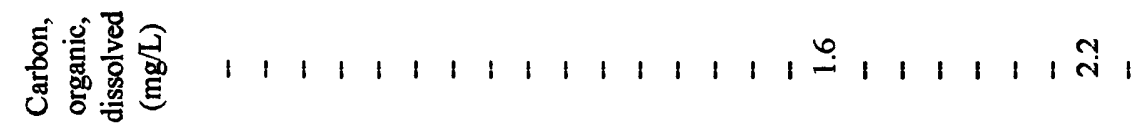

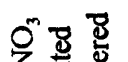

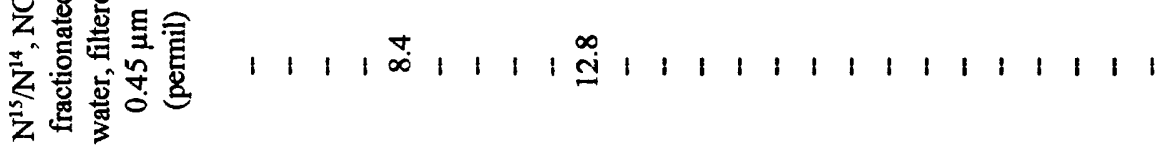

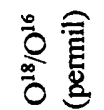

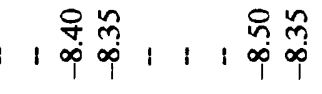

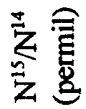

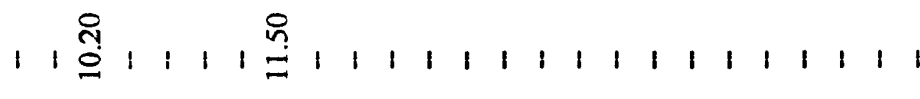

昰

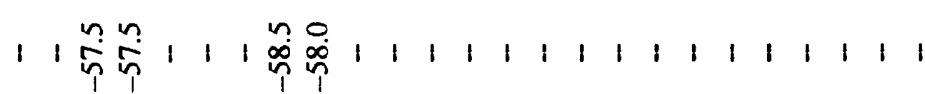

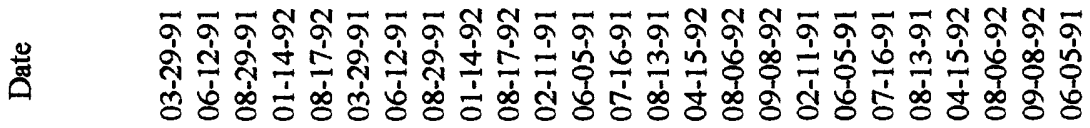

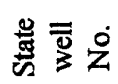

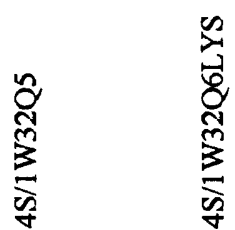

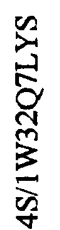




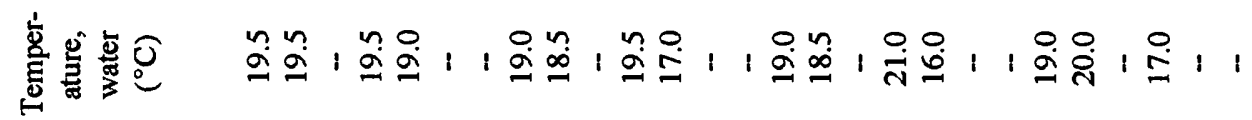

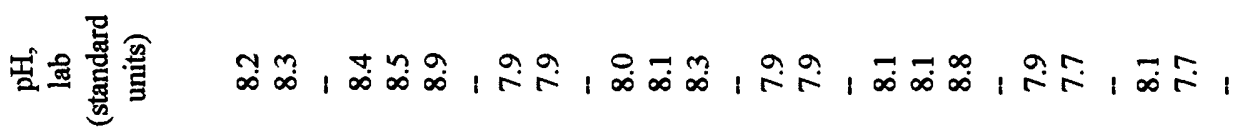

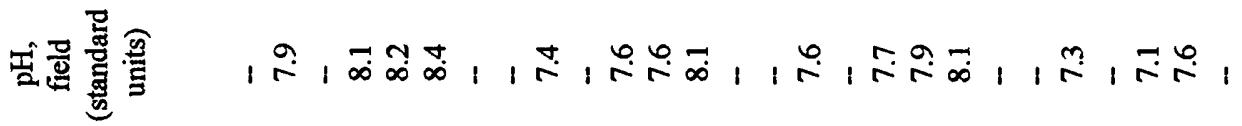

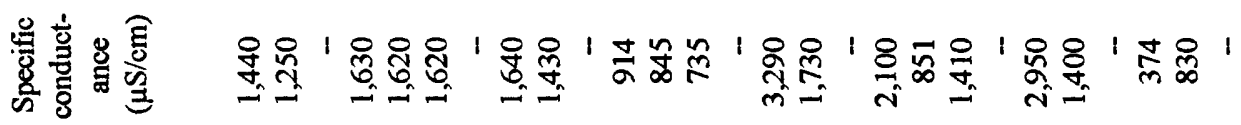

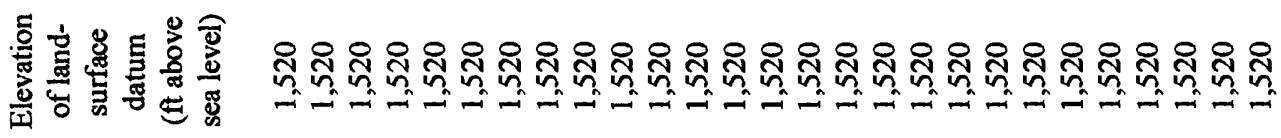

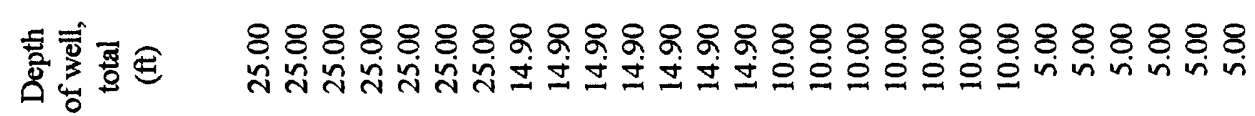

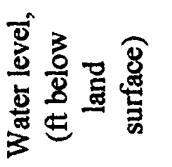

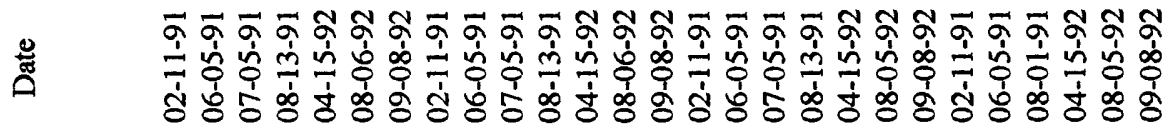

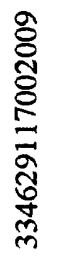

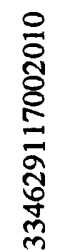

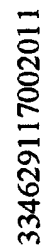




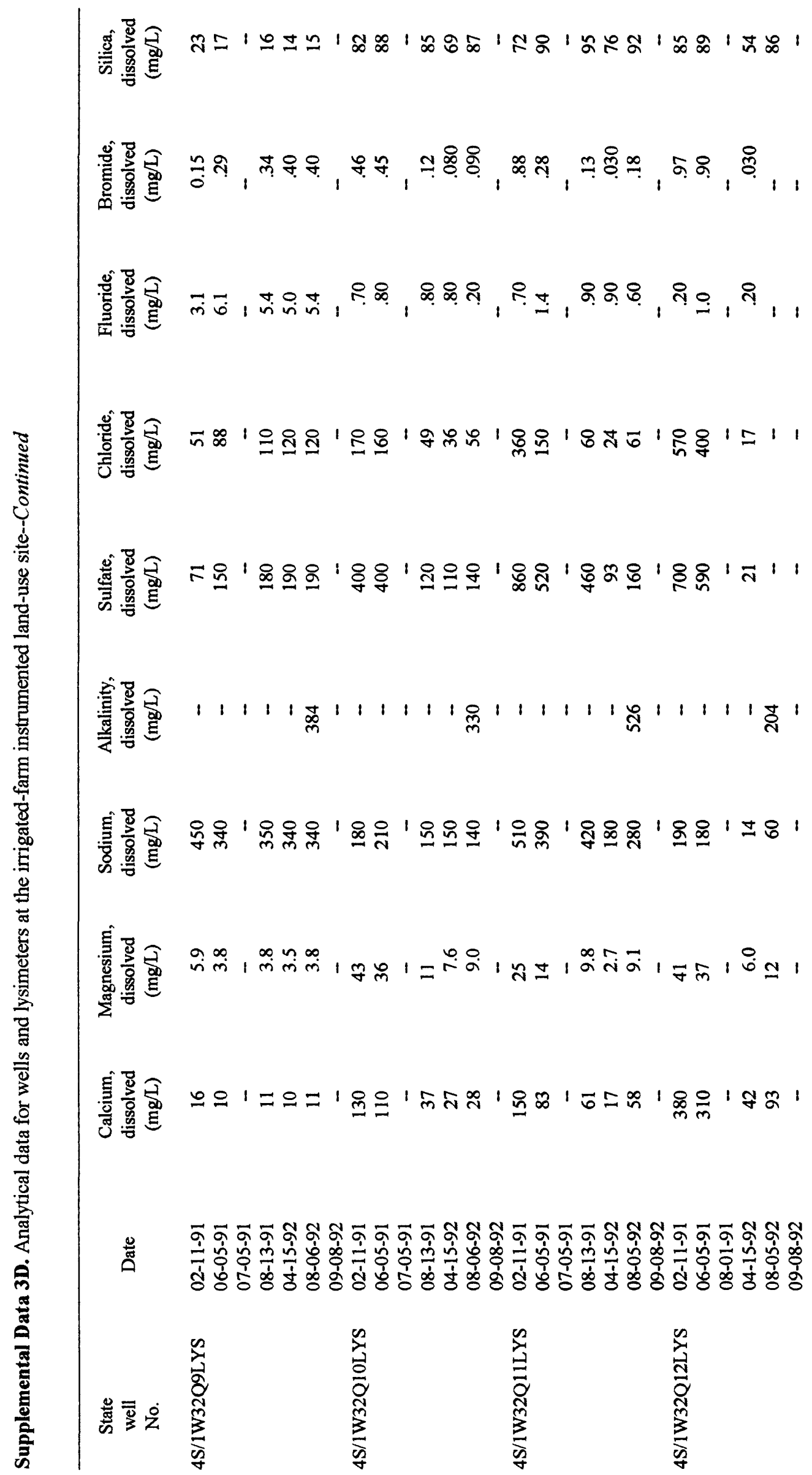




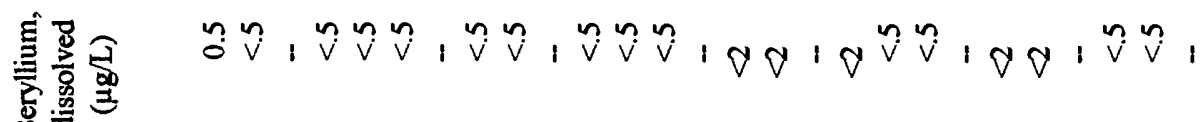
m.

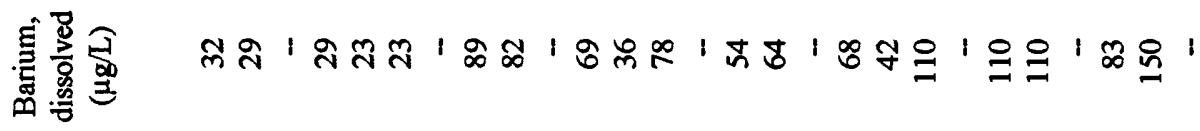

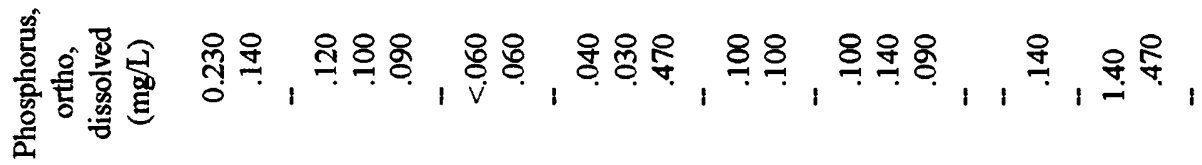

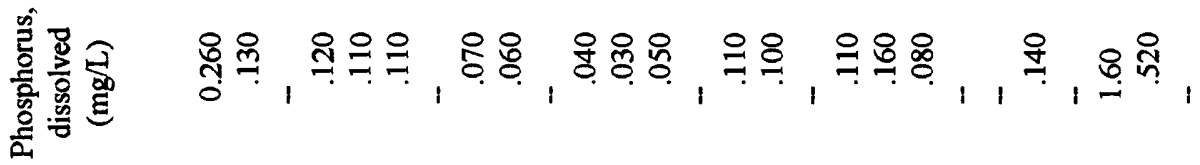

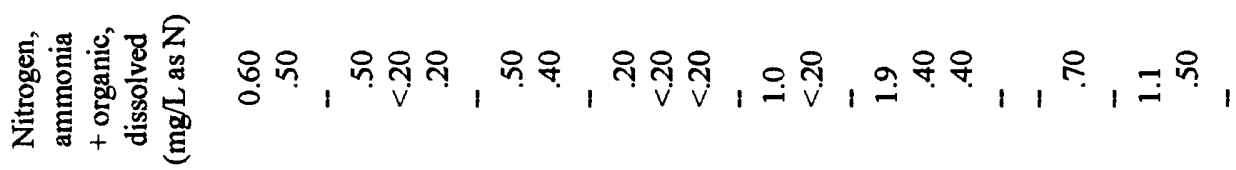

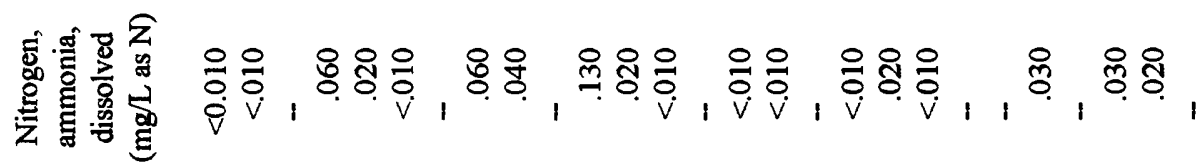

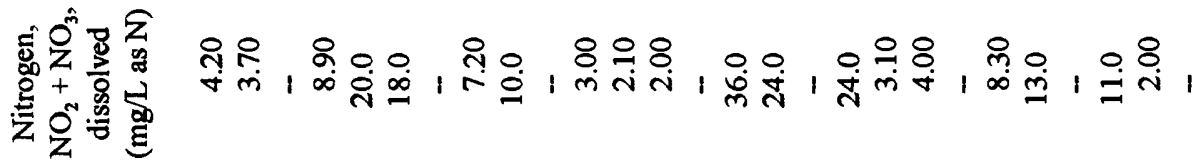

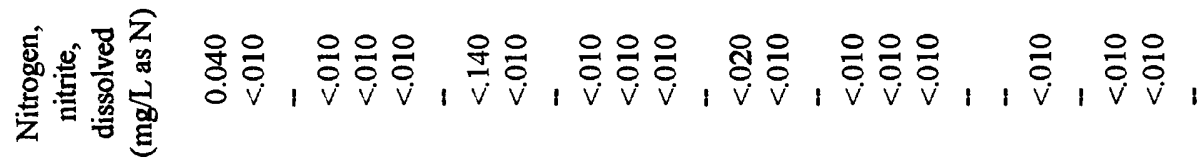

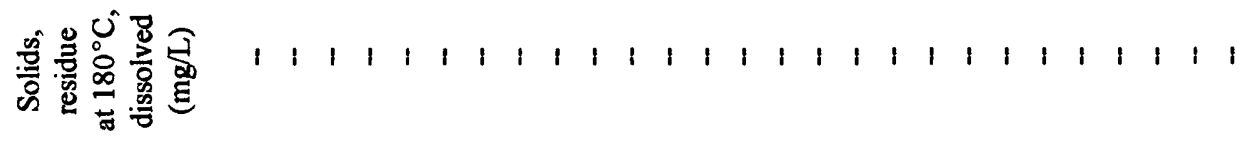
矢

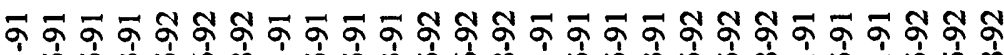

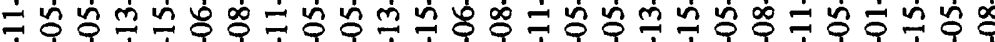

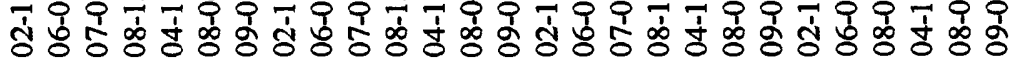
善高弯安
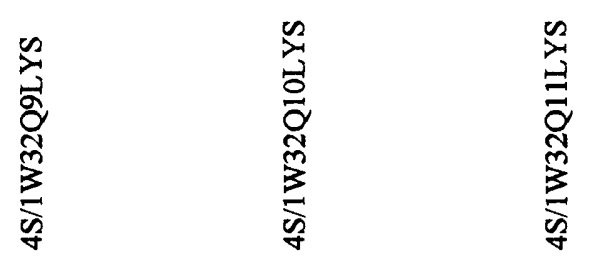


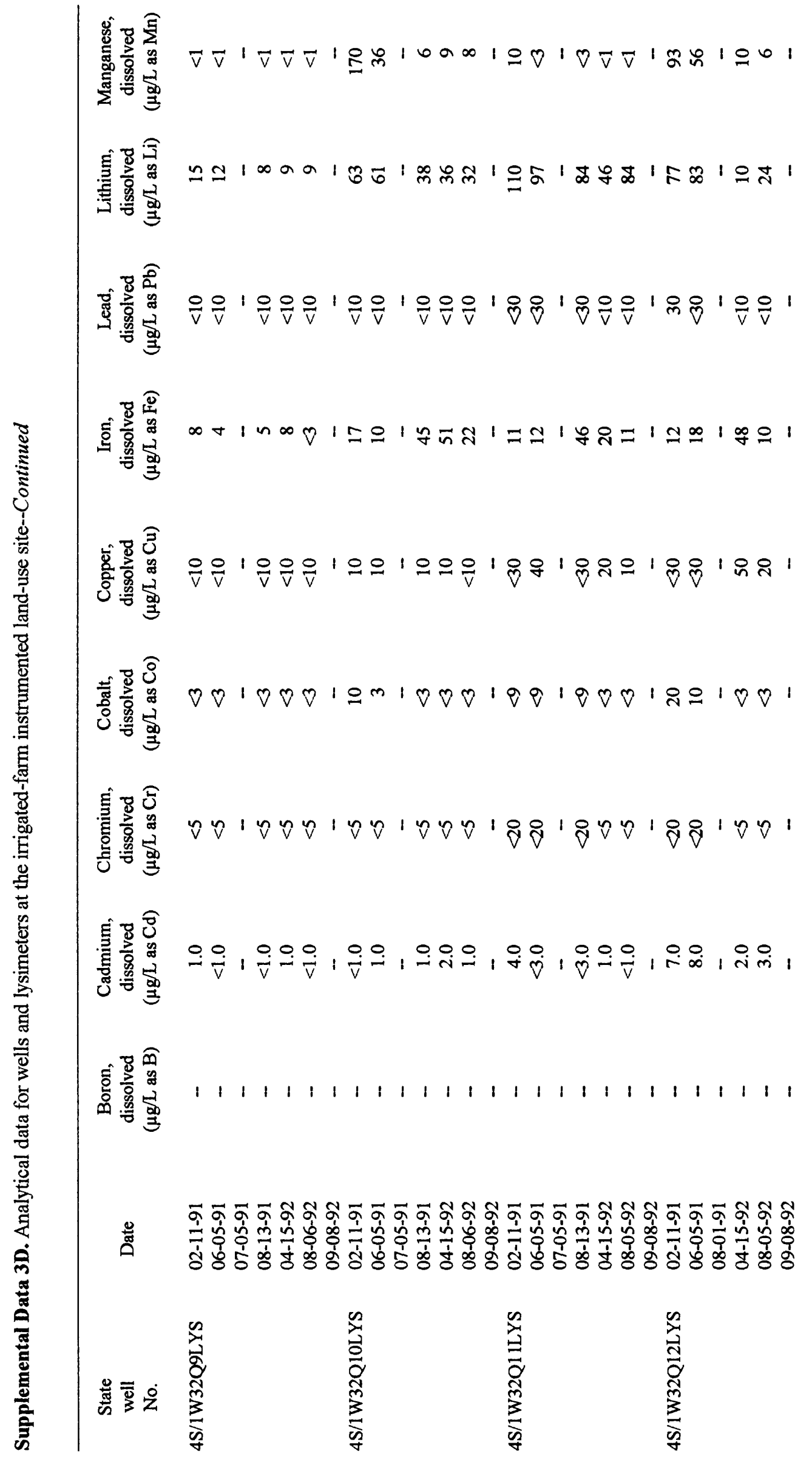




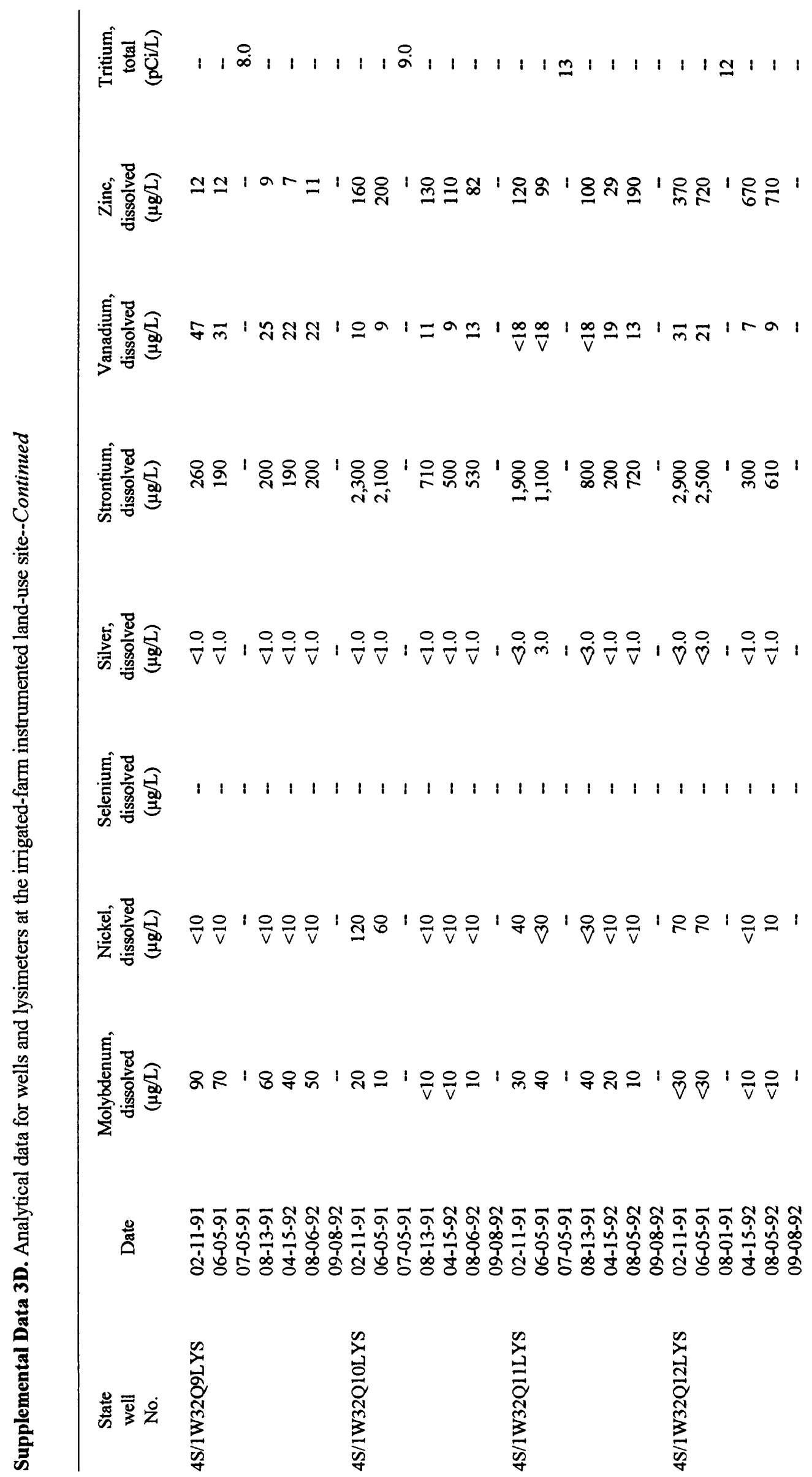




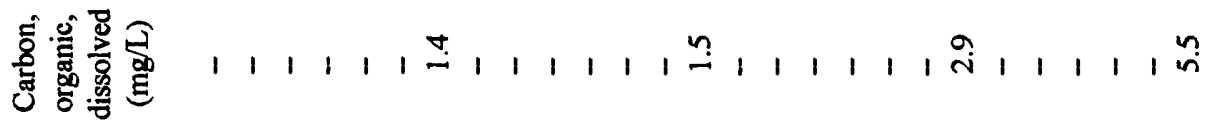

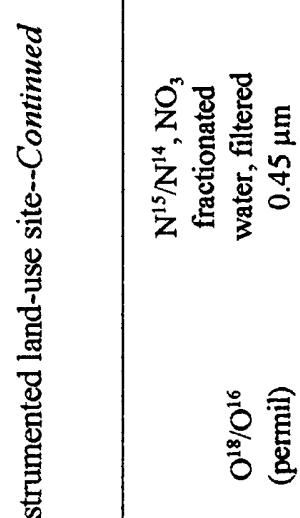

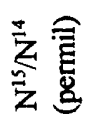

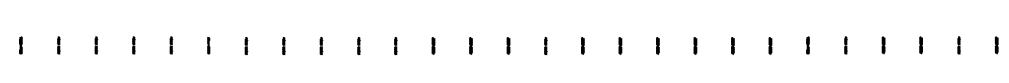

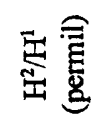

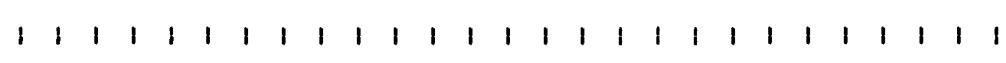




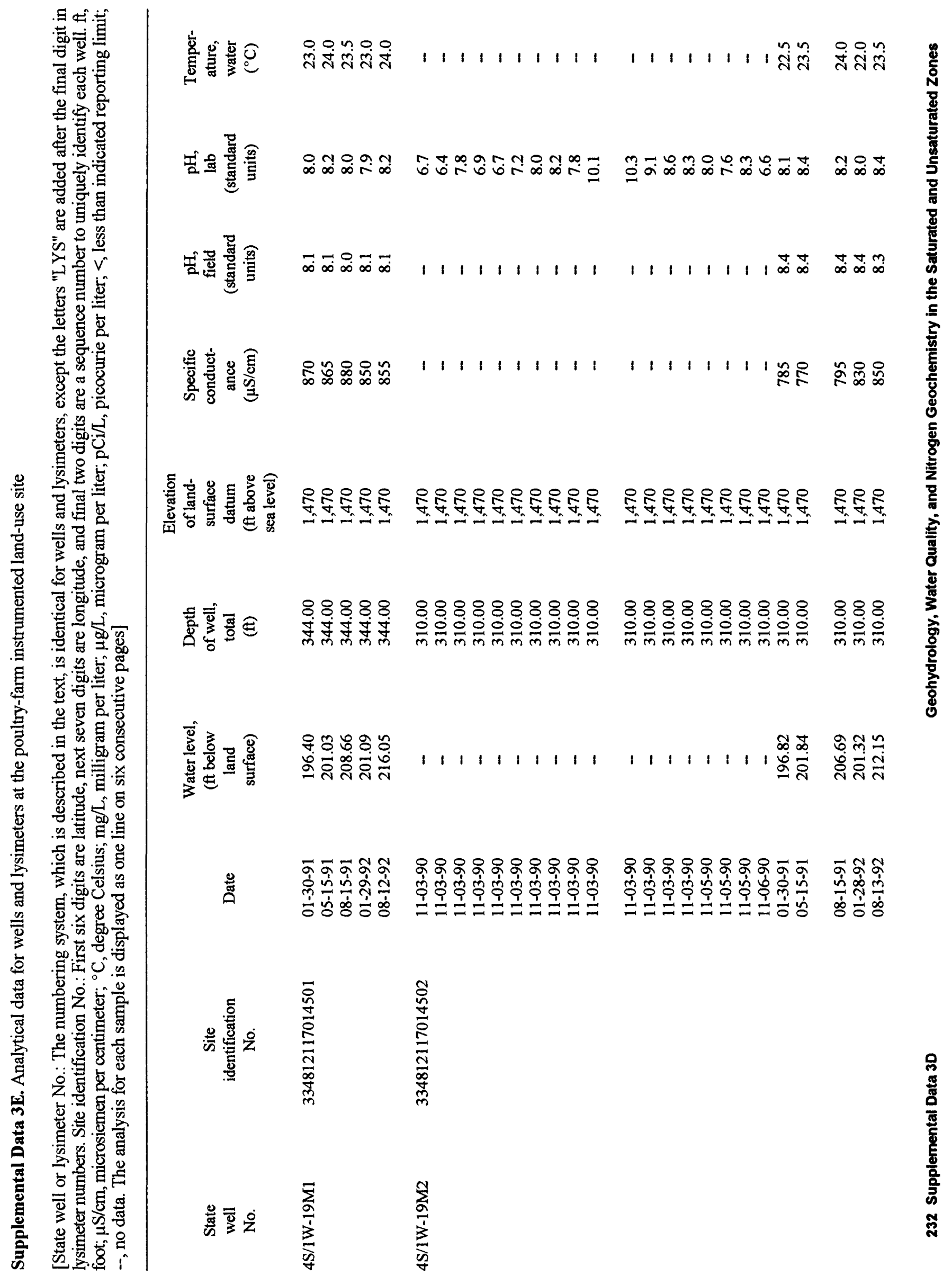




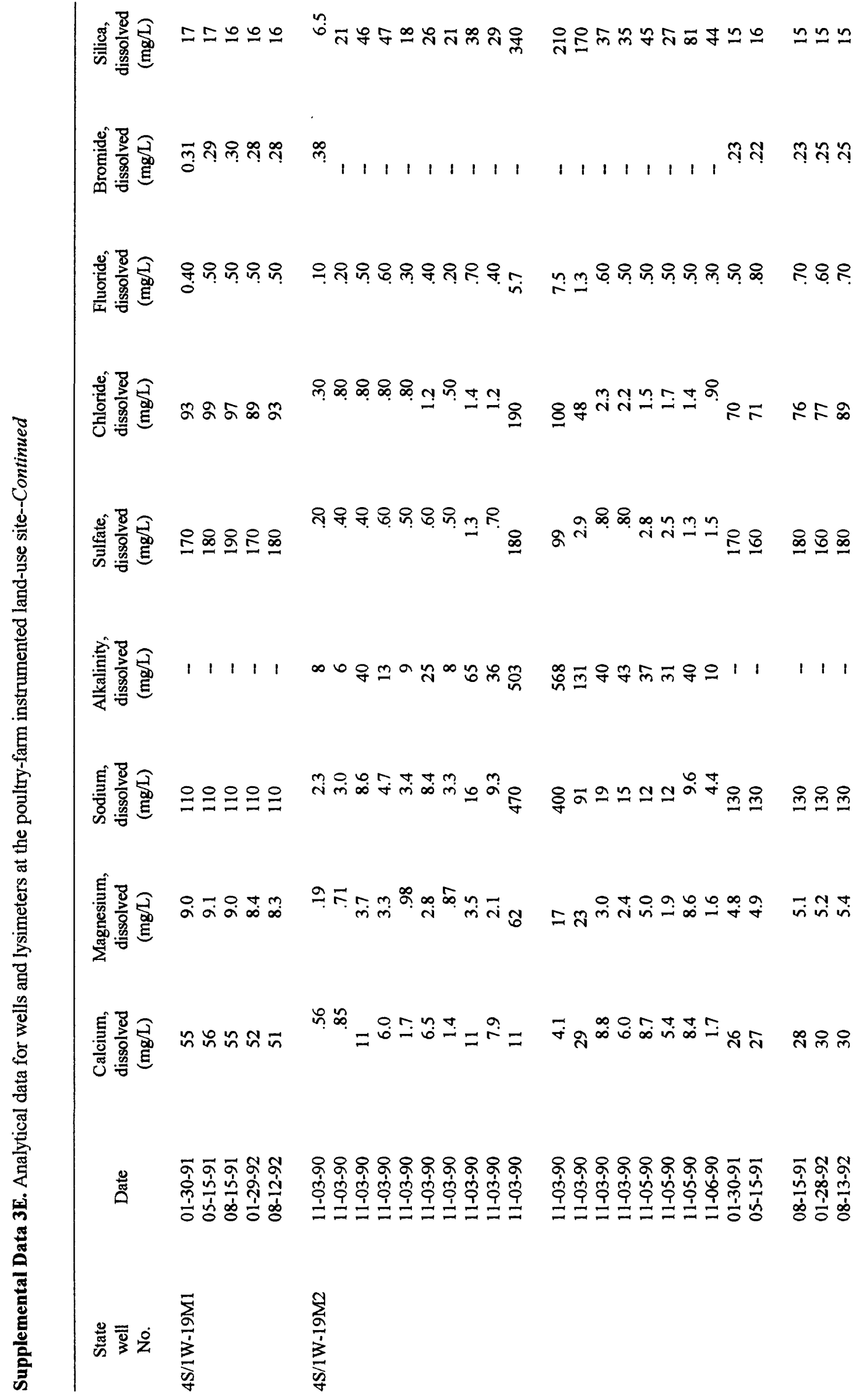




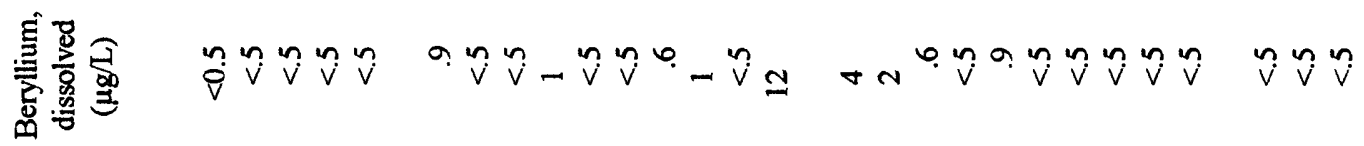

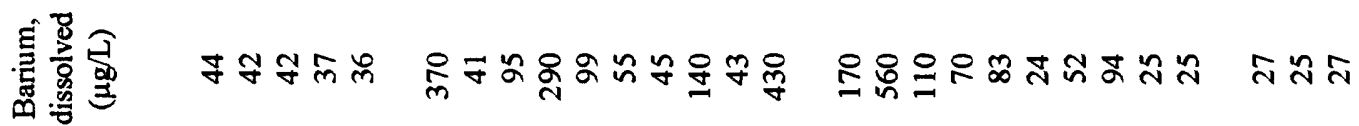

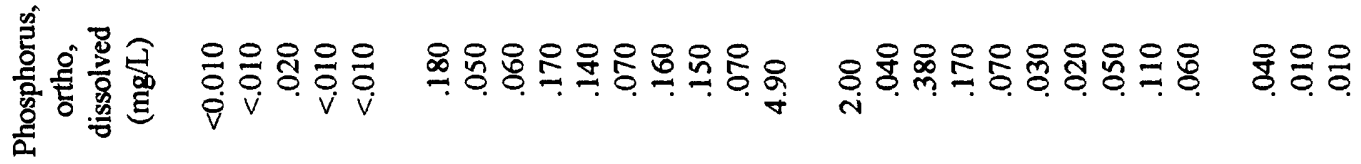

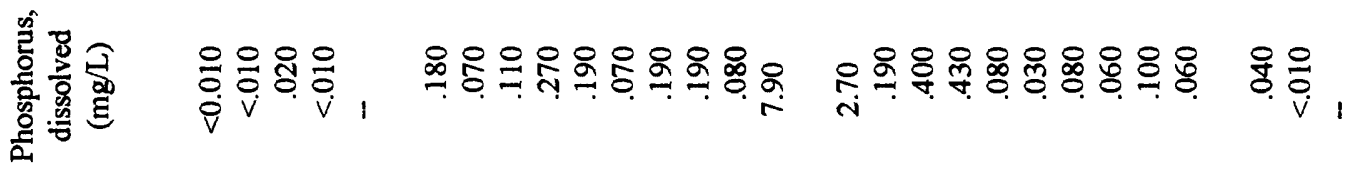

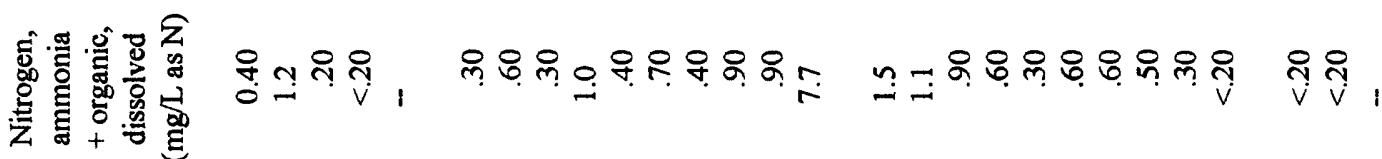

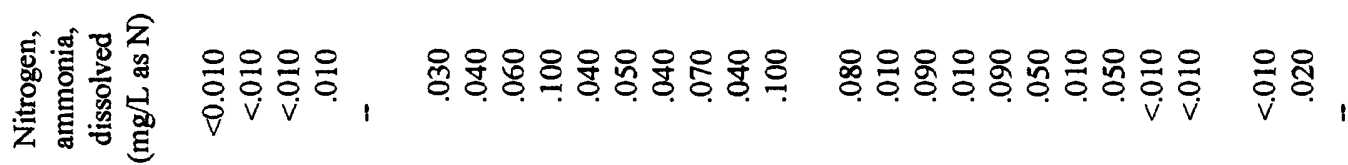

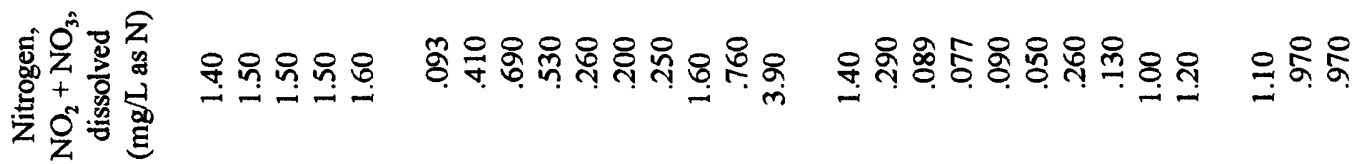

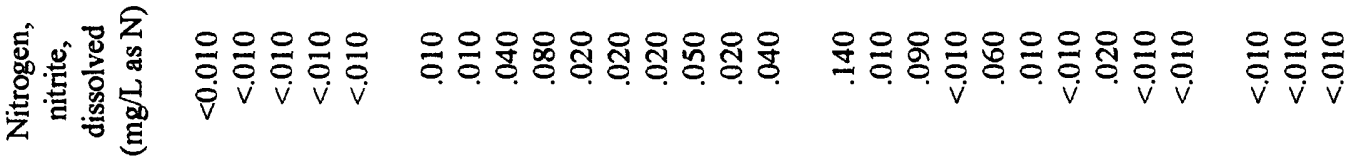

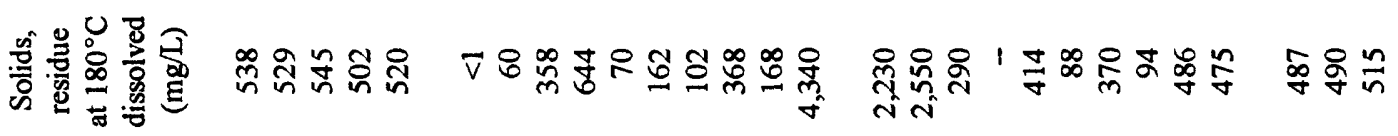

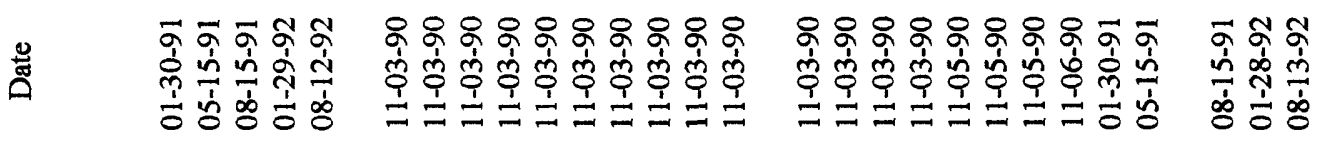

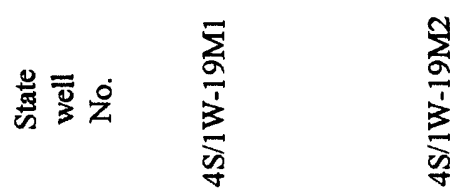




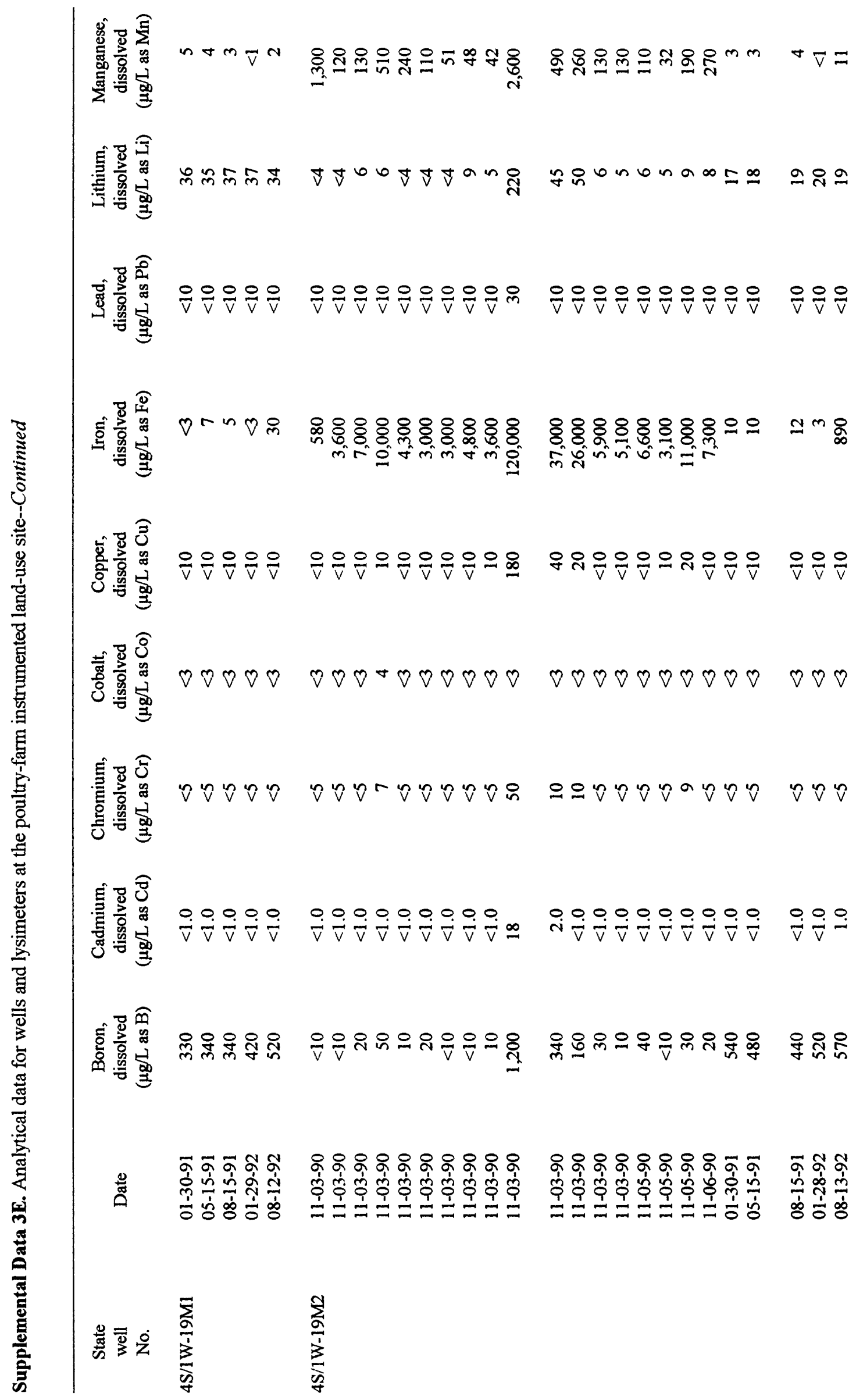


:

过总高

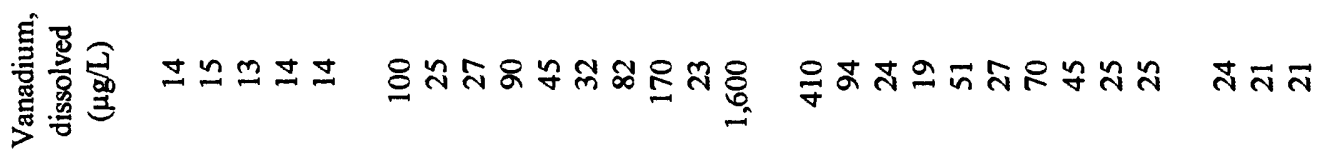

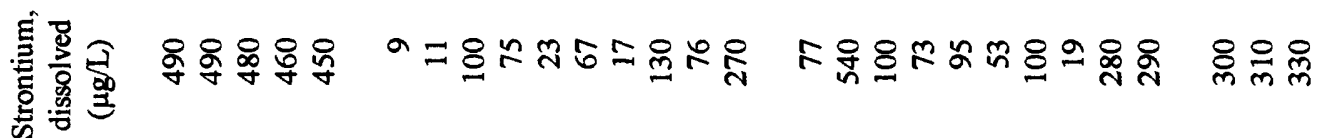

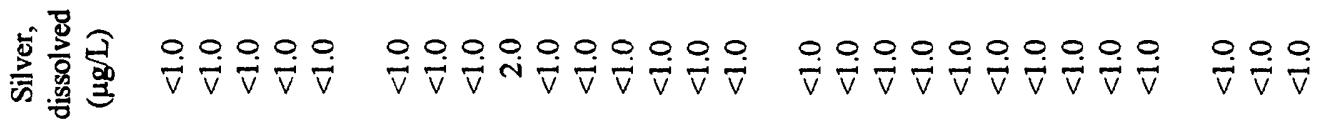

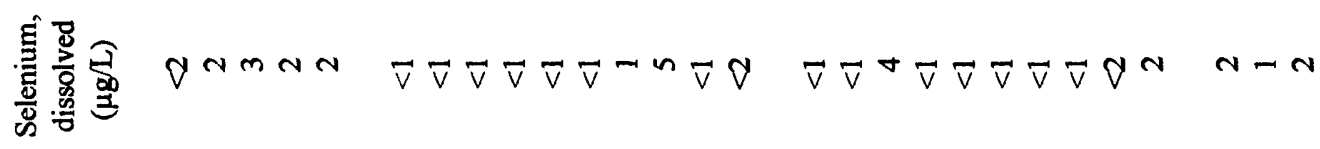

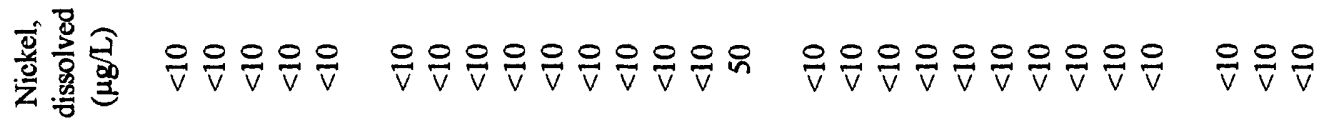

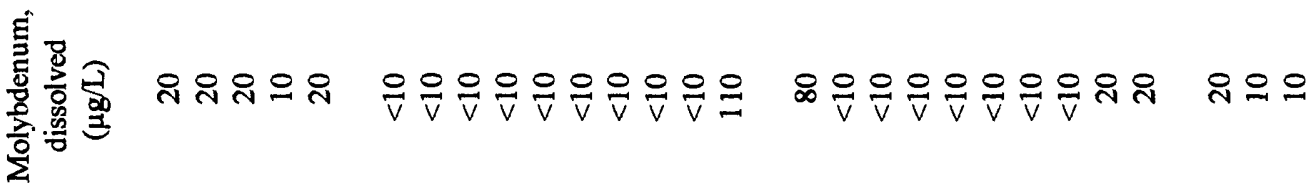




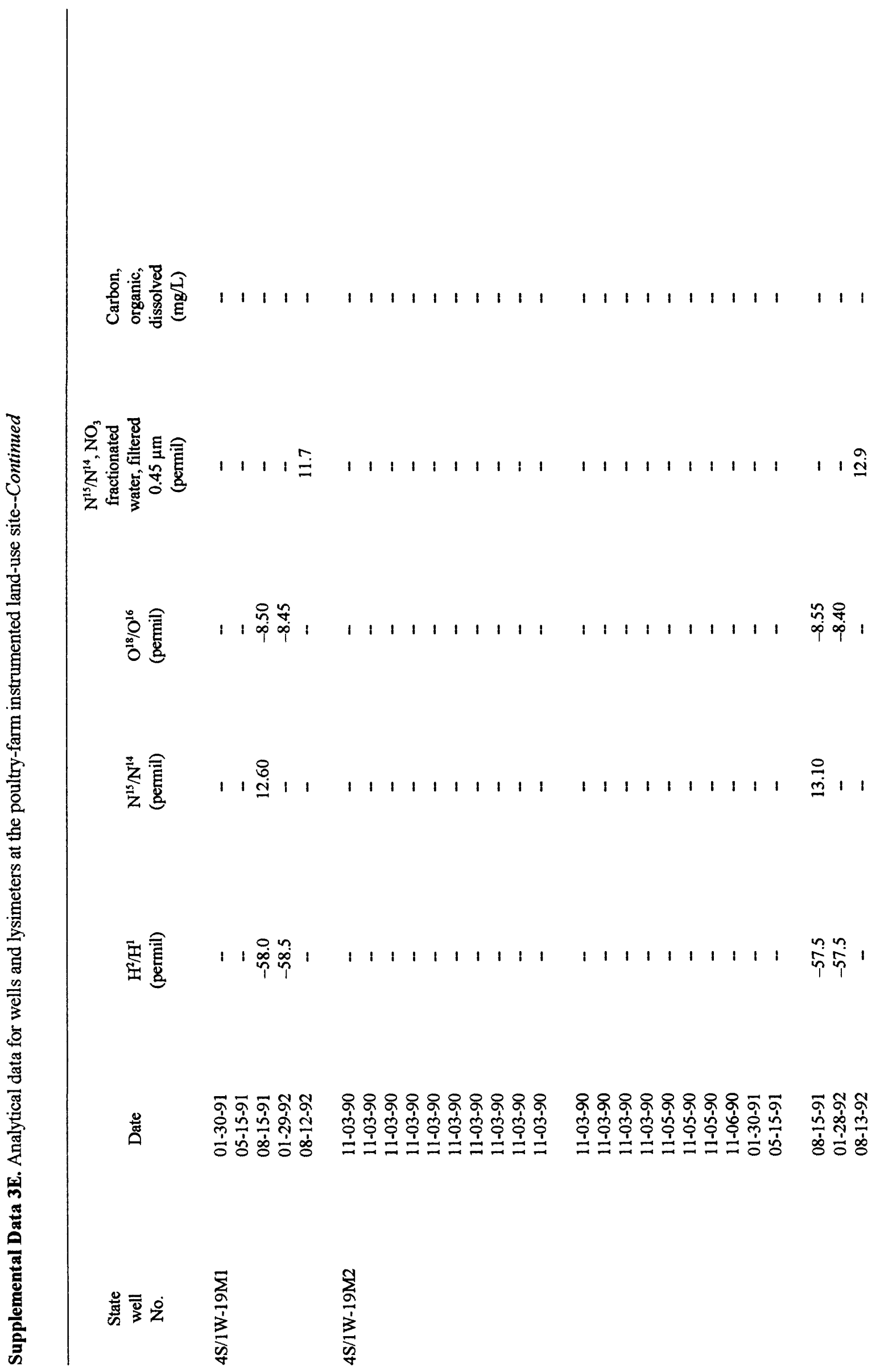




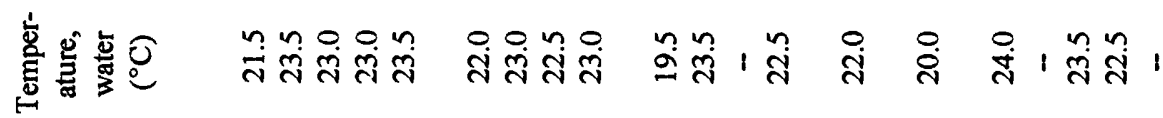

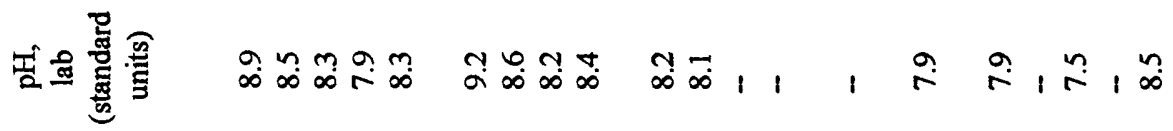

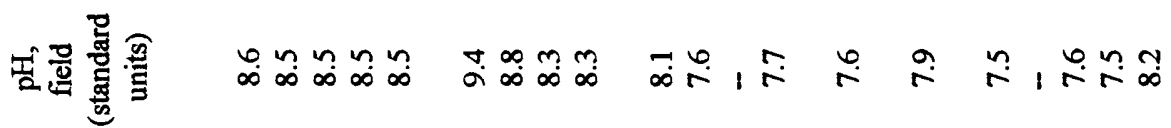

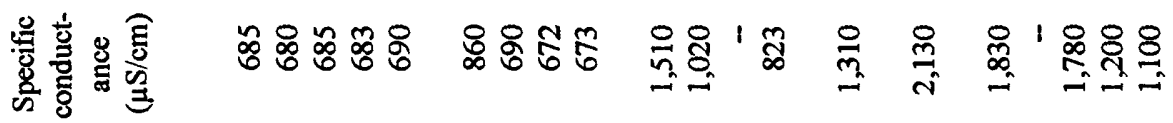

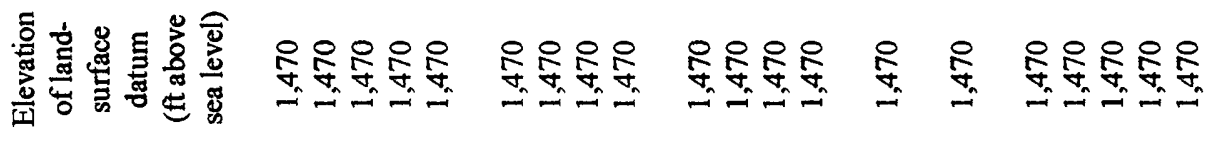

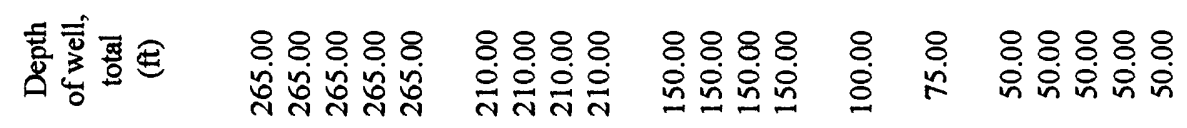

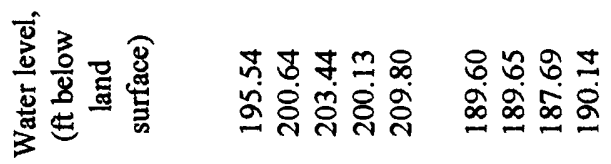

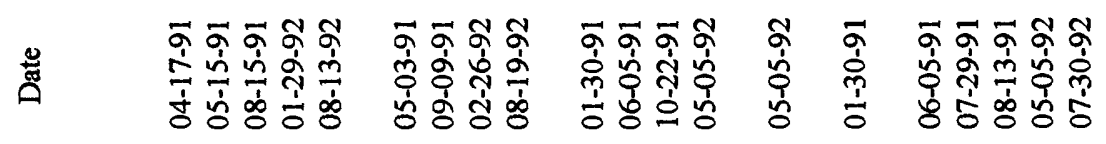

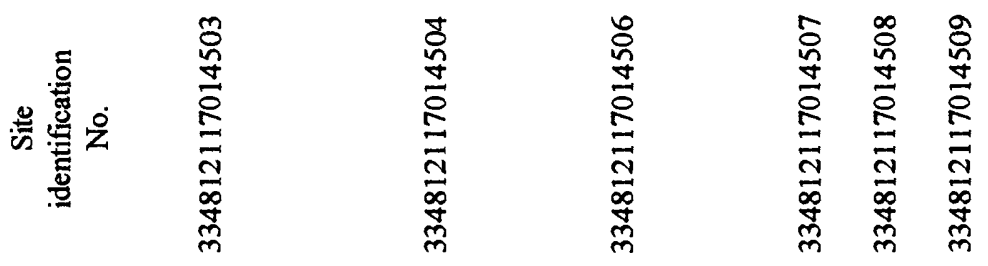

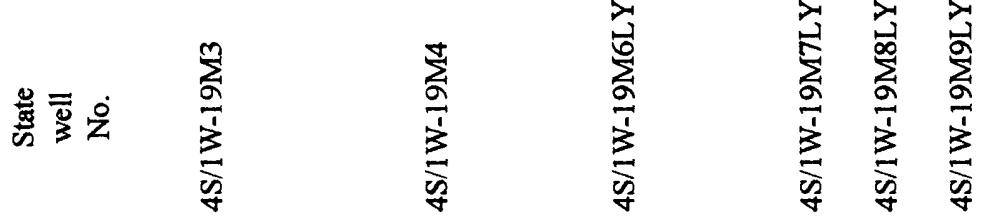




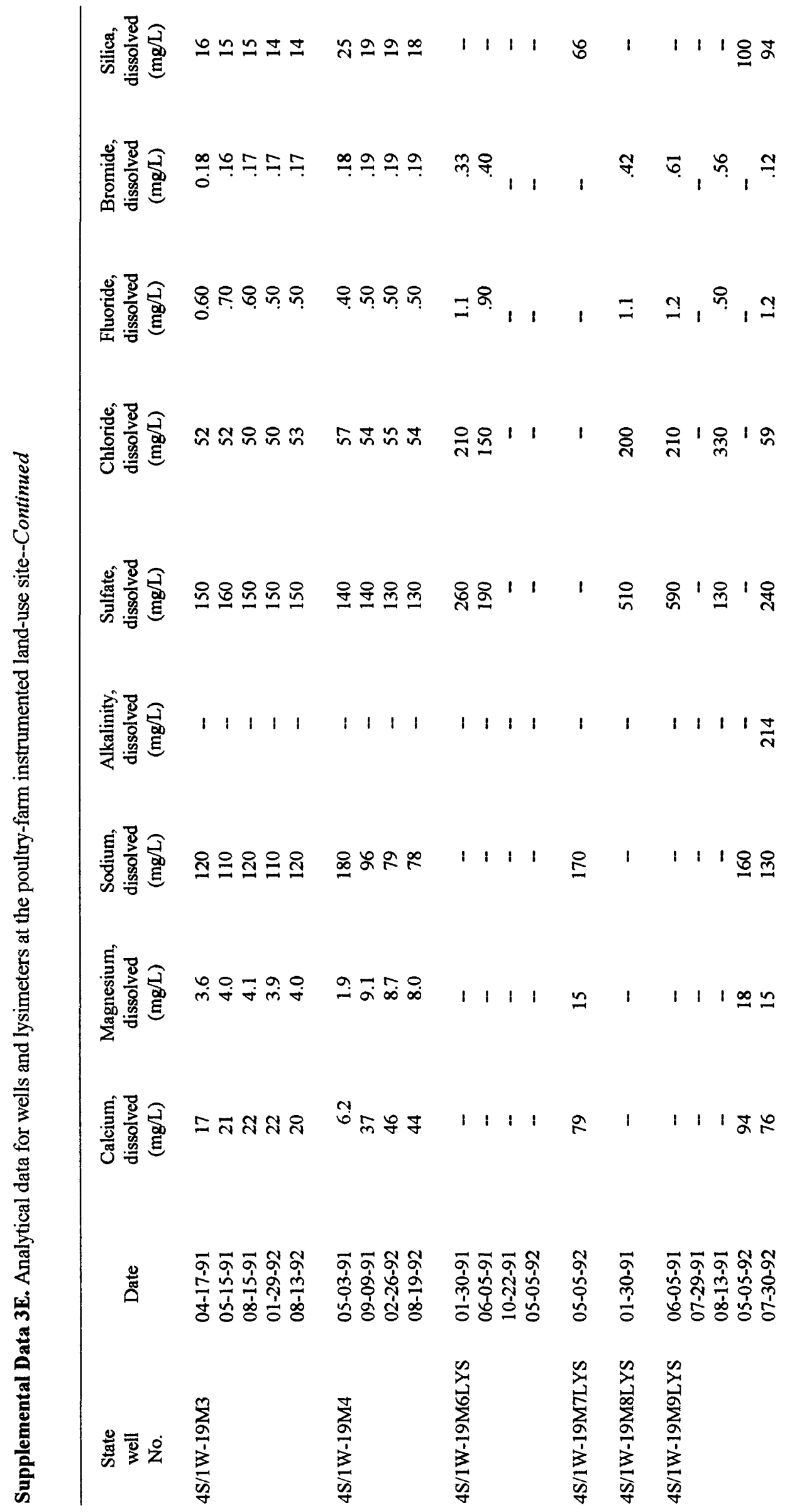




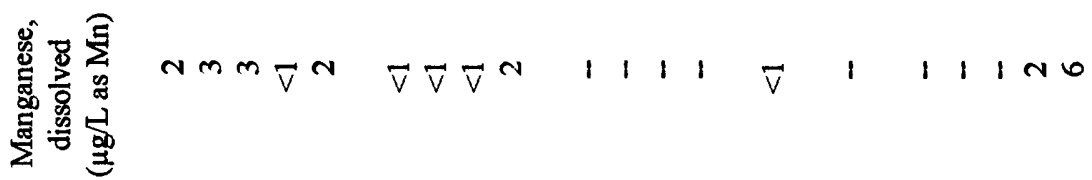

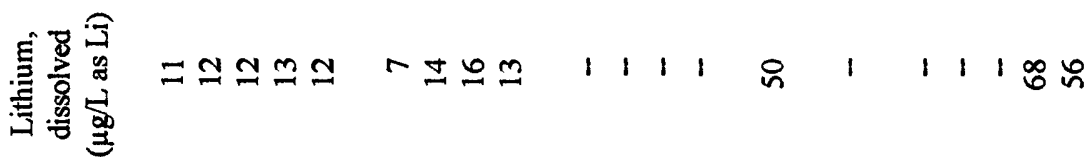

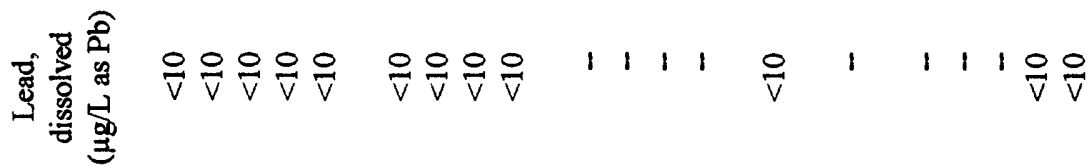

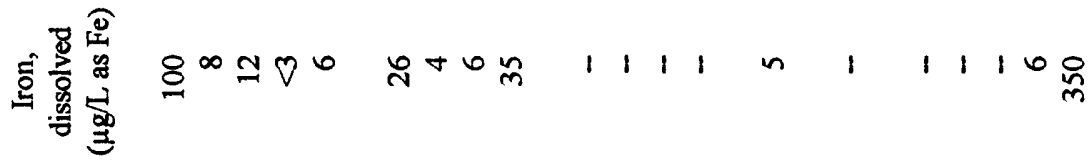

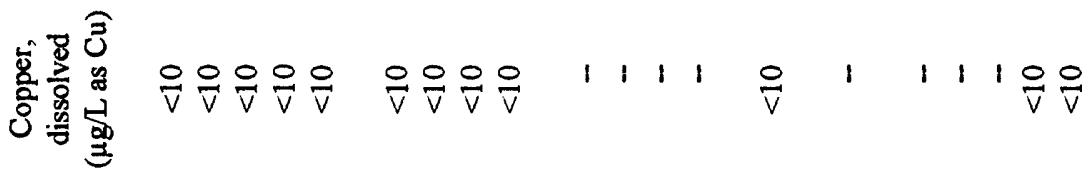

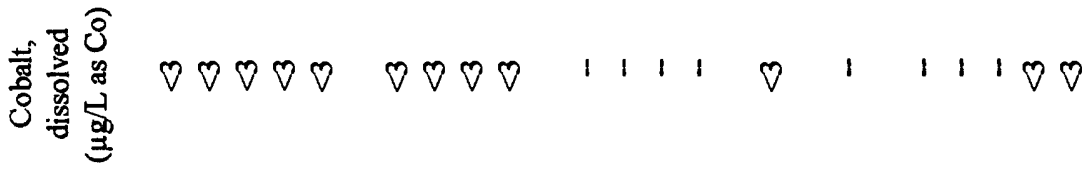

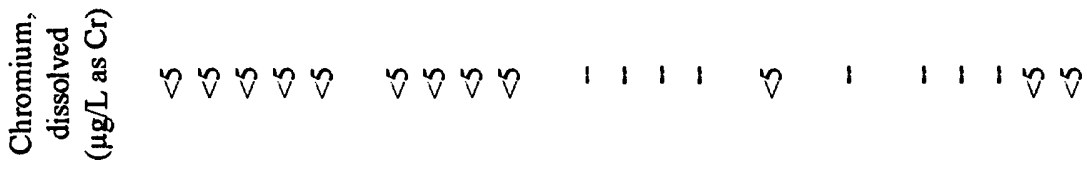

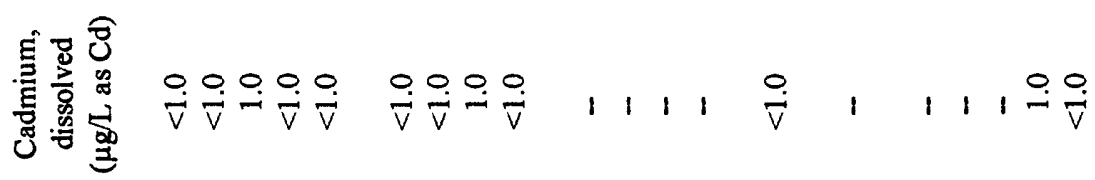

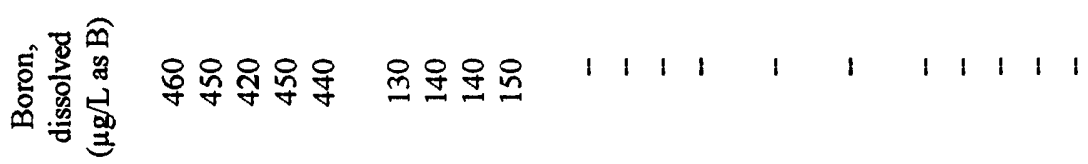

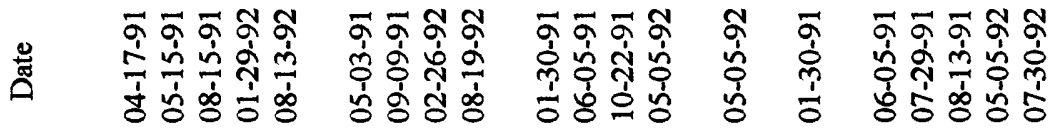

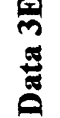

$$
\begin{aligned}
& \text { ह⿱艹 }
\end{aligned}
$$

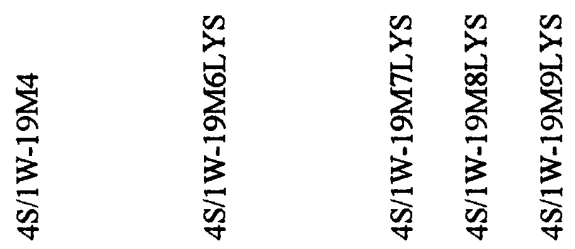




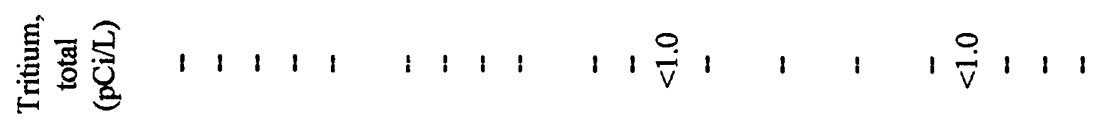

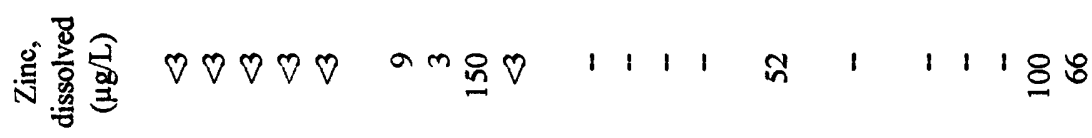

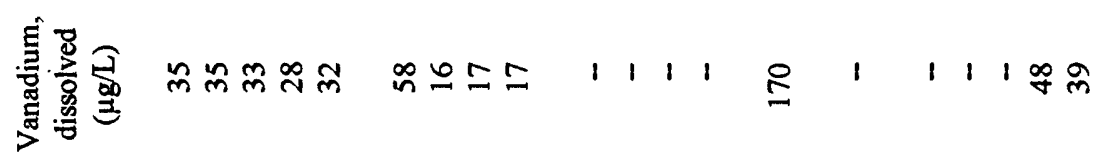

胥

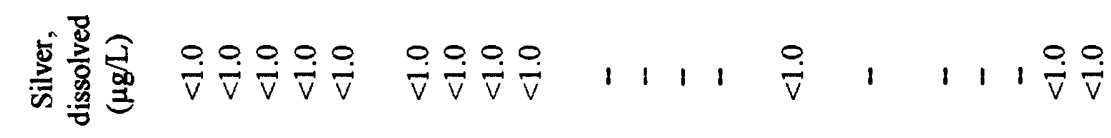

镸尊兽 家 娄

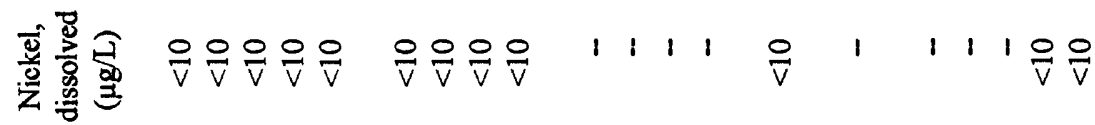

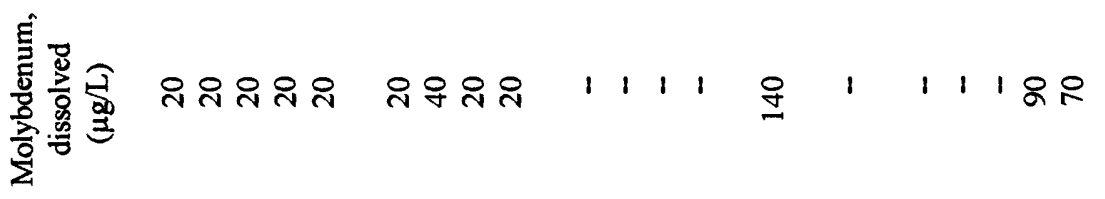

क्ष

䒕

莺

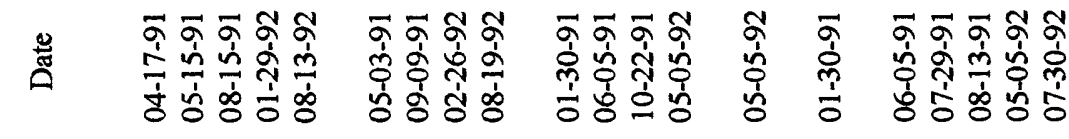




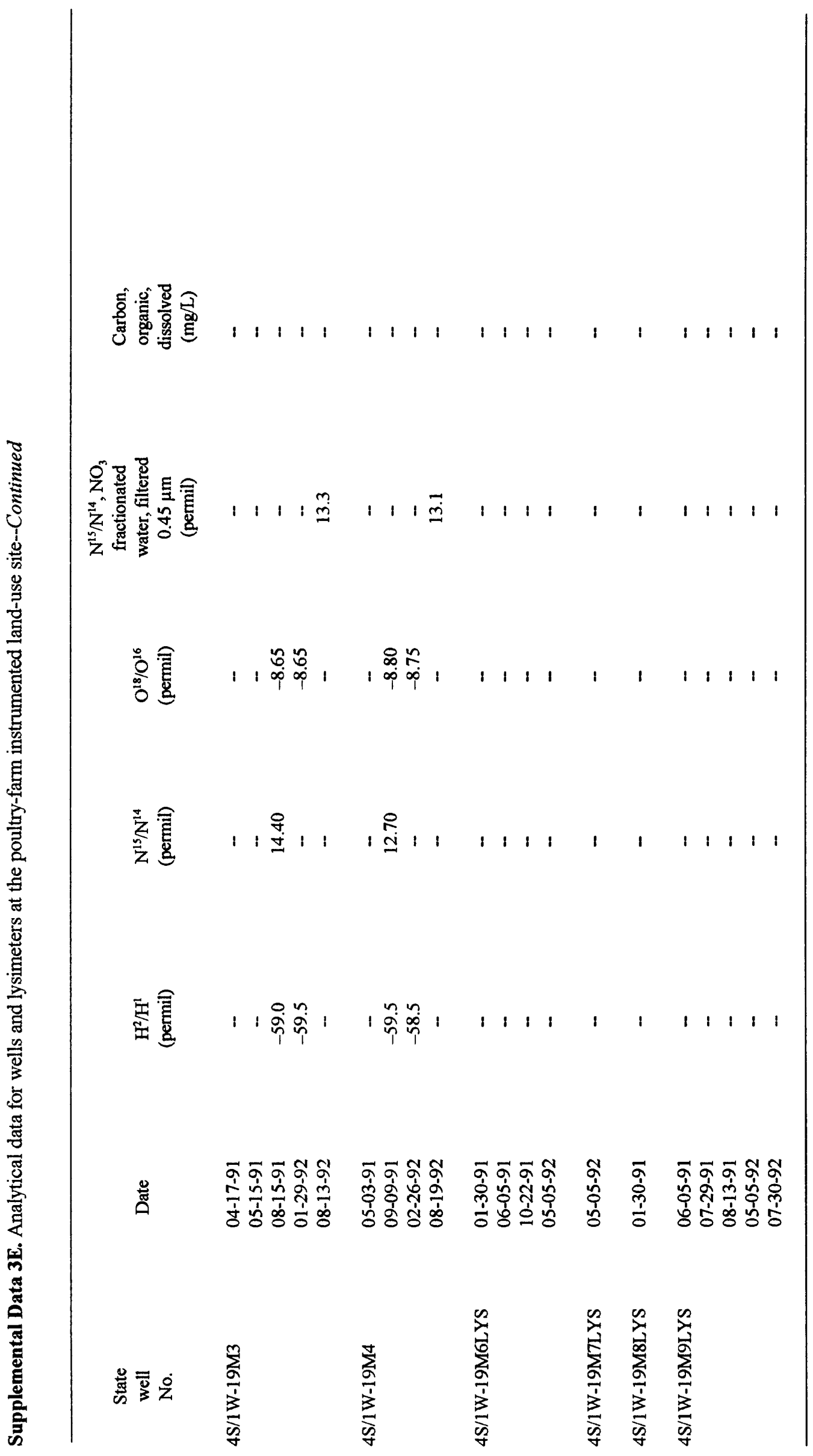

है 


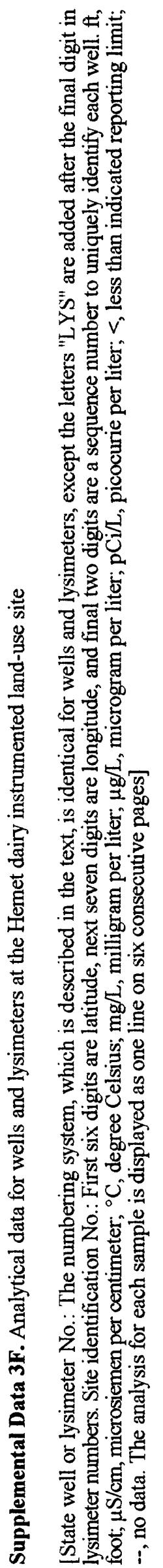

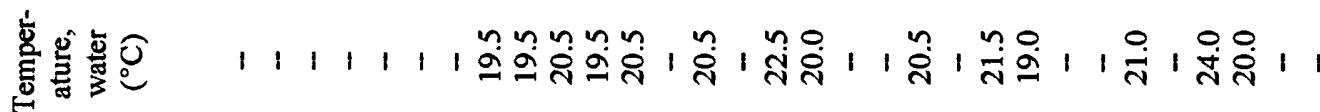

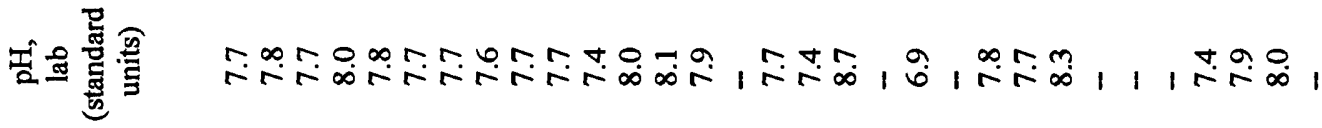

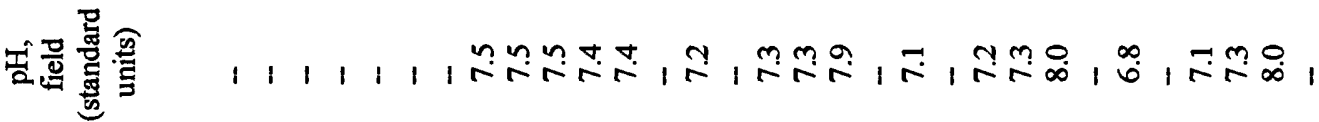

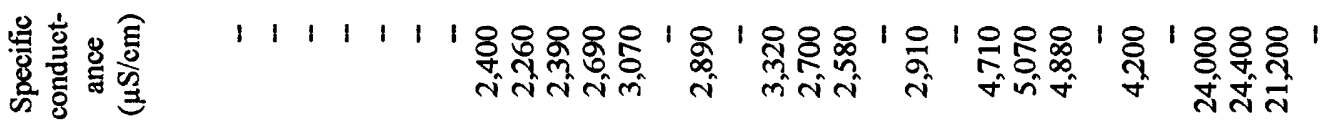

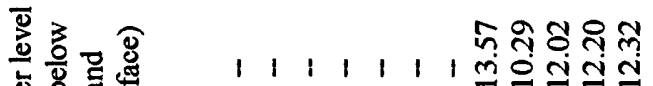

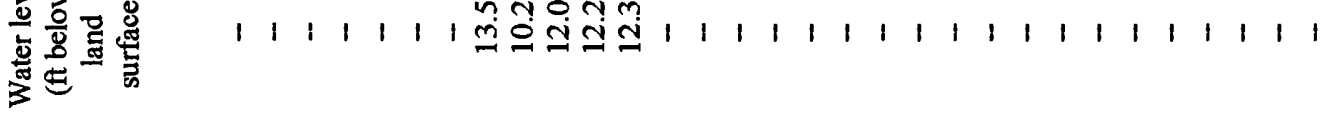

言這

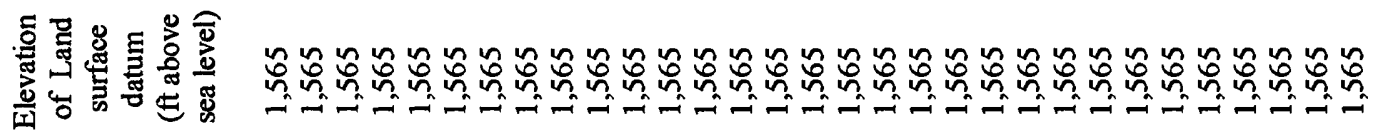

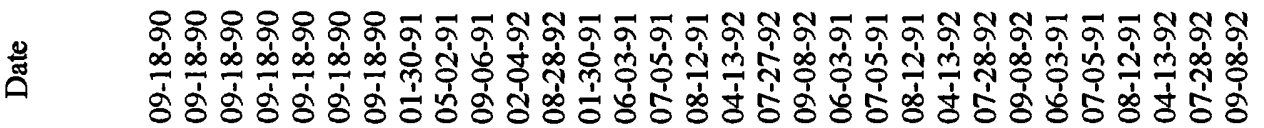

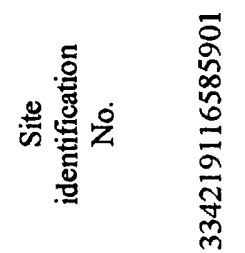

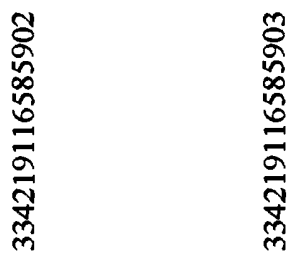

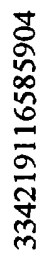

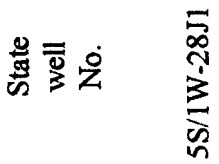

悹

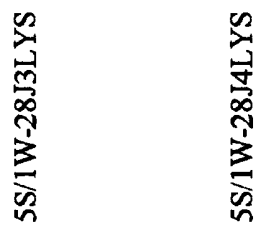




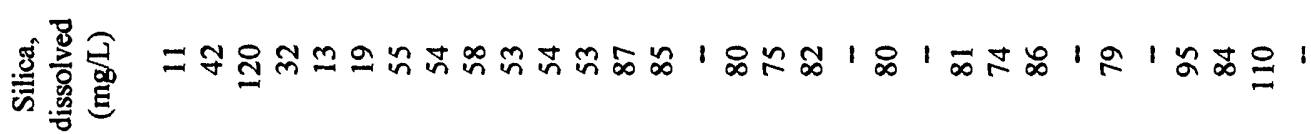

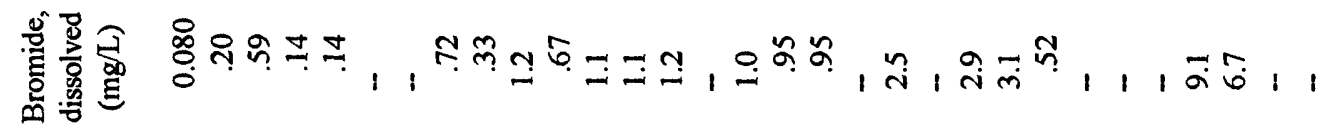

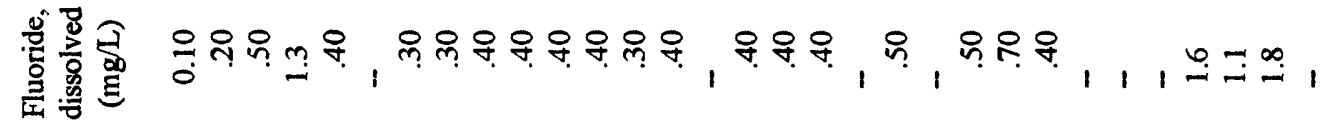

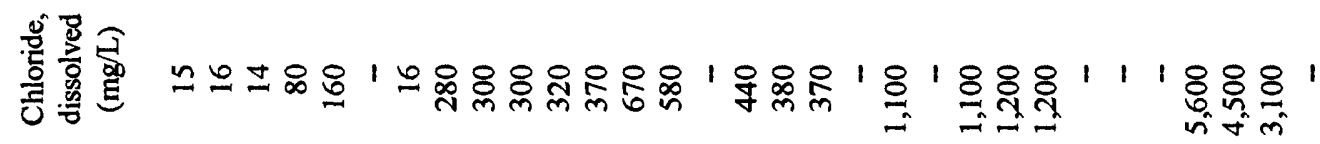

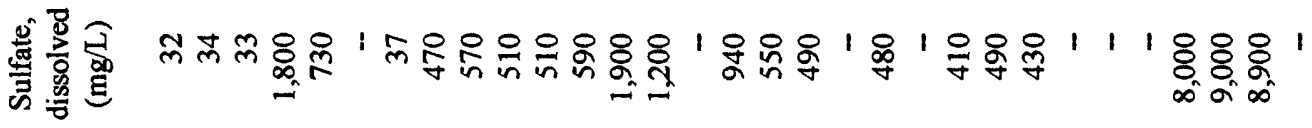

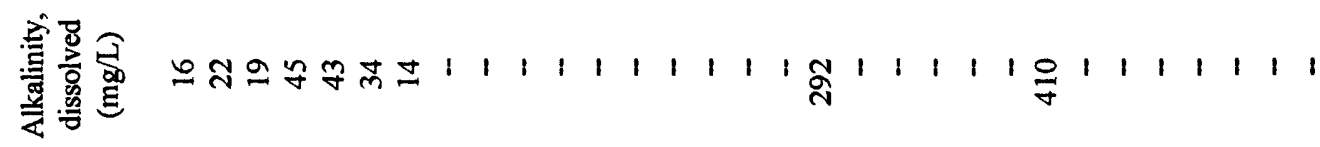

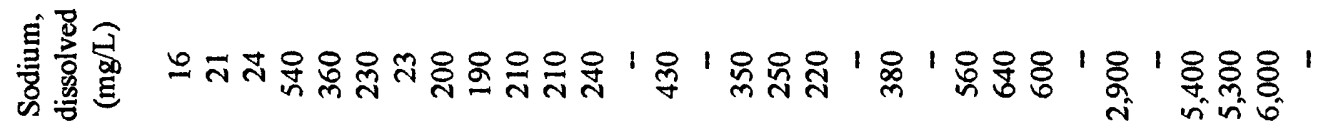

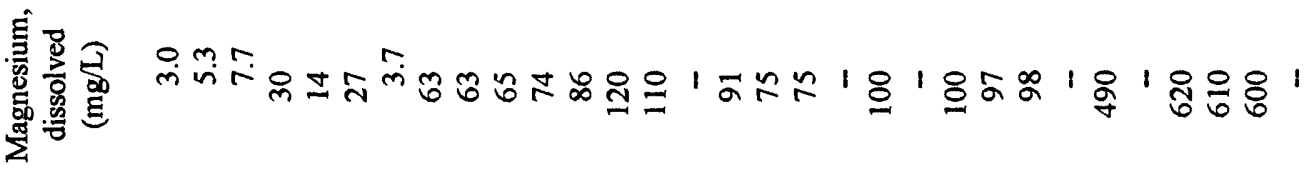

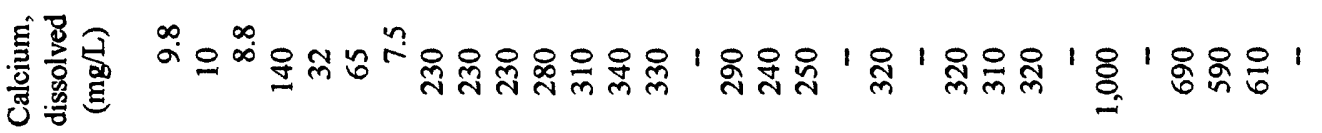

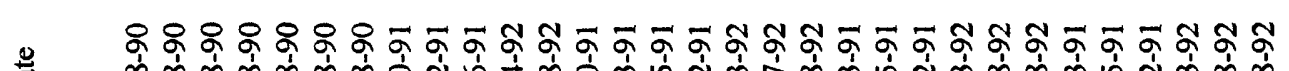

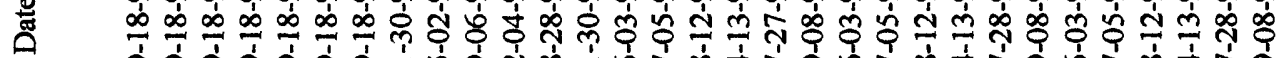

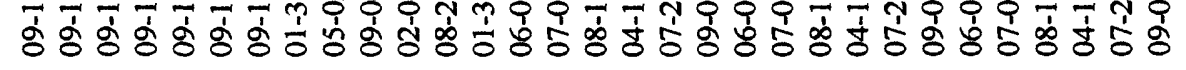

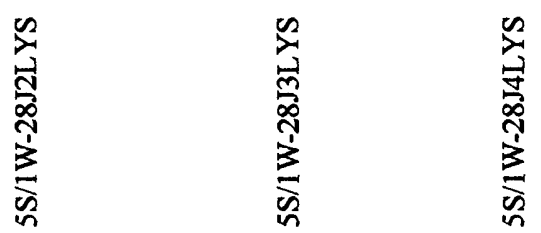




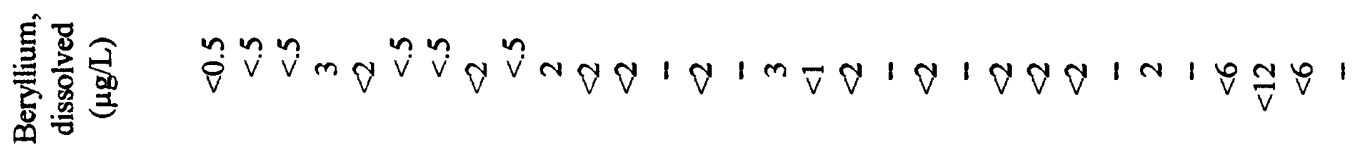

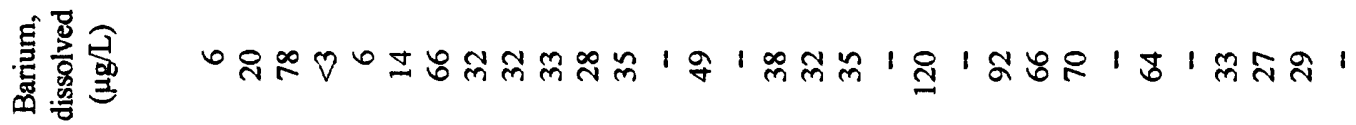

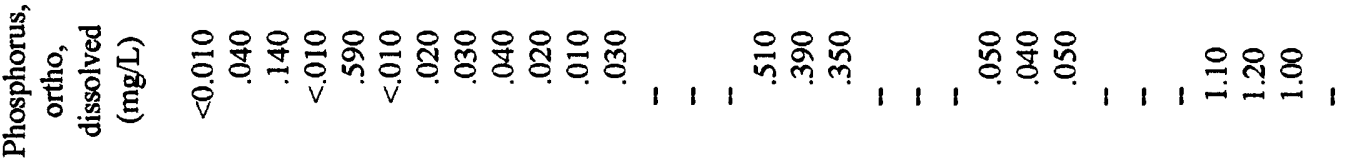

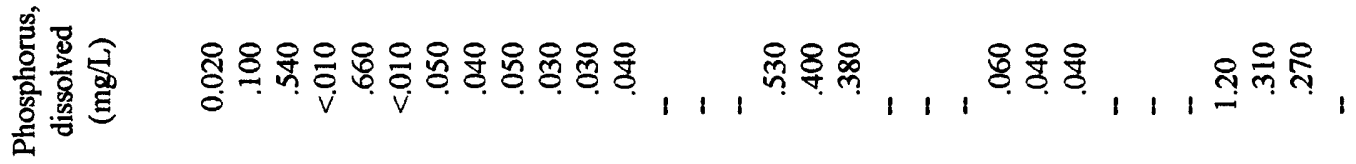

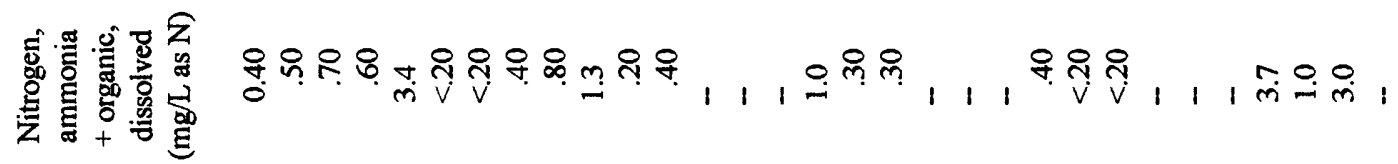

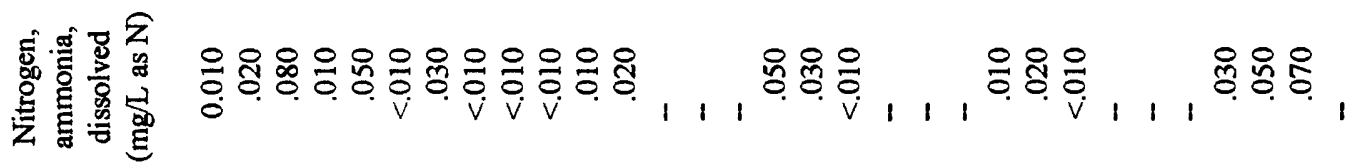

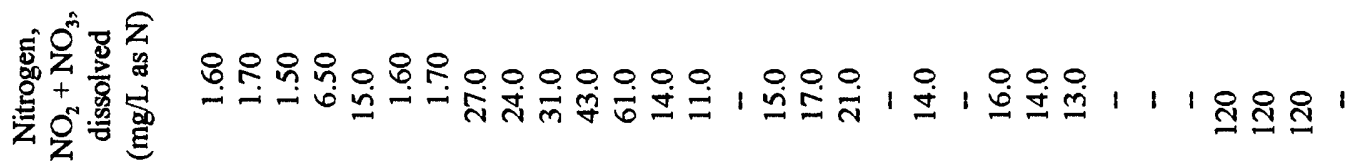

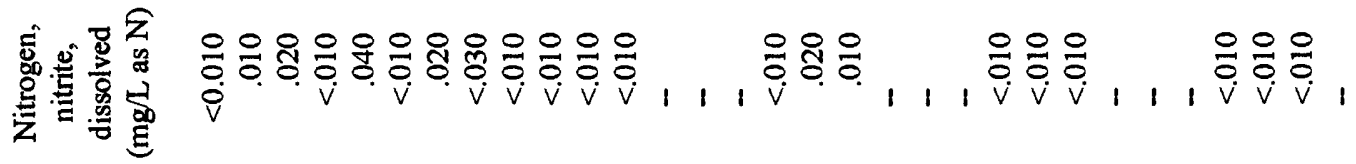

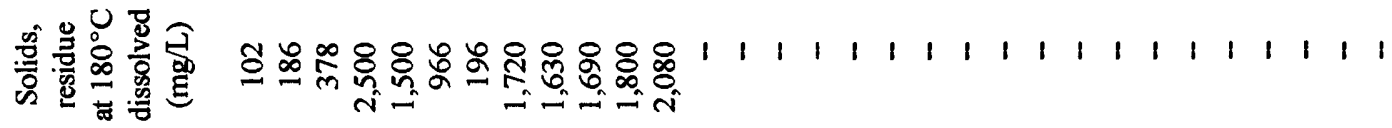

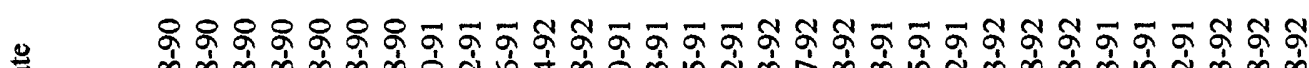

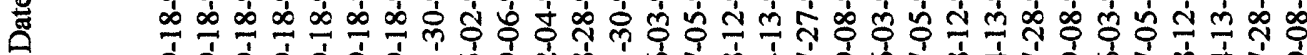

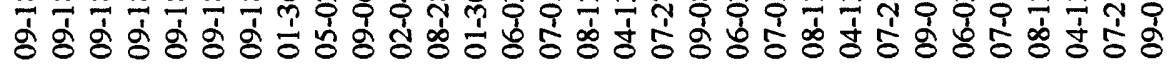




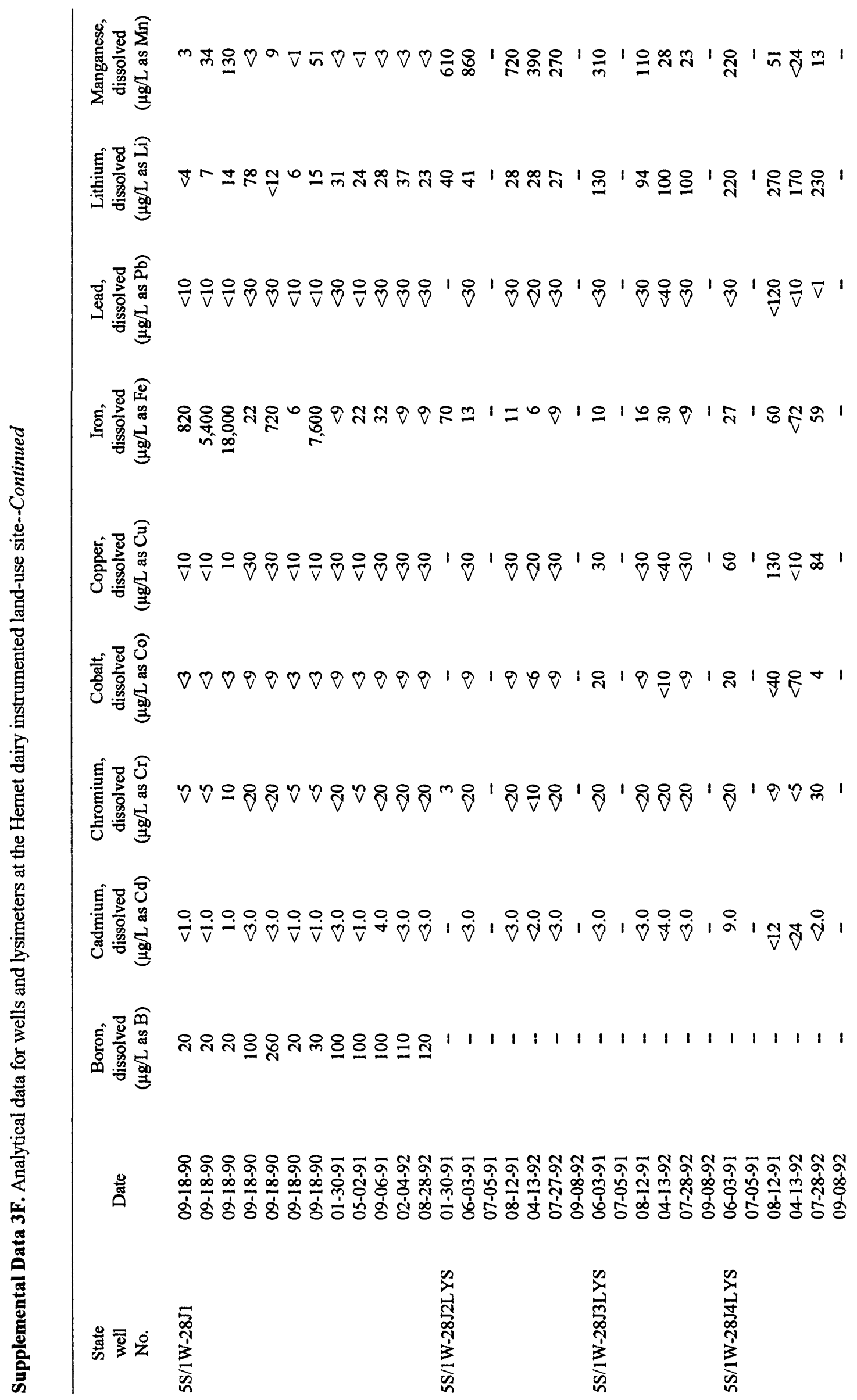




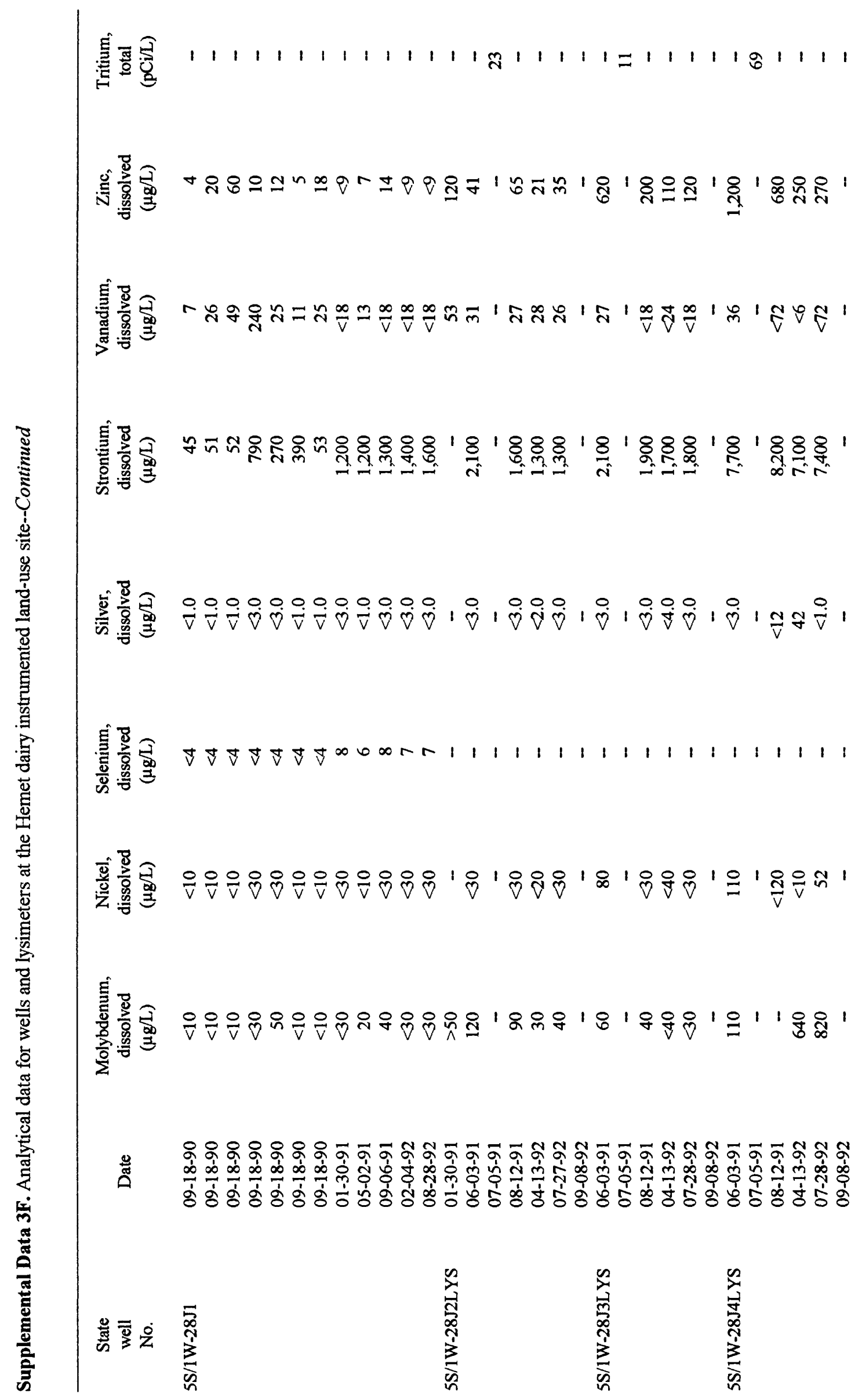




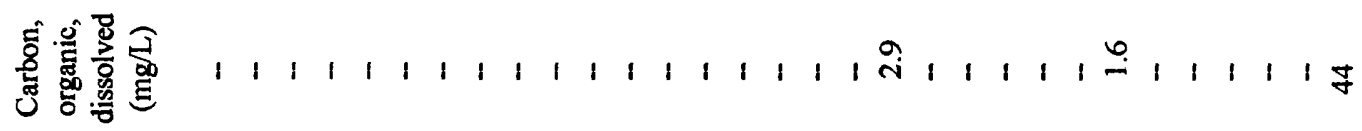

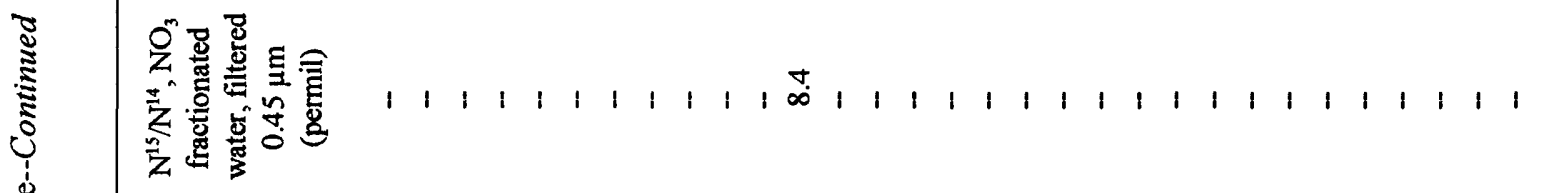

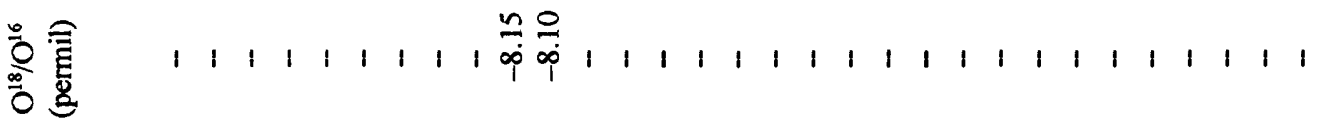
艺兽

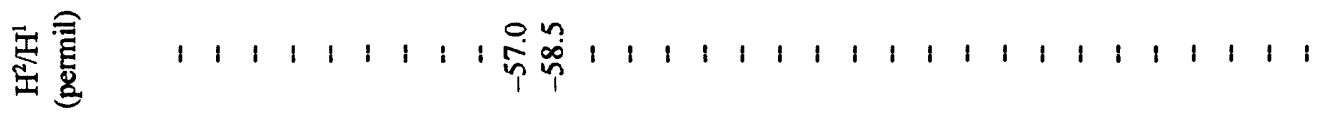

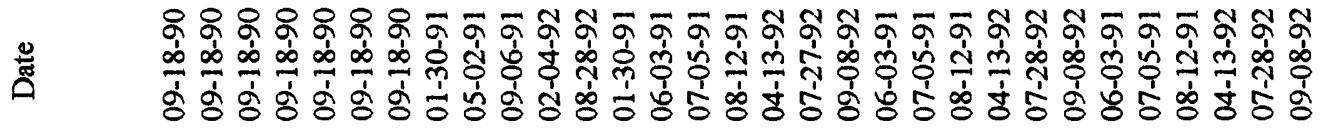


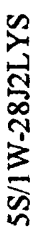

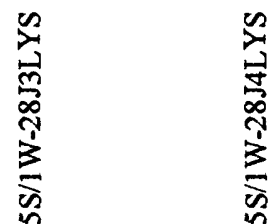




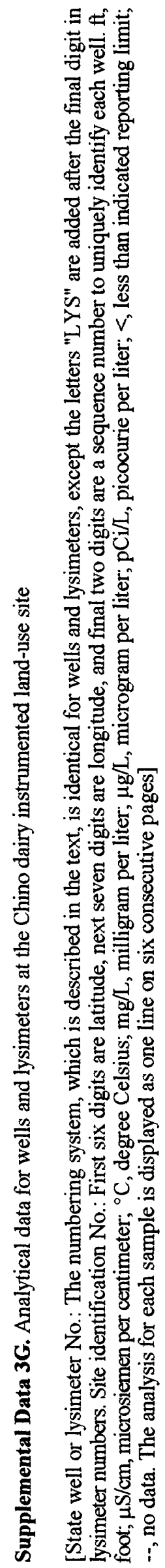

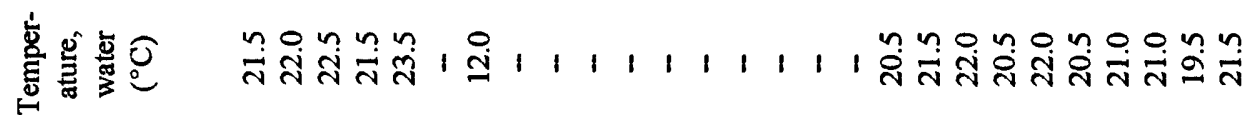

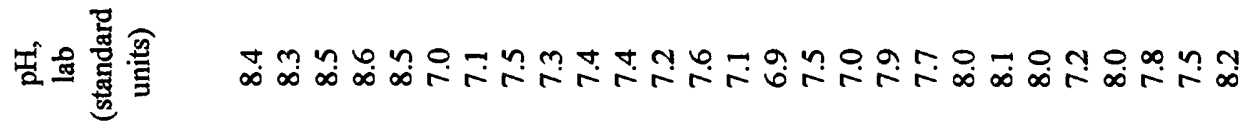

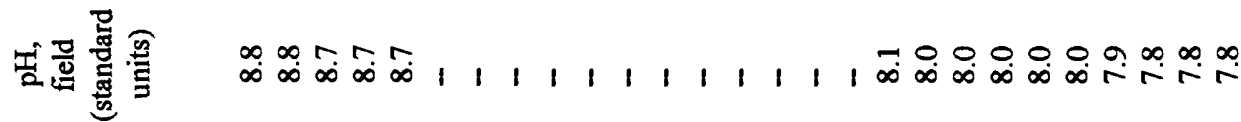

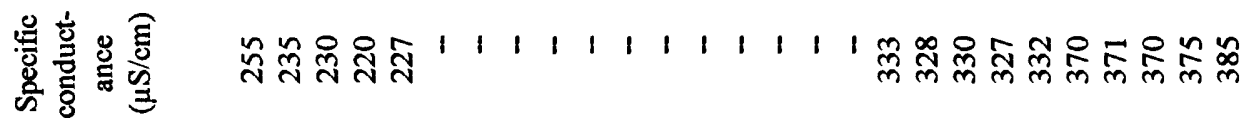

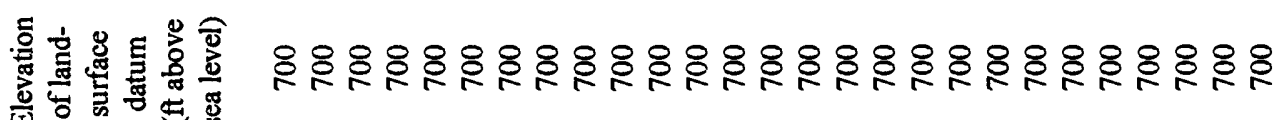

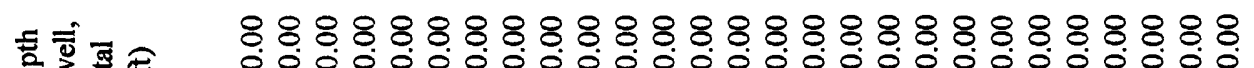

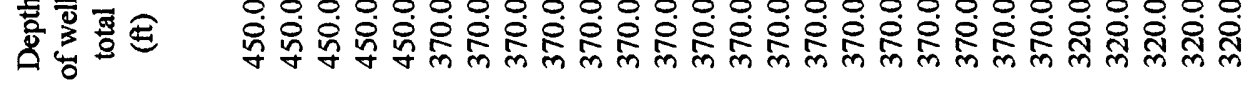

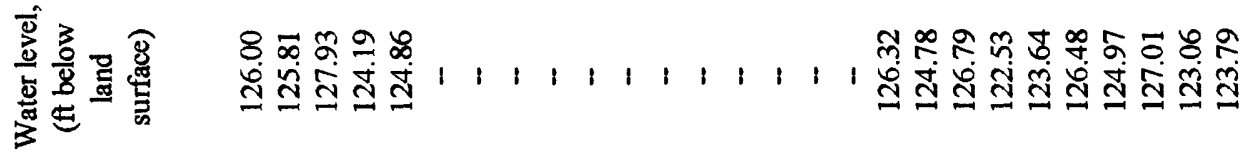

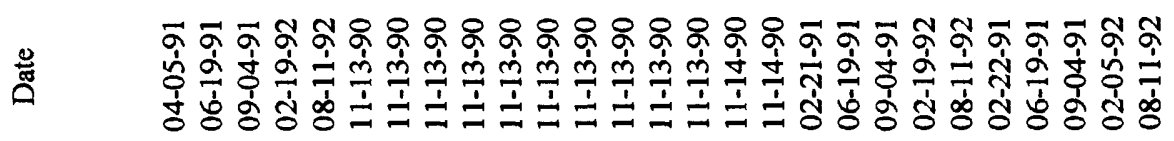

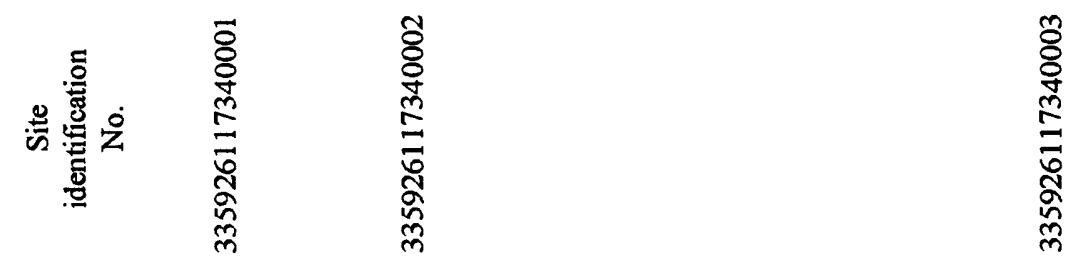

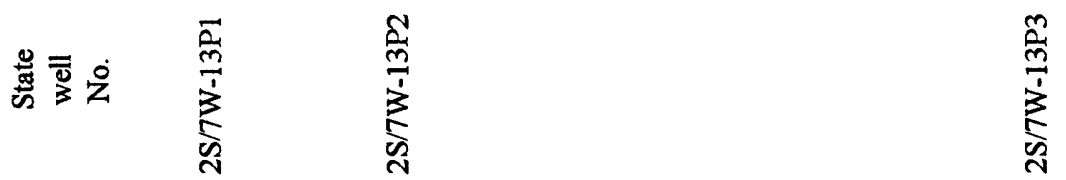




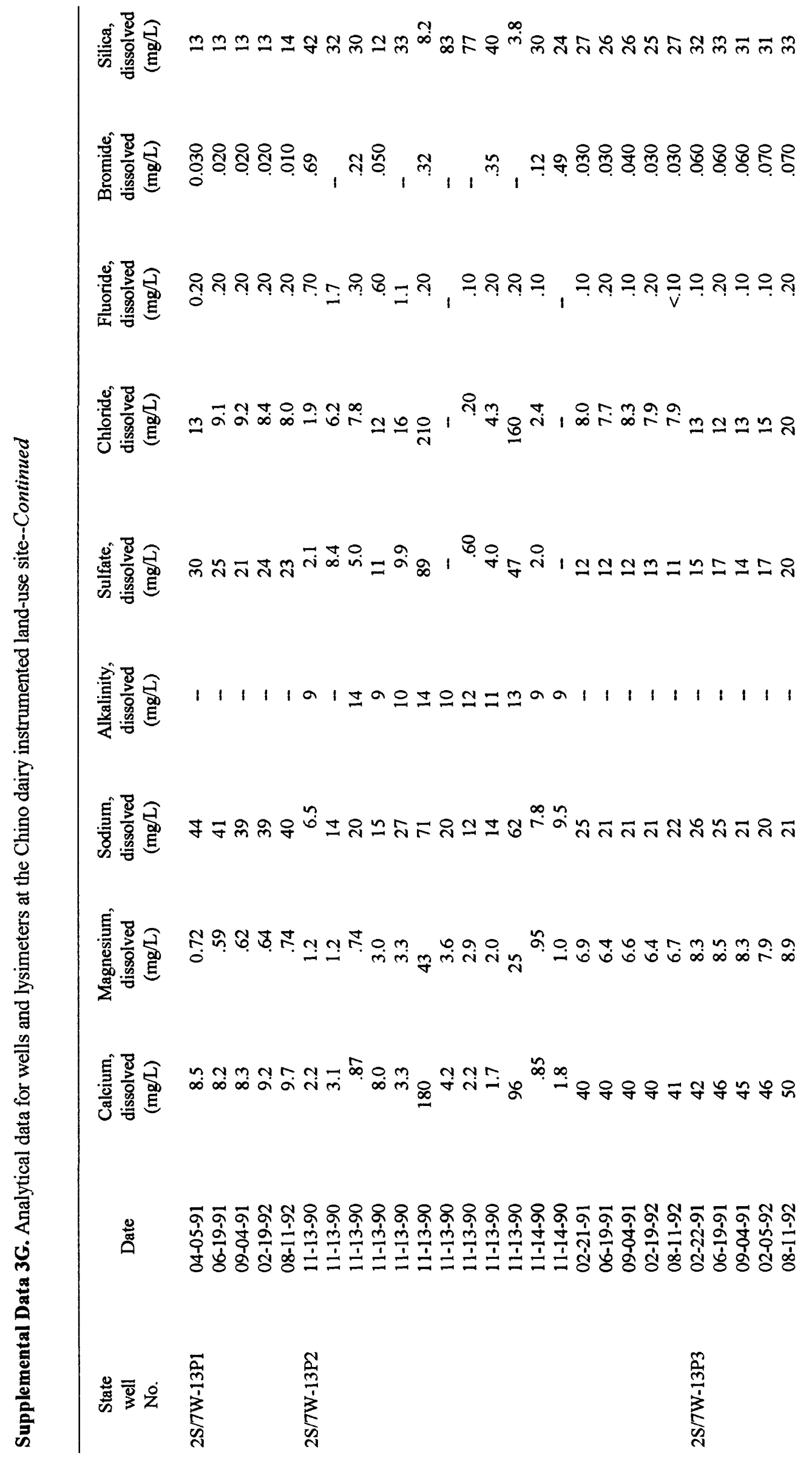




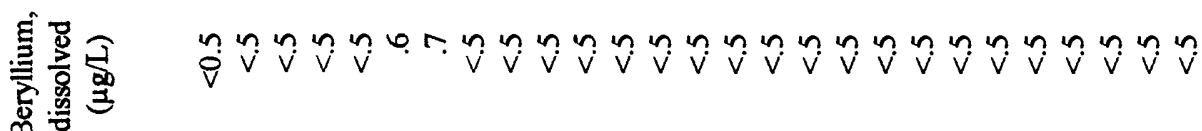

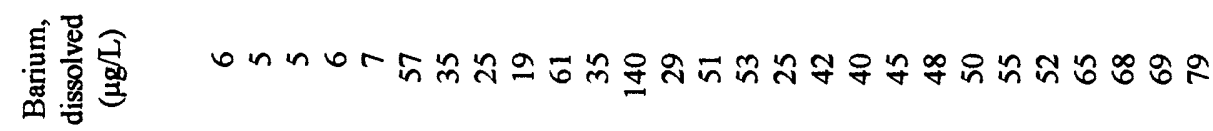

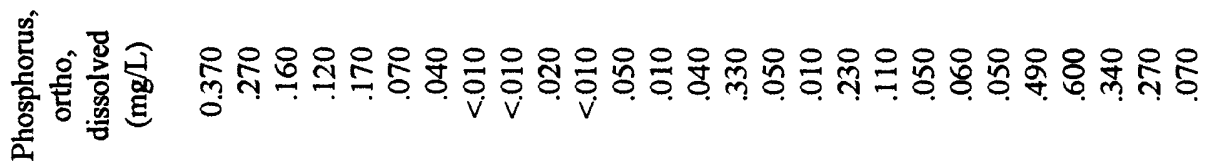

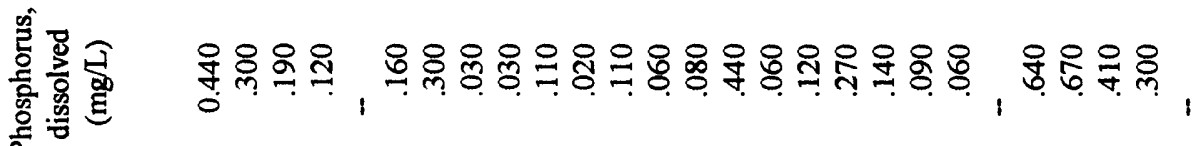

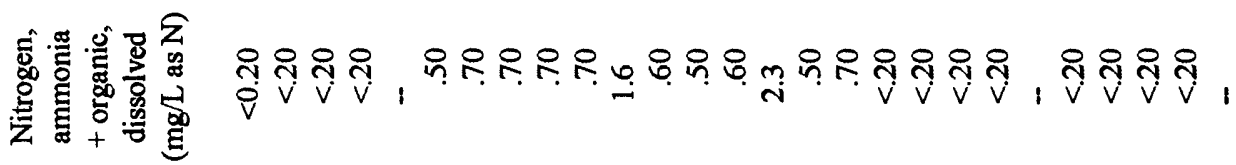

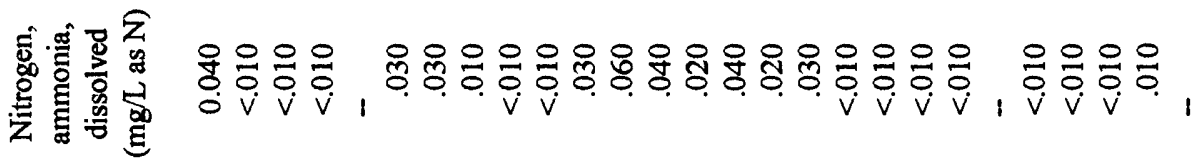

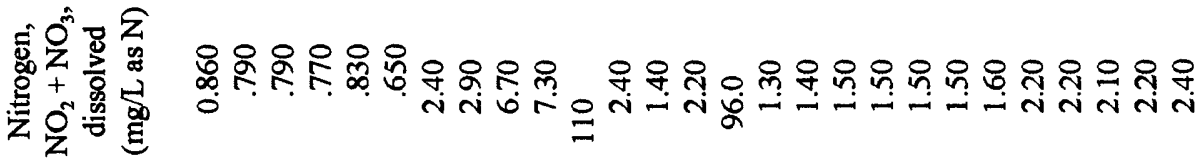

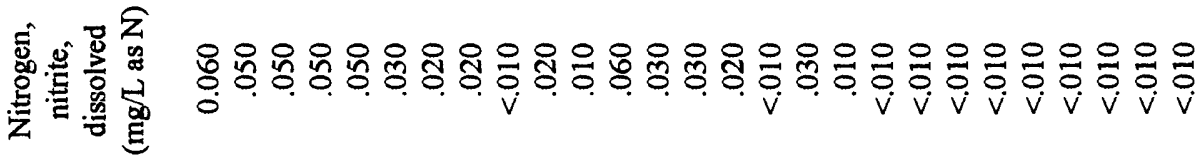

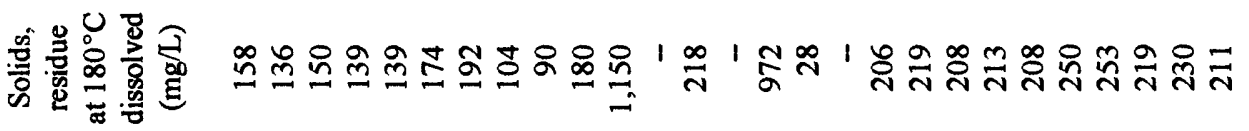

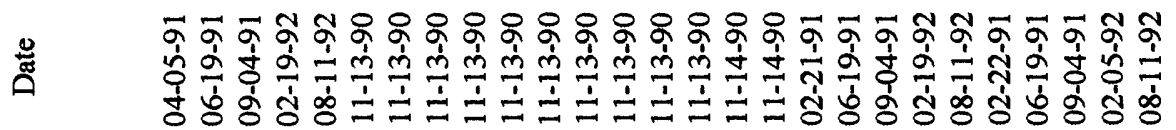




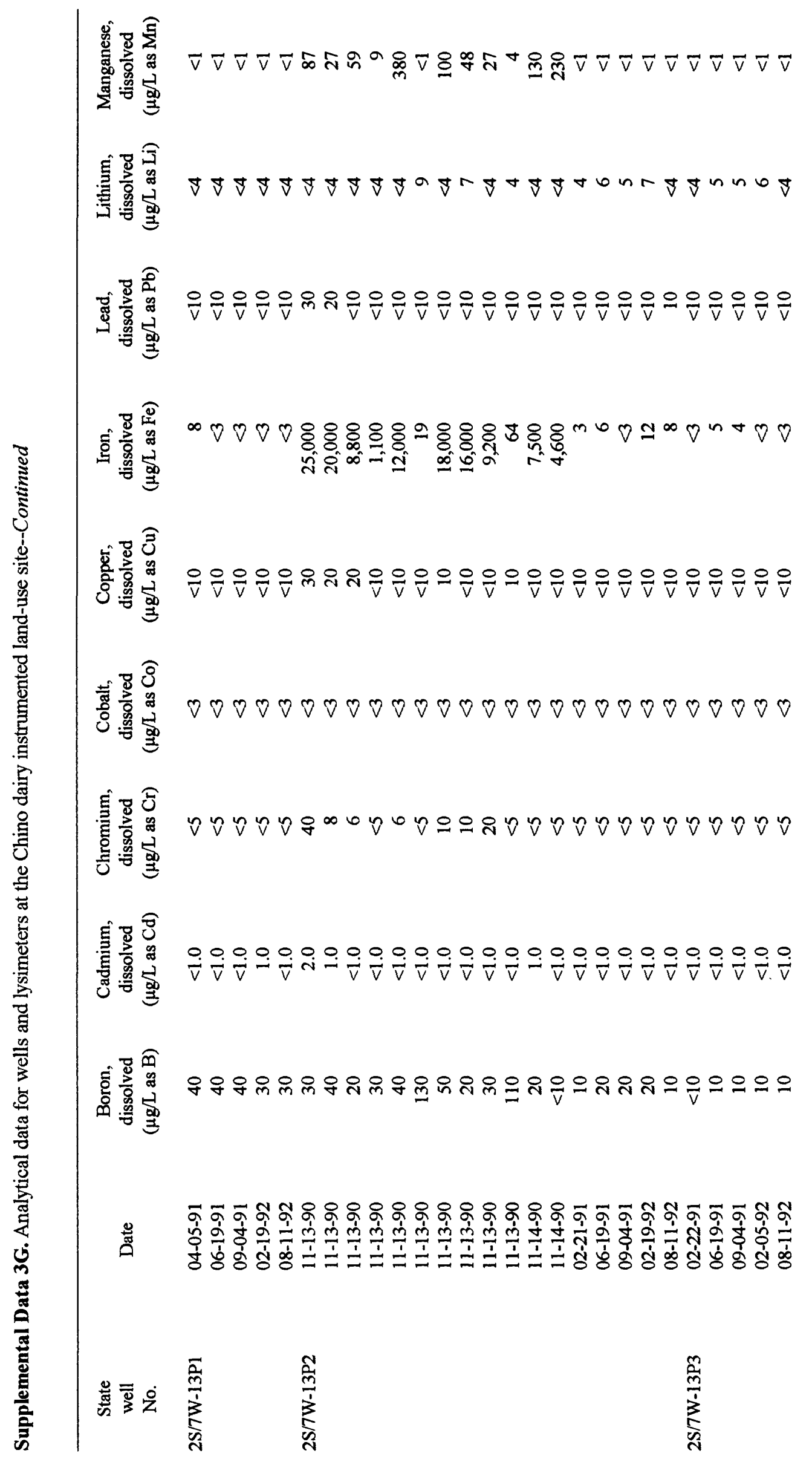




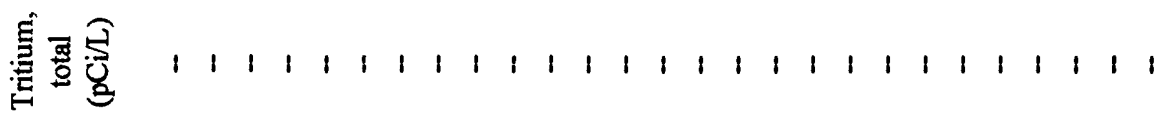

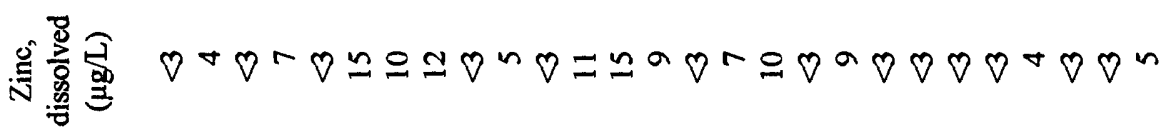

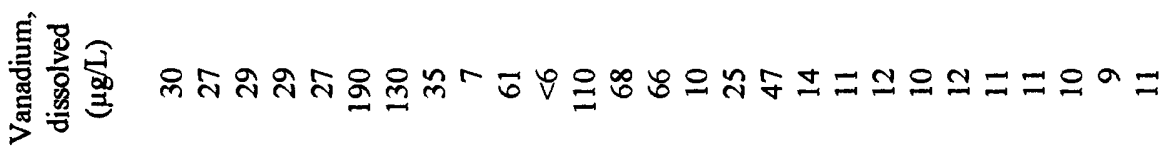

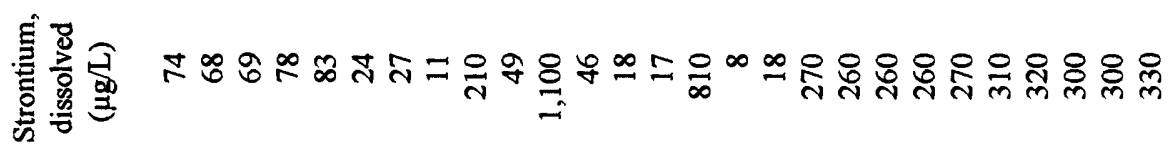

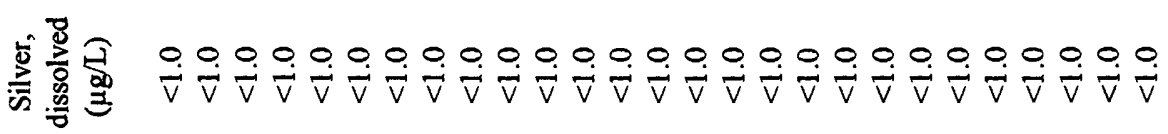

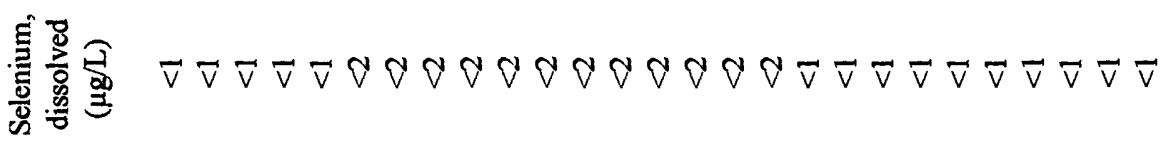

突

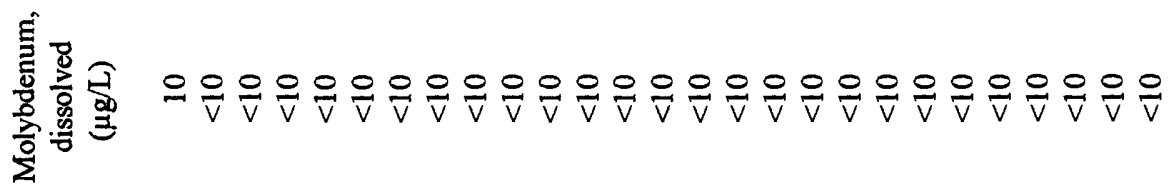

胥

표

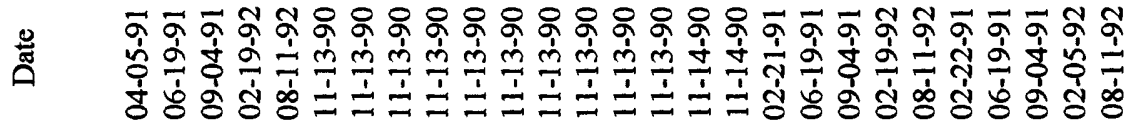




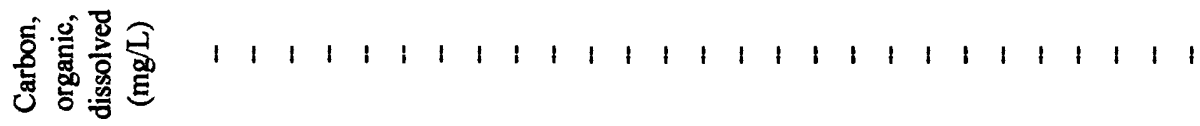

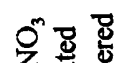

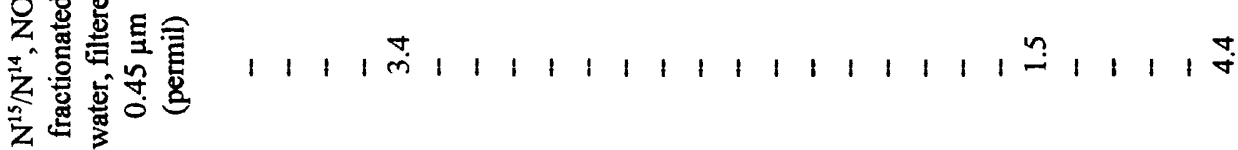

鱼

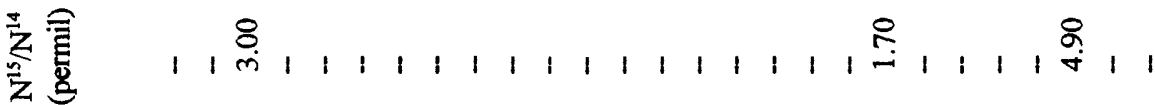

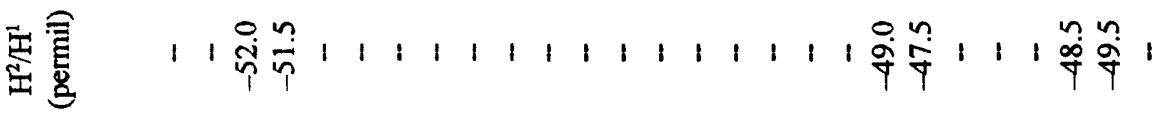

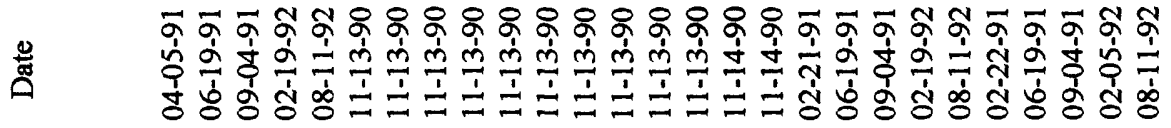

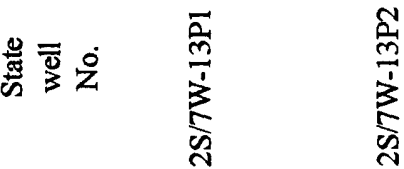

$\frac{n}{\frac{n}{n}}$ 


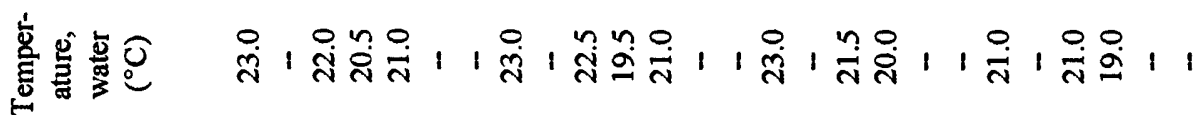

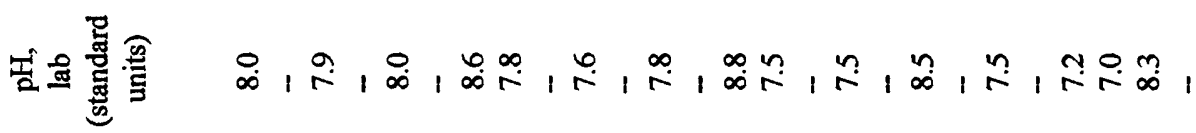

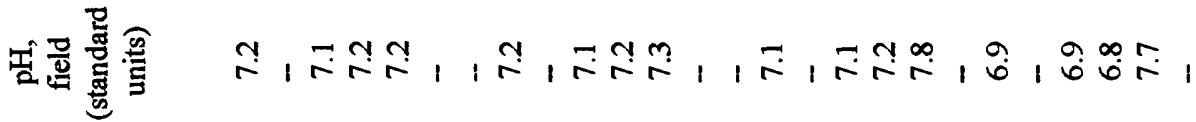

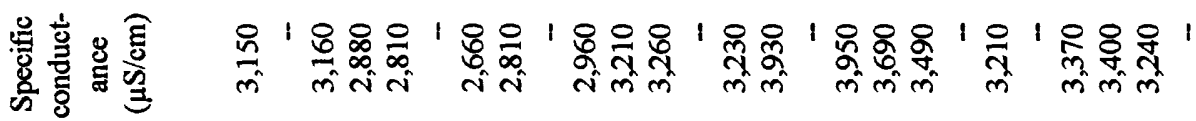

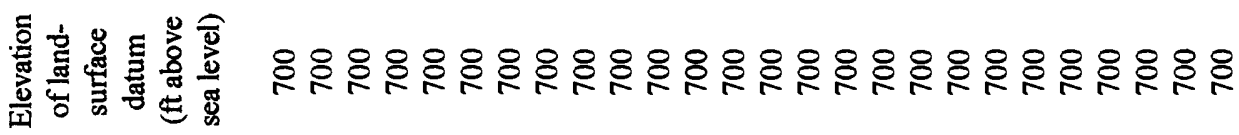

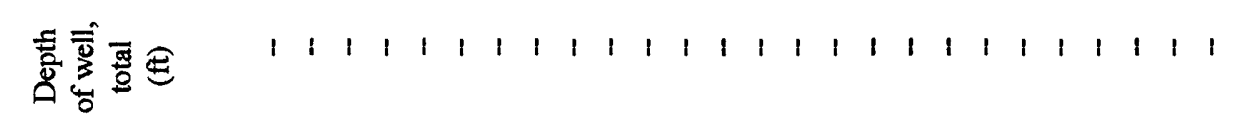

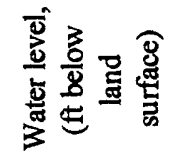

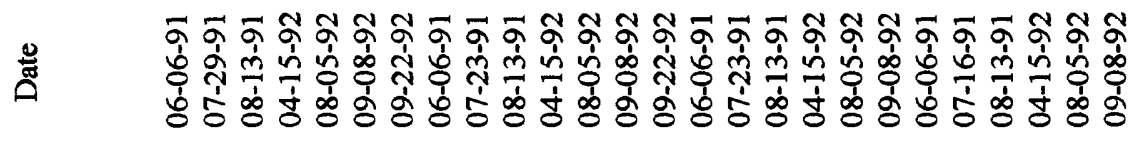

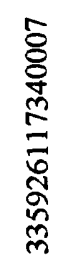

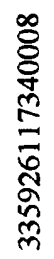

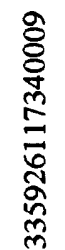

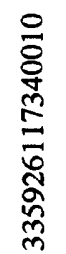

点

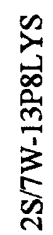

离

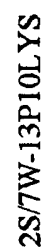




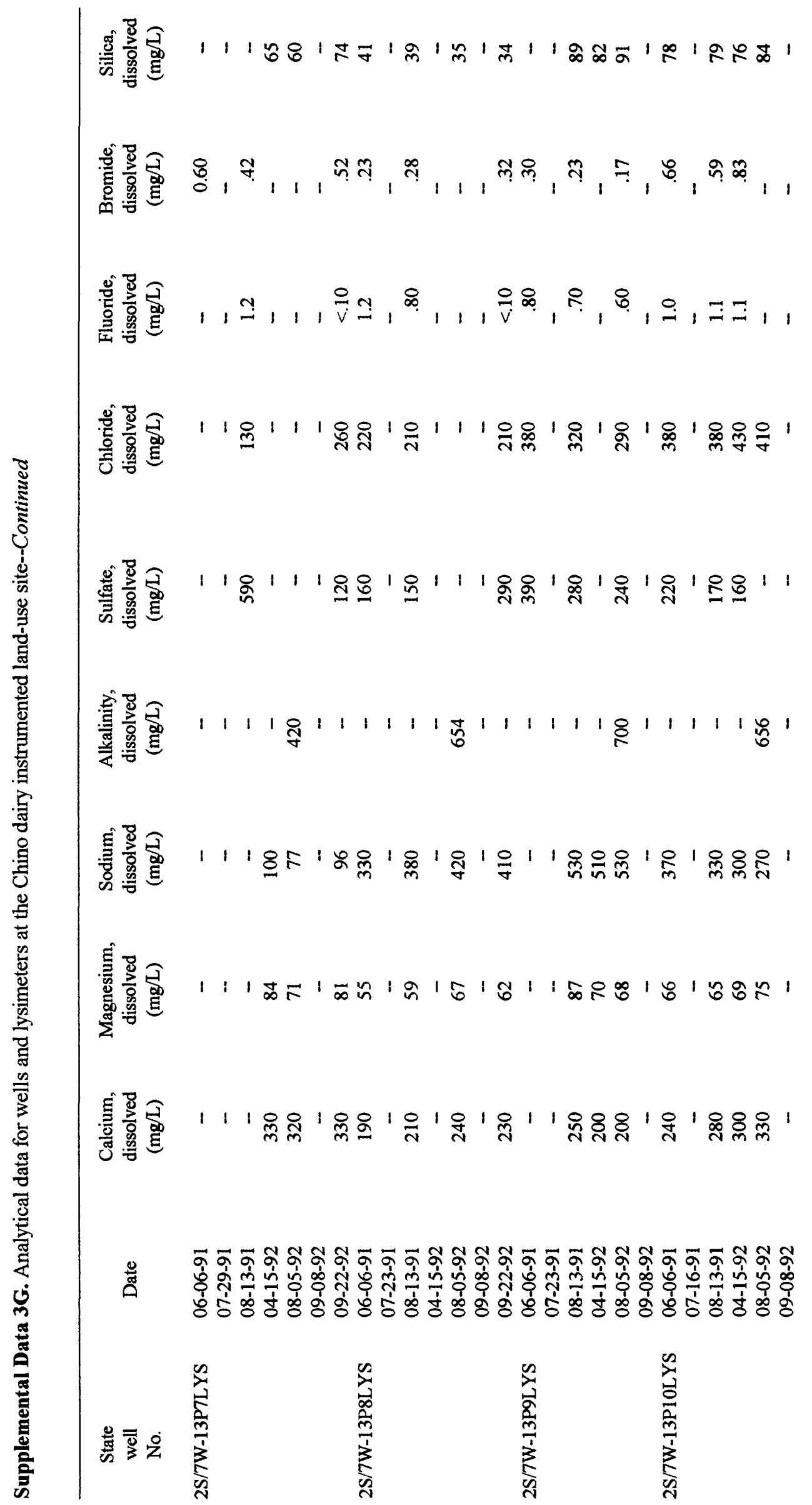




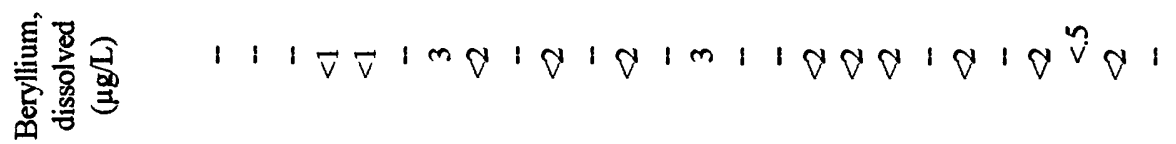

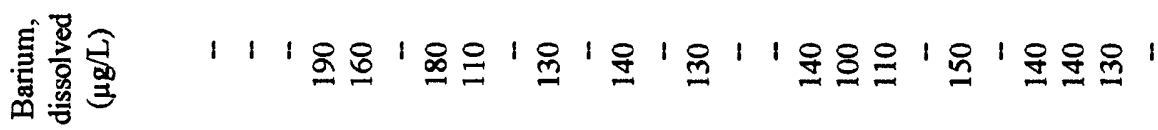

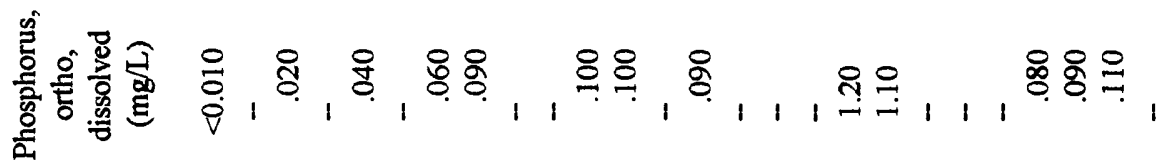

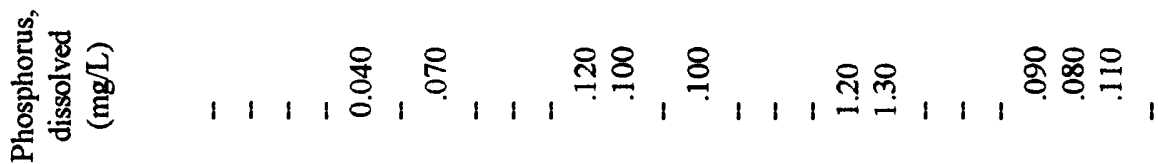

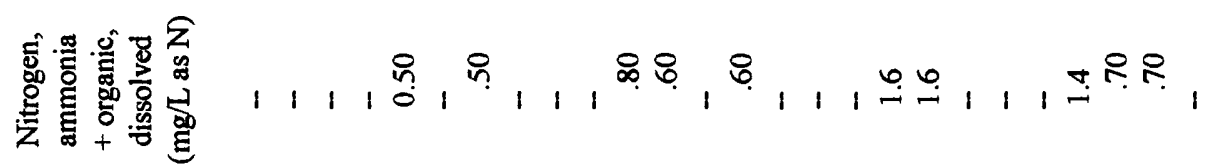

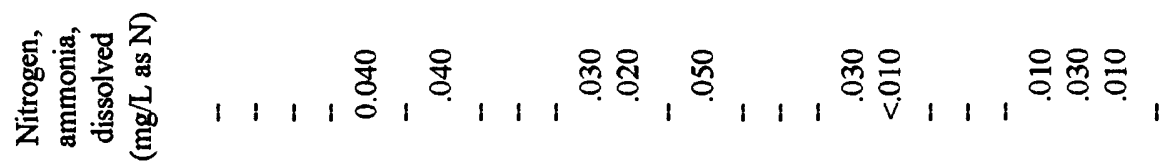

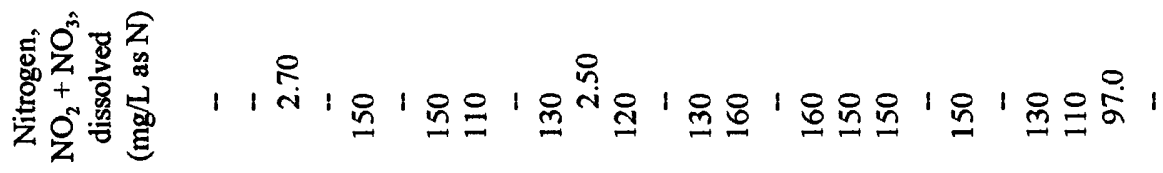

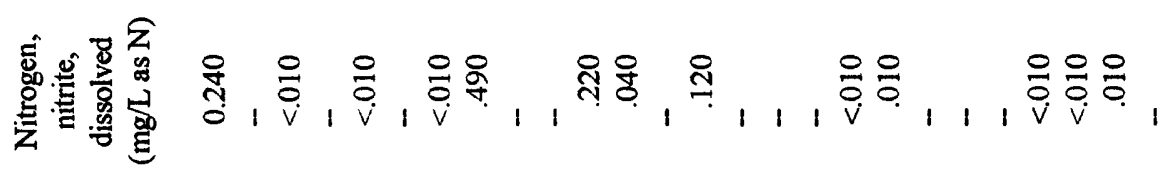

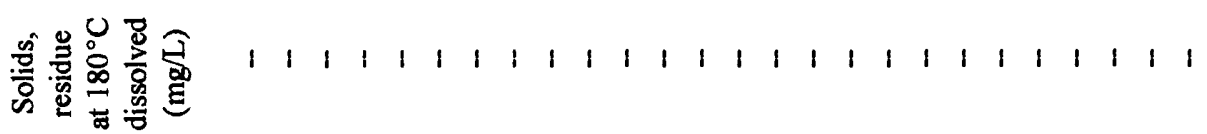




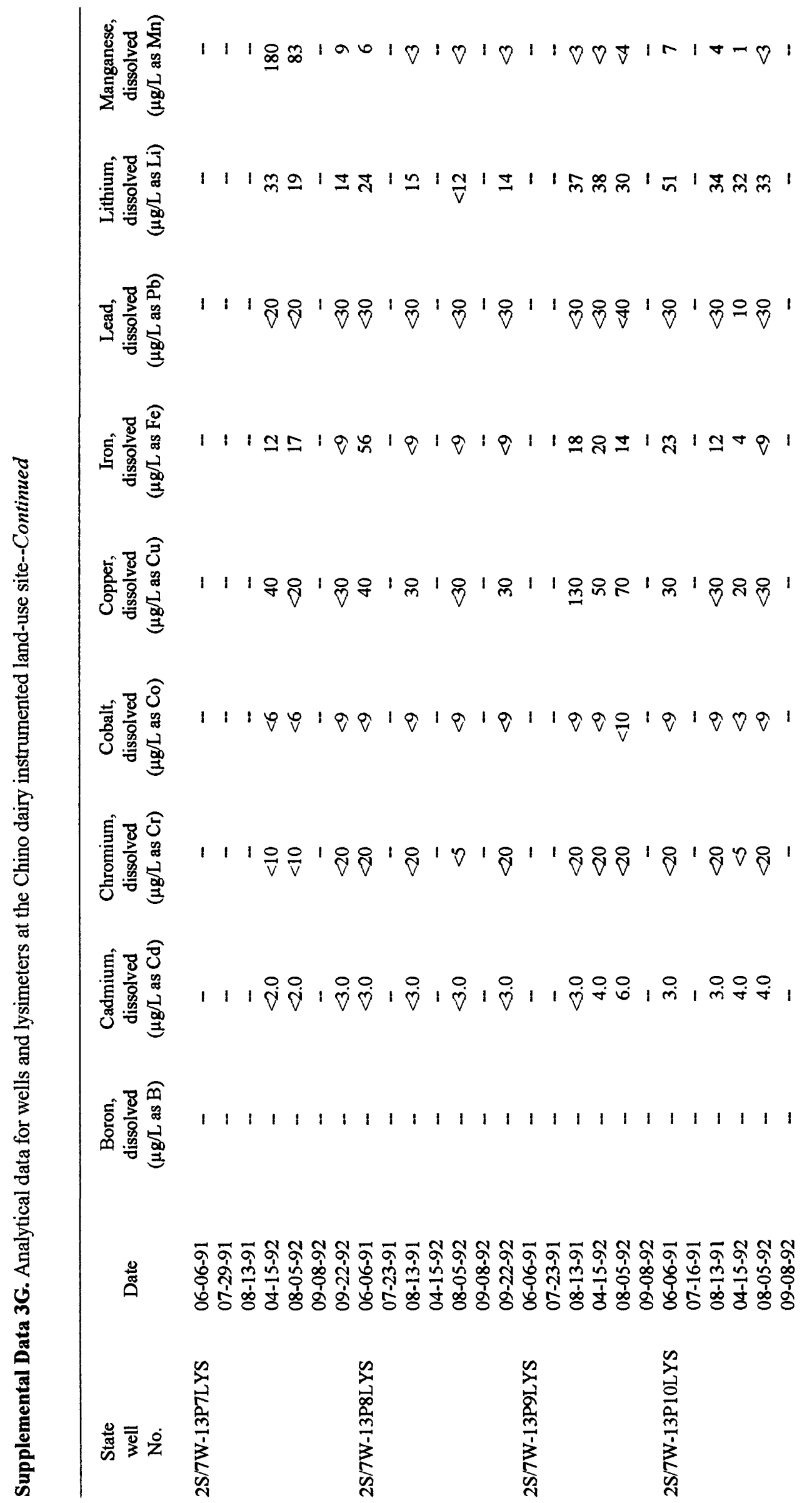




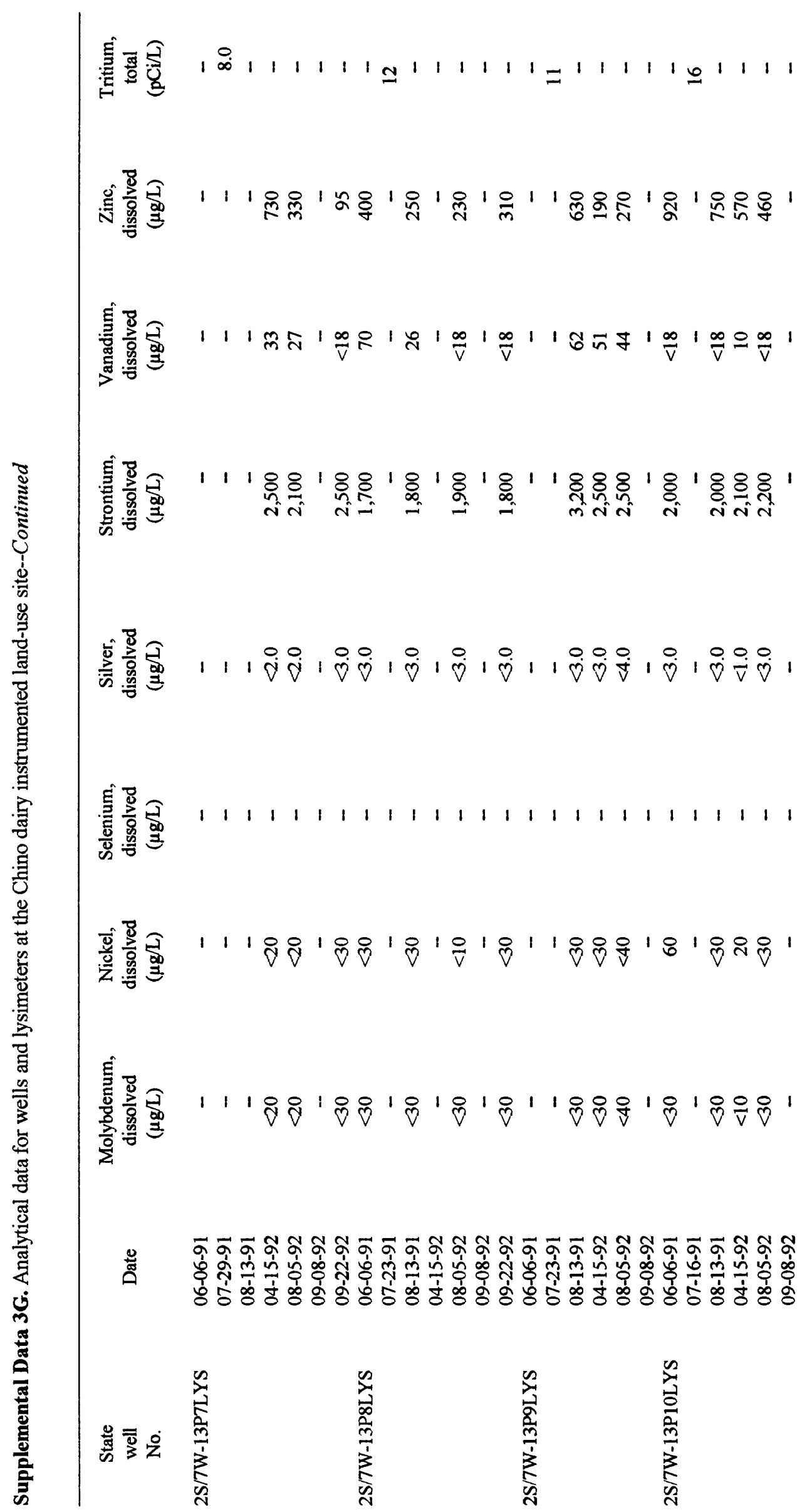




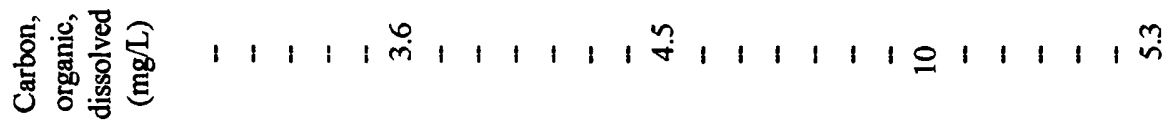

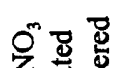

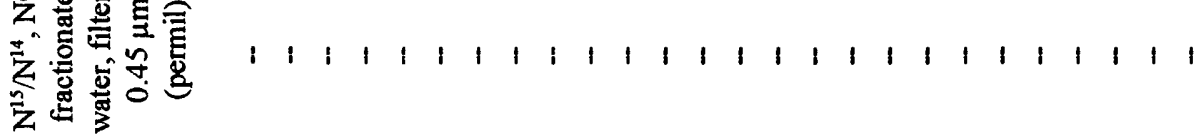

串

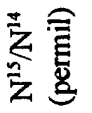

$\begin{array}{llllllllllllllllllllllllll}1 & 1 & 1 & 1 & 1 & 1 & 1 & 1 & 1 & 1 & 1 & 1 & 1 & 1 & 1 & 1 & 1 & 1 & 1 & 1 & 1 & 1 & 1 & 1 & 1 & 1\end{array}$

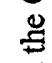

I

退

형

焉 总

$\begin{array}{llllllllllllllllllllllllll}1 & 1 & 1 & 1 & 1 & 1 & 1 & 1 & 1 & 1 & 1 & 1 & 1 & 1 & 1 & 1 & 1 & 1 & 1 & 1 & 1 & 1 & 1 & 1 & 1\end{array}$

$\frac{n}{2}$

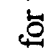

苂

莺

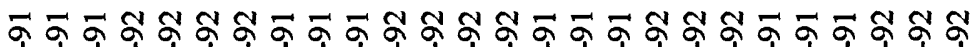

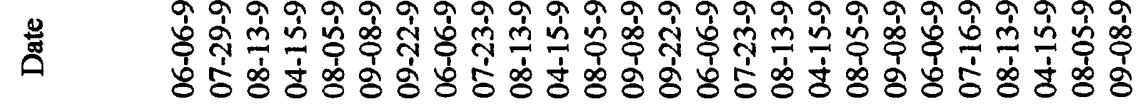

ن

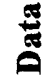




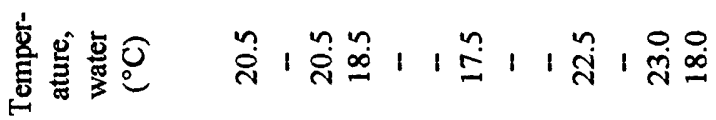

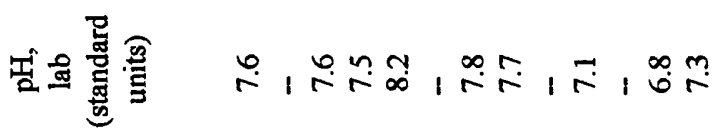

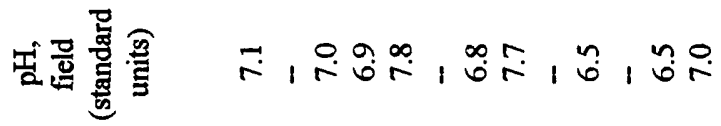

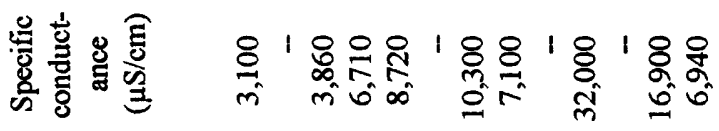

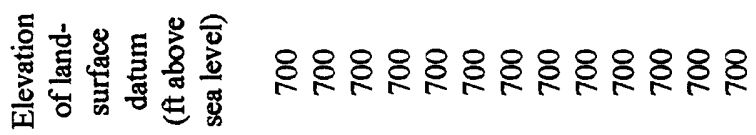

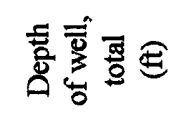

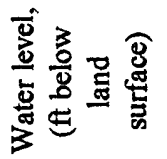

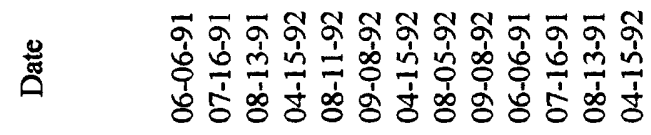

$\cong$

है

趂

莺

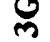

$\stackrel{\varpi}{\text { ⿷匚⿱ }}$

芩

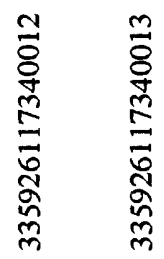

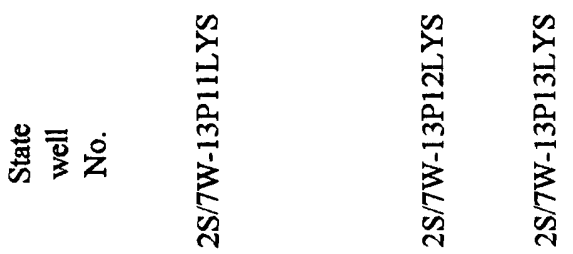




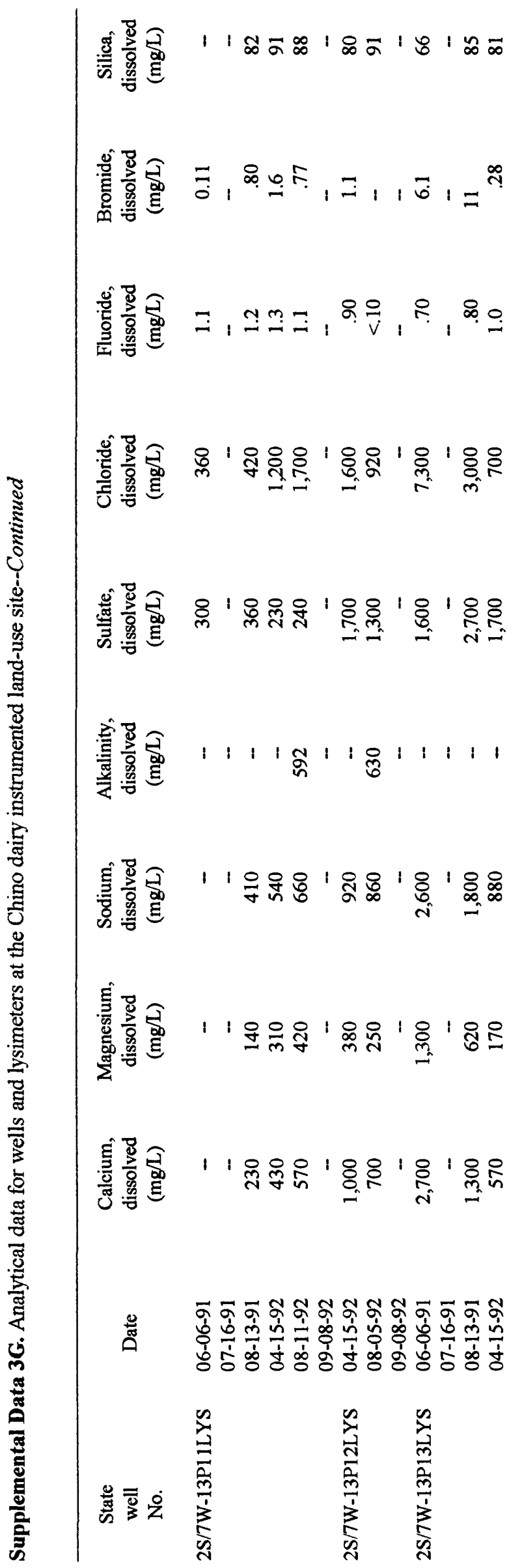




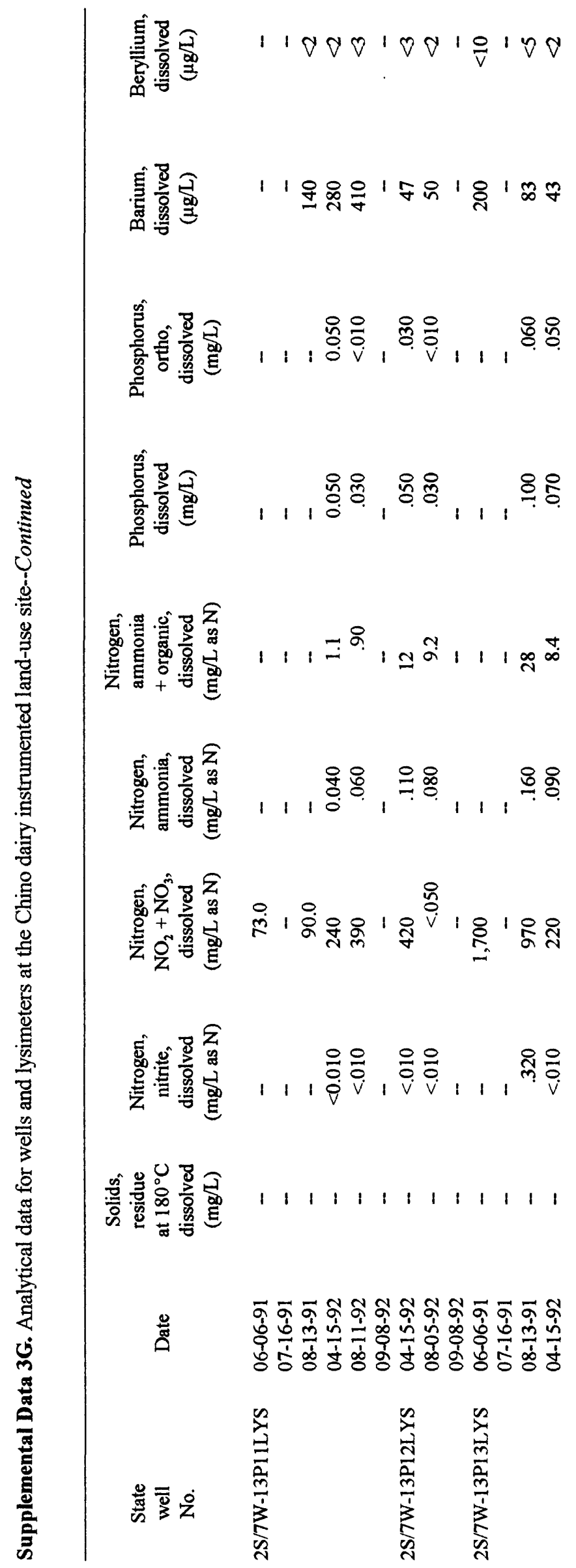




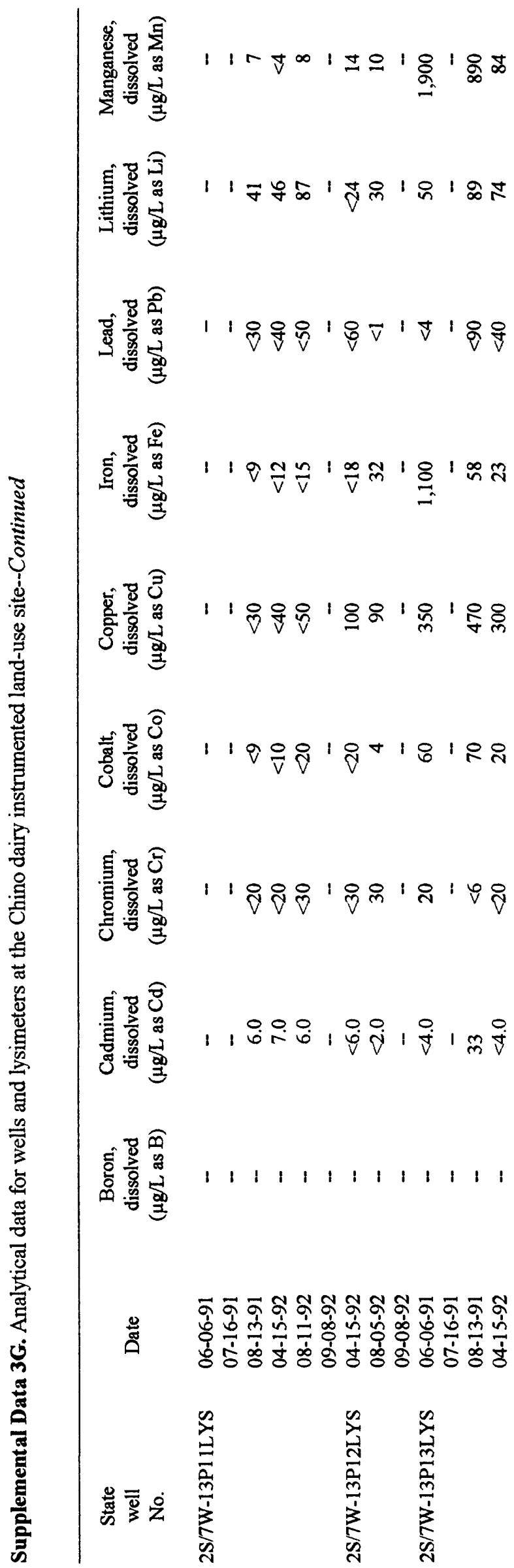




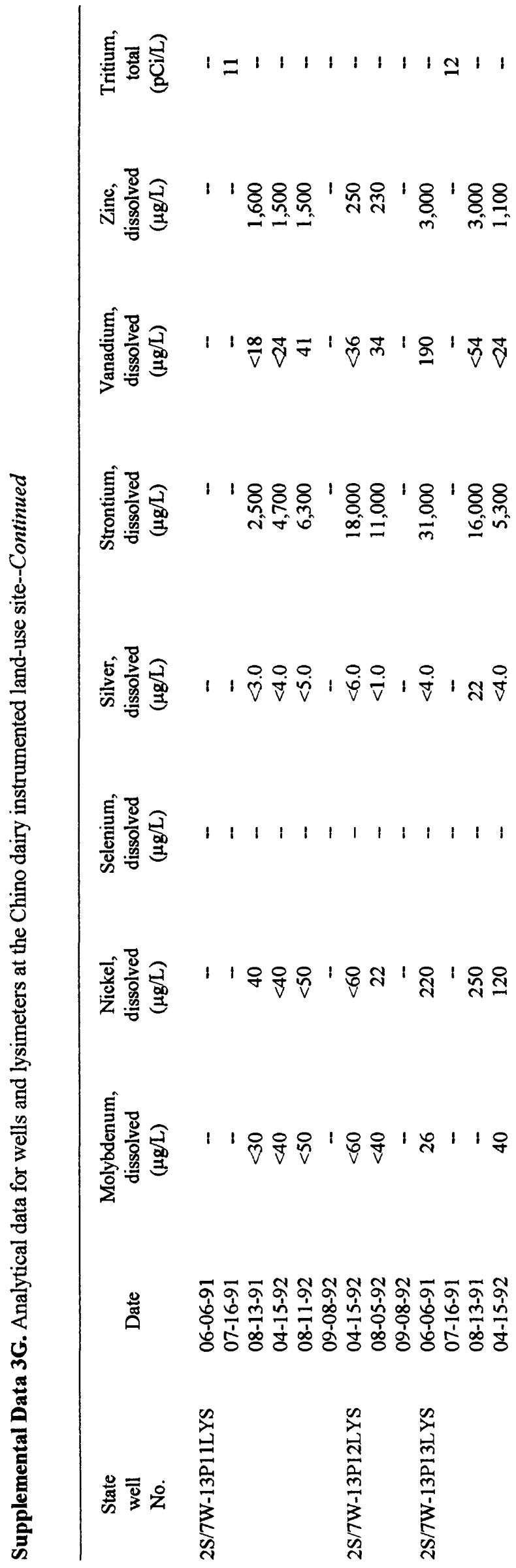




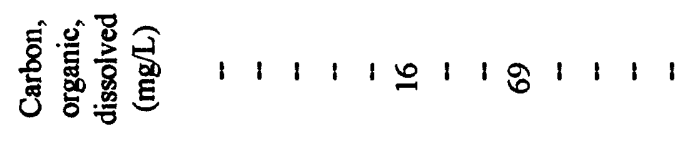

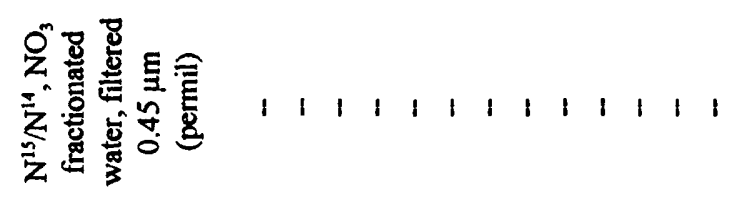

$\stackrel{\circ}{\stackrel{0}{0}}$

$\begin{array}{lllllllllllll}1 & 1 & 1 & 1 & 1 & 1 & 1 & 1 & 1 & 1 & 1 & 1 & 1\end{array}$

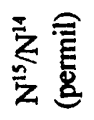

111111111111111

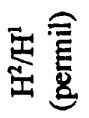

$\begin{array}{lllllllllllll}1 & 1 & 1 & 1 & 1 & 1 & 1 & 1 & 1 & 1 & 1 & 1 & 1\end{array}$

$\frac{20}{\overline{0}}$

它

苂

总

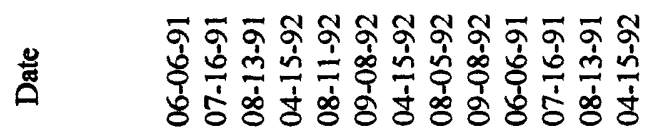

ن

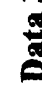

를

कह के 